UNIVERSIDADE DE SÃO PAULO

FACULDADE DE ECONOMIA, ADMINISTRAÇÃO E CONTABILIDADE DE RIBEIRÃO PRETO

DEPARTAMENTO DE ECONOMIA

CARLOS CÉSAR SANTEJO SAIANI

ORIENTADOR: PROF. DR. RUDINEI TONETO JÚNIOR

RESTRIÇÕES À EXPANSÃO DOS INVESTIMENTOS EM SANEAMENTO BÁSICO NO BRASIL: DÉFICIT DE ACESSO E DESEMPENHO DOS PRESTADORES 
PROFA. DRA. SUELY VILELA

Reitora da Universidade de São Paulo

PROF. DR. RUDINEI TONETO JÚNIOR

Diretor da Faculdade de Economia, Administração e Contabilidade de Ribeirão Preto

PROFA. MARIA CHRISTINA SIQUEIRA DE SOUZA CAMPOS

Chefe do Departamento de Economia 


\section{RESTRIÇÕES À EXPANSÃO DOS INVESTIMENTOS EM SANEAMENTO BÁSICO NO BRASIL: DÉFICIT DE ACESSO E DESEMPENHO DOS PRESTADORES}

Dissertação apresentada ao Programa de PósGraduação em Economia Aplicada do Departamento de Economia da Faculdade de Economia, Administração e Contabilidade de Ribeirão Preto, Universidade de São Paulo, para obtenção do título de Mestre em Economia.

Orientador: Prof. Dr. Rudinei Toneto Júnior 
AUTORIZO A REPRODUÇÃO E DIVULGAÇÃO TOTAL OU PARCIAL DESTE TRABALHO, POR QUALQUER MEIO CONVENCIONAL OU ELETRÔNICO, PARA FINS DE ESTUDO E PESQUISA, DESDE QUE CITADA A FONTE.

\section{FICHA CATOLOGRÁFICA}

Saiani, Carlos César Santejo

Restrições à expansão dos investimentos em saneamento básico no Brasil: déficit de acesso e desempenho dos prestadores. Ribeirão Preto, 2006. 315 p.

Dissertação de Mestrado, apresentada ao Programa de Pós-Graduação em Economia Aplicada, Faculdade de Economia, Administração e Contabilidade de Ribeirão Preto, Universidade de São Paulo. Concentração: Economia Aplicada - Desenvolvimento Econômico

Orientador: Toneto Júnior, Rudinei.

1. Saneamento básico. 2. Déficit de acesso. 3. Economias de escala e densidade. 4. Desestatização. 5 Descentralização. 6. Probit. 


\section{FOLHA DE APROVAÇÃO}

\section{Carlos César Santejo Saiani}

Restrições à Expansão dos Investimentos em Saneamento Básico no Brasil: Déficit de Acesso e Desempenho dos Prestadores

Dissertação apresentada ao Programa de PósGraduação em Economia Aplicada do Departamento de Economia da Faculdade de Economia, Administração e Contabilidade de Ribeirão Preto, Universidade de São Paulo, para obtenção do título de Mestre em Economia.

Aprovada em:

BANCA EXAMINADORA

Prof. Dr.

Instituição: Assinatura:

Prof. Dr.

Instituição: Assinatura:

Prof. Dr.

Instituição: Assinatura: 
Realizado, dedico esse trabalho a meus pais, a Marilu e a meu irmão, as pessoas que mais acreditaram em meu sucesso. Sem eles, nada disso seria possível. 


\section{AGRADECIMENTOS}

Em um dos momentos mais importantes e felizes da minha vida, algumas pessoas merecem os meus sinceros agradecimentos. Primeiramente, devo compartilhar essa conquista com meus pais, Paulo e Lúcia. Agradeço a eles pela vida, pela dedicação, pelo apoio, pela abnegação,

pelos sacrifícios, pelo incentivo, pela torcida, pela alegria, pelos conselhos, enfim, por tudo. É mais um sonho que realizamos juntos. Mais uma vez, obrigado por tudo. Amo muito vocês.

A Marilu, minha namorada, meu amor. Por todos os conselhos em momentos de dúvida, pelo incentivo dado para o meu ingresso no curso de Mestrado e durante a elaboração desse trabalho. Por todos os momentos de alegria, de preocupação e de mau-humor que ela esteve ao meu lado, sempre me apoiando e me motivando a seguir em busca de novas conquistas.

A meu irmão, Renato, pela amizade, pelo companheirismo e pela cumplicidade demonstrados ao longo de minha vida e pelas tentativas frustradas de mudança do meu humor nos momentos de preocupação, principalmente durante a realização dessa dissertação.

Ao meu orientador e amigo professor Rudinei Toneto Júnior, pelos conselhos, pelo apoio e pelo auxílio durante todo o meu período acadêmico, por me incentivar a ingressar no Mestrado e pela importante orientação dada para o desenvolvimento desse trabalho.

A Deus, por me dar a oportunidade de conviver com tais pessoas.

Ao apoio da Fundação de Amparo à Pesquisa do Estado de São Paulo (FAPESP).

Por último, devo agradecer a ajuda de amigos (Mazinha e Maúna) e de professores (Maria Christina, Júlio e Elaine), assim como as dicas recebidas de participantes do X e XI Encontro Nacional de Economia Política. 


\section{RESUMO}

SAIANI, C. C. S. Restrições à Expansão dos Investimentos em Saneamento Básico no Brasil: Déficit de Acesso e Desempenho dos Prestadores. 2007. 317 f. Dissertação de Mestrado - Faculdade de Administração, Economia e Contabilidade, Universidade de São Paulo, Ribeirão Preto, 2007.

O Brasil apresenta elevado déficit de acesso a serviços de saneamento básico. Devido aos impactos positivos desses serviços sobre o desenvolvimento econômico, é de fundamental importância que a universalização do acesso seja alcançada. No entanto, um conjunto de fatores restringe a expansão dos investimentos no setor: ausência de uma política clara, fragmentação de competências, ausência de uma regulação específica, ineficiência de grande parte dos prestadores, forte presença pública no setor, fazendo com que os investimentos sejam inviabilizados pelos limites de endividamento, pelas metas de superávit e pelos contingenciamentos de crédito ao setor público. Nesse contexto, o presente trabalho buscou identificar e avaliar os fatores que restringem a expansão dos investimentos no saneamento básico brasileiro. Inicialmente, foram discutidos os principais problemas institucionais existentes. Após isso, o déficit de acesso domiciliar foi caracterizado, por meio de análises descritivas e de estimações econométricas - método Probit. Constatou-se que esse déficit está intimamente relacionado ao perfil de renda dos consumidores e à existência de economias de escala e de densidade no setor, o que acaba sendo uma forte restrição à expansão dos investimentos. Por último, foi comparado o desempenho dos diferentes tipos de prestadores existentes em relação a diversos aspectos. Os dados sinalizaram que uma maior descentralização e uma maior desestatização poderiam gerar ganhos de eficiência e elevar a cobertura dos serviços.

Palavras-chave: Saneamento básico. Déficit de acesso. Economias de escala e densidade. Desestatização. Descentralização. Probit. 


\begin{abstract}
SAIANI, C. C. S. Restrictions to the Expansion of the Investments in Brazilian's Sanitation: Deficit of Access and Performance of the Services Offered. 2007. $317 \mathrm{f}$. Dissertation (Master) - Faculdade de Administração, Economia e Contabilidade, Universidade de São Paulo, Ribeirão Preto, 2007.
\end{abstract}

Brazil presents elevated access deficit to basic sanitation services. Due to the positive impact of these services on economic development, it is fundamentally important that generalized access be achieved. However, a number of factors restrict investment expansion in this area: absence of clear politics, competency fragmentation, absence of specific regulations, inefficiency in great part of services offered, strong public presence in the area, all of which make it unviable because of indebtedness limits, superavit goals and credit contingency to the public sector. Then, within this context, the principal aim of this paper is to identify and evaluate the factors which restrict investment expansion in Brazilian basic sanitation. At first, principal institutional problems were discussed; afterwards domestic deficit access was distinguished by descriptive analyses and econometrics estimates - Probit method. It was verified that this deficit is closely related to the consumers' income profile - economical scale and density in the sector, which leads to strong restriction in investment expansion. Finally, the performance of the different types of services offered was compared in several aspects. The data indicate that more decentralization and non-state conditions could bring benefits to the efficiency and improve service coverage.

Key words: Basic sanitation. Access deficit. Economical scale and density. Privatization. Decentralization. Probit. 


\section{LISTA DE GRÁFICOS}

\section{Capítulo 1}

Gráfico 1.1 - Brasil: evolução da taxa de crescimento do Produto Interno Bruto (PIB), de 1901 a 2005

Gráfico 1.2 - Brasil: evolução dos investimentos totais e em infra-estrutura (\% do PIB), de 1971 a 2000

Gráfico 1.3 - Brasil: evolução dos investimentos em setores de infra-estrutura (\% do PIB), de 1971 a 2000

Gráfico 1.4 - Brasil: receitas municipais per capita, segundo o porte dos municípios (2005)

Gráfico 1.5 - Brasil: despesa per capita com o poder legislativo, segundo o porte dos municípios (2005)

Gráfico 1.6 - Brasil: evolução da taxa de urbanização brasileira, de 1940 a 2000 52

Gráfico 1.7 - Brasil: participação de cada serviço de saneamento básico nos investimentos totais realizados no setor, de 1968 a 1993

Gráfico 1.8 - Brasil: evolução da participação dos recursos do FGTS no total investido (\%), de 1968 a 1993

Gráfico 1.9 - Brasil: evolução da arrecadação bruta, dos saques e da arrecadação do FGTS (US\$), de 1968 a 1993

Gráfico 1.10 - Brasil: evolução da arrecadação bruta, dos saques e da arrecadação líquida do FGTS (R \$ milhões), de 1988 a 2005

Gráfico 1.11 - Brasil: contratação média anual de recursos do FGTS para o saneamento básico (R \$ bilhões), de 1995 a 2006

Gráfico 1.12 - Brasil: investimento per capita realizados pelas CESBs (R\$ milhões por habitante), segundo a situação dos contratos de concessão (2004)

\section{Capítulo 2}

Gráfico 2.1 - Brasil: acesso a serviços de saneamento básico por rede geral, segundo o PIB per capita estadual e do Distrito Federal ....

Gráfico 2.2 - Brasil: proporção de domicílios com acesso a serviços de saneamento básico, segundo o porte (tamanho da população) dos municípios (2000) ... 117

Gráfico 2.3 - Brasil: proporção de domicílios com acesso a serviços de saneamento básico, segundo a taxa de urbanização dos municípios (2000)

Gráfico 2.4 - Brasil: proporção de domicílios com acesso a serviços de saneamento básico, segundo a renda per capita mensal dos municípios (2000)

Gráfico 2.5 - Brasil: proporção de domicílios com acesso a serviços de saneamento básico, segundo a renda domiciliar mensal (2000) 
Gráfico 2.6 - Brasil: proporção de domicílios com acesso a serviços de saneamento básico, segundo a renda domiciliar per capita mensal .

Gráfico 2.7 - Brasil: evolução da proporção de domicílios com acesso a serviços de saneamento básico (1970-2004)

Gráfico 2.8 - Brasil: variação da proporção de domicílios com acesso a serviços de saneamento básico (1970-2000)

Gráfico 2.9 - Brasil: convergência dos índices de acesso domiciliar, segundo os tipos de serviços (1970-2000)

Gráfico 2.10 - Brasil: convergência dos índices de acesso domiciliar, segundo os tipos de serviços (2001-2004)

Gráfico 2.11 - Brasil: evolução da proporção de domicílios com acesso a abastecimento de água por rede geral, segundo as grandes regiões, o Distrito Federal e o Estado de São Paulo (1970-2000)

Gráfico 2.12 - Brasil: convergência dos índices de acesso a abastecimento de água por rede geral, segundo as grandes regiões, o Distrito Federal e o Estado de São Paulo (1970-2000)

Gráfico 2.13 - Brasil: evolução da proporção de domicílios com acesso a coleta de esgoto por rede geral, segundo as grandes regiões, o Distrito Federal e o Estado de São Paulo (1970-2000)

Gráfico 2.14 - Brasil:convergência dos índices de acesso a coleta de esgoto por rede geral, segundo as grandes regiões, o Distrito Federal e o Estado de São Paulo (1970-2000)

Gráfico 2.15 - Brasil: evolução da proporção de domicílios com acesso a abastecimento de água por rede geral, segundo o porte dos municípios (1970-2000)

Gráfico 2.16 - Brasil: evolução da proporção de domicílios com acesso a coleta de esgoto por rede geral, segundo o porte dos municípios (1970-2000)

Gráfico 2.17 - Brasil: convergência dos índices de acesso a abastecimento de água por rede geral, segundo o porte dos municípios (1970-2000)

Gráfico 2.18 - Brasil: convergência dos índices de acesso a coleta de esgoto por rede geral, segundo o porte dos municípios (1970-2000)

Gráfico 2.19 - Brasil: evolução da proporção de domicílios com acesso a serviços de saneamento básico, segundo a taxa de urbanização dos municípios (19702000)

Gráfico 2.20 - Brasil: convergência dos índices de acesso a abastecimento de água por rede geral, segundo a taxa de urbanização dos municípios (1970-2000).....

Gráfico 2.21 - Brasil: convergência dos índices de acesso a coleta de esgoto por rede geral, segundo a taxa de urbanização dos municípios (1970-2000)

Gráfico 2.22 - Brasil: evolução da proporção de domicílios com acesso a serviços de saneamento básico, segundo a localização do domicílio (1970-2000)

Gráfico 2.23 - Brasil: evolução da proporção de domicílios com acesso a serviços de saneamento básico, segundo a localização do domicílio (2001-2004) 
Gráfico 2.24 - Brasil: convergência dos índices de acesso a serviços de saneamento básico, segundo a localização do domicílio (1970-2000) ...

Gráfico 2.25 - Brasil: evolução da proporção de domicílios com acesso a abastecimento de água por rede geral, segundo a renda mensal dos domicílios (19802000)

Gráfico 2.26 - Brasil: evolução da proporção de domicílios com acesso a coleta de esgoto por rede geral, segundo a renda mensal dos domicílios (19802000)

Gráfico 2.27 - Brasil: convergência dos índices de acesso a abastecimento de água por rede geral, segundo a renda mensal dos domicílios (1980-2000)

Gráfico 2.28 - Brasil: convergência dos índices de acesso a coleta de esgoto por rede geral, segundo a renda mensal dos domicílios (1980-2000)

Gráfico 2.29 - Brasil: distribuição dos municípios, segundo o porte, as grandes regiões e o Estado de São Paulo (2000)

Gráfico 2.30 - Brasil: distribuição dos municípios, segundo a taxa de urbanização, as grandes regiões e o Estado de São Paulo (2000)

Gráfico 2.31 - Brasil: distribuição dos municípios, segundo a renda municipal per capita mensal, as grandes regiões e o Estado de São Paulo (2000)

Gráfico 2.32 - Brasil: distribuição dos domicílios, segundo a localização (zona urbana ou zona rural), as grandes regiões, o Distrito Federal e o Estado de São Paulo (2000)

Gráfico 2.33 - Brasil: distribuição dos domicílios, segundo a renda domiciliar mensal, as grandes regiões, o Distrito Federal e o Estado de São Paulo (2000)

Gráfico 2.34 - Brasil: distribuição dos domicílios sem acesso a serviços de saneamento básico, segundo a renda domiciliar mensal (2000)

\section{Capítulo 3}

Gráfico 3.1 - Brasil: evolução dos investimentos anuais em saneamento básico (\% do PIB), de 1970 a 2005

Gráfico 3.2 - Brasil: proporção de domicílios com acesso a serviços de saneamento básico por rede geral, segundo o tipo de prestador (2000)

Gráfico 3.3 - Brasil: proporção de domicílios com acesso a abastecimento de água por rede geral, segundo o tipo de prestador (1991 e 2000)

Gráfico 3.4 - Brasil: proporção de domicílios com acesso a coleta de esgoto por rede geral, segundo o tipo de prestador (1991 e 2000)

Gráfico 3.5 - Saneamento básico no Brasil: variação dos índices de perdas de faturamento, de perdas na distribuição e de hidrometração (valor médio e desvio-padrão), segundo o tipo de prestador (2000 e 2004)

Gráfico 3.6 - Saneamento básico no Brasil: variação dos índices de atendimento total de água, de coleta e de tratamento de esgoto (valor médio e desvio-padrão), segundo o tipo de prestador (2000 e 2004) 
Gráfico 3.7 - Saneamento básico no Brasil: variação dos índices de economia por pessoal total e de pessoal próprio por mil ligações (valor médio e desviopadrão), segundo o tipo de prestador (2000 e 2004)

Gráfico 3.8 - Saneamento básico no Brasil: variação das tarifas médias praticadas, de água e de esgoto (valor médio e desvio-padrão), segundo o tipo de prestador (2000 e 2004)

Gráfico 3.9 - Saneamento básico no Brasil: variação dos índices de evasão de receita e de desempenho financeiro (valor médio e desvio-padrão), segundo o tipo de prestador (2000 e 2004)

Gráfico 3.10 - Saneamento básico no Brasil: variação dos índices de duração média das intermitências e de extravasamento de esgoto (valor médio e desviopadrão), segundo o tipo de prestador (2000 e 2004)

Gráfico 3.11 - Saneamento básico no Brasil: evolução do resultado médio, segundo o tipo de prestador (2000 e 2004)

Gráfico 3.12 - Saneamento básico no Brasil: investimento per capita anual médio (água e esgoto), segundo o tipo de prestador (2000-2004)

Gráfico 3.13 - Saneamento básico no Brasil: investimento per capita anual médio (água e esgoto), segundo o tipo de prestador e o porte (tamanho da população) dos municípios (2000-2004)

Gráfico 3.14 - Saneamento básico no Brasil: investimento per capita anual médio (água e esgoto), segundo o tipo de prestador e a taxa de urbanização dos municípios (2000-2004)

Gráfico 3.15 - Saneamento básico no Brasil: origem dos recursos investidos, segundo o tipo de prestador (2004)

Gráfico 3.16 - Saneamento básico no Brasil: recursos comprometidos pelo governo federal, segundo a fonte e o destino (jan/2003-jun/2006) 


\section{LISTA DE QUADROS}

\section{Capítulo 1}

Quadro 1.1 - Brasil: principais programas federais para o saneamento básico após o Planasa ..................................................................................... 72

Quadro 1.2 - Brasil: principais legislações relacionadas ao saneamento básico ............... 89

Quadro 1.3 - Saneamento básico no Brasil: concessões privadas em operação (2007) ...... 104

\section{Capítulo 3}

Quadro 3.1 - SNIS: formulários utilizados para a coleta dos dados 191

Quadro 3.2 - Etapas para a concretização de operações de crédito com o Ministério das Cidades

Quadro 3.3 - Saneamento básico no Brasil: qual é o tipo de prestador que apresenta os melhores indicadores de acesso por rede geral? (1991 e 2000) ................ 258

Quadro 3.4 - Saneamento básico no Brasil: qual é o tipo de prestador com melhor desempenho? (2004)

Quadro 3.5 - Saneamento básico no Brasil: quais são os tipos de prestadores que apresentaram melhora do desempenho? (2000-2004)

Quadro 3.6 - Saneamento básico no Brasil: qual é o tipo de prestador que apresenta maior resultado médio? Qual investe mais? 


\section{LISTA DE TABELAS}

\section{Capítulo 1}

Tabela 1.1 - Brasil: evolução da receita tributária por nível de governo, de 1960 a 2000 . 42

Tabela 1.2 - Brasil: resultado setorial da desestatização, de 1990 a 1994 (US\$ milhões) .. 48

Tabela 1.3 - Brasil: resultado setorial da desestatização, de 1995 a 2002 (US\$ milhões) .. 50

Tabela 1.4 - Brasil: evolução dos recursos do FGTS contratados para o saneamento básico (R \$ milhões), de 2000 a 2006 ........................................................... 81

Tabela 1.5 - Brasil: situação contratual (abastecimento de água), segundo a amostra do SNIS (2004)

\section{Capítulo 2}

Tabela 2.1 - Brasil: proporção de domicílios com acesso a serviços de saneamento básico (\% dos domicílios) e PIB per capita, segundo as grandes regiões, o Estado de São Paulo e o Distrito Federal (2000)

Tabela 2.2 - Brasil: proporção de domicílios com acesso a serviços de saneamento básico (\% total), segundo as grandes regiões e os Estados, e ranking estadual (2000)

Tabela 2.3 - Brasil: proporção de domicílios com acesso a serviços de saneamento básico, segundo o porte (tamanho da população) dos municípios, as grandes regiões e o Estado de São Paulo (2000) ....

Tabela 2.4 - Brasil: proporção de domicílios com acesso a serviços de saneamento básico, segundo a taxa de urbanização dos municípios, as grandes regiões e o Estado de São Paulo (2000)

Tabela 2.5 - Brasil: proporção de domicílios com acesso a serviços de saneamento básico, segundo a renda per capita mensal dos municípios, as grandes regiões e o Estado de São Paulo (2000)

Tabela 2.6 - Brasil: proporção de domicílios com acesso a serviços de saneamento básico, segundo o tipo de município, as grandes regiões e o Estado de São Paulo (2000)

Tabela 2.7 - Brasil: proporção de domicílios urbanos e rurais com acesso a serviços de saneamento básico (\% dos domicílios), segundo as grandes regiões, o Estado de São Paulo e o Distrito Federal (2000)

Tabela 2.8 - Brasil: proporção de domicílios com acesso a serviços de saneamento básico, segundo a renda domiciliar mensal, as grandes regiões, o Estado de São Paulo e o Distrito Federal (2000)

Tabela 2.9 - Brasil: proporção de domicílios com acesso a serviços de saneamento básico, segundo a renda domiciliar per capita mensal, as grandes regiões, o Estado de São Paulo e o Distrito Federal (2000) 
Tabela 2.10 - Brasil: volume per capita de água distribuída diariamente, 1989 e 2000 ....

Tabela 2.11 - Brasil: volume de água distribuída diariamente, segundo o porte (tamanho da população) dos municípios e as grandes regiões

Tabela 2.12 - Brasil: proporção de municípios, segundo a condição do esgotamento sanitário e as grandes regiões (2000)

Tabela 2.13 - Sinais esperados dos coeficientes a serem estimados

Tabela 2.14 - Brasil: distribuição dos domicílios com acesso a serviços de saneamento básico (Censo e amostra), segundo as grandes regiões, o Distrito Federal e o Estado de São Paulo

Tabela 2.15 - Estatísticas descritivas das variáveis utilizadas nas estimações (amostra) ... 140

Tabela 2.16 - Resultados das estimações: variável dependente abastecimento de água por rede geral (2000)

Tabela 2.17 - Resultados das estimações: variável dependente coleta de esgoto por rede geral (2000)

Tabela 2.18 - Resultados das estimações: variável dependente esgotamento sanitário por fossa séptica (2000)

Tabela 2.19 - Resultados das estimações com dummies tipos de municípios (2000)

Tabela 2.20 - Resumo dos resultados das estimações: variável dependente abastecimento de água por rede geral (1971, 1980, 1991, 2000 e 2004)

Tabela 2.21 - Resumo dos resultados das estimações: variável dependente coleta de esgoto por rede geral (1971, 1980, 1991, 2000 e 2004)

Tabela 2.22 - Resumo das estimações: variável dependente esgotamento sanitário por fossa séptica $(1971,1980,1991,2000$ e 2004) ....

Tabela 2.23 - Brasil: participação da despesa com água e esgoto na despesa média mensal familiar, 2002-2003

\section{Capítulo 3}

Tabela 3.1 - SNIS: distribuição dos prestadores de serviços da amostra (2004)

Tabela 3.2 - SNIS: distribuição dos municípios da amostra e suas respectivas populações, segundos as grandes regiões geográficas

Tabela 3.3 - Brasil: proporção de domicílios com acesso a serviços de saneamento básico, segundo o tipo de prestador, as grandes regiões e o Estado de São Paulo (2000)

Tabela 3.4 - Brasil: distribuição dos domicílios (Censo e amostra), segundo o tipo de prestador e o acesso a serviços de saneamento básico por rede geral

Tabela 3.5 - Estatísticas descritivas das variáveis contínuas utilizadas nas estimações e comparação entre as amostras

Tabela 3.6 - Resultados das estimações com dummies tipos de prestadores: variável dependente acesso a abastecimento de água por rede geral (2000) 
Tabela 3.7 - Resultados das estimações com dummies tipos de prestadores: variável dependente acesso a coleta de esgoto por rede geral (2000)

Tabela 3.8 - Resumo dos resultados das estimações com dummies tipos de prestadores: comparação entre os resultados obtidos

Tabela 3.9 - Saneamento básico no Brasil: indicadores operacionais e de cobertura, segundo o tipo de prestador do serviço (2004)

Tabela 3.10 - Saneamento básico no Brasil: indicadores econômicos, financeiros e administrativos, segundo o tipo de prestador do serviço (2004)

Tabela 3.11 - Saneamento básico no Brasil: indicadores de qualidade, segundo o tipo de prestador do serviço (2004)

Tabela 3.12 - Saneamento básico no Brasil: tarifa média praticada e despesa total com os serviços por $\mathrm{m}^{3}$ faturado, segundo o tipo de prestador do serviço (2004) . 233

Tabela 3.13 - Resultados da estimação: variável dependente binária resultado do prestador (2004)

Tabela 3.14 - Resultados da estimação: variável dependente contínua investimentos realizados (2004)

Tabela 3.15 - Saneamento básico no Brasil: distribuição dos prestadores da amostra, segundo a abrangência espacial e o resultado obtido (2004)

Tabela 3.16 - Saneamento básico no Brasil: receita total, despesa total e resultado (total e médio), segundo o tipo de prestador (2004)

Tabela 3.17 - Saneamento básico no Brasil: resultado médio (R \$ milhões), segundo o tipo de prestador do serviço, as grandes regiões e o Estado de São Paulo (2004)

Tabela 3.18 - Saneamento básico no Brasil: investimento per capita anual médio, segundo o tipo de prestador do serviço, as grandes regiões e o Estado de São Paulo (2000-2004)

Tabela 3.19 - Saneamento básico no Brasil: gastos federais, segundo a origem dos recursos (jan/2003-jun/2006)

\section{Apêndice}

Tabela 1 - Brasil: PIB per capita estadual e do Distrito Federal, segundo as grandes regiões, e ranking estadual (2000)

Tabela 2 - Brasil: proporção de domicílios com acesso simultâneo a água e a esgoto por rede geral, segundo o porte (tamanho da população) dos municípios, as grandes regiões e o Estado de São Paulo (2000)

Tabela 3 - Brasil: proporção de domicílios com acesso simultâneo a água e a esgoto por rede geral, segundo a taxa de urbanização dos municípios, as grandes regiões e o Estado de São Paulo (2000)

Tabela 4 - Brasil: proporção de domicílios com acesso simultâneo a água e a esgoto por rede geral, segundo a renda per capita mensal dos municípios, as grandes regiões e o Estado de São Paulo (2000) 
Tabela 5 - Brasil: proporção de domicílios com acesso simultâneo a água e a esgoto por rede geral, segundo o tipo de município, as grandes regiões e o Estado de São Paulo (2000)

Tabela 6 - Brasil: proporção de domicílios com acesso simultâneo a água e a esgoto por rede geral, segundo a renda domiciliar mensal, as grandes regiões, o Distrito Federal e o Estado de São Paulo (2000)

Tabela 7 - Brasil: proporção de domicílios com acesso simultâneo a água e a esgoto por rede geral, segundo a renda domiciliar per capita mensal, as grandes regiões, o Distrito Federal e o Estado de São Paulo (2000)

Tabela 8 - Brasil: proporção de domicílios com acesso a serviços de saneamento básico, segundo o porte dos municípios, as grandes regiões e o Estado de São Paulo (1970)

Tabela 9 - Brasil: proporção de domicílios com acesso a serviços de saneamento básico, segundo o porte dos municípios, as grandes regiões e o Estado de São Paulo (1980)

Tabela 10 - Brasil: proporção de domicílios com acesso a serviços de saneamento básico, segundo o porte dos municípios, as grandes regiões e o Estado de São Paulo (1991)

Tabela 11 - Brasil: proporção de domicílios com acesso a serviços de saneamento básico, segundo a taxa de urbanização dos municípios, as grandes regiões e o Estado de São Paulo (1970)

Tabela 12 - Brasil: proporção de domicílios com acesso a serviços de saneamento básico, segundo a taxa de urbanização dos municípios, as grandes regiões e o Estado de São Paulo (1980)

Tabela 13 - Brasil: proporção de domicílios com acesso a serviços de saneamento básico, segundo a taxa de urbanização dos municípios, as grandes regiões e o Estado de São Paulo (1991)

Tabela 14 - Brasil: proporção de domicílios com acesso a serviços de saneamento básico, segundo a renda per capita mensal dos municípios, as grandes regiões e o Estado de São Paulo (1970)

Tabela 15 - Brasil: proporção de domicílios com acesso a serviços de saneamento básico, segundo a renda per capita mensal dos municípios, as grandes regiões e o Estado de São Paulo (1980)

Tabela 16 - Brasil: proporção de domicílios com acesso a serviços de saneamento básico, segundo a renda per capita mensal dos municípios, as grandes regiões e o Estado de São Paulo (1991)

Tabela 17 - Brasil: proporção de domicílios com acesso a serviços de saneamento básico, segundo a renda do chefe da família, as grandes regiões, o Distrito Federal e o Estado de São Paulo (1970) 286

Tabela 18 - Brasil: proporção de domicílios com acesso a serviços de saneamento básico, segundo a renda domiciliar mensal, as grandes regiões, o Distrito Federal e o Estado de São Paulo (1980) 
Tabela 19 - Brasil: proporção de domicílios com acesso a serviços de saneamento básico, segundo a renda domiciliar mensal, as grandes regiões, o Distrito Federal e o Estado de São Paulo (1991)

Tabela 20 - Brasil: proporção de domicílios com acesso a serviços de saneamento básico, segundo a renda domiciliar mensal, as grandes regiões, o Distrito Federal e o Estado de São Paulo (2001)

Tabela 21 - Brasil: proporção de domicílios com acesso a serviços de saneamento básico, segundo a renda domiciliar mensal, as grandes regiões, o Distrito Federal e o Estado de São Paulo (2002)

Tabela 22 - Brasil: proporção de domicílios com acesso a serviços de saneamento básico, segundo a renda domiciliar mensal, as grandes regiões, o Distrito Federal e o Estado de São Paulo (2003)

Tabela 23 - Brasil: proporção de domicílios com acesso a serviços de saneamento básico, segundo a renda domiciliar mensal, as grandes regiões, o Distrito Federal e o Estado de São Paulo (2004)

Tabela 24 - Brasil: proporção de domicílios urbanos e rurais com acesso a serviços de saneamento básico, segundo as grandes regiões, o Distrito Federal e o Estado de São Paulo (1970-1991)

Tabela 25 - Brasil: proporção de domicílios urbanos e rurais com acesso a serviços de saneamento básico, segundo as grandes regiões, o Distrito Federal e o Estado de São Paulo (2001-2004)

Tabela 26 - Resultados das estimações: variável dependente acesso a abastecimento de água por rede geral (1970) ....

Tabela 27 - Resultados das estimações: variável dependente acesso a abastecimento de água por rede geral (1980)

Tabela 28 - Resultados das estimações: variável dependente acesso a abastecimento de água por rede geral (1991)

Tabela 29 - Resultados das estimações: variável dependente acesso a coleta de esgoto por rede geral (1970)

Tabela 30 - Resultados das estimações: variável dependente acesso a coleta de esgoto por rede geral (1980)

Tabela 31 - Resultados das estimações: variável dependente acesso a coleta de esgoto por rede geral (1991)

Tabela 32 - Resultados das estimações: variável dependente acesso a fossa séptica por rede geral (1970)

Tabela 33 - Resultados das estimações: variável dependente acesso a fossa séptica por rede geral (1980)

Tabela 34 - Resultados das estimações: variável dependente acesso a fossa séptica por rede geral (1991)

Tabela 35 - Resultados das estimações (2004) 
Tabela 36 - Brasil: variação da proporção de domicílios com acesso a serviços de saneamento básico, segundo as grandes regiões, o Distrito Federal e o Estado de São Paulo (1970-2000)

Tabela 37 - Brasil: variação da proporção de domicílios com acesso a serviços de saneamento básico, segundo o porte dos municípios (1970-2000)

Tabela 38 - Brasil: variação da proporção de domicílios com acesso a serviços de saneamento básico, segundo a taxa de urbanização dos municípios (19702000)

Tabela 39 - Brasil: variação da proporção de domicílios com acesso a serviços de saneamento básico, segundo a renda domiciliar mensal (1980-2000)

Tabela 40 - Brasil: variação da proporção de domicílios com acesso a serviços de saneamento básico, segundo a localização dos domicílios (1970-2000)

Tabela 41 - Brasil: distribuição dos municípios em 2000, segundo o porte (tamanho da população) dos municípios, as grandes regiões e o Estado de São Paulo (\%) 307

Tabela 42 - Brasil: distribuição dos municípios em 2000, segundo a taxa de urbanização dos municípios, as grandes regiões e o Estado de São Paulo (\%)

Tabela 43 - Brasil: distribuição dos municípios em 2000, segundo a renda municipal per capita mensal, as grandes regiões e o Estado de São Paulo (\%)

Tabela 44 - Brasil: distribuição dos domicílios em 2000, segundo a localização do domicílio, as grandes regiões, o Distrito Federal e o Estado de São Paulo $(\%)$

Tabela 45 - Brasil: distribuição dos domicílios em 2000, segundo a renda domiciliar mensal, as grandes regiões, o Distrito Federal e o Estado de São Paulo (\%) . 308

Tabela 46 - Brasil: distribuição dos domicílios sem acesso aos serviços (\%), segundo a renda domiciliar mensal (2000)

Tabela 47 - Brasil: distribuição dos municípios (2006), segundo o tipo de prestador (abrangência de atuação)

Tabela 48 - Resultados das estimações com dummies tipos de prestadores: variável dependente acesso a abastecimento de água por rede geral (1991)

Tabela 49 - Resultados das estimações com dummies tipos de prestadores: variável dependente acesso a coleta de esgoto por rede geral (1991)

Tabela 50 - Saneamento básico no Brasil: evolução de alguns indicadores (valor médio e desvio-padrão), segundo o tipo de prestador do serviço (2000-2004)

Tabela 51 - Saneamento básico no Brasil: receita total, despesa total e resultado (total e médio), segundo o tipo de prestador (2000-2003)

Tabela 52 - Saneamento básico no Brasil: investimento per capita anual médio, segundo o tipo de prestador do serviço e o porte dos municípios (2000-2004)

Tabela 53 - Saneamento básico no Brasil: investimento per capita anual médio, segundo o tipo de prestador do serviço e taxa de urbanização dos municípios (20002004) 


\section{LISTA DE SIGLAS}

ABCON Associação Brasileira das Concessionárias Privadas de Serviços Públicos de Água e Esgoto

AESBE Associação das Empresas de Saneamento Básico Estaduais

AGESPISA Águas e Esgotos do Piauí S/A

ANA Agência Nacional de Água

ANVISA Agência Nacional de Vigilância Sanitária

ASSEMAE Associação dos Serviços Municipais de Água e Esgoto

BACEN Banco Central

BID Banco Interamericano de Desenvolvimento

BIRD Banco Mundial

BNDES Banco Nacional de Desenvolvimento Econômico e Social

BNH Banco Nacional de Habitação

CAEMA Companhia de Águas e Esgotos do Maranhão

CAER Companhia de Águas e Esgotos de Roraima

CAERD Companhia de Águas e Esgotos de Rondônia

CAEN Companhia de Águas e Esgotos do Rio Grande do Norte

CAESA Companhia de Água e Esgoto do Amapá

CAESB Companhia de Saneamento do Distrito Federal

CAGECE Companhia de Água e Esgoto do Ceará

CAGEPA Companhia de Águas e Esgotos da Paraíba

CASAL Companhia de Abastecimento de Água e Saneamento do Estado de Alagoas

CASAN Companhia Catarinense de Águas e Saneamento

CEDAE Companhia Estadual de Águas e Esgotos

CESAN Companhia Espírito-Santense de Saneamento

CESB Companhia Estadual de Saneamento Básico

CEF Caixa Econômica Federal

CMN Conselho Monetário Nacional

CODEVASF Companhia de Desenvolvimento dos Vales do São Francisco e Parnaíba

COMPESA Companhia Pernambucana de Saneamento

COPASA Companhia de Saneamento de Minas Gerais 


\begin{tabular}{|c|c|}
\hline CORSAN & Companhia Rio-Grandense de Saneamento \\
\hline COSAMA & Companhia de Saneamento do Amazonas \\
\hline COSANPA & Companhia de Saneamento do Pará \\
\hline $\mathrm{CSN}$ & Companhia Siderúrgica Nacional \\
\hline CVM & Comissão de Valores Mobiliários \\
\hline CVRD & Companhia Vale do Rio Doce \\
\hline DEAS & Departamento Estadual de Água e Saneamento \\
\hline DESO & Companhia de Saneamento do Sergipe \\
\hline DNERU & Departamento Nacional de Endemias Rurais \\
\hline DNOCS & Departamento Nacional de Obras contra as Secas \\
\hline DNOS & Departamento Nacional de Obras de Saneamento \\
\hline EFISAN & Subprograma de Estímulo do Sistema Financeiro de Saneamento \\
\hline EMBASA & Empresa Baiana de Águas e Saneamento \\
\hline FAE & Fundo Estadual de Água e Esgoto \\
\hline FAT & Fundo de Amparo ao Trabalhador \\
\hline FCP/SAN & $\begin{array}{l}\text { Programa de Financiamento a Concessionários Privados de Serviços de } \\
\text { Saneamento }\end{array}$ \\
\hline FGTS & Fundo de Garantia por Tempo de Serviço \\
\hline FICON & $\begin{array}{l}\text { Subprograma de Financiamento Suplementar para Controle da Poluição das } \\
\text { Águas }\end{array}$ \\
\hline FIDC & Fundos de Investimento em Direitos Creditórios \\
\hline FIDREN & $\begin{array}{l}\text { Subprograma de Financiamento e/ou Refinanciamento para Implantação ou } \\
\text { Melhoria de Sistemas de Drenagem }\end{array}$ \\
\hline FII & Fundos de Investimento Imobiliário \\
\hline FINANSA & Programa de Financiamento de Saneamento \\
\hline FINEST & $\begin{array}{l}\text { Subprograma Suplementar para Composição da Participação dos Estados na } \\
\text { Execução do Planasa }\end{array}$ \\
\hline FISAG & Subprograma de Financiamento Suplementar para Abastecimento de Água \\
\hline FMI & Fundo Monetário Internacional \\
\hline FPE & Fundo de Participação Estadual \\
\hline FPM & Fundo de Participação Municipal \\
\hline FSEP & Fundação Serviços de Saúde Pública \\
\hline FUNASA & Fundação Nacional de Saúde \\
\hline FUNDEF & $\begin{array}{l}\text { Fundo de Manutenção e Desenvolvimento do Ensino Fundamental e } \\
\text { Valorização do Magistério }\end{array}$ \\
\hline
\end{tabular}




\begin{tabular}{|c|c|}
\hline $\begin{array}{l}\text { IBAMA } \\
\text { IBGE }\end{array}$ & $\begin{array}{l}\text { Instituto Brasileiro do Meio Ambiente e dos Recursos Naturais Renováveis } \\
\text { Instituto Brasileiro de Geografia e Estatística }\end{array}$ \\
\hline IPEA & Instituto de Pesquisa Econômica Aplicada \\
\hline IPTU & Imposto Predial e Territorial Urbano \\
\hline INCRA & Instituto Nacional de Colonização e Reforma Agrária \\
\hline ISS & Imposto sobre Serviços de Qualquer Natureza \\
\hline LRF & Lei de Responsabilidade Fiscal \\
\hline MAS & Ministério da Ação Social \\
\hline MBES & Ministério do Bem-Estar Social \\
\hline MCIDADES & Ministério das Cidades \\
\hline MDA & Ministério do Desenvolvimento Agrário \\
\hline MDU & Ministério do Desenvolvimento Urbano e Meio Ambiente \\
\hline MHU & Ministério da Habitação, Urbanismo e Meio Ambiente \\
\hline MPO & Ministério do Planejamento e Orçamento \\
\hline OGU & Orçamento Geral da União \\
\hline PAEG & Programa de Ação Econômica do Governo \\
\hline PASS & Programa de Ação Social em Saneamento \\
\hline PAT & $\begin{array}{l}\text { Programa Urbanização, Regularização e Integração de Assentamentos } \\
\text { Precários }\end{array}$ \\
\hline PIB & Produto Interno Bruto \\
\hline PIPS & Programa de Incentivo à Implementação de Projetos de Interesse Social \\
\hline PLANASA & Plano Nacional de Saneamento Básico \\
\hline PMSS & Programa de Modernização do Setor de Saneamento \\
\hline PNAD & Pesquisa Nacional por Amostra de Domicílios \\
\hline PNCDA & Programa Nacional de Combate ao Desperdício de Água \\
\hline PND & Plano Nacional de Desestatização \\
\hline PNSB & Pesquisa Nacional de Saneamento Básico \\
\hline POF & Pesquisa de Orçamentos Familiares \\
\hline PPP & Parceria Público-Privada \\
\hline PRODISAN & $\begin{array}{l}\text { Subprograma de Desenvolvimento Institucional das Companhias de } \\
\text { Saneamento Básico }\end{array}$ \\
\hline PRONAF & Programa Nacional de Agricultura Familiar \\
\hline PRONURB & Programa de Saneamento para Núcleos Urbanos \\
\hline PROPAR & $\begin{array}{l}\text { Programa de Assistência Técnica à Parceria Público-Privada em } \\
\text { Saneamento }\end{array}$ \\
\hline
\end{tabular}




\begin{tabular}{|c|c|}
\hline PROSAB & Programa de Pesquisa em Saneamento Básico \\
\hline PROSANEAR & Programa de Saneamento para População de Baixa Renda \\
\hline PROSEGE & $\begin{array}{l}\text { Programa Social de Emergência e Geração de Empregos em Obras de } \\
\text { Saneamento }\end{array}$ \\
\hline REFINAG & $\begin{array}{l}\text { Subprograma de Financiamento e Refinanciamento da Implantação e } \\
\text { Melhoria dos Sistemas de Abastecimento de Água }\end{array}$ \\
\hline REFINESG & $\begin{array}{l}\text { Subprograma de Financiamento e Refinanciamento da Implantação, } \\
\text { Ampliação e Melhoria dos Sistemas de Esgotos Sanitários }\end{array}$ \\
\hline SABESP & Companhia de Saneamento Básico do Estado de São Paulo \\
\hline SAC & Sistema de Amortização Constante \\
\hline SAF & Secretaria da Agricultura Familiar \\
\hline SANAT & Subprograma de Apoio Técnico ao Sistema Financeiro de Saneamento \\
\hline SANEAGO & Saneamento de Goiás S/A \\
\hline SANEATINS & Companhia de Saneamento do Tocantins \\
\hline SANEPAR & Companhia de Saneamento do Paraná \\
\hline SANESUL & Empresa de Saneamento do Mato Grosso do Sul \\
\hline SBPE & Sistema Brasileiro de Poupança e Empréstimo \\
\hline SEDU & Secretaria do Desenvolvimento Urbano \\
\hline SEPURB & Secretaria de Política Urbana \\
\hline SFH & Sistema Financeiro da Habitação \\
\hline SFS & Sistema Financeiro do Saneamento \\
\hline SNIS & Sistema Nacional de Informações sobre Saneamento Básico \\
\hline SNVS & Sistema Nacional de Vigilância Sanitária \\
\hline SPE & Sociedade de Propósito Específico \\
\hline SUCAM & Superintendência de Campanhas de Saúde \\
\hline SUS & Sistema Único de Saúde \\
\hline
\end{tabular}




\section{SUMÁRIO}

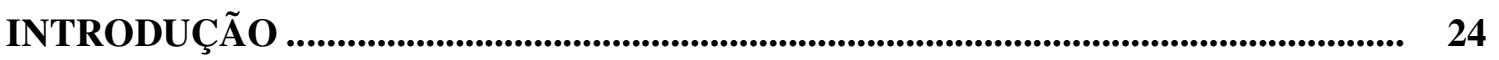

1 HISTÓRICO E PROBLEMAS INSTITUCIONAIS ............................................... 31

1.1 ESTADO DESENVOLVIMENTISTA, DESCENTRALIZAÇÃO E DESESTATIZAÇÃO ……………………………………………………... 35

1.2 HISTÓRICO DO SANEAMENTO BÁSICO NO BRASIL .......................................... 50

1.3 PROBLEMAS INSTITUCIONAIS E FINANCIAMENTO DE LONGO PRAZO ..... 83

2 DÉFICIT DE ACESSO AOS SERVIÇOS DE SANEAMENTO BÁSICO ............... 107

2.1 CARACTERIZAÇÃO DO DÉFICIT DE ACESSO …………………………........... 109

2.2 PROBABILIDADE DE ACESSO: ESTIMAÇÃO PELO MÉTODO PROBIT ............ 131

2.3 EVOLUÇÃO DO DÉFICIT DE ACESSO ......................................................... 146

2.4 DETERMINANTES DO DÉFICIT DE ACESSO ………..................................... 177

3 PRESTADORES DE SERVIÇOS: DESEMPENHO E INVESTIMENTOS ............. 186

3.1 O SISTEMA NACIONAL DE INFORMAÇÕES SOBRE SANEAMENTO (SNIS) .. 189

3.2 PROBABILIDADE DE ACESSO E TIPOS DE PRESTADORES ………................. 194

3.3 DESEMPENHO DOS PRESTADORES DE SERVIÇOS ........................................... 209

3.4 RESTRIÇÕES À EXPANSÃO DOS INVESTIMENTOS ………………………..... 229

3.5 INVESTIMENTOS REALIZADOS PELOS PRESTADORES …………………...... 248

3.6 DESCENTRALIZAÇÃO E DESESTATIZAÇÃO: SOLUÇÕES? .............................. 258

CONSIDERAÇÕES FINAIS ................................................................................................ 262

REFERÊNCIAS BIBLIOGRÁFICAS ........................................................................ 265

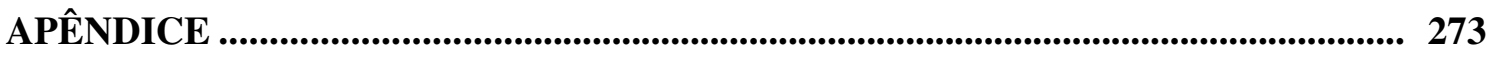




\section{INTRODUÇÃO}

A partir do trabalho seminal de Aschauer (1989), vários foram os estudos que apresentaram resultados claros de uma relação positiva entre o capital/investimento em infraestrutura e a produtividade total dos fatores e entre o capital/investimento em infra-estrutura e o crescimento econômico - por exemplo: Ferreira e Malliagros (1997), Munnell (1992), Gramlich (1994) e Ferreira e Issler (1995). Esses trabalhos apontaram um novo aspecto com o qual as políticas fiscais deveriam preocupar-se - muitos economistas e políticos passaram a defender o aumento dos investimentos em infra-estrutura como uma forma de estimular o desenvolvimento econômico.

No entanto, conforme aponta Munnell (1992), surgiram também críticos que não concordaram com os resultados obtidos por Aschauer e seus seguidores (p. 190). Na opinião desses críticos, foram utilizadas metodologias inadequadas e os resultados obtidos nos vários estudos diferem bastante para serem considerados como indicadores relevantes para políticas correntes. Além disso, afirmam que a direção de causalidade entre o investimento em infraestrutura e o crescimento do produto não ficou clara.

Apesar das críticas, não se pode ignorar a importância econômica da infra-estrutura. Para Munnell (1992), o mínimo que pode ser sugerido é que a infra-estrutura é um insumo produtivo que pode ter grandes benefícios (p. 195).

O Banco Mundial (1994) também compartilha essa visão, afirmando que os serviços de infra-estrutura são insumos no processo de produção de quase todos os setores e que os "usuários demandam serviços infra-estruturais para aumentar suas produtividades". Porém, a infra-estrutura deve ser considerada como uma precondição necessária, mas não suficiente, para o crescimento econômico, devendo ser complementada por outros fatores, como a 
eliminação de gargalos em certos pontos do sistema e a localização da área onde serão efetuados os acréscimos à capacidade - uma vez que o investimento em infra-estrutura só gera resultados positivos em locais em que há um "clima" propício à atividade econômica. Além disso, para a infra-estrutura ter impacto na produtividade é necessário que ela consiga atender de forma eficaz às necessidades dos que a demandam (p. 15).

De acordo com Rigolon e Piccinini (1997), o investimento em infra-estrutura contribui para o crescimento econômico à medida que eleva o retorno dos insumos privados, incentivando novos investimentos e a diminuição do desemprego (p. 7). Munnell (1992), por sua vez, afirma que o investimento em infra-estrutura tende a expandir a capacidade produtiva de um local, tanto por incrementar recursos como por aumentar a produtividade dos recursos já existentes (p. 191).

Além disso, a infra-estrutura pode proporcionar grandes benefícios em termos de mitigação da pobreza e de sustentabilidade ambiental. A mitigação da pobreza ocorre porque a construção e a manutenção de certos tipos de infra-estrutura, além de proporcionarem empregos diretos, melhoram a qualidade de vida das pessoas e garantem maiores oportunidades de acesso, de forma mais barata, aos mercados. A implementação de serviços compatíveis com o meio ambiente, por sua vez, também é essencial para a qualidade de vida e para a saúde pública. Nesse sentido, deve-se destacar a importância do saneamento básico .

Segundo o MPO/Sepurb/IPEA (1995), a ausência de serviços adequados de saneamento básico é causa de diversas doenças transmitidas pela água, cuja qualidade é afetada pela disposição inadequada dos resíduos domésticos, agrícolas e/ou industriais produzidos pela população (p. 43). Devem ser apontados, também, os impactos negativos sobre o meio ambiente e sobre a saúde causados pela ausência de condições adequadas de esgotamento

\footnotetext{
1 Deve-se destacar que são considerados como serviços de saneamento básico o abastecimento de água (tratamento e distribuição), o esgotamento sanitário (coleta e tratamento), a coleta e disposição dos resíduos sólidos (lixo) e a drenagem urbana. No presente trabalho, serão analisados apenas os dois primeiros: abastecimento de água e esgotamento sanitário.
} 
sanitário e de disposição de resíduos sólidos: contaminação dos mananciais e dos cursos d'água; assoreamento dos rios, contribuindo para inundações, e formação de ambientes propícios à proliferação de agentes transmissores de doenças.

Assim, algumas ações básicas no setor ganham destaque, dado os profundos impactos na situação da saúde pública, podendo-se destacar (MPO/SEPURB/IPEA, 1995):

(i) água de boa qualidade para o consumo (potável) e fornecimento contínuo - asseguram a redução e controle de diarréias, cólera, dengue, febre amarela, tracoma, hepatites, conjuntivites, poliomielite, febre tifóide, esquistossomose e outras verminoses;

(ii) coleta regular, acondicionamento e destino final adequado do lixo - diminuem a incidência de casos de peste, febre amarela, dengue, toxoplasmose, leishmaniose, cisticercose, salmonelose, teníase, leptospirose, cólera e febre tifóide;

(iii) realização de drenagem - contribui para a eliminação, redução dos criadouros dos vetores transmissores da malária e de seus índices de prevalência e incidência;

(iv) esgotamento sanitário adequado (coleta e tratamento) - contribui para reduzir ou eliminar doenças e agravos como a esquistossomose, outras verminoses, diarréias, cólera, febre tifóide, cisticercose, teníase e hepatites - e

(v) melhorias sanitárias nos domicílios - reduzem a incidência de esquistossomose e de outras verminoses, de cólera, de diarréias, de febre tifóide, de hepatites etc.

Auniversalização do acesso aos serviços de saneamento básico deve ser considerada, portanto, como uma das principais metas a ser atingida nos países em desenvolvimento, principalmente se for considerado que condições inadequadas no setor também geram impactos econômicos negativos.

As perdas econômicas estão relacionadas à produção e à produtividade do trabalho. A morbidade (dias de permanência em internações hospitalares) [...] pode diminuir a produtividade do trabalhador que está debilitado e, conseqüentemente, a produção total (OHIRA, 2005, p. 10). 
Além disso, é importante destacar que, de acordo com Moreira (s.d.), cerca de $80 \%$ das doenças e $65 \%$ das internações hospitalares no país estão correlacionadas com o saneamento (p. 3), o que acaba caracterizando uma alocação ineficiente de recursos públicos, uma vez que, conforme aponta Mello (2001), cada um real aplicado em saneamento básico gera dois reais e cinqüenta centavos de economia em saúde (p. 19) - tal relação varia bastante de estudo para estudo.

Estudo recente realizado pela Organização da Saúde [...] indica que, em países em desenvolvimento, o retorno proporcionado por projetos de saneamento situa-se entre US\$ 5 e US\$ 28 para cada US\$ 1 investido. Ademais, o gasto em saneamento gera externalidades positivas na saúde pública, tais como prevenção de pelo menos $80 \%$ dos casos de febre tifóide, redução de 60 a $70 \%$ de casos de tracoma e esquistossomose e prevenção de 40 a $50 \%$ dos casos de desinteria bacilar, amebíase gastroenterites e infecções cutâneas (MCIDADES, 2005, p. 2).

Portanto, em função dos vários benefícios que podem ser gerados, é fundamental que a situação dos serviços de saneamento básico seja adequada, o que não se observa no Brasil. De acordo com o MPO/Sepurb/IPEA (s.d), ocorre, atualmente uma "crise do setor saneamento no Brasil", que pode ser caracterizada por quatro fatores: (i) déficit de acesso aos serviços, tanto ao abastecimento de água como, principalmente, ao esgotamento sanitário (coleta e tratamento de esgoto); (ii) dificuldades de financiamento dos operadores públicos; (iii) ineficiência na prestação dos serviços e (iv) inadequação do desenho institucional e do marco regulatório (p. 9). Moreira (1998), por sua vez, afirma que o saneamento básico brasileiro apresenta grandes oportunidades e significativo potencial de crescimento, mas, ao mesmo tempo, há reduzidos níveis de eficiência e produtividade (p. 189).

Nos últimos três anos, a proporção de domicílios ligados à rede de abastecimento de água subiu pouco mais de um ponto percentual, passando de $81,1 \%$ para $82,2 \%$, enquanto a de casas e apartamentos com rede de esgoto sanitário passou de $66,7 \%$ para $68,9 \%$. Nesse ritmo, a meta de universalizar os serviços de saneamento básico no país só será atingida em 2047, no caso do esgoto, e em 2053, no da água. Para antecipar essa meta em duas décadas, seria necessário aplicar 10 bilhões de reais ao ano. No entanto, os investimentos realizados por todas as esferas de governo não têm alcançado sequer um terço desse valor. A grande dificuldade para sanar o déficit histórico é que a demanda continua crescendo em ritmo acelerado. Nos últimos três anos, o número de domicílios no país saltou de 46,9 milhões para 51,7 milhões. Assim, o aumento absoluto da cobertura ocorrido no período [...] foi praticamente anulado pelo crescimento da demanda (EXAME, 2006, p. 116). 
Diante do déficit de acesso aos serviços (água e esgoto), da conseqüente necessidade de investimentos e da existência de uma série de fatores que restringem a expansão destes serão apresentados ao longo do trabalho -, é clara a importância de se aprofundar o debate sobre questões relacionadas ao setor. Ou seja, justifica-se a relevância do presente trabalho.

Uma opção que vem sendo incentivada para reverter a situação desfavorável do saneamento básico brasileiro é o aprofundamento dos processos de descentralização e de desestatização no setor. Contudo, a descentralização e a maior participação da iniciativa privada podem ser consideradas soluções ideais para a retomada dos investimentos no setor (conseguiriam elevar a eficiência e, conseqüentemente, a capacidade dos provedores de alavancarem recursos)?

As análises que serão realizadas para responder essa questão também gerarão as respostas de outros importantes problemas investigativos: quais são as restrições existentes, atualmente, que limitam os investimentos no setor (e, dentro destas, quais impedem um aprofundamento dos processos de descentralização e de desestatização no saneamento básico)? Quais são os determinantes do déficit domiciliar de acesso aos serviços de saneamento básico no Brasil? As características do déficit de acesso também podem ser consideradas como um entrave à expansão dos investimentos no setor?

Em consonância com esses problemas, o objetivo principal da dissertação é identificar e avaliar os fatores que restringem a expansão dos investimentos no saneamento básico brasileiro. Paralelamente ao objetivo principal e complementando este, alguns objetivos específicos deverão ser atingidos:

(i) analisar o quadro regulatório referente aos vários aspectos que serão levantados no decorrer do trabalho (Constituição Federal, Lei de Concessões, Lei de Parcerias Público-Privadas, Lei de Responsabilidade Fiscal, Resoluções do Senado Federal e do 
Conselho Monetário Nacional, entre outras), apontando as principais restrições impostas por esse quadro aos investimentos em saneamento básico; caracterizar o setor de saneamento básico brasileiro (evolução histórica, situação institucional atual, problemas atuais etc.), principalmente no que se refere ao déficit de acesso domiciliar a abastecimento de água e a esgotamento sanitário e

(iii) comparar o desempenho (eficiência) dos diferentes tipos de prestadores de serviços.

Para atingir os objetivos propostos - e, conseqüentemente, responder aos problemas investigativos -, além da revisão da bibliografia referente ao assunto e da análise de várias leis brasileiras, serão avaliadas informações (dados) disponibilizadas pelo Instituto Brasileiro de Geografia e Estatística (IBGE) - Pesquisa de Orçamentos Familiares (POF) 2002-2003; Censos Demográficos de 1970, 1980, 1991 e 2000; Pesquisa Nacional de Saneamento Básico (PNSB) de 1989 e 2000 e Pesquisa Nacional por Amostra de Domicílios (PNAD) de 2000 a 2004 - e pelo Ministério das Cidades - Sistema Nacional de Informações sobre Saneamento Básico (SNIS) de 2000 a 2004.

Por último, é importante apontar que a presente dissertação é dividida em três capítulos, além dessa introdução e das considerações finais. No primeiro capítulo, além do histórico do setor, será analisada a situação institucional atual do saneamento básico no Brasil, apontando seus principais problemas e impactos sobre o setor. Esse capítulo iniciará, também, a discussão sobre as principais regras fiscais existentes que limitam o endividamento público e, conseqüentemente, a expansão dos investimentos em saneamento.

No segundo capítulo, serão realizadas análises quantitativas descritivas, além de estimações econométricas - método Probit -, para avaliar a evolução e as características do déficit de acesso domiciliar aos serviços de saneamento básico. Deve-se destacar que a literatura especializada em saúde aponta a rede geral como a forma ideal de abastecimento de água e de esgotamento sanitário - “a fossa séptica pode ser uma solução satisfatória em 
localidades pouco adensadas, desde que não haja contaminação das águas subterrâneas e dos solos, seja uma solução provisória e sua instalação permita interligação à sua futura rede coletora" (BNDES, 1996, p. 5). Dessa forma, as análises levarão em conta apenas o abastecimento de água por rede geral, a coleta de esgoto por rede geral e o esgotamento sanitário por fossa séptica².

No terceiro capítulo, serão realizadas análises descritivas e estimações econométricas para comparar o desempenho (eficiência) dos diferentes tipos de provedores de serviços de saneamento básico existentes atualmente no Brasil - pretende-se, dessa forma, avaliar se os processos de descentralização e desestatização, tão defendidos, podem ser considerados como soluções para os problemas existentes no setor, principalmente aumentando a eficiência dos prestadores e, consequentemente, elevando a capacidade interna de geração de recursos. Nesse capítulo, também será aprofundada a discussão sobre as regras fiscais.

\footnotetext{
${ }^{2}$ O IBGE, na realização de suas pesquisas, considera que o domicílio possui rede geral de esgoto quando a canalização das águas servidas e dos dejetos provenientes do banheiro ou do sanitário é ligada a um sistema de coleta que os conduza a um desaguadouro geral da área, região ou município, mesmo que o sistema não disponha de estação de tratamento da matéria esgotada. Por outro lado, o domicílio possui fossa séptica quando a canalização do banheiro ou sanitário esgota a matéria para uma fossa próxima, onde passa por um processo de tratamento ou decantação sendo, ou não, a parte líquida conduzida em seguida para um desaguadouro geral da área, região ou município. No caso da água, é considerado como abastecimento por rede geral quando o domicílio, o terreno ou a propriedade onde ele está localizado é ligado a um sistema geral de abastecimento.
} 


\section{I - HISTÓRICO E PROBLEMAS INSTITUCIONAIS}

Segundo Jouravlev (2000), é possível dividir os serviços públicos em dois grupos distintos: (i) aqueles que podem ser reestruturados para assegurar a competição efetiva em, pelo menos, alguns de seus segmentos e que são caracterizados por rápidas transformações na tecnologia e nas condições do mercado - por exemplo, eletricidade e telecomunicação - e (ii) aqueles que possuem características próprias que os classificam como monopólios naturais ${ }^{1}$ (p. 10). O saneamento básico pode ser considerado como um caso clássico de monopólio natural - "the water industry is perhaps the most monopolistic of all public utility services" (p. 3). As principais características do saneamento básico - inclusive as que o qualificam como um caso clássico de monopólio natural - são as seguintes:

(i) custos fixos elevados em capital altamente específico (sunk costs) - "in the water sector, sunk costs are more significant because most of the sector's fixed assets have few alternative uses" (SPILLER; SAVEDOFF, 1999, p. 5);

(ii) existência de economias de escala e/ou densidade: os custos de expansão e de manutenção das redes tendem a diminuir à medida que aumenta o número de domicílios conectados e que a concentração destes é maior;

(iii) duplicação das redes de água e esgoto nas ruas das cidades é economicamente inviável - a rede de canalização, tanto de abastecimento de água como de coleta de esgoto, é "o principal elemento dos custos totais" (BNDES, 1998b, p. 6);

\footnotetext{
${ }^{1}$ Indústria na qual, em virtude de suas próprias características técnicas, os custos totais de produção são menores quando há um único produtor no mercado. Desse modo, a entrada no mercado não é lucrativa e é eficiente manter um único prestador do serviço em uma dada área geográfica.
} 
(iv) especificidade dos ativos;

(v) investimentos têm altas escalas de inversão - redes de distribuição e estações de tratamento -, com retornos de longa maturação e custos crescentes ligados à preservação do meio ambiente;

(vi) serviços públicos e meritórios, sem substitutos diretos e com caráter social - "serviços de água e esgoto são [...] identificados como aqueles que possuem o maior caráter social entre todas as indústrias de utilidades públicas" (FOSTER, 1996, p. 8);

(vii) essencialidade superior aos demais serviços públicos - a água é fundamental para a sobrevivência e serviços adequados de esgoto diminuem a incidência de algumas doenças;

(viii) consumo de massa - "water is the quintessential massively consumed product, and access to water is generally perceived to be more of a "social" and "basic" service than other utility services" (SPILLER; SAVEDOFF, 1999, p. 6) - e

(ix) serviços geram externalidades importantes sobre o meio ambiente, a saúde e o desenvolvimento urbano e econômico - fato apontado na introdução;

Por se tratar de um monopólio natural, não é possível incentivar a produtividade e a eficiência alocativa dos prestadores e, ao mesmo tempo, fazer com que estes atendam as demandas dos consumidores por meio da simples exposição ao mercado. Por um lado, a ausência de competição e de fontes alternativas de oferta dos serviços demandados pelos consumidores pode viabilizar a maximização dos lucros do monopolista por meio de práticas que diminuam o bem-estar da população - preços de monopólio, redução da qualidade dos serviços, investimentos abaixo do nível de eficiência e discriminação de preços. No caso do saneamento básico, a perda de bem-estar em função da prática de preços de monopólio é bem alta, uma vez que os serviços 
têm uma pequena elasticidade preço de demanda e que a falta de competição no setor transforma os consumidores em "reféns" dos prestadores monopolistas.

Por outro lado, a possibilidade de rivais entrarem no mercado (contestabilidade) é baixíssima, o que diminui o incentivo à redução de custos, à busca de inovações e ao aumento de eficiência - o que acaba sendo um sério problema, uma vez que falhas nos serviços geram elevadas perdas financeiras, sociais e políticas (JOURAVLEV, 2000).

Dessa forma, a provisão de serviços de saneamento básico apresenta um trade-off entre eficiência produtiva - prestação com o máximo de rendimento e menor custo -, eficiência distributiva - redução da apropriação de excedentes por parte do prestador, aumentando o bemestar do consumidor - e eficiência alocativa - maior volume de transações econômicas, com geração da maior renda agregada possível.

Destaca-se também o fato das decisões referentes ao setor sofrerem uma politização superior à dos demais serviços públicos. Isso ocorre em função do saneamento básico possuir uma maior importância política, uma vez que a expansão do acesso a água e a coleta de esgoto têm uma grande capacidade de atrair votos - serviços públicos e meritórios, com consumo de massa e caráter social (SHIRLEY, 2000). Assim, mesmo que ganhos de qualidade e de acesso possam ser obtidos por meio da concessão dos serviços à iniciativa privada, o setor público pode optar por não implantar o processo para não perder uma "fonte" de votos.

É importante apontar que o consumo de massa, a essencialidade dos serviços, a especificidade do capital e o longo prazo de maturação dos investimentos tornam o setor mais suscetível a ações oportunistas por parte dos governos responsáveis pelos serviços. As duas primeiras características fazem com que os consumidores demandem os serviços sob quaisquer circunstâncias. Já a terceira e a quarta, tornam o prestador "refém" do empreendimento, uma vez que, depois de realizados os investimentos, o retorno é de longo prazo e os ativos não podem ser 
utilizados em outras atividades - a especificidade dos ativos é um dos principais fatores que desestimulam os investimentos no setor.

O governo pode, por exemplo, interferir de forma prejudicial nos ajustes tarifários do setor, fixando tarifas abaixo do nível financeiramente recomendável - motivações políticas -, o que descapitaliza as empresas públicas e privadas que prestam serviços de saneamento básico. As conseqüências diretas de tal ação são: redução dos investimentos, fraco desempenho dos provedores, baixo índice de cobertura e queda na qualidade dos serviços. "Com esse resultado, os consumidores tornam-se resistentes a aumentos de preços, pois não acreditam na melhoria dos serviços. Há, portanto, falta de suporte político para que o governo possa reverter a situação mediante aumento de preços", gerando, assim, um círculo vicioso (FARIA; NOGUEIRA; MUELLER, 2005, p. 482-3). Esse círculo vicioso foi chamado por Spiller e Savedoff (1999) de “equilíbrio de baixo nível”.

Diante desses fatos, pode-se dizer que as características do saneamento básico impõem uma série de obstáculos para o desenvolvimento do setor. Nesse contexto, é fundamental que exista um quadro institucional eficiente que, além de inibir as ações oportunistas por parte do governo: (i) assegure a prestação dos serviços de acordo com padrões aceitáveis; (ii) proteja os cidadãos de práticas monopolistas e (iii) crie um ambiente de negócio que viabilize o empreendimento (IDELOVITCH; RINGSKOG, 1995, p. 27).

Ou seja, é necessário um quadro institucional que estimule o desempenho geral do setor e que garanta estabilidade e credibilidade, aspectos fundamentais para a atração de investimentos. Para isso, também é importante a existência de um mercado de financiamento de longo prazo bem desenvolvido, uma vez que os investimentos para a construção de redes de distribuição e de estações de tratamento têm altas escalas de inversão e seus retornos são de longa maturação. 
No Brasil, não existe um quadro institucional eficiente e o mercado de financiamento de longo prazo é pouco desenvolvido. Tais problemas serão caracterizados no presente capítulo (terceira seção). Antes disso, é importante analisar a evolução do saneamento básico no país (segunda seção), enfatizando alguns aspectos institucionais - as formas de provisão dos serviços, as políticas públicas adotadas para o setor e suas fontes de financiamento. Conforme ficará claro, essa evolução é intimamente relacionada à conjuntura econômica e política pela qual o país e passou em cada momento (primeira seção).

\section{Estado desenvolvimentista, descentralizacão e desestatização}

De acordo com Moreira (1994), ao analisar as características fundamentais da industrialização brasileira, principalmente após a década de 1950, deve-se destacar, além do mecanismo de substituição de importações ${ }^{2}$, a forte participação do Estado, seja como investidor e produtor direto, seja como indutor e sinalizador de investimentos (p. 107) - conhecido como modelo do Estado keynesiano-desenvolvimentista ou, simplesmente, modelo do Estado desenvolvimentista. Ou seja, o governo federal desempenhava um papel central na condução do desenvolvimento econômico, tanto planejando a industrialização como investindo diretamente em segmentos considerados estratégicos para esse processo, como o de infra-estrutura - com o objetivo de induzir os investimentos privados no setor industrial.

O Estado nacional foi, historicamente, o grande protagonista do processo de desenvolvimento do Brasil. Sobre ele recaía a responsabilidade não apenas de investir diretamente (em infra-estrutura e em setores considerados estratégicos) como a de atrair investimentos (por meio de incentivos fiscais, crédito subsidiado, regimes tarifários diferenciados, intervenção no mercado de trabalho etc.) e de prover proteção social aos segmentos excluídos (REIS; URANI, 2004, p. 9).

\footnotetext{
${ }^{2}$ Para maiores detalhes, ver Tavares (1975).
} 
A maior intervenção do Estado na economia decorreu da incapacidade e/ou desinteresse do setor privado em atuar em setores marcados pela necessidade de elevados recursos para investimentos com longo prazo de maturação. Conforme salientam Giambiagi e Além (2001), o objetivo não era a ampliação deliberada da intervenção do Estado em detrimento da iniciativa privada, mas, sobretudo, a ocupação de espaços vazios correspondentes a atividades essenciais para o desenvolvimento econômico e para o fortalecimento do próprio setor privado. A Companhia Siderúrgica Nacional (CSN) exemplifica bem esse fato, uma vez que o governo federal arcou com o investimento para sua criação somente após várias tentativas fracassadas de induzir o investimento privado (p. 86). Além disso, deve-se destacar a existência de segmentos nos quais o monopólio estatal era a estrutura de mercado mais viável, em função de aspectos tecnológicos e/ou do próprio mercado.

Assim, para incentivar a industrialização e o desenvolvimento econômico do país, o governo federal teve de agir de forma complementar ao setor privado, investindo em indústrias tecnologicamente mais sofisticadas - petroquímica, siderúrgica e equipamentos de transporte - e suprindo as necessidades infra-estruturais do país.

O setor de infra-estrutura, devido às externalidades positivas que podem gerar comentadas na introdução -, tem elevada importância para o sistema econômico como um todo. Percebendo essa importância, o governo federal, principalmente a partir dos anos 1950, passou a aumentar gradativamente sua participação no setor. Além disso, o governo utilizava as próprias tarifas dos serviços públicos para induzir a industrialização, mantendo-as em níveis baixos, o que, ao subsidiar o consumo, reduzia os custos e incentivava os investimentos privados.

Nem sempre a provisão de infra-estrutura no Brasil foi centrada no Estado. A fase inicial dos investimentos tanto em transportes e energia como em vários outros setores é caracterizada pela forte presença do capital estrangeiro. A passagem para o modelo estatal decorre de vários fatores [...]: fraco desempenho do setor privado em alguns setores, elevado custo fiscal para o governo cumprir as garantias de retorno para os 
investimentos privados, ausência de mecanismos de financiamento adequados [...], entre outros fatores. [...] Com isso, na maior parte dos setores, foram sendo abandonados, ao longo do tempo, os modelos de provisão privados baseados no capital estrangeiro e os setores foram passando por processos de nacionalização e estatização da prestação dos serviços. Com o golpe militar de 1964 e as reformas institucionais que se seguiram, verificou-se a consolidação do modelo de provisão estatal "centralizado" (TONETO JÚNIOR, 2004, p. 81-2).

A participação do governo federal teve sua importância elevada com as políticas empregadas de 1967 a $1979^{3}$. Nesse período, o país atingiu elevadas taxas de crescimento econômico, conforme pode ser observado no gráfico 1.1 - principalmente entre 1967 e 1973, os anos do "milagre econômico". Para atingir um nível tão elevado de crescimento, foi fundamental o papel desempenhado pelo governo federal, seja estimulando a demanda e o investimento em setores e regiões específicas, por meio de incentivos e/ou subsídios, seja mantendo um elevado nível de dispêndio, particularmente com novos investimentos em infra-estrutura. Na década de 1980, contudo, não foi possível manter uma elevada taxa de crescimento, em função, principalmente, da profunda crise financeira pela qual o país nesse momento.

Tal crise resultou, principalmente, do segundo choque do preço do petróleo (1979), do aumento da taxa de juros norte-americana, da insolvência da Polônia e da Argentina e da moratória mexicana de 1982, fatores que levaram à redução do fluxo de recursos externos, do qual o país tornara-se bastante dependente para a realização de investimentos. A conseqüente recessão acabou levando à queda das receitas tributárias, o que reduziu ainda mais os recursos disponíveis para a realização de investimentos - deve-se ter em mente, conforme salientam Afonso et alii (s.d.), que a arrecadação tributária brasileira sempre foi "bastante sensível ao desempenho da economia, uma vez que há grande participação dos tributos sobre vendas em relação àqueles que incidem sobre o patrimônio" (p. 2).

\footnotetext{
${ }^{3}$ Para maiores detalhes sobre esse período, ver Lago (1990) e Carneiro (1990).
} 


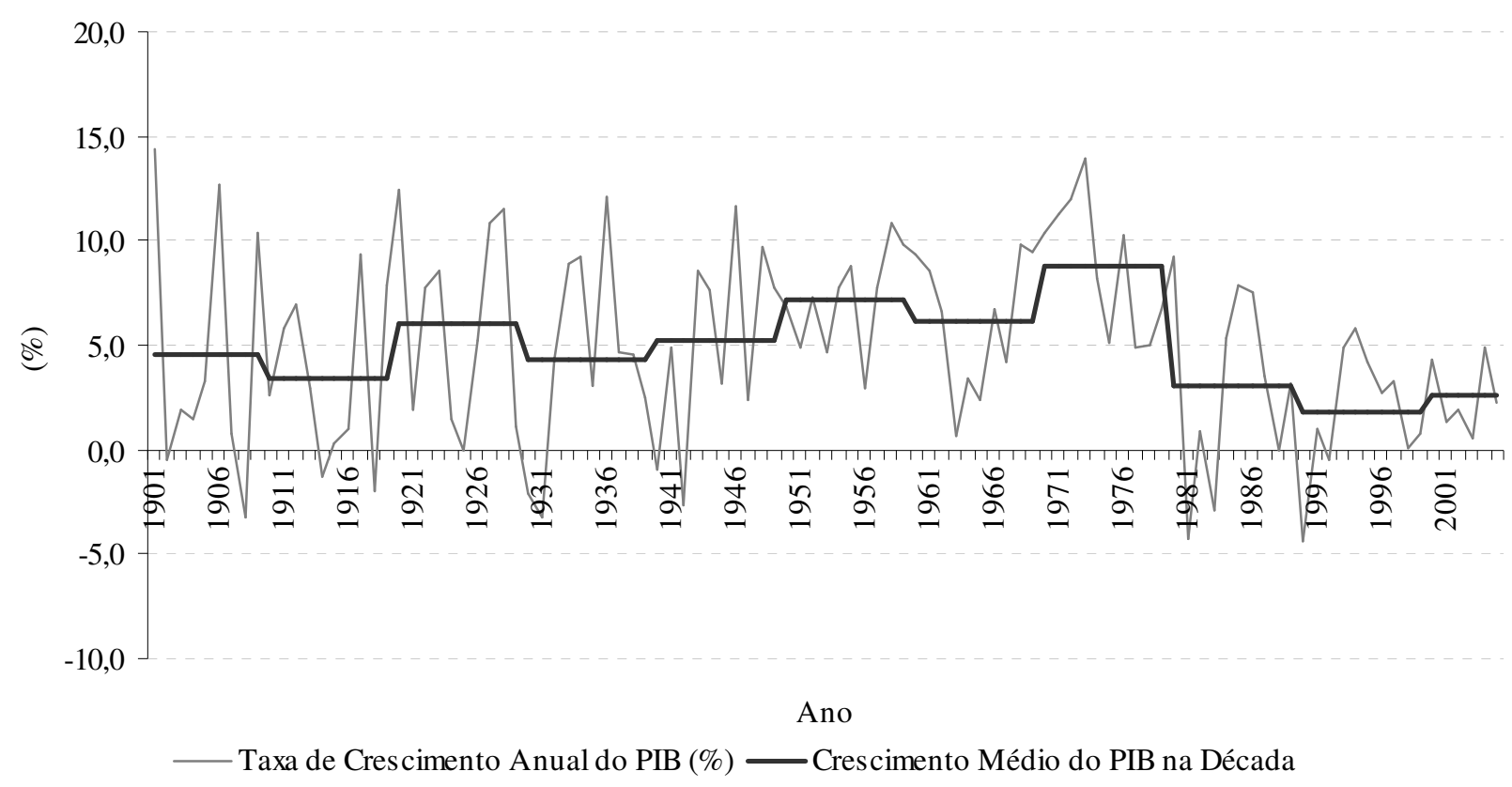

Fonte: IPEA. Elaboração própria.

\section{Gráfico 1.1}

Brasil: evolução da taxa de crescimento do Produto Interno Bruto (PIB), de 1901 a 2005

Paralelamente, ocorreu também uma deterioração da base de formação dos fundos de poupança compulsória, principalmente a base do Fundo de Garantia por Tempo de Serviço (FGTS) - em decorrência da liberalização das regras de saque, da inadimplência e da informalização das relações de trabalho (GREMAUD; TONETO JÚNIOR, 2000, p. 1). A importância do FGTS para os investimentos públicos ficará clara no decorrer do capítulo.

Segundo Giambiagi e Além (2001), a crise também contribuiu para a deterioração da situação econômico-financeira das empresas estatais, fato que decorreu, principalmente, da utilização dessas empresas como instrumento de política econômica - seja na manutenção das tarifas com o objetivo de conter o processo inflacionário, seja pelo incentivo ao endividamento das estatais como meio de captação de recursos externos (p. 372-3). Assim, no momento em que 
os empréstimos externos se tornaram mais difíceis, com elevadas taxas de juros e maiores exigências, e que o governo federal tornou-se incapaz de transferir recursos fiscais para financiar os investimentos necessários, as empresas estatais viram-se em uma situação bastante difícil.

Baer (1993) relata que, após a crise de 1982 até o início da década de 1990, “o setor público brasileiro não conseguiu recompor um fluxo mínimo de recursos financeiros externos de longo prazo que lhe permitisse retomar investimentos e reestruturar sua base patrimonial mais ordenadamente" (p. 203). Além disso, a crise "intensificou as pressões políticas de estados e municípios por um federalismo fiscal, sem que isso tivesse como contrapartida uma descentralização equivalente das responsabilidades de com custeio" (p. 201) - tal argumento será retomado mais adiante.

Uma conseqüência direta dos fatos comentados até o momento foi a forte retração dos investimentos nas décadas de 1980 e 1990, conforme pode ser observado no gráfico 1.2. Além da evolução dos investimentos totais (como parcela do PIB), também é apresentado a evolução dos investimentos em infra-estrutura (como parcela do PIB). Verifica-se que os investimentos em infra-estrutura também sofreram uma significativa redução durante toda a década de 1980 e meados dos anos 1990. No biênio 1995-1996, a queda dos investimentos em infra-estrutura foi parcialmente revertida.

Diante da incapacidade do governo federal e de suas estatais de realizar investimentos que impulsionariam o desenvolvimento e a modernização da economia, passou-se a buscar uma reforma do papel desempenhado pelo Estado na economia, reforma esta cujos "principais objetivos passaram a ser a privatização e a descentralização" (SANTOS et alii, s.d., p. 3) de serviços e programas essenciais, na esperança de que as esferas subnacionais e o setor privado conseguissem provê-los de forma mais eficiente e melhor atendendo às demandas dos cidadãos. Nesse contexto, "o Estado produtor cede cada vez mais espaço ao Estado regulador" 
(GIAMBIAGI; ALÉM, 2000, p. 374). Na infra-estrutura como um todo, tal reforma, apesar de ter ajudado a reverter a tendência de queda, não conseguiu gerar níveis de investimentos semelhantes aos obtidos na década de 1970 - conforme também pode ser observado no gráfico 1.2.

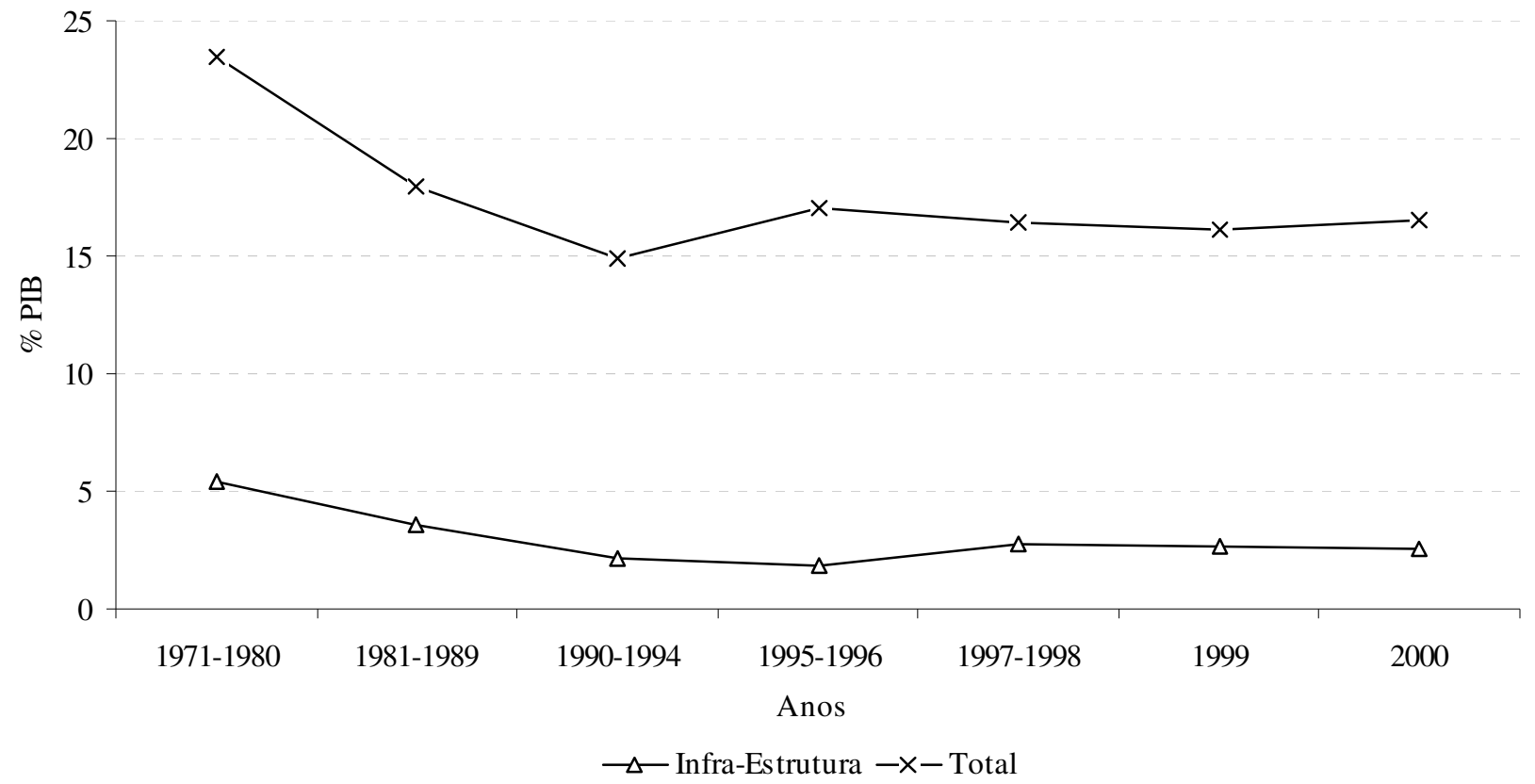

Fonte: Bielschowsky et alii (2002, p. 28). Elaboração própria.

\section{Gráfico 1.2}

Brasil: evolução dos investimentos totais e em infra-estrutura (\% do PIB), de 1971 a 2000

Bielschowsky et alii (2002), analisando quatro setores específicos de infra-estrutura energia elétrica, telecomunicações, transportes e saneamento básico -, observaram que apenas o setor de telecomunicações não apresentou a mesma tendência dos investimentos totais em infraestrutura, sendo o único dos quatro com taxas recentes de investimento superiores "ao auge inversor dos anos 1970" (p. 27). O saneamento básico foi um dos três setores que sofreram uma sensível queda de investimentos na década de 1980 e meados dos anos 1990 - situação parcialmente revertida a partir de1995. 


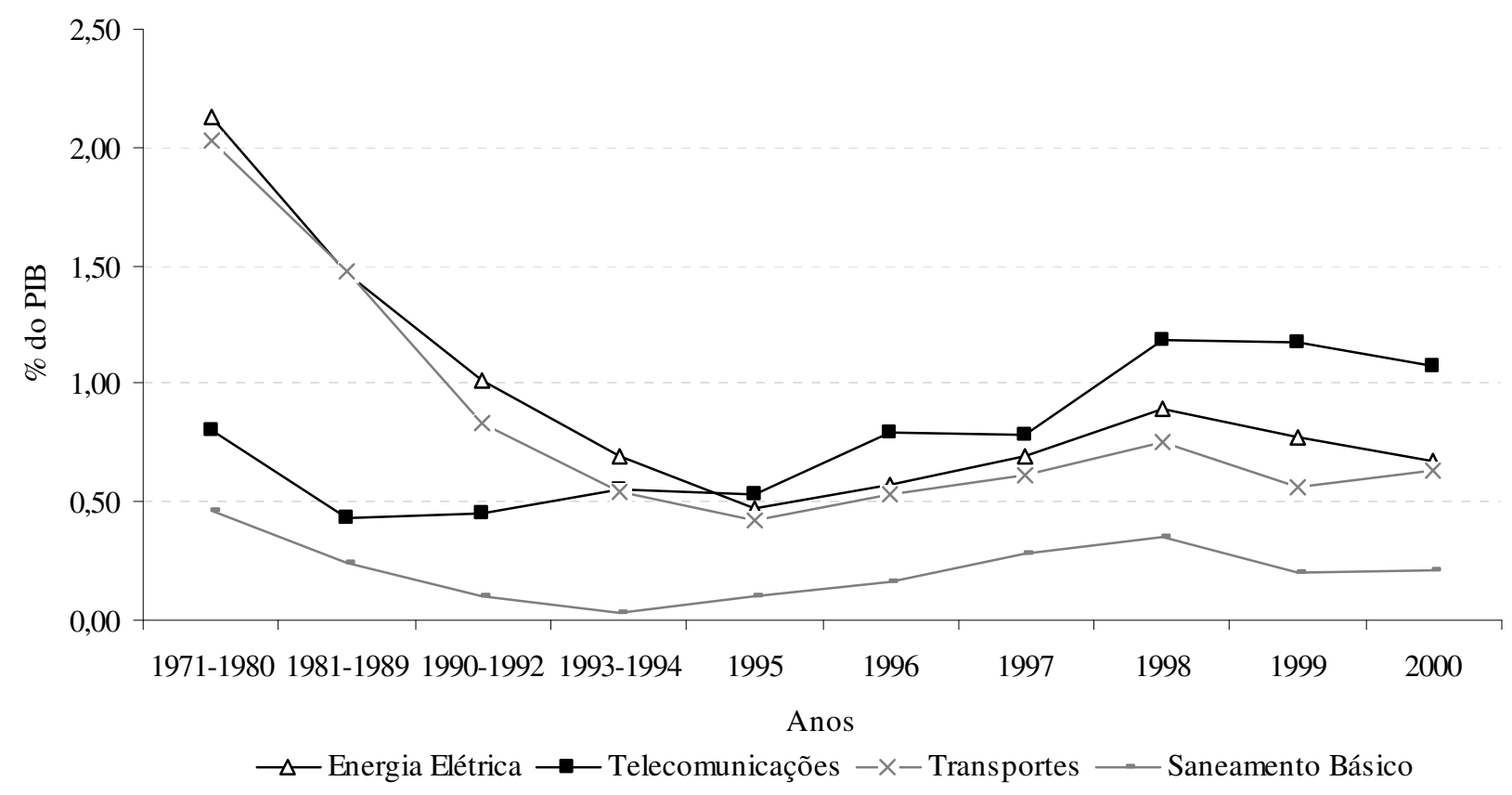

Fonte: Bielschowsky et alii (2002, p. 29). Elaboração própria.

\section{Gráfico 1.3}

Brasil: evolução dos investimentos em setores de infra-estrutura (\% do PIB), de 1971 a 2000

A dinâmica dos investimentos em saneamento básico é o tema norteador das análises que serão realizadas no presente trabalho. Tais análises iniciam-se na próxima seção. Antes disso, porém, é importante discutir brevemente as características e as consequiências dos processos de descentralização fiscal e de desestatização adotados no Brasil.

\section{$\underline{1.1 \text { Descentralização fiscal no Brasil }}$}

O processo de descentralização fiscal no Brasil teve início ainda nos primeiros anos da década de 1980, sendo aprofundado pela Constituição de 1988, que assegurou "a regulamentação 
e a regularização" necessárias ao processo em andamento (AFONSO et alii, s.d., p. 5) ${ }^{4}$. Uma vez que os condutores do processo foram os políticos ligados aos estados e municípios, principalmente aos menos desenvolvidos, a nova Constituição teve como principal objetivo e resultado o fortalecimento financeiro das esferas subnacionais. Conseqüentemente, gerou-se uma profunda distribuição de receitas entre os diferentes níveis de governo, tanto pelo aumento das competências tributárias dos governos subnacionais quanto, principalmente, pelo aumento excessivo das transferências intergovernamentais, sendo os municípios os mais beneficiados, conforme pode ser observado na tabela 1.1 .

Tabela 1.1

Brasil: evolução da receita tributária por nível de governo, de 1960 a 2000

\begin{tabular}{|c|c|c|c|c|c|c|c|}
\hline \multirow{2}{*}{ Ano } & \multicolumn{4}{|c|}{ Receita Tributária (\% do PIB) } & \multicolumn{3}{|c|}{ Distribuição da Receita Tributária (\%) } \\
\hline & União & Estados & Municípios & Total & União & Estados & Municípios \\
\hline \multicolumn{8}{|c|}{ Arrecadação Direta } \\
\hline 1960 & 11,1 & 5,5 & 0,8 & 17,4 & 64,0 & 31,2 & 4,8 \\
\hline 1980 & 18,5 & 5,4 & 0,7 & 24,6 & 75,1 & 22,0 & 2,9 \\
\hline 1988 & 15,8 & 6,0 & 0,7 & 22,4 & 70,5 & 26,6 & 2,9 \\
\hline 2000 & 22,6 & 9,1 & 1,7 & 33,4 & 67,7 & 27,2 & 5,1 \\
\hline \multicolumn{8}{|c|}{ Receita Disponível } \\
\hline 1960 & 10,4 & 5,9 & 1,1 & 17,4 & 59,4 & 34,0 & 6,6 \\
\hline 1980 & 17,0 & 5,5 & 2,1 & 24,6 & 69,2 & 22,2 & 8,6 \\
\hline 1988 & 14,0 & 6,0 & 2,4 & 22,4 & 62,3 & 26,9 & 10,8 \\
\hline 2000 & 19,1 & 8,6 & 5,6 & 33,4 & 57,3 & 25,9 & 16,9 \\
\hline
\end{tabular}

Fonte: Araújo e Oliveira (2001, p. 5).

O fortalecimento financeiro subnacional, contudo, ocorreu em detrimento ao federal. A União, vendo-se com menos recursos disponíveis - após ter sua competência tributária reduzida, suas transferências às outras esferas incrementadas e seus gastos com seguridade social elevados -, "abandonou" a provisão de alguns serviços e programas, que passaram a ser assumidos pelos

\footnotetext{
${ }^{4}$ Em um processo de descentralização fiscal, as esferas subnacionais passam a contar com certo grau de autonomia para tomar suas decisões de gasto e de arrecadação, ao mesmo tempo em que aumentam suas responsabilidades em relação à promoção de políticas de desenvolvimento, à prestação de serviços públicos e ao financiamento destes (GREMAUD, 2000, p. 3).
} 
governos subnacionais, principalmente pelos municípios, à medida que estes eram pressionados por suas populações.

Ou seja, a descentralização de encargos (ou de custeio) não foi prevista pela nova Constituição. Na verdade, ocorreu como uma conseqüência da maneira pela qual foi conduzida a descentralização de receitas, o que gerou sérios problemas de competências conjuntas ou concorrentes ou, mesmo, de lacunas na provisão de alguns serviços - algumas medidas foram tomadas, recentemente, na tentativa de solucionar esses problemas, como a municipalização da saúde - Sistema Único de Saúde (SUS) - e a criação do Fundo de Manutenção e Desenvolvimento do Ensino Fundamental e Valorização do Magistério (Fundef) - vinculação de recursos das três esferas de governo para serem investidos na educação.

O processo de descentralização gerou também um sério de "desequilíbrio horizontal" das receitas (REZENDE, 1995) - municípios pequenos com maiores receitas per capita. Esse desequilíbrio ocorre devido ao "caráter redistributivo" dos critérios de rateio do fundo de participação municipal (FPM) - principal mecanismo de transferência de recursos federais para os municípios. A definição dos critérios levou em conta o fato dos grandes municípios tenderem a ter uma arrecadação própria maior, em função da maior concentração de propriedades valorizadas e de atividades de serviços, bases dos principais tributos cobrados diretamente pelas prefeituras (IPTU e ISS) - o desequilíbrio horizontal, o "caráter redistributivo" do FPM e a maior arrecadação própria nos municípios grandes são ilustrados no gráfico 1.4.

O grande problema é que não foi considerada a dinâmica demográfica pela qual os grandes municípios e, principalmente, as metrópoles brasileiras passam, assim como suas respectivas demandas. Os municípios de maior porte possuem uma grande concentração populacional e um alto grau de urbanização e agem como pólos de atração de pessoas, principalmente de baixa 
renda, em busca de empregos e melhores condições de vida, fenômeno conhecido como “metropolização da pobreza” (REZENDE, 1998).

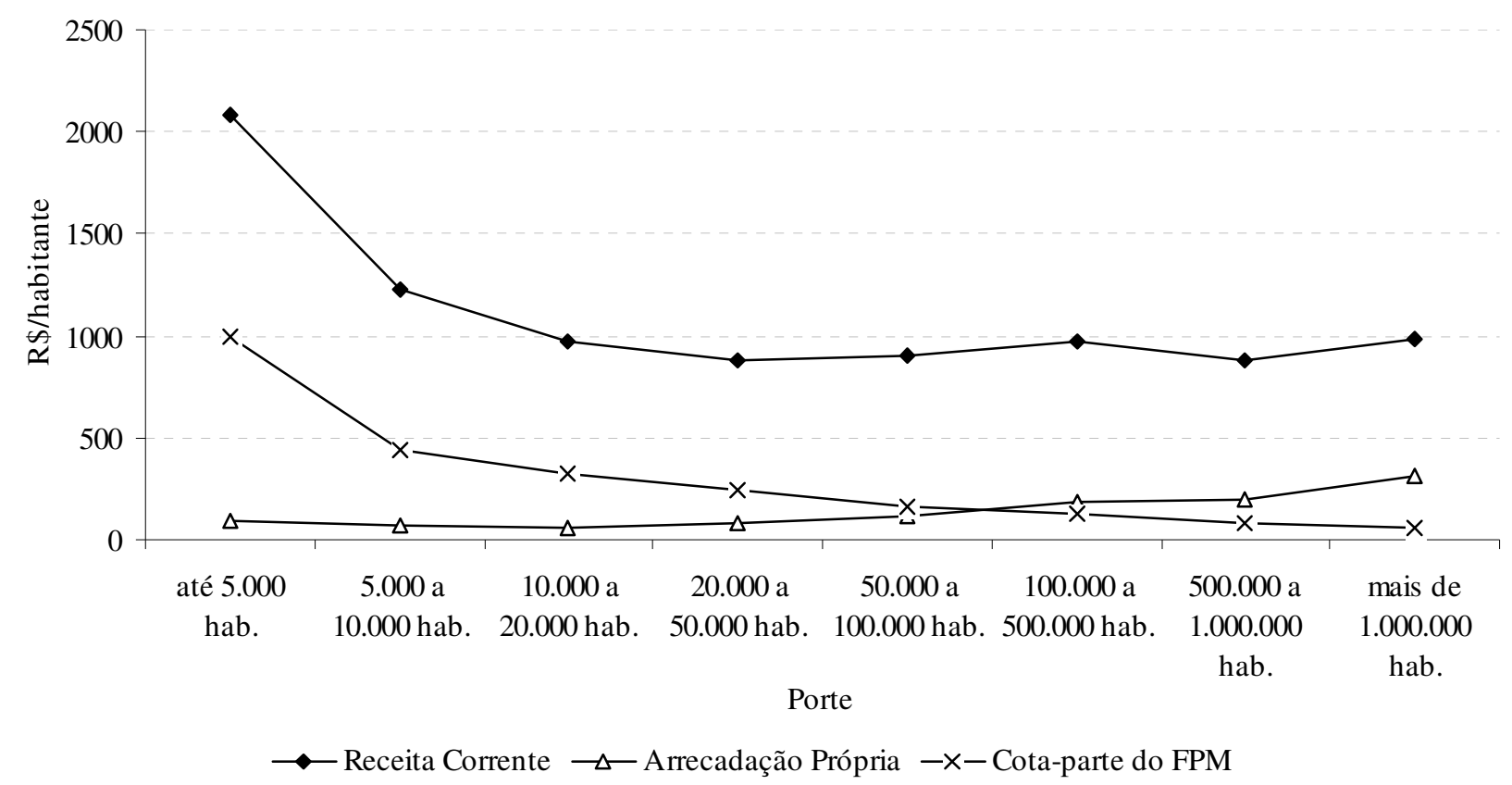

Fonte: Secretaria do Tesouro Nacional (receitas) e IBGE (população). Elaboração própria.

\section{Gráfico 1.4}

Brasil: receitas municipais per capita, segundo o porte dos municípios (2005)

Nesse contexto, mesmo que os grandes municípios utilizassem plenamente a capacidade de arrecadação própria, talvez não conseguiriam suprir todas as suas necessidades. Enquanto isso, há "excesso" de recursos nos municípios pequenos. Um resultado direto desse desequilíbrio é ilustrado no gráfico 1.5: maior despesa per capita com o poder legislativo nos municípios de pequeno porte, principalmente naqueles com até cinco mil habitantes - a curva da despesa per capita com o poder legislativo é semelhante à curva da a receita corrente per capita (gráfico 1.4).

Deve-se destacar também que os critérios de rateio do FPM incentivaram a criação de novos municípios, principalmente de pequeno porte. A possibilidade de maiores recursos 
despertou o interesse das populações e das elites políticas de certos distritos, que, frente à facilidade das regras impostas pela Constituição, optaram pela emancipação - de 1984 a 1997, foram instalados 1.405 novos municípios no Brasil, sendo aproximadamente $95 \%$ destes com menos de vinte mil habitantes (GOMES; MAC DOWELL, 2000).

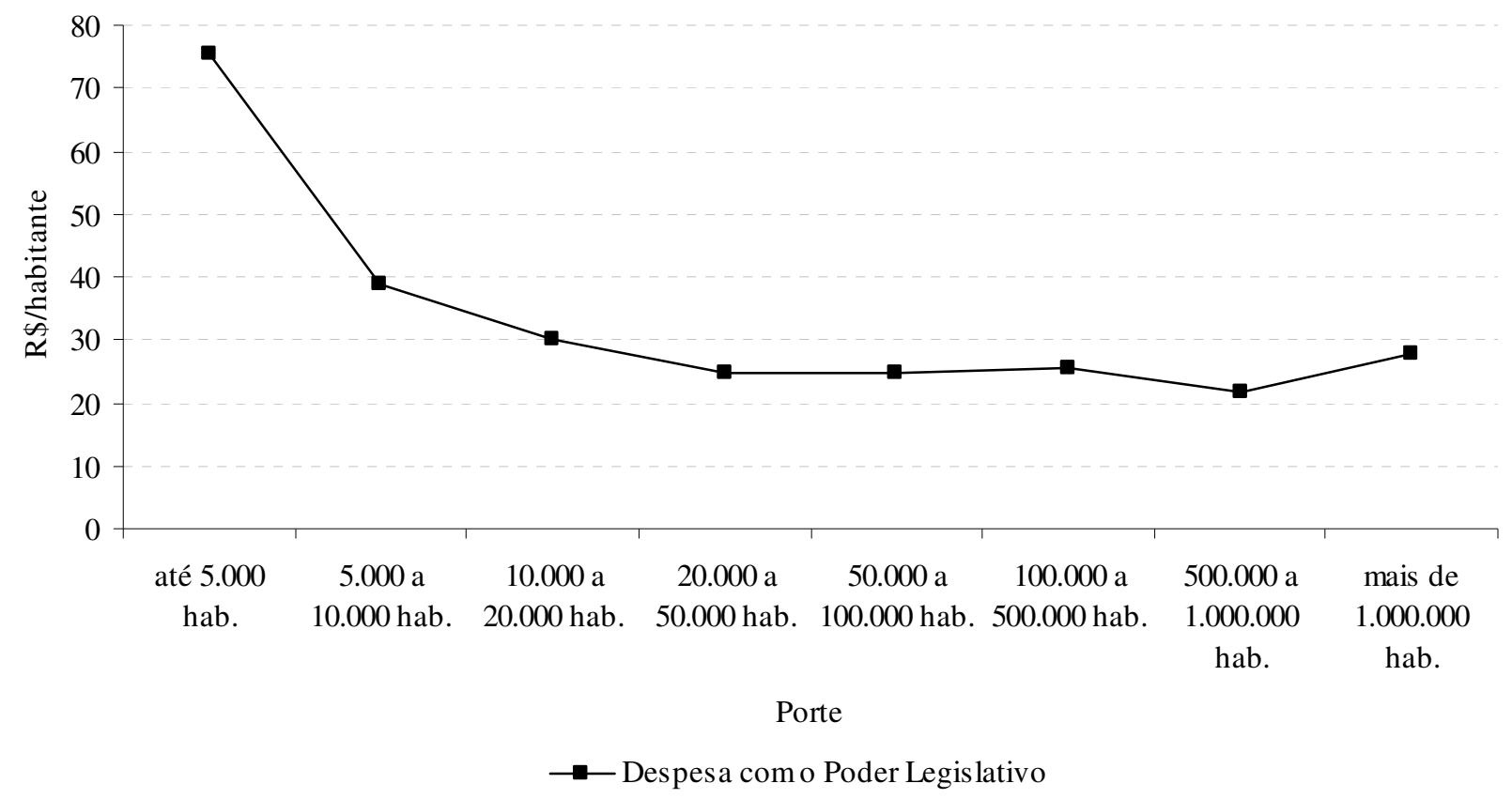

Fonte: Secretaria do Tesouro Nacional (despesa) e IBGE (população). Elaboração própria.

\section{Gráfico 1.5}

Brasil: despesa per capita com o poder legislativo, segundo o porte dos municípios (2005)

Conseqüentemente, elevaram-se os gastos com o pagamento do poder legislativo e com custeio em geral, reduzindo os recursos disponíveis para programas sociais e para investimentos, inclusive em infra-estrutura. Ou seja, ocorreu uma deterioração dos gastos públicos, uma vez que recursos que deveriam ser aplicados em "atividades fim" (saúde, transporte, educação, saneamento etc.) foram alocados em "atividades meio" (poder legislativo). 


\subsection{Desestatizacão no Brasil}

A origem do processo de desestatização brasileiro remonta aos anos 1980, porém, somente na década 1990 passou a ser uma política econômica prioritária. É possível dividir esse processo em três fases, de acordo com as características assumidas em momentos diferentes. A primeira fase (anos 1980) foi marcada por pequenas "reprivatizações" de empresas que já haviam sido privadas, mas que, naquele momento, pertenciam à carteira do Banco Nacional de Desenvolvimento Econômico e Social (BNDES) - das trinta e oito empresas privatizadas, treze eram controladas direta ou indiretamente pela instituição. O objetivo, portanto, era o saneamento financeiro da carteira do BNDES (GIAMBIAGI; ALÉM, 2000).

A compra das empresas só era possível mediante moeda corrente, à vista ou a prazo, sendo permitido, em muitos casos, o financiamento de até $70 \%$ do valor - o que aumentou o número de candidatos interessados e, consequentemente, o valor obtido nas vendas. $\mathrm{O}$ resultado total para o setor público foi de, aproximadamente, US\$ 700 milhões, dos quais aproximadamente $70 \%$ foram obtidos por meio das "reprivatizações" - conforme ficará claro mais adiante, esse montante é muito inferior aos obtidos nas outras duas fases. Para Giambiagi e Além (2000), o principal resultado dessa primeira fase não se reflete em números, mas sim na experiência adquirida, principalmente, pelo BNDES, que se tornou, ao longo de todo o processo, o principal agente de privatização do governo (p. 377).

A segunda fase do processo de desestatização (de 1990 a 1994) iniciou-se com a promulgação da Medida Provisória nº 155, em 12 de abril de 1990 - posteriormente transformada na Lei $n^{\circ} 8.031$-, que instituiu o Programa Nacional de Desestatização (PND), tornando a desestatização uma das prioridades da política econômica. O BNDES era o gestor do programa. De acordo com Giambiagi e Além (2001, p. 383-4), eram cinco os principais objetivos do PND: 
(i) reordenamento estratégico do papel do Estado na economia: o Estado deveria concentrarse em atividades tipicamente públicas, como educação, saúde, justiça, segurança e regulação, e retirar-se de setores nos quais a iniciativa privada estivesse apta a operar;

(ii) redução da dívida pública e, conseqüentemente, da vulnerabilidade financeira do governo: utilização das receitas geradas pela desestatização;

(iii) retomada dos investimentos: a iniciativa privada realizaria os investimentos necessários tanto para a expansão da capacidade produtiva das empresas e como para a modernização das mesmas, "buscando, dessa forma, aumentar seus níveis de produtividade, com reflexos positivos no sentido de aumento de sua eficiência e, conseqüentemente, da competitividade da economia brasileira como um todo" (p. 383) - deve-se lembrar que o "Estado desenvolvimentista" estava em crise, ou seja, o governo federal não conseguiria realizar tais investimentos -, e

(iv) fortalecimento do mercado de capitais: aumentar a colocação de ações junto ao público e reduzir a concentração das atividades das bolsas de valores em poucos papéis.

As desestatizações também foram utilizadas de forma estratégica pelo governo, na tentativa de recuperar a imagem externa do Brasil, que fora negativamente afetada pela alta inflação e pela crise da dívida externa, e de "credenciar" o país para se beneficiar da reabertura do mercado de crédito internacional, que havia se fechado aos países latino-americanos após a moratória mexicana de 1982. Por meio das desestatizações, o governo queria demonstrar que o país estava comprometido com a realização de reformas estruturais que poderiam abrir espaço para uma nova fase de desenvolvimento - a escolha da Usiminas para inaugurar o processo ilustra bem essa preocupação, por se tratar de uma empresa que era lucrativa e atualizada tecnologicamente.

Percebe-se, portanto, que a privatização era justificada tanto por argumentos microeconômicos, com a possibilidade de ampliação da eficiência e da competitividade 
da economia, além da retomada dos investimentos; como por argumentos macroeconômicos associados ao ajuste fiscal e à atração de capitais estrangeiros que contribuiriam para o equacionamento das contas externas e o afrouxamento das restrições cambiais (TONETO JÚNIOR, 2004, p. 90).

$\mathrm{Na}$ segunda fase, foram desestatizadas trinta e três empresas - dezoito empresas estatais e quinze participações minoritárias da Petroquisa e da Petrofértil -, pertencentes, principalmente, a setores estratégicos da economia, como o siderúrgico (oito empresas), o petroquímico (cinco empresas) e o de fertilizantes (cinco empresas) - “dos grandes setores industriais com presença do Estado, ficaram fora, nessa fase, a mineração e o petróleo" (TONETO JÚNIOR, 2004, p. 94). O resultado total para o setor público foi de US\$ 11,9 bilhões, sendo US\$ 8,6 bilhões em receitas de vendas - moeda corrente (19\%) e "moedas de privatização" $(81 \%)^{5}$ - e US\$ 3,3 bilhões em transferências de dívidas das estatais. Destaca-se as privatizações no setor siderúrgico, responsáveis por aproximadamente $69 \%$ do total arrecadado, e as do setor petroquímico, responsáveis por aproximadamente $18 \%$ do total arrecadado - fato ilustrado na tabela 1.2.

\section{Tabela 1.2}

Brasil: resultado setorial da desestatização, de 1990 a 1994 (US\$ milhões)

\begin{tabular}{l|c|c|c|c}
\hline \multicolumn{1}{c|}{ Setor } & Receita de Venda & Dívida Transferida & Resultado Total & Participação no Total (\%) \\
\hline Siderúrgico & 5.562 & 2.625 & 8.167 & 68,8 \\
Petroquímico & 1.882 & 296 & 2.178 & 18,3 \\
Fertilizantes & 418 & 75 & 493 & 4,2 \\
Outros & 350 & 269 & 619 & 5,2 \\
Decreto 1.068 & 396 & --- & 396 & 3,5 \\
Total & $\mathbf{8 . 6 0 8}$ & $\mathbf{3 . 2 6 6}$ & $\mathbf{1 1 . 8 7 4}$ & $\mathbf{1 0 0 , 0}$ \\
\hline
\end{tabular}

Fonte: BNDES (2002).

\footnotetext{
5 "Moedas de privatização" ou "moedas podres" eram títulos representativos da dívida pública federal. O governo permitiu a utilização desses títulos, inclusive criando novos, como os certificados de privatização $(\mathrm{CP})$, com o objetivo duplo de contribuir para o ajuste fiscal e incluir o sistema financeiro no PND. Esse último objetivo deve-se ao fato de ter ficado estipulado que os novos títulos lançados junto ao PND seriam nominativos, inegociáveis, emitidos somente pelo Tesouro Nacional e de aquisição compulsória pelos bancos, seguradoras e fundos de pensão o que garantia a antecipação das receitas de privatização por parte do governo independentemente das negociações de compra. A utilização dessas "moedas" é um dos pontos mais atacados pelos críticos da desestatização.
} 
A participação do investidor estrangeiro foi pequena, representando apenas $5 \%$ do total da receita arrecadada. Ou seja, os investidores nacionais foram predominantes na segunda fase - das empresas nacionais, das instituições financeiras, das pessoas físicas e dos fundos de pensão originaram-se, respectivamente, 36\%, 25\%, 20\% e 14\% da arrecadação total (BNDES, 2002).

Em 1995, com a inclusão dos setores de infra-estrutura e de serviços no PND, o processo de desestatização brasileiro entrou em sua terceira fase, na qual ocorreram as "megaprivatizações" de prestadores de serviços públicos e o aumento das concessões públicas à iniciativa privada contribuiu para isso a promulgação, no mesmo ano, da Lei de Concessões (Lei nº 8.987). Outra característica importante foi o significativo número de empresas estaduais incluídas no processo.

Na indústria, o governo federal concluiu a desestatização do setor petroquímico, vendendo doze participações acionárias da Petroquisa e da Petrofértil e realizando duas ofertas públicas de ações da Petrobrás - em agosto de 2000 e em julho de 2001. Destaca-se também a privatização da Companhia Vale do Rio Doce (CVRD), empresa que já era referência mundial no setor de mineração. Portanto, os setores de petróleo e de mineração foram incluídos no processo.

Apesar disso, prevaleceram as desestatizações nos setores de infra-estrutura e de serviços. De acordo com a tabela 1.3 , esses setores foram responsáveis por $79 \%$ do montante total arrecadado (receitas e transferências de dívidas), contra $16,2 \%$ do setor industrial e $4,8 \%$ da venda de participações minoritárias. No setor de serviços, além de uma empresa de informática vinculada à Caixa Econômica Federal $(\mathrm{CEF})$, foram privatizados doze bancos - oito estaduais e quatro federalizados. Já no setor de infra-estrutura, destacam-se as privatizações nos segmentos de telecomunicações e de energia elétrica - responsáveis por 66,9\%do montante arrecadado.

O resultado total da terceira fase foi de aproximadamente US\$ 93,4 bilhões, sendo US\$ 78,6 bilhões em receitas de vendas e US\$ 14,8 bilhões em transferências de dívidas. Ou seja, montantes bem superiores aos obtidos anteriormente. 


\section{Tabela 1.3}

Brasil: resultado setorial da desestatização, de 1995 a 2002 (US\$ milhões)

\begin{tabular}{c|c|c|c|c}
\hline Setor & Receita de Venda & $\begin{array}{c}\text { Dívida } \\
\text { Transferida }\end{array}$ & Resultado Total & $\begin{array}{c}\text { Participação no } \\
\text { Total (\%) }\end{array}$ \\
\hline Indústria & $\mathbf{1 0 . 8 5 2}$ & $\mathbf{4 . 2 6 5}$ & $\mathbf{1 5 . 1 1 7}$ & $\mathbf{1 6 , 2}$ \\
Petroquímica & 816 & 706 & 1.522 & 1,6 \\
Petróleo & 4.840 & --- & 4.840 & 5,2 \\
Mineração & 5.196 & 3.559 & 8.755 & 9,4 \\
Infra-Estrutura/Serviços & $\mathbf{6 3 . 2 8 1}$ & $\mathbf{1 0 . 5 4 5}$ & $\mathbf{7 3 . 8 2 6}$ & $\mathbf{7 9 , 0}$ \\
Financeiro & 6.329 & --- & 6.329 & 6,8 \\
Elétrico & 22.238 & 7.510 & 29.748 & 31,8 \\
Transporte & 2.321 & --- & 2.321 & 2,5 \\
Portuário & 421 & -- & 421 & 0,5 \\
Gás/Saneamento & 2.111 & 88 & 2.199 & 2,4 \\
Telecomunicações & 29.811 & 2.947 & 32.758 & 35,1 \\
Informática & 50 & --- & 50 & 0,1 \\
Participações Minoritárias & $\mathbf{4 . 4 8 1}$ & --- & $\mathbf{4 . 4 8 1}$ & $\mathbf{4 , 8}$ \\
Decreto n ${ }^{\mathbf{0}} 1.068$ & $\mathbf{7 5 3}$ & --- & 753 & 0,8 \\
Estaduais & 3.728 & -- & 3.728 & 4,0 \\
Total & $\mathbf{7 8 . 6 1 4}$ & $\mathbf{1 4 . 8 1 0}$ & $\mathbf{9 3 . 4 2 4}$ & $\mathbf{1 0 0 , 0}$ \\
\hline
\end{tabular}

Fonte: BNDES (2002).

Em comparação às fases antecedentes, também se destacam: (i) a queda da utilização de "moedas de privatização" - corresponderam a apenas 5\% do total das receitas - e (ii) o aumento da participação estrangeira, que foi responsável por $53 \%$ do total arrecadado - das empresas nacionais, das instituições financeiras, das pessoas físicas e dos fundos de pensão originaram-se, respectivamente, $26 \%, 7 \%, 8 \%$ e $6 \%$ (BNDES, 2002).

\section{Histórico do saneamento básico no Brasil}

A participação do setor público no saneamento básico brasileiro apresentou, ao longo do tempo, um "movimento pendular", tanto no que se refere à provisão dos serviços como às políticas públicas adotadas. Até a década de 1930, não havia uma política nacional e o governo federal limitava-se a incentivar uma maior participação privada no setor, mas, na maioria das 
localidades, o acesso aos serviços dependia de soluções individuais. A partir dos anos 1940, o governo federal começou a esboçar uma maior intervenção no setor, mas cabia aos municípios a oferta dos serviços. Em 1971, foi implantado um programa nacional para o setor, cujo resultado principal foi a centralização da provisão dos serviços e do financiamento dos investimentos. Após a extinção desse programa, não foi adotada uma nova política nacional e o governo federal voltou a incentivar uma maior descentralização e desestatização no setor.

O objetivo da presente seção é caracterizar, de forma detalhada, esse "movimento pendular" - ficará claro que ele ocorreu devido ao processo de urbanização e à conjuntura política e econômica pela qual o país passou em cada momento. Além disso, será avaliada a evolução das aplicações dos recursos do Fundo de Garantia por Tempo de Serviço (FGTS) no saneamento básico brasileiro - destacando-se o impacto das regras de contingenciamento de crédito ao setor público sobre essas aplicações.

\subsection{Ausência de uma política nacional (até 1970): provisão descentralizada}

Os serviços de saneamento básico no Brasil, "até o início da década de 30, [...] eram prestados segundo modelo institucional e financeiro bastante flexível, do qual participavam o setor público e empresas privadas”, por meio de concessões públicas realizadas pelo Estado. A atuação do governo federal limitava-se a algumas ações adotadas com o objetivo de aumentar a atratividade do setor, principalmente para as empresas estrangeiras, que praticamente monopolizavam a tecnologia e os recursos necessários ${ }^{6}$. Tal objetivo foi atingido apenas em

\footnotetext{
${ }^{6}$ Dentre as principais ações adotadas, pode-se destacar: (i) garantia de uma rentabilidade mínima às concessionárias; (ii) permissão para a livre importação de máquinas e de equipamentos, assim para a livre remessa de lucros para o
} 
algumas localidades. Nas demais, "a solução das questões de saneamento básico [...] dependia da ação individual” (MPO/SEPURB/IPEA, 1995, p. 76-7).

Em um contexto de cidades com pequena densidade populacional e com baixo crescimento da urbanização, até é possível uma atuação federal pouco efetiva no saneamento básico - mas não ideal, devido às externalidades desse setor sobre a saúde pública, o meio ambiente e o desenvolvimento econômico, discutidas na introdução. Contudo, à medida que a taxa de urbanização foi expandindo, impulsionada pelo processo de industrialização, a demanda por infra-estrutura urbana também foi crescendo - a evolução da taxa de urbanização brasileira pode ser observada no gráfico 1.6.

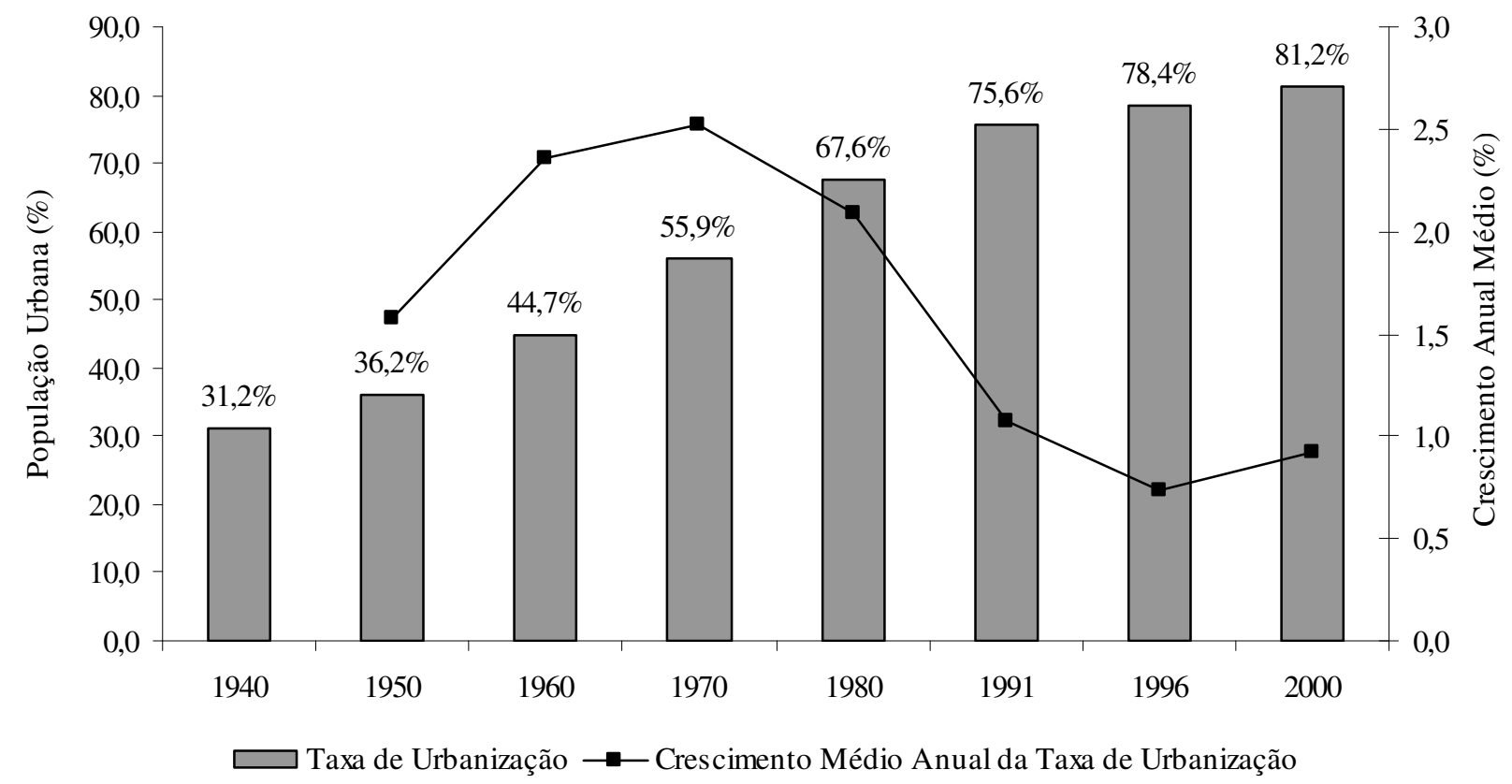

Fonte: IBGE. Elaboração própria.

\section{Gráfico 1.6}

Brasil: evolução da taxa de urbanização brasileira, de 1940 a 2000

exterior - essas não oneravam o balanço de pagamentos - e (iii) adoção de tarifas reais - ainda não existia a prática de subsídios cruzados, tão difundida posteriormente. 
A demanda por serviços de saneamento é determinada pelo crescimento da população total e, em especial, pelo crescimento da população urbana. Sem prejuízo da atenção que deve ser conferida pelo setor público à população rural, é nas cidades que se localiza a maior parte da demanda, bem como os problemas decorrentes da ausência de abastecimento de água e esgotamento sanitário, isto é, as questões de saúde pública e meio ambiente (MPO/SEPURB/IPEA, 1995, p. 35).

O grande problema foi que a grave crise econômica pela qual quase todos os países do mundo passaram - principalmente nos anos 1930 -, o que reduziu a possibilidade de atrair empresas estrangeiras para a realização dos investimentos necessários.

A convergência desses dois fatores - necessidade de investimentos e crise externa obrigou o governo federal a tomar, pela primeira vez, algumas medidas de maior intervenção no setor, destacando-se: (i) a promulgação do "Código de Águas" (Decreto n 24.643, de 1934), que garantiu a ele o poder de fixar tarifas; (ii) a nacionalização e a estatização das concessionárias estrangeiras - dessa forma, os recursos para investimentos passaram a originar-se, basicamente, do orçamento fiscal -; (iii) a criação da Fundação Serviços de Saúde Pública (FSESP), com o objetivo de implantar sistemas de saneamento básico nos municípios mais pobres das regiões menos desenvolvidas e implementar programas de educação sanitária, e (iv) a transferência da responsabilidade pelos serviços para os municípios. É importante destacar também que as tarifas foram mantidas "em níveis irrisórios, uma espécie de populismo que, na prática, estagnou os serviços de saneamento básico, com gravíssimos reflexos sobre a saúde da população e até mesmo sobre as atividades econômicas" (MAGALHÃES, 1993, p. 11-2).

As medidas adotadas, contudo, não geraram os resultados esperados. Os investimentos realizados não foram suficientes para elevar, significativamente, o acesso aos serviços, o que, juntamente com o aumento da taxa de urbanização, levou aos baixos índices de atendimento urbanos observados no início da década de 1960. De acordo com o MPO/Sepurb/IPEA (1995), os baixos investimentos em saneamento básico não eram condizentes com o desempenho econômico do período, uma vez que o final dos anos 1950 e o período 1960/62 foram marcados por um bom 
desempenho da economia - por exemplo, industrialização com taxas médias anuais de crescimento iguais a $8 \%$ do PIB (p. 78-9).

A qualidade dos serviços, na maioria dos casos, também não era ideal. No abastecimento de água, por exemplo, grande parte dos serviços não possuía tratamento químico e apresentava operação defeituosa.

A melhor situação era encontrada no estado de São Paulo: o governo estadual vinha desde 1934 incentivando a construção de sistemas de água e de esgoto, o que acarretou um atendimento que atingia $57 \%$ dos 369 municípios, sendo que 40 cidades contavam com tratamento químico em estações apropriadas e 127 já dispunham de redes de esgoto (TUROLLA, 2002, p. 11).

Portanto, a partir de meados de 1930, os municípios - em alguns casos, apoiados pelos estados - eram os principais responsáveis pela construção das redes e pela posterior provisão dos serviços de saneamento básico no Brasil, de modo que aqueles que possuíam maior disponibilidade de recursos financeiros conseguiam prestá-los mais adequadamente ${ }^{7}$. Contudo, na maioria dos casos, o orçamento dos municípios e as tarifas cobradas não eram suficientes para cobrir custos e necessidades de investimentos (BARAT, 1998, p. 140).

O resultado era um déficit considerável na oferta dos serviços fundamentais de água e esgoto, não obstante sua essencialidade para a saúde da população. Do estigma da deficiência não escaparam nem as duas maiores metrópoles brasileiras, a cidade do Rio de Janeiro e de São Paulo, atingidas, no correr da década dos 50 e início dos anos 60, por crônicas restrições no fornecimento de água (MAGALHÃES, 1993, p. 1).

Diante desse quadro, o Plano Trienal de Desenvolvimento ${ }^{8}$, que deveria vigorar de 1963 a 1965, previu o repasse de recursos para o Ministério da Saúde apoiar programas de saneamento básico. No entanto, esse plano acabou sendo precocemente abandonado, em função dos problemas políticos existentes naquele momento, que acabaram levando ao golpe militar (1964).

\footnotetext{
${ }^{7}$ A organização administrativa dos serviços de água e de esgoto no Brasil dessa época não possuía um padrão uniforme. Existiam municípios que operavam de forma autônoma, enquanto outros operavam conjuntamente com municípios vizinhos, como Santos, São Vicente e Guarujá. Havia ainda departamentos estaduais que centralizavam desde o planejamento e a execução das obras até a operação dos serviços (modelo mais bem sucedido). "Em muitos casos, a centralização estadual não se estendeu à fase de operação, com resultados menos satisfatórios em virtude de os municípios não disporem de elementos próprios na execução do serviço conforme os padrões sanitários apropriados" (TUROLLA, 2002, p. 11).
} 
O governo militar elegeu a ampliação da cobertura dos serviços de saneamento como uma de suas prioridades explicitadas nos planos de desenvolvimento do período. Isso reflete a consciência, que [...] já se havia formado na época entre os setores ligados ao planejamento, de que o cenário de baixo desenvolvimento desses serviços comprometia os objetivos de desenvolvimento socioeconômico e afetava as atividades industriais e as condições de saúde (TUROLLA, 2002, p. 11).

Já no primeiro ano do governo militar, foi formulado um novo plano econômico, o Programa de Ação Econômica do Governo (PAEG) ${ }^{9}$. No setor de saneamento básico, a meta do PAEG era elevar o acesso ao abastecimento de água por rede geral para $70 \%$ da população urbana e o acesso à coleta de esgoto por rede geral para $30 \%$ da população urbana. Porém, “mais importante para o setor de saneamento que o discurso do PAEG, foram as medidas adotadas entre 1964 e 1967, que iriam moldar, no futuro, a instituição de políticas explícitas para o setor" (MPO/SEPURB/IPEA, 1995, p. 82). Entre as principais medidas, pode-se destacar - a importância de algumas delas ficará clara mais adiante:

(i) promulgação da Lei n ${ }^{\circ} 4.380$, de 1964, que criou o Banco Nacional de Habitação (BNH), com a missão inicial de desenvolver programas habitacionais e de implantar uma política de desenvolvimento urbano;

(ii) obtenção de recursos junto ao Banco Interamericano de Desenvolvimento (BID) para implantação do Programa de Abastecimento de Água para Pequenas Comunidades primeiro programa federal de financiamento do setor, garantido certa experiência para a implantação dos programas posteriores;

(iii) promulgação da Lei $n^{\circ} 5.107$, de 1966, que criou o Fundo de Garantia por Tempo de Serviço (FGTS) - substitui a estabilidade de emprego de trabalhadores com mais de dez anos de serviço consecutivo em uma mesma empresa;

(iv) centralização dos poderes e dos recursos - reforma tributária de 1967 - na esfera federal;

\footnotetext{
${ }^{8}$ Para mais detalhes sobre o Plano Trienal, ver Abreu (1990).

${ }^{9}$ Para mais detalhes sobre o PAEG, ver Resende (1990).
} 
(v) promulgação do Decreto-Lei no 200 , de 1967, por meio do qual o então Ministério do Interior foi encarregado de formular e implantar uma política nacional para o saneamento básico - responsabilidade que foi delegada ao $\mathrm{BNH}$;

(vi) realização de estudos com o objetivo de definir as diretrizes básicas que deveriam constar em uma política nacional de saneamento básico e

(vii) promulgação da Lei $n^{\circ} 5.318$, de 1967, que tinha como objetivo instituir as diretrizes da futura política nacional de saneamento.

Em 1968, a conjuntura econômica favorável - "milagre econômico"10 - e a crescente arrecadação do FGTS viabilizaram a criação, pelo BNH, do Sistema Financeiro do Saneamento (SFS) e dos primeiros programas de financiamento do setor. Originalmente, o SFS contaria apenas com os recursos próprios do $\mathrm{BNH}$ e com as transferências a fundo perdido do governo federal. Porém, o Decreto-Lei n ${ }^{\circ}$ 949, de 31 de outubro de 1969, definiu algo que mudaria profundamente o saneamento básico brasileiro, viabilizando a realização de grandes investimentos: a partir da promulgação desse decreto, o BNH passou a poder aplicar recursos do FGTS no setor. "A utilização dos recursos do FGTS viabilizou o Sistema e permitiu a criação de diversos programas de financiamento” (MPO/SEPURB/IPEA, 1995, p. 96).

Os principais subprogramas/linhas de financiamento criados no período 1968/70 foram: (i) Subprograma de Estímulo do Sistema Financeiro de Saneamento (Efisan); (ii) Subprograma de Financiamento e Refinanciamento da Implantação e Melhoria dos Sistemas de Abastecimento de Água (Refinag) e (iii) Subprograma de Financiamento e Refinanciamento da Implantação, Ampliação e Melhoria dos Sistemas de Esgotos Sanitários (Refinesg). Estes compunham o Fundo de Financiamento para o Saneamento, que contava com recursos do FGTS, de empréstimos externos e de contribuições a fundo perdido do orçamento federal. 
Por último, é importante destacar que o BNH e o SFS adotaram, entre 1968 e 1970, diversas medidas que alteraram a configuração do setor, viabilizando a implantação, em 1971, de uma política nacional de saneamento básico. Entre essas medidas, destaca-se: (i) o estímulo à criação de companhias estaduais de saneamento básico (CESBs); (ii) a criação de fundos estaduais de água e esgoto (FAEs); (ii) o financiamento conjunto dos investimentos - o BNH/SFS e os estados, por meio dos FAEs, passaram a ser responsáveis, cada um, por 37,5\% dos recursos necessários e os demais $25 \%$ cabiam aos municípios, por meio de seus orçamentos e/ou de transferências a fundo perdido ${ }^{11}$ - e (iii) a centralização das transferências a fundo perdido da União no SFS, como forma de auxiliar os estados e municípios a compor a contrapartida local.

\subsection{O Plano Nacional de Saneamento (de 1971 a 1992): provisão centralizada}

Segundo o Censo Demográfico de 1970 (IBGE, 1970), apenas 50\% da população urbana possuíam, naquele ano, abastecimento de água por rede geral e $24 \%$ possuíam rede coletora de esgoto, mas sem tratamento adequado. Ou seja, o país apresentava um sério desequilíbrio entre a demanda e a oferta de serviços de água e esgoto, agravado pela aceleração da urbanização. O resultado era a existência de sérios problemas sociais nos municípios - mais uma vez é importante enfatizar que os serviços de saneamento básico impactam sobre a saúde pública, o meio ambiente e o desenvolvimento econômico. Diante desse quadro, o governo federal

\footnotetext{
${ }^{10}$ Para mais detalhes sobre esse período, ver Lago (1990).

${ }^{11}$ Essa medida baseava-se no princípio da reciprocidade ou do auto-financiamento. "Este saudável princípio do selfhelp tornava os Estados e Municípios participantes efetivos do esforço de investimento. E não, como habitual, em meios captores de fundos federais" (MAGALHÃES, 1993, p. 9).
} 
implantou, em 1971, o Plano Nacional de Saneamento (Planasa) ${ }^{12}$ - em consonância com as medidas adotadas no final da década de 1960, discutidas no tópico anterior.

Somente depois da criação dessas instituições [BNH, SFS e Planasa] é possível falar de uma política nacional de abastecimento de água e serviço de esgoto. Até então, a questão era tratada de modo totalmente descentralizado, compatível com os estágios relativamente precários de desenvolvimento das diversas regiões do país. As instituições criadas na década de 60 trazem na marca o regime autoritário que se instalou no país em 1964, pautado por forte centralização política e implantação de planos de desenvolvimento em âmbito nacional (PARLATORE, 2000, p. 283).

Conforme aponta Barat (1998), os principais objetivos do Planasa eram: (i) reverter o déficit do setor, atendendo à crescente demanda pelos serviços e instituindo, de forma centralizada, as funções de planejamento, coordenação e formulação de políticas tarifárias; (ii) reduzir custos operacionais pelas economias de escala, pois as empresas estatais - serão comentadas mais adiante - concentrariam esforços para a ampliação do sistema no maior número possível de municípios e (iii) desenvolver a capacitação técnica, financeira e institucional do setor (p. 141). "Para o atingimento das metas previstas no Planasa, organizou-se [...] um esquema de financiamento baseado em dois instrumentos: o Finansa [...] e o FAE" (TUROLLA, 2002, p. 12). O FAE já foi comentado anteriormente. O Finansa era o programa de financiamento de saneamento do BNH/SFS ${ }^{13}$.

Deve-se destacar que o "esquema de financiamento" englobava diferentes fontes de recursos. Na formulação inicial do Planasa, previu-se a utilização de recursos do FGTS, dos orçamentos fiscais da União, dos estados, dos municípios, do BNH, de empréstimos internos e externos e do retorno das aplicações. Os governos estaduais deveriam aplicar, no máximo, 5\% de

\footnotetext{
${ }^{12}$ Na verdade, o Planasa já havia sido institucionalizado pelo Decreto-Lei $n^{\circ}$ 949, de 1969, mas só foi efetivamente implantado em 1971.

13 De acordo com o MPO/Sepurb/IPEA (1995, p. 103-4), o Finansa agrupava as linhas de financiamento (subprogramas) adotadas no Planasa - algumas delas já haviam sido criadas quando este foi implantado: (i) Subprograma de Financiamento e Refinanciamento da Implantação, Ampliação e/ou Melhoria de Abastecimento de Água (Refinag); (ii) Subprograma de Estímulo do Sistema Financeiro do Saneamento (Efisan); (iii) Subprograma de Financiamento e Refinanciamento da Implantação, Ampliação e/ou Melhoria dos Sistemas de Esgotos Sanitários (Refinesg); (iv) Subprograma de Financiamento Suplementar para Abastecimento de Água (Fisag); (v) Subprograma
} 
suas receitas tributárias na constituição dos FAEs - para não comprometer os recursos para outros programas -, sendo que esses fundos seriam responsáveis por 37,5\% dos investimentos realizados pela CESB do respectivo estado - foi criada uma CESB para cada estado e uma para o Distrito Federal. Se a participação estadual não fosse suficiente para cobrir essa contrapartida, o BNH deveria emprestar o restante necessário - por meio de recursos do FGTS e de transferências a fundo perdido do orçamento fiscal da União.

Além disso, o BNH emprestaria, diretamente às CESBs, outros 37,5\% dos recursos necessários para os investimentos - FGTS, recursos próprios, empréstimos internos e externos e retorno das aplicações. Aos municípios, caberia 25\% do total necessário - recursos orçamentários e/ou transferências a fundo perdido da União. Ou seja, manteve-se, pelo menos inicialmente, o financiamento conjunto dos investimentos adotado no final dos anos 1960

A criação do FGTS em substituição à estabilidade no emprego, constituiu-se, assim, em condição absoluta para a implantação do Planasa. E por se constituir em fundo de poupança compulsória, com enorme estabilidade, formado com base num percentual do valor global da massa dos salários pagos no país, movimentável, por seu titular em condições especialíssimas, o FGTS permitiu ao BNH financiar, a longo prazo e a juros inferiores ao do mercado, programas e projetos de saneamento básico (MAGALHÃES, 1993, p. 3).

Ainda em relação ao financiamento, é importante enfatizar que, originalmente, os recursos só eram emprestados às companhias estaduais. Os municípios, principais responsáveis pelos serviços até então, eram "estimulados" a conceder os serviços às CESBs de seus respectivos estados - era obrigatória a celebração de contratos de concessão ${ }^{14}$. "Nessa tarefa, respaldados no autoritarismo do governo federal, os governos estaduais e as CESBs usaram todos os mecanismos de pressão política e de verdadeira chantagem econômica" (PEIXOTO, 1994 apud TUROLLA, 2002, p. 12). De acordo com Magalhães (1993), "na qualidade de administrador de recursos de

de Apoio Técnico ao Sistema Financeiro de Saneamento (Sanat) e (vi) Subprograma de Financiamento Suplementar para Controle da Poluição das Águas (Ficon).

14 "Em algumas cidades os serviços já eram prestados por órgãos estaduais que foram sucedidos pelas empresas do Planasa, sem nenhuma espécie de contrato" (MCIDADES, 2005, p. 10). 
terceiros - os trabalhadores titulares das contas do FGTS -, o BNH teria de ser, necessariamente, prudente na concessão de financiamentos" (p. 4).

Era, portanto, do ponto de vista operacional, bastante compreensível que o BNH optasse por operar [...] com Estados e não com os Municípios. Por conseqüência, sua preferência em tornar as companhias estaduais de água e esgoto os seus principais agentes operadores, era perfeitamente justificável. Era, sem dúvida, muito mais seguro operar, concentradamente, com [...] companhias estaduais que com um número muito maior de instituições municipais. [Além disso], a estadualização do sistema permitia a introdução de uma tarifa domiciliar diferenciada de modo a garantir significativos subsídios para os consumidores de baixa renda (p. 5-7).

Nesse contexto, conforme destaca o MPO/Sepurb/IPEA (1995), as tarifas cobradas pelas CESBs deveriam ser reais, assumindo valores suficientes para "operar e manter os serviços, retornar os empréstimos contratados junto ao BNH/SFS e permitir o uso de subsídios cruzados entre consumidores de maior e menor renda, considerados todos os sistemas situados na mesma unidade da Federação, sob operação das CESBs” (p. 99).

Os subsídios cruzados deveriam ser adotados de modo a permitir o atendimento das famílias mais pobres, conforme sua capacidade de pagamento, e a estender os serviços aos municípios dotados de sistemas de menor rentabilidade, sem comprometer o equilíbrio financeiro das CESBs e o retorno dos investimentos (p. 105).

Outro argumento utilizado para justificar a opção pela operação estadual - que constava explicitamente nos objetivos do Planasa, comentados anteriormente - é que esta poderia levar à redução de custos operacionais em função da existência de economias de escala no setor - quanto maior a população ou área atingida, menor o custo. De acordo com o MCidades (2005), "buscava-se a economia de escala reunindo diversos territórios para a prestação dos serviços, bem como a economia de escopo, atribuindo-se ao mesmo prestador os serviços de abastecimento de água e de esgotamento sanitário" (p. 10).

No papel de financiador, e de novo responsável pela aplicação de recursos de terceiros, o BNH se reservou, o que é comum nos organismos financiadores, competência para examinar e aprovar os programas estaduais e respectivos projetos, reduzindo [...] a liberdade das companhias estaduais. [...] Ocorreu, sem dúvida, uma acentuada padronização dos programas e dos projetos, adotando, afinal, os operadores do sistema, o ponto de vista do BNH e reduzindo sua capacidade de programação e projetação autônomos. [...] O BNH transformou-se [assim] no órgão central de um sistema nacional de saneamento no qual exercia decisivo papel na fixação das diretrizes e dos princípios a 
que deveriam se submeter as instâncias estaduais e municipais. E nesse sistema [...] hierarquizado, a competência operacional competia à esfera estadual, aderindo os Municípios por via de convênio (MAGALHÃES, 1993, p. 7-8).

Pode-se dizer, assim, que o Planasa foi um modelo centralizado de financiamento que se baseava na concessão, por parte dos municípios, dos direitos de exploração dos serviços às CESBs de seus respectivos estados - que passaram a ser responsáveis pela execução de obras e pela operação dos sistemas. Ao BNH cabia, além de parte do financiamento, a fixação de normas, o controle, a coordenação, a análise e a aprovação dos planos estaduais de saneamento, especialmente em relação à viabilidade técnica e tarifária, monitorando também os custos das concessionárias estaduais e a remuneração do capital - que deveria ser destinada à realização de investimentos para a ampliação da cobertura dos serviços. Portanto,

para a União [por meio do BNH], o Planasa reservava dois papéis centrais: (i) fornecer recursos financeiros para os investimentos, especialmente por meio do FGTS, e (ii) atuar como reguladora, aprovando as tarifas praticadas pelas empresas estaduais, definindo suas remunerações máximas [regulação por taxa de retorno] e aprovando seus planos de investimento. É evidente que a função reguladora federal substituía o papel dos Municípios, o que somente se tornou possível tendo em vista o quadro político de exceção (MCIDADES, 2005, p. 10).

Na verdade, conforme destaca Turolla (2002), "na concepção do sistema, previa-se que o papel do BNH seria gradualmente reduzido à medida que os fundos estaduais fossem capazes de obter autonomia financeira, a partir do fluxo de tarifas gerado pelos investimentos" (p. 12), contudo, ficará claro, a seguir, que isso não foi possível.

Dificuldades, adaptações, crise e extinção

De acordo com o MPO/Sepurb/IPEA (1995), “do período de sua criação, em 1971, até 1984, ao fim do ciclo dos governos militares, o Planasa encontrou dificuldades e [conseqüentemente] sofreu mudanças ao longo do tempo, sem, entretanto, modificar seus objetivos básicos". Tais mudanças ocorreram em função tanto da dinâmica econômica brasileira 
como de aspectos internos ao Plano (p.116). A primeira dificuldade enfrentada foi a não adesão de diversos municípios, o que acabou prejudicando a adoção de subsídios cruzados no âmbito de cada CESB. Destaca-se o caso de Porto Alegre (RS), capital de estado que permaneceu com serviços autônomos. Portanto, "apesar da hegemonia do Planasa, parcela importante dos serviços continuou a ser prestado pelos próprios municípios” (MCIDADES, 2005, p. 10).

De um modo geral, eram municípios de grande e médio porte, como Porto Alegre, Caxias do Sul, Pelotas e Bagé (RS); Campinas, Ribeirão Preto, São Bernardo do Campo, Santo André, Osasco, Sorocaba, Jundiaí, Bauru, Presidente Prudente, Araraquara e Piracicaba (SP); Juiz de Fora, Uberaba, Uberlândia, Barbacena e Sete Lagoas (MG); Petrópolis, Barra Mansa, Volta Redonda e Rezende (RJ); Cachoeiro do Itapemirim e Colatina (ES) (MPO/SEPURB/IPEA, 1995, p. 116).

No final dos anos 1970, aproximadamente $75 \%$ dos municípios brasileiros existentes naquele momento eram vinculados ao Planasa - principalmente, conforme aponta Moreira (s.d.), aqueles que não possuíam, anteriormente, serviços próprios e tampouco dispunham de recursos para o desenvolvimento, a implantação, a operação e a manutenção desses sistemas (p. 3). Ou seja, um quarto dos municípios existentes naquele momento não haviam concedido às CESBs o direito sobre a exploração dos serviços - esses municípios "se opuseram ao que consideravam como ingerência na vida das populações locais" (PNSB, 2000, p. 30). Isto porque

o poder concedente passou a não ter a menor ingerência no planejamento e implantação dos serviços nos municípios. Em decorrência, as prefeituras não puderam, por exemplo, harmonizar a expansão das redes de água e esgotos com os planos de ocupação físicoterritorial e de desenvolvimento local. [Já] os municípios que não aderiram ao Plano [...] ficaram à margem dos financiamentos e foram obrigados a custear os investimentos com recursos de outras fontes, notadamente os do orçamento fiscal. Apesar disso, os municípios de melhor situação financeira conseguiram elevar os níveis de atendimento em volume igual ou superior aos do Planasa (MPO/SEPUB/IPEA, 1995, p. 158).

A segunda dificuldade enfrentada pelo Planasa foi a impossibilidade de manter, por muito tempo, a estrutura de financiamento originalmente prevista $-37,5 \%$ federais, $37,5 \%$ estaduais e $25 \%$ municipais. A contrapartida municipal teve de ser logo abandonada, em decorrência da centralização dos recursos tributários nas mãos do governo federal - iniciada na reforma tributária de 1967. Assim, o BNH/SFS passou a se responsabilizar por 50\% dos investimentos e 
os FAEs pelos outros $50 \%$. Como as receitas estaduais também foram limitadas pela reforma tributária, “os FAEs [...] passaram a receber outros empréstimos do BNH para integralizar sua participação". Além disso, "as transferências a fundo perdido, que deveriam ser alocadas pela União ao SFS, em vez de aplicadas pulverizadamente, deixaram de existir a partir de 1974/75". Para compensar essa queda de recursos, o BNH passou a tomar empréstimos externos - em consonância com a política adotada pelo presidente Geisel para tentar manter níveis elevados de crescimento econômico (MPO/SEPURB/IPEA, 1995, p. 117) ${ }^{15}$.

Parlatore (2000) aponta a rigidez do modelo, “excessivamente uniforme e centralizado", como um sério problema do Planasa, uma vez que não eram consideradas "as diferenças regionais, as peculiaridades locais e as capacidades financeiras, organizacionais e institucionais das diversas esferas de governo". Além disso, destaca que o êxodo rural cresceu durante a vigência do Plano, "causando crescimento excessivo e desordenado na periferia das cidades médias e grandes, tornando cada vez mais difícil e oneroso o saneamento dessas áreas” (p. 286).

Conforme destaca Magalhães (1993), o Planasa enfrentou, ainda, dificuldades relacionadas à manutenção de tarifas realistas. Por um lado, grande parte da população de baixa renda não dispunha de recursos para pagar o preço necessário, mesmo com o uso de subsídios cruzados - “a possibilidade dos consumidores mais ricos subsidiarem os mais pobres tinha, obviamente, limites" (p. 8). Por outro lado, o país passou por um significativo processo inflacionário no final dos anos 1970 - e durante a década de 1980.

O governo federal tomou algumas medidas na tentativa de reverter tal processo, dentre as quais se destaca a política de contenção das tarifas e dos preços dos serviços e bens produzidos pelo setor (p. 11). Ou seja, ao final dos anos 1970, os estados perderam a autonomia para fixar as

\footnotetext{
${ }^{15}$ Para mais detalhes sobre a política adotada pelo presidente Geisel, ver Carneiro (1990).
} 
tarifas de água e de esgoto, o que contribuiu para a redução da capacidade de financiamento das CESBs e inadimplência das mesmas junto aos FAEs e ao $\mathrm{BNH}^{16}$.

É importante destacar que, mesmo com a recuperação da autonomia de fixar tarifas, na década de 1980, os governos estaduais parecem ter tido pouca disposição para assumir o ônus pela recuperação tarifária, uma vez que, vários deles mantiveram as defasagens tarifárias (FERREIRA, 1996).

A consistência do mecanismo financeiro do Planasa repousa[va], [...], no FGTS, como fonte primária de recursos para o programa, e na possibilidade de receita tarifária remunatória dos serviços de água e esgoto, lançada pelas Companhias Estaduais, garantir o pagamento dos empréstimos do BNH e do FAE, além de cobrir as despesas de custeio. Sem uma tarifa dita realista [...] a equação do Planasa estaria furada (MAGALHÃES, 1993, p. 11).

Diante desse quadro, "passados o período de carência dos empréstimos e os primeiros anos de retorno das aplicações, as CESBs e os governos estaduais tiveram dificuldades em saldar seus compromissos, tornando-se cada vez mais inadimplentes" (MPO/SEPURB/IPEA, 1995, p. 118). $\mathrm{Na}$ tentativa de solucionar tal problema, foram realizadas algumas adaptações na estrutura de financiamento do Planasa. Além da alteração da composição dos recursos para investimentos, comentada anteriormente, destaca-se a criação de novos subprogramas/linhas de financiamento ${ }^{17}$. Essas adaptações, contudo, não geraram o efeito desejado - na verdade, agravaram algumas dificuldades e criaram novas. O resultado foi o gradual enfraquecimento do Plano.

\footnotetext{
${ }^{16}$ Mesmo com a recuperação da autonomia de fixar tarifas, na década de 1980, os governos estaduais parecem ter tido pouca disposição para assumir o ônus pela recuperação tarifária, uma vez que, vários deles mantiveram as defasagens tarifárias (FERREIRA, 1996).

${ }^{17}$ As linhas de financiamento criadas foram: (i) Subprograma de Financiamento e/ou Refinanciamento para Implantação ou Melhoria de Sistemas de Drenagem (Fidren) - canalização de pequenos cursos de água, drenagem pluvial, pavimentação e urbanização de fundos de vale -; (ii) Subprograma Suplementar para Composição da Participação dos Estados na Execução do Planasa (Finest) - incorporação dos antigos subprogramas Efisan e Fisag, com o objetivo de viabilizar empréstimos para que os governos estaduais pudessem integralizar sua participação nos FAEs e ampliar os investimentos das CESBs nas comunidades de pequeno porte - e (iii) Subprograma de Desenvolvimento Institucional das Companhias de Saneamento Básico (Prodisan) - apoio às CESBs para melhoria de seu desempenho institucional, aumento de sua produtividade, redução de seus custos operacionais e qualificação de seus recursos humanos (MPO/SEPURB/IPEA, 1995, p. 118-9).
} 
A década de 1980 se iniciou com um índice de cobertura dos serviços de abastecimento de água próximo a $80 \%$ da população urbana, o que evidencia que o Planasa atingira resultados concretos. Entretanto, já naquele momento, vários fatores contribuíram para a deterioração da saúde financeira das companhias. As fontes de financiamento esgotaramse acompanhando as dificuldades macroeconômicas, ao mesmo tempo em que terminaram as carências dos empréstimos obtidos nos anos anteriores e aumentaram as despesas de amortizações e os encargos financeiros das dívidas. [...] O uso político das companhias e o crescimento da inflação impuseram um ônus adicional sobre os custos de operação (TUROLLA, 2002, p. 13).

Os problemas apresentados pelas CESBs, em função do excessivo endividamento e da cobrança de tarifas não realistas, foram agravados pelo fraco desenvolvimento institucional e operacional destas. De acordo com o MPO/Sepurb/IPEA (1995), o padrão de funcionamento foi prejudicado pelos sistemas de baixa produtividade, "que registraram perdas de $50 \%$ do volume de água produzido e excessivos custos operacionais e administrativos" (p. 159).

Esses últimos decorrentes de ingerências políticas na condução dos negócios que deveriam, por princípio, se reger por normas comerciais à margem do sistema políticopartidário. Às questões gerenciais das CESBs somaram-se os padrões excessivamente elevados na construção, ampliação e melhoria dos sistemas, a partir da adoção de tecnologias sofisticadas, que nem sempre redundavam em benefícios para a população. Não se buscou [...] o uso efetivo de tecnologias alternativas capazes de reduzir os custos das obras e serviços (MPO/SEPURB/IPEA, 1995, p. 159).

Deve-se destacar também que, em um contexto de luta pela redemocratização, de abertura política e de busca por um processo gradual de descentralização - início dos anos 1980 -, a recém criada Associação dos Serviços Municipais de Água e Esgoto (Assemae) passou a pressionar o governo federal para que os órgãos municipais autônomos também participassem do Planasa $^{18}$. Em 1985, essa reivindicação foi atendida, mantendo-se as mesmas condições estabelecidas para os governos estaduais. Ou seja, o $\mathrm{BNH}$ deveria emprestar 50\% dos investimentos e as prefeituras, por sua vez, seriam responsáveis pelos outros $50 \%$ necessários sendo facultativa a criação de fundos municipais semelhantes aos FAEs.

Naquele mesmo ano, o Ministério do Interior foi extinto. As funções relacionadas ao saneamento básico, que pertenciam a esse ministério, foram transferidas para o então criado 
Ministério do Desenvolvimento Urbano e Meio Ambiente (MDU) - que passou a ser responsável, conseqüentemente, pelo $\mathrm{BNH}$ e pelo Planasa. Iniciava-se aí um longo período de crise institucional do setor de saneamento - crise que, de certa forma, permanece até hoje (2007) -, cuja conseqüência principal foi a fragmentação das responsabilidades e dos recursos referentes ao setor - no decorrer desse capítulo, tal fato será retomado e discutido mais detalhadamente.

Em 1986, foi a vez do BNH ser extinto. Segundo Magalhães (1993), a extinção do BNH deveu-se à crise do Sistema Financeiro de Habitação (SFH) - generalização de subsídios aos seus devedores -, "mas atingiu, de tabela, o Planasa, cuja situação era incomparavelmente mais sólida que a do sistema habitacional" (p. 16). Todas as responsabilidades dessa instituição relacionadas ao saneamento básico - e à habitação - foram transferidas para a Caixa Econômica Federal (CEF), que, "submetida a limitações orçamentárias mais severas, teve de reduzir sensivelmente a oferta de recursos" (TUROLLA, 2002, p. 13). Além disso,

a estrutura anterior do BNH, responsável pelo Planasa, não foi assimilada pela CEF e acabou desintegrada e pulverizada na instituição. Esse fenômeno de decomposição [...] deveu-se, inclusive, ao contraste entre a filosofia do Planasa e a cultura da CEF, especializada em administrar um sistema de crédito de estritamente social e sem vocação para desempenhar as funções da orientação, coordenação e controle que o Planasa reservava ao BNH (MAGALHÃES, 1993, p. 17).

O governo federal, com a extinção do $\mathrm{BNH}$, deixou de atuar na regulação do setor, desaparecendo os controles sobre as tarifas e a remuneração das empresas, "que deixa[ra]m de considerar inclusive as concessões, passando a prevalecer somente a realidade econômica e financeira de seus custos" (MCIDADES, 2005, p. 10).

Uma outra séria dificuldade à continuidade do Planasa foi a significativa queda da arrecadação do FGTS no período 1983/85 e em 1988 - em função da crise econômica ocorrida na década de 1980, comentada anteriormente. Além disso, ocorreu um aumento constante dos

\footnotetext{
${ }^{18}$ Associação criada em 1984 - integrada, naquele momento, "por mais de mil municípios que não se filiaram ao Planasa e que, por essa razão, não recebiam financiamento do BNH/SFS” (MPO/SEPURB/IPEA, 1995 c, p. 116-7).
} 
saques ao longo do período, em função, principalmente, da liberalização das regras - aumento das possibilidades de uso dos depósitos. Contribuiu para esse aumento "a mudança do status jurídico dos funcionários públicos, que compulsoriamente deixaram de ter suas relações de emprego regidas pela Consolidação das Leis do Trabalho, passando a se subordinar ao Regime Jurídico Único, conforme determinado pela Constituição de 1988” (MPO/SEPURB/IPEA, 1995, p. 155). Tais fatos prejudicaram o aporte dos elevados recursos que se tornaram necessários em um contexto de baixa capacidade financeira dos estados e das CESBs - a evolução do FGTS será discutida detalhadamente no decorrer do presente capítulo.

Por meio da análise realizada até o momento, é possível observar que o Planasa foi enfrentando uma série de dificuldades ao longo de sua vigência, que contribuíram, juntamente com fatores conjunturais, para o seu colapso financeiro e para sua posterior extinção. Diante desse quadro desfavorável, o governo federal realizou várias adaptações na tentativa de solucionar os problemas enfrentados, culminando na introdução de significativas alterações em 1990. “As mudanças introduzidas [naquele ano] foram de tal monta que correspondem, praticamente, à extinção do Planasa e à criação do Programa de Saneamento para Núcleos Urbanos (Pronurb), que só viria a ser formalizada mais tarde, pela Resolução $\mathrm{n}^{\circ}$ 076, de 09/07/92" - essa resolução unificou as antigas linhas de financiamento (Refinag, Refinesg, Fidren, Prodisan e Finest) em um único programa (MPO/SEPURB/IPEA, 1995, p. 146-7).

\section{$\underline{\text { Resultados alcançados pelo Planasa }}$}

De acordo com Parlatore (2000), "nas décadas de 70 e 80, o Planasa realizou grandes investimentos e melhorou expressivamente o abastecimento de água e os serviços de esgoto em relação aos baixos níveis observados na década anterior" - apesar das "diretrizes e metas 
propostas não terem sido totalmente atingidas" (p. 285-6). O abastecimento de água, por meio de rede geral, que atendia a menos de $50 \%$ da população urbana em 1971, atingiu $86 \%$ da população urbana em 1991 e a coleta de esgoto, por meio de rede coletora, evoluiu de $24 \%$, em 1971, a $49 \%$ da população urbana em 1991.

Tais números mostram que o Planasa elevou de forma substancial a parcela da população atendida com água e, em menor escala, com coleta de esgoto, "embora não se tenha avançado muito na questão do tratamento dos esgotos” (BNDES, 1996, p. 1) - “o atendimento [com água] das populações das periferias urbanas e nas pequenas localidades do meio rural [também] ficou comprometido" (MPO/SEPURB/IPEA, 1995, p. 158). Dada a limitação de recursos institucionais e financeiros, as empresas públicas de saneamento básico (CESBs) investiram mais em abastecimento de água, "em detrimento dos serviços de esgotamento sanitário, distanciando-se do previsto em sua concepção original" (MCIDADES, 2005, p. 10). O gráfico 1.7 ilustra esses fatos, mostrando que a proporção dos investimentos em abastecimento água, durante todo o Planasa (1971/1992), sempre foi superior a dos investimentos em esgoto - alternando períodos em que a diferença entre eles aumentava e períodos em que esta diminuía.

Turolla (2002) apresenta uma importante característica do Planasa: a ênfase na construção e na ampliação dos sistemas em detrimento aos aspectos operacionais. Na verdade, o setor de operação não era financiado pelo BNH. O resultado dessa ênfase foi a posterior degradação dos sistemas e o nível bastante elevado de perdas de água, que acabaram contribuindo para a descontinuidade do modelo (p. 12-3). De acordo com Parlatore (2000), a prioridade para a produção de água, em detrimento da otimização da distribuição, "se explica pela perspectiva histórica de executar obras, como meio de prestar serviços satisfatórios, dando preferência à ampliação da produção, ao invés da redução de perdas e racionalização do consumo” (p. 290). 


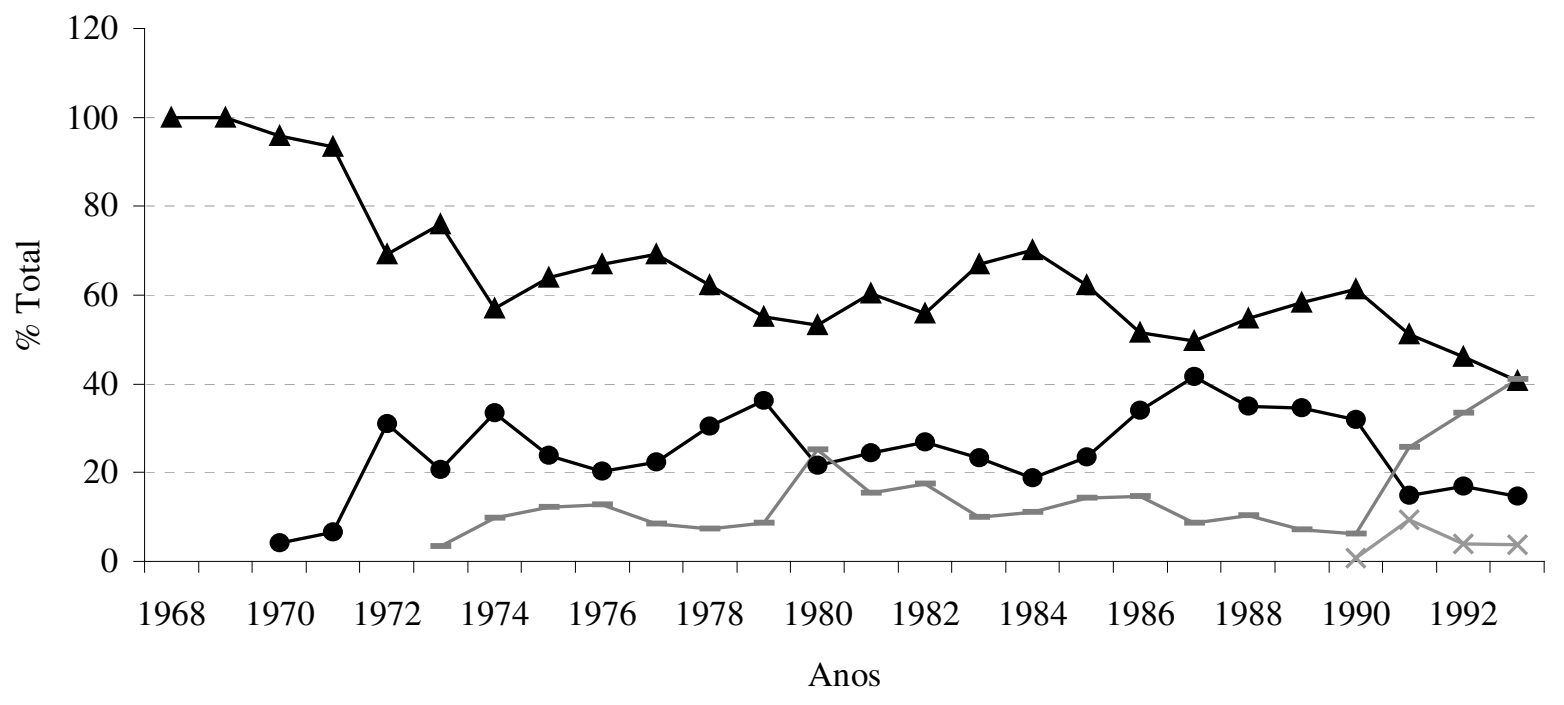

$\longrightarrow$ Água/Total $(\%) \multimap$ Esgoto/Total $(\%) \longrightarrow$ Drenagem Urbana/Total $(\%) \multimap$ Outros/Total $(\%)$

Fonte: BNH e CEF (apud MPO/SEPURB/IPEA, 1995, p. 179). Elaboração própria

\section{Gráfico 1.7}

Brasil: participação de cada serviço de saneamento básico nos investimentos totais realizados no setor (\%), de 1968 a 1993

O MPO/Sepurb/IPEA (1995) defende que, mesmo inexistindo critérios que orientassem a distribuição espacial dos investimentos - instituídos apenas em 1990 -, o Planasa, ao contrário de "muitos outros programas supostamente sociais", não concentrou suas aplicações nas regiões mais desenvolvidas do país. "A arrecadação líquida do FGTS no Sudeste, somada a outras fontes de financiamento, permitiu que o Norte e o Nordeste recebessem o dobro da arrecadação líquida do Fundo nessas regiões, enquanto o Sul e o Centro-Oeste tiveram investimentos do mesmo nível de sua arrecadação". Além disso, "foi também possível beneficiar os municípios mais pobres e atender, por meio de subsídios cruzados, grande número de famílias de baixa renda" (p. 156-7). 
Tal fato, de certo modo, é verdadeiro, mas ficará claro no próximo capítulo que o Planasa não eliminou os desequilíbrios inter-regionais e inter-municipais de acesso aos serviços.

\section{$\underline{\text { 2.3 Políticas após o Planasa (a partir de 1992) e diversidade de prestadores }}$}

O Planasa, conforme destaca Turolla (2002), foi o "único mecanismo articulado de financiamento e de modernização do setor de saneamento no Brasil”, de modo que as iniciativas governamentais posteriores podem ser consideradas como "pontuais e desarticuladas" (p. 13). Ou seja, ainda não foi implantada uma nova política nacional - apesar de vários projetos já terem tramitado pelo Congresso Nacional. Nesse contexto, o autor destaca também que as políticas públicas relativas ao setor empregadas na década de 1990 "apresentaram um padrão comum, caracterizado pela ênfase na modernização e na ampliação marginal da cobertura dos serviços" (p. 14). Na verdade, a maioria das políticas empregadas de 1992 - extinção do Planasa - até hoje (2007) possui essas características.

A gestão do período também enfatizou a integração da política de saneamento com as políticas de desenvolvimento urbano, de saúde e de meio ambiente. No caso das políticas de saúde, a integração apresenta vitórias mais importantes com a atuação da Fundação Nacional de Saúde (Funasa) (TUROLLA, 2002, p. 17).

Após o Planasa, passou-se a incentivar também uma maior participação da iniciativa privada (desestatização) e dos governos subnacionais (descentralização) nas decisões, no financiamento e na provisão dos serviços. Ou seja, ações que estão em consonância com a busca de alteração do papel do Estado na economia, devido à crise financeira pela qual o país passou na década de 1980, cuja conseqüência principal foi o esgotamento do modelo de desenvolvimento econômico conhecido como Estado desenvolvimentista - conforme discutido anteriormente. 
Em face das tendências de redefinição do papel do Estado, a partir da Constituição de 1988, a ênfase na descentralização e privatização traz de volta a responsabilidade de políticas públicas ao poder local. No que se refere aos serviços de saneamento básico, o processo de municipalização encontra vários desafios, entre eles, a capacidade desigual dos municípios em atender às demandas na implantação e/ou aprimoramento dos serviços prestados (PNSB, 2000, p. 30).

Assim, os programas federais pós-Planasa podem ser divididos, grosso modo, em três grupos, de acordo com seus objetivos: (i) programas para a redução das desigualdades socioeconômicas e que privilegiavam os sistemas sem viabilidade econômico-financeira; (ii) programas voltados para a modernização e o desenvolvimento institucional dos sistemas de saneamento e (iii) programas para aumentar a participação privada no setor.

No quadro 1.1, são apresentados os principais programas federias implantados de 1992 até hoje (2007). Uma análise mais detalhada de todos os programas foge do escopo do presente trabalho. Dessa forma, optou-se por comentar brevemente apenas alguns deles - devido às suas características próprias, que ajudam a ilustrar as políticas públicas após-Planasa:

O Programa de Saneamento para Núcleos Urbanos (Pronurb), cuja criação, em 1992, formalizou a extinção do Planasa, tinha como objetivo principal financiar empreendimentos que elevassem o acesso aos serviços, principalmente os que priorizavam o atendimento à população urbana de baixa renda. Para isso, contava com recursos do FGTS e de contrapartidas. Tal programa foi extinto 1994.

Destaca-se ainda, entre os programas que visa(va)m a redução das desigualdades socioeconômicas o Programa de Saneamento Básico da Fundação Nacional de Saúde (Funasa), vinculada ao Ministério da Saúde. A Funasa "aloca recursos para o desenvolvimento de ações de saneamento a partir de critérios epidemiológicos e de indicadores sociais" (TUROLLA, 2002, p. 16), privilegiando localidades de até trinta mil habitantes, áreas rurais e indígenas e periferias de grandes cidades - em muitos dos municípios, a Fundação atua também na gestão e na assistência técnica dos serviços municipais autônomos de saneamento básico. 
Quadro 1.1

Brasil: principais programas federais para o saneamento básico após o Planasa

\begin{tabular}{|c|c|c|c|}
\hline Objetivos & Programa & $\begin{array}{l}\text { Recursos/ } \\
\text { Situação }\end{array}$ & $\begin{array}{c}\text { Benefícios/ } \\
\text { Desdobramentos }\end{array}$ \\
\hline \multirow{7}{*}{$\begin{array}{c}\text { redução das } \\
\text { desigualdades } \\
\text { socioeconômicas } \\
\text { e privilégio aos } \\
\text { sistemas sem } \\
\text { viabilidade } \\
\text { econômico- } \\
\text { financeira } \\
\text { (A) }\end{array}$} & $\begin{array}{l}\text { Programa de Saneamento para } \\
\text { Núcleos Urbanos (Pronurb) }\end{array}$ & $\begin{array}{c}\text { FGTS e } \\
\text { contrapartida / } \\
\text { Extinto }\end{array}$ & $\begin{array}{c}\text { população urbana em geral, com prioridade } \\
\text { à de baixa renda }\end{array}$ \\
\hline & $\begin{array}{l}\text { Programa de Saneamento para } \\
\text { População de Baixa Renda } \\
\text { (Pró-Saneamento e Prosanear) }\end{array}$ & $\begin{array}{l}\text { FGTS e } \\
\text { contrapartida / } \\
\text { Extinto }\end{array}$ & $\begin{array}{c}\text { áreas com famílias com renda de até } 12 \\
\text { S.M. (Pró-Saneamento) ou de até } 3 \text { S.M. } \\
\text { (Prosanear) }\end{array}$ \\
\hline & $\begin{array}{c}\text { Programa Urbanização, } \\
\text { Regularização e Integração de } \\
\text { Assentamentos Precários (PAT } \\
\text { - Prosanear) }\end{array}$ & (*) / Vigente & $\begin{array}{l}\text { assentamentos precários (favelas ou outros } \\
\text { núcleos urbanos de baixa renda) }\end{array}$ \\
\hline & $\begin{array}{l}\text { Programa de Ação Social em } \\
\text { Saneamento (Pass) }\end{array}$ & $\begin{array}{l}\text { OGU, BIRD, } \\
\text { BID e } \\
\text { contrapartida / } \\
\text { Vigente (BID) }\end{array}$ & $\begin{array}{l}\text { população de baixa renda em municípios } \\
\text { com maior concentração de pobreza }\end{array}$ \\
\hline & $\begin{array}{l}\text { Programa Social de } \\
\text { Emergência e Geração de } \\
\text { Empregos em Obras de } \\
\text { Saneamento (Prosege) }\end{array}$ & $\begin{array}{l}\text { BID e } \\
\text { contrapartida / } \\
\text { Extinto }\end{array}$ & $\begin{array}{l}\text { população de baixa renda, privilegiando } \\
\text { comunidades com renda de até } 7 \text { S.M. }\end{array}$ \\
\hline & $\begin{array}{l}\text { Programa de Saneamento } \\
\text { Integrado em Pequenos } \\
\text { Municípios (Sede Zero) }\end{array}$ & (*) / Vigente & $\begin{array}{l}\text { municípios de até } 20 \text { mil habitantes da área } \\
\text { de abrangência do Programa Fome Zero } \\
\text { (semi-árido com incidência de seca) }\end{array}$ \\
\hline & $\begin{array}{c}\text { Fundação Nacional de Saúde - } \\
\text { Programa de Saneamento } \\
\text { Básico (Funasa/SB) }\end{array}$ & $\begin{array}{c}\text { OGU e } \\
\text { contrapartida / } \\
\text { Vigente }\end{array}$ & $\begin{array}{l}\text { apoio técnico e financeiro no } \\
\text { desenvolvimento de ações com base em } \\
\text { critérios epidemiológicos e sociais }\end{array}$ \\
\hline \multirow{3}{*}{$\begin{array}{l}\text { modernização e } \\
\text { desenvolvimento } \\
\text { institucional dos } \\
\text { sistemas de } \\
\text { saneamento } \\
\text { (B) }\end{array}$} & $\begin{array}{l}\text { Programa de Pesquisa em } \\
\text { Saneamento Básico (Prosab) }\end{array}$ & $\begin{array}{l}\text { Finep, CNPq e } \\
\text { Capes / Extinto }\end{array}$ & $\begin{array}{l}\text { desenvolvimento de pesquisa em tecnologia } \\
\text { de saneamento ambiental }\end{array}$ \\
\hline & $\begin{array}{l}\text { Programa de Modernização do } \\
\text { Setor de Saneamento (PMSS) }\end{array}$ & $\begin{array}{l}\text { BIRD e } \\
\text { contrapartida / } \\
\text { Vigente }\end{array}$ & $\begin{array}{l}\text { estudos e assistência técnica aos estados e } \\
\text { municípios; investimentos em } \\
\text { modernização empresarial e aumento de } \\
\text { cobertura e estudos de desenvolvimento } \\
\text { institucional }\end{array}$ \\
\hline & $\begin{array}{c}\text { Programa Nacional de } \\
\text { Combate ao Desperdício de } \\
\text { Água (PNCDA) }\end{array}$ & $\begin{array}{c}\text { OGU e } \\
\text { contrapartida / } \\
\text { Vigente }\end{array}$ & $\begin{array}{l}\text { uso racional de água em prestadores de } \\
\text { serviços de saneamento, fornecedores e } \\
\text { segmentos de usuários }\end{array}$ \\
\hline \multirow{2}{*}{$\begin{array}{l}\text { aumento da } \\
\text { participação } \\
\text { privada no setor } \\
\text { (C) }\end{array}$} & $\begin{array}{l}\text { Programa de Assistência } \\
\text { Técnica à Parceria Público- } \\
\text { Privada em Saneamento } \\
\text { (Propar) }\end{array}$ & $\begin{array}{l}\text { BNDES / } \\
\text { Extinto }\end{array}$ & $\begin{array}{l}\text { estados, municípios e concessionários } \\
\text { contratando consultoria para viabilização de } \\
\text { parcerias público-privadas }\end{array}$ \\
\hline & $\begin{array}{c}\text { Programa de Financiamento a } \\
\text { Concessionários Privados de } \\
\text { Serviços de Saneamento } \\
\text { (FCP/SAN) }\end{array}$ & $\begin{array}{l}\text { FGTS, BNDES } \\
\text { e contrapartida } \\
\text { / Extinto }\end{array}$ & $\begin{array}{l}\text { concessionários privados em } \\
\text { empreendimentos de ampliação de } \\
\text { cobertura de áreas com renda de até } 12 \\
\text { S.M. }\end{array}$ \\
\hline$(\mathrm{A}+\mathrm{B}$ & $\begin{array}{c}\text { Programa Saneamento para } \\
\text { Todos }\end{array}$ & $\begin{array}{l}\text { FGTS, FAT e } \\
\text { OGU }\end{array}$ & $\begin{array}{c}\text { substituiu os programas Pró-Saneamento, } \\
\text { Prosanear e FCP/SAN }\end{array}$ \\
\hline
\end{tabular}

Fonte: Turolla (2002). Adaptações e atualizações próprias, com informações do Ministério das Cidades.

(*) informação não encontrada. S.M.: salários mínimos. 
Atualmente, as ações da Funasa são desenvolvidas em parceria com outros órgãos do governo: (i) Instituto Brasileiro do Meio Ambiente e dos Recursos Naturais Renováveis (Ibama), quando implantadas em reservas extrativistas; (ii) Fundação Palmares e Secretaria Especial de Promoção da Igualdade Racial, quando implantadas em comunidades remanescentes de quilombos; (iii) Instituto Nacional de Colonização e Reforma Agrária (Incra), quando implantadas em assentamentos da reforma agrária, e (iv) Ministério das Cidades, quando implantadas em áreas carentes de regiões metropolitanas.

O Programa de Modernização do Setor de Saneamento (PMSS) pode ser considerado como um dos mais importantes programas adotados após o Planasa. Criado em 1993, o PMSS financia, com recursos do BIRD e de contrapartidas (União e prestadores), a elaboração de estudos, projetos e planos para: (i) o desenvolvimento institucional e operacional do setor; (ii) a capacitação de recursos humanos; (iii) a reformulação dos marcos regulatórios e (iv) a estruturação e a consolidação de sistemas de informação. Destaca-se, nesse último aspecto, a criação e o desenvolvimento do Sistema Nacional de Informações em Saneamento (SNIS), em 1995, principal base de dados sobre o setor existente atualmente no Brasil - por conforme ficará claro no decorrer do presente trabalho.

A primeira etapa do PMSS foi concluída no ano de 2000 e procurou induzir a reforma do setor mediante ações institucionais em âmbito nacional por meio de estudos e de assistência técnica dada a estados e municípios, bem como mediante a realização de investimentos e de ações de desenvolvimento empresarial nas companhias estaduais dos estados de Santa Catarina, Bahia e Mato Grosso do Sul. A segunda etapa do PMSS [que se iniciou em junho de 1999 e se encerrará em outubro de 2007] ampliou o escopo dos financiamentos de investimentos e desenvolvimento empresarial nos estados das regiões Norte, Nordeste e Centro-Oeste (TUROLLA, 2002, p. 16)

O Programa Nacional de Combate ao Desperdício de Água (PNCDA), por sua vez, tem como principal objetivo promover o uso racional da água de abastecimento público. Para isso, além de agir de forma complementar aos demais programas federais, estaduais e municipais não tem caráter executivo, ou seja, não gere recursos para ações fim -, o programa apoia o 
desenvolvimento, a transferência e a disseminação de ações e tecnologias que obtiveram sucesso no combate ao desperdício de água - por meio de seminários nacionais e internacionais e de cursos de capacitação.

Atualmente, no âmbito PNCDA, participam diversos parceiros, tanto do setor público como do setor privado: (i) ministérios - Ministério das Cidades, Ministério do Meio Ambiente e Ministério das Minas e Energias -; (ii) entidades representativas do setor - Associação Brasileira de Engenharia Sanitária e Ambiental (Abes), Associação das Empresas de Saneamento Básico Estaduais (Aesbe) e Associação dos Serviços Municipais de Água e Esgoto (Assemae) -; (iii) organizações não-governamentais; (iv) entidades normativas - Associação Brasileira de Norma Técnicas (ABNT) e Instituto Nacional de Metrologia, Normatização e Qualidade Industrial (INMETRO) -; (v) fabricantes de materiais e equipamentos; (vi) prestadores de serviços (públicos e privados) e (vii) comunidade acadêmica (universidades e centros de pesquisa).

O Programa de Assistência Técnica à Parceria Público-Privada em Saneamento (Propar) foi criado a partir do convênio de cooperação mútua, firmado pela CEF e pelo BNDES em 1997, para incentivar o desenvolvimento da desestatização do setor. Tal programa financiava a contratação, pelos estados e municípios, de consultoria técnica para a implantação de modelos de parcerias público-privadas no setor.

O FCP/SAN, por sua vez, "inaugura um incentivo explícito do BNDES aos sistemas operados pela iniciativa privada. Ainda que moderadamente, o FCP/SAN introduziu a possibilidade de competição pelos recursos do FGTS, inovação essa que tende a constituir-se num incentivo à eficiência" (TUROLLA, 2002, p. 17). O programa pretendia aumentar a atratividade do setor para investidores privados, garantindo um fluxo de recursos relativamente estável para a realização de investimentos - recursos do BNDES e do FGTS. 
Deve-se apontar o Programa Saneamento para Todos - destacado no quadro 1.1 por possuir características dos três grupos considerados. Criado em 2005 para substituir os programas PróSaneamento, Prosanear e FCP/SAN, tem como objetivo principal, segundo informações da Secretaria Nacional de Saneamento Ambiental, promover a melhoria das condições de saúde e da qualidade de vida da população por meio de ações de saneamento integradas com outras políticas públicas. Utiliza, para isso, recursos do FGTS, do Fundo de Amparo ao Trabalhador (FAT) e do Orçamento Geral da União (OGU). As principais modalidades de financiamento do Programa Saneamento para Todos são as seguintes: abastecimento de água, esgotamento sanitário, saneamento integrado, desenvolvimento institucional, manejo de resíduos sólidos e de águas pluviais, estudos e projetos, preservação e recuperação de mananciais e manejo de resíduos de construção e demolição.

A criação desse programa trouxe uma mudança significativa em relação às práticas até então adotadas: as esferas governamentais e as concessionárias privadas obtêm recursos em um mesmo processo de seleção. Tanto para o setor público como para o setor privado aplicam-se regras semelhantes: (i) carência igual ao prazo de execução mais quatro meses, com limites variáveis entre doze e quarenta e oito meses, conforme modalidade pleiteada; (ii) amortização de até 240 meses (SAC), limitada à vida útil do empreendimento; (iii) desembolso por meio de parcelas mensais, respeitando o cronograma fisico-financeiro; (iv) taxa de juros entre 5 e $8 \%$ ao ano; (v) taxa de administração igual a $2 \%$ ao ano e (vi) vinculação de receitas tarifárias como garantia - assim como outras que se julgarem necessárias. A diferença está na contrapartida: para o setor público exige-se, no mínimo, $10 \%$ do valor investido; para o setor privado, 25\%. Em 2006, o orçamento de contratação para o setor público foi de $\mathrm{R} \$ 2,06$ bilhões e para o setor privado foi de R $\$ 640$ milhões (TAVARES, 2006). 
Deve-se destacar, por último, que também podem ser enquadrados no programa operações estruturadas de financiamento em que, uma Sociedade de Propósito Específico (SPE), de caráter privado, tome recursos para implantação de projeto de água, esgoto ou lixo, com garantia de recebíveis (estrutura de Project Finance ${ }^{19}$ ). Financia-se, nesse caso, 100\% do investimento.

\section{$\underline{\text { Provisão dos serviços hoje (2007): diversidade de prestadores }}$}

Conforme destaca o MCidades (2005), os serviços de saneamento básico no Brasil são, atualmente, "prestados em uma diversidade de arranjos institucionais, em que convivem prestadores municipais, estaduais e privados" (p. 9).

No abastecimento de água, as empresas estaduais são responsáveis pela prestação dos serviços a aproximadamente três quartos da população urbana [70\%]; os serviços municipais a $25 \%$ e a iniciativa privada a aproximadamente $3 \%$. No esgotamento sanitário, as empresas estaduais operam em cerca de $14 \%$ dos municípios. Os municípios são responsáveis pela demanda restante, sendo irrelevante a participação da iniciativa privada nestes serviços. [...] A situação atual deriva, em boa parte, do Plano Nacional de Saneamento [Planasa] (p. 9).

Ou seja, a estrutura organizacional existente hoje (2007) no setor originou-se no Planasa que, conforme foi apontado anteriormente, "incentivou e induziu a estadualização do setor" (MOREIRA, 1998, p. 191). Assim, a prestação dos serviços de saneamento básico ainda é concentrada em operadores públicos. A participação privada é recente e pequena - conforme ficará claro no decorrer do trabalho, alguns fatores limitam a expansão da iniciativa privada no setor. Outro tipo de provedor de serviços que, nos últimos anos, tem ganhado destaque são os

${ }^{19}$ O Project Finance é uma estrutura/técnica de financiamento de projetos. De acordo com Finnerty (1999), tal estrutura pode ser utilizada quando uma determinada instalação ou um conjunto de ativos relacionados forem capazes de funcionar de forma lucrativa como unidade econômica independente. " $\mathrm{O}(\mathrm{s})$ patrocinador(es) de tal unidade pode $(\mathrm{m})$ achar vantajoso formar uma nova entidade jurídica [SPE] para construir, deter a propriedade e operar o projeto. Se forem previstos lucros suficientes, a empresa do projeto poderá financiar a construção com base no projeto, que envolve a emissão de títulos patrimoniais (geralmente por patrocinadores do projeto) e de títulos de dívida que são projetados para serem autoliquidáveis através das receitas derivadas das operações do projeto" (p. 1). 
prestadores microrregionais - trata-se dos consórcios municipais, sejam eles de responsabilidade pública ou privada.

Deve-se apontar, por último, que são várias as naturezas jurídico-administrativas assumidas pelos prestadores de serviços de saneamento básico existentes atualmente no Brasil, podendo-se destacar: (i) secretarias, departamentos ou outros órgãos da administração pública direta; (ii) autarquia; (iii) empresa pública; (iii) sociedade de economia mista com gestão pública; (iv) sociedade de economia mista com gestão privada; (v) empresa privada e (vi) organização social. Esse assunto será retomado no terceiro capítulo.

\subsection{Evolucão dos recursos do FGTS e contingenciamento de crédito ao setor público}

De acordo com Faria, Nogueira e Muller (2005), "historicamente, no Brasil, os programas de saneamento básico têm sido financiados por meio de três fontes de recursos: (i) os orçamentos fiscais da União, Estados, Distrito Federal e municípios; (ii) recursos do FGTS e (iii) empréstimos internos e externos" (p. 494) - o quadro 1.1, apresentado anteriormente, ilustra bem esse fato, ao mostrar as fontes de financiamento dos programas pós-Planasa. No presente item, serão avaliados alguns aspectos relacionados ao FGTS.

Os recursos do FGTS são fundamentais para a execução de uma política de saneamento com qualidade e coerência, pois, em função das peculiaridades do sistema político representativo brasileiro, os recursos do OGU [Orçamento Geral da União], em sua maior parte, já saem comprometidos do processo orçamentário legislativo, restando pouca margem de manobra para o Executivo alocar livremente os recursos disponíveis (OLIVEIRA FILHO, 2006, p. 30-1).

É importante destacar que o FGTS é uma das principais fontes de recursos para investimentos em saneamento básico desde 1968 - ano em que foi permitida a aplicação de seus recursos no setor. Tal fato é ilustrado no gráfico 1.8, que apresenta a evolução da participação dos 
recursos do FGTS no total investido no setor durante a vigência do Planasa e do Pronurb (19681993). Observa-se que essa participação é relevante em todos os anos analisados e que ela aumentou ao longo do tempo - em função dos problemas financeiros apresentados pelos estados e suas CESBs, comentados anteriormente.

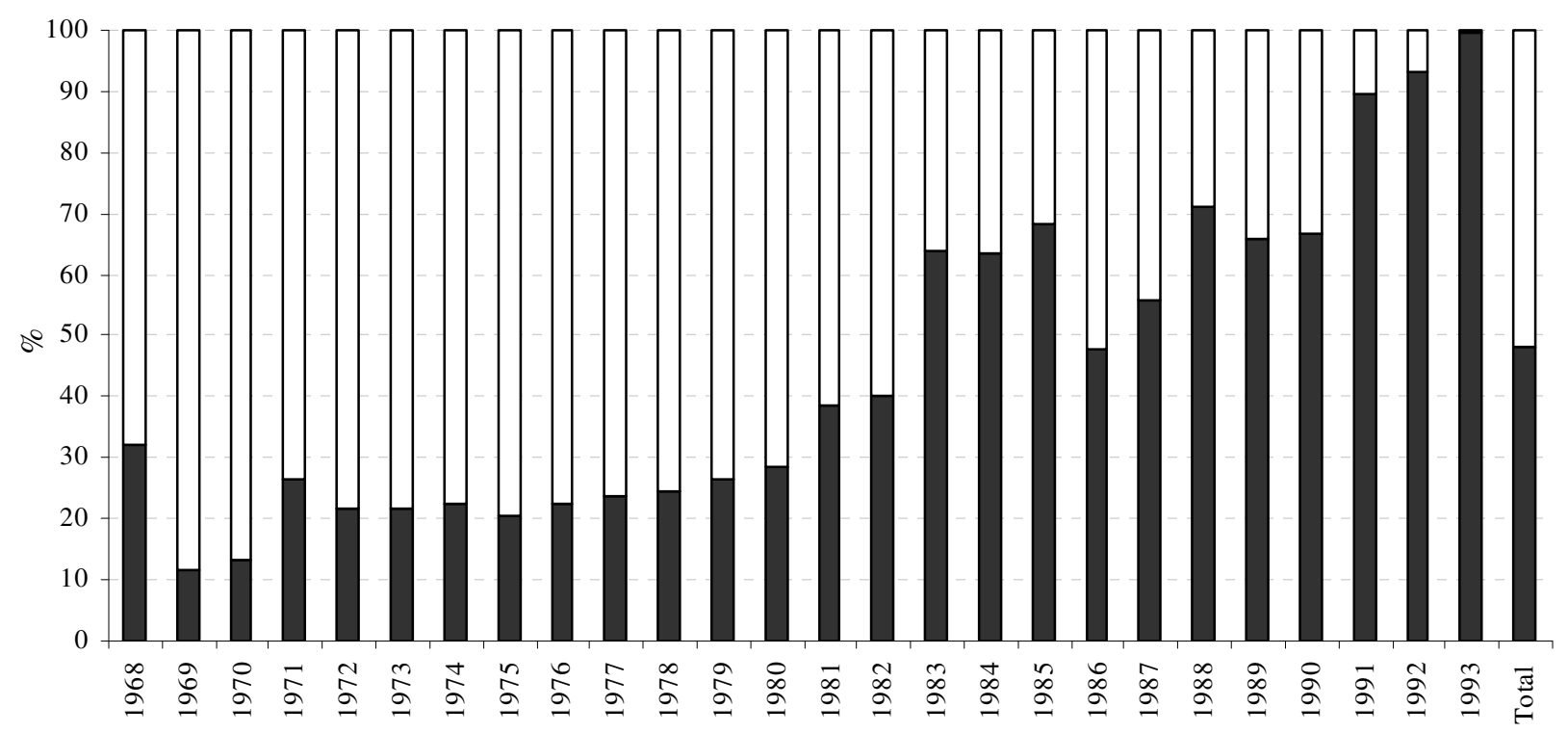

口 Recursos do FGTS $\square$ Outros Recursos

Fonte: BNH e CEF (apud MPO/SEPURB/IPEA, 1995, p. 179). Elaboração própria

\section{Gráfico 1.8}

Brasil: evolução da participação dos recursos do FGTS no total investido (\%), de 1968 a 1993

Após 1983, apenas em um ano (1986) a participação dos recursos do FGTS no total investido em saneamento básico foi inferior a 50\%. No período como um todo, os recursos do Fundo foram responsáveis por pouco menos da metade do investimento total realizado (48,2\%). Fica claro, assim, o porquê da queda da arrecadação líquida do FGTS ter sido apontada, no item 2.2, como um dos principais fatores que levaram ao colapso financeiro do Planasa. 
A evolução da arrecadação bruta, dos saques e da arrecadação líquida do FGTS, durante a vigência do Planasa e do Pronurb, é apresentada no gráfico 1.9. Observa-se que, após um longo período de expansão, a arrecadação líquida sofreu uma redução no início dos anos 1980. Tal queda foi revertida em meados dessa mesma década, mas voltou a sofrer uma inflexão no início dos anos 1990. É importante fazer uma ressalva em relação ao gráfico: devido à disponibilidade de dados, foram utilizados valores em dólares para a sua confecção, o que prejudica um pouco a análise - uma vez que esses valores ficam sujeitos às valorizações e desvalorizações cambiais.

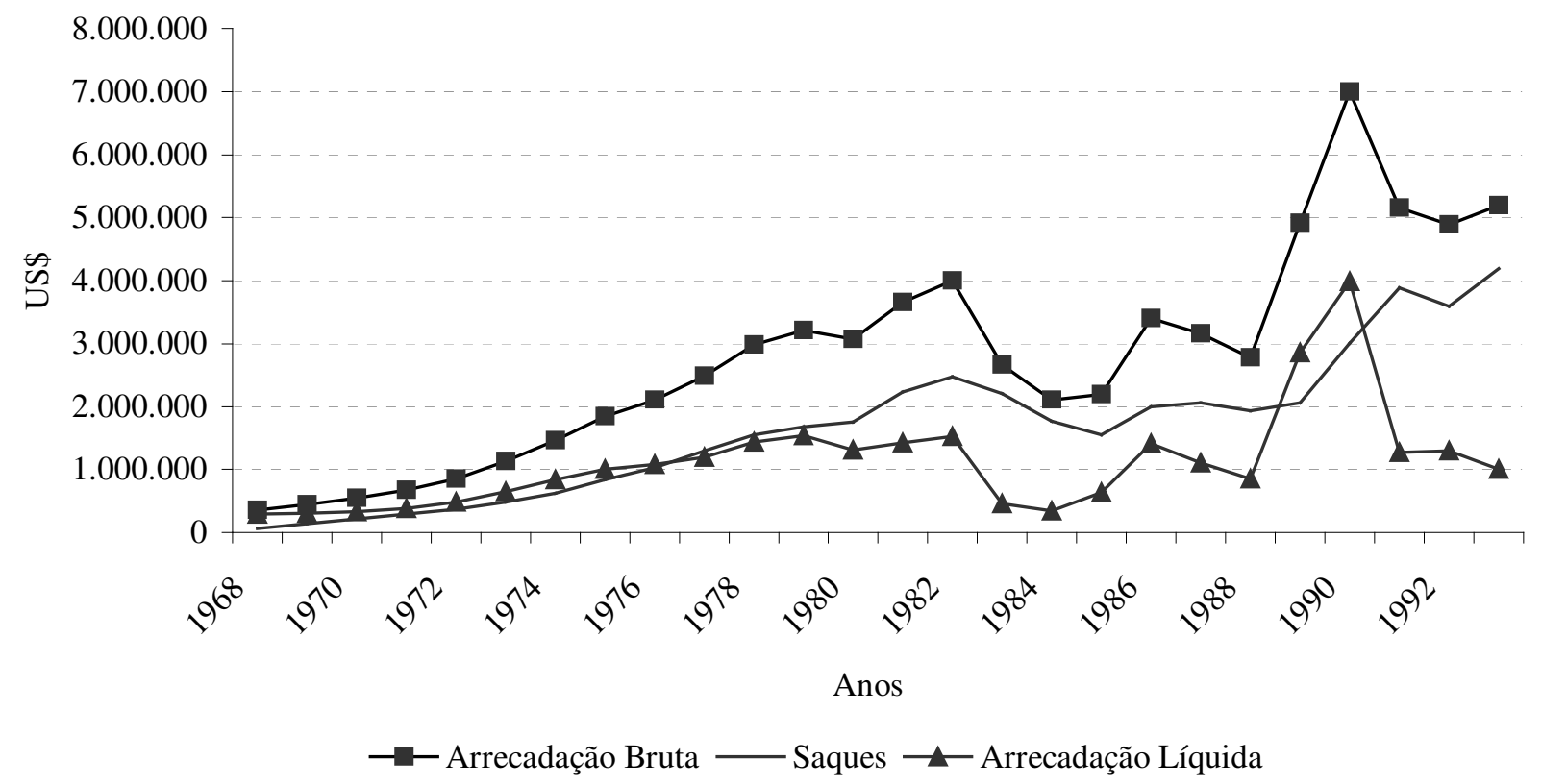

Fonte: BNH e CEF (apud MPO/SEPURB/IPEA, 1995, p. 177). Elaboração própria.

\section{Gráfico 1.9}

Brasil: evolução da arrecadação bruta, dos saques e da arrecadação líquida do FGTS(US\$), de 1968 a 1993

O gráfico 1.10, por sua vez, apresenta a evolução da arrecadação bruta, dos saques e da arrecadação líquida do FGTS (em milhões de reais) de 1988 a 2005. Observa-se que a arrecadação bruta sofreu uma significativa expansão a partir do início da década de 1990. No 
entanto, os saques também cresceram. Durante a década de 1990, a arrecadação líquida foi pequena - chegando a ser negativa em alguns anos. Conseqüentemente, os recursos disponíveis do Fundo para serem aplicados no saneamento básico também foram baixos no período. Nos anos mais recentes - primeira metade da década de 2000 -, a arrecadação líquida do FGTS apresentou uma tendência de crescimento - a arrecadação bruta elevou-se mais do que os saques. Conforme pode ser observado na tabela 1.4, as contratações de recursos do Fundo - para serem aplicados no saneamento básico - não acompanharam a tendência da arrecadação líquida.

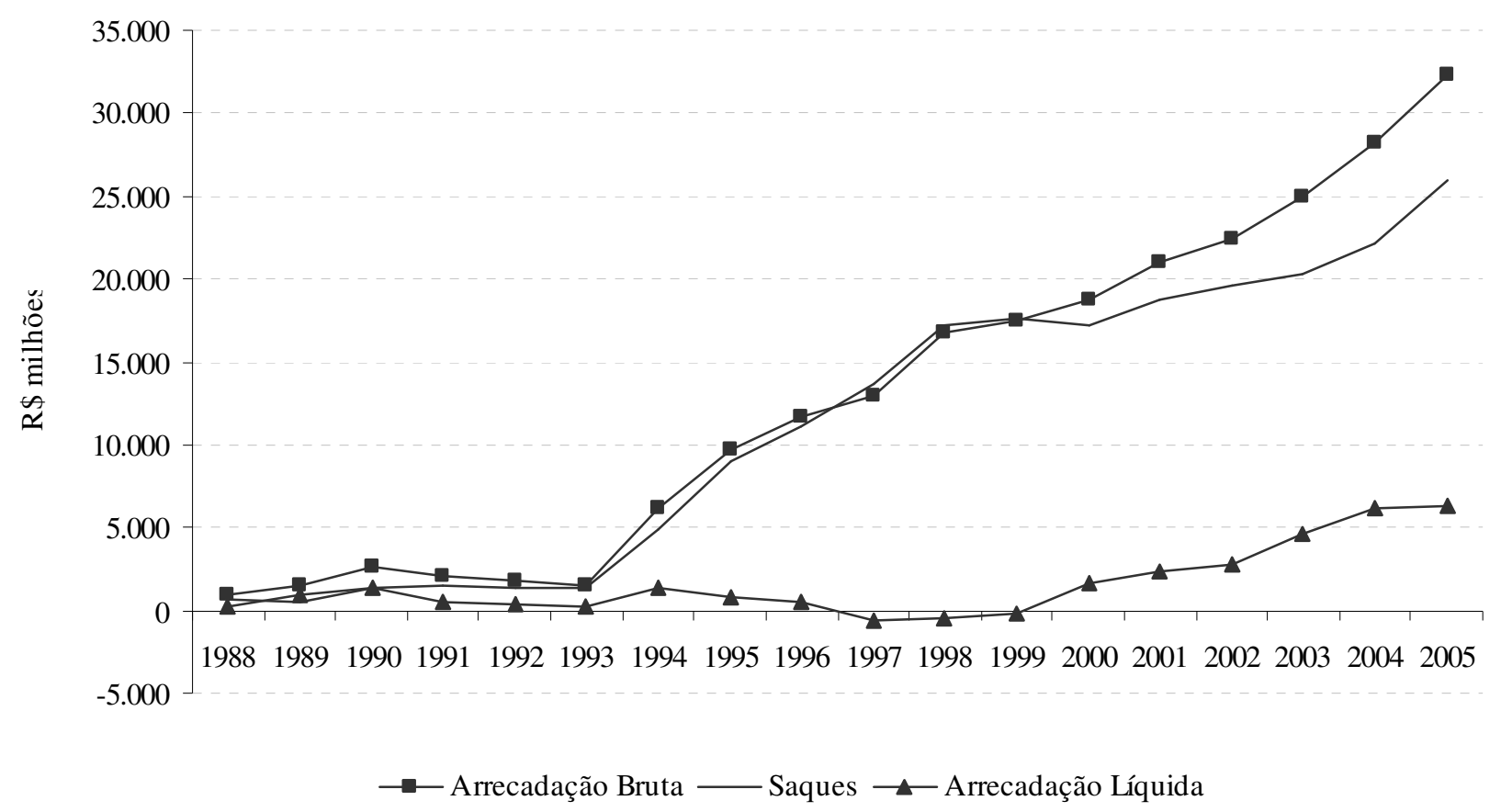

Fonte: CEF, Relatório de Gestão. Elaboração própria.

Gráfico 1.10

Brasil: evolução da arrecadação bruta, dos saques e da arrecadação líquida do FGTS (R\$ milhões), de 1988 a 2005

As contratações não seguiram a tendência apresentada pela arrecadação líquida devido à existência de regras de contingenciamento de crédito ao setor público, impostas por resoluções do 
Conselho Monetário Nacional (CMN) - promulgadas a partir de meados da década de 1990 com o objetivo de garantir que as metas de superávit primário fossem atingidas. Conseqüentemente,

entre 1995 e 1998, cerca de 7,4 bilhões retornaram aos cofres do FGTS como serviço da dívida, amortizações e juros de empréstimos contraídos em períodos anteriores pelas CESBs e autarquias municipais. Nesse mesmo período, o FGTS desembolsou como empréstimo ao setor público apenas $\mathrm{R}$ \$ 1,8 bilhão, gerando um saldo líquido de $\mathrm{R} \$ 5,7$ bilhões para o Fundo (OLIVEIRA FILHO, 2006, p. 30).

\section{Tabela 1.4}

Brasil: evolução dos recursos do FGTS contratados para o saneamento básico (R\$ milhões), de 2000 a 2006

\begin{tabular}{c|c|c|c}
\hline Ano & Caixa Econômica Federal & Outros Agentes Financeiros & Total \\
\hline 2000 & 0 & 16.656 & 16.656 \\
2001 & 0 & 0 & 0 \\
2002 & 184.190 & 41.707 & 225.897 \\
2003 & 1.583 .956 & 53.183 & 1.637 .139 \\
2004 & 1.744 .494 & 198.446 & 1.942 .940 \\
2005 & 33.903 & 0 & 33.903 \\
$2006 *$ & 1.027 .853 & 0 & 1.027 .853 \\
Total & $\mathbf{4 . 5 7 4 . 3 9 6}$ & $\mathbf{3 0 9 . 9 9 2}$ & $\mathbf{4 . 8 8 4 . 3 8 8}$ \\
\hline
\end{tabular}

Fonte: Caixa Econômica Federal (CEF).

* Até 20 de outubro de 2006.

A Resolução $n^{\circ}$ 2.827, por exemplo, definiu, entre outros aspectos: (i) a limitação do montante das operações de crédito de cada instituição financeira e demais instituições autorizadas a funcionar pelo Banco Central (Bacen) com órgãos e entidades do setor público a $45 \%$ do valor do patrimônio líquido dessas instituições (art. $1^{\circ}$ ) e (ii) a fixação de um montante máximo para todas as operações de crédito entre o setor público e as instituições financeiras $\left(\operatorname{art.} 9^{\circ}\right)$.

No caso específico do saneamento básico, “tendo em vista o valor global [...] ser menor do que a demanda por financiamentos, o Conselho Monetário Nacional (CMN) deliberou um montante específico" para o setor, que foi publicado na Resolução no 3.153, de 2003 (OLIVEIRA FILHO, 2005, p. 172-3). Essa resolução autorizou a contratação de novas operações de crédito para a execução de ações de saneamento, definindo inclusive os limites permitidos. 
A Resolução $\mathrm{n}^{\circ} 3.153$, na verdade, foi promulgada para oficializar a autorização do FMI e do Ministério da Fazenda que excluiu os investimentos em saneamento básico das metas de superávit primário vigentes naquele momento. "Foi ampliado o montante de crédito de estados e municípios e respectivas empresas, junto ao sistema financeiro interno, em até $\mathrm{R} \$ 2,9$ bilhões para a contratação de operações destinadas exclusivamente a financiar projetos para a execução de obras de saneamento ambiental [básico]" (MCIDADES, 2004, p. 6). Esse limite foi, posteriormente, redefinido por outras resoluções, sendo, atualmente, igual a $\mathrm{R}$ \$ 2,2 bilhões.

O gráfico 1.11 compara as contratações anuais médias de recursos do FGTS realizadas em três períodos: (i) de 1995 a 1998; (ii) de 1999 a 2002 e (iii) de 2003 a 2006. Observa-se as contratações "salta[m] de uma média anual de R\$ 68 milhões entre 1999 e 2002 para R\$ 1,3 bilhão no período 2003-2006" (OLIVEIRA FILHO, 2006, p. 30).

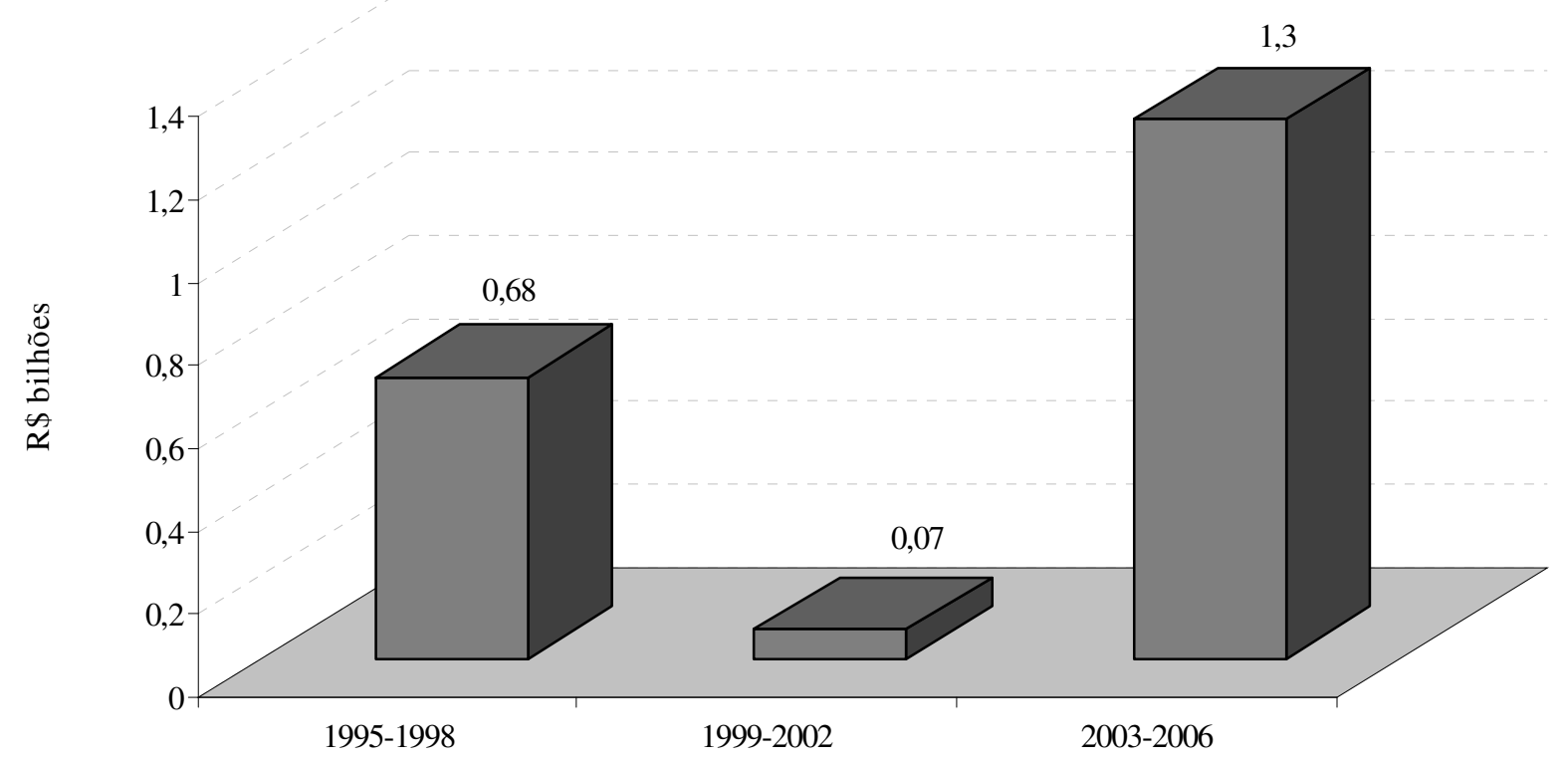

Fonte: Oliveira Filho (2006, p. 30).

Gráfico 1.11

Brasil: contratação média anual de recursos do FGTS para o saneamento básico (R\$ bilhões), de 1995 a 2006 
Por meio da análise da evolução das contratações de recursos do FGTS, ficou claro, portanto, que as regras de contingenciamento de crédito ao setor público tornaram-se uma das principais restrições à expansão dos investimentos em saneamento básico. Durante a década de 1990 e o início dos anos 2000, as regras eram mais rígidas. A partir de 2003, elas foram abrandadas - o que explica a dinâmica das contratações do FGTS ao longo do tempo -, mas continuaram a existir e a limitar os investimentos. Esse assunto será retomado no terceiro capítulo

\section{$\underline{3 \text { Problemas institucionais e financiamento de longo prazo }}$}

No início do presente capítulo, foi apontado que, devido às características do saneamento básico, é de fundamental importância a existência de um quadro institucional eficiente. Esse quadro, no entanto, está longe de ser alcançado no saneamento básico brasileiro. Além da ausência de uma política nacional - fato comentado na seção anterior - o setor enfrenta uma série de outras dificuldades institucionais. Tais dificuldades serão analisadas na presente seção, assim como a ausência de um mercado de financiamento de longo prazo bem desenvolvido. Finalizando o capítulo -, serão apontadas as principais conseqüências desses dois fatores.

\subsection{Fragmentacão das responsabilidades e dos recursos federais}

Até o início da década de 1970, um dos grandes problemas do saneamento básico brasileiro era a existência de vários órgãos da esfera federal exercendo funções dispersas relativas ao setor 
- por exemplo, o Departamento Nacional de Obras de Saneamento (DNOS), o Departamento Nacional de Endemias Rurais (DNERU) e o Departamento Nacional de Obras contra as Secas (DNOCS) -, sem, contudo, possuírem recursos e poderes suficientes para reduzir os problemas ou para coordenar uma ação mais integrada. A implantação do Planasa reverteu esse quadro, ao centralizar o financiamento e, conseqüentemente, as principais decisões do setor no BNH, vinculado ao Ministério do Interior.

Em 1985, contudo, o Ministério do Interior foi extinto, sendo todas as suas funções relacionadas ao saneamento básico transferidas para o então criado Ministério do Desenvolvimento Urbano e Meio Ambiente (MDU) - ou seja, esse ministério passou a ser responsável pelo BNH e pelo Planasa. Em 1986, foi a vez do BNH ser extinto. Todas as responsabilidades dessa instituição relacionadas ao setor - e à habitação - foram repassadas para a CEF. Conforme apontado anteriormente, iniciava-se aí um longo período de crise institucional do saneamento básico brasileiro - “o final dos anos 1980 e o início dos anos 1990 são marcados por uma série de mudanças administrativas (ministeriais) [...] que foram, na melhor das hipóteses, inócuas para setor saneamento" (FARIA; NOGUEIRA; MUELLER, 2005, p. 481)..

Em 1987, o MDU foi transformado em Ministério da Habitação, Urbanismo e Meio Ambiente (MHU), incorporando a Caixa Econômica Federal - que deixou de fazer parte do Ministério da Fazenda. Contudo, um ano depois (1988), o MHU foi transformado em Ministério do Bem-Estar Social (MBES) e a CEF voltou a vincular-se ao Ministério da Fazenda. Em 1989, o Ministério do Interior foi recriado, incorporando novamente as funções relativas ao saneamento básico - o MBES foi extinto.

O governo Collor, logo que assumiu, extinguiu o Ministério do Interior e “criou, em 1990, a Secretaria do Saneamento vinculada ao então criado Ministério da Ação Social (MAS). A antiga Superintendência de Campanhas de Saúde (Sucam) foi transformada em Fundação 
Nacional de Saúde (Funasa) e incorporou funções de outros órgãos também extintos" (TUROLLA, 2002, p. 14). A administração do FGTS ficou no Ministério do Trabalho e da Previdência Social - mas o MAS era o gestor da aplicação de seus recursos - e a CEF permaneceu na área fazendária, no Ministério da Economia, Fazenda e Planejamento.

Em 1993, o Ministério da Ação Social foi transformado em Ministério do Bem-Estar Social. Em 1995, com a extinção daquele órgão, as atribuições da política de saneamento passam à Secretaria de Política Urbana (Sepurb), ligada ao Ministério do Planejamento [...]. A partir de 1999, a Sepurb passou a se vincular à Secretaria do Desenvolvimento Urbano (Sedu), ligada à Presidência da República (TUROLLA, 2002, p. 14).

No início do governo Luís Ignácio Lula da Silva, a responsabilidade pelo saneamento básico passou para a então criada Secretaria de Saneamento Ambiental, vinculada ao também criado Ministério das Cidades (MCidades) - o que se mantém até hoje (2007). Esse ministério passou a ser o gestor da aplicação dos recursos do FGTS destinados ao setor e CEF continuou a desempenhar as funções de agente operador e de agente financeiro desses recursos - outras instituições financeiras também podem atuar como agente financeiro, desde que sejam devidamente habilitadas pela CEF.

Além das constantes mudanças de ministérios com a responsabilidade sobre o saneamento básico, havia (e ainda há) vários órgãos com competências relacionadas ao setor. Por exemplo, o Ministério da Saúde teve (e ainda tem) importância fundamental na condução de serviços de saneamento básico, principalmente apoiando os municípios autônomos de até trinta mil habitantes, as áreas rurais e indígenas e as periferias de grandes cidades, por meio da FUNASA.

Ainda em relação ao Ministério da Saúde, é importante apontar que, de acordo com o artigo 200 da Constituição de 1988, as ações de vigilância sanitária fazem parte das competências do Sistema Único de Saúde (SUS) - "executar as ações de vigilância sanitária e epidemiológica, bem como as de saúde do trabalhador". Diante desse fato, o SUS integra o Sistema Nacional de Vigilância Sanitária (SNVS), definido na Lei no 9.782, de 26 de janeiro de 1999, que também 
criou a Agência Nacional de Vigilância Sanitária (ANVISA) - agência reguladora responsável pelo estabelecimento de normas e pela execução das políticas, das diretrizes e das ações de vigilância sanitária.

Estão sujeitos ao controle e à fiscalização sanitária: (i) os serviços voltados para a atenção ambulatorial, tanto de rotina quanto de emergência; (ii) os serviços realizados em regime de internação; (iii) os serviços de apoio diagnóstico e terapêutico; (iv) os serviços que impliquem em incorporação de novas tecnologias e (v) as instalações físicas, equipamentos, tecnologias, ambientes e procedimentos envolvidos em todas as fases do processo de produção dos bens e produtos submetidos ao controle e fiscalização sanitária, incluindo a destinação dos respectivos resíduos, o que reduz o impacto destes sobre os serviços de saneamento - ou seja, diminui a incidência de águas contaminadas.

Alguns órgãos vinculados ao Ministério do Meio Ambiente também possuem competências relacionadas, direta ou indiretamente, ao saneamento, destacando-se a Secretaria de Recursos Hídricos, responsável pela formulação da Política Nacional de Recursos Hídricos, e a Agência Nacional de Água (ANA) - criada pela Lei nº 9.984 -, responsável pela implementação dessa política. Além disso, conforme foi apontado anteriormente, o Ministério do Meio Ambiente e o Ministério das Minas e Energias são parceiros do Ministério das Cidades na execução do Programa Nacional de Combate ao Desperdício de Água (PNCDA).

Deve-se apontar ainda que a Secretaria da Agricultura Familiar (SAF), vinculada ao Ministério do Desenvolvimento Agrário (MDA) e o Ministério da Integração Nacional também possuem ações relacionadas ao setor. A primeira por meio do Programa Nacional de Agricultura Familiar (Pronaf), que tem como uma de suas principais linhas de ação o financiamento da infraestrutura necessária para o desenvolvimento da agricultura familiar em determinada localidade zona rural. O Ministério da Integração Nacional, por sua vez, constrói, por intermédio da 
Companhia de Desenvolvimento dos Vales do São Francisco e Parnaíba (Codevasf), obras de saneamento básico - principalmente de abastecimento de água para atendimento comunitário ao longo das bacias dos rios São Francisco e Parnaíba.

Em um setor como o de saneamento básico, cujos serviços são essenciais ao bem-estar das pessoas e à economia como um todo - conforme ficou claro na introdução -, até é justificável a existência de vários órgãos com competências a ele relacionadas. Contudo, no caso brasileiro, isto ocorre em demasia, gerando uma fragmentação e uma superposição das responsabilidades, assim como uma pulverização dos recursos federais destinados ao setor.

\section{$\underline{\text { 3.2 Indefinicões regulatórias e problemas contratuais }}$}

De acordo com Rees (1998), um quadro regulatório “ideal” para o saneamento básico deve ser composto pelos seguintes elementos legais (p. 27):

(i) estrutura geral de leis - deve conter, entre outras definições, a divisão constitucional de responsabilidades entre as diferentes esferas de governo e a titularidade dos serviços;

(ii) leis ambientais e de recursos hídricos - definição de mecanismos de alocação e de proteção dos direitos sobre a água e de controle/fiscalização da conservação dos recursos;

(iii) lei específica do setor - definição dos termos para a autorização da participação privada no setor, dos poderes e capacidade do(s) regulador(es), dos instrumentos regulatórios, dos mecanismos de fiscalização e de consulta pública, entre outras - e

(iv) contratos individuais - no caso de concessões, define de que modo ocorrerá a participação privada, assim como, no caso brasileiros, a participação das CESBs. 
No Brasil, a maioria desses elementos já existe - estrutura geral de leis, contratos individuais e leis ambientais e de recursos hídricos. O grande problema é que ainda não foi promulgada uma lei específica para o saneamento básico. Além disso, as leis existentes não são claras em relação a alguns aspectos e se omitem em relação a outros. Ou seja, o setor apresenta sérias indefinições regulatórias - as principais consequiências dessas indefinições serão discutidas no final da seção.

O quadro 1.2 mostra as principais leis brasileiras relacionadas, direta ou indiretamente, ao saneamento básico. Uma análise detalhada dessas leis foge do escopo do presente trabalho. Interessa, na verdade, comentar suas principais definições referentes ao setor.

É importante destacar, primeiramente, que a Constituição de 1988 não definiu, de maneira clara, as atribuições de cada esfera governamental no que se refere ao setor. Isso porque, "a promoção de ações de saneamento enquadra-se constitucionalmente como atividade de responsabilidade comum da União, dos estados, do Distrito Federal e dos municípios”. No artigo 21 da Constituição, ficou estabelecido como competência da União "instituir diretrizes para o desenvolvimento urbano, inclusive habitação, saneamento básico e transportes urbanos”. Já no artigo 23, definiu-se que é uma competência conjunta da União, dos estados, do Distrito Federal e dos municípios, "promover programas de construção de moradias e melhoria das condições habitacionais e de saneamento básico” (MPO/SEPURB/IPEA, s.d., p. 16).

Ou seja, "fica evidente a sobreposição [...] de competência dos diferentes níveis de governo no setor de saneamento básico" (PARLATORE, 2000, p. 289). De acordo com Barat (1998), se for considerada "a abrangência do conceito de saneamento e suas inevitáveis interfaces com os aspectos relacionados à saúde pública, ao meio ambiente, assim como ao gerenciamento dos recursos hídricos, a definição de competências entre os níveis de governo torna-se ainda mais complexa" (p. 142). 
Quadro 1.2

Brasil: principais legislações relacionadas ao saneamento básico

\begin{tabular}{|c|c|}
\hline \multicolumn{2}{|r|}{ Constituição Federal de 1988} \\
\hline \multicolumn{2}{|r|}{ Lei no 8.666} \\
\hline$\rightarrow$ & “nome popular”: Lei de Licitações; \\
\hline$\rightarrow$ & ano de promulgação: 1993 \\
\hline$\rightarrow$ & $\begin{array}{l}\text { estabelece normas gerais sobre licitações e contratos administrativos pertinentes a obras, serviços - inclusive } \\
\text { de publicidade -, compras, alienações e locações no âmbito dos poderes da União, dos estados, do Distrito } \\
\text { Federal e dos municípios. }\end{array}$ \\
\hline \multicolumn{2}{|r|}{ Lei no 8.987} \\
\hline$\rightarrow$ & “nome popular”: Lei de Concessões; \\
\hline$\rightarrow$ & ano de promulgação: 1995 \\
\hline$\rightarrow$ & $\begin{array}{l}\text { dispõe sobre o regime de concessão e permissão da prestação de serviços públicos previsto no artigo } 175 \text { da } \\
\text { Constituição Federal. }\end{array}$ \\
\hline \multicolumn{2}{|r|}{ Lei no 9.074} \\
\hline$\rightarrow$ & ano de promulgação: 1995; \\
\hline$\rightarrow$ & $\begin{array}{l}\text { estabelece normas para outorga e prorrogações das concessões e permissões de serviços públicos e dá outras } \\
\text { providências. }\end{array}$ \\
\hline \multicolumn{2}{|r|}{ Lei no 9.433} \\
\hline$\rightarrow$ & "nome popular": Lei dos Recursos Hídricos ou Lei de Águas; \\
\hline$\rightarrow$ & ano de promulgação: 1997 \\
\hline$\rightarrow$ & institui a Política Nacional de Recursos Hídricos, cria o Sistema Nacional de Gerenciamento de Recursos \\
\hline & $\begin{array}{l}\text { Hídricos e regulamenta o inciso XIX do artigo } 21 \text { da Constituição Federal - inciso que define como } \\
\text { competência da União instituir sistema nacional de gerenciamento de recursos hídricos e definir critérios de } \\
\text { outorga de direitos de seu uso. }\end{array}$ \\
\hline \multicolumn{2}{|r|}{ Lei no 9.984} \\
\hline$\rightarrow$ & ano de promulgação: 2000 ; \\
\hline$\rightarrow$ & cria a Agência Nacional de Água (ANA), autarquia federal responsável pela implementação da Política \\
\hline & $\begin{array}{l}\text { Nacional de Recursos Hídricos e pela coordenação do Sistema Nacional de Gerenciamento de Recursos } \\
\text { Hídricos. }\end{array}$ \\
\hline \multicolumn{2}{|r|}{ Lei n⿳ 10.735} \\
\hline$\rightarrow$ & “nome popular”: Programa de Incentivo à Implementação de Projetos de Interesse Social (PIPS); \\
\hline$\rightarrow$ & ano de promulgação: 2003 \\
\hline$\rightarrow$ & $\begin{array}{l}\text { dispõe sobre o direcionamento de depósitos à vista captados pelas instituições financeiras para operações de } \\
\text { crédito destinadas à população de baixa renda e a microempreendedores. }\end{array}$ \\
\hline \multicolumn{2}{|r|}{ Lei no 11.079} \\
\hline$\rightarrow$ & “nome popular”: Lei de Parcerias Público-Privadas (PPP) \\
\hline$\rightarrow$ & ano de promulgação: 2004 \\
\hline$\rightarrow$ & $\begin{array}{l}\text { institui normas gerais para licitação e contratação de parceria público-privada no âmbito da administração } \\
\text { pública. }\end{array}$ \\
\hline \multicolumn{2}{|r|}{ Lei $n^{\circ} 11.107$} \\
\hline$\rightarrow$ & "nome popular": Lei dos Consórcios Públicos e Gestão Associada; \\
\hline$\rightarrow$ & ano de promulgação: 2005 \\
\hline$\rightarrow$ & $\begin{array}{l}\text { dispõe sobre normas gerais para a União, os Estados, o Distrito Federal e os Municípios contratarem } \\
\text { consórcios públicos para a realização de objetivos de interesse comum. }\end{array}$ \\
\hline
\end{tabular}


Tal fato deve-se, entre vários aspectos, ao artigo 200 da Constituição, que prevê a participação do Sistema Único de Saúde (SUS) na formulação da política e na execução das ações de saneamento básico, e à Lei de Recursos Hídricos (Lei no 9.433), que instituiu a Política Nacional de Recursos Hídricos e criou o Sistema Nacional de Gerenciamento de Recursos Hídricos, sendo que esses contam com a participação de membros provenientes das três esferas governamentais - União, estados e municípios. Para implementar a política de recursos hídricos foi criada a Agência Nacional de Água (ANA) - Lei no 9.984. Essas duas últimas leis afetam diretamente o saneamento básico, uma vez que disciplinam "o uso da água no que se refere à [sua] extração dos recursos (corpos) hídricos e à sua devolução (coleta e tratamento de esgoto)" (TONETO JÚNIOR, 2004, p. 205).

A Lei dos Recursos Hídricos pode ser considerada como um importante avanço do arcabouço legal-institucional relacionado às questões sócio-ambientais e, conseqüentemente, ao desenvolvimento sustentável. De acordo com Borsoi e Torres (1997), essa lei reúne os mais modernos princípios e instrumentos de gestão de águas, contribuindo para a implantação, no Brasil, de estruturas realmente eficientes e eficazes de planejamento e gerenciamento - “[...] vem ao encontro dos principais aspectos do modelo sistêmico de integração participativa, que requer instrumentos legais específicos para a sua implementação" (p. 1-2).

Além disso, considera a água como um bem/recurso econômico - finito, vulnerável e essencial para a conservação da vida e do meio ambiente -, definindo mecanismos que buscam um consumo mais racional desse recurso na tentativa de retardar sua escassez. Para Motta (2004),

sendo a água de uso múltiplo e, muitas vezes, excludente, a Lei de Recursos Hídricos surge para gerir a escassez de água e corrigir as externalidades negativas da sua poluição. Em situações similares, quando se disciplina o acesso a redes de telefonia e gasodutos, entre outros, o instrumento mais importante é o preço desse acesso. Assim, outra inovação da Lei de Recursos Hídricos foi a introdução do instrumento de cobrança pelo uso das águas para orientar o acesso aos nossos rios (p. 7). 
Retornando à Constituição de 1988, o artigo 30 estabelece que compete aos municípios "legislar sobre assuntos de interesse local, suplementar a legislação federal e a estadual no que couber e organizar e prestar, diretamente ou sob regime de concessão ou permissão, os serviços públicos de interesse local [...] que tem caráter essencial”. Ou seja, esse artigo garante aos municípios a titularidade dos serviços de saneamento básico, pois estes podem ser considerados como essenciais. Contudo, essa mesma Constituição, em seu artigo 25, estabelece que "os estados poderão, mediante lei complementar, instituir regiões metropolitanas, aglomerações urbanas e microrregiões, constituídas por agrupamentos de municípios limítrofes, para integrar a organização, o planejamento e a execução de funções públicas de interesse comum”.

A quem caberia, então, a titularidade dos serviços nos casos em que existe alguma interligação ou integração dos sistemas de distribuição com uma única fonte de captação regiões metropolitanas, aglomerados urbanos e microrregiões? Aos municípios, como defende o artigo 30, ou ao estado, por se tratar de funções públicas de interesse comum (artigo 25)? Esse é um dos principais questionamentos - juntamente com a necessidade de universalização dos serviços, a baixa eficiência dos prestadores e a falta de uma lei específica ao setor - que movem os principais debates sobre os problemas atuais do saneamento básico brasileiro.

Outro aspecto importante sobre a Constituição de 1988 é que essa instituiu, em seu artigo 175, a obrigação de serem promulgadas leis para reger os serviços públicos - que deveriam ser prestados diretamente ou sob regime de concessão ou permissão, sempre precedidos de licitação. Dentre outros aspectos, essas leis deveriam dispor sobre: (i) o regime das empresas concessionárias e permissionárias de serviços públicos, o caráter especial de seu contrato e de sua prorrogação, bem como as condições de caducidade, fiscalização e rescisão da concessão ou permissão; (ii) os direitos dos usuários; (iii) a política tarifária e (iv) a obrigação de manter 
serviço adequado. Nesse sentido, foram promulgadas a Lei $n^{\circ} 8.666$, a Lei $n^{\circ} 8.987$, a Lei $n^{\circ}$ 9.074 e, mais recentemente, a Lei no 11.079 .

A Lei $n^{\circ} 8.666$ - conhecida como Lei de Licitações - estabeleceu que qualquer obra, serviço, compra, alienação, concessão, permissão e locação realizados pela Administração Pública, quando contratados com terceiros, devem ser, obrigatoriamente, precedidos por uma licitação - que deve ser processada e julgada "em estrita conformidade com os princípios básicos da legalidade, da impessoalidade, da moralidade, da igualdade, da publicidade, da probidade administrativa, da vinculação ao instrumento convocatório, do julgamento objetivo e dos que lhes são correlatos". Nesse contexto, os agentes públicos não podem: (i) “admitir, prever, incluir ou tolerar", nos atos de convocação, cláusulas ou condições que "comprometam, restrinjam ou frustrem o seu caráter competitivo e estabeleçam preferências ou distinções em razão da naturalidade, da sede ou domicílio dos licitantes ou de qualquer outra circunstância impertinente ou irrelevante para o específico objeto do contrato" e (ii) "estabelecer tratamento diferenciado de natureza comercial, legal, trabalhista, previdenciária ou qualquer outra, entre empresas brasileiras e estrangeiras" $\left(\operatorname{artigo} 3^{\circ}\right)$

A Lei n ${ }^{\circ} 8.987$, ou Lei de Concessões, é a legislação que dispõe diretamente sobre o regime de concessão e permissão da prestação de serviços públicos - de acordo com o previsto no artigo 175 da Constituição Federal. A primeira definição da lei que deve ser apontada é a necessidade das concessões e as permissões serem formalizadas em um contrato, que tem de respeitar a lei e o edital de licitação (artigo $4^{\circ}$ ) - no sexto capítulo da lei, são apresentadas as cláusulas que devem constar em um contrato. Nesse contexto, é fundamental que se defina um agente regulador/fiscalizador desses contratos - o que é previsto na própria Lei de Concessões. No entanto, no saneamento básico, essa questão ainda foi solucionada. 
De acordo com Toneto Júnior (2004), a concessão pública deve ser encarada como um empreendimento público comercial, que concilie o interesse público de obter os serviços em condições adequadas (quantidade e qualidade) com o interesse privado de obter lucro com o negócio. "Pode-se dizer que a Lei de Concessões brasileira possui este objetivo e faz uma série de referências às questões acima: interesse público e rentabilidade privada”.

Para garantir o interesse público, a lei prevê uma série de itens: fiscalização do poder concedente $\left(\operatorname{art.~} 3^{\circ}\right)$, acesso à concessão por meio de licitação $\left(\operatorname{art.~} 4^{\circ}\right)$, prestação de serviços adequados (Capítulo II), possibilidades de cassação e caducidade da concessão, entre outros aspectos. Em relação à rentabilidade privada, vários são os pontos contemplados na lei [...]: possibilidades de revisão tarifária para manter o equilíbrio econômico-financeiro; possibilidade de exploração de fontes alternativas de receitas complementares ao objeto da concessão; proteção contra alterações unilaterais dos contratos de concessão, entre outras garantias (p. 194).

Destaca-se também, entre outras, suas definições em relação ao regime tarifário dos serviços públicos concedidos - as tarifas deverão ser fixadas pelo preço da proposta vencedora da licitação e preservadas pelas regras de revisão previstas nessa lei, no edital e no contrato, assim como poderão ser diferenciadas em função das características técnicas e dos custos específicos provenientes do atendimento aos distintos segmentos de usuários.

Conforme aponta Motta (2004), a Lei de Concessão “declarou que a aprovação de ajustes nas tarifas estaria a critério do outorgante da concessão. Conseqüentemente, estabelece riscos para qualquer concessionário quando não existe uma política tarifária clara e bem definida [como ocorre no saneamento básico]". A lei também especificou que os municípios apenas poderiam renovar o contrato de concessão por meio de licitações públicas - "as empresas estaduais poderiam participar desses leilões, mas competindo com operadores [...] do setor privado" (p. 6).

Além disso, ficou estabelecido, em seu artigo 42, que as concessões de serviços públicos outorgadas anteriormente à entrada de vigor da lei deverão ser consideradas válidas pelo prazo fixado no contrato ou no ato de outorga. O artigo 43, por sua vez, tornou obrigatória a extinção de todas as concessões de serviços públicos outorgados sem licitação na vigência da Constituição de 
1988 e de todas as concessões outorgadas sem licitação anteriormente a essa constituição, cujas obras ou serviços não tinham sido iniciados ou que se encontravam paralisados no momento em que a Lei entrou em vigor. "Os novos contratos devem conter termos totalmente diferentes e mais detalhados, não sendo mais admitido que os Municípios apenas entreguem os serviços para as empresas estaduais confiando numa regulação federal” (MCIDADES, 2005, p. 11-2).

Nesse contexto, encontra-se um dos grandes problemas existentes atualmente no saneamento básico brasileiro: muitos dos contratos firmados pelos municípios e pelas CESBs encontram-se vencidos, mas o(s) serviço(s) continua(m) sendo prestado(s). Ao mesmo tempo, em muitos municípios nem existe o contrato de concessão - principalmente naqueles que surgiram de desdobramentos de antigos municípios que haviam concedido o serviço para as companhias. Além disso, conforme aponta Moreira (1998), em grande parte dos casos, os contratos apresentam condições precárias, sem a definição adequada das obrigações, direitos e padrões da prestação dos serviços, assim como estruturas e mecanismos de controle, fiscalização e regulação dos serviços por parte dos municípios (poder concedente) sobre os prestadores (p. 204-5).

$\mathrm{Na}$ tentativa de solucionar, pelo menos em parte, esse problema, algumas CESBs conseguiram renovar vários contratos de concessão, mas não da forma prevista pela legislação. Como a maioria das concessões às CESBs foi efetivada nos anos 1970, com um prazo máximo de vinte e cinco anos (em geral, vinte), "elas tendem a estar vencidas, não havendo uma situação uniforme perante as CESBs. Algumas relatam terem logrado renovar suas concessões por mais 20 anos", [...], porém não através de licitações", desrespeitando os aspectos estabelecidos na Lei de Licitações, na Lei de Concessões e na Lei nº 9.074 (MOREIRA, s.d., p. 6).

Tais problemas são ilustrados na tabela 1.5. Observa-se que, do total dos municípios constantes na amostra do SNIS em 2004, em 13,4\% as concessões (abastecimento de água) estão 
vencidas e em $7,5 \%$ o serviço é prestado sem concessão ${ }^{20}$. Destaca-se, negativamente, os casos das CESBs de Roraima (CAER), Rondônia (CAERD) e Amapá (CAESA) e da autarquia do Acre (DEAS), com uma grande proporção de municípios sem concessões, e das CESBs do Rio Grande do Norte (CAERN), Paraíba (CAGEPA), Alagoas (CASAL), Sergipe (DESO) e Rio de Janeiro (CEDAE), com grande parcela de suas concessões vencidas.

Complementando a Lei de Concessões, a Lei $\mathrm{n}^{\mathrm{o}} 9.074$ estabelece normas para outorga e prorrogações das concessões e permissões de serviços públicos. Apesar de tratar de forma mais detalhada dos serviços de energia elétrica, algumas definições estabelecidas nessa lei são de relevante importância para o setor de saneamento básico. Em seu segundo artigo, estabeleceu que é vedado à União, aos Estados, ao Distrito Federal e aos Municípios executarem obras e serviços públicos por meio de concessão e permissão, sem lei que lhes autorize e fixe os termos respeitadas as definições da Lei de Concessões -, dispensada a lei autorizativa nos casos de saneamento básico e limpeza urbana. Além disso, estabeleceu - em seu artigo 35 - que a concessão de qualquer benefício tarifário somente poderá ser atribuída a uma classe ou coletividade de usuários dos serviços, vedado, sob qualquer pretexto, o benefício singular.

A Lei $n^{\circ} 11.079$ - Lei de Parcerias Público-Privadas - também complementa a Lei de Concessões. Deve-se apontar, primeiramente, que ela institui normas gerais sobre parcerias público-privadas, no âmbito dos poderes da União, dos estados, do Distrito Federal e dos municípios. Para a lei, parceria público-privada (PPP) é o contrato administrativo de concessão, na modalidade patrocinada ou administrativa. Concessão patrocinada é a concessão de serviços públicos ou de obras públicas de que trata a Lei de Concessões, quando envolver, adicionalmente à tarifa cobrada dos usuários, contraprestação pecuniária do parceiro público ao parceiro privado.

\footnotetext{
${ }^{20}$ A metodologia do Sistema Nacional de Informação sobre Saneamento (SNIS), a representatividade de sua amostra e seus principais problemas serão discutidos de forma mais detalhada no terceiro capítulo.
} 
Concessão administrativa é o contrato de prestação de serviços de que a Administração Pública seja a usuária direta ou indireta, ainda que envolva execução de obra ou fornecimento e instalação de bens.

Tabela 1.5

Brasil: situação contratual (abastecimento de água), segundo a amostra do SNIS (2004)

\begin{tabular}{|c|c|c|c|c|c|c|c|}
\hline \multirow{2}{*}{$\begin{array}{l}\text { Prestador/ } \\
\text { Região }\end{array}$} & \multirow{2}{*}{\begin{tabular}{|c|}
$\begin{array}{c}\text { Municípios } \\
\text { Atendidos } \\
\text { (Água) }\end{array}$ \\
\end{tabular}} & \multicolumn{2}{|c|}{ Concessão em Vigor } & \multicolumn{2}{|c|}{ Concessão Vencida } & \multicolumn{2}{|c|}{ Concessão Inexistente } \\
\hline & & Municípios & $\%$ do Total & Municípios & $\%$ do Total & Municípios & $\%$ do Total \\
\hline CAER/RR & 15 & 1 & 6,7 & 0 & 0,0 & 14 & 93,3 \\
\hline CAERD/RO & 37 & 3 & 8,1 & 0 & 0,0 & 34 & 91,9 \\
\hline CAESA/AP & 14 & 0 & 0,0 & 0 & 0,0 & 14 & 100,0 \\
\hline COSANPA/PA & 59 & 48 & 81,4 & 0 & 0,0 & 11 & 18,6 \\
\hline DEAS/AC & 17 & 0 & 0,0 & 0 & 0,0 & 17 & 100,0 \\
\hline SANEATINS/TO & 118 & 118 & 100,0 & 0 & 0,0 & 0 & 0,0 \\
\hline AGESPISA/PI & 142 & 81 & 57,0 & 32 & 22,5 & 29 & 20,4 \\
\hline CAEMA/MA & 140 & 89 & 63,6 & 37 & 26,4 & 14 & 10,0 \\
\hline CAERN/RN & 147 & 42 & 28,6 & 63 & 42,9 & 42 & 28,6 \\
\hline CAGECE/CE & 148 & 115 & 77,7 & 32 & 21,6 & 1 & 0,7 \\
\hline CAGEPA/PB & 171 & 40 & 23,4 & 115 & 67,3 & 16 & 9,4 \\
\hline CASAL/AL & 77 & 6 & 7,8 & 53 & 68,8 & 18 & 23,4 \\
\hline COMPESA/PE & 169 & 166 & 98,2 & 0 & 0,0 & 3 & 1,8 \\
\hline DESO/SE & 71 & 26 & 36,6 & 31 & 43,7 & 14 & 19,7 \\
\hline EMBASA/BA & 349 & 332 & 95,1 & 17 & 4,9 & 0 & 0,0 \\
\hline CAESB/DF & 1 & 1 & 100,0 & 0 & 0,0 & 0 & 0,0 \\
\hline SANEAGO/GO & 223 & 179 & 80,3 & 34 & 15,2 & 10 & 4,5 \\
\hline SANESUL/MS & 68 & 66 & 97,1 & 0 & 0,0 & 2 & 2,9 \\
\hline CEDAE/RJ & 64 & 23 & 35,9 & 32 & 50,0 & 9 & 14,1 \\
\hline CESAN/ES & 52 & 49 & 94,2 & 0 & 0,0 & 3 & 5,8 \\
\hline COPASA/MG & 561 & 561 & 100,0 & 0 & 0,0 & 0 & 0,0 \\
\hline SABESP/SP & 368 & 368 & 100,0 & 0 & 0,0 & 0 & 0,0 \\
\hline CASAN/SC & 216 & 176 & 81,5 & 15 & 6,9 & 25 & 11,6 \\
\hline CORSAN/RS & 318 & 300 & 94,3 & 12 & 3,8 & 6 & 1,9 \\
\hline SANEPAR/PR & 342 & 290 & 84,8 & 44 & 12,9 & 8 & 2,3 \\
\hline Norte & 260 & 170 & 65,4 & 0 & 0,0 & 90 & 34,6 \\
\hline Nordeste & 1.414 & 897 & 63,4 & 380 & 26,9 & 137 & 9,7 \\
\hline Centro-Oeste & 292 & 246 & 84,2 & 34 & 11,6 & 12 & 4,1 \\
\hline Sudeste & 1.045 & 1.001 & 95,8 & 32 & 3,1 & 12 & 1,1 \\
\hline Sul & 876 & 766 & 87,4 & 71 & 8,1 & 39 & 4,5 \\
\hline Brasil & 3.887 & 3.079 & 79,2 & 521 & 13,4 & 292 & 7,5 \\
\hline
\end{tabular}

Fonte: SNIS (2004). Elaboração própria. 
No caso do saneamento básico, por meio de uma PPP, os riscos de construção e operação seriam transferidos para o setor privado - o que poderia garantir uma gestão eficiente - e o setor público compartilharia o risco de demanda - o que poderia viabilizar o investimento. A lei prevê a criação de um fundo fiduciário para garantir o cumprimento das obrigações assumidas pelo setor público. Além disso, suas contraprestações podem ser liquidadas em favor da instituição que financiou o projeto. Deve-se destacar, ainda, que o pagamento dos créditos da PPP podem ser vinculadas a receitas e/ou instituídos fundos especiais - respeitando a proibição constitucional de vinculação de impostos - e que as garantias oferecidas ao parceiro privado podem ser tomadas como garantias colaterais para os financiadores (FIOCCA, 2004).

Do conjunto de leis apresentadas no quadro 1.2, resta comentar duas: (i) a Lei $\mathrm{n}^{\mathrm{o}} 10.735 \mathrm{e}$ (ii) a Lei no 11.107. Em relação à primeira lei, é importante apontar que, ao determinar que uma parcela dos depósitos à vista das instituições financeiras deve ser direcionada para operações de crédito destinadas à população de baixa renda - e a microempreendedores -, ela ampliou as possibilidades de financiamento de investimentos em saneamento básico voltados para esse segmento da população.

Além disso, essa lei autorizou o poder executivo federal a instituir o Programa de Incentivo à Implementação de Projetos de Interesse Social (PIPS), voltado à implementação de projetos estruturados na área de desenvolvimento urbano em infra-estrutura, nos segmentos de saneamento básico, energia elétrica, gás, telecomunicações, rodovias, sistemas de irrigação e drenagem, portos e serviços de transporte em geral, habitação, comércio e serviços. Tal incentivo dar-se-á por meio de Fundos de Investimento Imobiliário (FII) e de Fundos de Investimento em Direitos Creditórios (FIDC), ambos lastreados em recebíveis originados de contratos de compromisso de compra, de venda, de aluguéis e de taxas de serviços, provenientes de financiamento de projetos sociais, com participação dos setores público e privado - a esses 
fundos são aplicadas as regras estabelecidas pelo Conselho Monetário Nacional (CMN) e pela Comissão de Valores Mobiliários (CVM).

O objetivo básico desse programa é facilitar o acesso à moradia e à universalização da infra-estrutura. Os recursos do PIPS devem ser destinados ao financiamento, pelo prazo máximo de sessenta meses, de até $35 \%$ do valor total de cada projeto. As instituições financeiras poderão comprar cotas dos FIIs e dos FIDCs, que também poderão contar com outros tipos de recursos por exemplo, da União, com o objetivo de financiar os projetos de interesse social.

Finalmente, a Lei n ${ }^{\circ} 11.107$ - ou simplesmente Lei dos Consórcios Públicos e Gestão Associada - dispõe sobre normas gerais para a União, os Estados, o Distrito Federal e os municípios contratarem consórcios públicos para a realização de objetivos de interesse comum. De acordo com essa lei, os consórcios públicos poderão outorgar concessão, permissão ou autorização de obras ou serviços públicos. Ou seja, é possível a celebração de um consórcio municipal para a provisão de serviços de saneamento básico. O prestador do(s) serviço(s) poderia ser: (i) um já existente em algum desses municípios, (ii) uma nova entidade, criada com esse objetivo, ou (iii) um concessionário - seja ele público (CESBs, por exemplo) ou privado.

\subsection{Poucas fontes alternativas de financiamento de longo prazo}

Conforme foi apontado no início do capítulo, os investimentos em saneamento básico têm altas escalas de inversão - redes de distribuição e estações de tratamento - e retornos de longa maturação. Dessa forma, para que os investimentos sejam realizados, é fundamental que exista um mercado de financiamento de longo prazo bem desenvolvido - seja por meio de instituições financeiras, seja por meio do mercado de capitais (ou ambos). 
No Brasil, os recursos financeiros de longo prazo para a realização de investimentos sempre foram obtidos no exterior ou junto aos fundos de poupança compulsória - uma vez que, historicamente, o país nunca apresentou um mercado de capitais desenvolvido. Destaca-se, nesse sentido, o papel desempenhado pelo BNDES, no financiamento de empreendimentos industriais e de infra-estrutura em geral - utilizando, para isso, principalmente os recursos do Fundo de Amparo do Trabalhador (FAT). No caso específico do saneamento básico, a análise realizada ao longo do presente capítulo, mostrou o papel desempenhado, inicialmente, pelo BNH e, depois, pela CEF - com recursos externos, do OGU e do FGTS.

Atualmente, a situação é praticamente a mesma. O mercado de capitais brasileiro continua pouco desenvolvido e não há muitas experiências de sua utilização para investimentos em saneamento básico. Os prestadores de serviços de saneamento básico pleiteiam recursos junto ao BNDES ou, principalmente, à CEF. As únicas mudanças relevantes foram: (i) algumas instituições financeiras particulares passaram a poder emprestar recursos do FGTS para empreendimentos em saneamento básico - desde que sejam devidamente aprovadas pela CEF e respeitem as regras de contingenciamento de crédito - e (ii) aumentou, relativamente, os casos de estados e municípios que obtiveram empréstimos externos diretamente, junto a agências multilaterais de crédito, como o Banco Mundial (BIRD) e o Banco Interamericano de Desenvolvimento (BID) - segundo Motta (2004), o aporte das agências multilaterais, entre 2001 e 2003, "foi expressivo, atingindo quase $30 \%$ do total de investimentos em saneamento no Brasil [no período]" (p. 10).

No decorrer do presente capítulo, o papel da CEF no financiamento do setor foi, várias vezes, comentado. Na seção 2.4, analisou-se, inclusive, a evolução dos recursos do FGTS aplicados no setor - lembrando que a CEF atua com agente gestor e financeiro desses recursos. Dessa forma, é importante comentar, agora, alguns aspectos relacionados à participação do 
BNDES no setor. Primeiramente, deve-se apontar que essa instituição iniciou suas operações com saneamento em 1996. Até 2006, já tinha apoiado estados, companhias estaduais de capital fechado ou aberto, municípios com serviços autônomos e concessionárias privadas - naquele ano, sua carteira referente ao setor era de aproximadamente R \$ 5,4 bilhões (GASPAR, 2006).

As modalidades de apoio do BNDES são as seguintes: (i) contratos de financiamento; (ii) subscrição de debêntures públicas ou privadas; (iii) operações indiretas e (iv) financiamento à contrapartida de projetos apoiados por organismo multilaterais. Por último, é importante apontar as garantias exigidas pela instituição: (i) garantias reais; (ii) seguro; (iii) vinculação de recebíveis; (iv) fiança bancária e (v) parcela do Fundo de Participação Municipal (FPM), no caso de municípios, ou do Fundo de Participação Estadual (FPE), no caso de estados (GASPAR, 2006).

\section{$\underline{\text { 3.4 Acões coordenadas, participação privada e investimentos (consideracões finais) }}$}

Ao longo do presente capítulo, foram apontados vários problemas institucionais existentes, atualmente, no saneamento básico brasileiro. Resta comentar seus principais impactos negativos sobre o setor.

Primeiramente, deve-se destacar que, em um setor como o de saneamento básico, cujos serviços são essenciais ao bem-estar das pessoas e à economia como um todo, até é justificável a existência de vários órgãos com competências a ele relacionadas. Contudo, no caso brasileiro, isso ocorre em demasia, gerando uma fragmentação das responsabilidades e, conseqüentemente, dos recursos federais destinados ao setor, o que acaba prejudicando a adoção de ações coordenadas que possam melhorar a qualidade dos investimentos - o que é fundamental em um contexto de poucas fontes alternativas de financiamento de longo prazo e de contingenciamento 
de crédito ao setor público, ou seja, de recursos restritos. Nesse sentido, mesmo que os resultados das políticas "pontuais e desarticuladas" sejam relevantes - conforme ficará claro no segundo capítulo -, também é importante a implantação de uma política nacional articulada.

Outro problema institucional existente no setor, apontado anteriormente, é o grande número de concessões para as CESBs em condições irregulares - contratos vencidos ou inexistentes. A principal conseqüência negativa de tal situação seria um montante menor investido pelas companhias nos municípios com concessões irregulares, uma vez que estas enfrentariam riscos mais elevados do que em uma concessão adequada - os dados do gráfico 1.12 sinalizam que, pelo menos na média, isso realmente ocorre.

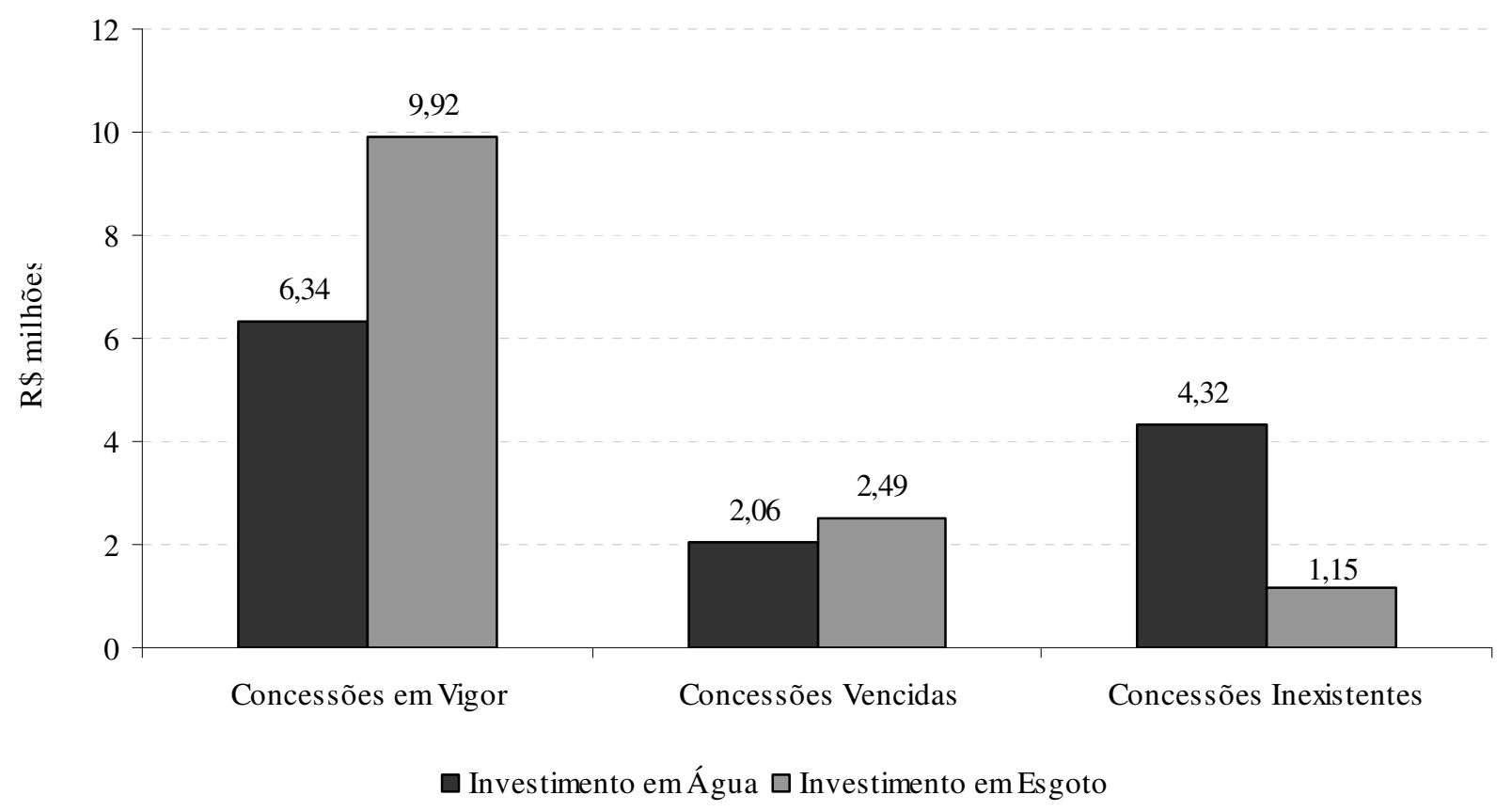

Fonte: Ministério das Cidades, SNIS (2004).

Gráfico 1.12

Saneamento básico no Brasil: investimento per capita realizado pelas CESBs (R\$ milhões por habitante), segundo a situação dos contratos de concessão (2004) 
Deve-se destacar também que, no quadro 1.2 foram apresentadas várias leis com definições relacionadas, direta ou indiretamente, ao saneamento básico brasileiro. Apesar da existência de todas essas leis, ainda persiste uma série de indefinições regulatórias no setor, o que torna fundamental a promulgação de uma lei específica que institua as diretrizes nacionais para a prestação desses serviços. Além da questão da titularidade dos serviços, tal lei deveria estabelecer os parâmetros em que se daria a prestação dos serviços - questão tarifária, por exemplo - e definir o agente regulador/fiscalizador, aspectos que viabilizariam o processo de concessões tanto para o setor privado como para as empresas públicas. Conforme destaca Motta (2004), as "indefinições regulatórias criam incertezas nos investidores privados e desestimulam os investimentos nas empresas estaduais com concessões prestes a encerrarem-se" (p. 8).

O importante é definir a titularidade e as regras, de modo que as incertezas sejam eliminadas e que as pendências hoje existentes sejam sanadas: concessões vencidas, prestação de serviços sem existência de concessões, concessões realizadas sem licitação (ilegais), entre outros aspectos (TONETO JÚNIOR; SAIANI, 2005, p. 10).

Apesar da Lei ${ }^{\circ} 9.074$ ter estabelecido que não é necessária uma lei autorizativa para a execução de obras e de serviços de saneamento básico por meio de concessão e permissão, uma lei específica a esse setor também é fundamental para atrair uma maior participação privada e, conseqüentemente, para viabilizar os investimentos necessários, devido às características próprias do setor e às vantagens de uma regulação eficiente diante de tais características.

\section{Participação privada no saneamento básico brasileiro}

Para o BNDES (1998b), "as restrições ao aumento do endividamento público, a crescente necessidade de recursos para investimentos no setor e a necessária agilidade para dar rápidas respostas aos clientes mostram um claro espaço para a participação da iniciativa privada" (p. 1). 
As empresas privadas tendem a desenvolver, em geral, estratégias bem distintas daquelas desenvolvidas pelas empresas públicas [...]. Isto porque, ao tomar decisões, o setor público esbarra numa série de limitações. A principal delas é o restrito orçamento para garantir investimentos e outras melhorias operacionais. A alternativa seria recorrer ao endividamento. Mas a capacidade de endividamento da empresa pública também não comporta o investimento necessário (BNDES, 1998b, p. 1).

Contudo, decorridos alguns anos da promulgação da Lei de Concessões (1995), ainda são relativamente poucas as concessões à iniciativa privada no setor. Ou seja, "o ritmo de entrada do setor privado não tem sido condizente com a informação veiculada no próprio mercado, quanto às possibilidades de retorno do investimento no setor de saneamento" (BNDES, 1998a, p. 10).

Por um lado, isso pode denotar pouca iniciativa das municipalidades em deflagrar processos de desestatização, devido ao impacto político negativo que tal ação pode resultar rejeição por parte dos eleitores - e/ou à permanência de certo grau de insegurança em relação ao processo - ausência de um quadro regulatório ideal para o setor. Por outro lado, pode denotar certa insegurança do próprio setor privado, em função da existência de indefinições regulatórias e da ausência de fontes alternativas de financiamento de longo prazo. Conforme aponta o BNDES (1999), “acredita-se que as indefinições acerca da titularidade dos serviços, além da ausência de estruturas de regulação, tenham atuado como fator de inibição a novas iniciativas privadas, uma vez que o retorno do investimento no setor é considerado atraente em muitas áreas” (p. 5).

A falta de regras claras também gerou conflitos, como o que ocorreu com a empresa Águas de Limeira, controlada pela construtora brasileira Norberto Odebrecht e pelo grupo francês Suez Ambiental, que formara a primeira concessionária privada de serviços de água e esgoto do Brasil. Em 1995, o consórcio ganhou a concessão em Limeira, no interior de São Paulo, mas ficou vários anos sem poder reajustar as tarifas, o que resultou numa disputa judicial com a prefeitura. Sem um claro marco legal, cada troca do comando municipal pode implicar disputas ou mesmo rupturas de contratos (FERNANDES JÚNIOR, 2006, p. 21).

A participação privada vem ocorrendo, principalmente, por meio de algumas concessões realizadas pelos municípios autônomos, "segmento que a iniciativa privada tem encontrado um melhor ambiente institucional para participar no setor de saneamento" (BNDES, 1998a, p. 7). O quadro 1.3 apresenta as concessões privadas em operação atualmente (2007). 


\section{Quadro 1.3}

Saneamento básico no Brasil: concessões privadas em operação (2007)

\begin{tabular}{|c|c|c|c|c|}
\hline Município(s) Atendido(s) & $\begin{array}{c}\text { População } \\
\text { Atendida }\end{array}$ & Modalidade & $\begin{array}{l}\text { Prazo } \\
\text { (Anos) }\end{array}$ & $\begin{array}{c}\text { Investimentos } \\
\text { Comprometidos } \\
\text { (R\$ Milhões) }\end{array}$ \\
\hline Guará & 20.300 & Plena & 25 & 6,00 \\
\hline Limeira & 262.000 & Plena & 30 & 170,21 \\
\hline Mairinque & 38.186 & Plena & 30 & 30,00 \\
\hline Mineiros do Tietê & 9.462 & Plena & 20 & 2,00 \\
\hline Mirassol & 48.312 & Plena & 5 & 0,75 \\
\hline Araçatuba & 231.050 & Esgoto & 21 & 17,00 \\
\hline Birigui & 40.000 & Água & 15 & 2,00 \\
\hline Birigui & 30.000 & Água & 15 & 3,10 \\
\hline Cajamar & 55.000 & Sub-Concessão Água & 14 & 3,50 \\
\hline Itu & 123.956 & Esgoto & 20 & 25,30 \\
\hline Jaú & 92.000 & Água & 21 & 10,00 \\
\hline Jaú & 92.000 & Esgoto & 25 & 29,13 \\
\hline Jundiaí & 289.103 & Esgoto & 20 & 40,00 \\
\hline Marília & 50.000 & Água & 20 & 3,88 \\
\hline Matão & 72.200 & Esgoto & 30 & 18,00 \\
\hline Mauá & 398.482 & Esgoto & 30 & 135,75 \\
\hline Ourinhos & 22.000 & Água & 17 & 1,75 \\
\hline Ribeirão Preto & 580.000 & Esgoto & 23 & 106,49 \\
\hline São Carlos & 25.000 & Água & 10 & 0,83 \\
\hline Araruama, Silva Jardim, Saquarema & 148.200 & Plena & 25 & 72,94 \\
\hline $\begin{array}{l}\text { Armação de Búzios, Arraial do Cabo, Cabo Frio, } \\
\text { Iguaba Grande, São Pedro da Aldeia }\end{array}$ & 489.340 & Plena & 25 & 419,06 \\
\hline Campos dos Goytacazes & 366.000 & Plena & 30 & 120,00 \\
\hline Guapimirim & 25.788 & Plena & 30 & 6,08 \\
\hline Niterói & 480.200 & Plena & 30 & 314,30 \\
\hline Petrópolis & 238.835 & Sub-Concessão Plena & 30 & 105,77 \\
\hline Nova Friburgo & 125.686 & Plena & 25 & 139,91 \\
\hline Santo Antônio de Pádua & 13.929 & Água & 30 & 3,29 \\
\hline Cachoeiro de Itapemirim & 183.969 & Plena & 30 & 60,00 \\
\hline Carlinda & 6.000 & Plena & 30 & 0,14 \\
\hline Cláudia & 10.150 & Plena & 30 & 0,18 \\
\hline Guarantã do Norte & 26.120 & Plena & 30 & 4,53 \\
\hline Matupá & 10.350 & Plena & 30 & 0,27 \\
\hline Nobres & 12.600 & Plena & 30 & 2,60 \\
\hline Primavera do Leste & 30.739 & Plena & 30 & 31,95 \\
\hline Sorriso & 68.000 & Plena & 30 & 35,50 \\
\hline Campo Grande & 804.902 & Plena & 30 & 332,98 \\
\hline Itapema & 31.510 & Plena & 25 & 48,00 \\
\hline Araújos & 5.280 & Plena & 30 & 1,19 \\
\hline Bom Sucesso & 15.709 & Plena & 25 & 3,09 \\
\hline Paraguaçu & 16.545 & Plena & 30 & 5,28 \\
\hline Paranaguá & 131.100 & Sub-Concessão Plena & 28 & 56,81 \\
\hline Novo Progresso & 4.400 & Plena & 30 & 1,20 \\
\hline Manaus & 1.100 .000 & Plena & 30 & $1.293,80$ \\
\hline
\end{tabular}

Fonte: Abcon. 
Embora, no caso dos municípios autônomos a situação institucional seja mais clara, [ainda] pesa o fato de algumas posições divergentes, relativas àqueles municípios localizados em regiões metropolitanas, aglomerados urbanos e microrregiões, por força de projetos de lei em tramitação no Congresso (BNDES, 1998a, p. 10).

De acordo com Moreira (s.d.), observa-se uma tendência, no Brasil, para as concessões "na ponta" nos grandes municípios - principalmente para a implantação de tratamento de esgotos - e um movimento de concessões plenas - água e esgoto - nos municípios de menor porte, notadamente no estado de São Paulo (p. 6). Segundo Parlatore (2000), há um grande interesse de empreiteiros de obras públicas, "motivados [...] pela expectativa de poder seguir construindo obras por meio de suas concessões". Além disso, é comum a constituição de consórcios de empreiteiras que incluem uma empresa estrangeira especializada em operação e gestão, suprindo a falta de experiência nacional. Deve-se apontar também que as concessões à iniciativa privada já realizadas "apresentam relativa diversidade de características quanto ao financiamento e às estruturas tarifárias" - em alguns casos o capital é exclusivamente aportado pelos sócios, em outros, são formuladas operações financeiras (p. 302).

\section{$\underline{\text { O novo marco regulatório para o setor }}$}

Em julho de 2006, o Senado aprovou o Projeto de Lei no 5.296/05 - ou Projeto de Lei $n^{\circ}$ 219 do Senado Federal. No início de 2007 (5 de janeiro), esse projeto foi sancionado pelo

Presidente da República. Ou seja, hoje (final de janeiro de 2007), o saneamento básico brasileiro já possui um novo marco regulatório.

O acordo em torno desse projeto de lei define uma regulamentação, mas deixa de estabelecer, deliberadamente, quem será o responsável pelos serviços de saneamento básico - estados ou municípios. Isso porque a questão aguarda julgamento no Supremo Tribunal Federal (STF). [...] Definido quem será o titular, o projeto de lei do Senado estabelece sua responsabilidade de planejar, regulamentar, fiscalizar e prestar ou contratar os serviços públicos de saneamento. [...] O novo marco regulatório deixa a propriedade dos ativos - represas, adutoras, encanamentos, estações de tratamento - a quem tem a titularidade, mas estabelece regras claras para os contratos de concessão dos 
serviços, inclusive o ressarcimento dos investimentos realizados pela concessionária, ao final do contrato ou em caso de rompimento. [Além disso], estabelece com precisão os direitos e deveres de todas as partes envolvidas: do detentor da titularidade, dos usuários e dos prestadores de serviços [...]. Assim, deverá estimular a competição no setor (FERNANDES JÚNIOR, 2006, p. 20-1).

Outras definições importantes do projeto são as seguintes: (i) criação de órgãos colegiados para exercerem o controle social (fiscalização); (ii) formulação de um plano de saneamento condição indispensável para validar os contratos de prestação dos serviços e para a delegação destes -; (iii) no caso de concessões onerosas, veda o repasse de recursos federais e financiamentos com recursos do FGTS e do FAT; (iv) institucionalização de um fundo de universalização - alocação de recursos públicos federais e financiamentos com recursos da União -; (v) os investimentos em ativos fixos realizados pelos prestadores poderão ser compensados com reduções do valor da Contribuição para o Financiamento da Seguridade Social (Cofins) e do Programa de Integração Social (PIS); (vi) respeito à Lei de Consórcios Públicos e Gestão Associada e (vii) em casos de cortes por inadimplência, obediência a prazos e critérios que preservem condições mínimas de manutenção da saúde das pessoas atingidas.

Especialistas apontam como falhas do novo marco regulatório a possibilidade do detentor da titularidade contratar serviços de saneamento básico sem licitação pública, o que poderá gerar acordos entre prefeitos e governadores para a entrega da prestação de serviços a empresas estaduais de saneamento. Além disso, o projeto de lei não define regras que estimulem os prestadores a buscarem ganhos de produtividade (FERNANDES JÚNIOR, 2006, p. 21). 


\section{II - DÉFICIT DE ACESSO AOS SERVIÇOS DE SANEAMENTO BÁSICO}

Em 2000, o Brasil possuía aproximadamente 9,9 milhões de domicílios sem acesso a abastecimento de água por rede geral - de acordo com o Censo Demográfico de 2000. No caso do esgoto, pouco menos de vinte milhões de domicílios não possuíam coleta por rede geral - se for considerado também o acesso à fossa séptica, o número de domicílios sem acesso a formas adequadas de esgotamento sanitário cai para aproximadamente treze milhões. Há, portanto, um sério déficit de acesso domiciliar aos serviços de saneamento básico no país.

Esse déficit distribui-se “de forma desigual pelo país” (BARAT, 1998, p. 145). É possível observar, por exemplo: (i) um sério desequilíbrio entre o número de domicílios servidos por rede de água e o número de domicílios que possuem rede coletora de esgoto (BNDES, 1996, p. 5); (ii) um menor acesso rural aos serviços e (iii) uma "concentração do melhor atendimento nos grandes centros, em detrimento da periferia e do interior" (BNDES, 1998b, p. 2). Além disso, conforme destacam Mejia et alii (2003), a proporção de domicílios com acesso aos serviços difere bastante de uma região para outra e "os mais pobres têm menor probabilidade de obter acesso a um nível adequado de serviços do que o restante da população" (p. 3). Portanto, “o padrão de investimentos do setor não logrou universalizar os serviços tanto em termos regionais quanto distributivos" (MOTTA, 2004, p. 3).

Nesse contexto, o objetivo principal do presente capítulo é caracterizar o déficit de acesso domiciliar aos serviços de saneamento básico no Brasil. Por meio de análises descritivas (primeira seção) e econométricas (segunda seção), será avaliado se o déficit de acesso relaciona-se a: (i) duas variáveis estaduais - localização geográfica (grandes regiões) e PIB per capita -; (ii) quatro variáveis municipais - tamanho da população (porte), taxa de urbanização, renda municipal per capita mensal e tipos de municípios (capitais estaduais ou 
capital Federal, municípios do interior e municípios pertencentes a uma região metropolitana) - e (iii) três variáveis domiciliares - localização do domicílio (urbano ou rural), renda domiciliar mensal e renda domiciliar per capita mensal. Para a realização de tais análises, serão utilizadas as informações disponibilizadas pela Pesquisa Nacional de Saneamento Básico (PNSB) de 2000 e, principalmente, pelo Censo Demográfico de 2000.

Complementando o estudo, será analisada a evolução da cobertura dos serviços do início da década de 1970 até 2004 (terceira seção) - levando em consideração algumas das variáveis estaduais, municipais e domiciliares apresentadas anteriormente. Serão utilizadas as informações disponibilizadas pelos Censos Demográficos de 1970, 1980, 1991 e 2000 e pelas Pesquisas Nacionais por Amostra de Domicílios (PNAD) de 2001, 2002, 2003 e 2004.

Essa análise permitirá avaliar: (i) se as características do déficit de acesso domiciliar são recentes ou já existiam em 1970 e (ii) se está ocorrendo uma convergência dos índices de acesso domiciliar - ou seja, se dentro das categorias analisadas, está diminuindo a diferença entre os melhores e os piores índices de acesso Além disso, será possível averiguar qual tipo de política pública adotada para o setor gerou investimentos que conseguiram atingir as localidades mais necessitadas - as políticas adotadas no período foram comentadas no primeiro capítulo.

Finalizando o capítulo, serão discutidas as principais causas (determinantes) e consequiências das características do déficit de acesso domiciliar aos serviços de saneamento básico (quarta seção). Além das análises realizadas ao longo do capítulo, tal discussão também levará em conta outras informações disponibilizadas pelo Censo Demográfico de 2000 e pela Pesquisa de Orçamentos Familiares (POF) 2002-2003.

Antes de começar as análises, é importante fazer uma ressalva em relação aos Censos Demográficos e às PNADs: por se tratarem de pesquisas domiciliares, as informações dependem do "entendimento do morador sobre a natureza dos serviços disponíveis em seu 
próprio domicílio", o que pode prejudicar, em parte a qualidade das informações ${ }^{1}$. Além disso, as características domiciliares são investigadas apenas nos "domicílios particulares permanentes ocupados, o que significa dizer que [aproximadamente] nove milhões de domicílios classificados como fechados, vagos ou de uso ocasional e onde não são encontrados moradores não respondem ao questionário" (PNSB, 2000, p. 30). Uma vez que o IBGE toma medidas para contorná-los e que serão utilizadas amostras relativamente grandes, tais problemas não prejudicarão as análises do presente capítulo.

\section{Caracterizacão do déficit de acesso}

De acordo com o Censo Demográfico de 2000, 78\% dos domicílios brasileiros possuíam, naquele ano, abastecimento de água por rede geral, 52\% estavam ligados à rede geral de esgoto e em $16 \%$ o esgotamento sanitário se dava por meio de fossa séptica. Tais indicadores são apresentados na tabela 2.1, na qual também é possível observar outras importantes características do acesso domiciliar a serviços de saneamento básico no Brasil:

(i) existência de profundos desequilíbrios inter-regionais - por exemplo, região Norte com os piores índices de acesso por rede geral e região Sudeste com os melhores;

(ii) pior desempenho da coleta de esgoto por rede geral - em todas as regiões, com exceção do Sudeste, o índice de acesso a esse serviço, por rede geral, é menos da metade do índice de abastecimento de água;

(iii) tendência de aumento dos índices de acesso aos serviços por rede geral à medida que se eleva o PIB per capita;

\footnotetext{
1 "Nem sempre o entrevistado informa adequadamente sobre as condições de saneamento. [Por exemplo], são comuns casos de domicílios com algum tipo de encanamento, de água ou esgoto, ser confundido pelo entrevistado como sendo ligação à rede geral de esgoto ou de água” (PNSB, 2000, p. 29).
} 
(iv) significativa redução dos índices de acesso por rede geral do Sudeste ao excluir os dados de São Paulo da região, o mesmo ocorrendo com o Centro-Oeste ao excluir o Distrito Federal - nesse último caso, deve-se destacar a sensível diferença do índice de acesso a coleta de esgoto $^{2}$;

Tabela 2.1

Brasil: proporção de domicílios com acesso a serviços de saneamento básico (\% dos domicílios) e PIB per capita, segundo as grandes regiões, o Estado de São Paulo e o Distrito Federal (2000)

\begin{tabular}{|c|c|c|c|c|c|c|}
\hline \multirow[b]{2}{*}{ Serviço / Região } & \multirow{2}{*}{$\begin{array}{c}\text { Água } \\
\text { (Rede Geral) }\end{array}$} & \multicolumn{3}{|c|}{ Esgoto } & \multirow{2}{*}{$\begin{array}{c}\text { Água e } \\
\text { Esgoto } \\
\text { (Rede Geral) }\end{array}$} & \multirow{2}{*}{$\begin{array}{c}\text { PIB } \\
\text { per capita } \\
(\mathbf{R} \$)\end{array}$} \\
\hline & & $\begin{array}{l}\text { Rede } \\
\text { Geral }\end{array}$ & $\begin{array}{c}\text { Fossa } \\
\text { Séptica }\end{array}$ & $\begin{array}{c}\text { Rede Geral ou } \\
\text { Fossa Séptica }\end{array}$ & & \\
\hline Norte & 48,24 & 11,36 & 30,29 & 41,66 & 9,64 & 3.871 \\
\hline Nordeste & 66,73 & 33,06 & 16,71 & 49,77 & 31,37 & 2.998 \\
\hline Centro-Oeste (1) & 73,34 & 35,10 & 7,82 & 42,92 & 33,71 & 6.498 \\
\hline Centro-Oeste (2) & 70,11 & 24,34 & 8,17 & 32,52 & 22,73 & --- \\
\hline Distrito Federal & 88,72 & 84,29 & 6,2 & 90,49 & 83,9 & 14.224 \\
\hline Sudeste (3) & 88,45 & 74,98 & 9,02 & 84,00 & 73,48 & 8.713 \\
\hline Sudeste (4) & 83,12 & 67,13 & 11,69 & 78,82 & 64,56 & --- \\
\hline São Paulo & 93,51 & 82,27 & 6,54 & 88,81 & 81,75 & 9.919 \\
\hline Sul & 80,11 & 30,69 & 34,75 & 65,44 & 29,87 & 7.650 \\
\hline Brasil & 77,99 & 51,73 & 16,24 & 67,97 & 50,29 & 6.430 \\
\hline
\end{tabular}

Fonte: IBGE, Censo Demográfico de 2000 e PIB Municipal. Elaboração própria.

(1) Centro-Oeste incluindo o Distrito Federal.

(2) Centro-Oeste excluindo o Distrito Federal.

(3) Sudeste incluindo São Paulo.

(4) Sudeste excluindo São Paulo.

(v) considerando apenas São Paulo, observa-se que os índices de acesso por rede geral desse estado são superiores aos apresentados por todas as regiões, excetuando-se a coleta de esgoto, cujo índice de acesso era inferior ao do Distrito Federal;

(vi) existência de domicílios apenas com coleta de esgoto ligada à rede geral, o que, inicialmente, não era esperado - tal fato pode ser constatado comparando os índices de acesso a esgoto por rede geral com os índices de acesso simultâneo a água e a esgoto

\footnotetext{
${ }^{2}$ Na coleta dos dados, observou-se que o Estado de São Paulo e o Distrito Federal apresentam, ao mesmo tempo, os maiores PIBs per capita e os melhores indicadores de cobertura por rede geral. Assim, sempre que possível, também serão avaliados seus indicadores separadamente, retirando suas influências sobre os indicadores regionais, o que permitirá uma visualização mais clara da atual situação do setor.
} 
por rede geral, ou seja, comparando os valores da terceira coluna da tabela $2.1 \mathrm{com}$ os da penúltima coluna - e

(vii) aumento significativo da cobertura de esgoto ao considerar também os domicílios com fossa séptica - deve-se destacar os casos das regiões Norte e, surpreendentemente, Sul, com índices de fossa séptica superiores aos de coleta de esgoto por rede geral.

Observa-se, portanto, que o Brasil apresenta um sério déficit de acesso domiciliar aos serviços de saneamento básico. Deve-se destacar também que o déficit não se distribui de maneira uniforme ao longo do país, o que ficará mais claro nas análises a seguir.

\subsection{Caracterização estadual do déficit de acesso}

A distribuição não uniforme do déficit, apontada anteriormente, também pode ser observada ao analisar índices estaduais de acesso domiciliar aos serviços. A tabela 2.2 apresenta a proporção de domicílios com acesso aos serviços de saneamento básico em todos os estados brasileiros e no Distrito Federal. Em relação ao abastecimento de água por rede geral, o estado que possuía, em 2000, uma maior proporção de domicílios com acesso era São Paulo e o que possuía uma menor proporção era Rondônia - diferença de aproximadamente sessenta e dois pontos percentuais entre os dois.

Em relação à coleta de esgoto por rede geral, o Distrito Federal possuía a maior proporção de domicílios com acesso e Tocantins a menor - diferença de aproximadamente setenta e nove pontos percentuais. Já em relação à fossa séptica, o Piauí possuía a maior proporção de domicílios com acesso e Minas Gerais a menor - diferença de aproximadamente cinquienta e nove pontos percentuais. 
A tabela 2.2 também apresenta um ranking estadual de acesso aos serviços de saneamento básico, por meio do qual é possível comparar a cobertura em cada um dos estados brasileiros e no Distrito Federal. É interessante observar que:

(i) as cinco primeiras posições do ranking de acesso a abastecimento de água por rede geral são ocupadas por três estados do Sudeste, um do Sul e pelo Distrito Federal; já as cinco últimas, são ocupadas por quatro estados do Norte e um do Nordeste;

Tabela 2.2

Brasil: proporção de domicílios com acesso a serviços de saneamento básico (\% do total), segundo as grandes regiões e os Estados, e ranking estadual (2000)

\begin{tabular}{|c|c|c|c|c|c|c|c|}
\hline \multirow[t]{2}{*}{ Região } & \multirow[t]{2}{*}{ Estado } & \multicolumn{2}{|c|}{$\begin{array}{l}\text { Abastecimento de } \\
\text { Água (Rede Geral) }\end{array}$} & \multicolumn{2}{|c|}{$\begin{array}{c}\text { Coleta de Esgoto } \\
\text { (Rede Geral) }\end{array}$} & \multicolumn{2}{|c|}{ Fossa Séptica } \\
\hline & & $\%$ & Posição & $\%$ & Posição & $\%$ & Posição \\
\hline \multirow{7}{*}{ Norte } & Acre & 35,7 & $26^{\circ}$ & 19,5 & $17^{\circ}$ & 14,5 & $17^{\circ}$ \\
\hline & Amapá & 50,3 & $24^{\circ}$ & 6,4 & $24^{\circ}$ & 19,7 & $11^{\circ}$ \\
\hline & Amazonas & 59,4 & $22^{\circ}$ & 20,3 & $15^{\circ}$ & 30,7 & $6^{\circ}$ \\
\hline & Pará & 42,0 & $25^{\circ}$ & 7,4 & $23^{\circ}$ & 34,9 & $5^{\circ}$ \\
\hline & Rondônia & 30,2 & $27^{\circ}$ & 3,7 & $26^{\circ}$ & 19,6 & $12^{\circ}$ \\
\hline & Roraima & 77,0 & $10^{\circ}$ & 11,1 & $21^{\circ}$ & 58,4 & $2^{\circ}$ \\
\hline & Tocantins & 65,2 & $18^{\circ}$ & 3,0 & $27^{\circ}$ & 23,1 & $9^{\circ}$ \\
\hline \multirow{9}{*}{ Nordeste } & Alagoas & 78,5 & $7^{\circ}$ & 22,8 & $13^{\circ}$ & 13,6 & $18^{\circ}$ \\
\hline & Bahia & 69,0 & $15^{\circ}$ & 34,6 & $7^{\circ}$ & 10,2 & $22^{\circ}$ \\
\hline & Ceará & 60,5 & $20^{\circ}$ & 21,7 & $14^{\circ}$ & 16,4 & $14^{\circ}$ \\
\hline & Maranhão & 52,8 & $2^{\circ}$ & 9,3 & $22^{\circ}$ & 25,9 & $8^{\circ}$ \\
\hline & Paraíba & 68,2 & $17^{\circ}$ & 29,3 & $10^{\circ}$ & 12,3 & $19^{\circ}$ \\
\hline & Pernambuco & 70,0 & $14^{\circ}$ & 34,5 & $8^{\circ}$ & 11,2 & $20^{\circ}$ \\
\hline & Piauí & 60,5 & $21^{\circ}$ & 4,2 & $25^{\circ}$ & 61,6 & $1^{\circ}$ \\
\hline & Rio Grande do Norte & 77,8 & $9^{\circ}$ & 17,0 & $18^{\circ}$ & 26,8 & $7^{\circ}$ \\
\hline & Sergipe & 74,7 & $12^{\circ}$ & 28,2 & $11^{\circ}$ & 17,2 & $13^{\circ}$ \\
\hline \multirow{4}{*}{$\begin{array}{c}\text { Centro- } \\
\text { Oeste }\end{array}$} & Distrito Federal & 87,2 & $2^{\circ}$ & 82,4 & $1^{\mathrm{o}}$ & 6,2 & $25^{\circ}$ \\
\hline & Goiás & 68,5 & $16^{\circ}$ & 30,4 & $9^{\circ}$ & 5,7 & $26^{\circ}$ \\
\hline & Mato Grosso do Sul & 61,6 & $19^{\circ}$ & 15,7 & $19^{\circ}$ & 6,8 & $\mathbf{2 3}^{\circ}$ \\
\hline & Mato Grosso do Sul & 76,4 & $11^{\circ}$ & 12,0 & $20^{\circ}$ & 15,1 & $16^{\circ}$ \\
\hline \multirow{4}{*}{ Sudeste } & Espírito Santo & 80,0 & $6^{\circ}$ & 56,1 & $5^{\circ}$ & 10,4 & $21^{\circ}$ \\
\hline & Minas Gerais & 82,1 & $5^{\circ}$ & 67,8 & $3^{\circ}$ & 2,7 & $27^{\circ}$ \\
\hline & Rio de Janeiro & 82,1 & $4^{\circ}$ & 62,3 & $4^{\circ}$ & 21,6 & $10^{\circ}$ \\
\hline & São Paulo & 91,7 & $\mathbf{1}^{\mathbf{o}}$ & 80,4 & $2^{\circ}$ & 6,5 & $24^{\circ}$ \\
\hline \multirow{3}{*}{ Sul } & Paraná & 82,3 & $3^{\circ}$ & 37,7 & $6^{\circ}$ & 15,6 & $15^{\circ}$ \\
\hline & Rio Grande do Sul & 78,4 & $8^{\circ}$ & 27,4 & $12^{\circ}$ & 41,7 & $4^{0}$ \\
\hline & Santa Catarina & 73,6 & $13^{\circ}$ & 19,8 & $16^{\circ}$ & 54,6 & $3^{\circ}$ \\
\hline
\end{tabular}

Fonte: IBGE, Censo Demográfico de 2000. Elaboração própria. 
(ii) as cinco primeiras posições do ranking de acesso a coleta de esgoto por rede geral são ocupadas por quatro estados do Sudeste e pelo Distrito Federal, enquanto que as cinco últimas posições são ocupadas por quatro estados do Norte e um do Nordeste;

(iii) as cinco primeiras posições do ranking de esgotamento sanitário por fossa séptica são ocupadas por dois estados do Norte, um do Nordeste e, surpreendentemente, por dois estados do Sul; as cinco últimas posições, por sua vez, são ocupadas por dois estados do Sudeste, por dois estados do Centro-Oeste e pelo Distrito Federal.

Portanto, mais uma vez é possível observar a inferioridade da cobertura dos serviços de saneamento básico na região Norte. Os índices estaduais de acesso por rede geral dessa região são, na média, inferiores aos índices das demais regiões - principalmente aos do Sudeste. O grande problema é que, no caso do esgoto, eram esperados indicadores maiores de acesso à fossa séptica nessa região, para compensar a deficiência do acesso a coleta por rede geral apenas dois estados do Norte estão entre o melhores no ranking de acesso à fossa séptica, enquanto quatro estão entre os piores no ranking de acesso a coleta de esgoto por rede geral.

Diante desse quadro, uma pergunta vem à tona: quais os fatores determinantes da distribuição não uniforme do déficit de acesso domiciliar aos serviços de saneamento básico? Uma primeira pista já havia sido dada na tabela 2.1 e é retomada no gráfico 2.1 , que relaciona o acesso aos serviços e o PIB per capita estadual e do Distrito Federal. Observa-se, nesse gráfico, a existência de uma tendência de aumento da cobertura por rede geral à medida que se eleva o PIB per capita ${ }^{3}$. Já em relação à fossa séptica, a tendência - menos acentuada - é de redução da cobertura à medida que se eleva o PIB per capita.

\footnotetext{
${ }^{3}$ A tabela 1 do Apêndice apresenta o valor do PIB per capita, em 2000, de cada estado e do Distrito Federal.
} 


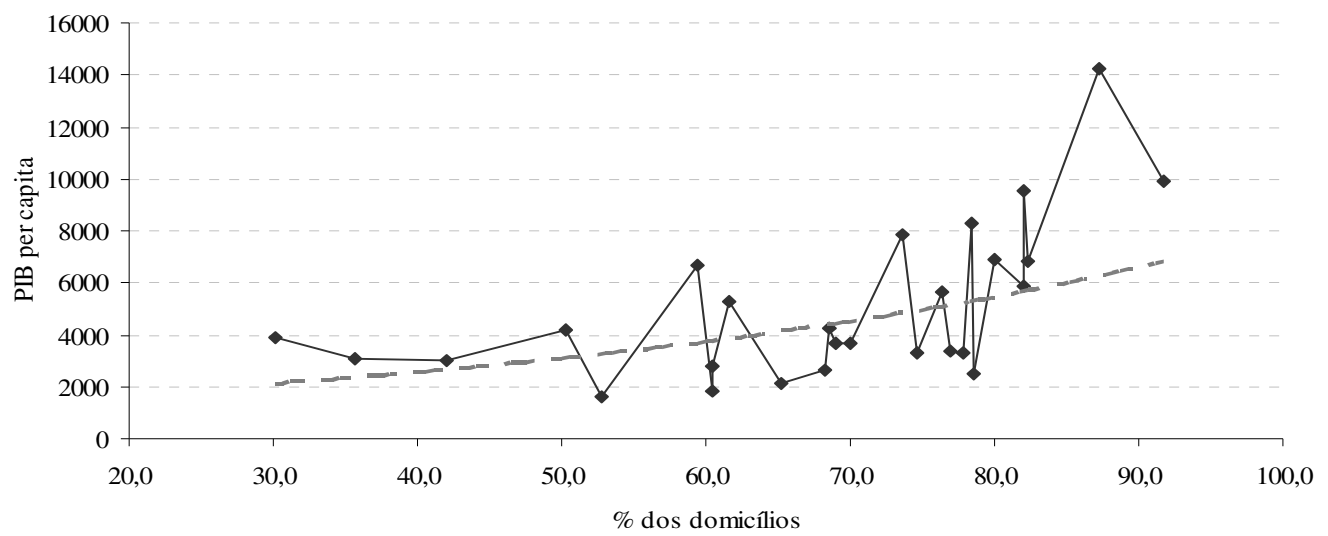

$\longrightarrow$ Abastecimento de Água (rede geral) $-\longrightarrow$ Tendência (exponencial)
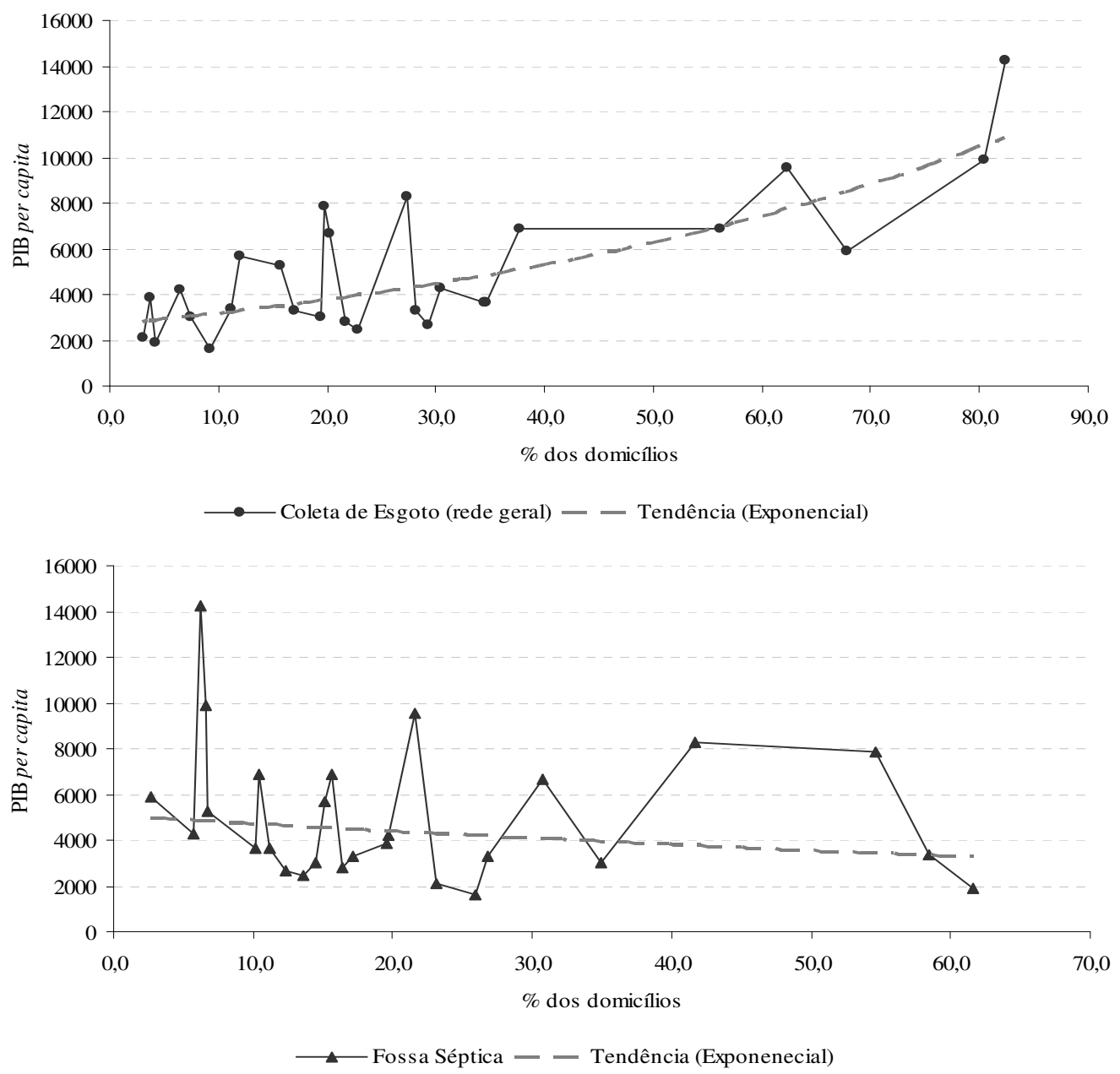

Fonte: IBGE, Censo Demográfico de 2000 e PIB Municipal. Elaboração própria.

Gráfico 2.1

Brasil: acesso a serviços de saneamento básico por rede geral, segundo o PIB per capita estadual e do Distrito Federal (2000) 


\section{$\underline{1.2}$ Caracterização municipal do déficit de acesso}

Conforme foi apontado anteriormente, serão utilizadas quatro variáveis municipais para caracterizar o déficit de acesso domiciliar aos serviços de saneamento básico no Brasil: (i) tamanho da população (porte), (ii) taxa de urbanização, (iii) renda per capita mensal e (iv) tipo de município (capital estadual ou federal, município do interior ou pertencente a uma região metropolitana). Em relação ao porte municipal (tamanho da população), é possível observar, por meio da tabela 2.3, alguns aspectos interessantes:

(i) os índices de acesso domiciliar apresentam uma tendência de aumento à medida que o porte do município se eleva - o que pode ser observado em todas as regiões e no Brasil como um todo;

(ii) a região Norte possui, em quase todos os estratos populacionais, os piores índices de acesso por rede geral - excetuando-se o abastecimento de água nos municípios de até cinco mil habitantes, faixa em que o Nordeste apresenta o pior indicador;

(iii) a exclusão do Estado de São Paulo altera significativamente os índices de acesso do Sudeste - o mesmo ocorre no último estrato populacional do Centro-Oeste com a exclusão dos dados do Distrito Federal - e

(iv) exceto no Sudeste, com e sem São Paulo, a fossa séptica é superior à coleta de esgoto por rede geral nos municípios de menor porte - na região Norte, essa superioridade ocorre em todos os estratos populacionais e, na Sul, só não ocorre no último estrato.

A relação entre o acesso domiciliar aos serviços de saneamento básico e o porte dos municípios pode ser ilustrada graficamente - o que é feito no gráfico 2.2 , que considera dados do Brasil como um todo. Observa-se, claramente, a tendência de aumento do acesso por rede 
geral - abastecimento de água, coleta de esgoto e, conseqüentemente, ambos ${ }^{4}$ - à medida que se eleva o porte dos municípios. Já no caso do esgotamento sanitário por fossa séptica, não é possível observar uma tendência clara.

Tabela 2.3

Brasil: proporção de domicílios com acesso a serviços de saneamento básico, segundo o porte (tamanho da população) dos municípios, as grandes regiões e o Estado de São Paulo (2000)

\begin{tabular}{|c|c|c|c|c|c|c|c|c|c|}
\hline $\begin{array}{l}\text { Região / } \\
\text { Porte }\end{array}$ & $\mathbf{N}$ & $\mathbf{N E}$ & CO (1) & CO (2) & SE (3) & SE (4) & $\begin{array}{c}\text { São } \\
\text { Paulo }\end{array}$ & $\mathbf{S}$ & Brasil \\
\hline \multicolumn{10}{|c|}{ Água - Rede Geral (\% dos domicílios) } \\
\hline até 5.000 hab. & 46,20 & 43,27 & 60,55 & 60,55 & 66,87 & 61,41 & 74,40 & 44,70 & 53,82 \\
\hline 5.000 a 10.000 hab. & 43,64 & 48,69 & 59,24 & 59,24 & 67,68 & 62,63 & 79,16 & 56,29 & 57,23 \\
\hline 10.000 a 20.000 hab. & 28,98 & 48,26 & 62,66 & 62,66 & 71,05 & 66,21 & 80,15 & 65,49 & 57,40 \\
\hline 20.000 a 50.000 hab. & 35,57 & 52,74 & 67,05 & 67,05 & 79,65 & 72,92 & 87,46 & 75,97 & 64,13 \\
\hline 50.000 a 100.000 hab. & 39,80 & 67,65 & 69,23 & 69,23 & 86,04 & 83,21 & 88,76 & 84,38 & $\mathbf{7 5 , 8 7}$ \\
\hline 100.000 a 500.000 hab. & 52,69 & 83,53 & 69,46 & 69,46 & 90,38 & 85,09 & 94,90 & 90,93 & 86,29 \\
\hline 500.000 a 1.000 .000 hab. & * & 87,30 & 87,72 & 87,72 & 90,36 & 83,21 & 96,89 & * & 89,27 \\
\hline mais de 1.000 .000 hab. & 74,30 & 91,53 & 88,24 & 87,41 & 98,22 & 98,18 & 98,25 & 98,40 & $\mathbf{9 4 , 7 3}$ \\
\hline Total & 48,24 & 66,73 & 73,34 & 70,11 & $\mathbf{8 8 , 4 5}$ & 83,12 & 93,51 & 80,11 & 77,99 \\
\hline \multicolumn{10}{|c|}{ Esgoto - Rede Geral (\% dos domicílios) } \\
\hline até 5.000 hab. & 1,09 & 9,23 & 1,92 & 1,92 & 53,01 & 44,73 & 63,46 & 3,23 & 22,28 \\
\hline 5.000 a 10.000 hab. & 0,56 & 13,06 & 4,54 & 4,54 & 56,46 & 48,54 & 72,66 & 7,08 & 25,10 \\
\hline 10.000 a 20.000 hab. & 1,56 & 16,14 & 6,15 & 6,15 & 59,65 & 52,40 & 72,49 & 13,62 & 27,35 \\
\hline 20.000 a 50.000 hab. & 1,62 & 21,53 & 14,27 & 14,27 & 67,07 & 55,70 & 79,60 & 23,74 & 35,56 \\
\hline 50.000 a 100. & 4,71 & 3. & 82 & & 7 & 1 & 7 &, 20 & 09 \\
\hline 100.000 a 50 & 11,05 & 42,35 & 31,54 & 31,54 & 76,55 & 70,08 & 82,05 & 38,47 & $\mathbf{5 7 , 7 2}$ \\
\hline 1.000 .000 hab. & * & 30,73 & 19,76 & 19,76 & 73,86 & 60,58 & 85,97 & * & 58,05 \\
\hline mais de 1.000 .000 hab. & 31,23 & 58,97 & 81,12 & 75,61 & 85,00 & 82,51 & 86,85 & 64,28 & 75,22 \\
\hline Total & 11,36 & 33,06 & 35,10 & 24,34 & $\mathbf{7 4 , 9 8}$ & 67,13 & 82,27 & 30,69 & 51,73 \\
\hline \multicolumn{10}{|c|}{ Fossa Séptica (\% dos domicílios) } \\
\hline até 5.000 hab. & 10,54 & 19,66 & 7,62 & 7,62 & 4,93 & 3,17 & 7,15 & 21,72 & 13,02 \\
\hline 5.000 a 10.000 hab. & 15,09 & 13,10 & 5,10 & 5,10 & 4,65 & 3,52 & 6,96 & 23,38 & 12,49 \\
\hline 10.000 a 20.000 hab. & 14,71 & 11,88 & 6,15 & 6,15 & 6,82 & 6,17 & 7,97 & 30,45 & 14,12 \\
\hline 20.000 a 50.000 hab. & 15,33 & 13,49 & 5,41 & 5,41 & 8,40 & 9,49 & 7,21 & 36,13 & 15,44 \\
\hline 50.000 a 100.000 hab. & 23,90 & 13,56 & 10,30 & 10,30 & 11,03 & 10,68 & 11,36 & 35,47 & 17,70 \\
\hline 100.000 a 500.000 hab. & 44,87 & 20,14 & 12,94 & 12,94 & 9,78 & 12,61 & 7,37 & 42,80 & 20,25 \\
\hline 500.000 a 1.000 .000 hab. & * & 32,20 & 10,54 & 10,54 & 14,12 & 22,68 & 6,32 & * & 19,29 \\
\hline mais de 1.000 .000 hab. & 44,79 & 13,96 & 5,86 & 5,28 & 7,14 & 11,58 & 3,86 & 29,11 & 12,53 \\
\hline Total & 30,29 & 16,71 & 7,82 & 8,17 & 9,02 & 11,69 & 6,54 & 34,75 & 16,24 \\
\hline
\end{tabular}

Fonte: IBGE, Censo Demográfico de 2000. Elaboração própria.

(1) Centro-Oeste incluindo o Distrito Federal.

(2) Centro-Oeste excluindo o Distrito Federal.

(3) Sudeste incluindo São Paulo.

(4) Sudeste excluindo São Paulo.

* Não há município com esse porte na região.

\footnotetext{
${ }^{4}$ Para cada uma das tabelas que relacionam o acesso a uma variável municipal ou domiciliar, há, no Apêndice, uma tabela correspondente com informações sobre o acesso simultâneo a abastecimento de água e a coleta de esgoto por rede geral - tabelas 2, 3, 4, 5, 6 e 7 .
} 


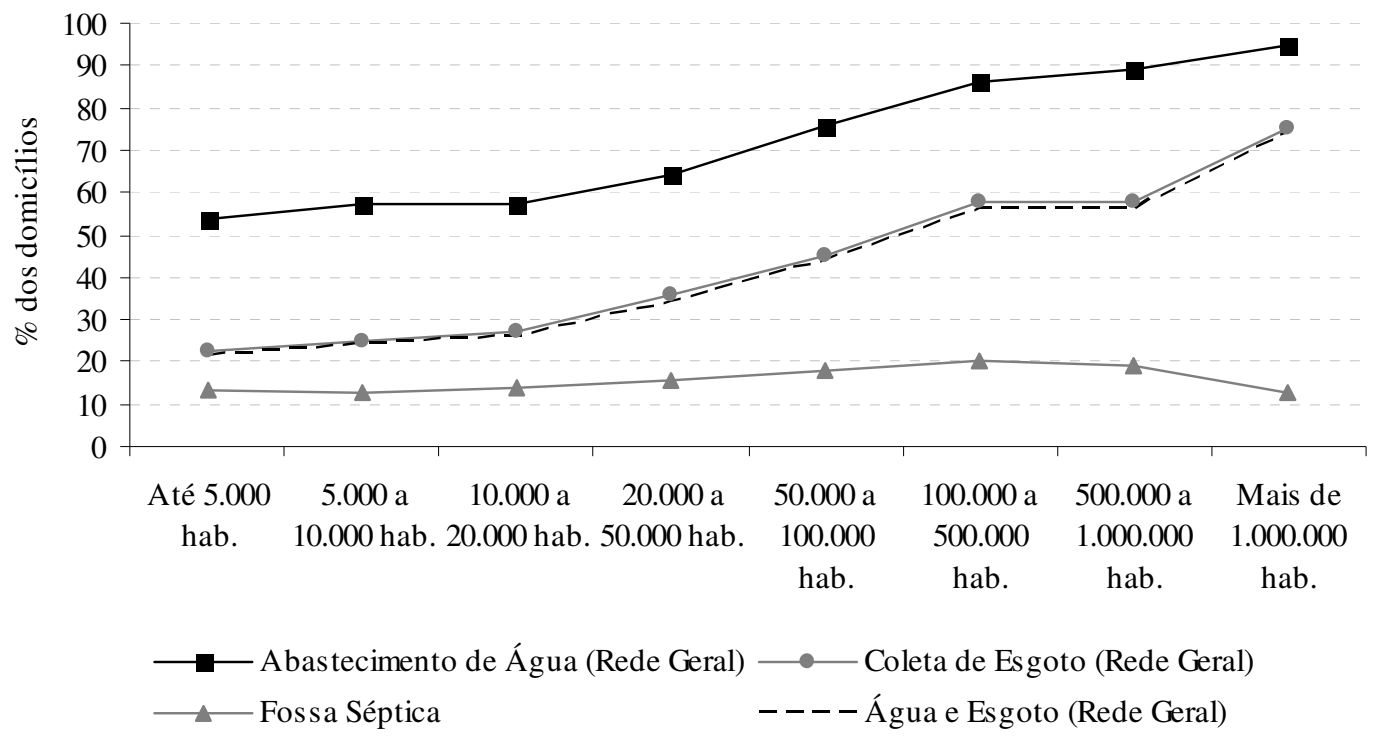

Fonte: IBGE, Censo Demográfico de 2000. Elaboração própria.

\section{Gráfico 2.2}

Brasil: proporção de domicílios com acesso a serviços de saneamento básico, segundo o porte (tamanho da população) dos municípios (2000)

A taxa de urbanização - população urbana do município dividida por sua população total - é a segunda variável municipal utilizada para caracterizar o déficit de acesso domiciliar a serviços de saneamento básico - o que é feito na tabela 2.4. Primeiramente, deve-se apontar a existência de uma tendência de elevação da proporção de domicílios com acesso aos serviços por rede geral à medida que aumenta a taxa de urbanização dos municípios - fato observado em todas as regiões. No caso do esgotamento sanitário por fossa séptica, não é observada uma tendência clara de aumento ou diminuição do acesso a esse serviço à medida que a taxa de urbanização se eleva.

Além disso, é importante destacar que a região Sudeste apresenta indicadores de acesso por rede geral superiores às demais regiões em quase todos os estratos de urbanização - o que se mantém mesmo desconsiderando São Paulo. Por outro lado, a região Norte apresenta os 
piores indicadores em todas as faixas e nos dois tipos de serviços - mais uma vez fica clara a existência de um desequilíbrio inter-regional no acesso.

Tabela 2.4

Brasil: proporção de domicílios com acesso a serviços de saneamento básico, segundo a taxa de urbanização dos municípios, as grandes regiões e o Estado de São Paulo (2000)

\begin{tabular}{|c|c|c|c|c|c|c|c|c|c|}
\hline $\begin{array}{c}\text { Região / Taxa de } \\
\text { Urbanização }\end{array}$ & $\mathbf{N}$ & NE & CO (1) & $\mathbf{C O}(2)$ & SE (3) & SE (4) & $\begin{array}{c}\text { São } \\
\text { Paulo }\end{array}$ & $\mathbf{S}$ & Brasil \\
\hline \multicolumn{10}{|c|}{ Água - Rede Geral (\% dos domicílios) } \\
\hline menos de $50 \%$ & 25,03 & 41,72 & 40,52 & 40,52 & 46,97 & 46,49 & 49,53 & 43,27 & 40,44 \\
\hline de $50 \%$ a $60 \%$ & 36,55 & 52,27 & 49,48 & 49,48 & 60,64 & 60,14 & 63,99 & 60,19 & 53,39 \\
\hline de $60 \%$ a $70 \%$ & 45,48 & 61,34 & 58,49 & 58,49 & 66,67 & 66,76 & 66,39 & 65,73 & 61,26 \\
\hline de $70 \%$ a $80 \%$ & 45,67 & 70,58 & 64,48 & 64,48 & 76,83 & 76,61 & 77,27 & 75,72 & $\mathbf{7 1 , 0 1}$ \\
\hline de $80 \%$ a $90 \%$ & 44,53 & 77,02 & 75,49 & 75,49 & 81,46 & 78,68 & 85,44 & 81,49 & $\mathbf{7 7 , 5 1}$ \\
\hline de $90 \%$ a $95 \%$ & 59,71 & 82,31 & 70,98 & 70,98 & 93,36 & 79,09 & 96,76 & 88,07 & 89,76 \\
\hline mais de $95 \%$ & 70,94 & 89,65 & 81,77 & $\mathbf{7 7 , 9 4}$ & 93,73 & 92,28 & 95,44 & 93,99 & $\mathbf{9 0 , 9 7}$ \\
\hline Total & 48,24 & 66,73 & 73,34 & 70,11 & 88,45 & 83,12 & $\mathbf{9 3 , 5 1}$ & $\mathbf{8 0 , 1 1}$ & $\mathbf{7 7 , 9 9}$ \\
\hline \multicolumn{10}{|c|}{ Esgoto - Rede Geral (\% dos domicílios) } \\
\hline menos de $50 \%$ & 1,36 & 12,96 & 1,36 & 1,36 & 30,18 & 29,05 & 35,40 & 6,50 & 12,28 \\
\hline de $50 \%$ a $60 \%$ & 3,07 & 18,44 & 2,19 & 2,19 & 41,99 & 40,28 & 52,42 & 10,00 & 19,80 \\
\hline de $60 \%$ a $70 \%$ & 3,13 & 25,14 & 5,14 & 5,14 & 50,34 & 49,50 & 52,74 & 14,39 & 25,41 \\
\hline de $70 \%$ a $80 \%$ & 1,16 & 31,64 & 6,97 & 6,97 & 61,50 & 58,88 & 66,73 & 19,37 & 34,25 \\
\hline de $80 \%$ a $90 \%$ & 13,01 & 38,71 & 13,87 & 13,87 & 69,31 & 62,29 & 79,19 & 27,07 & 44,69 \\
\hline de $90 \%$ a $95 \%$ & 2,35 & 29,88 & 23,00 & 23,00 & 84,43 & 70,26 & 87,77 & 36,70 & 67,61 \\
\hline mais de $95 \%$ & 24,98 & 49,34 & $\mathbf{5 7 , 8 2}$ & 43,14 & 77,86 & 74,88 & 81,36 & 44,98 & 64,36 \\
\hline Total & 11,36 & 33,06 & 35,10 & 24,34 & 74,98 & 67,13 & 82,27 & 30,69 & 51,73 \\
\hline \multicolumn{10}{|c|}{ Fossa Séptica (\% dos domicílios) } \\
\hline menos de $50 \%$ & 12,66 & 11,45 & 6,65 & 6,65 & 7,30 & 6,04 & 13,16 & 23,57 & 13,49 \\
\hline de $50 \%$ a $60 \%$ & 21,15 & 14,20 & 7,93 & 7,93 & 6,82 & 6,46 & 9,04 & 24,85 & 14,97 \\
\hline de $60 \%$ a $70 \%$ & 19,97 & 12,59 & 4,84 & 4,84 & 10,70 & 10,12 & 12,36 & 27,79 & 14,68 \\
\hline de $70 \%$ a $80 \%$ & 24,63 & 15,60 & 8,06 & 8,06 & 7,59 & 6,51 & 9,76 & 32,47 & 16,29 \\
\hline de $80 \%$ a $90 \%$ & 27,37 & 15,57 & 6,32 & 6,32 & 9,72 & 12,08 & 6,40 & 34,80 & 17,76 \\
\hline de $90 \%$ a $95 \%$ & 39,47 & 37,44 & 8,76 & 8,76 & 5,15 & 10,96 & 3,78 & 35,32 & 13,47 \\
\hline mais de $95 \%$ & 47,40 & 17,82 & 8,40 & 9,62 & 11,07 & 13,32 & 8,42 & 40,86 & 17,85 \\
\hline Total & 30,29 & 16,71 & 7,82 & $\mathbf{8 , 1 7}$ & 9,02 & 11,69 & 6,54 & 34,75 & 16,24 \\
\hline
\end{tabular}

Fonte: IBGE, Censo Demográfico de 2000. Elaboração própria.

(1) Centro-Oeste incluindo o Distrito Federal.

(2) Centro-Oeste excluindo o Distrito Federal.

(3) Sudeste incluindo São Paulo.

(4) Sudeste excluindo São Paulo.

No caso do Distrito Federal, como este pertence à última faixa de urbanização (mais de 95\%), ao desconsiderá-lo, os indicadores do Centro-Oeste só se alteram - significativa redução - nessa faixa e no total (destacados em negrito). Deve-se apontar também que, apesar de possuir índices de cobertura por rede geral inferiores aos do Nordeste em quase todos os 
estratos de urbanização e nos dois tipos de serviços, o fato da população do Centro-Oeste ser mais concentrada em municípios com maiores taxas de urbanização faz com que o índice médio da região supere o do Nordeste. Destaca-se ainda o fato do esgotamento por fossa séptica ser superior à coleta de esgoto por rede geral em quase todas as faixas de urbanização das regiões Norte e, surpreendentemente, Sul.

A existência, ou não, de uma tendência de aumento da proporção de domicílios com acesso aos serviços à medida que a taxa de urbanização se eleva fíca mais visível graficamente, por meio do gráfico 2.3, que considera os dados do Brasil como um todo.

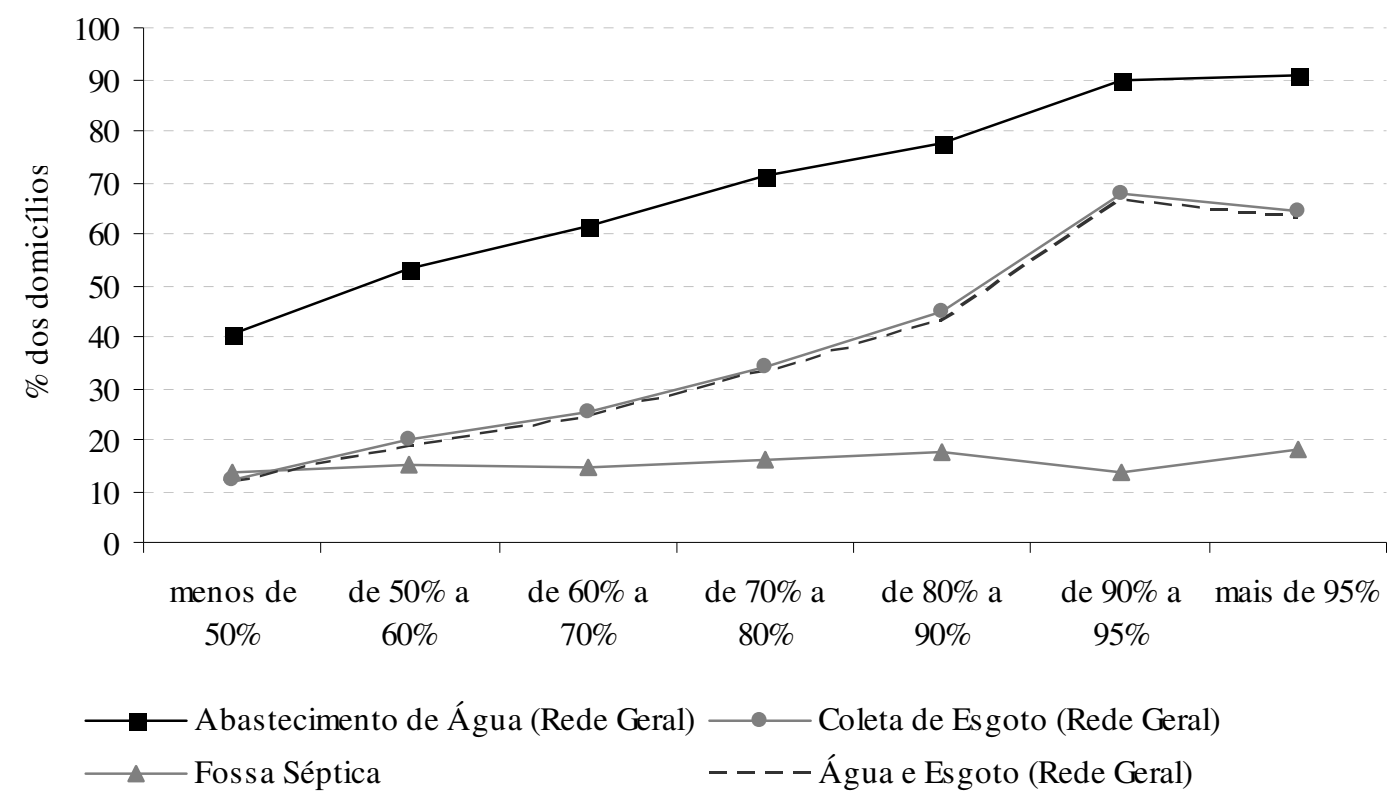

Fonte: IBGE, Censo Demográfico de 2000. Elaboração própria.

\section{Gráfico 2.3}

Brasil: proporção de domicílios com acesso a serviços de saneamento básico, segundo a taxa de urbanização dos municípios (2000)

Outra variável que pode ser utilizada para caracterizar o déficit de acesso domiciliar é a renda municipal per capita mensal - somatório das rendas mensais dos domicílios pertencentes ao município dividido por sua população total. Por meio da tabela 2.5, é possível 
observar que os índices de acesso por rede geral do Nordeste superam os apresentados pela região Sul em quase todas as faixas de renda, excetuando-se a maior faixa no caso do abastecimento de água. Tal fato faz com que a cobertura total de água por rede geral do Sul supere a do Nordeste, uma vez que nessa última há uma maior concentração da população (domicílios) em municípios de baixa renda per capita. Portanto, pode-se dizer que os municípios pobres do Nordeste possuem uma situação melhor do que os do Sul.

\section{Tabela 2.5}

Brasil: proporção de domicílios com acesso a serviços de saneamento básico, segundo a renda per capita mensal dos municípios, as grandes regiões e o Estado de São Paulo (2000)

\begin{tabular}{|c|c|c|c|c|c|c|c|c|c|}
\hline $\begin{array}{c}\text { Região / } \\
\text { Renda }\end{array}$ & $\mathbf{N}$ & NE & CO (1) & CO (2) & SE (3) & SE (4) & $\begin{array}{c}\text { São } \\
\text { Paulo }\end{array}$ & $\mathbf{S}$ & Brasil \\
\hline \multicolumn{10}{|c|}{ Água - Rede Geral (\% dos domicílios) } \\
\hline até 1 S.M. & 36,68 & 54,57 & 48,85 & 48,85 & 61,35 & 61,26 & 63,14 & 45,85 & 52,67 \\
\hline de 1 a 2 S.M. & 52,09 & 82,44 & 65,44 & 65,44 & 80,59 & 78,03 & 86,29 & 71,52 & 75,04 \\
\hline de 2 a 3 S.M. & 67,59 & 92,69 & 79,89 & 79,89 & 90,03 & 85,45 & 92,33 & 86,41 & 88,22 \\
\hline mais de 3 S.M. & $*$ & 82,44 & 87,89 & 86,54 & 97,38 & 96,96 & 97,60 & 95,37 & 96,25 \\
\hline Total & 48,24 & 66,73 & 73,34 & 70,11 & 82,95 & 83,12 & 93,51 & 80,11 & 77,99 \\
\hline \multicolumn{10}{|c|}{ Esgoto - Rede Geral (\% dos domicílios) } \\
\hline até 1 S.M. & 1,69 & 21,69 & 0,83 & 0,83 & 33,87 & 33,44 & 41,87 & 5,14 & 19,15 \\
\hline de 1 a 2 S.M. & 15,10 & 39,11 & 14,89 & 14,89 & 62,25 & 59,39 & 68,53 & 19,77 & 41,55 \\
\hline de 2 a 3 S.M. & 22,36 & 54,75 & 27,60 & 27,60 & 80,25 & 77,37 & 81,70 & 30,87 & 58,47 \\
\hline mais de 3 S.M. & $*$ & 60,66 & 79,10 & 70,67 & 86,49 & 82,25 & 88,79 & 59,28 & 82,06 \\
\hline Total & 11,36 & 33,06 & 35,10 & 24,34 & $\mathbf{7 5 , 7 3}$ & 67,13 & 82,27 & 30,69 & 51,73 \\
\hline \multicolumn{10}{|c|}{ Fossa Séptica (\% dos domicílios) } \\
\hline até 1 S.M. & 19,33 & 13,66 & 4,79 & 4,79 & 3,95 & 3,84 & 5,84 & 11,81 & 13,19 \\
\hline de 1 a 2 S.M. & 31,41 & 22,70 & 7,41 & 7,41 & 12,62 & 13,45 & 10,79 & 31,79 & 19,05 \\
\hline de 2 a 3 S.M. & 51,51 & 18,09 & 12,63 & 12,63 & 8,63 & 10,09 & 7,90 & 42,71 & 20,44 \\
\hline mais de 3 S.M. & $*$ & 35,40 & 6,01 & 5,69 & 6,53 & 11,46 & 3,85 & 31,55 & 9,96 \\
\hline Total & 30,29 & 16,71 & 7,82 & 8,17 & 13,39 & 11,69 & 6,54 & 34,75 & 16,24 \\
\hline
\end{tabular}

Fonte: IBGE, Censo Demográfico de 2000. Elaboração própria.

S.M.: Salário mínimo de 2000 (R\$ 151,00).

(1) Centro-Oeste incluindo o Distrito Federal.

(2) Centro-Oeste excluindo o Distrito Federal.

(3) Sudeste incluindo São Paulo.

(4) Sudeste excluindo São Paulo.

* Não há município com essa renda per capita na região.

Já no caso do Norte, mais uma vez é possível observar que essa região apresenta os piores indicadores em todas as faixas de renda, enquanto o Sudeste apresenta os melhores índices totais - que sofrem uma redução se os dados de São Paulo não forem agregados aos da 
região, o mesmo ocorrendo com o Centro-Oeste, na última faixa de renda e no total, ao excluir os dados do Distrito Federal.

É importante destacar também a existência de uma relação positiva entre a proporção de domicílios com acesso aos serviços por rede geral e a renda per capita mensal dos municípios. No caso do esgotamento por fossa séptica, mais uma vez não é possível observar uma tendência clara. Tais relações ficam mais claras graficamente, por meio do gráfico 2.4, que considera dados do Brasil como um todo.

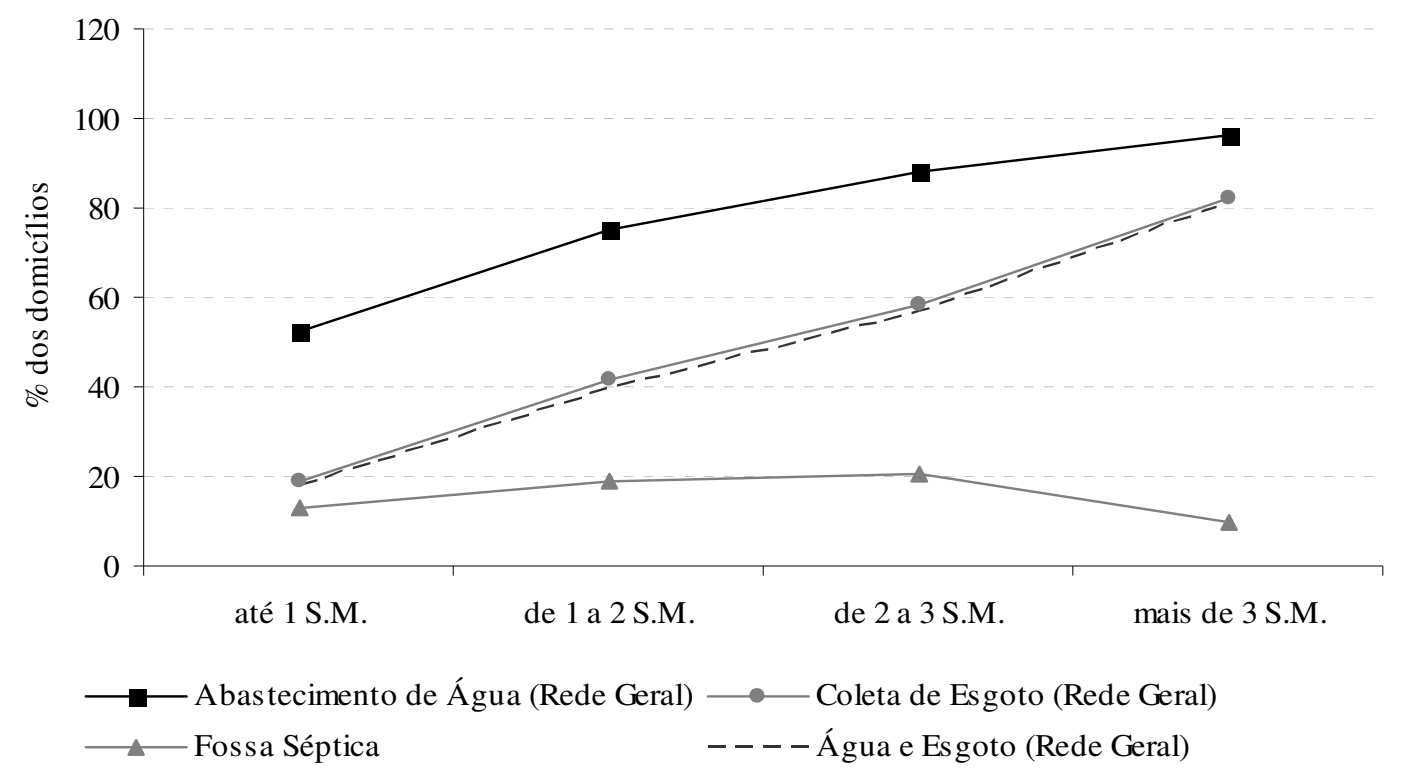

Fonte: IBGE, Censo Demográfico de 2000. Elaboração própria.

\section{Gráfico 2.4}

Brasil: proporção de domicílios com acesso a serviços de saneamento básico, segundo a renda per capita mensal dos municípios (2000)

Por último, é importante comparar o déficit de acesso domiciliar em três tipos distintos de municípios - a importância de tal análise ficará clara no decorrer do trabalho: (i) capitais (estaduais e Federal), (ii) municípios do interior e (iii) municípios pertencentes a uma região metropolitana - excetuando-se as capitais. A tabela 2.6 mostra que, no Brasil como um todo, 
as capitais são os municípios com maior proporção de domicílios com acesso aos serviços por rede geral, seguidos pelos municípios pertencentes a uma região metropolitana e, por último, pelos municípios do interior. Essa sequiência é observada em quase todas as regiões - só não ocorre, no abastecimento de água, no Norte e no Centro-Oeste (com e sem o Distrito Federal) e, na coleta de esgoto, no Sudeste e no Estado de São Paulo.

Tabela 2.6

Brasil: proporção de domicílios com acesso a serviços de saneamento básico, segundo o tipo de município, as grandes regiões e o Estado de São Paulo (2000)

\begin{tabular}{|c|c|c|c|c|c|c|c|c|c|}
\hline Região / Tipo de Município & $\mathbf{N}$ & NE & CO (1) & $\mathbf{C O}(2)$ & SE (3) & SE (4) & $\begin{array}{c}\text { São } \\
\text { Paulo }\end{array}$ & $\mathbf{S}$ & Brasil \\
\hline \multicolumn{10}{|c|}{ Água - Rede Geral (\% dos domicílios) } \\
\hline Capital * & 69,55 & 90,70 & 88,55 & 88,40 & 98,44 & 98,22 & 98,62 & 97,51 & 93,17 \\
\hline Região Metropolitana ** & 37,18 & 76,69 & 49,16 & 49,16 & 88,48 & 81,66 & 94,18 & 84,33 & 84,90 \\
\hline Municípios do Interior & 38,00 & 57,61 & 65,55 & 65,55 & 82,34 & 75,91 & 89,46 & 74,26 & 68,70 \\
\hline Total & 48,24 & 66,73 & 73,34 & 70,11 & 82,95 & 83,12 & 93,51 & 80,11 & 77,99 \\
\hline \multicolumn{10}{|c|}{ Esgoto - Rede Geral (\% dos domicílios) } \\
\hline Capital * & 27,20 & 49,81 & 68,45 & 54,58 & 85,52 & 82,76 & 87,84 & 62,58 & 68,98 \\
\hline Região Metropolitana ** & 5,79 & 28,64 & 14,86 & 14,86 & 66,91 & 58,41 & 73,96 & 27,69 & 52,89 \\
\hline Municípios do Interior & 2,37 & 26,21 & 14,21 & 14,21 & 73,57 & 63,38 & 84,37 & 24,38 & 42,49 \\
\hline Total & 11,36 & 33,06 & 35,10 & 24,34 & 75,73 & 67,13 & 82,27 & 30,69 & 51,73 \\
\hline \multicolumn{10}{|c|}{ Fossa Séptica (\% dos domicílios) } \\
\hline Capital * & 43,28 & 21,39 & 8,34 & 10,21 & 7,16 & 11,46 & 3,53 & 30,79 & 15,50 \\
\hline Região Metropolitana ** & 74,54 & 21,86 & 4,73 & 4,73 & 14,69 & 18,98 & 11,12 & 52,01 & 23,94 \\
\hline Municípios do Interior & 19,18 & 13,72 & 7,73 & 7,73 & 6,56 & 7,70 & 5,35 & 28,27 & 13,55 \\
\hline Total & 30,29 & 16,71 & $\mathbf{7 , 8 2}$ & 8,17 & 13,39 & 11,69 & 6,54 & 34,75 & 16,24 \\
\hline
\end{tabular}

Fonte: IBGE, Censo Demográfico de 2000. Elaboração própria.

(1) Centro-Oeste incluindo o Distrito Federal.

(2) Centro-Oeste excluindo o Distrito Federal - no caso, excluindo a Capital Federal (Brasília).

(3) Sudeste incluindo São Paulo.

(4) Sudeste excluindo São Paulo.

* Capitais estaduais e Federal (Brasília).

** Municípios pertencentes a uma região metropolitana.

No caso do esgotamento por fossa séptica, apenas no Centro-Oeste (com e sem o Distrito Federal) os municípios com maior acesso a esse serviço não são os pertencentes a uma região metropolitana e apenas no Estado de São Paulo o acesso dos municípios do interior é maior do que o acesso das capitais. Deve-se destacar também que, surpreendentemente, a fossa séptica está presente em mais de $50 \%$ dos domicílios localizados 
em áreas metropolitanas das regiões Norte e Sul - esperava-se o contrário, devido à existência de economias de escala e densidade no setor, fato que será detalhado no decorrer do trabalho.

\subsection{Caracterizacão domiciliar do déficit de acesso}

A localização do domicílio - isto é, se este é urbano ou rural - é a primeira variável domiciliar utilizada para caracterizar o déficit de acesso domiciliar a serviços de saneamento básico no Brasil. A tabela 2.7 mostra a superioridade do acesso urbano ao abastecimento de água por rede geral em relação ao rural. No caso do esgoto, o baixo grau de cobertura por rede geral não se limita à zona rural - apesar de ser maior nesta.

\section{Tabela 2.7}

Brasil: proporção de domicílios urbanos e rurais com acesso a serviços de saneamento básico (\% dos domicílios), segundo as grandes regiões, o Estado de São Paulo e o Distrito Federal (2000)

\begin{tabular}{|c|c|c|c|c|c|c|c|c|}
\hline \multirow{3}{*}{ Serviço / Região } & \multirow{2}{*}{\multicolumn{2}{|c|}{$\begin{array}{c}\text { Água } \\
\text { (Rede Geral) }\end{array}$}} & \multicolumn{4}{|c|}{ Esgoto } & \multirow{2}{*}{\multicolumn{2}{|c|}{$\begin{array}{c}\text { Água e Esgoto } \\
\text { (Rede Geral) }\end{array}$}} \\
\hline & & & \multicolumn{2}{|c|}{ Rede Geral } & \multicolumn{2}{|c|}{ Fossa Séptica } & & \\
\hline & Urbano & Rural & Urbano & Rural & Urbano & Rural & Urbano & Rural \\
\hline Norte & 62,66 & 9,90 & 14,07 & 1,40 & 36,09 & 8,98 & 11,91 & 1,29 \\
\hline Nordeste & 85,68 & 18,96 & 38,50 & 2,94 & 17,71 & 11,14 & 36,60 & 2,45 \\
\hline Centro-Oeste (1) & 82,53 & 10,78 & 39,19 & 1,12 & 7,93 & 6,90 & 37,67 & 0,84 \\
\hline Centro-Oeste (2) & 80,34 & 10,39 & 27,65 & 0,54 & 8,51 & 5,78 & 25,84 & 0,37 \\
\hline Distrito Federal & 91,83 & 17,31 & 87,46 & 9,06 & 5,52 & 22,34 & 87,13 & 7,32 \\
\hline Sudeste (3) & 94,58 & 22,28 & 80,18 & 12,04 & 8,46 & 15,80 & 78,68 & 10,41 \\
\hline Sudeste (4) & 91,49 & 15,65 & 73,46 & 6,37 & 11,75 & 11,14 & 70,82 & 4,44 \\
\hline São Paulo & 97,36 & 33,76 & 86,19 & 20,38 & 5,52 & 22,65 & 85,71 & 19,19 \\
\hline Sul & 93,44 & 18,06 & 36,58 & 1,61 & 37,01 & 23,58 & 35,65 & 1,31 \\
\hline Brasil & 89,82 & 18,19 & 58,01 & 5,15 & 16,40 & 15,08 & 56,49 & 4,40 \\
\hline
\end{tabular}

Fonte: IBGE, Censo Demográfico de 2000. Elaboração própria.

(1) Centro-Oeste incluindo o Distrito Federal.

(2) Centro-Oeste excluindo o Distrito Federal.

(3) Sudeste incluindo São Paulo.

(4) Sudeste excluindo São Paulo.

Além disso, é possível observar que os índices urbanos de esgotamento sanitário por fossa séptica, em quase todas as regiões - excetuando-se o Estado de São Paulo e o Distrito 
Federal -, eram superiores aos índices rurais. Verifica-se, portanto, um sério problema de acesso aos serviços na zona rural - mesmo considerando a fossa séptica.

O perfil da renda dos domicílios com e sem atendimento é outro aspecto relevante que deve ser considerado. Assim, a tabela 2.8 apresenta a relação entre a renda domiciliar mensal e o déficit de acesso domiciliar a serviços de saneamento básico.

Tabela 2.8

Brasil: proporção de domicílios com acesso a serviços de saneamento básico, segundo a renda domiciliar mensal, as grandes regiões, o Estado de São Paulo e o Distrito Federal (2000)

\begin{tabular}{|c|c|c|c|c|c|c|c|c|c|c|}
\hline $\begin{array}{c}\text { Região / } \\
\text { Renda }\end{array}$ & $\mathbf{N}$ & NE & CO (1) & CO (2) & DF & SE (3) & SE (4) & $\begin{array}{c}\text { São } \\
\text { Paulo }\end{array}$ & Sul & Brasil \\
\hline \multicolumn{11}{|c|}{ Água - Rede Geral (\% dos domicílios) } \\
\hline menos de 1 S.M. & 34,93 & 49,86 & 63,15 & 61,81 & 75,42 & 77,74 & 70,87 & 88,43 & 66,99 & $\mathbf{5 8 , 9 0}$ \\
\hline de 1 a 2 S.M. & 41,09 & 62,38 & 62,86 & 61,15 & 77,35 & 78,69 & 74,13 & 85,84 & 69,58 & 67,15 \\
\hline de 2 a 3 S.M. & 48,20 & 71,56 & 68,13 & 66,04 & 84,16 & 84,37 & 79,88 & 89,70 & 76,64 & $\mathbf{7 5 , 8 7}$ \\
\hline de 3 a 5 S.M. & 52,83 & 79,70 & 72,82 & 70,39 & 88,03 & 88,37 & 83,96 & 92,60 & 80,76 & 81,99 \\
\hline de 5 a 10 S.M. & 60,36 & 87,32 & 79,98 & 77,14 & 92,11 & 92,66 & 88,75 & 95,61 & 85,54 & 88,14 \\
\hline de 10 a 20 S.M. & 65,26 & 90,27 & 86,14 & 83,06 & 93,73 & 95,56 & 92,89 & 97,37 & 89,58 & 91,92 \\
\hline mais de 20 S.M. & 65,69 & 89,70 & 89,27 & 85,64 & 94,16 & 96,49 & 94,64 & 97,70 & 91,56 & 93,15 \\
\hline Total & 48,24 & 66,73 & 73,34 & 70,11 & $\mathbf{8 8 , 7 2}$ & 88,45 & 83,12 & $\mathbf{9 3 , 5 1}$ & 80,11 & 77,99 \\
\hline \multicolumn{11}{|c|}{ Esgoto - Rede Geral (\% dos domicílios) } \\
\hline menos de 1 S.M. & 5,35 & 22,76 & 20,51 & 14,29 & 71,93 & 60,12 & 52,43 & 71,09 & 19,53 & 33,76 \\
\hline de 1 a 2 S.M. & 6,17 & 25,52 & 20,61 & 13,98 & 73,47 & 61,16 & 55,28 & 70,02 & 19,66 & 35,84 \\
\hline de 2 a 3 S.M. & 8,16 & 30,13 & 24,88 & 17,36 & 80,39 & 67,23 & 61,22 & 74,23 & 23,59 & 43,51 \\
\hline de 3 a 5 S.M. & 10,46 & 36,14 & 30,37 & 21,48 & 84,84 & 72,76 & 66,41 & 78,79 & 27,67 & $\mathbf{5 0 , 8 4}$ \\
\hline de 5 a 10 S.M. & 16,45 & 45,12 & 41,74 & 30,56 & 88,84 & 80,09 & 73,41 & 85,11 & 34,03 & 61,01 \\
\hline de 10 a 20 S.M. & 23,79 & 54,34 & 56,85 & 43,34 & 90,02 & 86,66 & 80,56 & 90,78 & 43,92 & $\mathbf{7 0 , 4 5}$ \\
\hline mais de 20 S.M. & 31,47 & 63,10 & 67,73 & 54,20 & 85,90 & 90,62 & 85,57 & 93,94 & 54,92 & $\mathbf{7 7 , 5 5}$ \\
\hline Total & 11,36 & 33,06 & 35,10 & 24,34 & 84,29 & 74,98 & 67,13 & 82,27 & 30,69 & 51,73 \\
\hline \multicolumn{11}{|c|}{ Fossa Séptica (\% dos domicílios) } \\
\hline menos de 1 S.M. & 17,95 & 13,11 & 6,50 & 6,60 & 5,65 & 10,27 & 11,57 & 8,42 & 25,28 & 13,62 \\
\hline de 1 a 2 S.M. & 22,05 & 15,17 & 6,50 & 6,61 & 5,63 & 10,27 & 11,28 & 8,74 & 28,26 & 15,29 \\
\hline de 2 a 3 S.M. & 28,61 & 16,55 & 7,09 & 7,38 & 4,95 & 10,07 & 11,81 & 8,05 & 31,95 & 16,36 \\
\hline de 3 a 5 S.M. & 34,16 & 18,07 & 7,27 & 7,82 & 3,91 & 9,71 & 12,10 & 7,44 & 36,60 & 17,50 \\
\hline de 5 a 10 S.M. & 40,83 & 20,12 & 8,25 & 9,24 & 4,07 & 8,88 & 12,42 & 6,22 & 40,40 & 17,88 \\
\hline de 10 a 20 S.M. & 45,01 & 22,42 & 9,13 & 10,56 & 5,64 & 7,43 & 11,42 & 4,73 & 39,16 & 16,64 \\
\hline mais de 20 S.M. & 45,26 & 22,44 & 11,90 & 12,21 & 11,49 & 6,32 & 9,87 & 3,99 & 34,38 & 14,66 \\
\hline Total & 30,29 & 16,71 & $\mathbf{7 , 8 2}$ & $\mathbf{8 , 1 7}$ & 6,20 & $\mathbf{9 , 0 2}$ & 11,69 & 6,54 & 34,75 & 16,24 \\
\hline
\end{tabular}

Fonte: IBGE, Censo Demográfico de 2000. Elaboração própria.

S.M.: Salário mínimo de 2000 (R \$ 151,00).

(1) Centro-Oeste incluindo o Distrito Federal.

(2) Centro-Oeste excluindo o Distrito Federal.

(3) Sudeste incluindo São Paulo.

(4) Sudeste excluindo São Paulo. 
Observa-se, mais uma vez, a superioridade dos indicadores de acesso por rede geral da região Sudeste, principalmente em relação aos apresentados pela região Norte, sendo a cobertura de São Paulo superior à apresentada pelo restante do país em todas as faixas de renda e nos dois serviços - exceto em relação ao Distrito Federal no caso da coleta de esgoto. Além disso, verifica-se, claramente, a existência de uma tendência de aumento da proporção de domicílios com acesso aos serviços por rede geral à medida que aumenta a renda domiciliar. Já no caso do esgotamento sanitário por fossa séptica, não é possível identificar uma tendência clara de aumento ou redução do acesso à medida que a renda domiciliar se eleva. Esse fato pode ser ilustrado graficamente, o que é feito no gráfico 2.5, que considera os dados do Brasil como um todo.

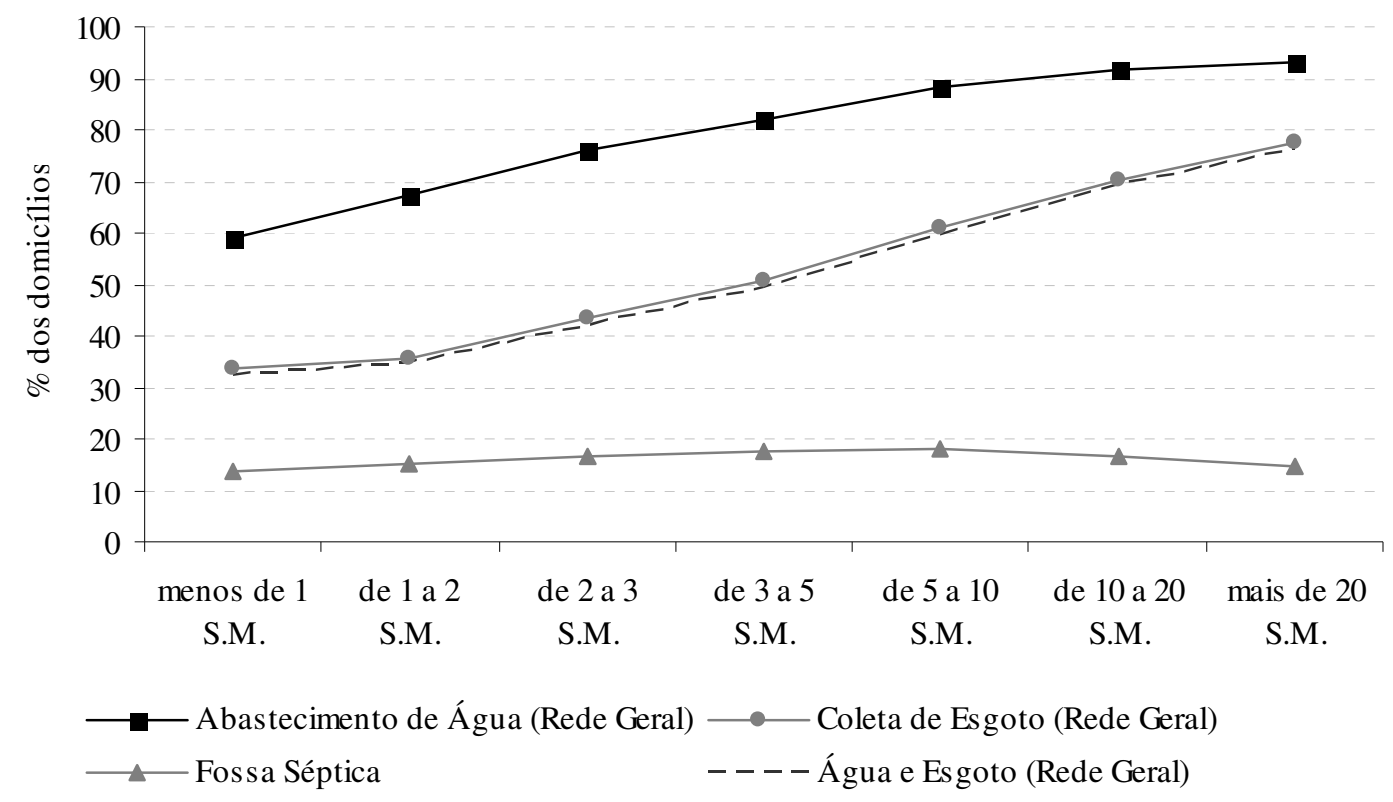

Fonte: IBGE, Censo Demográfico de 2000. Elaboração própria.

\section{Gráfico 2.5}

Brasil: proporção de domicílios com acesso a serviços de saneamento básico, segundo a renda domiciliar mensal (2000) 
Finalmente, a tabela 2.9 apresenta a relação entre o déficit de acesso domiciliar e a renda domiciliar per capita mensal. Observa-se, mais uma vez, a inferioridade dos índices de acesso por rede geral da região Norte e a superioridade dos índices da região Sudeste e do Estado de São Paulo. Além disso, assim como no caso da renda domiciliar, há uma relação positiva entre o acesso por rede geral e a renda domiciliar per capita mensal. No caso da fossa séptica, não é possível identificar uma relação positiva ou negativa entre o acesso e a renda.

\section{Tabela 2.9}

Brasil: proporção de domicílios com acesso a serviços de saneamento básico, segundo a renda domiciliar per capita mensal, as grandes regiões, o Estado de São Paulo e o Distrito Federal (2000)

\begin{tabular}{|c|c|c|c|c|c|c|c|c|c|c|}
\hline $\begin{array}{c}\text { Região / } \\
\text { Renda }\end{array}$ & $\mathbf{N}$ & NE & CO (1) & CO (2) & DF & SE (3) & SE (4) & $\begin{array}{c}\text { São } \\
\text { Paulo }\end{array}$ & Sul & Brasil \\
\hline \multicolumn{11}{|c|}{ Água - Rede Geral (\% dos domicílios) } \\
\hline menos de 1 S.M. & 42,22 & 59,82 & 65,43 & 63,54 & 80,37 & 80,51 & 75,05 & 88,03 & 71,22 & 67,22 \\
\hline de 1 a 2 S.M. & 56,48 & 83,62 & 75,05 & 72,45 & 89,75 & 90,18 & 85,77 & 93,96 & 81,77 & 84,69 \\
\hline de 2 a 3 S.M. & 63,28 & 89,19 & 81,49 & 78,45 & 92,80 & 93,83 & 90,20 & 96,43 & 87,01 & 89,87 \\
\hline de 3 a 5 S.M. & 64,76 & 90,15 & 85,23 & 82,47 & 93,15 & 95,29 & 92,47 & 97,23 & 89,53 & 91,81 \\
\hline de 5 a 10 S.M. & 65,61 & 90,45 & 87,79 & 84,86 & 93,21 & 96,23 & 94,14 & 97,70 & 92,00 & 93,20 \\
\hline de 10 a 20 S.M. & 63,94 & 88,93 & 89,82 & 85,82 & 94,67 & 96,69 & 95,08 & 97,83 & 93,28 & $\mathbf{9 3 , 8 1}$ \\
\hline mais de 20 S.M. & 63,24 & 88,29 & 89,60 & 83,28 & 96,39 & 96,60 & 95,18 & 97,57 & 92,46 & 93,65 \\
\hline Total & 48,24 & 66,73 & 73,34 & 70,11 & 88,72 & 88,45 & 83,12 & $\mathbf{9 3 , 5 1}$ & 80,11 & 77,99 \\
\hline \multicolumn{11}{|c|}{ Esgoto - Rede Geral (\% dos domicílios) } \\
\hline menos de 1 S.M. & 6,78 & 25,84 & 21,99 & 14,68 & 76,54 & 62,59 & 56,20 & 71,00 & 20,59 & 37,31 \\
\hline de 1 a 2 S.M. & 13,82 & 41,05 & 34,58 & 25,17 & 86,84 & 75,98 & 69,26 & 81,70 & 28,75 & 55,30 \\
\hline de 2 a 3 S.M. & 19,66 & 49,61 & 46,22 & 34,45 & 89,52 & 82,13 & 75,24 & 87,05 & 35,57 & 64,27 \\
\hline de 3 a 5 S.M. & 23,91 & 54,62 & 54,23 & 41,98 & 89,11 & 85,91 & 79,42 & 90,37 & 42,39 & 69,75 \\
\hline de 5 a 10 S.M. & 29,82 & 60,67 & 63,90 & 50,87 & 87,94 & 89,42 & 83,72 & 93,40 & 50,74 & $\mathbf{7 5 , 4 6}$ \\
\hline de 10 a 20 S.M. & 34,74 & 66,85 & 69,41 & 55,87 & 85,81 & 91,37 & 86,83 & 94,57 & 59,40 & 80,08 \\
\hline mais de 20 S.M. & 36,06 & 69,15 & 70,66 & 55,99 & 86,41 & 91,70 & 87,29 & 94,74 & 63,37 & 81,84 \\
\hline Total & 11,36 & 33,06 & 35,10 & 24,34 & 84,29 & 74,98 & 67,13 & 82,27 & 30,69 & 51,73 \\
\hline \multicolumn{11}{|c|}{ Fossa Séptica (\% dos domicílios) } \\
\hline menos de 1 S.M. & 23,75 & 15,10 & 6,80 & 7,05 & 4,94 & 10,21 & 11,41 & 8,64 & 28,80 & 15,32 \\
\hline de 1 a 2 S.M. & 39,23 & 18,95 & 7,47 & 8,07 & 4,19 & 9,48 & 12,41 & 6,98 & 38,37 & 17,89 \\
\hline de 2 a 3 S.M. & 44,16 & 20,41 & 8,48 & 9,58 & 4,41 & 8,65 & 12,76 & 5,71 & 41,50 & 17,88 \\
\hline de 3 a 5 S.M. & 44,86 & 21,78 & 9,10 & 10,15 & 6,10 & 7,79 & 12,05 & 4,87 & 40,05 & 16,93 \\
\hline de 5 a 10 S.M. & 44,11 & 22,60 & 10,43 & 11,53 & 8,42 & 6,68 & 10,51 & 4,02 & 37,21 & 15,49 \\
\hline de 10 a 20 S.M. & 43,86 & 21,10 & 12,14 & 12,26 & 12,01 & 6,09 & 9,42 & 3,74 & 32,43 & 13,66 \\
\hline mais de 20 S.M. & 42,00 & 19,35 & 12,43 & 13,02 & 11,79 & 6,16 & 9,36 & 3,96 & 28,94 & 12,46 \\
\hline Total & 30,29 & 16,71 & 7,82 & $\mathbf{8 , 1 7}$ & 6,20 & $\mathbf{9 , 0 2}$ & 11,69 & 6,54 & 34,75 & 16,24 \\
\hline
\end{tabular}

Fonte: IBGE, Censo Demográfico de 2000. Elaboração própria.

S.M.: Salário mínimo de 2000 (R\$ 151,00).

(1) Centro-Oeste incluindo o Distrito Federal.

(2) Centro-Oeste excluindo o Distrito Federal.

(3) Sudeste incluindo São Paulo.

(4) Sudeste excluindo São Paulo. 
A tendência de aumento do acesso por rede geral à medida que aumenta a renda domiciliar per capita mensal e a relação não clara entre o esgotamento por fossa séptica e a renda também podem ser ilustrados graficamente - o que é feito no gráfico 1.6. Para o Brasil como um todo, observa-se que o acesso por rede geral aumenta em função do aumento da renda domiciliar per capita mensal, mas de forma decrescente. A fossa séptica, por sua vez, apresenta uma pequena tendência de aumento até a segunda faixa de renda (de um a dois salários mínimos), a partir da qual apresenta uma tendência de queda.

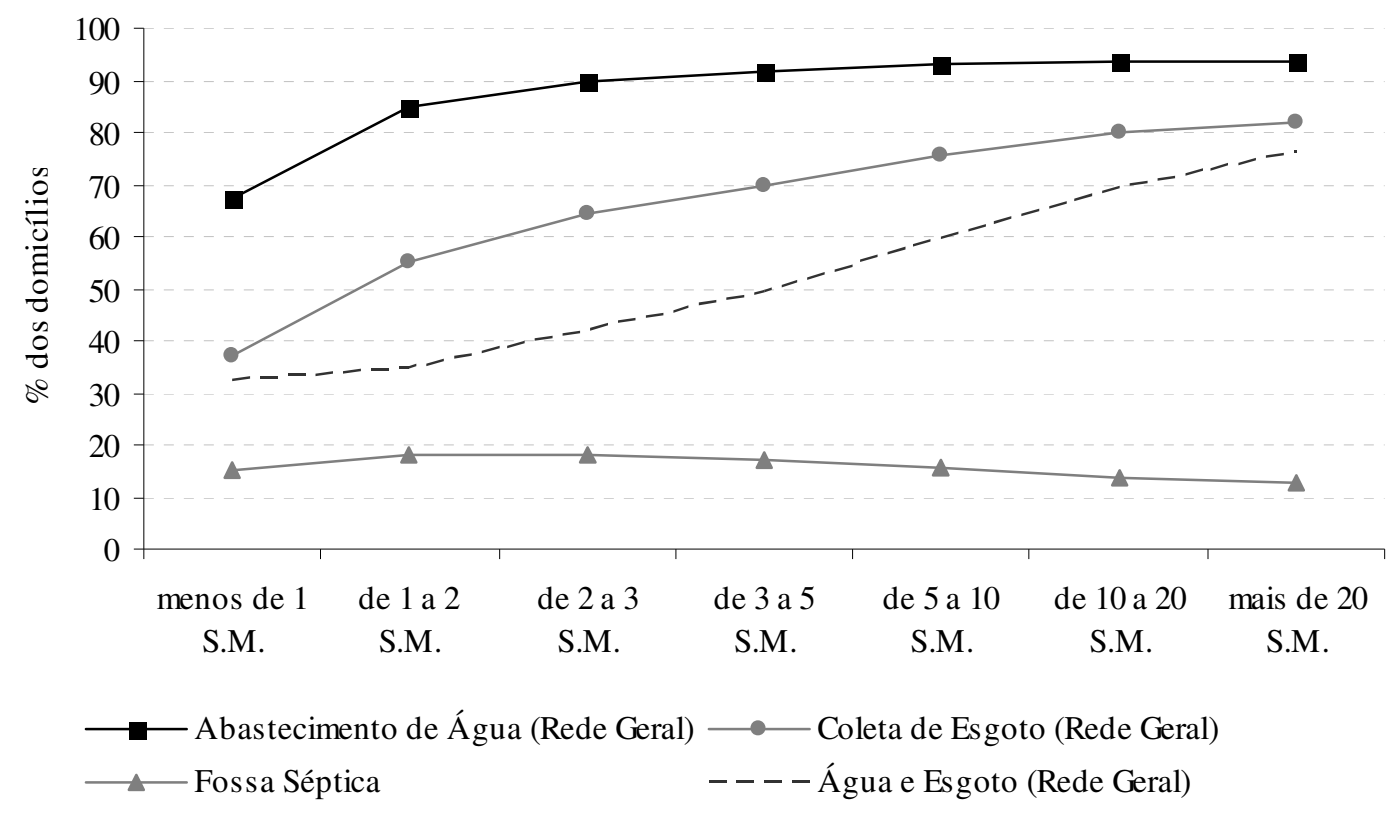

Fonte: IBGE, Censo Demográfico de 2000. Elaboração própria.

\section{Gráfico 2.6}

Brasil: proporção de domicílios com acesso a serviços de saneamento básico, segundo a renda domiciliar per capita mensal (2000)

A análise realizada até esse momento sugere, portanto, que os problemas de acesso domiciliar aos serviços de saneamento básico no Brasil concentram-se, principalmente, nas regiões menos desenvolvidas e nos municípios de menor porte, menor taxa de urbanização, 
menor renda per capita e localizados no interior, assim como nos domicílios de baixa renda e situados na zona rural. Na segunda seção, tais relações serão estimadas pelo método Probit.

\subsection{Tratamento de água e de esgoto}

Conforme destaca o BNDES (1997), grande parte do esgoto coletado no Brasil é despejado sem tratamento nos rios, lagos e mares que servem de corpos receptores. "Em conseqüência, a poluição das águas [...] é bastante elevada, dificultando e encarecendo, cada vez mais, a própria captação de água para abastecimento" (p. 1). Diante desse quadro, apesar do presente trabalho enfatizar mais a questão do acesso domiciliar aos serviços de saneamento básico - abastecimento de água por rede geral, coleta de esgoto por rede geral e esgotamento sanitário por fossa séptica -, é importante discutir, brevemente, a situação do tratamento de água e de esgoto no Brasil.

A tabela 2.10 apresenta o volume per capita de água distribuída e o volume per capita de água tratada distribuída, segundo as grandes regiões, nos anos 1989 e 2000.

Comparando-se os resultados obtidos em 2000 com os de 1989, observa-se que houve um aumento do volume de água per capita distribuída, tanto da água bruta quanto da água tratada. [...] É importante mencionar que, entre 1989 e 2000, o volume de água distribuída sem tratamento aumentou proporcionalmente. Do volume total de água distribuída no conjunto do país, em 1989, apenas 3,9\% não era tratado. Em 2000, esta proporção quase que dobrou, passando para 7,2\% (PNSB, 2000, p. 35-6).

Pode-se observar também que, em 2000, o volume de água distribuída diariamente na região Sudeste atingiu a média de $0,36 \mathrm{~m}^{3}$ per capita, enquanto as demais regiões permaneceram abaixo da média brasileira - destacando-se o caso da região Nordeste, na qual a média foi $35 \%$ menor do que a média brasileira. Além disso, observando a proporção do volume de água distribuída diariamente, com e sem tratamento, pode-se constatar uma diferença no nível de tratamento entre as regiões. A região Norte tratava apenas $67,6 \%$ de sua 
água distribuída diariamente, enquanto que, nas demais regiões e no Brasil como um todo, essa parcela era superior a $92 \%$.

Tabela 2.10

Brasil: volume per capita de água distribuída diariamente, 1989 e 2000

\begin{tabular}{l|c|c|c|c|c|c}
\hline \multirow{2}{*}{ Região } & \multicolumn{2}{|c|}{$\begin{array}{c}\text { Água Distribuída } \\
\left(\mathrm{m}^{3}\right)\end{array}$} & \multicolumn{2}{c|}{$\begin{array}{c}\text { Água Tratada } \\
\left(\mathrm{m}^{3}\right)\end{array}$} & \multicolumn{2}{c}{$\begin{array}{c}\text { Proporção do Volume de Água Distribuída } \\
\text { por dia em 2000 }(\%)\end{array}$} \\
\cline { 2 - 7 } & $\mathbf{1 9 8 9}$ & $\mathbf{2 0 0 0}$ & $\mathbf{1 9 8 9}$ & $\mathbf{2 0 0 0}$ & Com Tratamento & Sem Tratamento \\
\hline Norte & 0,17 & 0,19 & 0,15 & 0,13 & 67,6 & 32,4 \\
Nordeste & 0,12 & 0,17 & 0,11 & 0,15 & 93,6 & 6,4 \\
Centro-Oeste & 0,19 & 0,20 & 0,18 & 0,19 & 96,4 & 3,6 \\
Sudeste & 0,27 & 0,36 & 0,26 & 0,34 & 94,4 & 5,6 \\
Sul & 0,19 & 0,20 & 0,16 & 0,19 & 94,1 & $\mathbf{7 , 2}$ \\
Brasil & $\mathbf{0 , 2 0}$ & $\mathbf{0 , 2 6}$ & $\mathbf{0 , 1 9}$ & $\mathbf{0 , 2 4}$ & $\mathbf{9 2 , 8}$ & \\
\hline
\end{tabular}

Fonte: IBGE, Pesquisa Nacional de Saneamento Básico (PNSB, 2000, p. 35-6).

A tabela 2.11 aprofunda essa discussão, ao considerar o volume de água distribuída diariamente segundo o porte dos municípios (tamanho da população) e as grandes regiões.

Tabela 2.11

Brasil: volume de água distribuída diariamente, segundo o porte (tamanho da população) dos municípios e as grandes regiões (2000)

\begin{tabular}{l|cc|c|c|c|c|c}
\hline \multirow{2}{*}{ Porte } & \multicolumn{3}{c|}{$\begin{array}{c}\text { Proporção do Volume de Água } \\
\text { Distribuída Diariamente (\%) }\end{array}$} & \multicolumn{5}{c}{$\begin{array}{c}\text { Água Distribuída com Tratamento } \\
\text { (em m mer capita) }\end{array}$} \\
\cline { 2 - 8 } & Com Tratamento & Sem Tratamento & N & NE & CO & SE & S \\
\hline até 20 mil hab. & 67,9 & 32,1 & 0,04 & 0,08 & 0,12 & 0,16 & 0,10 \\
20 mil a 45 mil hab. & 89,6 & 10,4 & 0,05 & 0,09 & 0,15 & 0,41 & 0,18 \\
45 mil a 100 mil hab. & 92,0 & 8,0 & 0,08 & 0,16 & 0,14 & 0,34 & 0,22 \\
100 mil a 300 mil hab. & 98,2 & 1,8 & 0,19 & 0,18 & 0,14 & 0,45 & 0,24 \\
mais de 300 mil hab. & 98,5 & 1,5 & 0,26 & 0,27 & 0,28 & 0,34 & 0,25 \\
\hline
\end{tabular}

Fonte: IBGE, Pesquisa Nacional de Saneamento Básico (PNSB, 2000, p. 37).

Na tabela 2.11, observam-se três fatos interessantes: (i) a proporção de água tratada apresenta uma relação positiva com o tamanho populacional, ou seja, à medida que a população dos municípios aumenta, eleva-se a proporção de água tratada distribuída; (ii) o volume de água distribuída com tratamento $\left(\mathrm{em} \mathrm{m}^{3}\right.$ per capita $)$ é menor nos municípios de até vinte mil habitantes, independentemente da região a que pertencem e (iii) os municípios da 
região Sudeste possuem uma distribuição de água maior do que as demais, inclusive dentro de cada estrato populacional.

Em relação ao tratamento de esgoto, a tabela 2.12 mostra que, em 2000, 47,8\% dos municípios brasileiros não contavam com o serviço de coleta de esgoto, enquanto que $32 \%$ apenas coletavam o esgoto, sendo que o tratamento era realizado em somente $20,2 \%$ dos municípios. É possível observar, mais uma vez, a existência do desequilíbrio inter-regional de acesso aos serviços, com o Sudeste a maior proporção de municípios com coleta e tratamento de esgoto, acima da média do país, e o Norte a menor - contudo, nenhuma região possui índices ideais.

Tabela 2.12

Brasil: proporção de municípios, segundo a condição do esgotamento sanitário e as grandes regiões (2000)

\begin{tabular}{l|c|c|c}
\hline \multirow{2}{*}{ Região } & \multicolumn{2}{c}{ Proporção de Municípios por Condição de Esgotamento Sanitário $(\%)$} \\
\cline { 2 - 4 } & Sem Coleta & Só Coletam & \multicolumn{1}{c}{ Coletam e Tratam } \\
\hline Norte & 92,9 & 3,5 & 3,6 \\
Nordeste & 57,1 & 29,6 & 13,3 \\
Centro-Oeste & 82,1 & 5,6 & 12,3 \\
Sudeste & 7,1 & 59,8 & 33,1 \\
Sul & 61,1 & 17,2 & 21,7 \\
Brasil & $\mathbf{4 7 , 8}$ & $\mathbf{3 2 , 0}$ & $\mathbf{2 0 , 2}$ \\
\hline
\end{tabular}

Fonte: IBGE, Pesquisa Nacional de Saneamento Básico (PNSB, 2000, p. 44).

Deve-se destacar também que, segundo dados da Pesquisa Nacional de Saneamento Básico de 2000 (PNSB, 2000), o volume diário de esgoto tratado cresceu, aproximadamente, $77,4 \%$ de 1989 a 2000 , passando de $19,9 \mathrm{~m}^{3}$ para $35,3 \mathrm{~m}^{3}$. Contudo, apesar desse crescimento, “apenas $27 \%$ do esgoto coletado é tratado" atualmente no Brasil (MOTTA, 2004, p. 2). É importante ter em mente que o tratamento do esgoto gera alguns subprodutos que podem ser utilizados para algumas finalidades, conforme aponta o BNDES (1997): (i) lodo - rico em matéria orgânica, nitrogênio, fósforo e micronutrientes, podendo ser aproveitado na agricultura (aplicação direta no solo) -; (ii) efluente tratado - pode ser utilizado para fins não 
potáveis (reuso da água) - e (iii) biogás - pode ser utilizado para a geração de energia elétrica, como gás doméstico, gás industrial ou como combustível para veículos.

Portanto, além do déficit de acesso domiciliar a abastecimento de água e a coleta de esgoto - comentado anteriormente -, o saneamento básico brasileiro também apresenta um sério problema de falta de tratamento de água e de esgoto, o que torna a situação do setor ainda mais preocupante.

\section{Probabilidade de acesso: estimação pelo método Probit}

Conforme ficará claro mais adiante, os modelos a serem estimados nessa seção possuem variáveis dependentes binárias, ou seja, variáveis que assumem somente os valores zero e um - a distribuição de probabilidade de tais variáveis não é uma normal, mas sim uma distribuição de Bernoulli. De acordo com Johnston e DiNardo (2000, p. 452), modelos como estes partem do pressuposto de que existe uma variável latente $\mathbf{y}^{*}$ tal que:

$$
\mathrm{y}^{*}=\mathbf{x} \boldsymbol{\beta}+\varepsilon
$$

A variável latente é, portanto, função de um conjunto de características x. Contudo, ela não é observável. É possível observar, na verdade, uma variável y que assume valores 0 ou 1 de acordo com a seguinte regra:

$$
\mathrm{y}=\left\{\begin{array}{l}
1, \text { se } \mathrm{y}^{*}>0 \\
0, \text { caso contrário }
\end{array}\right.
$$

Ou seja, y representa um fato já concretizado - decorrência de y ${ }^{*}$. É importante destacar que esses modelos devem gerar como resultado a probabilidade de algum evento ocorrer, podendo ser representados, genericamente, da seguinte maneira (WOOLDRIDGE, 2002, p. 457-9): 
(3)

$$
\begin{aligned}
& \operatorname{Prob}(y=1 \mid \mathbf{x})=\operatorname{Prob}\left(y=1 \mid x_{1}, x_{2}, \ldots, x_{k}\right)=G(\mathbf{x} \beta) \equiv p(\mathbf{x}) \\
& \operatorname{Prob}(y=0 \mid \mathbf{x})=\operatorname{Prob}\left(y=0 \mid x_{1}, x_{2}, \ldots, x_{k}\right)=1-G(\mathbf{x} \boldsymbol{\beta}) \equiv 1-p(\mathbf{x}),
\end{aligned}
$$

em que:

(i) y: variável explicada (também chamada de variável de escolha, de variável dependente ou de variável endógena);

(ii) $\mathrm{y}=1$ : evento ocorre;

(iii) $\quad \mathrm{y}=0$ : evento não ocorre;

(iv) $\mathbf{x}$ : conjunto de variáveis explicativas (também chamado de regressores, de variáveis independentes ou de variáveis exógenas);

(v) G: função que restringe as probabilidades estimadas ao intervalo entre 0 e 1;

(vi) $\quad \boldsymbol{\beta}$ : conjunto de parâmetros que refletem o impacto de alterações de $\mathbf{x}$ sobre a probabilidade de um evento ocorrer;

(vii) $\quad \mathbf{x} \beta=\beta_{1}+\beta_{2} \mathrm{x}_{2}+\ldots+\beta_{\mathrm{k}} \mathrm{x}_{\mathrm{k}} \mathrm{e}$

(viii) $\mathrm{p}(\mathrm{x})$ : probabilidade de resposta.

O grande desafio desses modelos é, por se tratar de probabilidade, limitar o valor estimado de $\mathbf{x} \boldsymbol{\beta}$ ao intervalo entre 0 e 1, o que não ocorre na estimação por métodos convencionais (lineares). Para solucionar tal problema, costuma-se utilizar funções $(\mathrm{G})$ que limitam as probabilidades - ou seja, $0<\mathrm{G}(\mathbf{x} \boldsymbol{\beta})<1$. Uma função bastante utilizada para esse fim é a função cumulativa de probabilidade normal padronizada, gerando o chamado método Probit - utilizado na estimação dos modelos do presente trabalho.

Para uma variável independente contínua, $\mathrm{x}_{\mathrm{j}}$, o efeito marginal (parcial) de $\mathrm{x}_{\mathrm{j}}$ sobre a probabilidade de resposta é:

(4) $\left[\partial \mathrm{P}(\mathrm{y}=1 \mid \mathbf{x}) / \partial \mathrm{x}_{\mathrm{j}}\right]=\left[\partial \mathrm{p}(\mathbf{x}) / \partial \mathrm{x}_{\mathrm{j}}\right]=\mathrm{g}(\mathbf{x} \boldsymbol{\beta}) \beta_{\mathrm{j}}$, 
sendo: $\mathrm{g}(\mathrm{z}) \equiv[\mathrm{dG} / \mathrm{dz}](\mathrm{z})$ e $\mathrm{z}=\mathbf{x} \boldsymbol{\beta}$ (ou seja, $\mathrm{g}$ é a função densidade de probabilidade avaliada no ponto $\left.\mathrm{y}^{*}=\mathbf{x} \boldsymbol{\beta}\right)$.

Multiplicando a equação acima por $\Delta \mathrm{x}_{\mathrm{j}}$, obtém-se a variação aproximada em $\mathrm{P}(\mathrm{y}=1 \mid \mathbf{x})$ em função de uma variação $\Delta \mathrm{x}_{\mathrm{j}}$ em $\mathrm{x}_{\mathrm{j}}$, mantendo-se todas as outras variáveis fixas. Já para uma variável independente binária $\mathrm{x}_{\mathrm{k}}$, o efeito marginal (parcial) é obtido da seguinte maneira:

(5) $\mathrm{p}\left(\mathrm{x}_{1}, \mathrm{x}_{2}, \ldots, \mathrm{x}_{\mathrm{k}-1}, 1\right)-\mathrm{p}\left(\mathrm{x} 1, \mathrm{x} 2, \ldots, \mathrm{x}_{\mathrm{k}-1}, 0\right)=$

(6) $\mathrm{G}\left(\beta_{1}+\beta_{2} \mathrm{x}_{2}+\ldots+\beta_{\mathrm{K}-1} \mathrm{x}_{\mathrm{K}-1}+\beta_{\mathrm{K}}\right)-\mathrm{G}\left(\beta_{1}+\beta_{2} \mathrm{x}_{2}+\ldots+\beta_{\mathrm{K}-1} \mathrm{x}_{\mathrm{K}-1}\right)$

Ou seja, o efeito marginal (parcial) de uma variável independente binária $\mathrm{x}_{\mathrm{k}}$ é dado pela diferença entre a probabilidade de escolha quando $x_{k}=1$ e a probabilidade quando $x_{k}=0$. Contudo, conforme aponta Greene (1997), "simply taking the derivative with respect to the binary variable as if it were continuous provides an approximation that is often surprisingly accurate" (p. 878).

A equação (4) mostra que o efeito marginal (parcial) de $x_{j}$ sobre $p(\mathbf{x})$ depende de todas as variáveis explicativas pertencentes ao conjunto $\mathbf{x}$ por meio de $g(\mathbf{x} \boldsymbol{\beta})$ - as equações (5) e (6) também mostram a dependência de todos os outros valores de $\mathbf{x}$. Dessa forma, em uma estimação por Probit, "the parameters of the model [...] are not necessarily the marginal effects we are accustomed to analyzing (GREENE, 1997, p. 876). "The magnitude of $\beta_{j}$ is not especially meaningful except in special cases" (WOOLDRIDGE, 2002, p. 458).

Johnston e DiNardo (2001) também destacam esse fato, afirmando que, no método Probit, a derivada da probabilidade em relação a uma variável varia em função desta, mas também em função das demais variáveis explicativas do modelo. Conseqüentemente, "não é útil apresentar apenas os coeficientes [...], a não ser que estejamos apenas interessados no sinal e na significância" (p. 455) - a significância estatística de $\mathrm{x}_{\mathrm{j}}$ é determinada testando se é possível rejeitar a hipótese de que $\beta_{\mathrm{j}}$ seja igual a zero. 
Portanto, os sinais dos $\beta^{\prime}$ s estimados (parâmetros) indicarão as relações existentes (sinais) entre as variáveis explicativas e a probabilidade do evento ocorrer - uma vez que a função de densidade g é sempre positiva. Mas para encontrar a magnitude desses efeitos é necessário estimar as equações (4) e/ou (6) - no caso de uma variável explicativa contínua, esta é determinada por $\beta_{\mathrm{j}}$ e pela magnitude de $\mathrm{g}(\mathbf{x} \boldsymbol{\beta})$. É importante destacar também que "for computing marginal effects, one can evaluate the expressions at the sample means of the data or evaluate the marginal effects at every observation and use the sample average of the individual marginal effects" (GREENE, 1997, p. 876).

\section{$\underline{2.1 \text { Os modelos }}$}

Os modelos a serem estimados - com o objetivo de mensurar o impacto das variáveis municipais e domiciliares consideradas na seção anterior sobre a probabilidade de um domicílio brasileiro possuir acesso aos serviços de saneamento básico - possuem as seguintes formulações básicas:

(1) $y=\alpha+\beta_{1}$ renda domiciliar mensal $+\beta_{2}$ renda domiciliar per capita mensal $+\beta_{3}$ população do município (porte) $+\beta_{4}$ taxa de urbanização do município $+\beta_{5}$ renda municipal per capita mensal $+\beta_{6}$ localização do domicílio (urbano ou rural) $+\beta_{7}$ Norte $+\beta_{8}$ Nordeste $+\beta_{9}$ Centro-Oeste (2) $+\beta_{10}$ Distrito Federal $+\beta_{11}$ Sudeste (4) + $\beta_{12}$ Sul,

(2) $y=\alpha+\beta_{1}$ Norte $+\beta_{2}$ Nordeste $+\beta_{3}$ Centro-Oeste (2) $+\beta_{4}$ Distrito Federal $+\beta_{5}$ Sudeste (4) $+\beta_{6}$ Sul $+\beta_{7}$ Capital $+\beta_{8}$ Região Metropolitana, em que: 
(i) ㄴ: variáveis dependentes binárias, assumindo o valor um se o domicílio possuir acesso aos serviços - abastecimento de água por rede geral, coleta de esgoto por rede geral e esgotamento sanitário por fossa séptica - e zero caso contrário;

(ii) $\underline{\alpha}$ : constante;

(iii) $\underline{\beta}$ 's: parâmetros que refletem o impacto de alterações das variáveis explicativas sobre a probabilidade do domicílio possuir acesso aos serviços;

(iv) localização do domicílio: dummy representativa que assume o valor um se o domicílio está localizado na zona rural e zero se está localizado na zona urbana;

(v) Norte: dummy representativa que assume o valor um se o domicílio está localizado na região Norte e zero caso contrário;

(vi) Nordeste: dummy representativa que assume o valor um se o domicílio está localizado na região Nordeste e zero caso contrário;

(vii) Centro-Oeste (2): dummy representativa que assume o valor um se o domicílio está localizado na região Centro-Oeste e não pertence ao Distrito Federal e zero caso contrário;

(viii) Distrito Federal: dummy representativa que assume o valor um se o domicílio está localizado no Distrito Federal e zero caso contrário;

(ix) Sudeste (4): dummy representativa que assume o valor um se o domicílio está localizado na região Sudeste e não pertence ao Estado de São Paulo e zero caso contrário - ou seja, os domicílios de São Paulo serão utilizados como base de comparação (controle);

(x) Sul: dummy representativa que assume o valor um se o domicílio está localizado na região Sul e zero caso contrário;

(xi) Capital: dummy representativa que assume o valor um se o domicílio está localizado em uma capital estadual ou Federal e zero caso contrário e 
(xii) Região Metropolitana: dummy representativa que assume o valor um se o domicílio está localizado em um município pertencente a uma região metropolitana e zero caso contrário - os domicílios localizados em municípios do interior serão utilizados, portanto, como base de comparação (controle).

Portanto, serão estimados dois tipos de modelo: (i) um modelo com variáveis independentes contínuas e discretas (tipo 1) e (ii) um modelo apenas com variáveis independentes discretas (tipo 2). No primeiro, espera-se captar o impacto de algumas características municipais e domiciliares sobre a probabilidade de acesso. Já no segundo, o interesse é, basicamente, captar as diferenças do acesso em tipos distintos de municípios.

Tomando por base o pressuposto básico do método Probit, apresentado anteriormente, pode-se dizer, grosso modo, que a variável latente (não observada) dos modelos é o investimento realizado no setor ao longo do tempo. Ou seja, como é difícil obter o montante de investimento já realizado em cada localidade, utiliza-se a informação da existência ou não do acesso aos serviços para estimar, indiretamente, a influência (impacto) das variáveis explicativas sobre os investimentos já realizados no saneamento básico brasileiro.

Deve-se destacar que as variáveis independentes contínuas - renda domiciliar mensal, renda domiciliar per capita mensal, renda municipal per capita mensal e população do município - serão utilizadas em suas formas logarítmicas - logaritmo neperiano -, para evitar problemas decorrentes da grande variação destas e da baixa variação da variável dependente, que, por ser binária, só pode assumir os valores zero e um. Excetua-se, nesse caso, a variável taxa de urbanização municípios, que só pode assumir valores no intervalo entre 0 e 1 .

A análise realizada na seção anterior apontou evidências de uma relação positiva entre a proporção de domicílios com acesso aos serviços por rede geral e a população, a taxa de urbanização, a renda dos municípios e a renda dos domicílios. Além disso, mostrou que o acesso por rede geral é maior no Sudeste - principalmente em São Paulo, exceto na coleta de 
esgoto em relação ao Distrito Federal -, nas capitais estaduais ou na capital Federal, em municípios de regiões metropolitanas e na zona urbana. No caso da fossa séptica, as relações com essas variáveis, de uma maneira geral, não ficaram tão claras. Tomando por base tal análise, é possível fazer previsões sobre os sinais dos coeficientes a serem estimados, o que é ilustrado na tabela 2.13 .

Tabela 2.13

Sinais esperados dos coeficientes a serem estimados

\begin{tabular}{lccc|c}
\hline \multicolumn{1}{c|}{ Variáveis } & $\begin{array}{c}\text { Água } \\
\text { (rede geral) }\end{array}$ & $\begin{array}{c}\text { Esgoto } \\
\text { (rede geral) }\end{array}$ & Fossa Séptica \\
\hline Dummy Localização do Domicílio (rural ou urbano) & $(-)$ & $(-)$ & $(+)$ \\
Dummies Regionais & $(-)$ & $(-)$ & $(+)$ \\
Dummy Distrito Federal & $(-)$ & $(+)$ & $(-)$ \\
Renda Domiciliar Mensal & $(+)$ & $(+)$ & $(-)$ \\
Renda Domiciliar per capita Mensal & $(+)$ & $(+)$ & $(-)$ \\
População do Município & $(+)$ & $(+)$ & $(-)$ \\
Renda Municipal per capita Mensal & $(+)$ & $(+)$ & $(-)$ \\
Taxa de Urbanização Municipal & $(+)$ & $(+)$ & $(-)$ \\
Dummy Capital & $(+)$ & $(+)$ & $(-)$ \\
Dummy Região Metropolitana & $(+)$ & $(+)$ & $(-)$ \\
\hline
\end{tabular}

Dessa forma, para as variáveis dependentes abastecimento de água por rede geral e coleta de esgoto por rede geral, espera-se que os coeficientes da dummy localização e de todas as dummies regionais sejam negativos - exceto a dummy Distrito Federal no caso da coleta de esgoto - e que os coeficientes das demais variáveis sejam positivos. No caso da variável dependente acesso à fossa séptica, apesar das relações não terem ficado tão claras, o lógico e o ideal - seria que os coeficientes das variáveis apresentassem sinais contrários aos sinais dos coeficientes estimados para a coleta de esgoto por rede geral - isto porque, apesar de não ser ideal, a fossa séptica deveria ser a primeira alternativa no caso da ausência de rede coletora de esgoto. 


\section{$\underline{\text { 2.2 Os dados e a amostra }}$}

Antes de apresentar os resultados das estimações, é importante fazer alguns comentários sobre os dados utilizados. Primeiramente, deve-se apontar que foram coletadas informações para todos os domicílios que constavam no Censo Demográfico de 2000 - total de, aproximadamente, 5,3 milhões de domicílios. A análise descritiva do capítulo anterior considerou todas essas informações. Contudo, para a realização das estimações, optou-se por utilizar uma amostra aleatória menor, com aproximadamente $10 \%$ do total de domicílios com informações disponibilizadas pelo Censo, ou seja, aproximadamente quinhentos e trinta mil.

A tabela 2.14 mostra como os domicílios do Censo e da amostra utilizada distribuem-se entre as grandes regiões e de acordo com o acesso aos três tipos serviços. Deve-se destacar que a utilização de uma amostra aleatória pouco alterou a proporção de domicílios em cada região, assim como a proporção de domicílios com acesso aos serviços.

A tabela 2.15, por sua vez, apresenta as estatísticas descritivas das variáveis utilizadas nas estimações (amostra). A análise dessa tabela é importante, pois o cálculo dos efeitos marginais levará em conta a média das variáveis - grosso modo, as características do “domicílio médio" da amostra. Dessa forma, é possível apontar alguns aspectos relevantes:

(i) população do município: média da amostra superior a um milhão de habitantes devido ao maior número de domicílios em municípios mais populosos - e desviopadrão bastante elevado (2.740.688) - grande diferença entre o valor mínimo e o máximo;

(ii) taxa de urbanização: média igual a 0,83 e desvio-padrão igual a 0,22. Em relação a essa variável, o interessante a observar é que a amostra tem pelo menos um município com toda população morando na zona rural - mínimo igual a zero - e pelo menos um município com toda população morando na zona urbana - máximo igual a um; 
Tabela 2.14

Brasil: distribuição dos domicílios com acesso a serviços de saneamento básico (Censo e amostra), segundo as grandes regiões, o Distrito Federal e o Estado de São Paulo

\begin{tabular}{|c|c|c|c|c|}
\hline \multirow{2}{*}{$\begin{array}{l}\text { Domicílios / } \\
\text { Regiões }\end{array}$} & \multirow{2}{*}{$\begin{array}{l}\text { Domicílios } \\
\text { (\% do total) }\end{array}$} & \multirow{2}{*}{$\begin{array}{c}\text { Água } \\
\text { (Rede Geral) } \\
\text { (\% dos domicílios) }\end{array}$} & \multicolumn{2}{|c|}{$\begin{array}{c}\text { Esgoto } \\
\text { (\% dos domicílios) }\end{array}$} \\
\hline & & & Rede Geral & Fossa Séptica \\
\hline \multicolumn{5}{|c|}{ Censo } \\
\hline Norte & 6,32 & 48,24 & 11,36 & 28,35 \\
\hline Nordeste & 26,30 & 65,94 & 31,71 & 16,05 \\
\hline Centro-Oeste (1) & 7,29 & 73,34 & 35,1 & 7,45 \\
\hline Centro-Oeste (2) & 6,25 & 70,11 & 24,34 & 7,67 \\
\hline Distrito Federal & 1,03 & 88,72 & 84,29 & 6,18 \\
\hline Sudeste (3) & 43,20 & 85,64 & 72,46 & 8,85 \\
\hline Sudeste (4) & 21,76 & 83,12 & 67,13 & 10,94 \\
\hline São Paulo & 21,44 & 93,51 & 82,27 & 6,79 \\
\hline Sul & 16,90 & 80,11 & 30,69 & 32,89 \\
\hline Brasil & 100,00 & 77,89 & 51,62 & 15,83 \\
\hline \multicolumn{5}{|c|}{ Amostra } \\
\hline Norte & 6,27 & 47,99 & 11,71 & 30,05 \\
\hline Nordeste & 25,41 & 66,95 & 33,21 & 16,84 \\
\hline Centro-Oeste (1) & 7,10 & 73,05 & 35,08 & 7,90 \\
\hline Centro-Oeste (2) & 5,88 & 69,72 & 24,18 & 8,25 \\
\hline Distrito Federal & 1,22 & 88,91 & 84,88 & 6,32 \\
\hline Sudeste (3) & 45,15 & 88,40 & 75,03 & 8,98 \\
\hline Sudeste (4) & 21,95 & 82,99 & 67,19 & 11,57 \\
\hline São Paulo & 23,20 & 93,55 & 82,32 & 6,57 \\
\hline Sul & 16,08 & 80,00 & 30,67 & 34,94 \\
\hline Brasil & 100,00 & 77,97 & 51,78 & 16,28 \\
\hline
\end{tabular}

Fonte: IBGE, Censo Demográfico de 2000. Elaboração própria.

(1) Centro-Oeste incluindo o Distrito Federal.

(2) Centro-Oeste excluindo o Distrito Federal.

(3) Sudeste incluindo São Paulo.

(4) Sudeste excluindo São Paulo.

(iii) renda municipal per capita mensal: média igual a $\mathrm{R} \$ 310,05$ - aproximadamente 2,05 salários-mínimos de 2000 (R \$ 151,00) - e desvio-padrão igual a $\mathrm{R}$ \$176,43, sendo a renda mínima igual a $R$ \$ 4,54 (0,03 salário mínimo de 2000) e a máxima igual a $R$ \$ 1.672,90 (11,08 salários mínimos de 2000);

(iv) renda domiciliar mensal: média da amostra é de $\mathrm{R} \$ 1.119,75$ - 7,42 salários-mínimos de 2000. Deve-se apontar também que a renda altera-se bastante de domicílio para domicílio, o que leva a um desvio-padrão elevado ( $\mathrm{R} \$ 3.256,97)$, sendo o valor mínimo igual a zero e o máximo igual a R \$ 619.750,00; 
Tabela 2.15

Estatísticas descritivas das variáveis utilizadas nas estimações (amostra)

\begin{tabular}{|c|c|c|c|c|}
\hline Variáveis & Média & Desvio-Padrão & Mínimo & Máximo \\
\hline Abastecimento de Água por Rede Geral & --- & --- & 0 & 1 \\
\hline Coleta de Esgoto por Rede Geral & --- & --- & 0 & 1 \\
\hline Fossa Séptica & --- & --- & 0 & 1 \\
\hline Localização do Domicílio & --- & --- & 0 & 1 \\
\hline Dummies Regionais & --- & --- & 0 & 1 \\
\hline Dummy Distrito Federal & --- & --- & 0 & 1 \\
\hline Dummy Capital & --- & --- & 0 & 1 \\
\hline Dummy Região Metropolitana & --- & --- & 0 & 1 \\
\hline População do Município & $1.259 .482,89$ & $2.740 .688,40$ & 795,00 & $10.434 .252,00$ \\
\hline Taxa de Urbanização Municipal & 0,83 & 0,22 & 0,00 & 1,00 \\
\hline Renda Municipal per capita Mensal (R\$) & 310,05 & 176,43 & 4,54 & $1.672,90$ \\
\hline Renda Domiciliar Mensal (R\$) & $1.119,75$ & $3.256,97$ & 0,00 & $619.750,00$ \\
\hline Renda Domiciliar per capita Mensal (R\$) & 371,55 & $1.221,63$ & 0,00 & $229.395,00$ \\
\hline
\end{tabular}

(v) renda domiciliar per capita mensal: média igual a $\mathrm{R} \$ 371,55$ - 2,46 salários-mínimos de 2000 - e desvio-padrão elevado (R \$ 1.221,63), sendo o valor mínimo igual a zero e o máximo igual a $\mathrm{R} \$ 229.395,00$.

\section{$\underline{2.3 \text { Os resultados }}$}

Primeiramente, serão apresentados os resultados obtidos com as estimações dos modelos do tipo (1). Ou seja, modelos que buscam captar o impacto de algumas características municipais e domiciliares sobre a probabilidade de acesso aos serviços de saneamento básico no Brasil - abastecimento de água por rede geral, coleta de esgoto por rede geral e esgotamento sanitário por fossa séptica. É importante destacar que, devido à multicolinearidade existente entre algumas variáveis independentes e a coeficientes que se mostraram não significativos, foram estimados modelos "alternativos", que consideram um conjunto menor das variáveis explicativas apresentadas anteriormente. 
A tabela 2.16 apresenta os resultados das estimações com o acesso a abastecimento de água por rede geral como variável dependente. Além dos coeficientes, tal tabela também apresenta os efeitos marginais - e, em alguns casos, as elasticidades - das variáveis explicativas sobre a variável dependente.

Tabela 2.16

Resultados das estimações: variável dependente abastecimento de água por rede geral (2000)

\begin{tabular}{|c|c|c|c|c|c|c|}
\hline $\begin{array}{l}\text { Abastecimento de } \\
\text { Água (Rede Geral) }\end{array}$ & Coeficiente & $\begin{array}{c}\text { Efeito } \\
\text { Marginal } \\
\end{array}$ & Coeficiente & $\begin{array}{c}\text { Efeito } \\
\text { Marginal } \\
\end{array}$ & Coeficiente & $\begin{array}{c}\text { Efeito } \\
\text { Marginal } \\
\end{array}$ \\
\hline $\begin{array}{c}\text { Ln (Renda Domiciliar } \\
\text { Mensal) }\end{array}$ & $\begin{array}{l}0,0779 * \\
(0,0049)\end{array}$ & $\begin{array}{l}0,0205 * \\
(0,0013) \\
{[0,1297]}\end{array}$ & $\begin{array}{l}0,0883 * \\
(0,0049)\end{array}$ & $\begin{array}{l}0,0235 * \\
(0,0013) \\
{[0,1485]}\end{array}$ & $\begin{array}{l}0,0807 * \\
(0,0049)\end{array}$ & $\begin{array}{l}0,0214 * \\
(0,0013) \\
{[0,1351]}\end{array}$ \\
\hline $\begin{array}{l}\text { Ln (Renda Domiciliar } \\
\text { per capita Mensal) }\end{array}$ & $\begin{array}{l}0,0703 * \\
(0,0047)\end{array}$ & $\begin{array}{l}0,0185 * \\
(0,0012) \\
{[0,0945]}\end{array}$ & $\begin{array}{l}0,0780 * \\
(0,0046)\end{array}$ & $\begin{array}{c}0,0207 * \\
(0,0012) \\
{[0,1059]}\end{array}$ & $\begin{array}{l}0,0601 * \\
(0,0047)\end{array}$ & $\begin{array}{l}0,0159 * \\
(0,0012) \\
{[0,0812]}\end{array}$ \\
\hline $\begin{array}{l}\text { Ln (População do } \\
\text { Município) }\end{array}$ & $\begin{array}{l}0,0662 * \\
(0,0014)\end{array}$ & $\begin{array}{c}0,0174 * \\
(0,0004) \\
{[0,2022]}\end{array}$ & & & & \\
\hline $\begin{array}{c}\text { Taxa de Urbanização } \\
\text { do Município }\end{array}$ & & & $\begin{array}{l}0,2392 * \\
(0,0125)\end{array}$ & $\begin{array}{l}0,0636 * \\
(0,0033)\end{array}$ & & \\
\hline $\begin{array}{l}\text { Ln (Renda Municipal } \\
\text { per capita } \text { Mensal) }\end{array}$ & & & & & $\begin{array}{l}0,2425 * \\
(0,0055)\end{array}$ & $\begin{array}{c}0,0642 * \\
(0,0015) \\
{[0,3514]}\end{array}$ \\
\hline $\begin{array}{l}\text { Localização do } \\
\text { Domicílio }\end{array}$ & $\begin{array}{l}-2,0206 * \\
(0,0061)\end{array}$ & $\begin{array}{c}-0,6649 * \\
(0,0017)\end{array}$ & $\begin{array}{l}-2,0555 * \\
(0,0066)\end{array}$ & $\begin{array}{c}-0,6761 * \\
(0,0018)\end{array}$ & $\begin{array}{l}-2,0357 * \\
(0,0060)\end{array}$ & $\begin{array}{c}-0,6699 * \\
(0,0017)\end{array}$ \\
\hline Dummy Norte & $\begin{array}{l}-1,2970 * \\
(0,0110)\end{array}$ & $\begin{array}{c}-0,4595 * \\
(0,0040)\end{array}$ & $\begin{array}{l}-1,3003 * \\
(0,0111)\end{array}$ & $\begin{array}{r}-0,4621 * \\
(0,0040)\end{array}$ & $\begin{array}{l}-1,1609 * \\
(0,0116)\end{array}$ & $\begin{array}{r}-0,4088 * \\
(0,0044)\end{array}$ \\
\hline Dummy Nordeste & $\begin{array}{l}-0,4971 * \\
(0,0087)\end{array}$ & $\begin{array}{c}-0,1445 * \\
(0,0027)\end{array}$ & $\begin{array}{l}-0,5024 * \\
(0,0089)\end{array}$ & $\begin{array}{c}-0,1474 * \\
(0,0028)\end{array}$ & $\begin{array}{l}-0,3033 * \\
(0,0103)\end{array}$ & $\begin{array}{c}-0,0855 * \\
(0,0030)\end{array}$ \\
\hline $\begin{array}{c}\text { Dummy } \\
\text { Centro-Oeste (2) }\end{array}$ & $\begin{array}{l}-0,8019 * \\
(0,0112)\end{array}$ & $\begin{array}{c}-0,2681 * \\
(0,0043)\end{array}$ & $\begin{array}{c}-0,8726 * \\
(0,0111)\end{array}$ & $\begin{array}{c}-0,2973 * \\
(0,0042)\end{array}$ & $\begin{array}{l}-0,7986 * \\
(0,0112)\end{array}$ & $\begin{array}{c}-0,2679 * \\
(0,0043)\end{array}$ \\
\hline $\begin{array}{c}\text { Dummy Distrito } \\
\text { Federal }\end{array}$ & $\begin{array}{l}-0,6153 * \\
(0,0263)\end{array}$ & $\begin{array}{c}-0,2017 * \\
(0,0100)\end{array}$ & $\begin{array}{l}-0,4806 * \\
(0,0261)\end{array}$ & $\begin{array}{c}-0,1528 * \\
(0,0095)\end{array}$ & $\begin{array}{l}-0,5724 * \\
(0,0261)\end{array}$ & $\begin{array}{c}-0,1862 * \\
(0,0098)\end{array}$ \\
\hline Dummy Sudeste (4) & $\begin{array}{l}-0,4272 * \\
(0,0088)\end{array}$ & $\begin{array}{c}-0,1242 * \\
(0,0028)\end{array}$ & $\begin{array}{l}-0,4436 * \\
(0,0088)\end{array}$ & $\begin{array}{r}-0,1304 * \\
(0,0028)\end{array}$ & $\begin{array}{l}-0,3781 * \\
(0,0089)\end{array}$ & $\begin{array}{c}-0,1093 * \\
(0,0028)\end{array}$ \\
\hline Dummy Sul & $\begin{array}{l}-0,3231 * \\
(0,0094)\end{array}$ & $\begin{array}{c}-0,0930 * \\
(0,0029)\end{array}$ & $\begin{array}{l}-0,3836 * \\
(0,0093)\end{array}$ & $\begin{array}{r}-0,1130 * \\
(0,0030)\end{array}$ & $\begin{array}{l}-0,3598 * \\
(0,0092)\end{array}$ & $\begin{array}{r}-0,1050 * \\
(0,0029)\end{array}$ \\
\hline Constante & $\begin{array}{l}0,1123 * \\
(0,0231)\end{array}$ & & $\begin{array}{l}0,6003 * \\
(0,0207)\end{array}$ & & $\begin{array}{l}-0,4785 * \\
(0,0341) \\
\end{array}$ & \\
\hline $\mathbf{y}=\operatorname{Pr}($ agua $)$ (predict) & \multicolumn{2}{|c|}{0,819021} & \multicolumn{2}{|c|}{0,816204} & \multicolumn{2}{|c|}{0,817536} \\
\hline $\operatorname{LR} \aleph^{2}(10)$ & \multicolumn{2}{|c|}{$235.631,96$} & \multicolumn{2}{|c|}{$233.657,87$} & \multicolumn{2}{|c|}{$235.239,33$} \\
\hline Prob $>\aleph^{2}$ & \multicolumn{2}{|c|}{0,0000} & \multicolumn{2}{|c|}{0,0000} & \multicolumn{2}{|c|}{0,0000} \\
\hline Pseudo-R ${ }^{2}$ & \multicolumn{2}{|c|}{0,4228} & \multicolumn{2}{|c|}{0,4193} & \multicolumn{2}{|c|}{0,4221} \\
\hline
\end{tabular}

Obs.: Erro-padrão entre parênteses e elasticidades das variáveis contínuas entre colchetes, calculadas na forma d(y) / d(lnx). * Significativo a $1 \%$. 
Em primeiro lugar, deve-se apontar que todos os coeficientes são significativos e que a hipótese de todos eles serem iguais a zero deve ser rejeitada, o que pode ser observado nas estatísticas do teste LR com distribuição $\aleph^{2}$ (chi-quadrado). O “poder de explicação" do teste é dado pela estatística pseudo- $\mathrm{R}^{2}$ - o teste $\mathrm{R}^{2}$ convencional não é adequado em uma estimação pelo método Probit, uma vez que o resultado é uma probabilidade limitada ao intervalo entre 0 e 1 , o que gera, necessariamente, um valor muito baixo.

Observa-se também que a probabilidade de um domicílio qualquer da amostra possuir abastecimento de água por rede geral é superior a 80\%. Conforme era esperado, renda domiciliar mensal, renda domiciliar per capita mensal, renda municipal per capita mensal, população e taxa de urbanização do município impactam positivamente sobre a probabilidade (aumentam) de acesso ao serviço. Por outro lado, todas as dummies impactam negativamente sobre essa probabilidade (diminuem), comprovando o maior acesso urbano aproximadamente sessenta e sete pontos percentuais superior ao rural -, assim como a maior cobertura no Estado de São Paulo.

A tabela 2.17, por sua vez, apresenta os resultados das estimações que consideram o acesso domiciliar a coleta de esgoto por rede geral como variável dependente. Observa-se que a probabilidade de um domicílio qualquer da amostra possuir rede coletora de esgoto é de 44$45 \%$ - bastante inferior à probabilidade de possuir abastecimento de água por rede geral. Conforme era esperado, renda domiciliar mensal, renda domiciliar per capita mensal, renda municipal per capita mensal, população e taxa de urbanização impactam positivamente sobre a probabilidade (aumentam) de acesso ao serviço, enquanto as dummies impactam negativamente (diminuem) - maior acesso urbano e maior cobertura no Estado de São Paulo. Contrariando as expectativas, a dummy Distrito Federal apresentou sinal negativo. Além disso, deve-se apontar que todos os coeficientes são significativos e que a hipótese de todos eles serem nulos deve ser rejeitada. 
Tabela 2.17

Resultados das estimações: variável dependente coleta de esgoto por rede geral (2000)

\begin{tabular}{|c|c|c|c|c|c|c|}
\hline $\begin{array}{c}\text { Coleta de Esgoto } \\
\text { (Rede Geral) }\end{array}$ & Coeficiente & $\begin{array}{c}\text { Efeito } \\
\text { Marginal } \\
\end{array}$ & Coeficiente & $\begin{array}{c}\text { Efeito } \\
\text { Marginal } \\
\end{array}$ & Coeficiente & $\begin{array}{c}\text { Efeito } \\
\text { Marginal }\end{array}$ \\
\hline $\begin{array}{l}\text { Ln (Renda Domiciliar } \\
\text { Mensal) }\end{array}$ & $\begin{array}{l}0,0259 * \\
(0,0045)\end{array}$ & $\begin{array}{l}0,0103 * \\
(0,0018) \\
{[0,0660]}\end{array}$ & $\begin{array}{l}0,0320 * \\
(0,0045)\end{array}$ & $\begin{array}{l}0,0126 * \\
(0,0018) \\
{[0,0812]}\end{array}$ & $\begin{array}{l}0,0230 * \\
(0,0045)\end{array}$ & $\begin{array}{l}0,0091 * \\
(0,0018) \\
{[0,0584]}\end{array}$ \\
\hline $\begin{array}{l}\text { Ln (Renda Domiciliar per } \\
\text { capita } \text { Mensal) }\end{array}$ & $\begin{array}{l}0,2020 * \\
(0,0043)\end{array}$ & $\begin{array}{l}0,0185 * \\
(0,0799) \\
{[0,4172]}\end{array}$ & $\begin{array}{l}0,2098 * \\
(0,0043)\end{array}$ & $\begin{array}{l}0,0828 * \\
(0,0017) \\
{[0,4323]}\end{array}$ & $\begin{array}{l}0,1746 * \\
(0,0044)\end{array}$ & $\begin{array}{c}0,0690 * \\
(0,0017) \\
{[0,3602]}\end{array}$ \\
\hline $\begin{array}{l}\text { Ln (População do } \\
\text { Município) }\end{array}$ & $\begin{array}{l}0,0983 * \\
(0,0011)\end{array}$ & $\begin{array}{l}0,0389 * \\
(0,0004) \\
{[0,4569]}\end{array}$ & & & & \\
\hline $\begin{array}{c}\text { Taxa de Urbanização do } \\
\text { Município }\end{array}$ & & & $\begin{array}{l}1,0343 * \\
(0,0132)\end{array}$ & $\begin{array}{l}0,4081 * \\
(0,0052)\end{array}$ & & \\
\hline $\begin{array}{l}\text { Ln (Renda Municipal per } \\
\text { capita } \text { Mensal) }\end{array}$ & & & & & $\begin{array}{l}0,5697 * \\
(0,0050)\end{array}$ & $\begin{array}{l}0,2250 * \\
(0,0020) \\
{[1,2510]}\end{array}$ \\
\hline Localização do Domicílio & $\begin{array}{l}-1,6977 * \\
(0,0102)\end{array}$ & $\begin{array}{c}-0,4919 * \\
(0,0015)\end{array}$ & $\begin{array}{l}-1,6376 * \\
(0,0103)\end{array}$ & $\begin{array}{c}-0,4776 * \\
(0,0016)\end{array}$ & $\begin{array}{c}-1,7087 * \\
(0,0102)\end{array}$ & $\begin{array}{c}-0,4906 * \\
(0,0015)\end{array}$ \\
\hline Dummy Norte & $\begin{array}{l}-2,0295 * \\
(0,0124)\end{array}$ & $\begin{array}{c}-0,4733 * \\
(0,0012)\end{array}$ & $\begin{array}{l}-1,9665 * \\
(0,0125)\end{array}$ & $\begin{array}{c}-0,4630 * \\
(0,0012)\end{array}$ & $\begin{array}{c}-1,7172 * \\
(0,0128)\end{array}$ & $\begin{array}{c}-0,4433 * \\
(0,0015)\end{array}$ \\
\hline Dummy Nordeste & $\begin{array}{c}-1,1675 * \\
(0,0068)\end{array}$ & $\begin{array}{c}-0,3997 * \\
(0,0019)\end{array}$ & $\begin{array}{l}-1,0911 * \\
(0,0070)\end{array}$ & $\begin{array}{c}-0,3764 * \\
(0,0020)\end{array}$ & $\begin{array}{l}-0,7500 * \\
(0,0079)\end{array}$ & $\begin{array}{c}-0,2750 * \\
(0,0026)\end{array}$ \\
\hline $\begin{array}{c}\text { Dummy } \\
\text { Centro-Oeste (2) }\end{array}$ & $\begin{array}{c}-1,5911 * \\
(0,0103)\end{array}$ & $\begin{array}{c}-0,4359 * \\
(0,0015)\end{array}$ & $\begin{array}{c}-1,6512 * \\
(0,0101)\end{array}$ & $\begin{array}{c}-0,4381 * \\
(0,0014)\end{array}$ & $\begin{array}{c}-1,5351 * \\
(0,0103)\end{array}$ & $\begin{array}{c}-0,4255 * \\
(0,0015)\end{array}$ \\
\hline Dummy Distrito Federal & $\begin{array}{c}-0,1681 * \\
(0,0232)\end{array}$ & $\begin{array}{c}-0,0655 * \\
(0,0089)\end{array}$ & & & $\begin{array}{c}-0,2121 * \\
(0,0231)\end{array}$ & $\begin{array}{c}-0,0819 * \\
(0,0087)\end{array}$ \\
\hline Dummy Sudeste (4) & $\begin{array}{c}-0,3782 * \\
(0,0066)\end{array}$ & $\begin{array}{c}-0,1460 * \\
(0,0025)\end{array}$ & $\begin{array}{c}-0,3697 * \\
(0,0066)\end{array}$ & $\begin{array}{c}-0,1423 * \\
(0,0024)\end{array}$ & $\begin{array}{c}-0,2582 * \\
(0,0067)\end{array}$ & $\begin{array}{c}-0,1005 * \\
(0,0026)\end{array}$ \\
\hline Dummy Sul & $\begin{array}{c}-1,3740 * \\
(0,0072)\end{array}$ & $\begin{array}{c}-0,4434 * \\
(0,0017)\end{array}$ & $\begin{array}{l}-1,4071 * \\
(0,0065)\end{array}$ & $\begin{array}{c}-0,4470 * \\
(0,0016)\end{array}$ & $\begin{array}{l}-1,3971 * \\
(0,0071)\end{array}$ & $\begin{array}{c}-0,4462 * \\
(0,0017)\end{array}$ \\
\hline Constante & $\begin{array}{c}-1,4400 * \\
(0,0194) \\
\end{array}$ & & $\begin{array}{c}-1,2523 * \\
(0,0188) \\
\end{array}$ & & $\begin{array}{c}-3,4330 * \\
(0,0304)\end{array}$ & \\
\hline $\mathbf{y}=\operatorname{Pr}($ esgoto $)($ predict $)$ & \multicolumn{2}{|c|}{0,447570} & \multicolumn{2}{|c|}{0,440939} & \multicolumn{2}{|c|}{0,443365} \\
\hline $\operatorname{LR} \aleph^{2}(10)$ & \multirow{2}{*}{\multicolumn{2}{|c|}{$\begin{array}{r}210.787,85 \\
0,0000\end{array}$}} & \multicolumn{2}{|c|}{$209.302,17$} & \multicolumn{2}{|c|}{$216.528,17$} \\
\hline Prob $>x^{2}$ & & & \multirow{2}{*}{\multicolumn{2}{|c|}{$\begin{array}{l}0,0000 \\
0,3321\end{array}$}} & \multicolumn{2}{|c|}{0,0000} \\
\hline Pseudo-R ${ }^{2}$ & \multicolumn{2}{|c|}{0,3345} & & & & 436 \\
\hline
\end{tabular}

Obs.: Erro-padrão entre parênteses e elasticidades das variáveis contínuas entre colchetes, calculadas na forma d(y) / d( $\ln x)$. * Significativo a $1 \%$.

Os resultados das estimações que consideram como variável dependente a existência de esgotamento sanitário por fossa séptica no domicílio são apresentados na tabela 2.18. Mais uma vez, a hipótese de todos os coeficientes serem nulos deve ser rejeitada.

Contrariando as expectativas, observa-se que a probabilidade do domicílio ter acesso à fossa séptica aumenta à medida que se eleva a renda domiciliar mensal, a renda domiciliar per 
capita mensal, a renda municipal per capita mensal, a população e a taxa de urbanização. $\mathrm{O}$ sinal negativo da dummy localização também não era esperado - previa-se que o acesso a coleta de esgoto por rede geral menor na zona rural seria compensado por um maior acesso à fossa séptica. Em relação às dummies regionais e à dummy Distrito Federal, os sinais previstos foram observados.

Tabela 2.18

Resultados das estimações: variável dependente esgotamento sanitário por fossa séptica (2000)

\begin{tabular}{|c|c|c|c|c|c|c|}
\hline Fossa Séptica & Coeficiente & $\begin{array}{c}\text { Efeito } \\
\text { Marginal }\end{array}$ & Coeficiente & \begin{tabular}{|c|} 
Efeito \\
Marginal \\
\end{tabular} & Coeficiente & $\begin{array}{c}\text { Efeito } \\
\text { Marginal } \\
\end{array}$ \\
\hline $\begin{array}{l}\text { Ln (Renda Domiciliar } \\
\text { Mensal) }\end{array}$ & $\begin{array}{l}0,0533 * \\
(0,0024)\end{array}$ & $\begin{array}{l}0,0119 * \\
(0,0005) \\
{[0,0763]}\end{array}$ & $\begin{array}{l}0,0461 * \\
(0,0024)\end{array}$ & $\begin{array}{l}0,0102 * \\
(0,0005) \\
{[0,0656]}\end{array}$ & & \\
\hline $\begin{array}{l}\text { Ln (Renda Domiciliar } \\
\text { per capita Mensal) }\end{array}$ & & & & & $\begin{array}{l}0,0409 * \\
(0,0023)\end{array}$ & $\begin{array}{l}0,0091 * \\
(0,0005) \\
{[0,0476]}\end{array}$ \\
\hline $\begin{array}{l}\text { Ln (População do } \\
\text { Município) }\end{array}$ & $\begin{array}{l}0,0346 * \\
(0,0012)\end{array}$ & $\begin{array}{l}0,0077 * \\
(0,0003) \\
{[0,0905]}\end{array}$ & & & & \\
\hline $\begin{array}{c}\text { Taxa de Urbanização do } \\
\text { Município }\end{array}$ & & & $\begin{array}{l}0,7419 * \\
(0,0118)\end{array}$ & $\begin{array}{l}0,1643 * \\
(0,0026)\end{array}$ & & \\
\hline $\begin{array}{l}\text { Ln (Renda Municipal } \\
\text { per capita Mensal) }\end{array}$ & & & & & $\begin{array}{l}0,1505 * \\
(0,0053)\end{array}$ & $\begin{array}{l}0,0336 * \\
(0,0012) \\
{[0,1867]}\end{array}$ \\
\hline $\begin{array}{l}\text { Localização do } \\
\text { Domicílio }\end{array}$ & $\begin{array}{l}-0,1192 * \\
(0,0070)\end{array}$ & $\begin{array}{l}-0,0254 * \\
(0,0014)\end{array}$ & & & $\begin{array}{l}-0,1242 * \\
(0,0070)\end{array}$ & $\begin{array}{c}-0,0264 * \\
(0,0014)\end{array}$ \\
\hline Dummy Norte & $\begin{array}{l}1,0194 * \\
(0,0103)\end{array}$ & $\begin{array}{l}0,3254 * \\
(0,0039)\end{array}$ & $\begin{array}{l}1,0999 * \\
(0,0105)\end{array}$ & $\begin{array}{l}0,3554 * \\
(0,0040)\end{array}$ & $\begin{array}{l}1,1057 * \\
(0,0110)\end{array}$ & $\begin{array}{l}0,3589 * \\
(0,0042)\end{array}$ \\
\hline Dummy Nordeste & $\begin{array}{l}0,6126 * \\
(0,0079)\end{array}$ & $\begin{array}{l}0,1621 * \\
(0,0024)\end{array}$ & $\begin{array}{l}0,6854 * \\
(0,0080)\end{array}$ & $\begin{array}{l}0,1836 * \\
(0,0024)\end{array}$ & $\begin{array}{l}0,7175 * \\
(0,0091)\end{array}$ & $\begin{array}{l}0,1947 * \\
(0,0028)\end{array}$ \\
\hline $\begin{array}{c}\text { Dummy } \\
\text { Centro-Oeste (2) }\end{array}$ & $\begin{array}{l}0,1608 * \\
(0,0125)\end{array}$ & $\begin{array}{l}0,0386 * \\
(0,0032)\end{array}$ & $\begin{array}{l}0,1531 * \\
(0,0124)\end{array}$ & $\begin{array}{l}0,0364 * \\
(0,0031)\end{array}$ & $\begin{array}{l}0,1577 * \\
(0,0125)\end{array}$ & $\begin{array}{l}0,0378 * \\
(0,0032)\end{array}$ \\
\hline Dummy Distrito Federal & $\begin{array}{c}-0,1184 * \\
(0,0280)\end{array}$ & $\begin{array}{c}-0,0248 * \\
(0,0055)\end{array}$ & $\begin{array}{c}-0,0730 * \\
(0,0279)\end{array}$ & $\begin{array}{c}-0,0156 * \\
(0,0057)\end{array}$ & $\begin{array}{c}-0,1121 * \\
(0,0279)\end{array}$ & $\begin{array}{c}-0,0236 * \\
(0,0055)\end{array}$ \\
\hline Dummy Sudeste (4) & $\begin{array}{l}0,2970 * \\
(0,0079)\end{array}$ & $\begin{array}{l}0,0719 * \\
(0,0020)\end{array}$ & $\begin{array}{l}0,3082 * \\
(0,0079)\end{array}$ & $\begin{array}{l}0,0744 * \\
(0,0020)\end{array}$ & $\begin{array}{l}0,3188 * \\
(0,0079)\end{array}$ & $\begin{array}{l}0,0777 * \\
(0,0021)\end{array}$ \\
\hline Dummy Sul & $\begin{array}{l}1,1563 * \\
(0,0077)\end{array}$ & $\begin{array}{l}0,3476 * \\
(0,0026)\end{array}$ & $\begin{array}{l}1,1838 * \\
(0,0076)\end{array}$ & $\begin{array}{l}0,3560 * \\
(0,0026)\end{array}$ & $\begin{array}{l}1,1303 * \\
(0,0075)\end{array}$ & $\begin{array}{l}0,3386 * \\
(0,0026)\end{array}$ \\
\hline Constante & $\begin{array}{c}-2,2902 * \\
(0,0212)\end{array}$ & & $\begin{array}{c}-2,4979 * \\
(0,0184)\end{array}$ & & $\begin{array}{c}-2,6178 * \\
(0,0313)\end{array}$ & \\
\hline $\mathbf{y}=\operatorname{Pr}($ fossa) $($ predict $)$ & \multicolumn{2}{|c|}{0,140322} & \multicolumn{2}{|c|}{0,139008} & \multicolumn{2}{|c|}{0,140513} \\
\hline $\operatorname{LR} \aleph^{2}(10)$ & \multicolumn{2}{|c|}{$33.526,22$} & \multicolumn{2}{|c|}{$36.118,16$} & \multicolumn{2}{|c|}{$33.457,78$} \\
\hline Prob $>x^{2}$ & \multicolumn{2}{|c|}{0,0000} & \multicolumn{2}{|c|}{0,0000} & \multicolumn{2}{|c|}{0,0000} \\
\hline Pseudo-R ${ }^{2}$ & \multicolumn{2}{|c|}{0,0841} & \multicolumn{2}{|c|}{0,0906} & \multicolumn{2}{|c|}{0,0839} \\
\hline
\end{tabular}

Obs.: Erro-padrão entre parênteses e elasticidades das variáveis contínuas entre colchetes, calculadas na forma d(y) / d(lnx). * Significativo a $1 \%$. 
Finalmente, a tabela 2.19 apresenta os resultados obtidos com as estimações dos modelos do tipo (2), que consideram como explicativas apenas variáveis dummies. Confirmando as expectativas, observa-se que um domicílio localizado em uma capital estadual ou na capital Federal - ou em um município pertencente a uma região metropolitana - tem uma probabilidade maior de possuir acesso aos serviços de saneamento básico - tanto abastecimento de água e coleta de esgoto por rede geral como esgotamento sanitário por fossa séptica - do que um domicílio pertencente a um município do interior.

Tabela 2.19

Resultados das estimações com dummies tipos de municípios (2000)

\begin{tabular}{|c|c|c|c|c|c|c|}
\hline \multirow{2}{*}{ Variável } & \multicolumn{2}{|c|}{$\begin{array}{l}\text { Abastecimento de Água } \\
\text { (Rede Geral) }\end{array}$} & \multicolumn{2}{|c|}{$\begin{array}{l}\text { Coleta de Esgoto } \\
\text { (Rede Geral) }\end{array}$} & \multicolumn{2}{|c|}{ Fossa Séptica } \\
\hline & Coeficiente & $\begin{array}{c}\text { Efeito } \\
\text { Marginal }\end{array}$ & Coeficiente & $\begin{array}{c}\text { Efeito } \\
\text { Marginal }\end{array}$ & Coeficiente & $\begin{array}{c}\text { Efeito } \\
\text { Marginal }\end{array}$ \\
\hline Dummy Norte & $\begin{array}{l}-1,5614 * \\
(0,0093)\end{array}$ & $\begin{array}{c}-0,5624 * \\
(0,0029)\end{array}$ & $\begin{array}{l}-2,2915 * \\
(0,0117)\end{array}$ & $\begin{array}{r}-0,5190 * \\
(0,0010)\end{array}$ & $\begin{array}{l}1,1057 * \\
(0,0101)\end{array}$ & $\begin{array}{l}0,3363 * \\
(0,0038)\end{array}$ \\
\hline Dummy Nordeste & $\begin{array}{l}-0,9889 * \\
(0,0068)\end{array}$ & $\begin{array}{c}-0,3286 * \\
(0,0023)\end{array}$ & $\begin{array}{l}-1,4016 * \\
(0,0061)\end{array}$ & $\begin{array}{r}-0,4740 * \\
(0,0016)\end{array}$ & $\begin{array}{l}0,6396 * \\
(0,0076)\end{array}$ & $\begin{array}{l}0,1674 * \\
(0,0022)\end{array}$ \\
\hline $\begin{array}{c}\text { Dummy } \\
\text { Centro-Oeste (2) }\end{array}$ & $\begin{array}{c}-0,8551 * \\
(0,0094)\end{array}$ & $\begin{array}{c}-0,3053 * \\
(0,0037)\end{array}$ & $\begin{array}{c}-1,7065 * \\
(0,0096)\end{array}$ & $\begin{array}{c}-0,4733 * \\
(0,0013)\end{array}$ & $\begin{array}{l}0,2360 * \\
(0,0121)\end{array}$ & $\begin{array}{l}0,0575 * \\
(0,0033)\end{array}$ \\
\hline $\begin{array}{l}\text { Dummy Distrito } \\
\text { Federal }\end{array}$ & $\begin{array}{l}-1,0763 * \\
(0,0240)\end{array}$ & $\begin{array}{r}-0,3969 * \\
(0,0092)\end{array}$ & & & & \\
\hline Dummy Sudeste (4) & $\begin{array}{l}-0,5479 * \\
(0,0072)\end{array}$ & $\begin{array}{c}-0,1773 * \\
(0,0025)\end{array}$ & $\begin{array}{l}-0,4796 * \\
(0,0058)\end{array}$ & $\begin{array}{r}-0,1865 * \\
(0,0022)\end{array}$ & $\begin{array}{l}0,2893 * \\
(0,0077)\end{array}$ & $\begin{array}{l}0,0687 * \\
(0,0020)\end{array}$ \\
\hline Dummy Sul & $\begin{array}{l}-0,5981 * \\
(0,0074)\end{array}$ & $\begin{array}{c}-0,1984 * \\
(0,0027)\end{array}$ & $\begin{array}{l}-1,4196 * \\
(0,0064)\end{array}$ & $\begin{array}{r}-0,4691 * \\
(0,0015)\end{array}$ & $\begin{array}{l}1,1434 * \\
(0,0074)\end{array}$ & $\begin{array}{l}0,3398 * \\
(0,0025)\end{array}$ \\
\hline Dummy Capital & $\begin{array}{l}1,1682 * \\
(0,0069)\end{array}$ & $\begin{array}{l}0,2511 * \\
(0,0010)\end{array}$ & $\begin{array}{l}0,7512 * \\
(0,0051)\end{array}$ & $\begin{array}{c}0,2898 * \\
(0,018)\end{array}$ & $\begin{array}{l}0,2441 * \\
(0,0058)\end{array}$ & $\begin{array}{l}0,0572 * \\
(0,0015)\end{array}$ \\
\hline $\begin{array}{l}\text { Dummy Região } \\
\text { Metropolitana }\end{array}$ & $\begin{array}{l}0,3659 * \\
(0,0058)\end{array}$ & $\begin{array}{l}0,0965 * \\
(0,0014)\end{array}$ & $\begin{array}{c}0,0112 * * \\
(0,0053)\end{array}$ & $\begin{array}{c}0,0045 * * \\
(0,0021)\end{array}$ & $\begin{array}{l}0,5634 * \\
(0,0060)\end{array}$ & $\begin{array}{l}0,1467 * \\
(0,0018)\end{array}$ \\
\hline Constante & $\begin{array}{l}1,1191 * \\
(0,0059)\end{array}$ & & $\begin{array}{l}0,6882 * \\
(0,0048)\end{array}$ & & $\begin{array}{c}-1,7518 * \\
(0,0065) \\
\end{array}$ & \\
\hline $\mathbf{y}=\operatorname{Pr}(\mathbf{y})($ predict $)$ & \multicolumn{2}{|c|}{0,785089} & \multicolumn{2}{|c|}{0,478860} & \multicolumn{2}{|c|}{0,136415} \\
\hline LR $\operatorname{chi}^{2}(10)$ & \multicolumn{2}{|c|}{$84.199,97$} & \multicolumn{2}{|c|}{$146.787,43$} & \multicolumn{2}{|c|}{$40.122,36$} \\
\hline Prob $>$ chi $^{2}$ & \multicolumn{2}{|c|}{0,0000} & \multicolumn{2}{|c|}{0,0000} & \multicolumn{2}{|c|}{0,0000} \\
\hline Pseudo-R ${ }^{2}$ & \multicolumn{2}{|c|}{0,1413} & \multicolumn{2}{|c|}{0,2240} & \multicolumn{2}{|c|}{0,0970} \\
\hline
\end{tabular}

Obs.: Erro-padrão entre parênteses.

* Significativo a $1 \%$.

** Significativo a $5 \%$. 
Os resultados obtidos nas estimações comprovam, portanto, a grande maioria das relações levantadas na primeira seção, mostrando que as variáveis analisadas realmente impactam sobre a probabilidade de acesso domiciliar aos serviços.

\section{Evolucão do déficit de acesso}

As análises realizadas nas seções anteriores mostraram que, em 2000, o déficit de acesso domiciliar aos serviços de saneamento básico no Brasil concentrava-se, principalmente, nas regiões menos desenvolvidas e nos municípios de menor porte, menor taxa de urbanização e menor renda per capita, assim como nos domicílios rurais e de baixa renda.

Essas características do déficit de acesso são recentes ou "sempre" existiram? Como elas variaram ao longo do tempo - aumentaram ou diminuíram? Ocorreu uma convergência dos índices de acesso? Qual tipo de política impactou mais sobre as características do déficit de acesso e qual foi esse impacto - aumento ou redução? As análises que serão realizadas na presente seção tentarão responder a essas perguntas - utilizando, para isso, dados disponibilizados pelos Censos Demográficos de 1970, 1980, 1991 e 2000 e pelas PNADs de 2001, 2002, 2003 e 2004.

\subsection{Características do déficit de acesso: antigas ou recentes?}

Para avaliar se as características do déficit de acesso domiciliar a serviços de saneamento básico no Brasil são recentes ou não, o ideal seria repetir, para os anos de 1970, 1980, 1991 e 2004, o procedimento utilizado na primeira e segunda seções. Ou seja, fazer 
uma análise descritiva detalhada e, em seguida, estimar modelos pelo método Probit. O capítulo, contudo, ficaria muito longo e sua leitura cansativa. Optou-se, assim, por apresentar as tabelas descritivas no Apêndice ${ }^{5}$, assim como as tabelas com os resultados completos das estimações ${ }^{6}$.

Aqui, serão analisados apenas os resultados mais relevantes para o trabalho: efeitos marginais e, principalmente, seus sinais. Foram estimados modelos do tipo 1 - estrutura apresentada na segunda seção - para os anos de 1970, 1980, 1991 e 2004, além de 2000, cujos resultados já foram discutidos. Utilizou-se, assim como anteriormente, uma amostra aleatória de $10 \%$ para todos os anos - exceto 2004, para o qual foi utilizada a amostra total da PNAD. Deve-se destacar que algumas adaptações foram necessárias, devido à disponibilidade de informações: (i) em nenhum dos anos, foi considerada a variável explicativa renda domiciliar per capita mensal; (ii) em 1970, utilizou-se a renda mensal do chefe da família ao invés da renda domiciliar mensal e, (iii) em 2004, não foram utilizadas variáveis municipais.

A tabela 2.20 apresenta o resumo dos resultados - sinal dos coeficientes, efeito marginal mínimo e menor probabilidade estimada ${ }^{7}$ - obtidos nas estimações que consideraram como variável binária dependente a existência ou não de abastecimento de água por rede geral no domicílio. Por meio dessa tabela, é possível observar alguns aspectos interessantes:

as relações positivas entre o acesso por rede geral e as variáveis municipais, verificadas em 2000, já existiam em 1970 - e continuaram a existir em 1980 e 1991; a relação positiva entre o acesso por rede geral e a renda domiciliar mensal, verificada em 2000, existia em 1980 e em 1991 e se manteve em 2004 - em 1970, existia uma relação positiva entre o acesso e a renda do chefe da família;

\footnotetext{
${ }^{5}$ Da tabela 8 à tabela 25.

${ }^{6}$ Da tabela 26 à tabela 35.

${ }^{7}$ Para facilitar a visualização, optou-se por apresentar apenas o valor do menor efeito marginal estimado para cada uma das variáveis, em um contexto de pelo menos três "modelos alternativos" considerados. É bom lembrar que as tabelas completas com os resultados estimados estão no Apêndice.
} 
(iii) a dummy localização do domicílio apresentou, em todos os anos, sinal negativo, ou seja, o acesso urbano por rede geral sempre foi superior ao acesso rural e

(iv) as dummies regionais e Distrito Federal apresentaram, em todos os anos, sinais negativos - excetuando-se a dummy Distrito Federal em 1980 -, mostrando que a superioridade da cobertura no Estado de São Paulo já existia em 1970 e se manteve ao longo do tempo.

Tabela 2.20

Resumo dos resultados das estimações: variável dependente abastecimento de água por rede geral $(1971,1980,1991,2000$ e 2004)

\begin{tabular}{|c|c|c|c|c|c|c|c|c|c|c|}
\hline \multirow{2}{*}{$\begin{array}{c}\text { Abastecimento de Água } \\
\text { (Rede Geral) }\end{array}$} & \multicolumn{5}{|c|}{ Efeito Marginal (Mínimo) } & \multicolumn{5}{|c|}{ Sinal } \\
\hline & 1970 & 1980 & 1991 & 2000 & 2004 & 1970 & 1980 & 1991 & 2000 & 2004 \\
\hline Renda Domiciliar Mensal & $\begin{array}{l}0,17 * \\
{[0,89]}\end{array}$ & $\begin{array}{c}0,12 \\
{[1,08]}\end{array}$ & $\begin{array}{c}0,09 \\
{[0,98]}\end{array}$ & $\begin{array}{c}0,02 \\
{[0,13]}\end{array}$ & $\begin{array}{l}0,002 \\
{[0,02]}\end{array}$ & $(+)$ & $(+)$ & $(+)$ & $(+)$ & $(+)$ \\
\hline População do Município & $\begin{array}{c}0,02 \\
{[0,22]}\end{array}$ & $\begin{array}{c}0,05 \\
{[0,55]}\end{array}$ & $\begin{array}{c}0,04 \\
{[0,40]}\end{array}$ & $\begin{array}{c}0,02 \\
{[0,20]}\end{array}$ & --- & $(+)$ & $(+)$ & $(+)$ & $(+)$ & --- \\
\hline $\begin{array}{c}\text { Taxa de Urbanização } \\
\text { Municipal }\end{array}$ & 0,25 & 0,34 & 0,03 & 0,06 & --- & $(+)$ & $(+)$ & $(+)$ & $(+)$ & --- \\
\hline $\begin{array}{l}\text { Renda Municipal per } \\
\text { capita Mensal }\end{array}$ & $\begin{array}{c}0,15 \\
{[0,62]}\end{array}$ & $\begin{array}{c}0,10 \\
{[0,98]}\end{array}$ & $\begin{array}{c}0,10 \\
{[1,08]}\end{array}$ & $\begin{array}{c}0,06 \\
{[0,35]}\end{array}$ & --- & $(+)$ & $(+)$ & $(+)$ & $(+)$ & --- \\
\hline $\begin{array}{l}\text { Dummy Localização do } \\
\text { Domicílio }\end{array}$ & $-0,41$ & $-0,65$ & $-0,71$ & $-0,66$ & $-0,58$ & $(-)$ & $(-)$ & $(-)$ & $(-)$ & $(-)$ \\
\hline Dummy Norte & $-0,08$ & $-0,19$ & $-0,30$ & $-0,41$ & $-0,37$ & $(-)$ & $(-)$ & $(-)$ & $(-)$ & $(-)$ \\
\hline Dummy Nordeste & $-0,14$ & $-0,31$ & $-0,09$ & $-0,09$ & $-0,06$ & $(-)$ & $(-)$ & $(-)$ & $(-)$ & $(-)$ \\
\hline Dummy Centro-Oeste (2) & $-0,13$ & $-0,38$ & $-0,28$ & $-0,27$ & $-0,26$ & $(-)$ & $(-)$ & $(-)$ & $(-)$ & $(-)$ \\
\hline Dummy Distrito Federal & $-0,04$ & 0,15 & $-0,07$ & $-0,15$ & $-0,06$ & $(-)$ & $(+)$ & $(-)$ & $(-)$ & $(-)$ \\
\hline Dummy Sudeste (4) & $-0,004$ & $-0,18$ & $-0,03$ & $-0,11$ & $-0,14$ & $(-)$ & $(-)$ & $(-)$ & $(-)$ & $(-)$ \\
\hline Dummy Sul & $-0,07$ & $-0,17$ & $-0,10$ & $-0,10$ & $-0,12$ & $(-)$ & $(-)$ & $(-)$ & $(-)$ & $(-)$ \\
\hline \multicolumn{6}{|c|}{$\mathbf{y}=\operatorname{Pr}$ (agua) (predict) } & $\mathbf{0 , 2 0}$ & 0,49 & $\mathbf{0 , 7 3}$ & $\mathbf{0 , 8 2}$ & 0,90 \\
\hline
\end{tabular}

Obs.: Elasticidades entre colchetes, calculadas na forma d(y) / d(lnx).

* As estimações para o ano de 1970 consideraram a renda do chefe da família ao invés da renda domiciliar.

Os dados da tabela 2.20 mostram também que a probabilidade de um domicílio qualquer possuir acesso a abastecimento de água por rede geral elevou-se ao longo dos anos - reflexo direto da expansão da cobertura do serviço. Além disso, no caso das variáveis explicativas contínuas, os dados "sugerem" que ocorreu, de uma maneira geral, a redução do impacto dessas variáveis sobre a probabilidade de acesso, principalmente a partir de 1991. No caso das 
variáveis explicativas dummies, os dados "sugerem" um aumento da diferença entre o acesso urbano e o rural e a inexistência de uma tendência clara de aumento ou de diminuição do impacto da localização geográfica - ou seja, de aumento ou de diminuição da diferença do acesso em relação ao Estado de São Paulo.

A tabela 2.21, por sua vez, apresenta o resumo dos resultados obtidos nas estimações que consideraram como variável binária dependente a existência ou não de coleta de esgoto por rede geral no domicílio.

Tabela 2.21

Resumo dos resultados das estimações: variável dependente coleta de esgoto por rede geral

$(1971,1980,1991,2000$ e 2004)

\begin{tabular}{|c|c|c|c|c|c|c|c|c|c|c|}
\hline \multirow{2}{*}{$\begin{array}{l}\text { Coleta de Esgoto } \\
\text { (Rede Geral) }\end{array}$} & \multicolumn{5}{|c|}{ Efeito Marginal (Mínimo) } & \multicolumn{5}{|c|}{ Sinal } \\
\hline & 1970 & 1980 & 1991 & 2000 & 2004 & 1970 & 1980 & 1991 & 2000 & 2004 \\
\hline Renda Domiciliar Mensal & $\begin{array}{l}0,03 * \\
{[0,18]}\end{array}$ & $\begin{array}{c}0,07 \\
{[0,64]}\end{array}$ & $\begin{array}{c}0,08 \\
{[0,88]}\end{array}$ & $\begin{array}{c}0,01 \\
{[0,06]}\end{array}$ & $\begin{array}{c}0,01 \\
{[0,06]}\end{array}$ & $(+)$ & $(+)$ & $(+)$ & $(+)$ & $(+)$ \\
\hline População do Município & $\begin{array}{c}0,01 \\
{[0,09]}\end{array}$ & $\begin{array}{c}0,03 \\
{[0,32]}\end{array}$ & $\begin{array}{c}0,02 \\
{[0,25]}\end{array}$ & $\begin{array}{c}0,04 \\
{[0,46]}\end{array}$ & --- & $(+)$ & $(+)$ & $(+)$ & $(+)$ & -- \\
\hline $\begin{array}{c}\text { Taxa de Urbanização } \\
\text { Municipal }\end{array}$ & 0,05 & 0,28 & 0,01 & 0,41 & -- & $(+)$ & $(+)$ & $(+)$ & $(+)$ & --- \\
\hline $\begin{array}{l}\text { Renda Municipal per } \\
\quad \text { capita Mensal }\end{array}$ & $\begin{array}{c}0,04 \\
{[0,16]}\end{array}$ & $\begin{array}{c}0,10 \\
{[0,86]}\end{array}$ & $\begin{array}{c}0,10 \\
{[1,07]}\end{array}$ & $\begin{array}{c}0,23 \\
{[1,25]}\end{array}$ & -- & $(+)$ & $(+)$ & $(+)$ & $(+)$ & --- \\
\hline $\begin{array}{l}\text { Dummy Localização do } \\
\text { Domicílio }\end{array}$ & $-0,12$ & -0 & -0 & $-0,48$ & $-0,46$ & $(-)$ & $(-)$ & $(-)$ & $(-)$ & $(-)$ \\
\hline Dummy Norte & $-0,03$ & $-0,14$ & $-0,22$ & $-0,44$ & $-0,52$ & $(-)$ & $(-)$ & $(-)$ & $(-)$ & $(-)$ \\
\hline Dummy Nordeste & $-0,04$ & $-0,21$ & $-0,27$ & $-0,28$ & $-0,46$ & $(-)$ & $(-)$ & $(-)$ & $(-)$ & $(-)$ \\
\hline Dummy Centro-Oeste (2) & $-0,03$ & $-0,14$ & $-0,18$ & $-0,43$ & $-0,44$ & $(-)$ & $(-)$ & $(-)$ & $(-)$ & $(-)$ \\
\hline Dummy Distrito Federal & 0,01 & $-0,07$ & $-0,02$ & $-0,07$ & $-0,07$ & $(+)$ & $(-)$ & $(-)$ & $(-)$ & $(-)$ \\
\hline Dummy Sudeste (4) & 0,02 & $-0,02$ & $-0,08$ & $-0,10$ & $-0,24$ & $(+)$ & $(-)$ & $(-)$ & $(-)$ & $(-)$ \\
\hline Dummy Sul & $-0,02$ & $-0,15$ & $-0,26$ & $-0,44$ & $-0,50$ & $(-)$ & $(-)$ & $(-)$ & $(-)$ & $(-)$ \\
\hline \multicolumn{6}{|c|}{$\mathbf{y}=\operatorname{Pr}($ esgoto $)($ predict $)$} & 0,03 & 0,14 & $\mathbf{0 , 1 8}$ & 0,44 & 0,39 \\
\hline
\end{tabular}

Obs.: Elasticidades entre colchetes, calculadas na forma d(y) / d(lnx).

* As estimações para o ano de 1970 consideraram a renda do chefe da família ao invés da renda domiciliar.

No caso da coleta de esgoto, também é possível observar que as relações positivas entre o acesso por rede geral e algumas características municipais - porte, taxa de urbanização e renda per capita mensal - e entre o acesso e a renda domiciliar mensal - em 1970, a renda 
mensal do chefe da família -, verificadas em 2000, já existiam em 1970 e se mantiveram ao longo do tempo. O mesmo pode ser dito sobre a superioridade do acesso urbano e do acesso no Estado de São Paulo - excetuando-se, nesse último caso, o acesso em relação ao Distrito Federal e ao restante da região Sudeste em 1970. Verifica-se também um aumento, ao longo do tempo, da probabilidade de um domicílio qualquer possuir acesso a coleta de esgoto reflexo direto da expansão da cobertura do serviço, que será discutida no item 3.2.

Finalmente, a tabela 2.22 apresenta o resumo dos resultados obtidos nas estimações que consideraram como variável binária dependente a existência ou não de esgotamento sanitário por fossa séptica no domicílio. Nesse caso, também é possível observar um aumento da probabilidade de acesso ao longo do tempo.

Tabela 2.22

Resumo dos resultados das estimações: variável dependente esgotamento sanitário por fossa séptica $(1971,1980,1991,2000$ e 2004)

\begin{tabular}{|c|c|c|c|c|c|c|c|c|c|c|}
\hline \multirow{2}{*}{ Fossa Séptica } & \multicolumn{5}{|c|}{ Efeito Marginal } & \multicolumn{5}{|c|}{ Sinal } \\
\hline & 1970 & 1980 & 1991 & 2000 & 2004 & 1970 & 1980 & 1991 & 2000 & 2004 \\
\hline Renda Domiciliar Mensal & $\begin{array}{l}0,06 * \\
{[0,30]}\end{array}$ & $\begin{array}{c}0,02 \\
{[0,17]}\end{array}$ & $\begin{array}{c}0,02 \\
{[0,26]}\end{array}$ & $\begin{array}{c}0,01 \\
{[0,07]}\end{array}$ & $\begin{array}{l}0,004 \\
{[0,03]}\end{array}$ & $(+)$ & $(+)$ & $(+)$ & $(+)$ & $(+)$ \\
\hline População do Município & $\begin{array}{c}0,04 \\
{[0,41]}\end{array}$ & $\begin{array}{c}0,01 \\
{[0,13]}\end{array}$ & $\begin{array}{c}0,02 \\
{[0,20]}\end{array}$ & $\begin{array}{c}0,01 \\
{[0,09]}\end{array}$ & --- & $(+)$ & $(+)$ & $(+)$ & $(+)$ & --- \\
\hline $\begin{array}{c}\text { Taxa de Urbanização } \\
\text { Municipal }\end{array}$ & 0,17 & 0,18 & 0,002 & 0,16 & --- & $(+)$ & $(+)$ & $(+)$ & $(+)$ & --- \\
\hline $\begin{array}{l}\text { Renda Municipal per } \\
\text { capita Mensal }\end{array}$ & $\begin{array}{c}0,07 \\
{[0,28]}\end{array}$ & $\begin{array}{c}0,03 \\
{[0,34]}\end{array}$ & $\begin{array}{c}0,05 \\
{[0,56]}\end{array}$ & $\begin{array}{c}0,03 \\
{[0,19]}\end{array}$ & --- & $(+)$ & $(+)$ & $(+)$ & $(+)$ & --- \\
\hline $\begin{array}{c}\text { Dummy Localização do } \\
\text { Domicílio }\end{array}$ & $-0,11$ & $-0,09$ & $-0,09$ & $-0,03$ & $-0,09$ & $(-)$ & $(-)$ & $(-)$ & $(-)$ & $(-)$ \\
\hline Dummy Norte & $-0,04$ & 0,05 & 0,26 & 0,33 & 0,64 & $(-)$ & $(+)$ & $(+)$ & $(+)$ & $(+)$ \\
\hline Dummy Nordeste & $-0,04$ & 0,01 & 0,16 & 0,16 & 0,27 & $(-)$ & $(+)$ & $(+)$ & $(+)$ & $(+)$ \\
\hline Dummy Centro-Oeste (2) & $-0,01$ & $-0,10$ & $-0,03$ & 0,04 & 0,12 & $(-)$ & $(-)$ & $(-)$ & $(+)$ & $(+)$ \\
\hline Dummy Distrito Federal & $-0,03$ & 0,12 & 0,03 & $-0,02$ & 0,18 & $(-)$ & $(+)$ & $(+)$ & $(-)$ & $(+)$ \\
\hline Dummy Sudeste (4) & $-0,02$ & $-0,03$ & 0,01 & 0,07 & 0,21 & $(-)$ & $(-)$ & $(+)$ & $(+)$ & $(+)$ \\
\hline Dummy Sul & $-0,002$ & 0,15 & 0,39 & 0,34 & 0,67 & $(-)$ & $(+)$ & $(+)$ & $(+)$ & $(+)$ \\
\hline \multicolumn{6}{|c|}{$\mathbf{y}=\operatorname{Pr}(\mathbf{f o s s a})($ predict $)$} & $\mathbf{0 , 0 7}$ & $\mathbf{0 , 1 3}$ & 0,14 & 0,14 & 0,22 \\
\hline
\end{tabular}

Obs.: Elasticidades entre colchetes, calculadas na forma $\mathrm{d}(\mathrm{y}) / \mathrm{d}(\ln \mathrm{x})$.

* As estimações para o ano de 1970 consideraram a renda do chefe da família ao invés da renda domiciliar. 
Conforme foi apontado anteriormente, o ideal seria que a fossa séptica fosse uma “segunda melhor escolha", ou seja, ela deveria ser utilizada nos locais em que não houvesse coleta de esgoto por rede geral. Contudo, verificou-se que isso não ocorria em 2000. Isto porque o acesso a esgotamento sanitário por fossa séptica também apresentava relações positivas com algumas características municipais - porte, taxa de urbanização e renda per capita mensal - e com a renda domiciliar mensal. Além disso, surpreendentemente, era maior na zona urbana do que na rural. Tais características, de acordo com a tabela 2.22, também existiam em 1970 e mantiveram-se ao longo do tempo. Essa tabela mostra também a existência de uma tendência de queda do acesso à fossa séptica no Estado de São Paulo em relação às regiões geográficas e ao Distrito Federal - os sinais de todas as dummies regionais e da dummy Distrito Federal foram se tornando positivos ao longo do tempo.

Nesse momento, é possível responder à primeira questão levantada no início da seção: as características do déficit de acesso a serviços de saneamento básico no Brasil são recentes ou "sempre" existiram? A análise realizada nesse item mostrou que essas características não são recentes, uma vez que a grande maioria das relações verificadas nas primeiras seções já existia em 1970. Resta saber se essas relações diminuíram ou aumentaram ao longo do tempo.

\section{$\underline{3.2}$ Evolução e convergência dos índices de acesso domiciliar $^{8}$}

A proporção de domicílios brasileiros com abastecimento de água por rede geral e com rede coletora de esgoto elevou-se significativamente de 1970 a 2000, conforme pode ser verificado no gráfico 2.7. Já a proporção de domicílios com esgotamento sanitário por fossa séptica elevou-se um pouco até 1991, momento em que sofreu uma pequena queda. Nos 
primeiros anos da década de 2000, a proporção de domicílios com acesso a qualquer um dos serviços não variou significativamente.
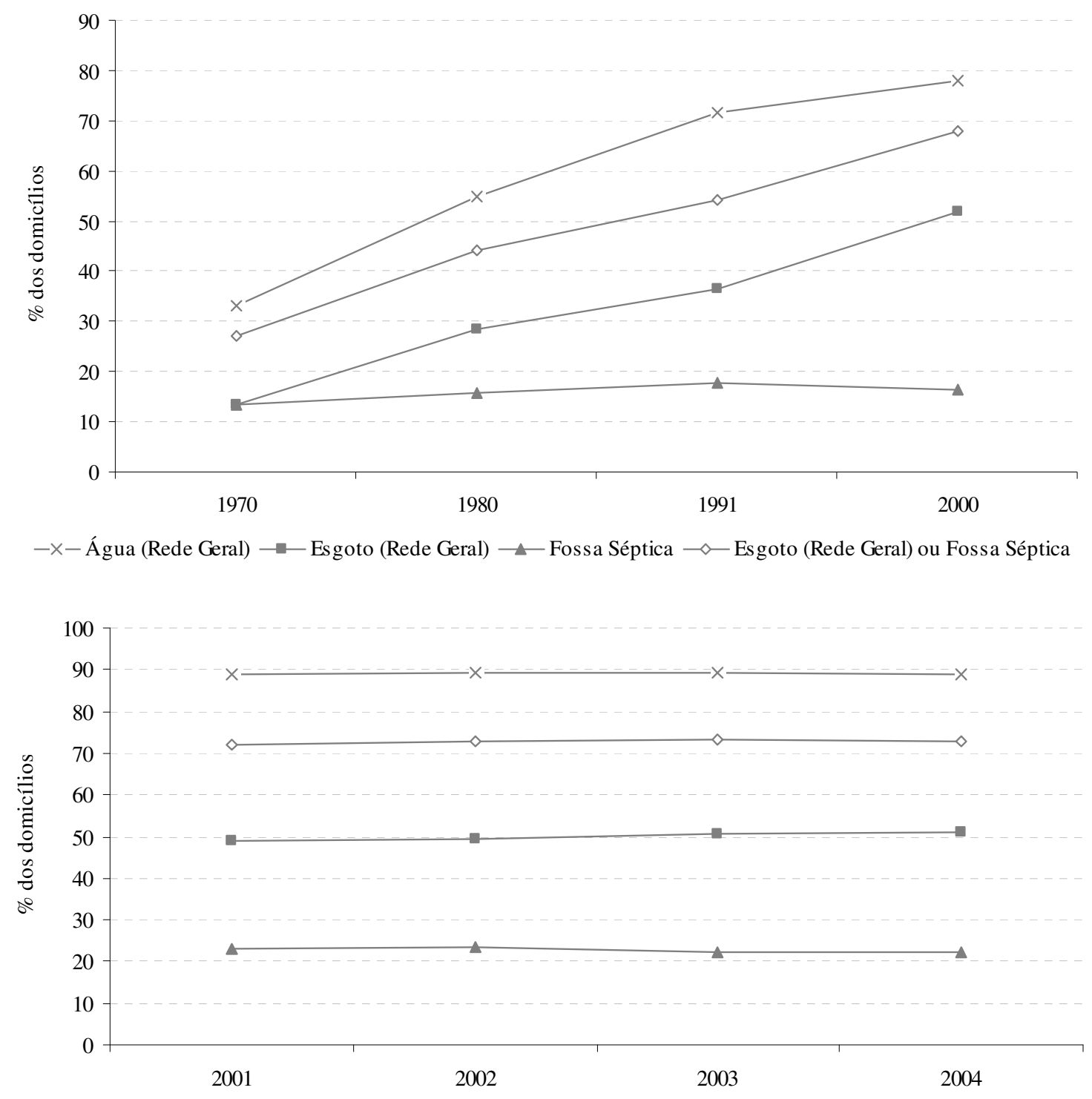

$-\times-$ Água (Rede Geral) $\longrightarrow$ Esgoto (Rede Geral) $\longrightarrow-$ Fossa Séptica $\multimap-$ Esgoto (Rede Geral) ou Fossa Séptica

Fonte: IBGE, Censos Demográficos de 1970, 1980, 1991 e 2000 e PNADs 2001, 2002, 2003 e 2004. Elaboração própria.

Gráfico 2.7

Brasil: evolução da proporção de domicílios com acesso a serviços de saneamento básico (1970-2004)

\footnotetext{
${ }^{8}$ A análise desse item, para facilitar a visualização, será realizada por meio de gráficos. Os dados utilizados para a confecção desses gráficos estão no Apêndice - da tabela 8 à tabela 25 (proporção de domicílios com acesso) e
} 
O maior crescimento do acesso, tanto a abastecimento de água por rede geral quanto a coleta de esgoto por rede geral, ocorreu na década de 1970 - conforme é ilustrado no gráfico 2.8. Nos anos 1980, a variação do acesso aos dois serviços sofreu uma significativa redução. Já na década de 1990, a variação do acesso à água voltou a cair e a variação do acesso a coleta de esgoto elevou-se sensivelmente.

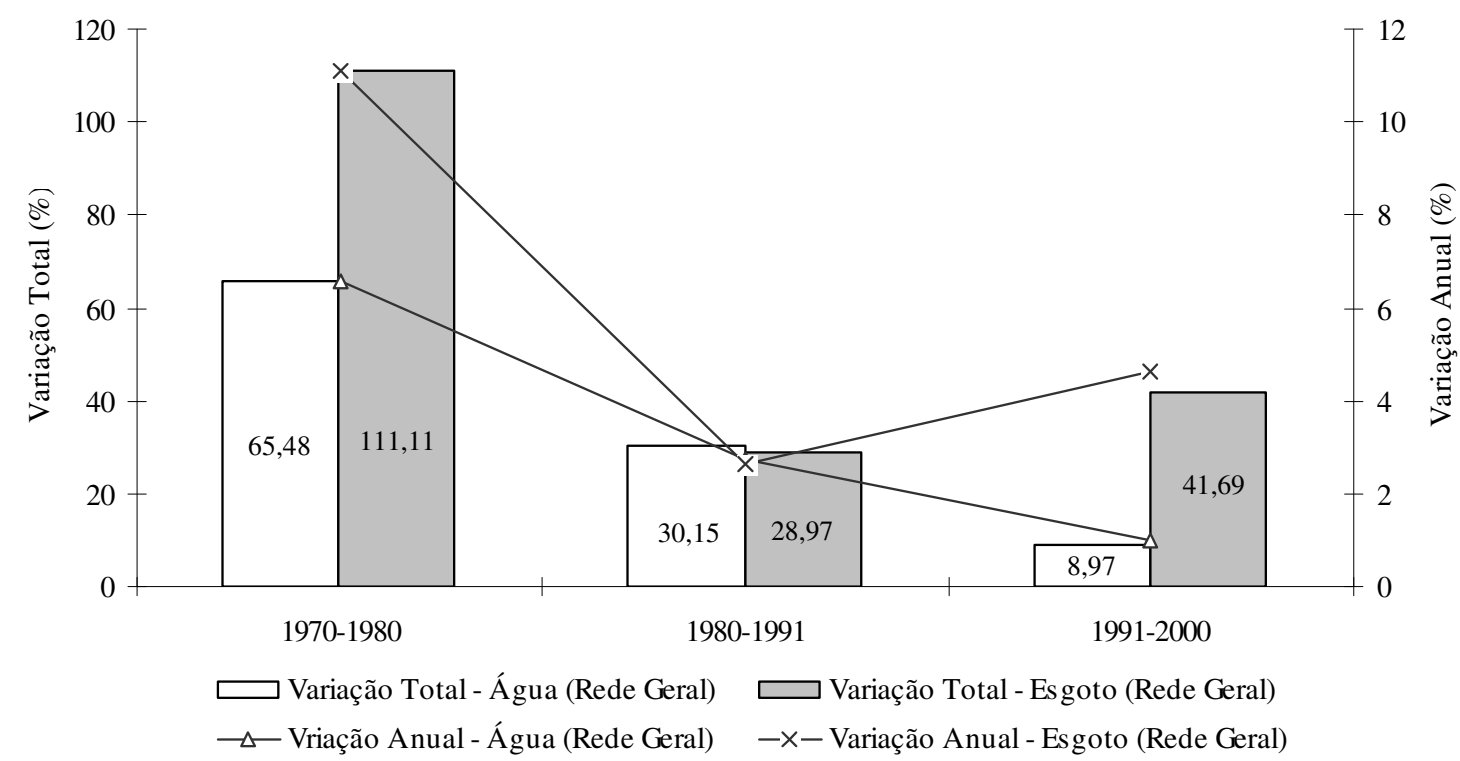

Fonte: IBGE, Censos Demográficos de 1970, 1980, 1991 e 2000. Elaboração própria.

\section{Gráfico 2.8}

Brasil: variação da proporção de domicílios com acesso a serviços de saneamento básico (1970-2000)

Por meio do gráfico 2.8, também é possível observar que a variação do acesso a coleta de esgoto foi bastante superior à variação do acesso a água nas décadas de 1970 (1,7 vezes) e, principalmente, de 1990 (4,65 vezes) - e um pouco inferior na década de 1980. Apesar disso, o gráfico 2.9 mostra que a superioridade do acesso a água em relação ao acesso a coleta de esgoto só se reduziu um pouco nos anos 1990. Ou seja, a cobertura da coleta de esgoto por rede geral era tão deficitária que, mesmo crescendo mais, ou praticamente o mesmo (1980), a 
diferença entre esta e a cobertura de água só diminuiu um pouco na última década - nas anteriores, ocorreu um aumento dessa diferença.

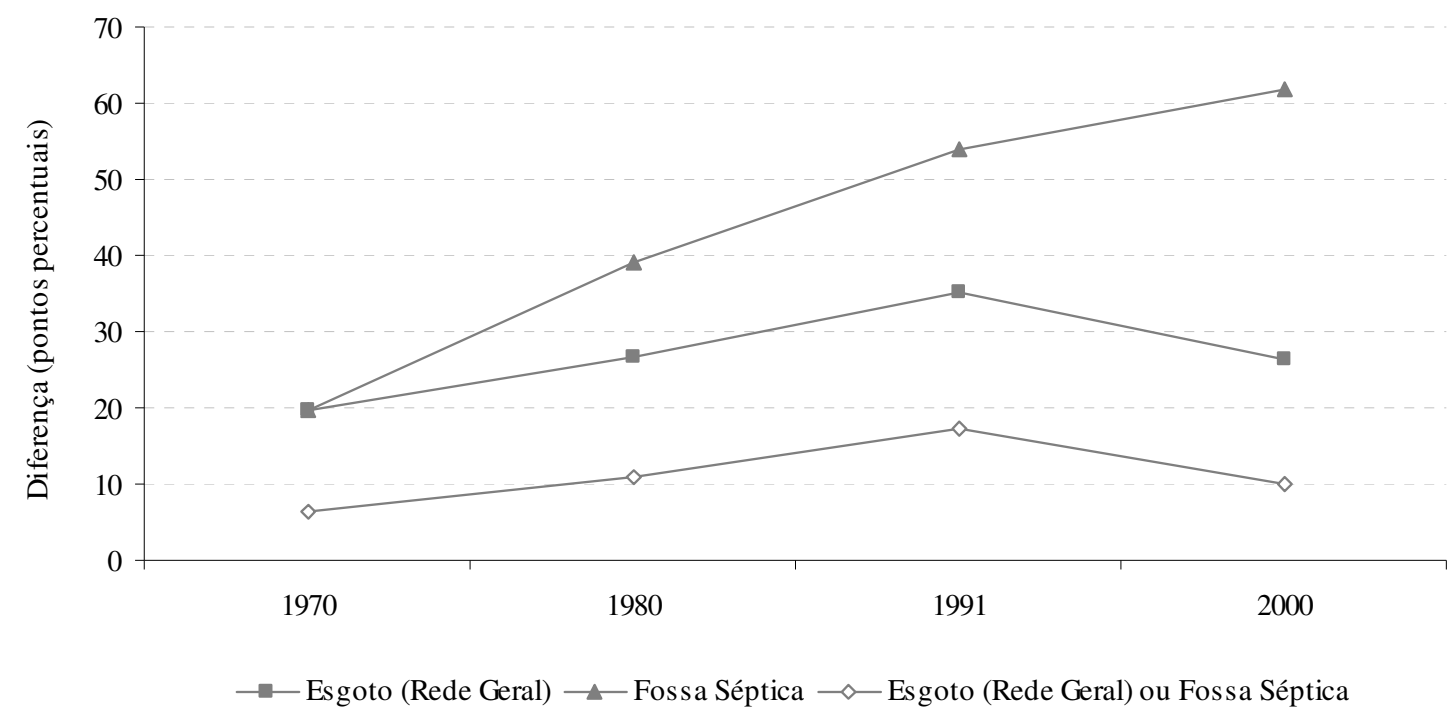

Fonte: IBGE, Censos Demográficos de 1970, 1980, 1991 e 2000. Elaboração própria.

Gráfico 2.9

Brasil: convergência dos índices de acesso domiciliar, segundo os tipos de serviços (1970-2000)

Em relação à fossa séptica, a superioridade do acesso a água por rede geral aumentou durante todo o período analisado. Conseqüentemente, ao considerar o acesso a coleta de esgoto ou à fossa séptica, observa-se o mesmo padrão existente na coleta de esgoto por rede geral - ou seja, aumento da superioridade do acesso à água nas duas primeiras décadas e significativa redução na última década.

Diante da análise realizada nesse item, é possível dizer que ocorreu uma convergência entre os índices brasileiros de acesso a abastecimento de água e à coleta de esgoto por rede geral durante a década de 1990. No entanto, tal convergência não se concretizou plenamente nessa década - a superioridade do acesso à água, apesar de menor, ainda persistiu - e tudo indica que não se concretizará na década seguinte. Isto porque não ocorreu, no início dos anos 
2000, uma queda acentuada da diferença entre os índices de acesso, semelhante à observada anteriormente - fato ilustrado no gráfico 2.10.

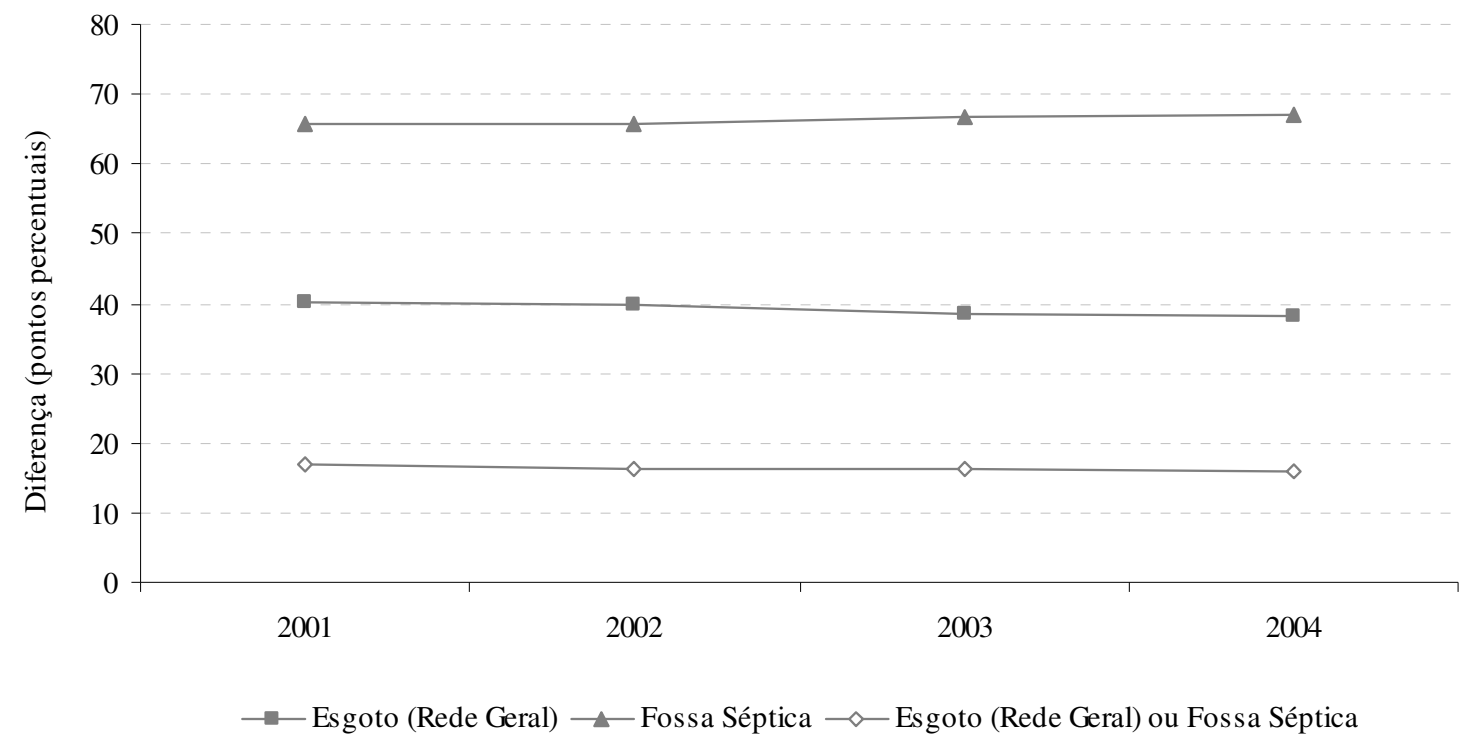

Fonte: IBGE, PNADs de 2001, 2002, 2003 e 2004. Elaboração própria.

Gráfico 2.10

Brasil: convergência dos índices de acesso domiciliar, segundo os tipos de serviços (2001-2004)

A seguir, essa análise será aprofundada. Considerando algumas das variáveis utilizadas nas análises anteriores ${ }^{9}$ - e a mesma tipologia -, pretende-se avaliar: (i) como as características do déficit de acesso variaram ao longo do tempo - de 1970 a 2004 - e (ii) se, dentro das categorias analisadas, diminuiu a diferença entre os melhores e os piores índices de acesso - ou seja, se os índices de acesso aos serviços de saneamento básico convergiram no período analisado.

\footnotetext{
${ }^{9}$ Além da região geográfica, serão utilizadas duas variáveis municipais - porte (tamanho da população) e taxa de urbanização - e duas variáveis domiciliares - localização do domicílio (zona urbana ou rural) e renda mensal.
} 
$\underline{\text { Análise regional }}$

O gráfico 2.11 mostra que aumentou, de 1970 a 2000, a proporção de domicílios com acesso a abastecimento de água por rede geral em todas as regiões - o mesmo ocorreu no Estado de São Paulo e no Distrito Federal. Analisando por décadas, verifica-se que a tendência sempre foi de crescimento do acesso à água por rede geral, exceto no caso do Distrito Federal. É interessante observar que este possuía o maior índice de acesso até 1980, sendo ultrapassado, em 1991, pelo Estado de São Paulo.

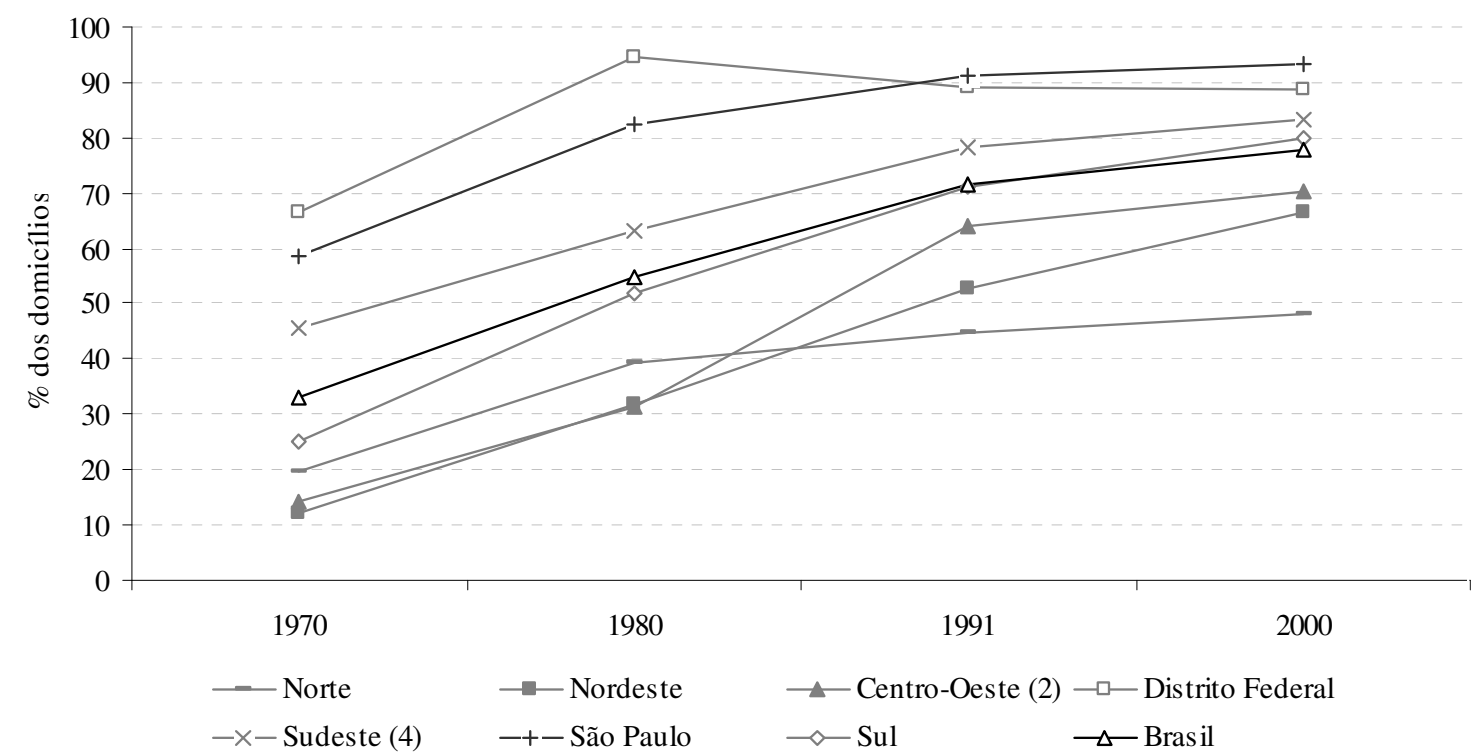

Fonte: IBGE, Censos Demográficos de 1970, 1980, 1991 e 2000. Elaboração própria.

(2) Centro-Oeste excluindo o Distrito Federal.

(4) Sudeste excluindo São Paulo.

Gráfico 2.11

Brasil: evolução da proporção de domicílios com acesso a abastecimento de água por rede geral, segundo as grandes regiões, o Distrito Federal e o Estado de São Paulo (1970-2000)

Para avaliar se houve ou não uma convergência do acesso à água no período, serão utilizados os índices do Estado de São Paulo como base de comparação. De acordo com gráfico 2.12, a diferença entre o acesso nesse estado e o acesso nas demais regiões aumentou 
na década de 1970 - exceto em relação ao Sul. A partir de 1980, essa diferença passou a apresentar uma tendência de queda - o que também pode ser observado pela redução do desvio-padrão entre os índices regionais de acesso. Tal tendência não ocorreu em relação: (i) ao Norte, até 1991 - a diferença em relação a essa região diminuiu um pouco em 2000 -, e (ii) ao Distrito Federal, a partir de 1991 - momento em que seu índice de acesso foi "ultrapassado" pelo índice paulista, conforme apontado anteriormente.

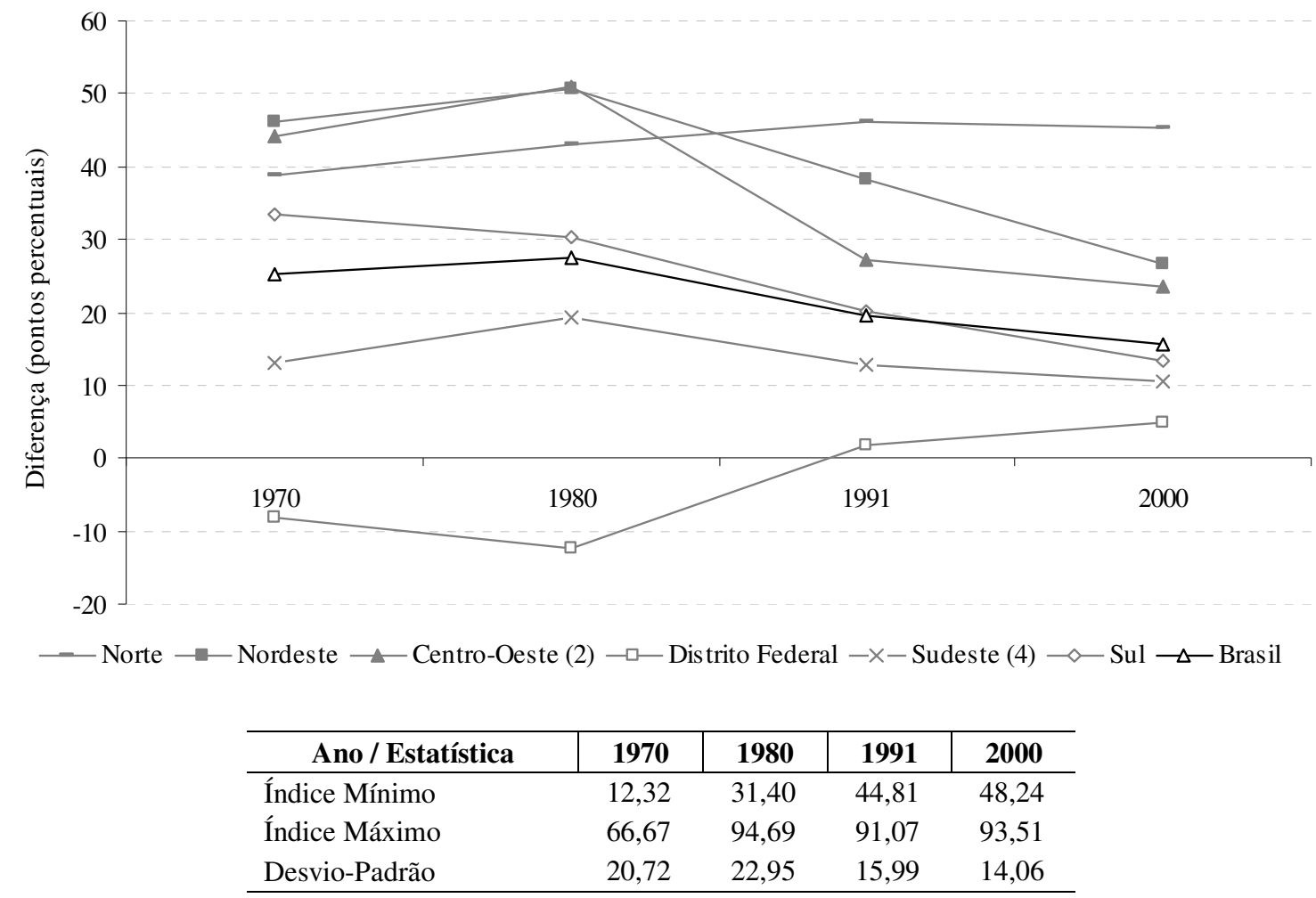

Fonte: IBGE, Censos Demográficos de 1970, 1980, 1991 e 2000. Elaboração própria.

(2) Centro-Oeste excluindo o Distrito Federal.

(4) Sudeste excluindo São Paulo.

Gráfico 2.12

Brasil: convergência dos índices de acesso a abastecimento de água por rede geral, segundo as grandes regiões, o Distrito Federal e o Estado de São Paulo (1970-2000)

No caso da coleta de esgoto por rede geral, o gráfico 2.13 mostra que os índices regionais de acesso a esse serviço também se elevaram de 1970 a 2000 - mesmo na região 
Norte, que sofreu uma queda do acesso na década de 1980. Deve-se destacar também que o Distrito Federal possuía o maior índice de acesso a coleta de esgoto em 1970 e em 2000 e o Estado de São Paulo em 1980 e em 1991.

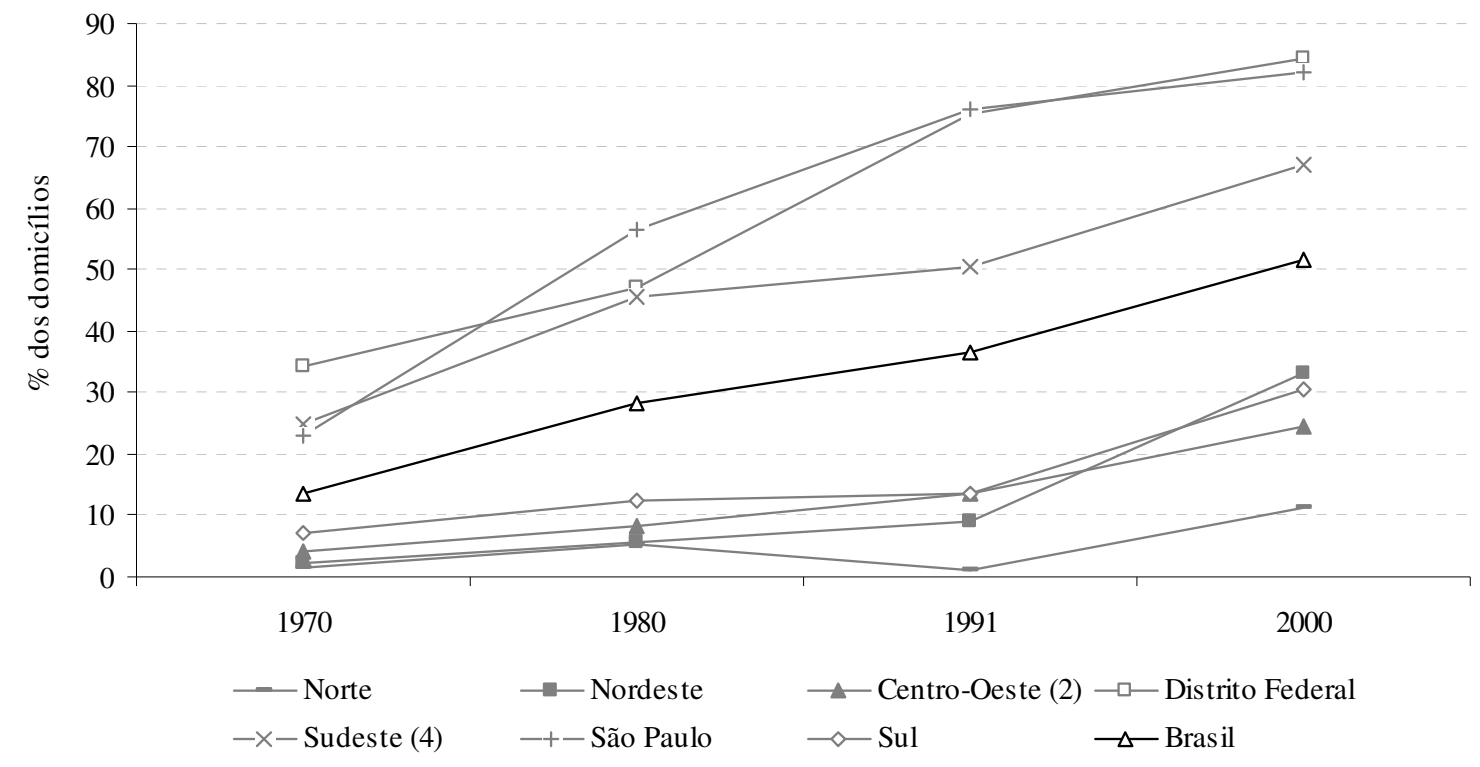

Fonte: IBGE, Censos Demográficos de 1970, 1980, 1991 e 2000. Elaboração própria.

(2) Centro-Oeste excluindo o Distrito Federal.

(4) Sudeste excluindo São Paulo.

\section{Gráfico 2.13}

Brasil: evolução da proporção de domicílios com acesso a coleta de esgoto por rede geral, segundo as grandes regiões, o Distrito Federal e o Estado de São Paulo (1970-2000)

Apesar do crescimento durante todo o período analisado, os índices regionais de acesso a coleta de esgoto por rede geral só apresentaram uma tendência de convergência a partir de 1991. Utilizando, mais uma vez, os índices do Estado de São Paulo como base de comparação, o gráfico 2.14 ilustra esse fato. Observa-se que a diferença entre o índice paulista e os índices regionais elevou-se significativamente durante as décadas de 1970 e 1980 , situação que se reverteu nos anos 1990. Em relação ao Distrito Federal, essa diferença sempre foi pequena em comparação às demais e seu sinal oscilou ao longo do período - nos momentos em que o Distrito Federal possuía o maior índice de acesso (1970 e 2000), a 
diferença era negativa; nos momentos em que o índice paulista era o maior (1980 e 1991), a diferença era positiva. A queda do desvio-padrão na década de 1990 é outro indicador da diminuição, nesse momento, da diferença entre os índices regionais de acesso ao serviço.

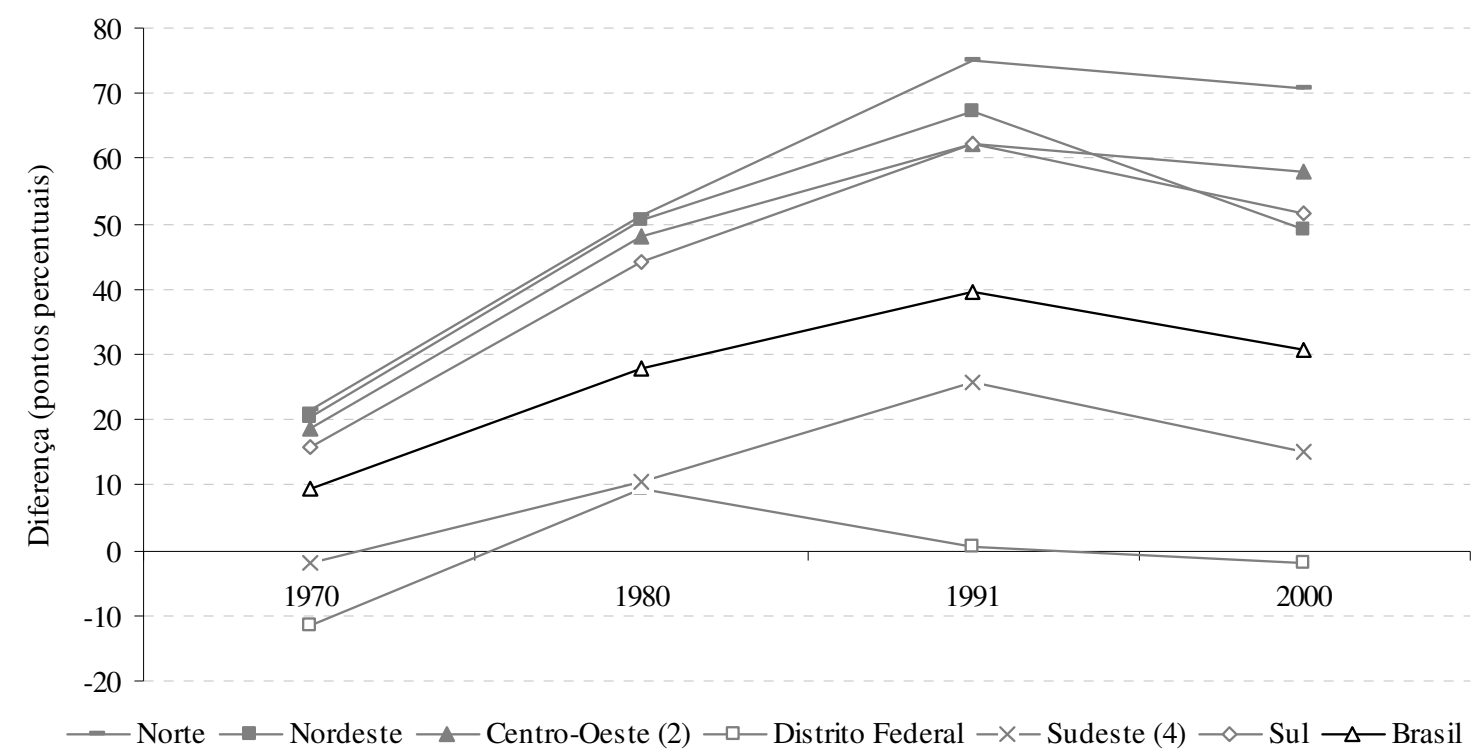

\begin{tabular}{l|r|r|r|r}
\hline \multicolumn{1}{c|}{ Ano / Estatística } & $\mathbf{1 9 7 0}$ & $\mathbf{1 9 8 0}$ & $\mathbf{1 9 9 1}$ & $\mathbf{2 0 0 0}$ \\
\hline Índice Mínimo & 1,55 & 5,16 & 1,05 & 11,36 \\
Índice Máximo & 34,45 & 56,32 & 76,02 & 84,29 \\
Desvio-Padrão & 12,19 & 21,89 & 29,70 & 27,76 \\
\hline
\end{tabular}

Fonte: IBGE, Censos Demográficos de 1970, 1980, 1991 e 2000. Elaboração própria.

(2) Centro-Oeste excluindo o Distrito Federal.

(4) Sudeste excluindo São Paulo.

\section{Gráfico 2.14}

Brasil: convergência dos índices de acesso a coleta de esgoto por rede geral, segundo as grandes regiões, o

\section{Distrito Federal e o Estado de São Paulo (1970-2000)}

Diante da análise realizada, é possível dizer que ocorreu uma convergência dos índices regionais de acesso a abastecimento de água por rede geral (a partir de 1980) e a coleta de esgoto por rede geral (a partir de 1991) - exceto nos casos já comentados. Essa convergência, contudo, não foi completa. Conseqüentemente, o desequilíbrio inter-regional do acesso - uma 
das características do déficit de acesso domiciliar aos serviços de saneamento básico reduziu-se, mas não foi eliminado.

\section{Análise municipal}

Considerando o porte do município (tamanho da população), os gráficos 2.15 e 2.16 mostram que aumentou a proporção de domicílios com acesso a abastecimento de água e a coleta de esgoto por rede geral em todos os estratos populacionais analisados - no período como um todo e em todas as décadas. Destaca-se a grande expansão do acesso a coleta de esgoto em municípios com mais de um milhão de habitantes - principalmente durante a década de 1970.

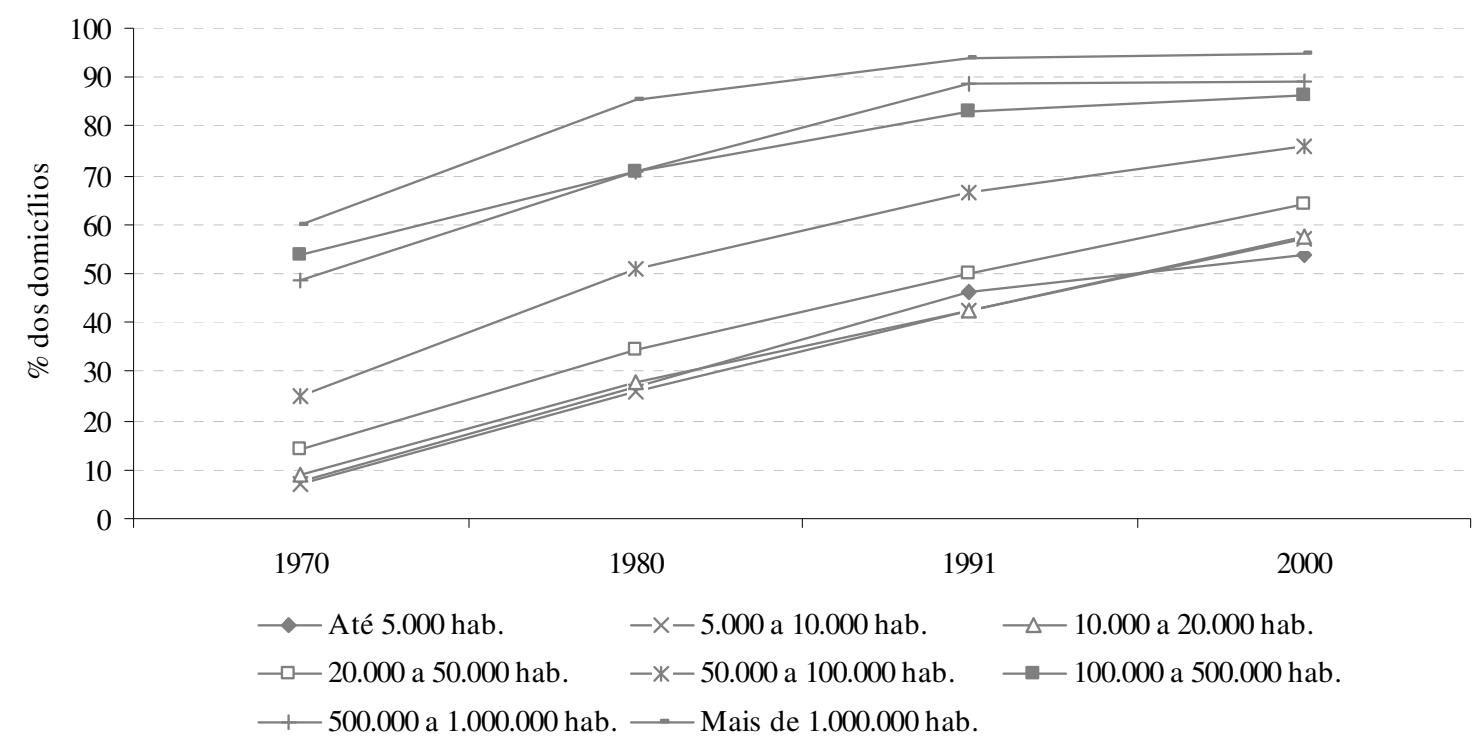

Fonte: IBGE, Censos Demográficos de 1970, 1980, 1991 e 2000. Elaboração própria.

Gráfico 2.15

Brasil: evolução da proporção de domicílios com acesso a abastecimento de água por rede geral, segundo o porte dos municípios (1970-2000) 


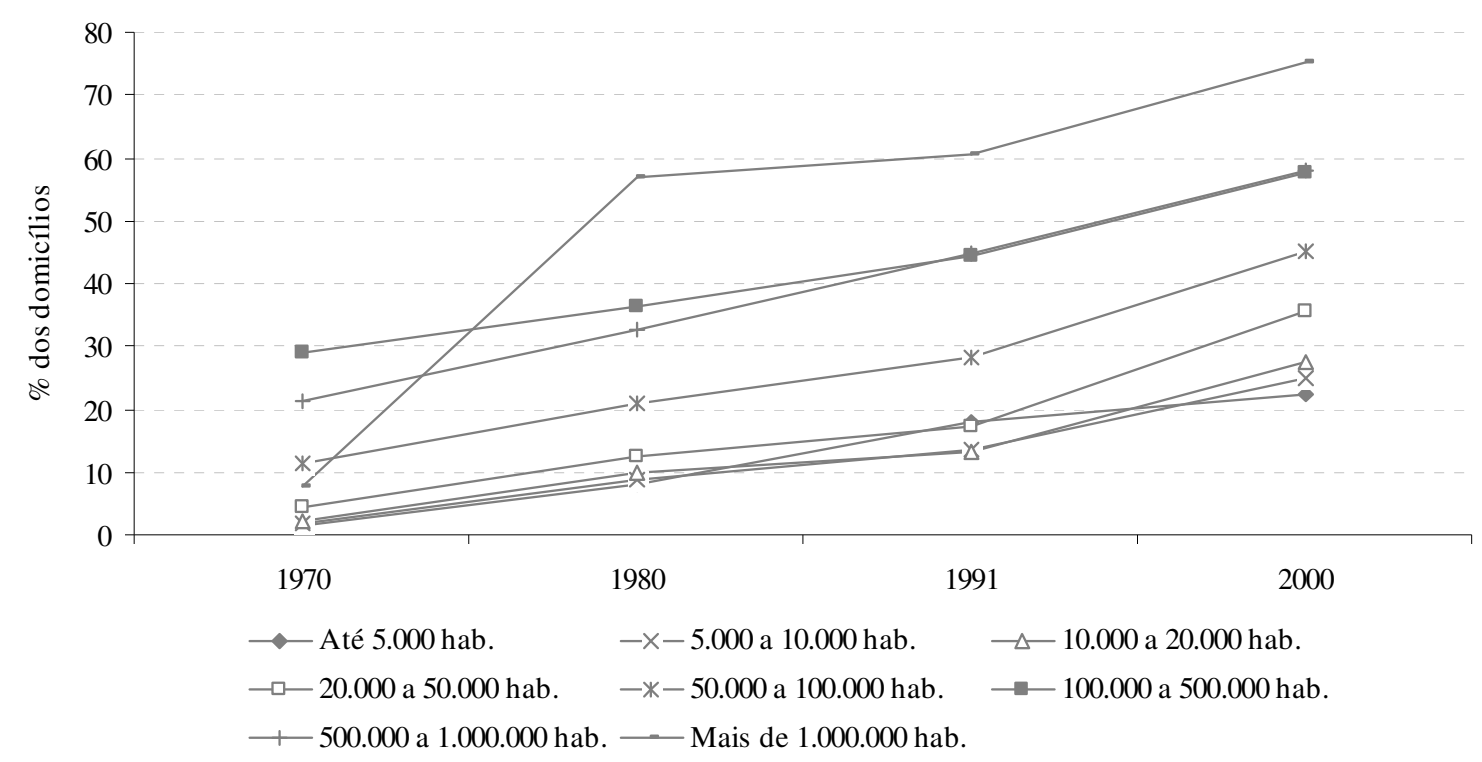

Fonte: IBGE, Censos Demográficos de 1970, 1980, 1991 e 2000. Elaboração própria.

\section{Gráfico 2.16}

Brasil: evolução da proporção de domicílios com acesso a coleta de esgoto por rede geral, segundo o porte dos municípios (1970-2000)

Conforme foi constatado anteriormente, há uma tendência de aumento do acesso domiciliar aos serviços de saneamento básico por rede geral à medida que se eleva a população do município - fato que pode ser observado nos gráficos 2.15 e 2.16. Dessa forma, para avaliar se os índices de acesso de municípios de diferentes portes convergiram ao longo do tempo - ou seja, se diminuiu a diferença entre os piores e os melhores indicadores -, serão utilizados como base de comparação os índices do último estrato populacional considerado municípios com mais de um milhão de habitantes.

No caso do abastecimento de água por rede geral, o gráfico 2.17 mostra que ocorreu, na década de 1970, um aumento da diferença entre o acesso em municípios com mais de um milhão de habitantes e o acesso nos demais - exceto em relação aos municípios com população entre cinqüenta e cem mil habitantes. A partir da década de 1980, essa diferença 
apresentou uma tendência de queda em todos os estratos populacionais - o que levou à redução do desvio-padrão entre os índices de acesso dos estratos populacionais.

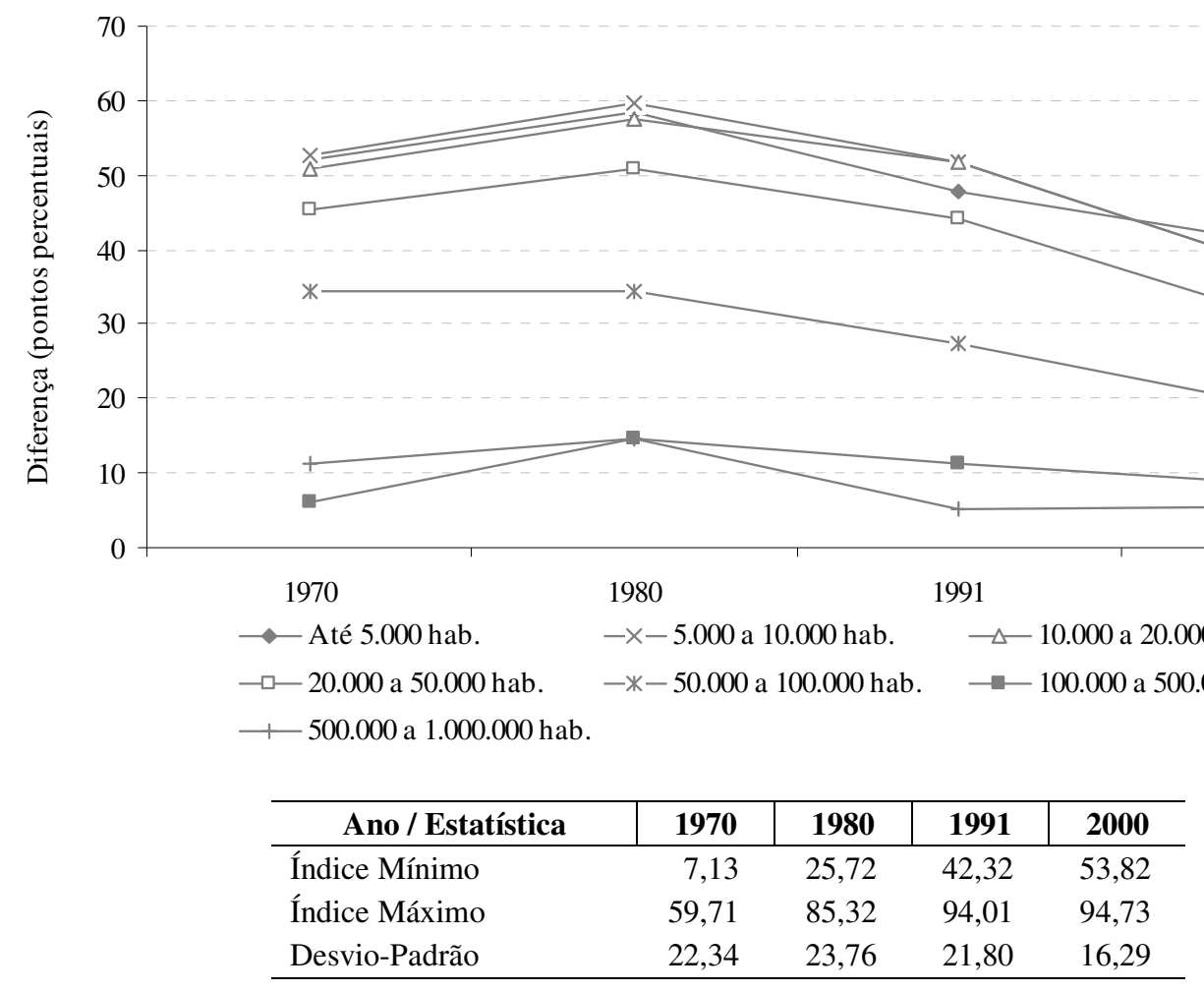

Fonte: IBGE, Censos Demográficos de 1970, 1980, 1991 e 2000. Elaboração própria.

\section{Gráfico 2.17}

Brasil: convergência dos índices de acesso a abastecimento de água por rede geral, segundo o porte dos municípios (1970-2000)

No caso da coleta de esgoto por rede geral, também houve, na década de 1970, um aumento da diferença entre o acesso em municípios com mais de um milhão de habitantes e o acesso nos demais - mais acentuado do que no abastecimento de água, em função do grande crescimento do acesso a esgoto nos municípios com mais de um milhão de habitantes. A partir da década de 1980, ocorreu, de uma maneira geral, uma redução da diferença dos índices de acesso. Contudo, essa redução foi pequena e, em alguns casos, foi revertida. Destaca-se, nesse sentido, a diferença em relação aos municípios de até cinco mil habitantes - 
que, após uma diminuição na década de 1980, atingiu, em 2000, seu maior patamar durante todo o período considerado. Outro fato interessante é o aumento, em todas as décadas, do desvio-padrão entre os índices de acesso dos estratos populacionais. Esses fatos são ilustrados no gráfico 2.18 .

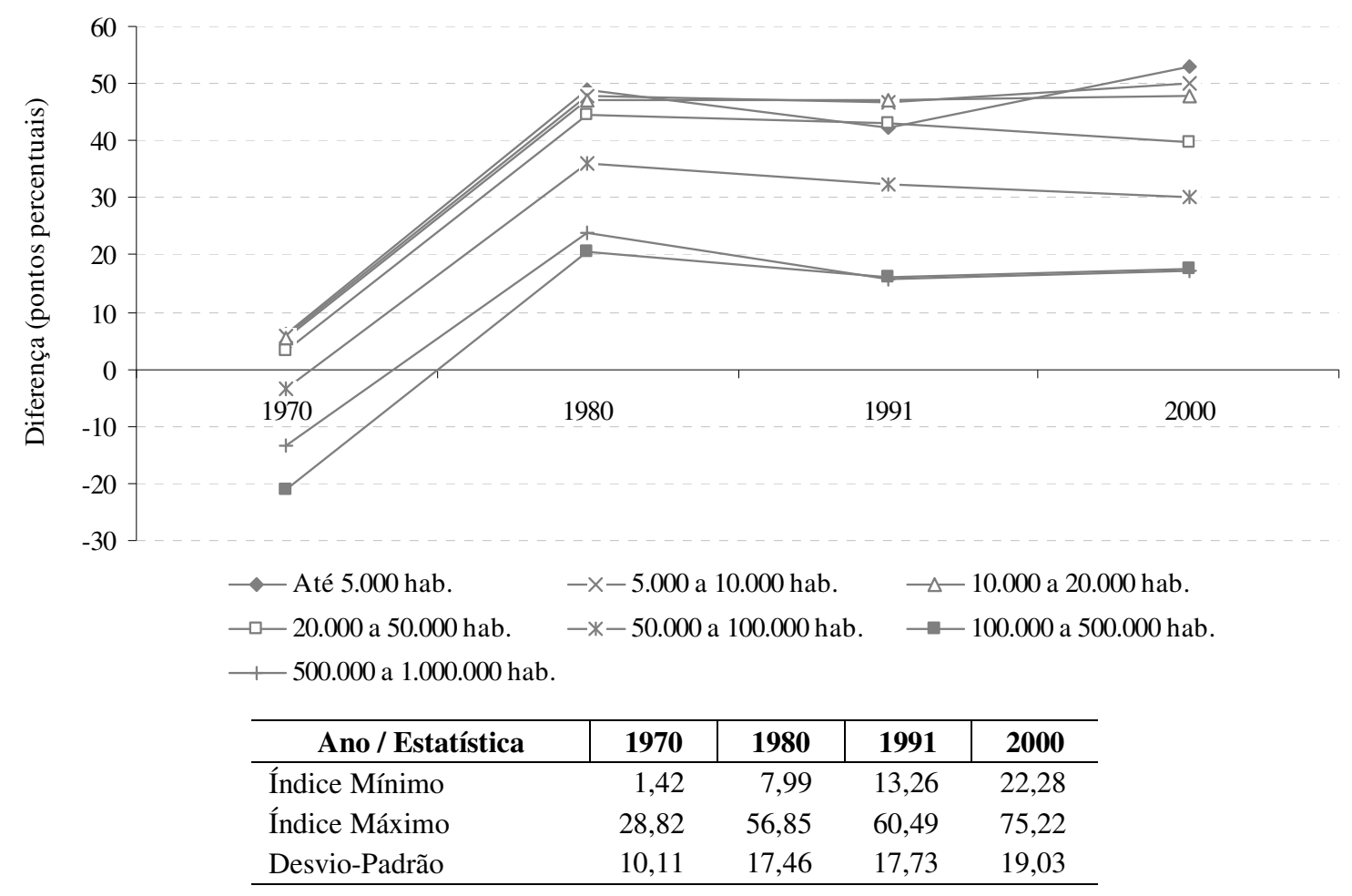

Fonte: IBGE, Censos Demográficos de 1970, 1980, 1991 e 2000. Elaboração própria.

\section{Gráfico 2.18}

Brasil: convergência dos índices de acesso a coleta de esgoto por rede geral, segundo o porte dos municípios (1970-2000)

Outra característica municipal que pode ser utilizada na análise é a taxa de urbanização. O gráfico 2.19 mostra que, entre 1970 e 2000, aumentou a proporção de domicílios com acesso a abastecimento de água e a coleta de esgoto por rede geral em todas as faixas de urbanização consideradas - mesmo naquelas que apresentaram redução do acesso a um dos serviços em alguma década, o aumento no período como um todo foi observado. 

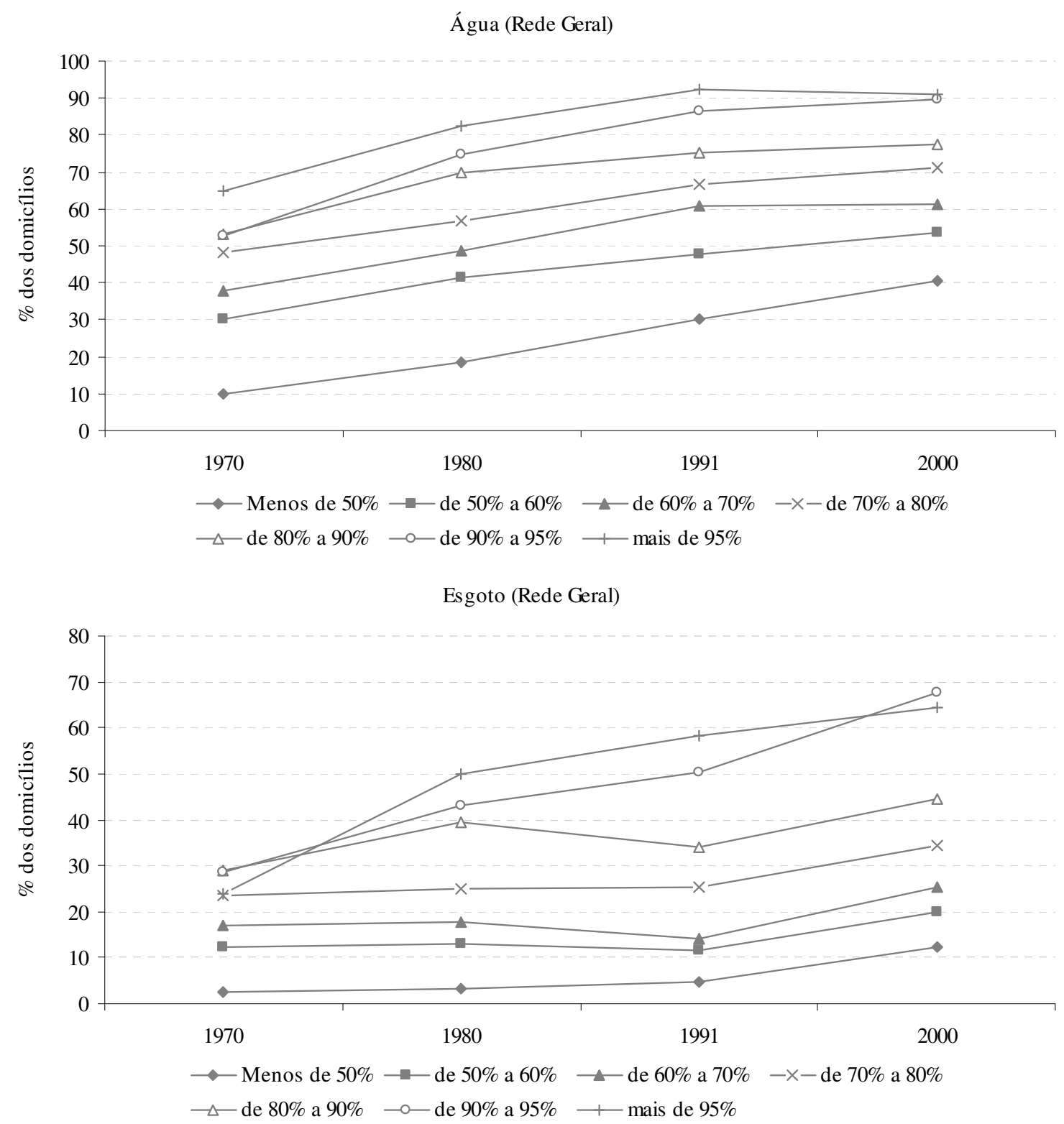

Fonte: IBGE, Censos Demográficos de 1970, 1980, 1991 e 2000. Elaboração própria.

Gráfico 2.19

Brasil: evolução da proporção de domicílios com acesso a serviços de saneamento básico, segundo a taxa de urbanização dos municípios (1970-2000)

A análise da existência ou não de convergência entre os índices de acesso aos serviços pode ser feita, nesse caso, avaliando se o acesso nas demais faixas de urbanização aproximouse ou não do acesso na última faixa - ou seja, nos municípios com mais de $95 \%$ de sua 
população vivendo na zona urbana. Tal escolha deve-se à tendência de aumento da cobertura dos serviços por rede geral à medida que se eleva a taxa de urbanização do município - fato constatado anteriormente e que pode ser observado no gráfico 2.19 .

De acordo com o gráfico 2.20, a superioridade do acesso a abastecimento de água por rede geral nos municípios com taxa de urbanização acima de 95\% aumentou durante a década de 1970 - exceto em relação aos municípios com taxa de urbanização entre 90 e 95\%. Nos anos 1980, em algumas faixas de urbanização essa superioridade apresentou uma tendência de queda. Já na década seguinte (1990), tal tendência ocorreu em todas as faixas analisadas. Analisando o desvio-padrão entre os índices de acesso das faixas de urbanização, observa-se que este passou a sofrer uma redução gradual a partira da década de 1980.

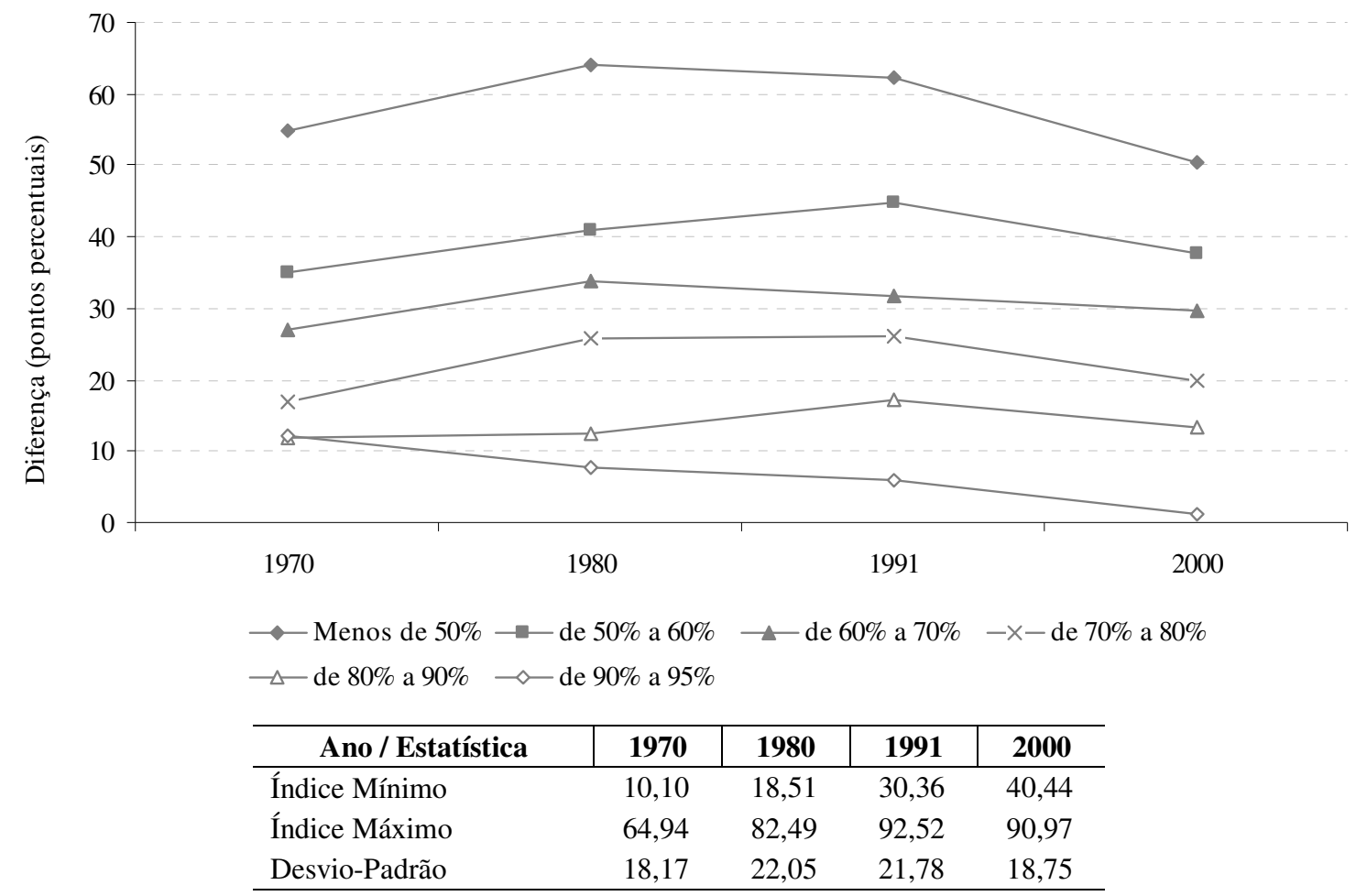

Fonte: IBGE, Censos Demográficos de 1970, 1980, 1991 e 2000. Elaboração própria.

Gráfico 2.20

Brasil: convergência dos índices de acesso a abastecimento de água por rede geral, segundo a taxa de urbanização dos municípios (1970-2000) 
No caso do acesso a coleta de esgoto por rede geral, o gráfico 2.21 mostra que a superioridade do índice de acesso dos municípios mais urbanizados aumentou sensivelmente nas décadas de 1970 e 1980 - principalmente na primeira. Nos anos 1990, essa superioridade diminuiu um pouco em todas as faixas - destaca-se a penúltima faixa de urbanização (de $90 \%$ a 95\%), cujo índice de acesso a coleta de esgoto "ultrapassou", nesse momento, o da última faixa (acima de 95\%). Destaca-se também o fato do desvio-padrão entre os índices de acesso das faixas de urbanização ter aumentado durante todo o período analisado.

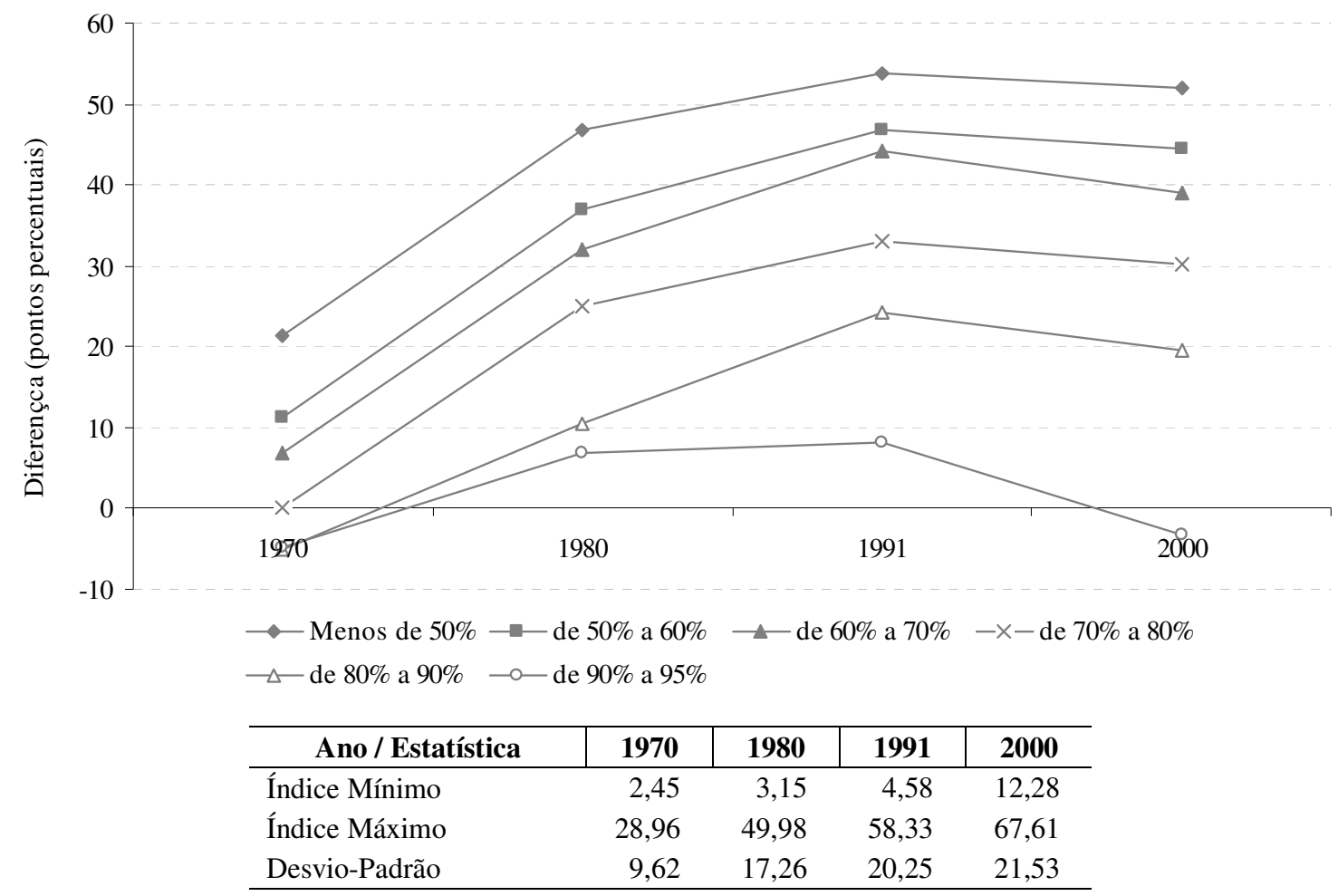

Fonte: IBGE, Censos Demográficos de 1970, 1980, 1991 e 2000. Elaboração própria.

\section{Gráfico 2.21}

Brasil: convergência dos índices de acesso a coleta de esgoto por rede geral, segundo a taxa de urbanização dos municípios (1970-2000)

A análise realizada nesse item mostrou que ocorreu, no início do período analisado, um aumento da superioridade do acesso aos serviços de saneamento básico por rede geral nos 
municípios mais populosos e mais urbanizados - principalmente durante os anos 1970. Após esse aumento, verificou-se uma tendência de queda de tal superioridade (convergência) - no caso da água, a partir da década de 1980; no caso do esgoto, na década seguinte. É importante enfatizar, mais uma vez, que essa convergência não foi completa - conforme foi constatado anteriormente, ainda há um sério desequilíbrio de acesso entre os municípios.

\section{$\underline{\text { Análise domiciliar }}$}

Nas primeiras seções do presente capítulo, foi constatado que o acesso urbano aos serviços de saneamento básico no Brasil era, em 2000, superior ao rural, mesmo no caso da fossa séptica. De acordo com o gráfico 2.22, essa superioridade já existia em 1970.

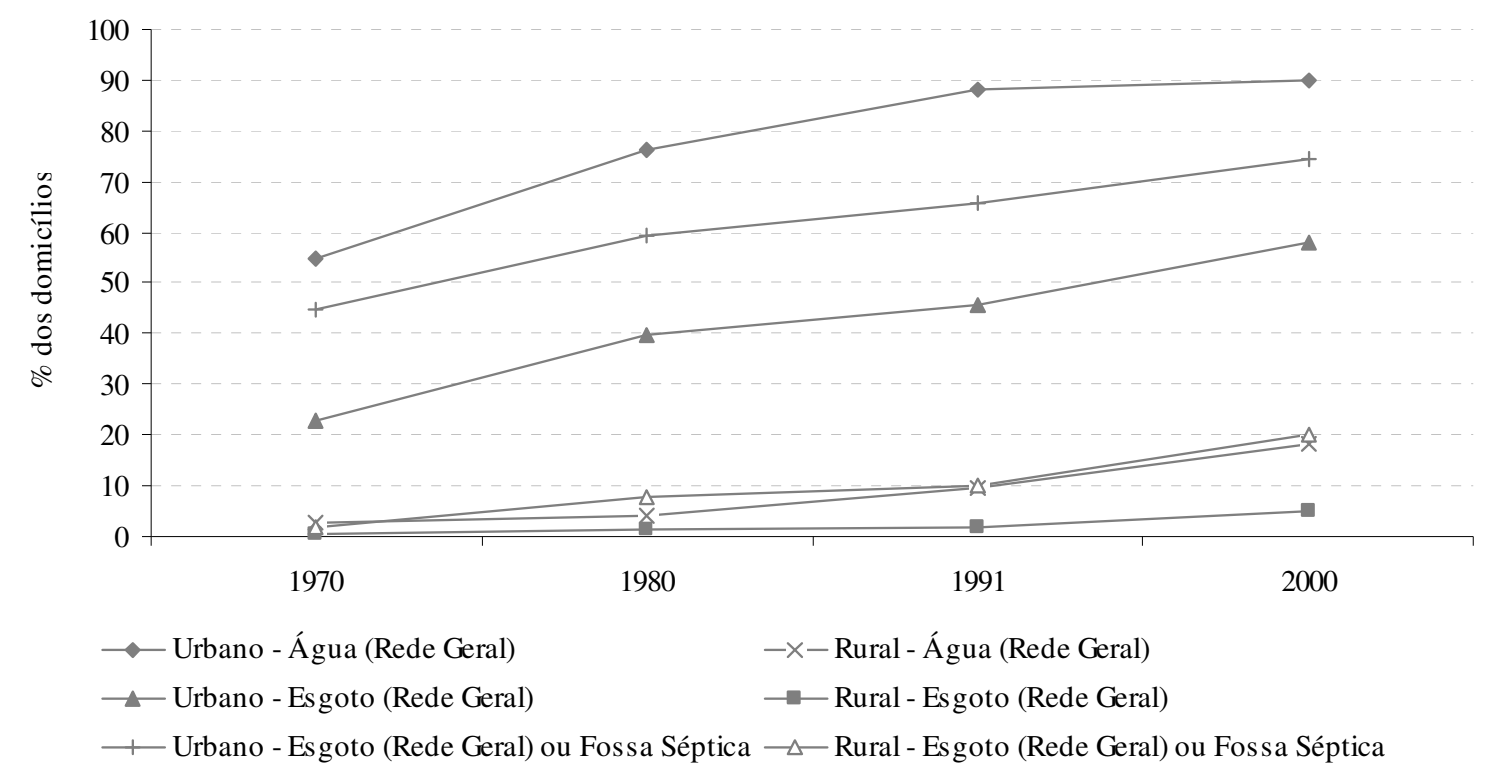

Fonte: IBGE, Censos Demográficos de 1970, 1980, 1991 e 2000. Elaboração própria.

Gráfico 2.22

Brasil: evolução da proporção de domicílios com acesso a serviços de saneamento básico, segundo a localização do domicílio (1970-2000) 
Por meio do gráfico 2.22, também é possível observar que a proporção de domicílios com acesso a qualquer um dos serviços considerados aumentou de 1970 a 2000, tanto na zona rural como na zona urbana - nesta última, o crescimento do acesso foi mais significativo. No início dos anos 2000, não ocorreu uma grande variação do acesso aos serviços e superioridade do acesso urbano persistiu - conforme ilustrado no gráfico 2.23 .

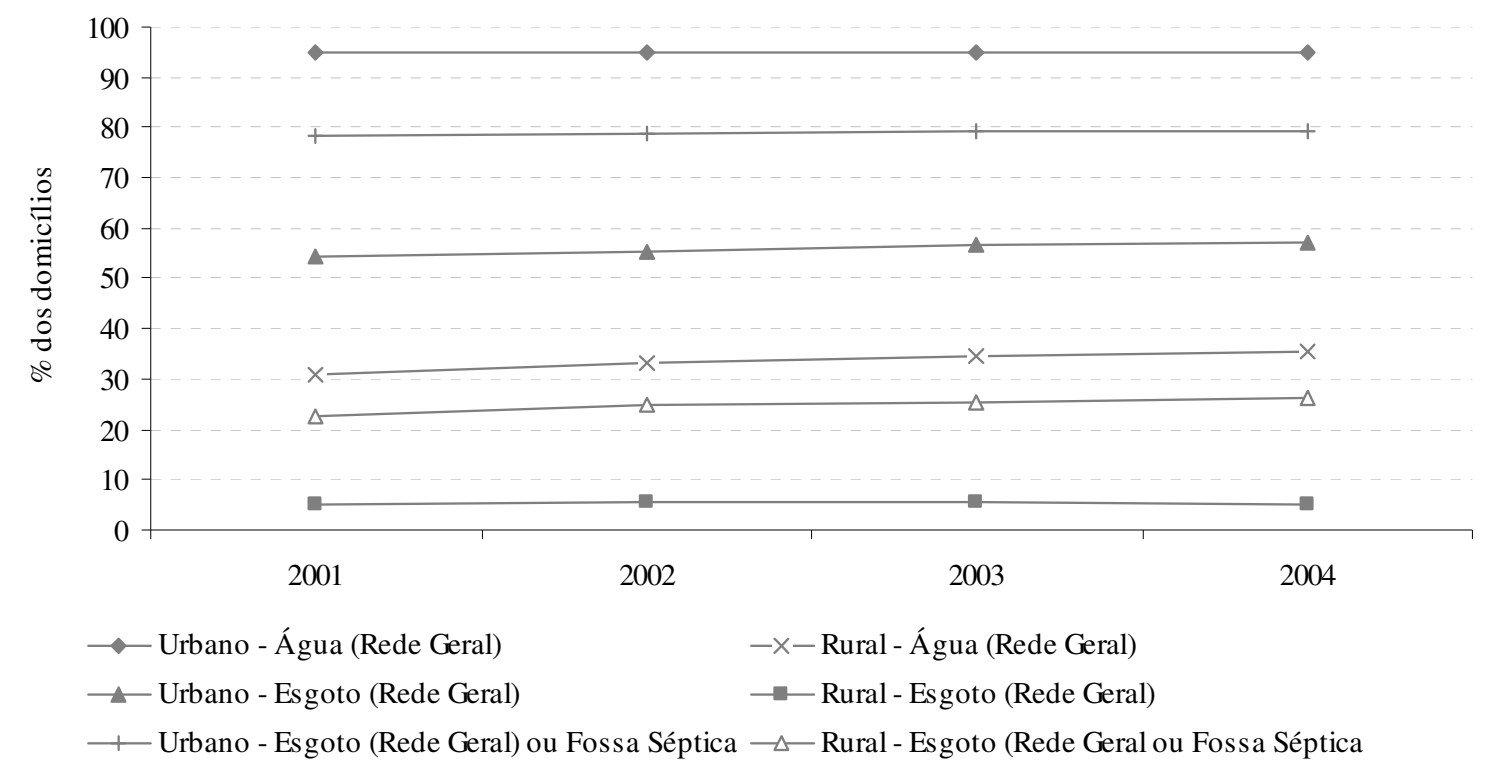

Fonte: IBGE, PNADs 2001, 2002, 2003 e 2004. Elaboração própria.

\section{Gráfico 2.23}

Brasil: evolução da proporção de domicílios com acesso a serviços de saneamento básico, segundo a localização do domicílio (2000-2004)

O gráfico 2.24, por sua vez, mostra que a superioridade do acesso urbano aumentou durante as décadas de 1970 e 1980. A partir dos anos 1990, no caso do abastecimento de água por rede geral e das duas formas de esgotamento sanitário, essa superioridade apresentou uma tendência de queda. Analisando a coleta de esgoto por rede geral isoladamente, observa-se que a diferença entre o acesso urbano e o rural aumentou durante todo o período. Ou seja, o 
resultado para as duas formas de esgotamento sanitário é influenciado por uma diminuição da diferença do acesso à fossa séptica - lembrando que a literatura aponta a fossa séptica como uma solução provisória que deve ser substituída pela rede geral, essa sim uma forma ideal.

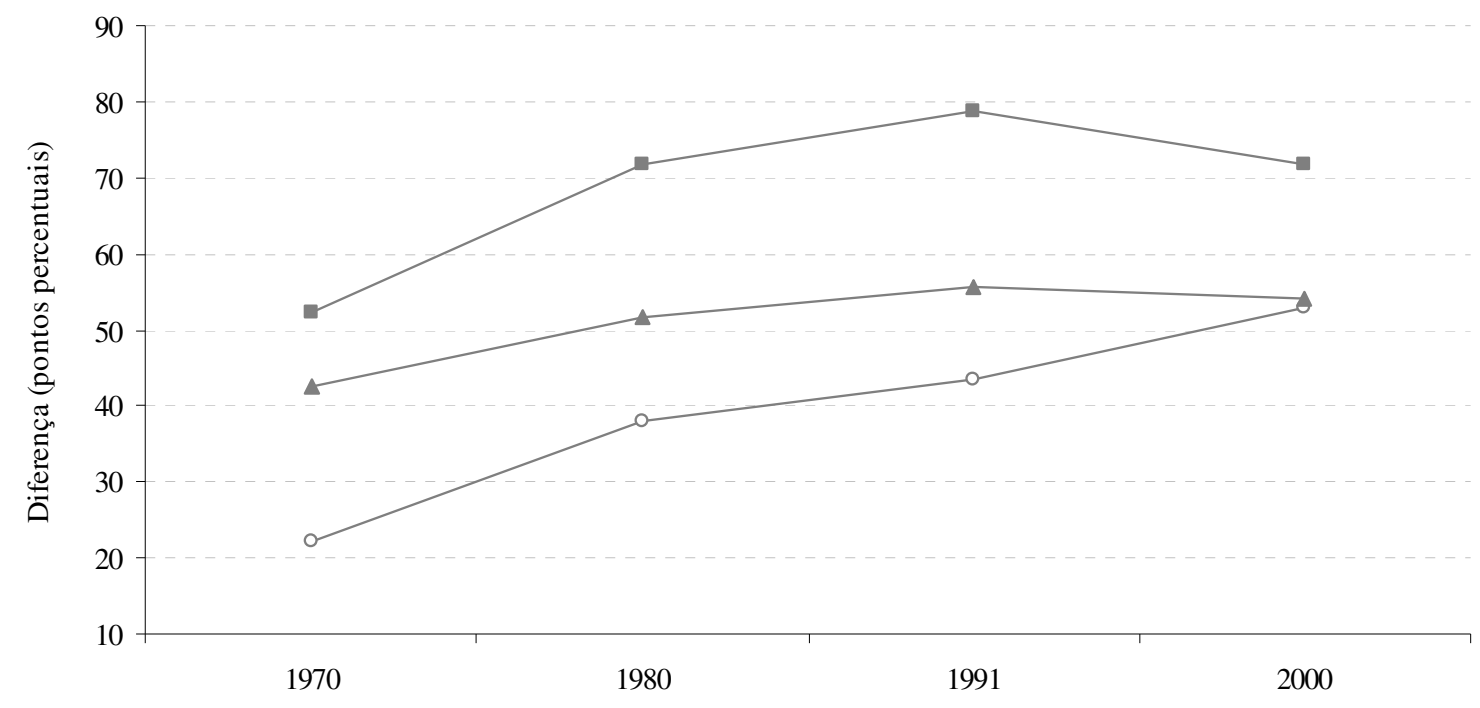

$\multimap-$ Água (Rede Geral) ———Esgoto (Rede Geral) $\_$Es goto (Rede Geral) ou Fossa Séptica

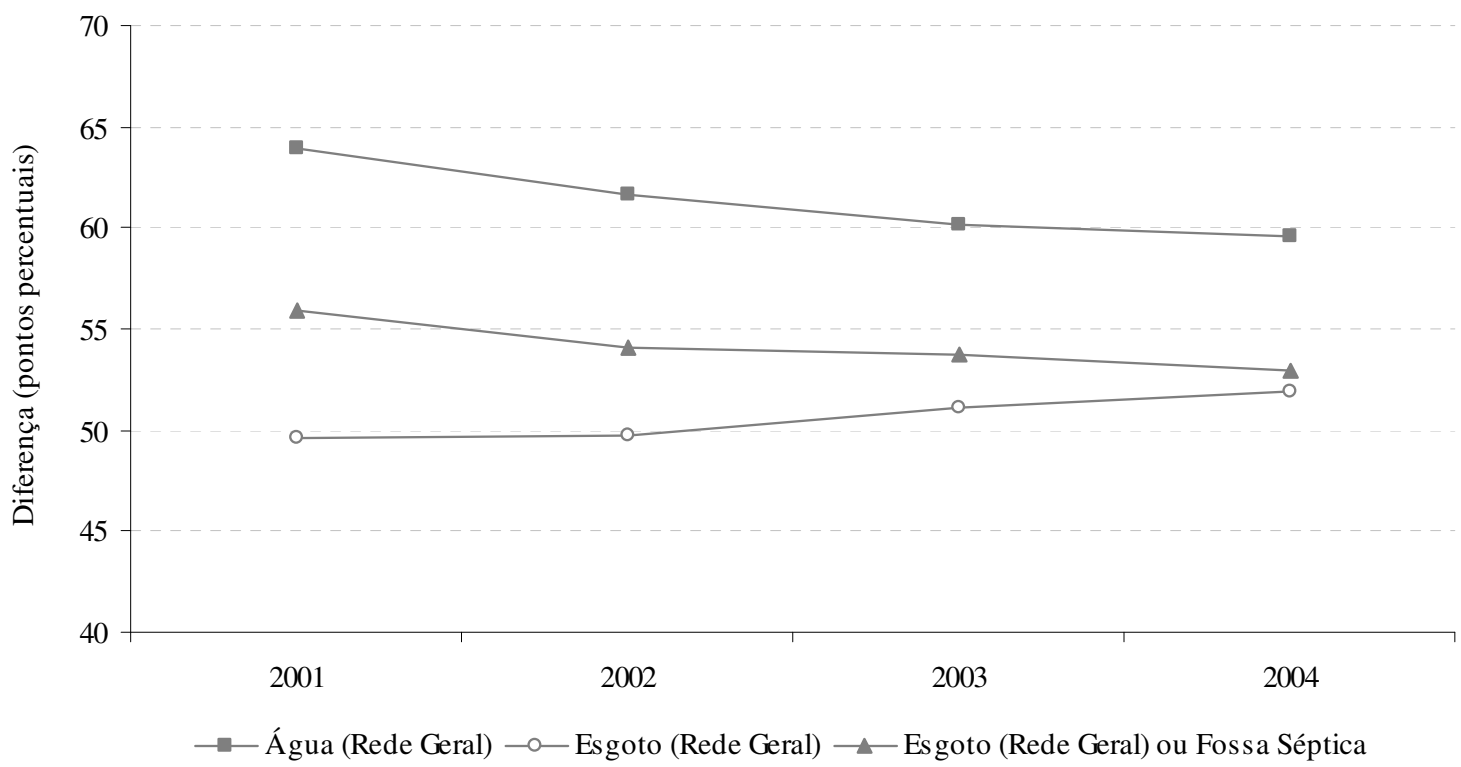

Fonte: IBGE, Censos Demográficos de 1970, 1980, 1991 e 2000 e PNADs 2001, 2002, 2003 e 2004. Elaboração própria.

Gráfico 2.24

Brasil: convergência dos índices de acesso a serviços de saneamento básico, segundo a localização do domicílio (1970-2004) 
A renda domiciliar mensal é a última variável que será considerada na análise. Deve-se destacar, primeiramente, que a proporção de domicílios com acesso a abastecimento de água por rede geral elevou-se significativamente, entre 1980 e 2000 , em todas as faixas de renda consideradas - mesmo naquelas que apresentaram redução do acesso em um determinado momento $^{10}$. Tal fato pode ser observado no gráfico 2.25 .

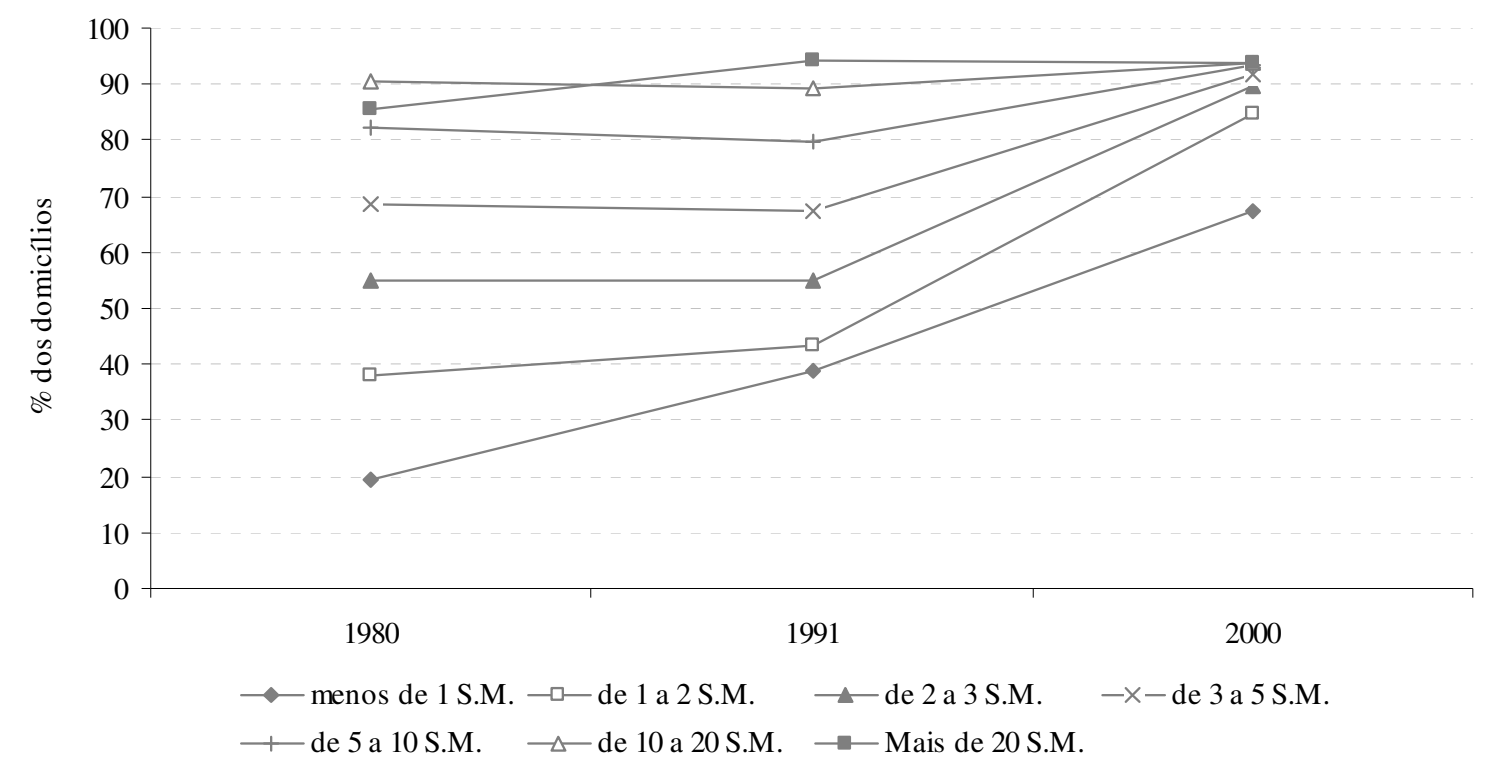

Fonte: IBGE, Censos Demográficos de 1980, 1991 e 2000. Elaboração própria.

\section{Gráfico 2.25}

Brasil: evolução da proporção de domicílios com acesso a abastecimento de água por rede geral, segundo a renda mensal dos domicílios (1980-2000)

No caso da coleta de esgoto por rede geral, o gráfico 2.26 mostra que a proporção de domicílios com acesso a esse serviço também aumentou, entre 1980 e 2000, em todas as faixas de renda consideradas. Analisando por décadas, observa-se que ocorreu, na primeira (década de 1980), uma redução do acesso a coleta de esgoto em quase todas as faixas de

\footnotetext{
${ }^{10}$ Lembrando que, em 1970, não foi possível calcular, com as informações disponibilizadas pelo Censo daquele ano, a renda mensal dos domicílios.
} 
renda. Nos anos 1991, essa redução foi revertida, fazendo com que os índices subissem significativamente em 2000 - superiores aos de 1980. As duas únicas faixas de renda que apresentaram crescimento durante todo o período analisado foram a maior (mais de 20 salários mínimos) e, surpreendentemente, a menor (até um salário mínimo).

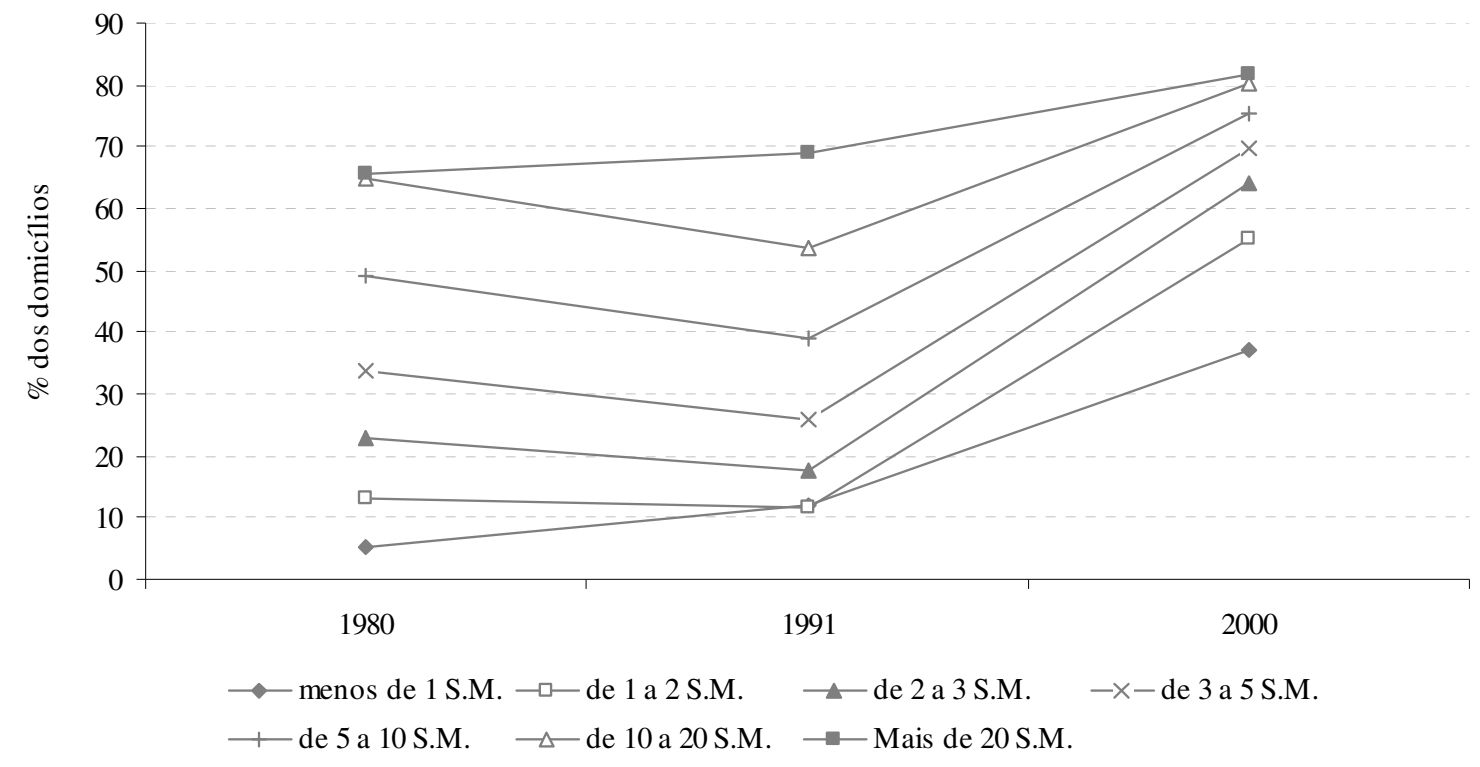

Fonte: IBGE, Censos Demográficos de 1980, 1991 e 2000. Elaboração própria.

\section{Gráfico 2.26}

Brasil: evolução da proporção de domicílios com acesso a coleta de esgoto por rede geral, segundo a renda mensal dos domicílios (1980-2000)

Anteriormente, constatou-se que o acesso aos serviços por rede geral possui uma relação positiva com a renda domiciliar mensal - ou seja, há uma tendência de aumento do acesso à medida que se eleva a renda mensal do domicílio. Dessa forma, para avaliar se houve ou não uma convergência entre os indicadores de acesso das diferentes faixas de renda domiciliar, serão utilizados como base de comparação os índices da maior faixa - ou seja, dos domicílios com renda mensal superior a vinte salários mínimos. 
No gráfico 2.27, é possível observar que a superioridade do acesso a água por rede geral nos domicílios de maior renda aumentou na década de 1980 e diminuiu, significativamente, na década de 1990 - no caso da menor faixa (menos de um salário mínimo), essa redução já vinha ocorrendo desde 1980. Destaca-se também a significativa redução do desvio-padrão entre os índices de acesso das faixas de renda ocorrido nos anos 1990.

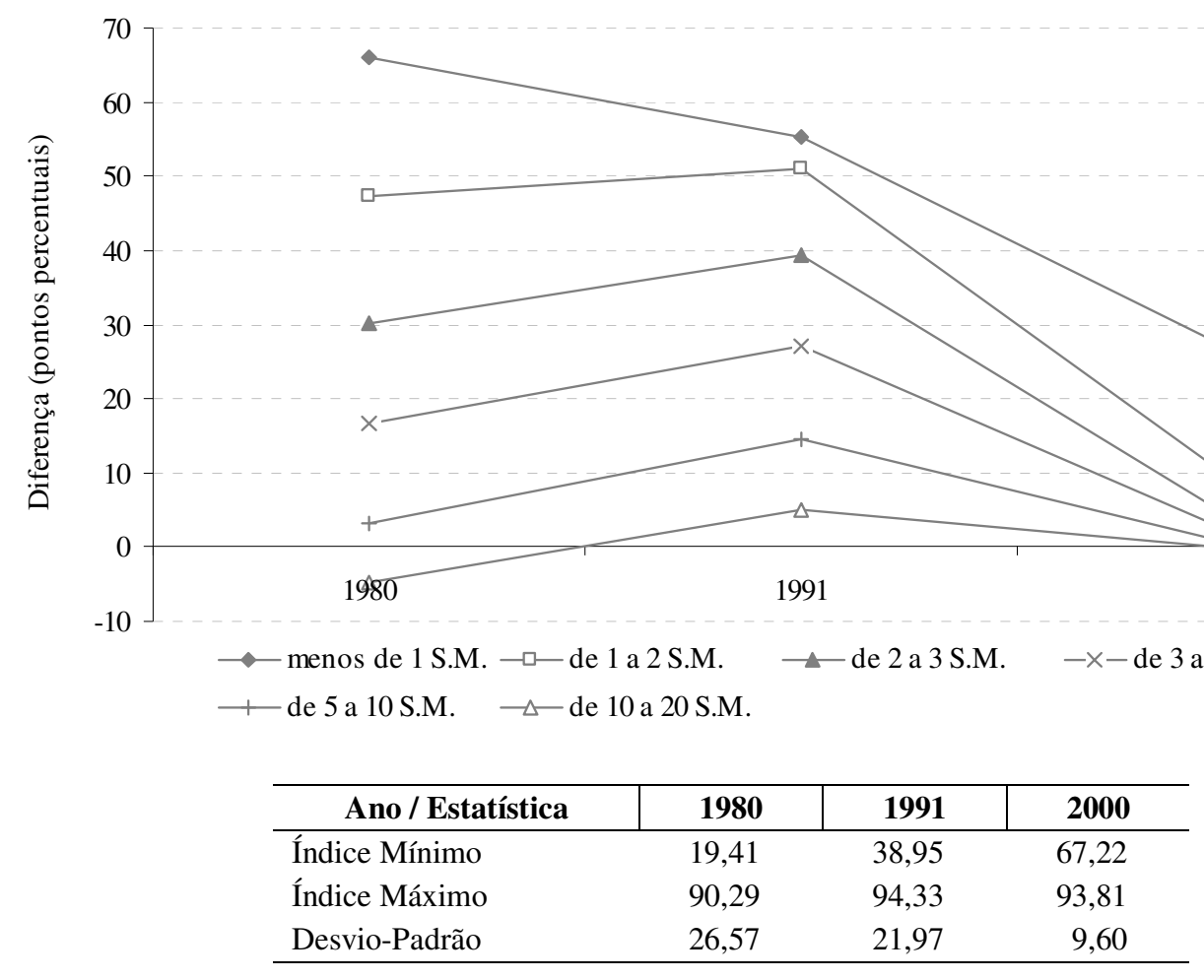

Fonte: IBGE, Censos Demográficos de 1980, 1991 e 2000. Elaboração própria.

\section{Gráfico 2.27}

Brasil: convergência dos índices de acesso a abastecimento de água por rede geral, segundo a renda mensal dos domicílios (1980-2000)

No caso da coleta de esgoto por rede geral, o gráfico 2.28 mostra que a superioridade do acesso nos domicílios de maior renda também aumentou na década de 1980 e diminuiu, significativamente, na década de 1990. O desvio-padrão entre os índices de acesso a coleta de 
esgoto das faixas de renda reduziu-se significativamente ao longo do tempo - principalmente nos anos 1990.

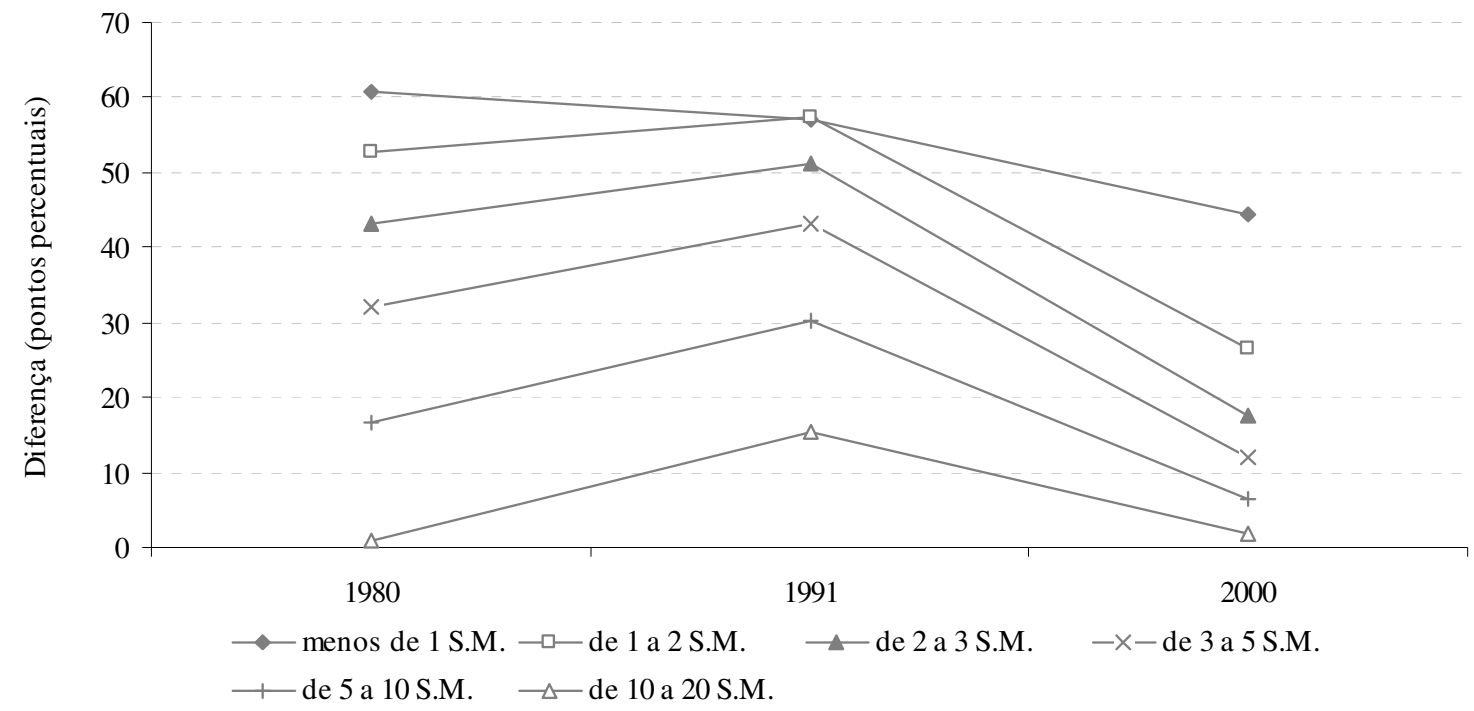

\begin{tabular}{l|r|r|r}
\hline \multicolumn{1}{c|}{ Ano / Estatística } & $\mathbf{1 9 8 0}$ & $\mathbf{1 9 9 1}$ & $\mathbf{2 0 0 0}$ \\
\hline Índice Mínimo & 5,09 & 11,78 & 37,31 \\
Índice Máximo & 65,78 & 69,05 & 81,84 \\
Desvio-Padrão & 24,36 & 22,11 & 15,77 \\
\hline
\end{tabular}

Fonte: IBGE, Censos Demográficos de 1980, 1991 e 2000. Elaboração própria.

\section{Gráfico 2.28}

Brasil: convergência dos índices de acesso a coleta de esgoto por rede geral, segundo a renda mensal dos domicílios (1980-2000)

Portanto, a análise por características domiciliares também mostrou que alguns índices de acesso a serviços de saneamento básico convergiram, de forma incompleta, ao longo do tempo. Em relação à renda domiciliar mensal, observou-se que a superioridade do acesso, tanto à água como à coleta de esgoto, nos domicílios de alta renda sofreu uma significativa redução na década de 1990 - mas ainda existe. Já em relação à localização do domicílio, ocorreu uma diminuição da superioridade do acesso urbano no caso do abastecimento de água - também na década de 1990 - e um aumento ao longo de todo o período analisado no caso da 
coleta de esgoto por rede geral - a situação do esgotamento sanitário rural só melhora se também for considerado o acesso à fossa séptica.

\section{$\underline{\text { 3.3 Análise das políticas públicas adotadas para o setor (1970-2004) }}$}

Para finalizar o estudo proposto nessa seção - e, de certa forma, complementar o histórico do setor apresentado no primeiro capítulo -, resta avaliar qual tipo de política impactou mais sobre as características do déficit de acesso domiciliar aos serviços de saneamento básico - e qual foi esse impacto.

Deve-se destacar, primeiramente, que as análises realizadas nos itens anteriores utilizaram dados disponibilizados pelos Censos Demográficos de 1970, 1980, 1991 e 2000 e pela PNADs de 2001, 2002, 2003 e 2004. Dessa forma, foi possível avaliar a evolução do acesso aos serviços de saneamento básico no Brasil ao longo de trinta e quatro anos - de 1970 a 2004. Em relação às políticas públicas adotadas para o setor, esse período engloba três momentos distintos: (i) auge do Planasa (década de 1970); (ii) crise do Planasa (década de 1980) e (iii) ausência de uma política nacional (a partir de 1992).

De acordo com o primeiro capítulo, pode-se dizer que o Plano Nacional de Saneamento (Planasa) foi, grosso modo, um modelo centralizado de financiamento de investimentos em saneamento básico. Baseava-se na concessão, por parte dos municípios, dos direitos de exploração dos serviços às Companhias Estaduais de Saneamento Básico (CESBs) de seus respectivos estados - responsáveis pela execução de obras e pela operação dos sistemas. Ao Banco Nacional de Habitação (BNH), órgão responsável pela administração do Sistema Financeiro de Saneamento (SFS), cabia, entre outras responsabilidades, a realização de empréstimos, com recursos do Fundo de Garantia por Tempo de Serviço (FGTS), para 
financiar parte dos investimentos. Até meados dos anos 1980, apenas as CESBs se beneficiavam desse financiamento.

O auge desse modelo de financiamento foi na década de 1970, momento em que foram realizados grandes investimentos e que, conseqüentemente, ocorreu a maior expansão dos índices de acesso aos serviços - conforme foi ilustrado no gráfico 2.8, apresentado anteriormente. Na década de 1980, várias dificuldades internas e conjunturais fizeram com que o Planasa entrasse em crise. Na tentativa de superá-las, foram tomadas algumas medidas, entre as quais, destaca-se a inclusão dos municípios no esquema de financiamento - ou seja, passaram a poder realizar empréstimos junto ao BNH. Essas medidas, contudo, não surtiram o efeito desejado. Em 1992, o Plano foi extinto.

Após esse ano, não foi adotada uma outra política nacional para o saneamento básico. As iniciativas governamentais passaram a ser "pontuais e desarticuladas" (TUROLLA, 2002, p. 13). Conforme foi apontado no primeiro capítulo, os programas federais pós-Planasa podem ser divididos em três grupos, de acordo com seus objetivos: (i) programas para a redução das desigualdades socioeconômicas e que privilegia(va)m os sistemas sem viabilidade econômico-financeira; (ii) programas voltados para a modernização e o desenvolvimento institucional dos sistemas de saneamento e (iii) programas para aumentar a participação privada no setor.

No item 3.2, foi constatado que, entre 1970 e 2000, o acesso aos serviços de saneamento básico no Brasil aumentou significativamente em todas as categorias analisadas. Na década de 1970, essa expansão gerou um agravamento dos desequilíbrios do déficit de acesso - ou seja, aumentou a diferença entre os melhores e os piores índices de acesso. Durante os anos 1980, no caso do abastecimento de água por rede geral, ocorreu uma tendência de redução (convergência) desses desequilíbrios em algumas categorias analisadas. Tal tendência tornouse mais acentuada na década de 1990, momento em que as diferenças entre os índices de 
acesso a coleta de esgoto por rede geral também sofreram uma queda. Já nos primeiros anos da década de 2000, a cobertura dos serviços não variou muito - os índices de acesso mantiveram-se praticamente constantes.

É possível relacionar essa dinâmica do acesso aos serviços de saneamento básico às características próprias das políticas adotadas em cada momento. Conforme foi apontado no primeiro capítulo, alguns autores defendem que o Planasa, apesar de ter elevado significativamente o acesso a coleta de esgoto, privilegiou o abastecimento de água, o que justifica o aumento inicial da diferença dos índices de acesso a esse serviço.

Esse privilégio tornou possível, em um segundo momento (década de 1980), o crescimento do acesso a água também nos locais mais necessitados - lembrando que, de uma maneira geral, a tendência de convergência dos índices de acesso a esse serviço é anterior à dos índices de acesso a coleta de esgoto. Outro fator que talvez tenha contribuído para isso foi a entrada dos municípios, em meados dos anos 1980, no esquema de financiamento do Plano.

Deve-se destacar ainda que a análise realizada no item anterior também sugere que, nos dois serviços, o Planasa ampliou quantitativamente o acesso, mas não conseguiu atingir, de maneira significativa, as localidades mais deficitárias, principalmente no caso da coleta de esgoto por rede geral - mesmo com o esquema de subsídios cruzados.

\begin{abstract}
A despeito dos avanços obtidos, principalmente no que se refere aos serviços de abastecimento de água, o modelo estava orientado fundamentalmente para realizar inversões nas áreas urbanas e nos serviços mais rentáveis, deixando de lado os serviços de esgotamento sanitário e os segmentos sociais que não podiam assumir os custos da política tarifária (OLIVEIRA FILHO, 2006, p. 29).
\end{abstract}

Já as políticas posteriores (a partir de 1992), apesar de "desarticuladas e pontuais", focalizaram mais suas ações nas localidades deficitárias, gerando uma maior convergência dos índices de acesso a água e o início de uma convergência também nos índices de acesso a coleta de esgoto. Vale notar que tal fato decorre, em grande parte, da natureza dos recursos direcionados ao setor, com origem em organismos internacionais de assistência, que definem 
critérios de natureza social para os investimentos - tal fato é ilustrado no quadro 1.1, apresentado no primeiro capítulo.

\section{Determinantes do déficit de acesso}

Finalizando o capítulo, a presente seção tem como objetivo apresentar os determinantes do déficit de acesso aos serviços de saneamento básico no Brasil. Ou seja, mostrar os fatores que motivaram os investimentos realizados no setor ao longo do tempo e que, conseqüentemente, geraram as características do déficit de acesso constatadas nas seções anteriores. Além disso, serão discutidas as principais conseqüências dessas características. Antes de entrar nessa discussão, é importante consolidar um pouco mais o argumento a ser utilizado. Para isso, será avaliada a distribuição dos municípios e dos domicílios brasileiros nas regiões geográficas, no Estado de São Paulo e no Distrito Federal.

\subsection{Distribuicão dos municípios e dos domicílios}

O gráfico 2.29 mostra que os municípios de pequeno porte - até vinte mil habitantes eram maioria em 2000, seguidos pelos municípios de médio porte - de vinte a cem mil habitantes - e, por último, pelos municípios de grande porte - mais de cem mil habitantes ${ }^{11}$. Esse padrão se repete em todas as regiões e no Estado de São Paulo. Outros aspectos podem ser destacados:

\footnotetext{
${ }^{11}$ A análise desse item também será realizada por meio de gráficos. Os dados utilizados para a confecção desses gráficos estão no Apêndice - da tabela 41 à tabela 45 .
} 
(i) a proporção de municípios de grande porte em São Paulo era bastante superior a do Brasil e a de todas as regiões e a proporção de municípios de pequeno porte era inferior às demais;

(ii) o Norte e o Nordeste possuíam uma grande proporção de municípios de pequeno e médio portes - em comparação às demais regiões - e, consequentemente, uma pequena proporção de municípios de grande porte e

(iii) no Sul e no Centro-Oeste, mais de $79 \%$ dos municípios eram de pequeno porte e menos de $20 \%$ eram de médio porte.

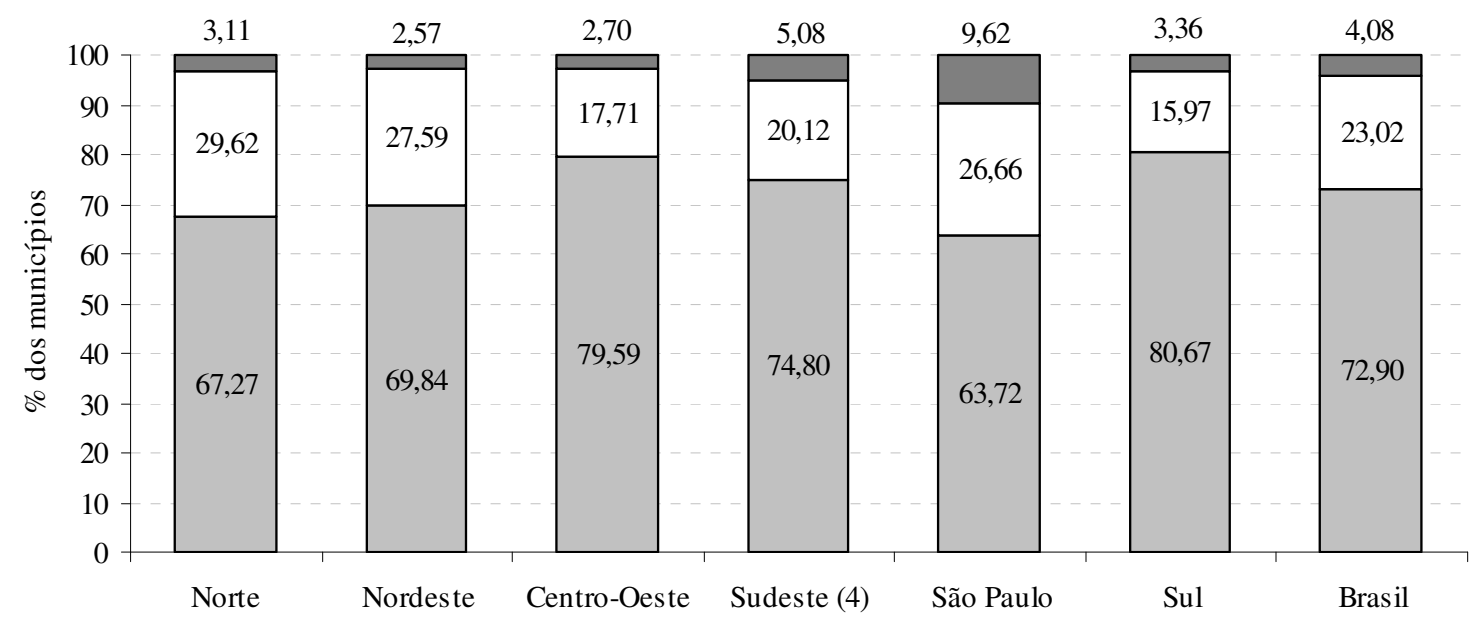

(1)

$\square$ Municípios Pequenos $\square$ Municípios Médios $\square$ Municípios Grandes

Fonte: IBGE, Censo Demográfico de 2000. Elaboração própria.

(1) Centro-Oeste incluindo o Distrito Federal.

(4) Sudeste excluindo São Paulo.

\section{Gráfico 2.29}

Brasil: distribuição dos municípios, segundo o porte, as grandes regiões e o Estado de São Paulo (2000)

Em 2000, 62\% dos municípios brasileiros possuíam a maioria de sua população vivendo na zona urbana, conforme pode ser observado no gráfico 2.30. Naquele ano, as regiões Norte e Nordeste eram as únicas que possuíam mais da metade de seus municípios com taxa de urbanização inferior a 50\%. Por outro lado, a maioria dos municípios das regiões Centro- 
Oeste e Sudeste, assim como do Estado de São Paulo, possuíam taxas de urbanização superiores a 50\% . No Sul, também havia uma maioria de municípios urbanos - maior parte da população vivendo na zona urbana -, mas a diferença em relação aos municípios rurais era menor do que no Centro-Oeste e no Sudeste.

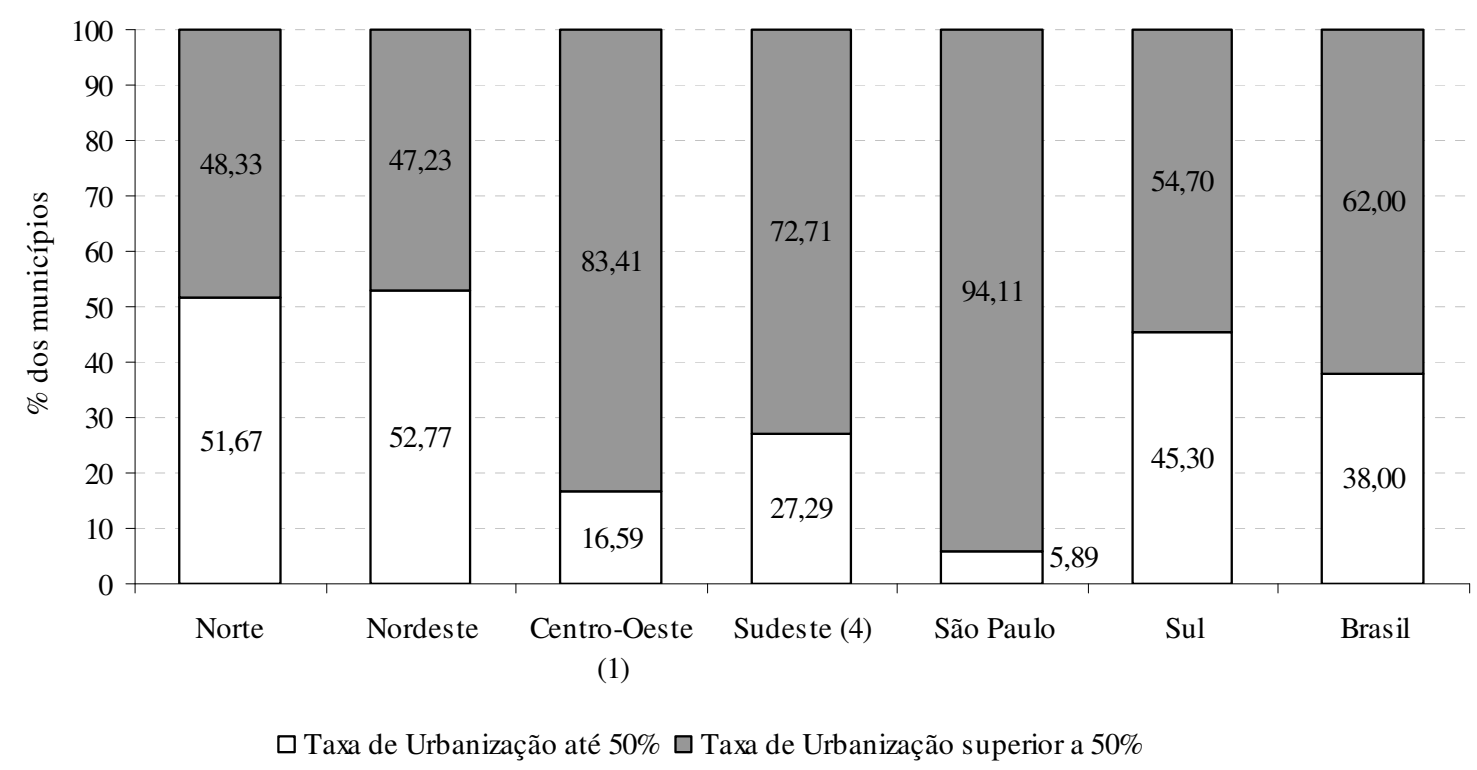

Fonte: IBGE, Censo Demográfico de 2000. Elaboração própria.

(1) Centro-Oeste incluindo o Distrito Federal.

(4) Sudeste excluindo São Paulo.

Gráfico 2.30

Brasil: distribuição dos municípios, segundo a taxa de urbanização, as grandes regiões e o

Estado de São Paulo (2000)

De acordo com o gráfico 2.31, 51\% dos municípios brasileiros possuíam, em 2000, renda per capita mensal superior a um salário mínimo. Ou seja, a renda per capita mensal de uma grande parcela dos municípios (49\%) inferior a um salário mínimo. Essa porcentagem decorria, em grande parte, do elevado número de municípios com renda per capita mensal baixa nas regiões Norte e Nordeste $-75,95 \%$ e 96,03\%, respectivamente. Nas demais regiões, os municípios de renda mais alta eram maioria. Deve-se destacar o Estado de São Paulo, no 
qual aproximadamente $96 \%$ dos municípios tinham renda per capita mensal superior a um salário mínimo.

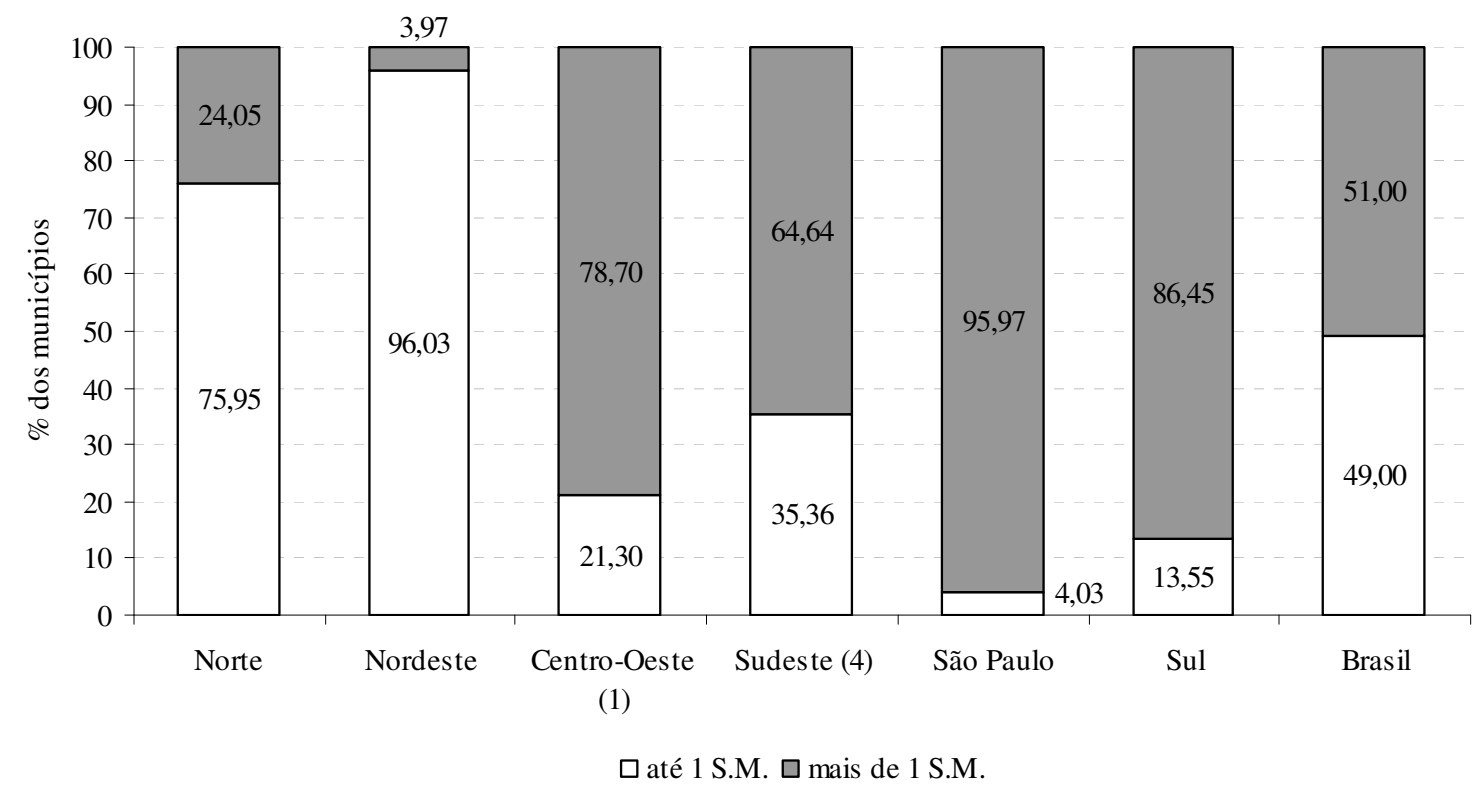

Fonte: IBGE, Censo Demográfico de 2000. Elaboração própria.

(1) Centro-Oeste incluindo o Distrito Federal.

(4) Sudeste excluindo São Paulo.

\section{Gráfico 2.31}

Brasil: distribuição dos municípios, segundo a renda municipal per capita mensal, as grandes regiões e o

Estado de São Paulo (2000)

Por último, é importante analisar a distribuição dos domicílios - não mais dos municípios -, levando em consideração duas variáveis: (i) a localização (zona urbana ou zona rural) e (ii) a renda domiciliar mensal. Em relação à primeira variável, deve-se apontar que, em 2000, a grande maioria dos domicílios brasileiros estava localizado na zona urbana (83,34\%). Nas regiões, no Estado de São Paulo e no Distrito Federal, a superioridade dos domicílios urbanos também existia em maior ou em menor grau. Destacam-se o Norte e o Nordeste, regiões em que mais de um quarto dos domicílios ainda se localizavam na zona 
rural $-27,71 \%$ e $28,49 \%$, respectivamente. Já em São Paulo e no Distrito de São Paulo, menos de $10 \%$ dos domicílios eram rurais. Tais fatos podem ser observados no gráfico 2.32 .

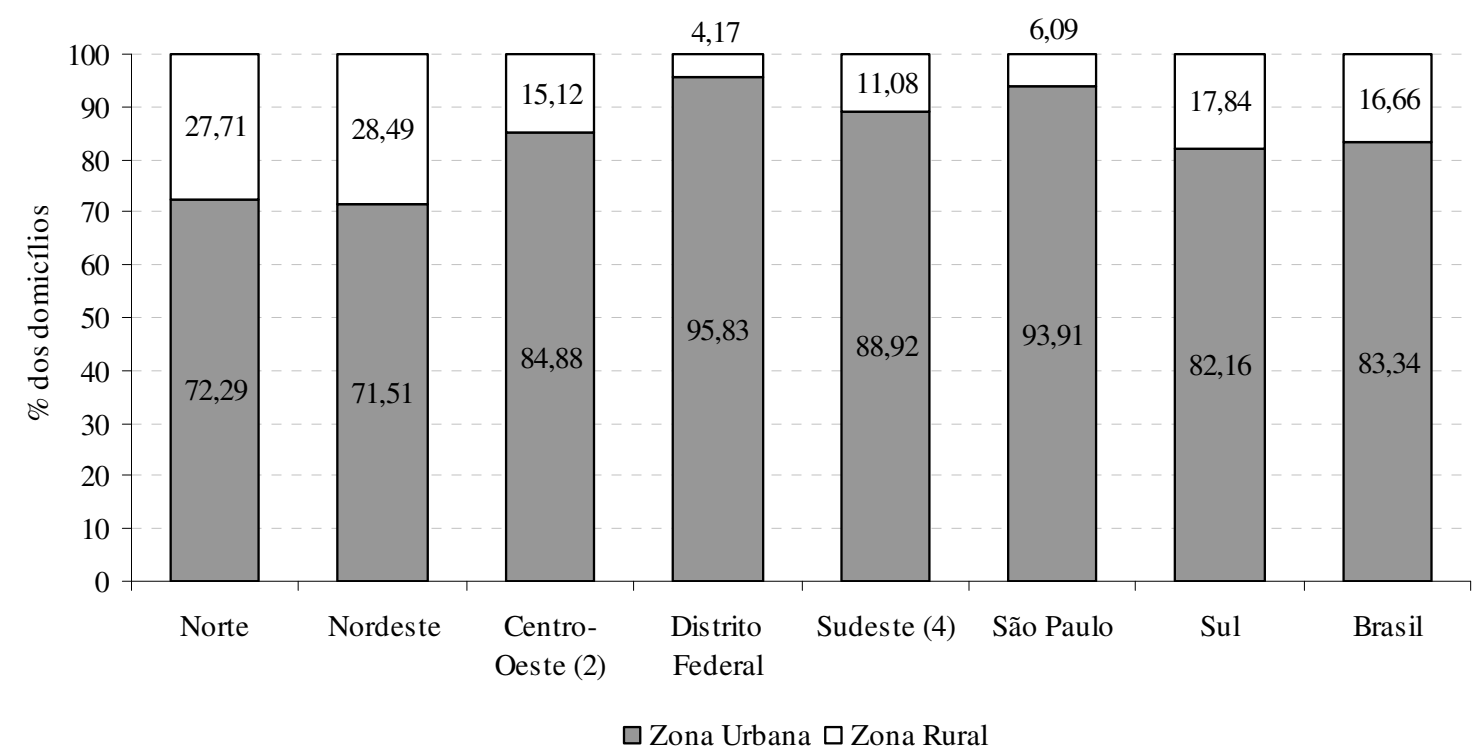

Fonte: IBGE, Censo Demográfico de 2000. Elaboração própria.

(2) Centro-Oeste excluindo o Distrito Federal.

(4) Sudeste excluindo São Paulo.

\section{Gráfico 2.32}

Brasil: distribuição dos domicílios, segundo a localização (zona urbana ou zona rural), as grandes regiões, o Distrito Federal e o Estado de São Paulo (2000)

Finalmente, o gráfico 2.33 mostra a distribuição dos domicílios nas regiões geográficas, no Estado de São Paulo e no Distrito Federal segundo a renda domiciliar mensal. Para a confecção desse gráfico, considerou-se baixa a renda domiciliar mensal de até cinco saláriosmínimos e média ou alta a renda superior a esse valor - seguindo a classificação adotada por Andrade e Lobão (1996).

É possível observar que, no Brasil como um todo, os domicílios de renda baixa eram predominantes em 2000. Essa predominância só não ocorria no Distrito Federal e no Estado de São Paulo. Destacam-se as regiões Norte e Nordeste, nas quais mais de $70 \%$ dos domicílios possuíam renda baixa -73,64\% e $81,54 \%$, respectivamente. 


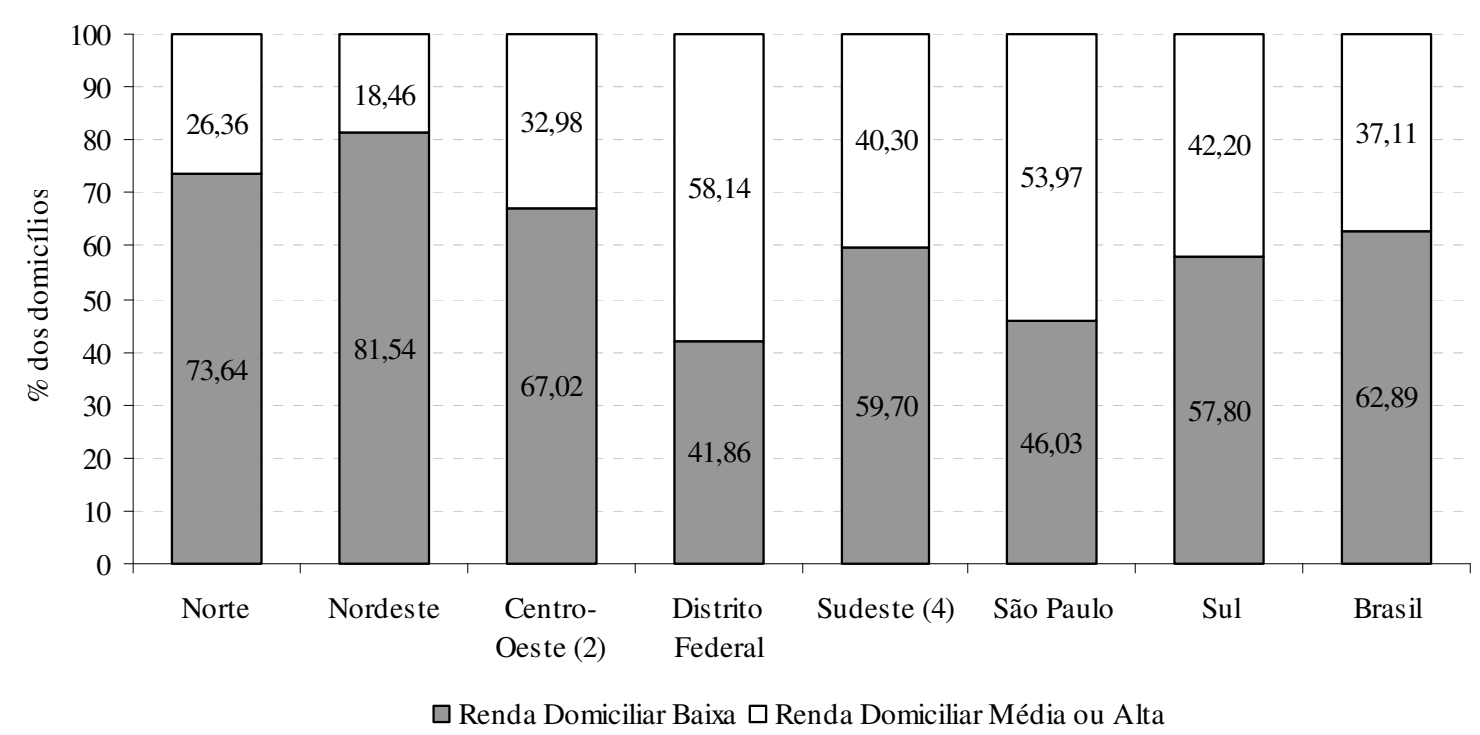

Fonte: IBGE, Censo Demográfico de 2000. Elaboração própria.

(2) Centro-Oeste excluindo o Distrito Federal.

(4) Sudeste excluindo São Paulo.

\section{Gráfico 2.33}

Brasil: distribuição dos domicílios, segundo a renda domiciliar mensal, as grandes regiões, o Distrito Federal e o Estado de São Paulo (2000)

Anteriormente, na tabela 2.1, observou-se que as regiões Norte e Nordeste eram as que possuíam, em 2000, os menores PIBs per capita regionais. Já a tabela 1, do Apêndice, mostra que os cinco piores PIBs per capita estaduais pertenciam a essas duas regiões. No presente item, ficou constatado que estas possuíam, naquele mesmo ano, uma proporção menor do que as demais de municípios grandes, urbanizados e de renda per capita mensal superior a um salário mínimo, assim como uma proporção menor de domicílios urbanos e de domicílios com renda média ou alta. Já as análises realizadas nas primeiras seções, mostraram que seus índices de acesso, por rede geral, aos serviços de saneamento básico eram, em 2000, inferiores aos das demais regiões - no caso da coleta de esgoto, o índice de acesso do Nordeste é um pouco superior ao do Sul (tabela 2.1). Esses fatos sinalizam, portanto, que o 
desequilíbrio inter-regional de acesso aos serviços de saneamento básico está intimamente relacionado à distribuição dos municípios e dos domicílios em cada região.

\subsection{Causas e conseqüências do déficit (consideracões finais)}

Diante das análises realizadas ao longo do capítulo, é possível afirmar que o déficit de acesso aos serviços de saneamento básico no Brasil está intimamente relacionado ao perfil de renda dos consumidores - capacidade de pagamento (tarifas) - e à existência de economias de escala e de densidade no setor - maior facilidade de ofertar os serviços em grandes concentrações populacionais (aglomerações), uma vez que a expansão e a manutenção destes tendem a ter custos reduzidos à medida que aumenta o tamanho da população a ser atingida ${ }^{12}$.

Tal fato sugere que os investimentos realizados, ao longo do tempo, no saneamento básico brasileiro foram motivados mais pela possibilidade de retorno econômico do que pelo grande retorno social que tais serviços podem gerar - apontados na introdução ${ }^{13}$. As características do déficit de acesso aos serviços - analisadas detalhadamente ao longo do capítulo - teriam resultado, portanto, dessa motivação econômica. O grande problema é que essas características acabam restringindo a expansão dos investimentos no setor e, conseqüentemente, a universalização do acesso aos serviços.

Isso porque, conforme foi constatado, as deficiências concentram-se, principalmente, nas localidades em que a provisão dos serviços possui um custo mais elevado - menor escala (menores aglomerações) - e que a capacidade de pagamento pelos serviços (tarifas) é

\footnotetext{
12 O porte municipal, a taxa de urbanização municipal, o tipo de município (capital ou região metropolitana) e a localização do domicílio (urbano ou rural) foram as variáveis utilizadas para captar a relação do déficit com as economias de escala e densidade. Já o PIB per capita (regional e estadual), a renda municipal per capita mensal e a renda domiciliar mensal (total e per capita) foram as variáveis utilizadas para captar as relações do déficit com o perfil de renda dos consumidores.
} 
significativamente mais reduzida. Para ilustrar esse último fato, o gráfico $2.34^{14}$ mostra que a grande maioria dos domicílios sem acesso aos serviços são aqueles que possuem renda domiciliar baixa. Na tabela 2.23, por sua vez, é possível observar que a participação das despesas com água e esgoto aumenta à medida que diminui a renda familiar - ou seja, é difícil para a população mais pobre pagar as tarifas necessárias para a universalização dos serviços.

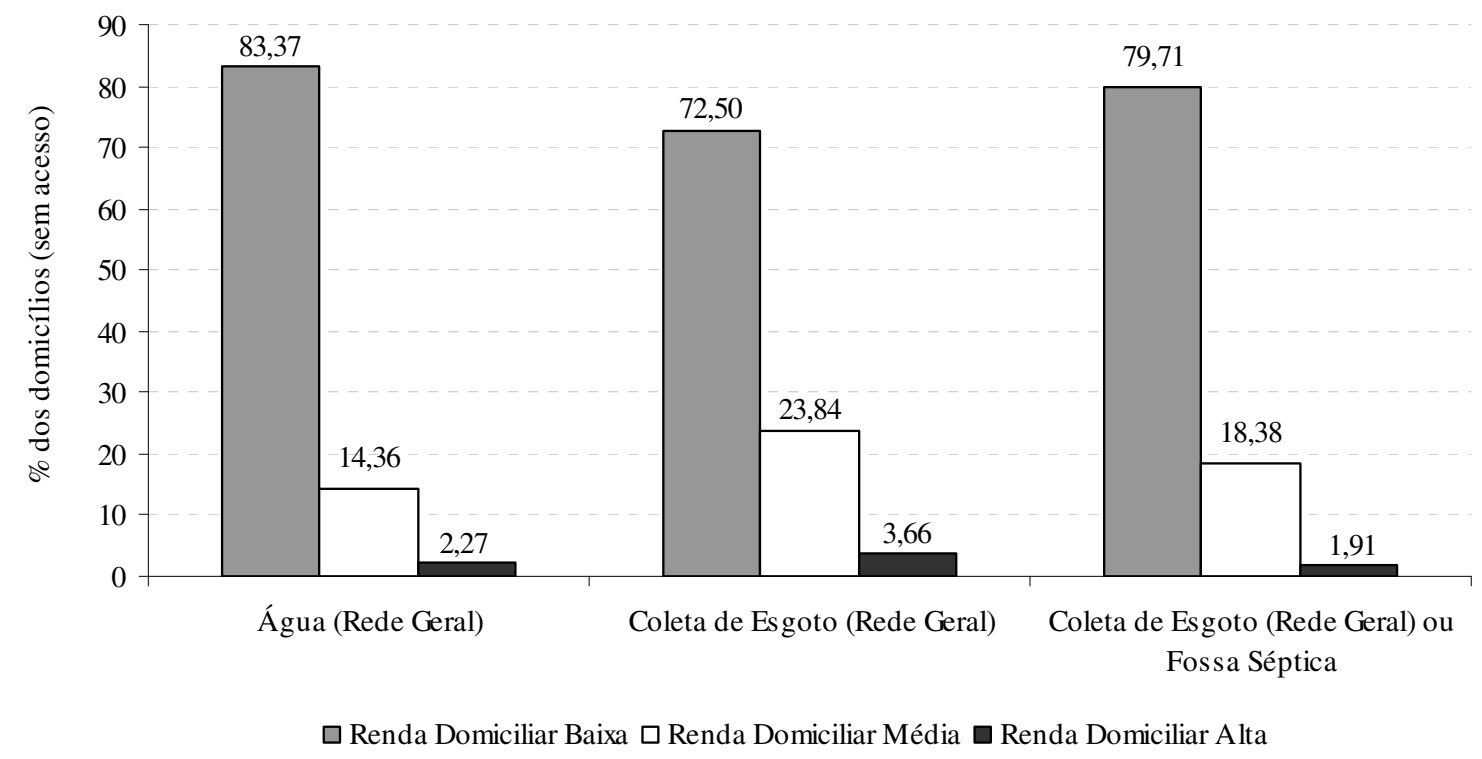

Fonte: IBGE, Censo Demográfico de 2000. Elaboração própria.

Gráfico 2.34

Brasil: distribuição dos domicílios sem acesso a serviços de saneamento básico, segundo a renda domiciliar mensal (2000)

A convergência desses dois fatores - maior custo e menor capacidade de pagamento pelos serviços (tarifas) - faz com que o retorno esperado dos investimentos, pela ótica privada, seja pequeno, desestimulando sua participação, além de também dificultarem os investimentos públicos. Portanto, dificilmente a universalização do acesso será alcançada

\footnotetext{
${ }^{13}$ O que é, no mínimo, "estranho”, pois grande parte dos investimentos no saneamento foi - e ainda é - realizado pelo setor público - conforme ficou claro no primeiro capítulo.
} 
apenas com uma maior participação privada ou uma maior descentralização das decisões e da provisão dos serviços de saneamento básico - processos incentivados após a extinção do Planasa. Ou seja, é necessário que o governo federal continue a atuar ativamente no setor, investindo e planejando - e não apenas fiscalizando e monitorando as ações de outros agentes, como ocorre em alguns setores.

Tabela 2.23

Brasil: participação da despesa com água e esgoto na despesa média mensal familiar, 2002-2003

\begin{tabular}{|c|c|c|c|c|c|c|c|c|c|c|c|}
\hline \multirow[b]{3}{*}{$\begin{array}{c}\text { Despesa com } \\
\text { Água e Esgoto / } \\
\text { Localização }\end{array}$} & \multicolumn{11}{|c|}{$\begin{array}{l}\text { Despesa com água e esgoto / Despesa monetária e não-monetária média mensal } \\
\text { familiar }(\%)\end{array}$} \\
\hline & \multicolumn{11}{|c|}{ Rendimento monetário e não-monetário mensal familiar (em R\$) } \\
\hline & Total & $\begin{array}{l}\text { Até } \\
400\end{array}$ & $\begin{array}{c}\text { Mais } \\
\text { de } \\
400 \text { a } \\
600\end{array}$ & $\begin{array}{c}\begin{array}{c}\text { Mais } \\
\text { de } \\
600 \\
\text { a } \\
1.000\end{array} \\
\end{array}$ & $\begin{array}{c}\text { Mais } \\
\text { de } \\
1.000 \\
\text { a } \\
1.200\end{array}$ & 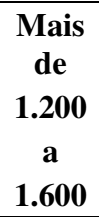 & 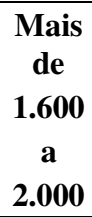 & $\begin{array}{c}\text { Mais } \\
\text { de } \\
2.000 \\
\text { a } \\
3.000\end{array}$ & $\begin{array}{c}\text { Mais } \\
\text { de } \\
3.000 \\
\text { a } \\
4.000\end{array}$ & $\begin{array}{c}\text { Mais } \\
\text { de } \\
4.000 \\
\text { a } \\
6.000\end{array}$ & $\begin{array}{c}\text { Mais } \\
\text { de } \\
6.000\end{array}$ \\
\hline & 0,23 & 0,30 & 0,2 & 0,28 & 0,1 & 0,18 & 0,2 & 0,16 & 0,18 & 0,25 & 0,09 \\
\hline Zona & 0,82 & 1,86 & 1,71 & 1,45 & 1,35 & 1,06 & 0,9 & 0,84 & 0,66 & 0,51 & 0,30 \\
\hline Brasil & $\mathbf{0 , 7 8}$ & $\mathbf{1 , 4 6}$ & 1,41 & 1,27 & 1,22 & 0,98 & $\mathbf{0 , 8 9}$ & $\mathbf{0 , 8 1}$ & 0,64 & 0,51 & $\mathbf{0 , 2 9}$ \\
\hline
\end{tabular}

Fonte: IBGE, Pesquisa de Orçamento Familiar (POF) 2002-2003. Elaboração própria.

Além disso, são necessárias fontes alternativas de recursos, públicos ou não, para reduzir o custo dos investimentos ou para possibilitar o pagamento pelos serviços. Uma outra possibilidade seria o desenho de mecanismos de provisão que possibilitem a geração necessária de escala (e densidade) para a oferta de serviços em localidades que hoje são deficitárias - por exemplo: subsídios, consórcios municipais, regionalizações etc.

14 Os dados para a confecção desse gráfico estão no Apêndice - tabela 46. Considerou-se baixa a renda domiciliar mensal de até cinco salários-mínimos, média a renda superior de cinco a vinte salários-mínimos e alta a renda superior a vinte salários-mínimos - seguindo a classificação adotada por Andrade e Lobão (1996). 


\section{III - PRESTADORES DE SERVIÇOS: DESEMPENHO E INVESTIMENTOS}

O déficit de acesso domiciliar aos serviços de saneamento básico no Brasil, caracterizado no segundo capítulo, poderia ser eliminado até 2020 com um investimento total de aproximadamente $\mathrm{R} \$ 178,4$ bilhões - essa estimativa levou em conta a demanda atual (atendida ou não) e a demanda futura decorrente do crescimento populacional no período, ou seja, a reposição e a expansão dos sistemas. Para atingir tal montante, seria necessário um investimento anual, a partir de 2000 , de $0,45 \%$ do PIB (aproximadamente $\mathrm{R} \$ 6$ bilhões anuais) - considerando a hipótese de crescimento médio do PIB de 4\% ao ano (MCIDADES, 2002).

Diante dessa necessidade, é importante destacar que, após o auge do Planasa (década de 1970), os investimentos em saneamento básico (como parcela do PIB) reduziram-se significativamente, conforme é ilustrado no gráfico 3.1. Tal queda só foi revertida durante a década de 1990. De 1995 a 1998, a parcela do PIB referente aos investimentos no setor elevou-se sensivelmente, mas voltou a se retrair em 1999. A partir de então, manteve-se praticamente constante ao longo do tempo.

Na primeira metade da década de 2000, o investimento médio anual foi de $0,20 \%$ do PIB e em nenhum ano foi alcançada a meta considerada ideal para a universalização do acesso aos serviços. Diante desse fato e do crescimento do PIB, no período, ter sido inferior a $4 \%$ ao ano ${ }^{1}$, a universalização dos serviços até 2020 só seria alcançada com um investimento anual de $0,63 \%$ do PIB (aproximadamente $\mathrm{R} \$ 11$ bilhões anuais) - mantendo a estimativa de um montante total de $\mathrm{R} \$ 178,4$ bilhões (AESBE, 2006). Ou seja, seria necessário um investimento anual superior ao do auge do Planasa - o investimento médio anual na década de 1970 foi de 0,46\% do PIB, conforme pode ser observado no gráfico 3.1 .

\footnotetext{
${ }^{1}$ Segundo dados divulgados pelo IPEA em seu site (www.ipea.gov.br), o crescimento médio anual do PIB no período foi de aproximadamente 2,29\%.
} 


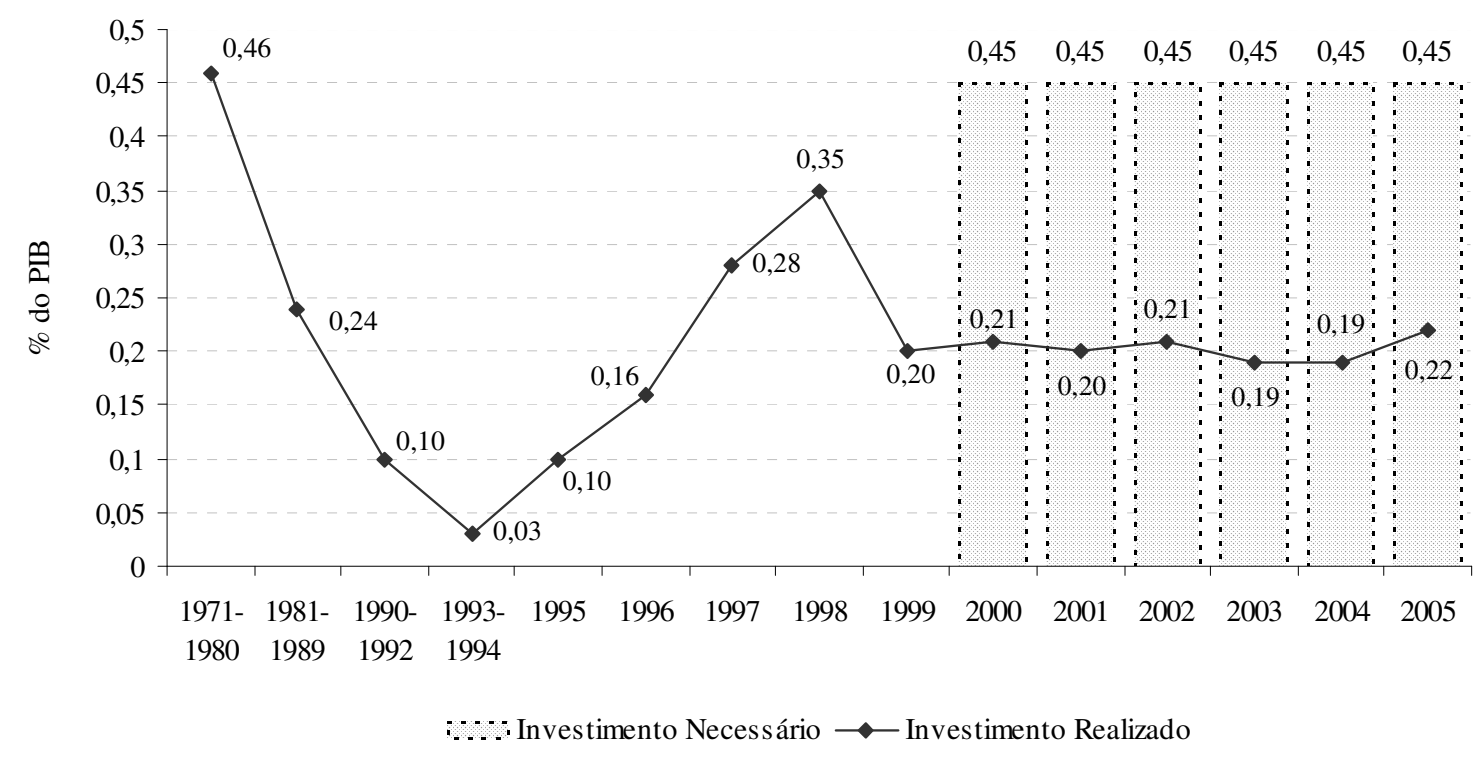

Fonte: Bielchowsky (2002, p. 29), Aesbe (2006) e MCidades (2002). Elaboração própria.

\section{Gráfico 3.1}

Brasil: evolução dos investimentos anuais em saneamento básico (\% do PIB), de 1970 a 2005

Os investimentos realizados no início da década de 2000 não atingiram o nível considerado ideal - e dificilmente atingirão nos próximos anos - em função da existência de uma série de questões institucionais, fiscais e internas ao setor que restringem a sua expansão: (i) problemas institucionais - fragmentação das responsabilidades e dos recursos federais, indefinições regulatórias, irregularidades contratuais -; (ii) poucas fontes alternativas de financiamento -; (iii) baixa eficiência operacional e financeira (fraco desempenho) dos prestadores de serviços; (iv) regras fiscais - metas de superávit, limites de endividamento e contingenciamento de crédito ao setor público e (v) alta tributação².

No primeiro capítulo, os problemas institucionais e de financiamento de longo prazo foram analisados. Além disso, iniciou-se a discussão sobre as regras fiscais. Já no segundo capítulo, foi apontado que o déficit de acesso domiciliar aos serviços de saneamento básico

\footnotetext{
2 "A tributação sobres as empresas de saneamento básico chega a consumir $20 \%$ da receita bruta, fator que contribui para desencorajar investimentos no setor" (EXAME, 2006, p. 118).
} 
também deve ser considerado como entrave à expansão dos investimentos, em função deste estar concentrado nas localidades em que o custo de construção, manutenção e operação dos sistemas é maior e que a capacidade de pagamento (tarifas) dos consumidores é menor. A principal conclusão que se chega por meio das análises realizadas naqueles capítulos é que, tanto os problemas institucionais e de financiamento como as características do déficit de acesso, dificultam as ações públicas e, principalmente, a maior participação privada no setor.

Um outro sério problema do saneamento básico brasileiro é o fraco desempenho - baixa eficiência - apresentado por grande parte dos prestadores de serviços existentes no setor, cuja principal conseqüência é a pequena geração de excedentes para a realização de investimentos. Ou seja, a maioria dos prestadores não tem recursos próprios disponíveis para investir. A opção seria a tomada de empréstimos, mas estes também sofrem restrições, impostas pelo próprio baixo desempenho dos provedores de serviços - que faz com que estes tenham uma pequena capacidade de pagamento - e pelas regras fiscais.

Tais fatores serão discutidos na quarta seção. Nessa seção, assim como nas demais do presente capítulo, o objetivo principal é avaliar qual tipo de prestador de serviços apresenta um melhor desempenho e qual tipo investe. Para isso, serão comparados alguns indicadores operacionais, econômicos, financeiros, administrativos, de atendimento (cobertura) e de investimento. Os dados necessários são disponibilizados pelos Censos Demográficos de 1991 e de 2000 e, principalmente, pelo Sistema Nacional de Informações sobre Saneamento (SNIS) de 2000 a 2004.

Por meio de tal análise, talvez seja possível apontar se uma maior descentralização ou se uma maior desestatização das decisões e da provisão dos serviços seria benéfica para o saneamento básico brasileiro - lembrando que, conforme defendido anteriormente, não será possível um afastamento total do governo federal das decisões e do financiamento do setor, devido às características do déficit de acesso e aos retornos sociais gerados pelos serviços. 


\section{O Sistema Nacional de Informacões sobre Saneamento (SNIS)}

Antes de iniciar as análises, é importante comentar, brevemente, alguns aspectos relacionados ao Sistema Nacional de Informações sobre Saneamento Básico (SNIS), principal fonte dos dados que serão utilizados no presente capítulo ${ }^{3}$. Conforme foi apontado anteriormente, o SNIS surgiu em 1995, no âmbito do Programa de Modernização do Setor Saneamento (PMSS). Atualmente, já conta com dez anos de informações - de 1995 a 2004.

Deve-se destacar, primeiramente, que os prestadores de serviços de saneamento básico são agrupados, no SNIS, segundo três categorias: (i) a abrangência da sua atuação diferencia os prestadores pela quantidade e complexidade dos seus sistemas, em suas dimensões físicas e em sua distribuição espacial/geográfica -; (ii) a natureza jurídicoadministrativa - diferencia os prestadores do ponto de vista da formalidade legal e administrativa a que estão submetidos em todas as dimensões da sua atuação - e (iii) o(s) tipo(s) de serviço(s) de saneamento ofertado(s) aos usuários (somente abastecimento de água, somente esgotamento sanitário ou ambos).

De acordo com a abrangência, os prestadores são classificados da seguinte maneira:

(i) prestador regional: entidade legalmente constituída para administrar serviços e operar sistema(s), atendendo a vários municípios com sistema(s) isolado(s) ou integrado(s) as companhias estaduais de saneamento (CESBs) e a autarquia estadual do Acre;

(ii) prestador microrregional: entidade legalmente constituída para administrar serviços e operar sistema(s) isolado(s) ou integrado(s), atendendo a mais de um município, normalmente adjacentes e agrupados em uma pequena quantidade - os consórcios intermunicipais;

\footnotetext{
${ }^{3}$ Disponibilizado pela Secretaria Nacional de Saneamento Ambiental, vinculada ao Ministério das Cidades.
} 
(iii) prestador local: entidade legalmente constituída para administrar serviços e operar sistema(s) no município em que está sediada, podendo atender, eventualmente e quase sempre em caráter não oficial, a frações de municípios adjacentes - os serviços municipais, públicos ou privados.

Segundo a natureza jurídica, os prestadores são classificados como: (i) entidades de direito público - serviços municipais administrados diretamente, por intermédio de departamentos da prefeitura ou de autarquias - ou (ii) entidades de direito privado - empresas públicas, sociedades de economia mista e empresas privadas.

Considerando conjuntamente a abrangência e a natureza jurídica, o SNIS agrupa seus dados em cinco tipos de prestadores: (i) prestadores de serviços de abrangência regional todos de direito privado, exceto a autarquia do Acre -; (ii) prestadores de serviços de abrangência microrregional - alguns de direito público e alguns de direito privado -; (iii) prestadores de serviços de abrangência local de direito público - departamentos, secretarias e autarquias -; (iv) prestadores de serviços de abrangência local de direito privado - empresas públicas municipais e sociedades de economia mista municipais - e (v) prestadores privados (abrangência local) - empresas privadas.

Os dados [...] são atualizados anualmente, a partir da coleta em uma amostra de prestadores de serviços de abastecimento de água e de esgotamento sanitário em todo o país, que fornece suas informações agregadas (correspondentes à soma dos municípios atendidos) e também desagregadas por município, neste caso para um sub-conjunto dos municípios atendidos (SNIS, 2004, p. 1).

As informações são coletadas por meio de questionários/formulários eletrônicos enviados aos prestadores - foi desenvolvido um aplicativo específico para essa finalidade. Os questionários/formulários utilizados são caracterizados no quadro 3.1. É importante destacar que cada prestador de abrangência regional preenche formulários adicionais, desagregando as informações para uma determinada amostra de municípios pertencentes ao seu universo de operação. Os prestadores de abrangência microrregional, por sua vez, desagregam as informações para todos os municípios nos quais eles ofertam os serviços. 
Quadro 3.1

SNIS: formulários utilizados para a coleta dos dados

\begin{tabular}{|c|c|c|c|}
\hline Formulário & & Descrição & Exemplos de Dados Coletados \\
\hline Formulário de Dados Descritivos & $\rightarrow$ & 30 informações de cadastro & $\begin{array}{l}\rightarrow \text { endereço, telefone, inscrições } \\
\text { fiscais etc. }\end{array}$ \\
\hline Formulário de Dados Gerais & $\rightarrow$ & 16 informações gerais & $\begin{array}{l}\rightarrow \text { situação das concessões, } \\
\text { população, quantidade de } \\
\text { funcionários etc. }\end{array}$ \\
\hline Formulário de Dados de Água & $\rightarrow$ & $\begin{array}{l}23 \text { informações específicas } \\
\text { sobre abastecimento de água }\end{array}$ & $\begin{array}{l}\rightarrow \text { cobertura, quantidades de } \\
\text { ligações e economias, } \\
\text { extensão de rede etc. }\end{array}$ \\
\hline Formulário de Dados de Esgoto & $\rightarrow$ & $\begin{array}{l}9 \text { informações específicas } \\
\text { sobre esgotamento sanitário }\end{array}$ & $\begin{array}{l}\rightarrow \text { cobertura, número de } \\
\text { ligações, volumes, extensão } \\
\text { da rede etc. }\end{array}$ \\
\hline Formulário de Dados Financeiros & $\rightarrow$ & 26 informações financeiras & $\begin{array}{l}\rightarrow \text { Receita, arrecadação, } \\
\text { despesas, custos etc. }\end{array}$ \\
\hline Formulário de Dados de Qualidade & $\rightarrow$ & $\begin{array}{l}21 \text { informações sobre a } \\
\text { qualidade dos serviços }\end{array}$ & $\begin{array}{l}\rightarrow \text { paralisações, intermitências, } \\
\text { reclamações, } \\
\text { extravasamentos etc. }\end{array}$ \\
\hline
\end{tabular}

Fonte: Ministério das Cidades, SNIS (2004). Elaboração própria.

O SNIS calcula, a partir das informações coletadas, uma série de indicadores: (i) trinta e dois índices econômicos, financeiros e administrativos; (ii) vinte e três índices operacionais de água; (iii) oito índices operacionais de esgoto; (iv) nove índices de balanço e (v) treze índices de qualidade. As informações coletadas junto aos prestadores de serviços e os indicadores calculados são divulgados no Diagnóstico dos Serviços de Água e Esgoto, publicação anual elaborada pela Unidade de Gerenciamento do PMSS - “o Diagnóstico apresenta também algumas análises com o objetivo de retratar as características e a situação do abastecimento de água e do esgotamento sanitário no Brasil” (SNIS, 2004, p. 1).

Deve-se destacar que as amostras do SNIS são bastante representativas. No diagnóstico mais recente (2004), por exemplo, a amostra de prestadores de serviços com dados disponibilizados foi formada por trezentos e setenta e quatro entidades, sendo: (i) vinte e cinco de abrangência regional; (ii) sete de abrangência microrregional e (iii) trezentos e quarenta e dois de abrangência local - trezentos e vinte e sete públicos e quinze privados. 
De acordo com a tabela 3.1, no caso do abastecimento de água, os prestadores informantes eram responsáveis pelo serviço em 4.241 municípios e, no caso do esgotamento sanitário, em 1.092 municípios - respectivamente, 76,2\% e 19,6\% do total de municípios brasileiros existentes em 20044. "Municípios que possuem uma população urbana de 137,8 milhões de pessoas, no caso dos serviços de água, e de 106,8 milhões no caso dos serviços de esgotos (respectivamente, 93,2\% e 72,3\% do total do país)" (SNIS, 2004, p. 42).

\section{Tabela 3.1}

SNIS: distribuição dos prestadores de serviços da amostra (2004)

\begin{tabular}{l|c|r|r|r|r}
\hline \multicolumn{2}{c}{ Prestador } & \multicolumn{2}{c}{$\begin{array}{c}\text { População Urbana dos } \\
\text { Municípios Atendidos } \\
\text { (em milhões) }\end{array}$} & \multicolumn{2}{c}{$\begin{array}{c}\text { Quantidade de Municípios } \\
\text { Atendidos }\end{array}$} \\
\hline Abrangência & Quantidade & Água & Esgoto & Água & Esgoto \\
\hline Regional & 25 & 109,3 & 81,0 & 3.887 & 893 \\
Microrregional & 7 & 0,6 & 0,3 & 20 & 11 \\
Local & 342 & 29,5 & 26,9 & 341 & 190 \\
Brasil & $\mathbf{3 7 4}$ & $\mathbf{1 3 9 , 4}$ & $\mathbf{1 0 8 , 3}$ & $\mathbf{4 . 2 4 8}$ & $\mathbf{1 . 0 9 4}$ \\
\hline
\end{tabular}

Fonte: Ministério das Cidades, SNIS (2004, p. 40-1).

A amostra de municípios com informações desagregadas também é bastante representativa. No diagnóstico mais recente (2004), o SNIS disponibilizou informações referentes a 2.693 municípios - aproximadamente 54\% dos municípios brasileiros existentes em 2004. "No total, esses municípios possuem uma população urbana de 128,3 milhões de pessoas (86,7\% do país)" (SNIS, 2004, p. 45). A tabela 3.2 apresenta a distribuição dos municípios da amostra desagregada do SNIS em 2004 - e suas respectivas populações.

Por último, é importante fazer algumas ressalvas em relação ao SNIS:

(i) como todo banco de dados auto-declarativo, ele tende a apresentar uma série de imperfeições decorrentes de erros de preenchimento por parte dos informantes, em

\footnotetext{
${ }^{4}$ A quantidade total de municípios brasileiros atendidos (água e esgoto) pelos diferentes tipos de prestadores é apresentada na tabela 47 do Apêndice.
} 
função de desconhecimento, de falta de entendimento da pergunta ou de qualquer outro motivo;

(ii) sua amostra de prestadores sofre alterações ao longo do tempo, tanto pela incorporação de novos informantes - a cada ano tenta-se manter os informantes anteriores e acrescentar novos informantes -, como pela ausência de informações sobre alguns prestadores em determinados anos - por algum motivo, estes deixam de informar $-\mathrm{e}$

Tabela 3.2

SNIS: distribuição dos municípios da amostra e suas respectivas populações, segundo as grandes regiões geográficas (2004)

\begin{tabular}{l|c|c|c|c|c|c}
\hline \multirow{2}{*}{ Região } & \multicolumn{2}{|c|}{ Quantidade de municípios } & \multicolumn{3}{c}{ População urbana } \\
\cline { 2 - 7 } & $\begin{array}{c}\text { Total } \\
\text { (a) }\end{array}$ & $\begin{array}{c}\text { Amostra do } \\
\text { SNIS } \\
\text { (b) }\end{array}$ & $\begin{array}{c}\text { \% } \\
\text { (b/a) }\end{array}$ & $\begin{array}{c}\text { Total } \\
\text { (em milhões) } \\
\text { (c) }\end{array}$ & $\begin{array}{c}\text { Amostra do SNIS } \\
\text { (em milhões) } \\
\text { (d) }\end{array}$ & $\begin{array}{c}\text { \% } \\
\text { (d/c) }\end{array}$ \\
\hline Norte & 449 & 281 & 62,6 & 10,1 & 9,8 & 97,8 \\
Nordeste & 1.793 & 800 & 44,6 & 35,0 & 29,1 & 83,1 \\
Centro-Oeste & 466 & 252 & 54,1 & 11,1 & 7,9 & 71,4 \\
Sudeste & 1.668 & 710 & 42,6 & 70,0 & 61,9 & 88,5 \\
Sul & 1.188 & 650 & 54,7 & 21,7 & 19,5 & 89,7 \\
Brasil & $\mathbf{5 . 5 6 4}$ & $\mathbf{2 . 6 9 3}$ & $\mathbf{4 8 , 4}$ & $\mathbf{1 4 7 , 9}$ & $\mathbf{1 2 8 , 3}$ & $\mathbf{8 6 , 7}$ \\
\hline
\end{tabular}

Fonte: Apud SNIS (2004, p. 46).

(iii) sua amostra desagregada, além de também variar ao longo do tempo, privilegia os municípios com mais de cem mil habitantes - "a escolha dos maiores serviços justificou-se pelo seu potencial de organização e, conseqüentemente, pela maior possibilidade de retorno das informações coletadas" (SNIS, 2004, p. 6), contudo, pode gerar um sério viés de seleção.

Apesar desses problemas, os dados do SNIS podem ser utilizados para realizar inferências sobre o setor como um todo - desde que sejam tomadas algumas precauções. 
Contribui para isso o fato das amostras do sistema (prestadores e municípios) serem bastante representativas, conforme foi ilustrado nas tabelas apresentadas anteriormente.

\section{Probabilidade de acesso e tipos de prestadores}

Nas primeiras seções do segundo capítulo, foram utilizadas algumas variáveis regionais, estaduais, municipais e domiciliares para caracterizar o déficit de acesso a serviços de saneamento básico no Brasil. Complementando essa análise, o objetivo agora é avaliar se o acesso por rede geral a água e a coleta de esgoto, em 2000, variava significativamente de um prestador para outro. Serão considerados, para isso, quatro tipos de prestadores - adaptando a classificação utilizada pelo SNIS: (i) prestadores regionais, (ii) prestadores microrregionais, (iii) prestadores locais privados e (v) prestadores locais públicos - os prestadores locais de direito público e os prestadores locais de direito privado serão analisados conjuntamente.

Conforme foi apontado anteriormente, o SNIS disponibiliza informações detalhadas apenas para uma amostra de municípios. Conseqüentemente, não foi possível identificar o tipo de prestador responsável pelos serviços em cada um dos municípios brasileiros existentes em 2000. Referentes a esse ano, são disponibilizados dados para 1.025 municípios, dos quais: (i) 826 com serviços providos por prestadores regionais (vinte e cinco companhias estaduais e uma autarquia estadual); (ii) cento e setenta por prestadores locais públicos; (iii) dezessete por prestadores locais privados e (iv) doze por prestadores microrregionais. Trata-se de uma amostra bastante representativa - correspondia a aproximadamente $19 \%$ dos municípios existentes naquele momento -, a partir da qual é possível fazer algumas inferências.

De acordo com o gráfico 3.2, a proporção de domicílios com acesso a abastecimento de água por rede geral era maior, em 2000, no conjunto dos municípios atendidos por prestadores 
locais públicos. O índice de acesso a água dos prestadores regionais era o segundo maior, seguido de perto pelo índice dos prestadores locais privados e, por último, pelo índice dos prestadores microrregionais - bastante inferior aos demais. No caso da coleta de esgoto por rede geral, os locais privados possuíam o melhor índice de acesso, seguidos pelos locais públicos, pelos locais regionais e, por último, pelos microrregionais.

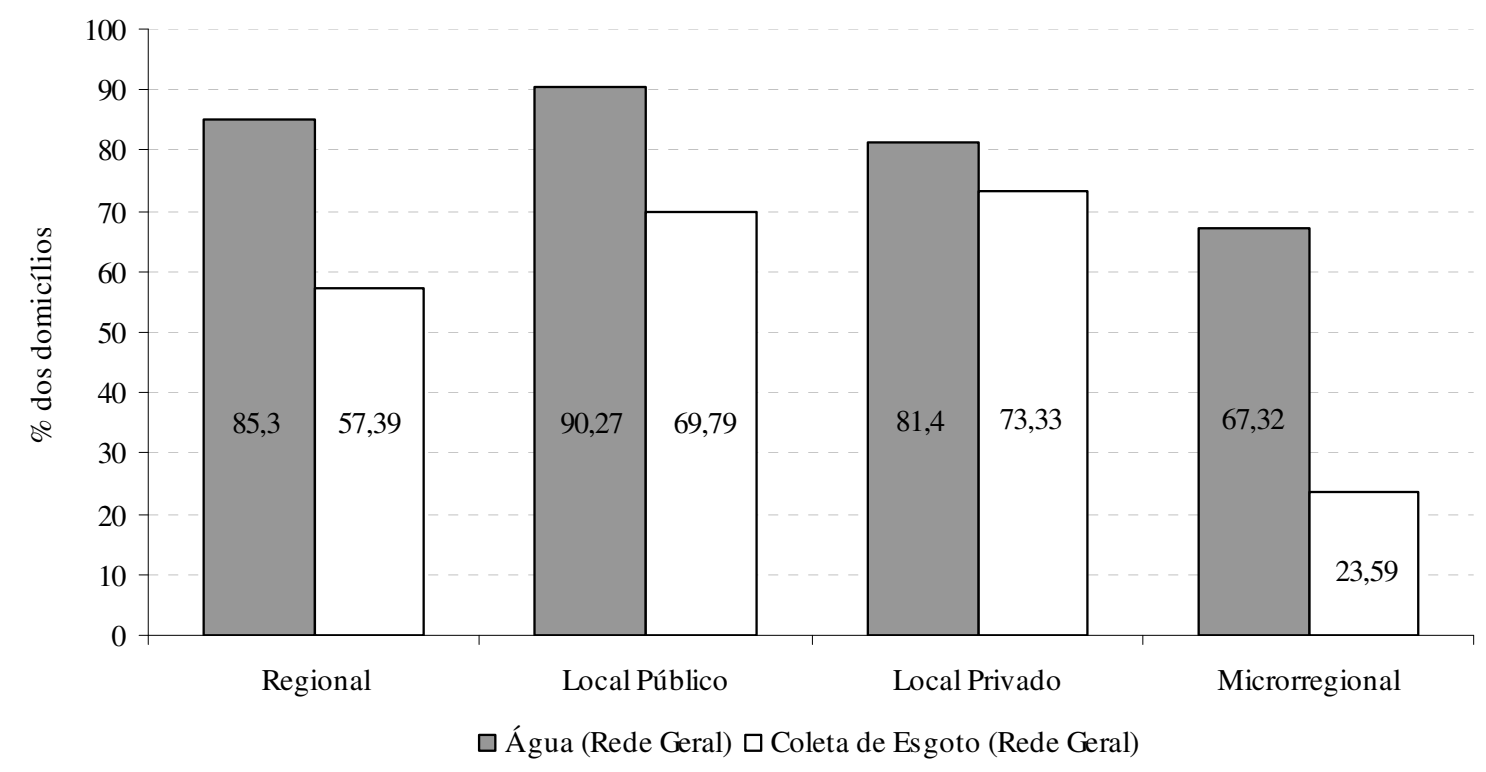

Fonte: IBGE e Ministério das Cidades, Censo Demográfico de 2000 e SNIS (2000). Elaboração própria.

\section{Gráfico 3.2}

Brasil: proporção de domicílios com acesso a serviços de saneamento básico por rede geral, segundo o tipo de prestador (2000)

Tais padrões de diferença da cobertura dos serviços entre os grupos considerados não se repetiam em todas as regiões, conforme pode ser observado na tabela 3.3. Dessa forma, é difícil apontar, apenas por meio de análises descritivas, em qual tipo de prestador a probabilidade de acesso domiciliar aos serviços de saneamento básico era maior em 2000. Justifica-se, assim, a estimação - método Probit - de modelos semelhantes aos da segunda seção do capítulo anterior, incorporando os tipos de prestadores como variáveis explicativas. 


\section{Tabela 3.3}

Brasil: proporção de domicílios com acesso a serviços de saneamento básico, segundo o tipo de prestador, as grandes regiões e o Estado de São Paulo (2000)

\begin{tabular}{|c|c|c|c|c|c|c|c|c|}
\hline $\begin{array}{c}\text { Região / } \\
\text { Tipo de Prestador }\end{array}$ & $\mathbf{N}$ & NE & $\mathrm{CO}$ & SE (3) & SE (4) & $\begin{array}{c}\text { São } \\
\text { Paulo }\end{array}$ & $\mathbf{S}$ & Brasil \\
\hline \multicolumn{9}{|c|}{ Água - Rede Geral (\% dos domicílios) } \\
\hline Regional & 50,74 & 81,17 & 80,49 & 91,70 & 88,22 & 95,72 & 88,31 & $\mathbf{8 5 , 3 0}$ \\
\hline Local Público & 54,23 & 71,69 & 84,72 & 94,57 & 91,89 & 95,48 & 92,64 & 90,27 \\
\hline Local Privado & $*$ & 91,39 & 73,34 & 80,36 & 74,00 & 96,74 & 88,56 & 81,40 \\
\hline Microrregional & $*$ & $*$ & $*$ & 64,19 & 64,19 & $*$ & 80,24 & 67,32 \\
\hline Total & 48,24 & 66,73 & 73,34 & 88,45 & 83,12 & $\mathbf{9 3 , 5 1}$ & 80,11 & $\mathbf{7 7 , 9 9}$ \\
\hline \multicolumn{9}{|c|}{ Esgoto - Rede Geral (\% dos domicílios) } \\
\hline Regional & 9,74 & 41,57 & 59,08 & 74,54 & 69,13 & 80,71 & 40,79 & $\mathbf{5 7 , 3 9}$ \\
\hline Local Público & 20,68 & 26,91 & 32,49 & 87,76 & 85,82 & 88,42 & 41,18 & 69,79 \\
\hline Local Privado & $*$ & 80,50 & 0,59 & 73,26 & 66,00 & 91,83 & 71,64 & 73,33 \\
\hline Microrregional & $*$ & $*$ & $*$ & 28,61 & 28,61 & $*$ & 3,22 & 23,59 \\
\hline Total & 11,36 & 33,06 & 35,10 & 74,98 & 67,13 & 82,27 & 30,69 & 51,73 \\
\hline
\end{tabular}

Fonte: IBGE, Censo Demográfico de 2000. Elaboração própria.

(3) Sudeste incluindo São Paulo.

(4) Sudeste excluindo São Paulo.

* Não há prestadores desse tipo na região ou no estado.

Os modelos a serem estimados possuem a seguinte formulação básica:

$\Rightarrow \quad y=\alpha+\beta_{1}$ renda domiciliar mensal $+\beta_{2}$ renda domiciliar per capita mensal $+\beta_{3}$ população do município (porte) $+\beta_{4}$ taxa de urbanização do município $+\beta_{5}$ renda municipal per capita mensal $+\beta_{6}$ localização do domicílio (urbano ou rural) $+\beta_{7}$ Norte $+\beta_{8}$ Nordeste $+\beta_{9}$ Centro-Oeste (2) $+\beta_{10}$ Distrito Federal $+\beta_{11}$ Sudeste (4) + $\beta_{12}$ Sul $+\beta_{13}$ local público $+\beta_{14}$ local privado $+\beta_{15}$ microrregional,

em que:

(i) $\quad$ : variáveis dependentes binárias, assumindo o valor um se o domicílio possuir acesso aos serviços - abastecimento de água por rede geral e coleta de esgoto por rede geral e zero caso contrário;

(ii) $\underline{\alpha}$ : constante; 
(iii) $\quad$ 's: parâmetros que refletem o impacto de alterações das variáveis explicativas sobre a probabilidade do domicílio possuir acesso aos serviços;

(iv) local público: dummy representativa que assume o valor um se o serviço no domicílio for ofertado por um prestador local público e zero caso contrário;

(v) local privado: dummy representativa que assume o valor um se o serviço no domicílio for ofertado por um prestador local privado e zero caso contrário e

(vi) microrregional: dummy representativa que assume o valor um se o serviço no domicílio for ofertado por um prestador microrregional e zero caso contrário portanto, serão utilizados como base de comparação (controle) os domicílios nos quais o serviço é ofertado por um prestador regional.

As demais variáveis foram apresentadas no segundo capítulo. Em relação aos coeficientes a serem estimados, deve-se apontar que são esperados sinais semelhantes aos obtidos no segundo capítulo para as variáveis explicativas já utilizadas naquele momento. No caso das novas variáveis explicativas - dummies tipos de prestadores -, é difícil prever os sinais dos coeficientes a serem estimados, pois a análise descritiva mostrou que não existia, em 2000, uma tendência clara de diferença do acesso aos serviços entre os prestadores.

\section{$\underline{2.1 \text { A amostra }}$}

Conforme apontado anteriormente, foi possível identificar o tipo de prestador responsável pelos serviços apenas para 1.025 municípios. Esses municípios possuíam mais de três milhões de domicílios pertencentes à amostra do Censo Demográfico de $2000-57 \%$ do total. Diante de um número tão elevado de observações, optou-se por utilizar, assim como no segundo capítulo, uma amostra aleatória menor, com $10 \%$ das observações - ou seja, 
aproximadamente trezentos mil domicílios. De acordo com a tabela 3.4, essa simplificação pouco alterou a distribuição dos domicílios (com e sem acesso) entre os diferentes tipos de prestadores, assim como a proporção de domicílios com acesso aos serviços.

Tabela 3.4

Brasil: distribuição dos domicílios (Censo e amostra), segundo o tipo de prestador e o acesso a serviços de saneamento básico por rede geral

\begin{tabular}{l|c|c|c}
\hline \multicolumn{1}{c|}{$\begin{array}{c}\text { Domicílio e Serviço / } \\
\text { Prestador }\end{array}$} & $\begin{array}{c}\text { Domicílios } \\
(\% \text { total })\end{array}$ & $\begin{array}{c}\text { Água - Rede Geral } \\
\text { \% dos domicílios) }\end{array}$ & $\begin{array}{c}\text { Esgoto - Rede Geral } \\
\text { (\% dos domicílios) }\end{array}$ \\
\hline Regional & Domicílios do Censo (que foram identificados os prestadores) & \\
Local Público & 77,61 & 85,30 & 57,39 \\
Local Privado & 19,33 & 90,27 & 69,79 \\
Microrregional & 2,70 & 81,40 & 73,33 \\
Total & 0,37 & 67,32 & 23,59 \\
& $\mathbf{1 0 0 , 0 0}$ & $\mathbf{8 6 , 0 9}$ & $\mathbf{6 0 , 1 1}$ \\
Regional & Domicílios da Amostra & \\
Local Público & 77,55 & 85,41 & 57,48 \\
Local Privado & 19,42 & 90,15 & 69,72 \\
Microrregional & 2,67 & 81,72 & 73,74 \\
Total & 0,37 & 69,26 & 24,45 \\
\hline
\end{tabular}

Fontes: IBGE e Ministério das Cidades, Censo Demográfico de 2000 e SNIS (2000). Elaboração própria.

A tabela 3.5, por sua vez, apresenta as estatísticas descritivas das variáveis explicativas contínuas utilizadas nas estimações (amostra). A análise dessa tabela é importante, pois o cálculo dos efeitos marginais levará em conta a média das variáveis - grosso modo, as características do "domicílio médio" da amostra. Dessa forma, é possível apontar alguns aspectos relevantes:

(i) população do município: média da amostra próxima de dois milhões de habitantes devido ao maior número de domicílios em municípios mais populosos - e desviopadrão bastante elevado (3.186.820);

(ii) taxa de urbanização: média igual a 0,91 e desvio-padrão igual a 0,16 - é interessante observar que a amostra tem pelo menos um município com quase toda população 
morando na zona rural (mínimo próximo de zero) e pelo menos um município com toda população morando na zona urbana (máximo igual a um);

Tabela 3.5

Estatísticas descritivas das variáveis contínuas utilizadas nas estimações e comparação entre as amostras

\begin{tabular}{lccccc}
\hline \multicolumn{1}{c}{ Variáveis } & Média & Desvio-Padrão & Mínimo & Máximo \\
\hline \multirow{2}{*}{ População do Município } & $1.841 .477,00$ & $3.186 .820,00$ & 958,00 & $10.434 .252,00$ \\
& $(1.259 .482,89)$ & $(2.740 .688,40)$ & $(795,00)$ & $(10.434 .252,00)$ \\
Taxa de Urbanização Municipal & 0,91 & 0,16 & 0,02 & 1,00 \\
& $(0,83)$ & $(0,22)$ & $(0,00)$ & $(1,00)$ \\
Renda Municipal per capita Mensal (R\$) & 368,15 & 173,98 & 38,32 & 876,16 \\
& $(310,05)$ & $(176,43)$ & $(4,54)$ & $(1.672,90)$ \\
Renda Domiciliar Mensal (R\$) & $1.310,93$ & $4.072,51$ & 0,00 & $901.600,00$ \\
& $(1.119,75)$ & $(3.256,97)$ & $(0,00)$ & $(619.750,00)$ \\
Renda Domiciliar per capita Mensal (R\$) & 436,02 & $1.332,79$ & 0,00 & $300.533,30$ \\
& $(371,55)$ & $(1.221,63)$ & $(0,00)$ & $(229.395,00)$ \\
\hline
\end{tabular}

Obs.: Estatísticas da amostra do segundo capítulo entre parênteses - apresentadas, anteriormente, na tabela 2.15.

(iii) renda municipal per capita mensal: média igual a $\mathrm{R} \$ 368,15$ - aproximadamente 2,44 salários-mínimos de 2000 (R\$ 151,00) - e desvio-padrão igual a R \$173,98, sendo a renda mínima igual a $\mathrm{R} \$ 38,32$ (0,25 salário mínimo de 2000) e a máxima igual a $\mathrm{R} \$$ 876,16 (5,80 salários mínimos de 2000);

(iv) renda domiciliar mensal: média da amostra é de $\mathrm{R} \$ 1.310,93$ - 8,68 salários-mínimos de 2000. A renda altera-se bastante de domicílio para domicílio, o que leva a um desvio-padrão elevado ( $\mathrm{R}$ 4.072,51), sendo o valor mínimo igual a zero e o máximo igual a $\mathrm{R} \$ 901.6000,00$;

(v) renda domiciliar per capita mensal: média igual a $\mathrm{R} \$ 436,02,55$ - 2,89 saláriosmínimos de 2000 - e desvio-padrão elevado ( $\mathrm{R}$ \$ 1.221,63), sendo o valor mínimo igual a zero e o máximo igual a $\mathrm{R} \$ 300.533,30$.

Por meio da tabela 3.5, também é possível comparar a amostra utilizada no segundo capítulo (tabela 2.15) e a amostra atual. Observa-se que as médias das variáveis explicativas contínuas na amostra atual são maiores do que as médias na amostra do segundo capítulo. Tal 
fato decorre do privilégio dado pelo SNIS aos municípios com mais de cem mil habitantes fato comentado anteriormente. Esse privilégio não prejudicará a análise dos resultados das estimações, uma vez que o interesse é apenas comparar em qual tipo de prestador a probabilidade de acesso aos serviços de saneamento básico era maior em 2000.

\section{$\underline{2.2}$ Os resultados}

Na tabela 3.6, são apresentados os resultados das estimações com o acesso a abastecimento de água por rede geral como variável dependente. Deve-se destacar, primeiramente, que todos os coeficientes estimados são significativos e que a hipótese de todos eles serem iguais a zero deve ser rejeitada - o que pode ser verificado nas estatísticas do teste LR com distribuição $\aleph^{2}$ (chi-quadrado).

Os sinais dos coeficientes e dos efeitos marginais das variáveis explicativas que também foram utilizadas no segundo capítulo são iguais aos obtidos naquele momento - ou seja, confirma-se, mais uma vez, as relações apontadas anteriormente. Já a análise dos sinais dos coeficientes e dos efeitos marginais das dummies tipos de prestadores - local público (positivo), local privado (negativo) e microrregional (negativo) - mostra que, em 2000:

(i) um domicílio atendido por um prestador local público tinha probabilidade maior de acesso ao serviço do que um domicílio atendido por um regional;

(ii) um domicílio atendido por um prestador local privado tinha probabilidade menor de acesso ao serviço do que um domicílio atendido por um regional e

(iii) um domicílio atendido por um prestador microrregional também tinha probabilidade menor de acesso ao serviço do que um domicílio atendido por um regional. 
Tabela 3.6

Resultados das estimações com dummies tipos de prestadores: variável dependente acesso a

abastecimento de água por rede geral (2000)

\begin{tabular}{|c|c|c|c|c|c|c|}
\hline $\begin{array}{c}\text { Abastecimento de } \\
\text { Água por Rede Geral }\end{array}$ & Coeficiente & $\begin{array}{c}\text { Efeito } \\
\text { Marginal }\end{array}$ & Coeficiente & $\begin{array}{c}\text { Efeito } \\
\text { Marginal }\end{array}$ & Coeficiente & $\begin{array}{c}\text { Efeito } \\
\text { Marginal } \\
\end{array}$ \\
\hline $\begin{array}{l}\text { Ln (Renda Domiciliar } \\
\text { Mensal) }\end{array}$ & $\begin{array}{l}0,0891 * \\
(0,0067)\end{array}$ & $\begin{array}{c}0,0147 * \\
(0,0012) \\
{[0,0966]}\end{array}$ & $\begin{array}{l}0,0976 * \\
(0,0069)\end{array}$ & $\begin{array}{l}0,0165 * \\
(0,0012) \\
{[0,1081]}\end{array}$ & $\begin{array}{l}0,0902 * \\
(0,0070)\end{array}$ & $\begin{array}{l}0,0149 * \\
(0,0012) \\
{[0,0981]}\end{array}$ \\
\hline $\begin{array}{l}\text { Ln (Renda Domiciliar } \\
\text { per capita } \text { Mensal) }\end{array}$ & $\begin{array}{l}0,0863 * \\
(0,0066)\end{array}$ & $\begin{array}{l}0,0143 * \\
(0,0011) \\
{[0,0767]}\end{array}$ & $\begin{array}{l}0,1036 * \\
(0,0066)\end{array}$ & $\begin{array}{l}0,0175 * \\
(0,0011) \\
{[0,0940]}\end{array}$ & $\begin{array}{l}0,0702 * \\
(0,0067)\end{array}$ & $\begin{array}{l}0,0116 * \\
(0,0011) \\
{[0,0626]}\end{array}$ \\
\hline $\begin{array}{l}\text { Ln (População do } \\
\text { Município) }\end{array}$ & $\begin{array}{l}0,0999 * \\
(0,0022)\end{array}$ & $\begin{array}{l}0,0165 * \\
(0,0004) \\
{[0,2131]}\end{array}$ & & & & \\
\hline $\begin{array}{c}\text { Taxa de Urbanização } \\
\text { do Município }\end{array}$ & & & $\begin{array}{l}0,1481 * \\
(0,0252)\end{array}$ & $\begin{array}{l}0,0250 * \\
(0,0043)\end{array}$ & & \\
\hline $\begin{array}{l}\text { Ln (Renda Municipal } \\
\text { per capita Mensal) }\end{array}$ & & & & & $\begin{array}{l}0,4086 * \\
(0,0085)\end{array}$ & $\begin{array}{l}0,0676 * \\
(0,0014) \\
{[0,3912]}\end{array}$ \\
\hline $\begin{array}{l}\text { Localização do } \\
\text { Domicílio }\end{array}$ & $\begin{array}{c}-1,8748 * \\
(0,0107)\end{array}$ & $\begin{array}{c}-0,5831 * \\
(0,0038)\end{array}$ & $\begin{array}{c}-1,9551 * \\
(0,0115)\end{array}$ & $\begin{array}{c}-0,6144 * \\
(0,0039)\end{array}$ & $\begin{array}{c}-1,8789 * \\
(0,0106)\end{array}$ & $\begin{array}{c}-0,5851 * \\
(0,0037)\end{array}$ \\
\hline Dummy Norte & $\begin{array}{c}-1,2851 * \\
(0,0148)\end{array}$ & $\begin{array}{c}-0,3722 * \\
(0,0055)\end{array}$ & $\begin{array}{c}-1,4476 * \\
(0,0148)\end{array}$ & $\begin{array}{c}-0,4384 * \\
(0,0055)\end{array}$ & $\begin{array}{l}-1,1566 * \\
(0,0156)\end{array}$ & $\begin{array}{c}-0,3242 * \\
(0,0057)\end{array}$ \\
\hline Dummy Nordeste & $\begin{array}{l}-0,4478 * \\
(0,0121)\end{array}$ & $\begin{array}{c}-0,0875 * \\
(0,0027)\end{array}$ & $\begin{array}{c}-0,5315 * \\
(0,0148)\end{array}$ & $\begin{array}{c}-0,1090 * \\
(0,0029)\end{array}$ & $\begin{array}{l}-0,2188 * \\
(0,0137)\end{array}$ & $\begin{array}{c}-0,0394 * \\
(0,0027)\end{array}$ \\
\hline $\begin{array}{c}\text { Dummy } \\
\text { Centro-Oeste (2) }\end{array}$ & $\begin{array}{l}-0,8325 * \\
(0,0169)\end{array}$ & $\begin{array}{c}-0,2114 * \\
(0,0056)\end{array}$ & $\begin{array}{c}-0,9648 * \\
(0,0166)\end{array}$ & $\begin{array}{c}-0,2610 * \\
(0,0059)\end{array}$ & $\begin{array}{c}-0,8230 * \\
(0,0169)\end{array}$ & $\begin{array}{c}-0,2086 * \\
(0,0056)\end{array}$ \\
\hline $\begin{array}{c}\text { Dummy Distrito } \\
\text { Federal }\end{array}$ & $\begin{array}{l}-0,6127 * \\
(0,0272)\end{array}$ & $\begin{array}{c}-0,1434 * \\
(0,0082)\end{array}$ & $\begin{array}{c}-0,5274 * \\
(0,0272)\end{array}$ & $\begin{array}{c}-0,1203 * \\
(0,0078)\end{array}$ & $\begin{array}{l}-0,6471 * \\
(0,0271)\end{array}$ & $\begin{array}{c}-0,1543 * \\
(0,0084)\end{array}$ \\
\hline Dummy Sudeste (4) & $\begin{array}{l}-0,4599 * \\
(0,0116)\end{array}$ & $\begin{array}{c}-0,0878 * \\
(0,0025)\end{array}$ & $\begin{array}{c}-0,5258 * \\
(0,0115)\end{array}$ & $\begin{array}{c}-0,1044 * \\
(0,0026)\end{array}$ & $\begin{array}{c}-0,3996 * \\
(0,0118)\end{array}$ & $\begin{array}{c}-0,0751 * \\
(0,0025)\end{array}$ \\
\hline Dummy Sul & $\begin{array}{c}-0,1996 * \\
(0,0138)\end{array}$ & $\begin{array}{c}-0,0362 * \\
(0,0027)\end{array}$ & $\begin{array}{c}-0,3440 * \\
(0,0134)\end{array}$ & $\begin{array}{c}-0,0677 * \\
(0,0030)\end{array}$ & $\begin{array}{c}-0,2668 * \\
(0,0135)\end{array}$ & $\begin{array}{c}-0,0499 * \\
(0,0028)\end{array}$ \\
\hline Dummy Local Público & $\begin{array}{l}0,2193 * \\
(0,0102)\end{array}$ & $\begin{array}{l}0,0331 * \\
(0,0014)\end{array}$ & $\begin{array}{l}0,1632 * \\
(0,0101)\end{array}$ & $\begin{array}{l}0,0258 * \\
(0,0015)\end{array}$ & $\begin{array}{l}0,1703 * \\
(0,0101)\end{array}$ & $\begin{array}{l}0,0263 * \\
(0,0015)\end{array}$ \\
\hline Dummy Local Privado & $\begin{array}{c}-0,3634 * \\
(0,0187)\end{array}$ & $\begin{array}{c}-0,0744 * \\
(0,0046)\end{array}$ & $\begin{array}{c}-0,4191 * \\
(0,0188)\end{array}$ & $\begin{array}{c}-0,0900 * \\
(0,0049)\end{array}$ & $\begin{array}{c}-0,4565 * \\
(0,0187)\end{array}$ & $\begin{array}{c}-0,0985 * \\
(0,0050)\end{array}$ \\
\hline Dummy Microrregional & $\begin{array}{l}-0,2753 * \\
(0,0430)\end{array}$ & $\begin{array}{c}-0,0541 * \\
(0,0098)\end{array}$ & $\begin{array}{c}-0,4565 * \\
(0,0431)\end{array}$ & $\begin{array}{c}-0,1011 * \\
(0,0119)\end{array}$ & $\begin{array}{c}-0,4333 * \\
(0,0427)\end{array}$ & $\begin{array}{c}-0,0934 * \\
(0,0114)\end{array}$ \\
\hline Constante & $\begin{array}{c}-0,5251 * \\
(0,0369)\end{array}$ & & $\begin{array}{l}0,5538 * \\
(0,0341)\end{array}$ & & $\begin{array}{c}-1,5680 * \\
(0,0534)\end{array}$ & \\
\hline $\mathbf{y}=\operatorname{Pr}(\mathbf{y})($ predict $)$ & \multicolumn{2}{|c|}{0,907993} & \multicolumn{2}{|c|}{0,905320} & \multicolumn{2}{|c|}{0,907622} \\
\hline LR chi²(10) & \multicolumn{2}{|c|}{$78.205,40$} & \multicolumn{2}{|c|}{$76.173,98$} & \multicolumn{2}{|c|}{$78.474,18$} \\
\hline Prob $>$ chi $^{2}$ & \multicolumn{2}{|c|}{0,0000} & \multicolumn{2}{|c|}{0,0000} & \multicolumn{2}{|c|}{0,0000} \\
\hline Pseudo-R $^{2}$ & \multicolumn{2}{|c|}{0,3298} & \multicolumn{2}{|c|}{0,3212} & \multicolumn{2}{|c|}{0,3310} \\
\hline
\end{tabular}

Obs.: Erro-padrão entre parênteses e elasticidades entre colchetes, calculadas na forma d(y)/d(lnx).

* Significativo a $1 \%$.

Ou seja, a probabilidade de acesso era maior nos prestadores locais públicos. Analisando a magnitude dos efeitos marginais, verifica-se que, na seqüência, vinham os 
regionais, os locais privados e, por último, os microrregionais - ou seja, por meio das estimações, foi comprovado o padrão de cobertura observado no gráfico 3.2. Destaca-se ainda o fato da probabilidade de um domicílio qualquer da amostra possuir acesso a água por rede geral (aproximadamente 91\%) ser bastante superior às probabilidades obtidas no segundo capítulo - o que pode ser um reflexo do critério de seleção do SNIS, apontado anteriormente.

A tabela 3.7, por sua vez, apresenta os resultados das estimações com o acesso a coleta de esgoto por rede geral como variável dependente. Observa-se que todos os coeficientes são significativos e que a hipótese de todos eles serem iguais a zero deve ser rejeitada. Deve-se destacar ainda que a probabilidade de um domicílio qualquer da amostra possuir acesso a coleta de esgoto por rede geral é aproximadamente $61 \%$ - superior às probabilidades obtidas no segundo capítulo, assim como havia acontecido no caso do abastecimento de água.

Os sinais dos coeficientes e dos efeitos marginais das variáveis explicativas que também foram utilizadas no segundo capítulo são iguais aos obtidos naquele momento Já os sinais dos coeficientes das dummies tipos de prestadores - local público (positivo), local privado (positivo) e microrregional (negativo) -, mostram que, em 2000:

(iv) um domicílio atendido por um prestador local público tinha probabilidade maior de acesso ao serviço do que um domicílio atendido por um regional;

(v) um domicílio atendido por um prestador local privado também tinha probabilidade maior de acesso ao serviço do que um domicílio atendido por um regional e

(vi) um domicílio atendido por um prestador microrregional tinha probabilidade menor de acesso ao serviço do que um domicílio atendido por um regional.

Analisando a magnitude dos efeitos marginais, verifica-se que a probabilidade de acesso era maior nos locais públicos - seguidos pelos locais privados, pelos regionais, e, por último, pelos microrregionais. Ou seja, o gráfico 3.2 sinalizou um acesso maior nos locais privados, mas as estimações apontaram uma probabilidade maior de acesso nos locais públicos. 
Tabela 3.7

Resultados das estimações com dummies tipos de prestadores: variável dependente acesso a

coleta de esgoto por rede geral (2000)

\begin{tabular}{|c|c|c|c|c|c|c|}
\hline $\begin{array}{c}\text { Coleta de Esgoto por } \\
\text { Rede Geral }\end{array}$ & Coeficiente & $\begin{array}{c}\text { Efeito } \\
\text { Marginal }\end{array}$ & Coeficiente & $\begin{array}{c}\text { Efeito } \\
\text { Marginal } \\
\end{array}$ & Coeficiente & $\begin{array}{c}\text { Efeito } \\
\text { Marginal } \\
\end{array}$ \\
\hline $\begin{array}{l}\text { Ln (Renda Domiciliar } \\
\text { Mensal) }\end{array}$ & $\begin{array}{l}0,0229 * \\
(0,0056)\end{array}$ & $\begin{array}{l}0,0088 * \\
(0,0022) \\
{[0,0582]}\end{array}$ & $\begin{array}{l}0,0269 * \\
(0,0055)\end{array}$ & $\begin{array}{l}0,0104 * \\
(0,0021) \\
{[0,0686]}\end{array}$ & $\begin{array}{l}0,0213 * \\
(0,0056)\end{array}$ & $\begin{array}{l}0,0082 * \\
(0,0022) \\
{[0,0543]}\end{array}$ \\
\hline $\begin{array}{l}\text { Ln (Renda Domiciliar } \\
\text { per capita } \text { Mensal) }\end{array}$ & $\begin{array}{l}0,2302 * \\
(0,0054)\end{array}$ & $\begin{array}{l}0,0886 * \\
(0,0021) \\
{[0,4814]}\end{array}$ & $\begin{array}{l}0,2483 * \\
(0,0053)\end{array}$ & $\begin{array}{l}0,0958 * \\
(0,0021) \\
{[0,5204]}\end{array}$ & $\begin{array}{l}0,2079 * \\
(0,0054)\end{array}$ & $\begin{array}{l}0,0800 * \\
(0,0021) \\
{[0,4350]}\end{array}$ \\
\hline $\begin{array}{l}\text { Ln (População do } \\
\text { Município) }\end{array}$ & $\begin{array}{l}0,1225 * \\
(0,0017)\end{array}$ & $\begin{array}{l}0,0471 * \\
(0,0007) \\
{[0,6122]}\end{array}$ & & & & \\
\hline $\begin{array}{c}\text { Taxa de Urbanização } \\
\text { do Município }\end{array}$ & & & $\begin{array}{l}1,0450 * \\
(0,0271)\end{array}$ & $\begin{array}{l}0,4030 * \\
(0,0105)\end{array}$ & & \\
\hline $\begin{array}{l}\text { Ln (Renda Municipal } \\
\text { per capita } \text { Mensal) }\end{array}$ & & & & & $\begin{array}{l}0,6147 * \\
(0,0070)\end{array}$ & $\begin{array}{l}0,2366 * \\
(0,0027) \\
{[1,3762]}\end{array}$ \\
\hline $\begin{array}{l}\text { Localização do } \\
\text { Domicílio }\end{array}$ & $\begin{array}{l}-1,5726 * \\
(0,0017)\end{array}$ & $\begin{array}{c}-0,5297 * \\
(0,0033)\end{array}$ & $\begin{array}{c}-1,5145 * \\
(0,0161)\end{array}$ & $\begin{array}{c}-0,5161 * \\
(0,0034)\end{array}$ & $\begin{array}{c}-1,5827 * \\
(0,0161)\end{array}$ & $\begin{array}{c}-0,5314 * \\
(0,0030)\end{array}$ \\
\hline Dummy Norte & $\begin{array}{c}-1,9155 * \\
(0,0163)\end{array}$ & $\begin{array}{c}-0,5839 * \\
(0,0023)\end{array}$ & $\begin{array}{c}-2,0011 * \\
(0,0163)\end{array}$ & $\begin{array}{c}-0,5927 * \\
(0,0021)\end{array}$ & $\begin{array}{c}-1,6981 * \\
(0,0168)\end{array}$ & $\begin{array}{c}-0,5499 * \\
(0,0029)\end{array}$ \\
\hline Dummy Nordeste & $\begin{array}{c}-0,9434 * \\
(0,0084)\end{array}$ & $\begin{array}{c}-0,3628 * \\
(0,0030)\end{array}$ & $\begin{array}{c}-0,9933 * \\
(0,0085)\end{array}$ & $\begin{array}{c}-0,3802 * \\
(0,0030)\end{array}$ & $\begin{array}{c}-0,6342 * \\
(0,0096)\end{array}$ & $\begin{array}{c}-0,2482 * \\
(0,0037)\end{array}$ \\
\hline $\begin{array}{c}\text { Dummy } \\
\text { Centro-Oeste (2) }\end{array}$ & $\begin{array}{l}-1,0488 * \\
(0,0137)\end{array}$ & $\begin{array}{c}-0,3919 * \\
(0,0042)\end{array}$ & $\begin{array}{l}-1,1917 * \\
(0,0135)\end{array}$ & $\begin{array}{c}-0,4329 * \\
(0,038)\end{array}$ & $\begin{array}{c}-1,0293 * \\
(0,0139)\end{array}$ & $\begin{array}{c}-0,3858 * \\
(0,0043)\end{array}$ \\
\hline $\begin{array}{c}\text { Dummy Distrito } \\
\text { Federal }\end{array}$ & & & $\begin{array}{l}0,0693 * \\
(0,0230)\end{array}$ & $\begin{array}{l}0,0265 * \\
(0,0087)\end{array}$ & $\begin{array}{l}-0,1168 * \\
(0,0231)\end{array}$ & $\begin{array}{c}-0,0456 * \\
(0,0091)\end{array}$ \\
\hline Dummy Sudeste (4) & $\begin{array}{c}-0,3115 * \\
(0,0079)\end{array}$ & $\begin{array}{c}-0,1215 * \\
(0,0031)\end{array}$ & $\begin{array}{c}-0,3734 * \\
(0,0079)\end{array}$ & $\begin{array}{c}-0,1459 * \\
(0,0031)\end{array}$ & $\begin{array}{c}-0,2230 * \\
(0,0082)\end{array}$ & $\begin{array}{c}-0,0868 * \\
(0,0032)\end{array}$ \\
\hline Dummy Sul & $\begin{array}{c}-1,0781 * \\
(0,0090)\end{array}$ & $\begin{array}{c}-0,4079 * \\
(0,0030)\end{array}$ & $\begin{array}{c}-1,2102 * \\
(0,0088)\end{array}$ & $\begin{array}{c}-0,4495 * \\
(0,0027)\end{array}$ & $\begin{array}{c}-1,1594 * \\
(0,0089)\end{array}$ & $\begin{array}{c}-0,4340 * \\
(0,0028)\end{array}$ \\
\hline Dummy Local Público & $\begin{array}{l}0,2841 * \\
(0,0075)\end{array}$ & $\begin{array}{l}0,1061 * \\
(0,0027)\end{array}$ & $\begin{array}{l}0,2127 * \\
(0,0075)\end{array}$ & $\begin{array}{l}0,0803 * \\
(0,0028)\end{array}$ & $\begin{array}{l}0,2032 * \\
(0,0075)\end{array}$ & $\begin{array}{l}0,0767 * \\
(0,0028)\end{array}$ \\
\hline Dummy Local Privado & $\begin{array}{l}0,2350 * \\
(0,0170)\end{array}$ & $\begin{array}{l}0,0871 * \\
(0,0060)\end{array}$ & $\begin{array}{l}0,1437 * \\
(0,0170)\end{array}$ & $\begin{array}{l}0,0543 * \\
(0,0063)\end{array}$ & $\begin{array}{l}0,1247 * \\
(0,0170)\end{array}$ & $\begin{array}{l}0,0471 * \\
(0,0063)\end{array}$ \\
\hline Dummy Microrregional & $\begin{array}{c}-0,7693 * \\
(0,0445)\end{array}$ & $\begin{array}{c}-0,2977 * \\
(0,0157)\end{array}$ & $\begin{array}{c}-0,9513 * \\
(0,0446)\end{array}$ & $\begin{array}{c}-0,3582 * \\
(0,0141)\end{array}$ & $\begin{array}{c}-0,9490 * \\
(0,0444)\end{array}$ & $\begin{array}{l}-0,3579 * \\
(0,0141)\end{array}$ \\
\hline Constante & $\begin{array}{l}-2,1109 * \\
(0,0288)\end{array}$ & & $\begin{array}{c}-1,5497 * \\
(0,0315) \\
\end{array}$ & & $\begin{array}{c}-4,0254 * \\
(0,0437) \\
\end{array}$ & \\
\hline $\mathbf{y}=\operatorname{Pr}(\mathbf{y})$ (predict) & \multicolumn{2}{|c|}{0,605870} & \multicolumn{2}{|c|}{0,602772} & \multicolumn{2}{|c|}{0,605151} \\
\hline LR $\operatorname{chi}^{2}(10)$ & \multicolumn{2}{|c|}{$96.479,52$} & \multicolumn{2}{|c|}{$92.796,69$} & \multicolumn{2}{|c|}{$99.190,94$} \\
\hline Prob $>$ chi $^{2}$ & \multicolumn{2}{|c|}{0,0000} & \multicolumn{2}{|c|}{0,0000} & \multicolumn{2}{|c|}{0,0000} \\
\hline Pseudo-R ${ }^{2}$ & \multicolumn{2}{|c|}{0,2580} & \multicolumn{2}{|c|}{0,2481} & \multicolumn{2}{|c|}{0,2652} \\
\hline
\end{tabular}

Obs.: Erro-padrão entre parênteses e elasticidades entre colchetes, calculadas na forma d(y)/d(lnx).

* Significativo a $1 \%$.

Tomando como base de comparação os prestadores regionais, as estimações realizadas mostraram, portanto, que a probabilidade de um domicílio da amostra possuir acesso a 
abastecimento de água por rede geral é maior se este estiver localizado em um município atendido por um prestador local público e menor se estiver localizado em um município atendido por um prestador local privado ou por um prestador microrregional. Em relação à coleta de esgoto, observou-se que a probabilidade de um domicílio da amostra possuir acesso a esse serviço é maior se este pertencer a um município atendido por um prestador local público ou por um local privado e menor se pertencer a um município atendido por um prestador microrregional.

A análise desses resultados, contudo, é limitada. É importante ter em mente que, para alcançá-los, foram considerados apenas os municípios da amostra do SNIS (2000). O problema é que, por ser um sistema com informações declaradas pelos próprios prestadores, pode existir um viés de seleção, ou seja, apenas os que possuem melhor desempenho disponibilizam as informações. Contribui para isso o fato do sistema privilegiar, na coleta de informações, os municípios com mais de cem mil habitantes.

Além disso, os resultados obtidos podem não estar refletindo apenas o desempenho dos prestadores. Por exemplo, o acesso em um município atendido por prestador regional é influenciado pelo custo de provisão não só em seu território, mas também pelo custo de provisão nos demais municípios por ele atendidos. Já o acesso a abastecimento de água inferior nos privados pode ser resultado de uma situação inadequada existente nos municípios antes mesmo da desestatização - talvez tenha sido o motivo que levou a esse processo.

\section{$\underline{2.3 \text { Evolução do acesso: } 0 \text { impacto da desestatização }}$}

Pode-se verificar se o último fato comentado no item anterior é verdadeiro ou não situação inadequada antes do processo de desestatização - avaliando a evolução do acesso por 
rede geral aos serviços de saneamento básico, de 1991 a 2000, segundo os tipos de prestadores considerados anteriormente. Uma vez que não há informações disponíveis que permitam identificar o tipo de prestador em cada município no ano de 1991, é necessário supor que os serviços já eram ofertados pelo mesmo tipo de prestador existente em 2000. Dessa forma, é possível utilizar a amostra de municípios do SNIS 2000 para servir de base para a coleta de informações no Censo Demográfico de 1991.

Deve-se enfatizar que, em 1991, o tipo de prestador existente em um município não era, necessariamente, o mesmo do ano de 2000. Os prestadores privados, por exemplo, só adquiriram alguma relevância no setor após a inclusão dos serviços públicos no Plano Nacional de Desestatização (PND), em 1996. Nesse contexto, a análise também permitirá verificar se, em 2000, o processo de desestatização no setor, apesar de recente e com poucos casos, já tinha contribuído para aumentar o acesso por rede geral aos serviços - conforme ficou claro no primeiro capítulo, a participação privada no setor é pequena até hoje (2006).

O gráfico 3.3 mostra que a proporção de domicílios com acesso a abastecimento de água por rede geral já era maior, em 1991, no conjunto dos municípios atendidos por prestadores locais públicos em 2000. O índice de acesso a água dos prestadores regionais era o segundo maior, seguido pelo índice dos prestadores locais privados e, por último, pelo índice dos prestadores microrregionais. Ou seja, em 1991 já era possível verificar o mesmo padrão de diferença do acesso a água existente em 2000. Observa-se também uma variação maior do acesso, no período considerado, no conjunto de municípios atendidos, em 2000, por prestadores locais públicos.

No caso da coleta de esgoto por rede geral, o gráfico 3.4 mostra que, ao contrário do ocorrido com o abastecimento de água, o mesmo padrão de diferença do acesso ao serviço não se manteve ao longo do tempo. Em 1991, o conjunto de municípios atendidos por prestadores locais públicos possuía o maior índice de acesso. Já em 2000, era o conjunto de 
municípios atendidos por prestadores locais privados que possuía o maior índice. Deve-se destacar a grande expansão do acesso nos municípios atendidos, em 2000, por prestadores microrregionais e por locais privados - o índice de acesso a coleta de esgoto destes últimos tornou-se superior aos índices dos demais no último ano analisado.

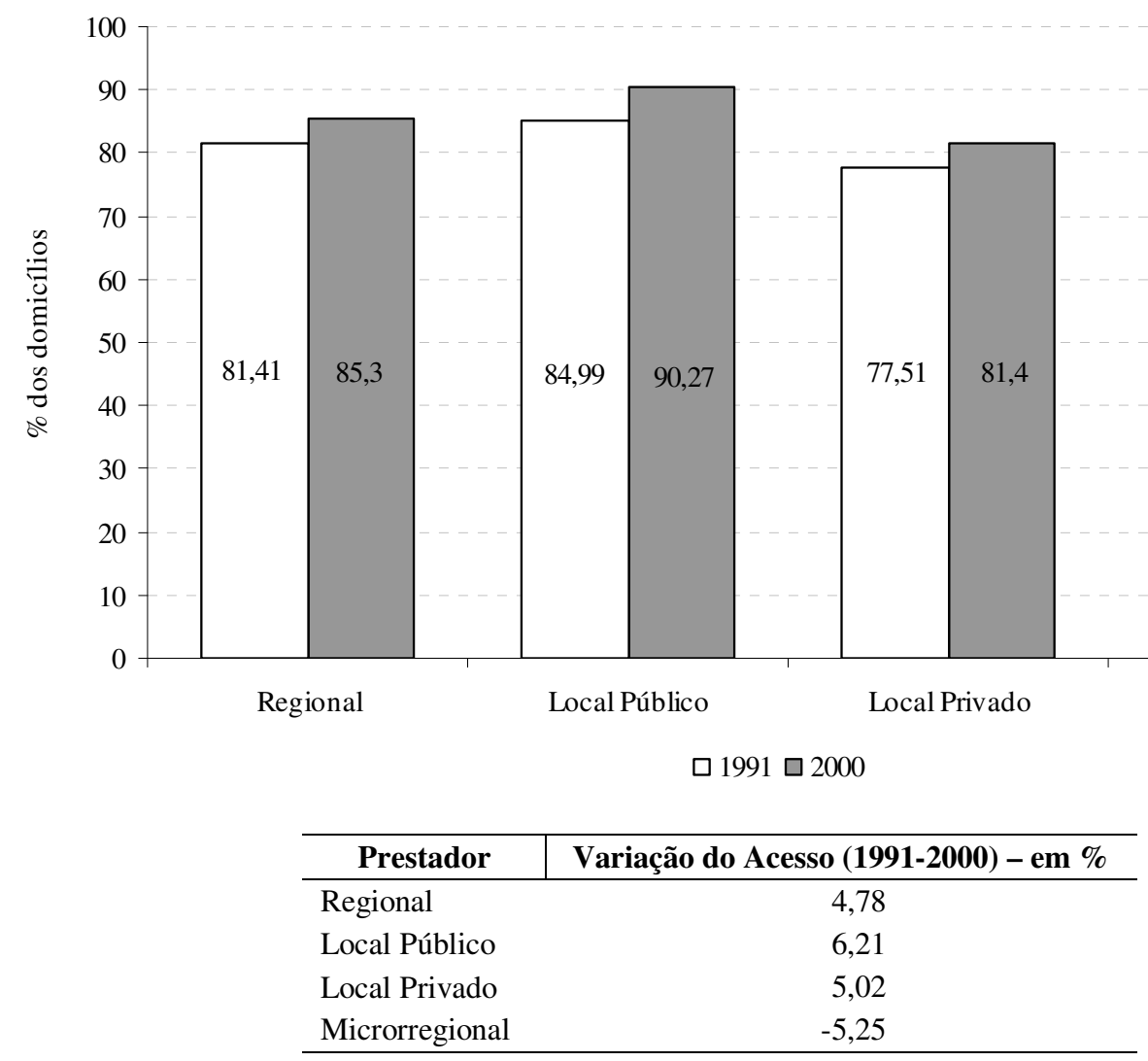

Fonte: IBGE e Ministério das Cidades, Censos Demográficos de 1991 e 2000 e SNIS (2000). Elaboração própria.

\section{Gráfico 3.3}

Brasil: proporção de domicílios com acesso a abastecimento de água por rede geral, segundo o tipo de prestador (1991 e 2000)

Por último, é importante repetir as estimações realizadas no início da seção, considerando, dessa vez, os dados do Censo Demográfico de 1991 - e mantendo a suposição de que os prestadores nesse ano eram os mesmos existentes em 2000. Os resultados completos dessas estimações são apresentados nas tabelas 46 e 47 do Apêndice. A tabela 3.8 mostra 
apenas um resumo desses resultados - sinais dos coeficientes e menor probabilidade estimada - e dos resultados obtidos anteriormente, com dados do ano de 2000. Comparando os sinais dos coeficientes e dos efeitos marginais obtidos nas duas estimações, verifica-se o mesmo que havia sido sugerido pelos gráficos 3.3 e 3.4: o padrão de diferença do acesso a abastecimento de água por rede geral entre os grupos considerados manteve-se ao longo do tempo; já o padrão de diferença do acesso a coleta de esgoto por rede geral sofreu uma alteração.

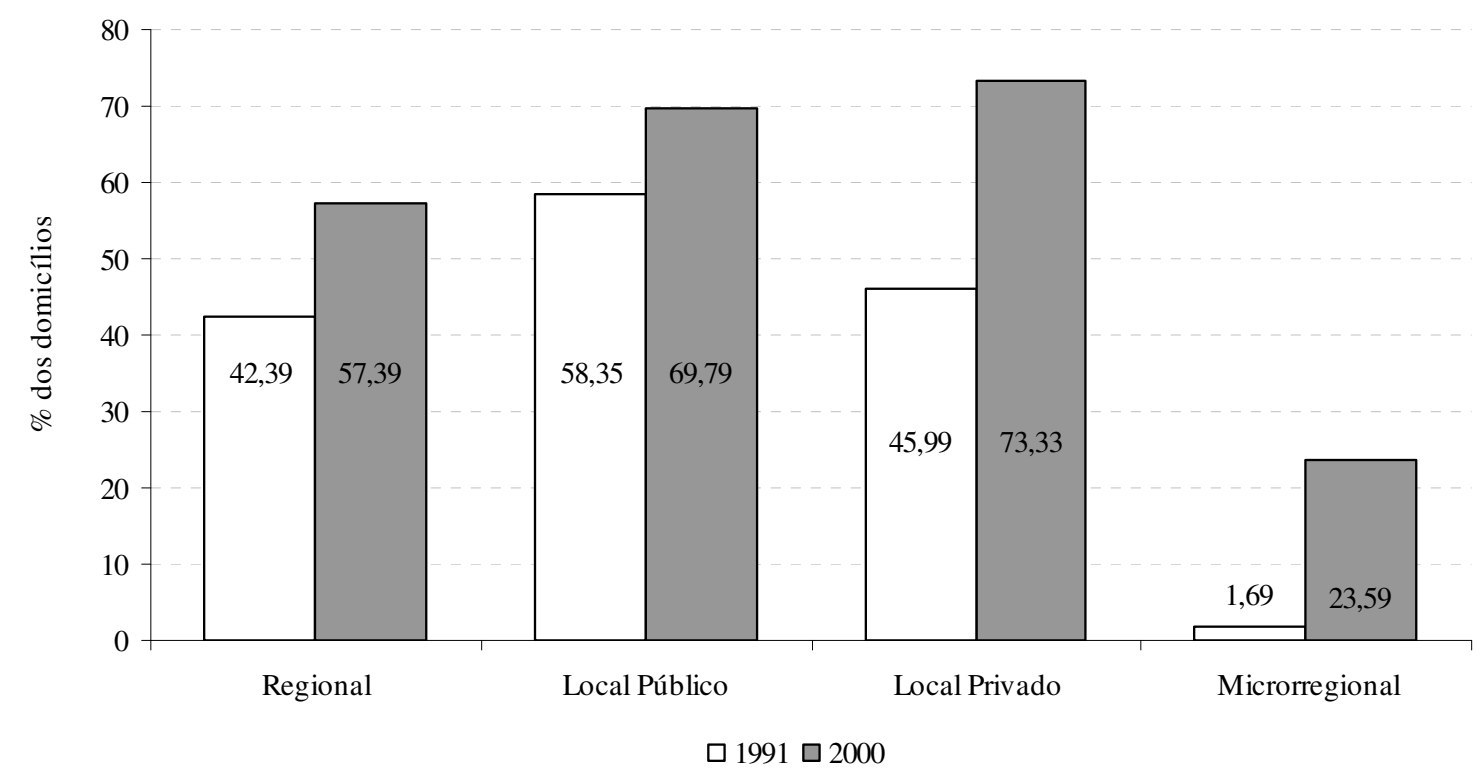

\begin{tabular}{l|c}
\hline \multicolumn{1}{c}{ Prestador } & Variação do Acesso (1991-2000) - em \% \\
\hline Regional & 35,39 \\
Local Público & 19,61 \\
Local Privado & 59,45 \\
Microrregional & $1.295,86$ \\
\hline
\end{tabular}

Fonte: IBGE e Ministério das Cidades, Censos Demográficos de 1991 e 2000 e SNIS (2000). Elaboração própria.

\section{Gráfico 3.4}

Brasil: proporção de domicílios com acesso a coleta de esgoto por rede geral, segundo o tipo de prestador (1991 e 2000)

Diante da análise realizada, pode-se dizer que o acesso a abastecimento de água por rede geral já era inferior, em 1991, no conjunto de municípios atendidos, em 2000, por 
prestadores locais privados - em comparação ao conjunto de municípios atendidos por prestadores regionais. Dessa forma, é difícil creditar o menor nível relativo de cobertura apenas a um baixo desempenho da iniciativa privada, principalmente se for levado em consideração que sua participação no setor era recente e pequena. Além disso, o gráfico 3.3, apresentado anteriormente, mostrou que ocorreu uma expansão de aproximadamente $5 \%$ do acesso a água no conjunto de municípios atendidos, em 2000, por prestadores privados.

\section{Tabela 3.8}

Resumo dos resultados das estimações com dummies tipos de prestadores: comparação entre os resultados obtidos (1991 e 2000)

\begin{tabular}{c|c|c|c|c}
\hline \multirow{2}{*}{ Serviço / Variável } & \multicolumn{4}{|c}{ Sinal do Coeficiente e do Efeito Marginal } \\
\cline { 2 - 5 } & \multicolumn{2}{|c}{ Água (Rede Geral) } & \multicolumn{2}{c}{ Coleta de Esgoto (Rede Geral) } \\
\cline { 2 - 5 } & $\mathbf{1 9 9 1}$ & $\mathbf{2 0 0 0}$ & $\mathbf{1 9 9 1}$ & $\mathbf{2 0 0 0}$ \\
\hline Dummy Local Público & $(+)$ & $(+)$ & $(+)$ & $(+)$ \\
Dummy Local Privado & $(-)$ & $(-)$ & $(-)$ & $(+)$ \\
Dummy Microrregional & $(-)$ & $(-)$ & $(-)$ & $(-)$ \\
\hline y = Pr (y) (predict) & $\mathbf{0 , 8 6}$ & $\mathbf{0 , 9 1}$ & $\mathbf{0 , 3 8}$ & $\mathbf{0 , 6 0}$ \\
\hline
\end{tabular}

No caso da coleta de esgoto por rede geral, o acesso a esse serviço nos municípios atendidos por prestadores locais privados também era, em 1991, inferior ao acesso nos municípios atendidos por prestadores regionais. Contudo, houve uma inversão dessa situação em 2000, devido à grande expansão do acesso ocorrida no primeiro grupo - conforme mostrou o gráfico 3.4, apresentado anteriormente. Pelo menos parte da expansão pode ter ocorrido devido à participação privada no setor, mesmo essa sendo, em 2000, pequena e recente - ainda hoje é pequena, devido aos fatos comentados nos capítulos anteriores.

É importante enfatizar que a análise realizada no presente item utilizou informações dos Censos Demográficos de 1991 e 2000 e que a participação privada no saneamento básico ganhou uma pequena relevância em 1996, com a inclusão dos serviços públicos no Plano Nacional de Desestatização (PND). Em função de ter considerado dois pontos no tempo 
relativamente distantes (nove anos) - devido à disponibilidade de dados - e tentar inferir se um acontecimento entre esses pontos - início do processo de desestatização no setor - teve algum impacto, a análise ficou um pouco comprometida e os resultados podem ser considerados apenas como sugestões. Na próxima seção, a questão do desempenho dos prestadores - entre estes, dos locais privados - será discutida mais detalhadamente.

\section{Desempenho dos prestadores de servicos}

A literatura especializada atribui uma maior eficiência à administração privada e a formas descentralizadas de gestão do que à centralização da provisão dos serviços públicos na esfera federal. A administração privada é tida como mais eficiente por possibilitar a eliminação - ou, pelo menos, a diminuição - de ingerências políticas, de conflitos de interesse, de empreguismo, de desperdícios, entre outros aspectos. A gestão descentralizada, por sua vez, é considerada como uma forma mais eficiente em função da maior proximidade entre os beneficiários dos serviços e os responsáveis por eles, o que faz com que estes últimos sofram uma maior pressão social, ampliando a possibilidade de que as demandas sejam atendidas, tanto em quantidade como em qualidade.

No caso do saneamento básico brasileiro, uma maior eficiência da administração privada e de formas descentralizadas de gestão, corresponderia a um melhor desempenho dos prestadores locais privados e dos prestadores locais públicos em comparação aos regionais. $\mathrm{O}$ objetivo do estudo a ser realizado na presente seção é contribuir para esse debate.

Antes de começar as análises, é importante destacar que Ohira (2005), ao medir e quantificar - pelo método de fronteira estocástica - o nível de eficiência dos prestadores de serviços de saneamento básico do Estado de São Paulo, constatou que não há diferenças 
significativas de eficiência entre a CESB paulista (Sabesp) e os prestadores públicos locais existentes no estado. Já Fujiwara (2005), ao estimar - pelo método de diferença-emdiferenças - o efeito da desestatização dos serviços de saneamento básico sobre a redução da mortalidade infantil, em municípios paulistas e cariocas, encontrou evidências de que a qualidade e não o maior acesso é afetado positivamente pelo processo - ao contrário do que tinha sido constatado por Galiani, Gertler e Schargrodsky (2005) para o caso argentino.

\section{$\underline{\text { 3.1 Comparacão do desempenho dos prestadores de servicos }}$}

Nesse item, o objetivo é verificar qual tipo de prestador de serviços de saneamento básico existente no Brasil apresenta um melhor desempenho - ou seja, é mais eficiente. Para atingir tal objetivo, será analisado um conjunto de indicadores de desempenho fornecidos pelo SNIS, referentes ao ano de 2004: (i) indicadores operacionais e de cobertura (água e esgoto); (ii) indicadores econômicos, financeiros e administrativos e (iii) indicadores de qualidade.

É importante destacar que, para cada um dos índices analisados, serão confrontados o valor médio e o desvio-padrão dos diferentes prestadores. A análise do valor médio permitirá comparar o desempenho dos prestadores em relação aos diferentes aspectos considerados. Já a análise do desvio-padrão tornará possível averiguar em qual grupo de prestador há uma maior padronização do desempenho entre as entidades que o compõem - ou seja, uma menor diferença dos índices dessas entidades.

Para a realização de tal análise, optou-se por não considerar os prestadores microrregionais - devido à existência de poucas entidades desse tipo, o que dificulta qualquer generalização e pode prejudicar a comparação do desempenho das demais - e por agregar os dados dos prestadores locais de direito público e dos locais de direito privado em um único 
tipo, chamado genericamente de prestador local público - assim como já havia sido feito na seção anterior. Dessa forma, será comparado o desempenho de três tipos de prestadores de serviços: (i) regionais, (ii) locais públicos e (iii) locais privados.

\section{Indicadores operacionais e de cobertura}

Iniciando a análise, a tabela 3.9 apresenta alguns indicadores operacionais e de cobertura referentes aos serviços de abastecimento de água e de esgotamento sanitário. Em relação ao abastecimento de água, é possível destacar os seguintes aspectos:

(i) índice de perdas de faturamento (grosso modo, parcela do volume não faturado de água no volume total produzido): maior valor médio nos prestadores regionais, mas com desvio-padrão menor do que os demais - ou seja, pior desempenho relativo nos regionais, mas o desempenho varia menos entre as entidades pertencentes a esse tipo de prestador. O melhor desempenho é o dos locais privados (menor valor médio);

(ii) índice de perdas na distribuição (grosso modo, parcela do volume não consumido de água no volume total produzido): assim como no índice anterior, pior desempenho relativo nos regionais (maior valor médio), mas o desempenho varia menos entre as entidades pertencentes a esse tipo de provedor de serviço (menor desvio-padrão). O melhor desempenho relativo é o dos prestadores locais públicos (menor valor médio);

(iii) índice de hidrometração (razão entre a quantidade de ligações micromedidas de água e a quantidade de ligações ativas): valor médio maior e desvio-padrão menor nos prestadores locais privados - ou seja, melhor desempenho relativo nos locais privados e o desempenho varia menos entre as entidades pertencentes a esse tipo de provedor. O pior desempenho relativo, nesse índice, é o dos locais públicos (menor valor médio) - que também apresentam maior desvio-padrão; 


\section{Tabela 3.9}

Saneamento básico no Brasil: indicadores operacionais e de cobertura, segundo

o tipo de prestador do serviço (2004)

\begin{tabular}{|c|c|c|c|}
\hline \multirow{2}{*}{ Prestador / Indicador Operacional } & \multirow{2}{*}{ Regional } & \multicolumn{2}{|c|}{ Local } \\
\hline & & Público & Privado \\
\hline \multicolumn{4}{|l|}{ Água } \\
\hline \multirow[t]{2}{*}{ - Índice de perdas de faturamento (\%) } & 44,19 & 29,46 & 27,30 \\
\hline & $(14,71)$ & $(23,70)$ & $(21,60)$ \\
\hline \multirow[t]{2}{*}{ - Índice de perdas na distribuição $(\%)$} & 48,67 & 27,13 & 29,36 \\
\hline & $(13,14)$ & $(20,14)$ & $(20,38)$ \\
\hline \multirow[t]{2}{*}{ - Índice de hidrometração $(\%)$} & 75,43 & 74,30 & 88,04 \\
\hline & $(27,17)$ & $(34,15)$ & $(15,84)$ \\
\hline \multirow[t]{2}{*}{ - Densidade de economias por ligação (econ./lig.) } & 1,23 & 1,11 & 1,20 \\
\hline & $(0,21)$ & $(0,16)$ & $(0,26)$ \\
\hline \multirow[t]{2}{*}{ - Extensão da rede de água por ligação (m/ligação) } & 12,18 & 15,70 & 14,07 \\
\hline & $(3,98)$ & $(12,90)$ & $(4,28)$ \\
\hline \multirow[t]{2}{*}{ - Consumo médio de água por economia (m³/mês/econ.) } & 14,36 & 19,30 & 16,00 \\
\hline & $(3,60)$ & $(12,33)$ & $(5,50)$ \\
\hline \multirow[t]{2}{*}{ - Consumo médio per capita (1/hab./dia) } & 129,20 & 170,52 & 132,01 \\
\hline & $(33,63)$ & $(96,53)$ & $(42,05)$ \\
\hline \multirow[t]{2}{*}{ - Índice de atendimento urbano de água (\% da população) } & 89,06 & 95,62 & 92,70 \\
\hline & $(15,59)$ & $(12,47)$ & $(10,74)$ \\
\hline \multirow[t]{2}{*}{ - Índice de atendimento total de água (\% da população) } & 71,37 & 83,52 & 81,08 \\
\hline & $(16,97)$ & $(19,99)$ & $(16,85)$ \\
\hline \multicolumn{4}{|l|}{ Esgoto } \\
\hline \multirow[t]{2}{*}{ - Índice de coleta de esgoto $(\%)$} & 28,96 & 65,45 & 43,92 \\
\hline & $(21,08)$ & $(34,45)$ & $(31,67)$ \\
\hline \multirow[t]{2}{*}{ - Índice de tratamento de esgoto $(\%)$} & 74,52 & 45,96 & 54,37 \\
\hline & $(33,59)$ & $(43,96)$ & $(42,98)$ \\
\hline \multirow[t]{2}{*}{ - Îndice de esgoto tratado por água consumida $(\%)$} & 22,23 & 20,67 & 18,02 \\
\hline & $(18,39)$ & $(28,42)$ & $(22,85)$ \\
\hline \multirow[t]{2}{*}{ - Índice de atendimento urbano de esgoto (\% da pop.) } & 25,07 & 73,56 & 53,49 \\
\hline & $(22,35)$ & $(33,57)$ & $(37,51)$ \\
\hline \multirow[t]{2}{*}{ - Índice de atendimento total de esgoto (\% da população) } & 20,86 & 64,09 & 48,86 \\
\hline & $(21,13)$ & $(33,10)$ & $(36,26)$ \\
\hline
\end{tabular}

Fonte: Ministério das Cidades, SNIS (2004). Elaboração própria. Obs.: Desvio-padrão entre parênteses.

(iv) densidade de economias por ligação ${ }^{5}$ (razão entre a quantidade de economias ativas de água e a quantidade de ligações ativas): valores médios próximos, com uma ligeira superioridade nos regionais. O menor desvio-padrão é o dos locais públicos;

\footnotetext{
5 "Por economias, pode-se entender o número de unidades consumidoras; e por ligação, a entrada de água. Assim, por exemplo, em um edifício existe uma ligação de água, mas várias economias, pois cada apartamento constitui-se uma unidade consumidora" (TONETO JÚNIOR, 2004, p. 269).
} 
(v) extensão da rede de água por ligação (razão entre a extensão da rede de água e a quantidade de ligações totais): maior valor médio nos prestadores locais públicos e menor desvio-padrão nos regionais. Por meio desse índice e do anterior, é possível inferir qual tipo de prestador tem seu desempenho beneficiado pela existência de economias de escala e de densidade em sua área de atuação - quanto maior a concentração dos consumidores, ou seja, quanto menor a distância entre eles, maior os ganhos que podem ser gerados. Como não foi verificada, nos dois índices, uma diferença significativa entre os tipos de prestadores, não é possível atribuir a ganhos de escala e de densidade o melhor desempenho apresentado por qualquer um deles;

(vi) consumo médio de água por economia ( grosso modo, razão entre o volume consumido de água e a quantidade de economias ativas): maior valor médio nos prestadores locais públicos, mas menor desvio-padrão nos prestadores regionais;

(vii) consumo médio per capita (grosso modo, razão entre o volume consumido de água e a população total atendida): maior valor médio nos prestadores locais públicos, mas menor desvio-padrão nos prestadores regionais. Os padrões observados nesse índice e no anterior podem estar refletindo a diferença média das tarifas entre os grupos;

(viii) índice de atendimento urbano de água (razão entre a população urbana atendida e a população urbana total do[s] município[s]): maior valor médio nos prestadores locais públicos e menor desvio-padrão nos prestadores locais privados - ou seja, os locais públicos atendem a uma parcela maior da população urbana que reside em sua área de atuação, mas há uma maior padronização do índice de atendimento entre as entidades que compõem o grupo dos prestadores locais privados;

(ix) índice de atendimento total de água (razão entre a população total atendida e a população total do[s] município[s]): maior valor médio nos prestadores locais públicos e menor desvio-padrão nos prestadores locais privados - ou seja, os locais públicos 
atendem a uma parcela maior da população que reside em sua área de atuação, mas há uma maior padronização do índice de atendimento entre as entidades que compõem o grupo dos prestadores locais privados. Observa-se, portanto, o mesmo padrão de atendimento à população urbana e à população total.

A tabela 3.9 apresenta também alguns índices referentes ao esgotamento sanitário. Em relação a esse serviço, é possível destacar os seguintes aspectos:

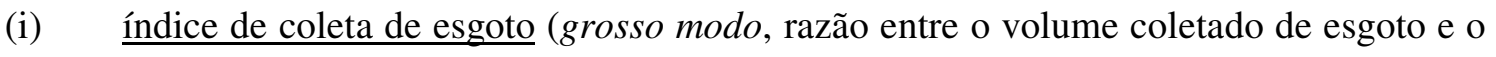
volume consumido de água): maior valor médio nos prestadores locais públicos e menor desvio-padrão nos regionais - ou seja, na média, os locais públicos coletam um volume maior de esgoto, mas há uma maior padronização da coleta (menor diferença entre o volume coletado pelas entidades pertencentes ao grupo) nos regionais;

(ii) índice de tratamento de esgoto (razão entre o volume tratado de esgoto e o volume coletado): maior valor médio e menor desvio-padrão nos regionais, ou seja, melhor desempenho e maior padronização dos índices das entidades nesse tipo de prestador. Comparando os dois últimos indicadores, observa-se que os locais públicos coletam mais e tratam menos e os regionais tratam mais e coletam menos ${ }^{6}$;

(iii) índice de esgoto tratado por água consumida (grosso modo, razão entre o volume de tratado esgoto e o volume consumido de água): assim como no índice anterior, observa-se um melhor desempenho e uma maior padronização nos regionais;

(iv) índices de atendimento urbano e total (razão entre a população atendida com esgotamento sanitário, urbana e total, e a população atendida com abastecimento de água, urbana e total): maiores valores médios nos locais públicos e menores desvios-

\footnotetext{
${ }^{6} \mathrm{O}$ baixo grau de tratamento nos prestadores locais públicos pode ser resultado da existência de externalidades ambientais e da necessidade de coordenação regional das políticas para o setor. Isto porque os prestadores locais podem estar preocupados com a coleta e com o afastamento do esgoto que beneficia diretamente seus habitantes, enquanto a ausência de tratamento distribui o ônus com os municípios vizinhos.
} 
padrão nos prestadores regionais - ou seja, maior cobertura nos locais públicos e maior padronização dos índices de acesso entre as entidades regionais.

A comparação dos indicadores operacionais e de cobertura não mostra, portanto, qual tipo de prestador é mais eficiente. Isto porque, em alguns indicadores, o desempenho dos prestadores regionais é melhor, enquanto em outros é o desempenho dos locais públicos ou dos locais privados que se destaca. Da mesma forma, não é possível apontar em qual grupo de prestador há uma maior padronização do desempenho entre as entidades que o compõem.

É importante destacar que baixo desempenho dos prestadores privados em alguns índices pode ser decorrência da relativa "juventude" da participação privada no setor e da situação inadequada existente antes mesmo da desestatização e ainda não revertida - situação que pode ter desencadeado o processo de concessão do serviço.

$\underline{\text { Indicadores econômicos, financeiros e administrativos }}$

Para comparar o desempenho dos diferentes tipos de prestadores de serviços de saneamento básico, é possível utilizar também alguns indicadores econômicos, financeiros e administrativos, ilustrados na tabela 3.10. Em relação a esses indicadores, destacam-se os seguintes aspectos:

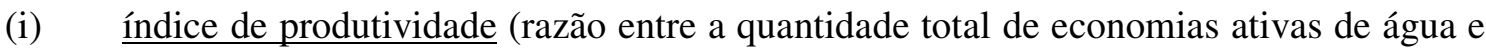
de esgoto e a quantidade de pessoal total - próprio e terceirizado): maior valor médio (maior produtividade) nos locais privados e menor desvio-padrão (maior padronização) nos regionais;

(ii) pessoal próprio por mil ligações (razão entre a quantidade total de empregados próprios e a quantidade total de ligações ativas de água e de esgoto): assim como o anterior, esse indicador mede a produtividade física do pessoal na prestação dos 
serviços. Observa-se um menor valor médio e um menor desvio-padrão nos locais privados - ou seja, melhor desempenho e maior padronização. O pior desempenho (maior valor médio) ocorre nos locais públicos, o que pode ser decorrência da maior proximidade entre o eleitor e o gestor do serviço - pressão por mais empregos que, muitas vezes, é atendida em função de interesses eleitorais;

Tabela 3.10

Saneamento básico no Brasil: indicadores econômicos, financeiros e administrativos, segundo o

tipo de prestador do serviço (2004)

\begin{tabular}{|c|c|c|c|}
\hline \multirow{2}{*}{$\begin{array}{l}\text { Prestador / Indicador Econômico, } \\
\text { Financeiro e Administrativo }\end{array}$} & \multirow{2}{*}{ Regional } & \multicolumn{2}{|c|}{ Local } \\
\hline & & Público & Privado \\
\hline \multirow[t]{2}{*}{ - Índice de produtividade: economias por pessoal total } & 328,19 & 245,85 & 352,12 \\
\hline & $(140,49)$ & $(165,89)$ & $(163,93)$ \\
\hline \multirow[t]{2}{*}{ - Pessoal próprio por mil ligações (água e esgoto) } & 3,63 & 5,03 & 3,09 \\
\hline & $(3,23)$ & $(16,55)$ & $(1,31)$ \\
\hline \multirow{2}{*}{ - Despesa total com serviço por $\mathrm{m}^{3}$ faturado $(\mathrm{R} \$)$ - água e esgoto } & 1,90 & 0,80 & 1,10 \\
\hline & $(0,71)$ & $(0,48)$ & $(0,46)$ \\
\hline \multirow[t]{2}{*}{ - Despesa de exploração por $\mathrm{m}^{3}$ faturado $(\mathrm{R} \$)$} & 1,42 & 0,74 & 0,80 \\
\hline & $(0,55)$ & $(0,43)$ & $(0,26)$ \\
\hline \multirow[t]{2}{*}{ - Despesa de exploração por economia $(\mathrm{R} \$)$} & 263,57 & 130,99 & 149,33 \\
\hline & $(107,06)$ & $(66,26)$ & $(57,00)$ \\
\hline \multirow[t]{2}{*}{ - Despesa média anual por empregado $(\mathrm{R} \$)$} & $46.596,04$ & $15.679,46$ & $18.861,73$ \\
\hline & $(16.233,80)$ & $(9.639,93)$ & $(9.831,86)$ \\
\hline \multirow[t]{2}{*}{ - Participação da despesa com pessoal na despesa de exploração $(\%)$} & 61,66 & 56,93 & 45,54 \\
\hline & $(9,31)$ & $(17,90)$ & $(14,53)$ \\
\hline \multirow[t]{2}{*}{ - Tarifa média praticada $\left(\mathrm{R} \$ / \mathrm{m}^{3}\right)$ - água e esgoto } & 1,56 & 0,83 & 1,33 \\
\hline & $(0,44)$ & $(0,43)$ & $(0,42)$ \\
\hline \multirow[t]{2}{*}{ - Tarifa média de água $\left(\mathrm{R} \$ / \mathrm{m}^{3}\right)$} & 1,59 & 0,85 & 1,37 \\
\hline & $(0,46)$ & $(0,43)$ & $(0,44)$ \\
\hline \multirow[t]{2}{*}{ - Tarifa média de esgoto $\left(\mathrm{R} \$ / \mathrm{m}^{3}\right)$} & 1,41 & 0,78 & 1,25 \\
\hline & $(0,34)$ & $(1,02)$ & $(0,72)$ \\
\hline \multirow[t]{2}{*}{ - Índice de evasão de receita $(\%)$} & 12,96 & 2,34 & 7,54 \\
\hline & $(11,98)$ & $(14,67)$ & $(12,65)$ \\
\hline \multirow[t]{2}{*}{ - Margem da despesa de exploração $(\%)$} & 96,03 & 99,55 & 82,76 \\
\hline & $(52,43)$ & $(66,23)$ & $(88,88)$ \\
\hline \multirow[t]{2}{*}{ - Dias de faturamento comprometidos com contas a receber } & 165,61 & 121,13 & 99,73 \\
\hline & $(132,82)$ & $(125,84)$ & $(74,98)$ \\
\hline \multirow[t]{2}{*}{ - Índice de desempenho financeiro $(\%)$} & 87,50 & 107,90 & 124,00 \\
\hline & $(24,63)$ & $(44,26)$ & $(45,71)$ \\
\hline
\end{tabular}

Fonte: Ministério das Cidades, SNIS (2004). Elaboração própria. Obs.: Desvio-padrão entre parênteses. 
(iii) indicadores de despesa: valores médios maiores nos regionais e, de uma maneira geral, menores nos locais públicos, exceto no caso do índice de participação da despesa com pessoal na despesa de exploração, no qual os locais privados apresentam melhor desempenho (menor valor médio). Esse último grupo de prestadores possuía também os menores desvios-padrão (maior uniformidade dos índices das entidades que o compõem) nos três primeiros indicadores de despesa - no quarto indicador, os locais públicos apresentam menor desvio-padrão e, no quinto, os regionais;

(iv) tarifas médias (razão entre a receita operacional direta - água, esgoto ou ambos - e o volume total faturado - água, esgoto ou ambos): nos três tipos de tarifas, os maiores valores médios são os dos regionais e os menores os dos locais públicos. O desviopadrão é menor nos locais públicos, no caso da tarifa média praticada; nos locais privados, no caso da tarifa de água; e nos regionais, no caso da tarifa de esgoto;

(v) Índice de evasão de receita (grosso modo, proporção da receita não arrecadada na receita operacional total que deveria ser arrecadada): valor médio bem menor nos prestadores locais públicos e menor desvio-padrão nos prestadores regionais - ou seja, os locais públicos deixam de arrecadar, na média, uma parcela menor do total da receita operacional que poderia ser obtida;

(vi) margem da despesa de exploração (grosso modo, razão entre as despesas de exploração e a receita operacional direta de água e de esgoto): valor médio menor nos prestadores locais privados e desvio-padrão menor nos prestadores regionais - ou seja, desempenho melhor nos locais privados, que apresentam um melhor comprometimento da receita com despesas de exploração;

(vii) dias de faturamento comprometidos com contas a receber: esse indicador reflete os atrasos nos pagamentos, mostrando quantos dias de faturamento encontram-se na 
forma de contas a receber. Observa-se um menor valor médio e menor desvio-padrão, ou seja, um melhor desempenho e uma maior padronização nos locais privados;

(viii) índice de desempenho financeiro (grosso modo, razão entre a receita operacional direta, água e esgoto, e as despesas totais com os serviços): relaciona as receitas totais às despesas totais com os serviços. Verifica-se um maior valor médio nos locais privados (melhor desempenho) e menor desvio-padrão (maior padronização) nos regionais. Deve-se destacar também que, na média, as receitas dos regionais não cobrem suas despesas.

Assim como no caso dos indicadores operacionais e de cobertura, a comparação dos indicadores econômicos, financeiros e administrativos também não aponta, claramente, qual grupo de prestador apresenta melhor desempenho e em qual há uma maior padronização dos índices das entidades que o compõem. Destaca-se o fato dos prestadores regionais não apresentarem melhor desempenho em nenhum dos indicadores analisados nesse item - mas, em alguns, apresentam maior padronização (maior desvio-padrão).

\section{$\underline{\text { Indicadores de qualidade }}$}

Por último, também é importante comparar o desempenho dos diferentes tipos de prestadores levando em consideração alguns aspectos relacionados à qualidade dos serviços ofertados. Analisando os dados da 3.11, é possível destacar os seguintes aspectos:

(i) duração média dos serviços executados (razão entre o tempo de execução e a quantidade de serviços executados): maior valor médio nos prestadores regionais e menor desvio-padrão nos prestadores locais públicos - ou seja, melhor desempenho médio nos regionais e maior padronização nos locais públicos; 
Tabela 3.11

Saneamento básico no Brasil: indicadores de qualidade, segundo o tipo de prestador do serviço (2004)

\begin{tabular}{|c|c|c|c|}
\hline \multirow{2}{*}{ Indicador de qualidade } & \multirow{2}{*}{ Regional } & \multicolumn{2}{|c|}{ Local } \\
\hline & & Público & Privado \\
\hline \multirow[t]{2}{*}{ - Duração média dos serviços executados (horas/serviço) } & 6,89 & 2,72 & 5,59 \\
\hline & $(12,80)$ & $(6,90)$ & $(12,69)$ \\
\hline \multirow[t]{2}{*}{ - Duração média das paralisações (horas/paralisação) } & 11,10 & 13,32 & 10,21 \\
\hline & $(13,46)$ & $(44,98)$ & $(7,86)$ \\
\hline \multirow[t]{2}{*}{ - Duração média das intermitências (horas/interrupção) } & 17,55 & 9,63 & 7,27 \\
\hline & $(68,05)$ & $(41,70)$ & $(11,93)$ \\
\hline \multirow[t]{2}{*}{ - Incidência de análises de cloro residual fora do padrão (\%) } & 3,32 & 4,12 & 0,92 \\
\hline & $(9,16)$ & $(11,31)$ & $(2,19)$ \\
\hline \multirow[t]{2}{*}{ - Incidência de análises de turbidez fora do padrão (\%) } & 6,77 & 4,04 & 0,38 \\
\hline & $(15,31)$ & $(10,03)$ & $(0,94)$ \\
\hline \multirow[t]{2}{*}{ - Incidência de análises de coliformes fecais fora do padrão (\%) } & 2,79 & 3,73 & 0,52 \\
\hline & $(7,65)$ & $(9,80)$ & $(1,03)$ \\
\hline \multirow[t]{2}{*}{ - Extravasamentos de esgoto por extensão de rede (extravas./Km) } & 3,93 & 3,44 & 3,79 \\
\hline & $(8,94)$ & $(6,40)$ & $(3,78)$ \\
\hline
\end{tabular}

Fonte: Ministério das Cidades, SNIS (2004). Elaboração própria.

* Dados não disponíveis.

(ii) duração média das paralisações (razão entre a duração e a quantidade de paralisações): melhor desempenho (menor valor médio) e maior padronização (menor desviopadrão) nos prestadores locais privados;

(iii) duração média das intermitências (razão entre a duração das intermitências prolongadas e a quantidade de interrupções sistemáticas): melhor desempenho (menor valor médio) e maior padronização (menor desvio-padrão) nos locais privados;

(iv) incidência de análises de cloro residual fora do padrão: melhor desempenho (menor valor médio) e maior padronização (menor desvio-padrão) nos locais privados;

(v) incidência de análises de turbidez fora do padrão: melhor desempenho (menor valor médio) e maior padronização (menor desvio-padrão) nos prestadores locais privados;

(vi) incidência de análises de coliformes fecais fora do padrão: melhor desempenho (menor valor médio) e maior padronização (menor desvio-padrão) nos privados;

(vii) extravasamentos de esgoto por extensão de rede: melhor desempenho (menor valor médio) nos locais públicos e maior padronização (menor desvio-padrão) nos privados; 
A comparação dos indicadores de qualidade sugere, portanto, que os prestadores locais privados apresentam, em relação a esse aspecto, um melhor desempenho e uma maior padronização entre os índices das entidades que compõem o grupo - melhor desempenho em quatro dos seis indicadores analisados e menor desvio-padrão em cinco. Ou seja, os dados sinalizam que a desestatização no setor, apesar de recente e com poucos casos, levou a uma melhora da qualidade dos serviços - corroborando o resultado do estudo de Fujiwara (2005), comentado no início da seção.

\section{$\underline{\text { 3.2 Evolucão do desempenho dos prestadores de servicos (2000-2004) }}{ }^{7}$}

As análises realizadas na seção anterior mostraram que, pela simples comparação dos indicadores referentes ao ano de 2004, é difícil apontar qual tipo de prestador é mais eficiente e em qual há uma maior padronização (menor desvio-padrão) dos índices das entidades que o compõem - em alguns indicadores, o desempenho dos regionais é melhor e, em outros, é melhor o desempenho dos locais públicos ou dos locais privados; da mesma forma, em alguns indicadores, a maior padronização ocorre nos regionais e, em outros, nos locais públicos ou nos locais privados.

Nesse contexto, também é importante analisar a evolução de alguns indicadores ao longo do tempo - de 2000 a 2004 -, com o objetivo de avaliar qual tipo de prestador conseguiu, nesse período, melhorar seu desempenho médio e aumentar a padronização dos índices das entidades que o compõem.

Para a realização da análise, optou-se por considerar apenas as entidades com informações disponibilizadas em 2000 e em 2004, na tentativa de reduzir o impacto da

\footnotetext{
7 As análises da presente seção, para facilitar a visualização, serão realizadas por meio de gráficos. Os dados utilizados para a confecção desses gráficos estão no Apêndice - tabela 50.
} 
variação, a cada ano, do tamanho da amostra de prestadores do SNIS - fato comentado anteriormente $^{8}$. Dessa forma, variações nos valores médios e nos desvios-padrão captarão mudanças no desempenho dos prestadores considerados e não a inclusão de novos informantes na amostra. Deve-se apontar também que, em função de tal adaptação, é possível que alguns valores médios e alguns desvios-padrão a serem calculados difiram daqueles apresentados na seção anterior.

\section{$\underline{\text { Indicadores operacionais e de cobertura }}$}

Do conjunto de indicadores operacionais e de cobertura analisados anteriormente, foram selecionados seis para avaliar a evolução do desempenho dos prestadores de serviços de saneamento básico: (i) índice de perdas de faturamento, (ii) índice de perdas na distribuição, (iii) índice de hidrometração, (iv) índice de atendimento total de água, (v) índice de coleta de esgoto e (vi) índice de tratamento de esgoto.

Conforme foi apontado anteriormente, o índice de perdas de faturamento mede a proporção não faturada do volume produzido de água, ou seja, a parcela da água produzida que não gera receita para o provedor do serviço. As perdas de faturamento podem ocorrer em função de problemas na rede de distribuição e de deficiências na medição da água consumida. Dessa forma, para reduzir tais perdas, é necessário que ocorra, grosso modo, uma redução das perdas na distribuição ou um esforço para elevar a micromedição (hidrometração) do consumo de água - ou ambos. Ou seja, há uma diminuição do índice de perdas de faturamento quando o índice de perdas na distribuição também se reduz ou quando o índice de hidrometração se eleva - ou quando os dois fatos ocorrem ao mesmo tempo.

\footnotetext{
${ }^{8}$ Obteve-se, assim, uma amostra com cento e noventa e oito prestadores, sendo: (i) vinte e cinco regionais $(12,6 \%)$, (ii) cento e cinqüenta e seis locais públicos $(78,8 \%)$, (iii) treze locais privados $(6,6 \%)$ e (iv) quatro microrregionais (2\%). Assim como foi feito na seção anterior, os prestadores microrregionais não serão considerados na análise.
} 
Analisando a evolução dos indicadores entre 2000 e 2004, o gráfico 3.5 mostra que os prestadores locais privados foram os que, na média, apresentaram uma melhora de desempenho nos três indicadores considerados: (i) redução das perdas na distribuição, (ii) aumento da hidrometração e, conseqüentemente, (iii) queda das perdas de faturamento. Nos prestadores locais públicos, os índices médios de perdas de faturamento e de perdas na distribuição também sofreram uma queda no período, mas o índice médio de hidrometração piorou. Nos prestadores regionais, apenas esse último índice apresentou uma pequena melhora - as perdas, tanto de faturamento como na distribuição, aumentaram.

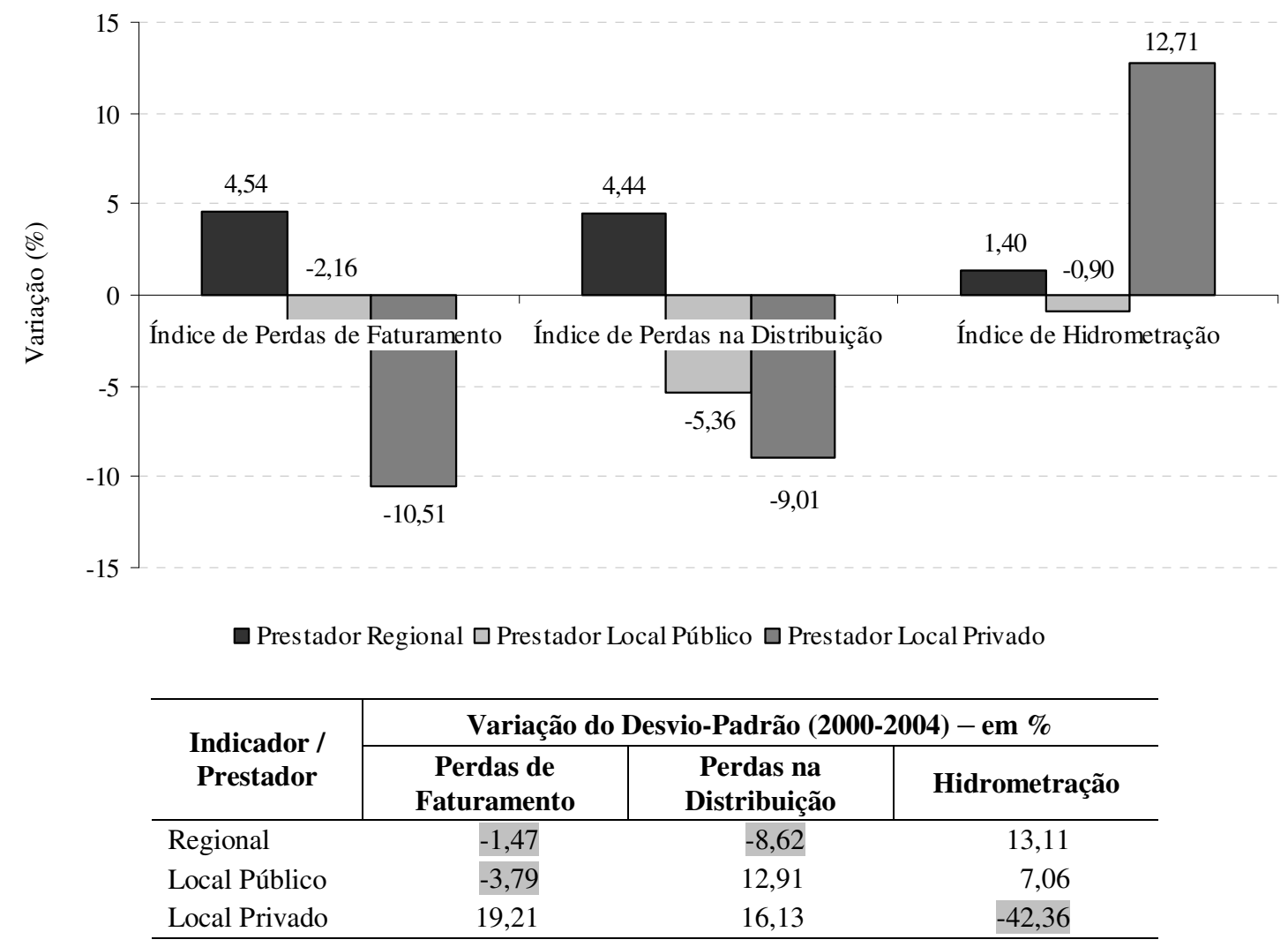

Fonte: Ministério das Cidades, SNIS (2000 e 2004). Elaboração própria.

Gráfico 3.5

Saneamento básico no Brasil: variação dos índices de perdas de faturamento, de perdas na distribuição e de hidrometração (valor médio e desvio-padrão), segundo o tipo de prestador (2000 e 2004) 
Por meio do gráfico 3.5, também é possível observar que a melhora do desempenho dos prestadores privados nos índices de perdas de faturamento e de perdas na distribuição ocorreu apenas na média, uma vez que, aumentou os desvios-padrão referentes a esses indicadores. Ou seja, uma entidade ou um conjunto de entidades privadas reduziram sensivelmente suas perdas, o que acabou levando a uma queda dos índices do grupo - já no caso da hidrometração, ocorreu uma melhora geral, que resultou em uma redução do desvio-padrão referente a esse indicador. Destacam-se também: (i) nos regionais, a queda dos desviospadrão referentes aos índices de perdas de faturamento e na distribuição e, (ii) nos locais públicos, a diminuição do desvio-padrão do índice de perdas na distribuição.

É importante analisar também a evolução dos índices de atendimento dos serviços. O gráfico 3.6 mostra que todos os tipos de prestadores apresentaram uma redução dos índices de atendimento de água e de coleta de esgoto, assim como um aumento dos desvios-padrão referentes a esses indicadores. Em relação ao índice de tratamento de esgoto, observa-se um aumento do valor médio nos locais privados bem superior ao ocorrido nos demais prestadores - essa melhora, contudo, não ocorreu no grupo dos privados como um todo. Deve-se destacar ainda o aumento da padronização dos índices de tratamento de esgoto dos regionais e dos locais públicos.

A análise da evolução dos indicadores operacionais e de cobertura mostrou, portanto, que os prestadores privados foram os que mais melhoraram, no período considerado, seu desempenho médio em relação aos aspectos operacionais e de cobertura considerados melhoraram o desempenho em quatro dos seis indicadores analisados, enquanto que os locais públicos melhoraram em três e os regionais apenas em dois. Deve-se destacar também que a melhora do desempenho, na maioria dos casos, não ocorreu em todas as entidades que compõem o grupo de prestadores privados - em alguns indicadores, houve um aumento dos desvio-padrão, ou seja, diminuiu a padronização dos índices das entidades. 


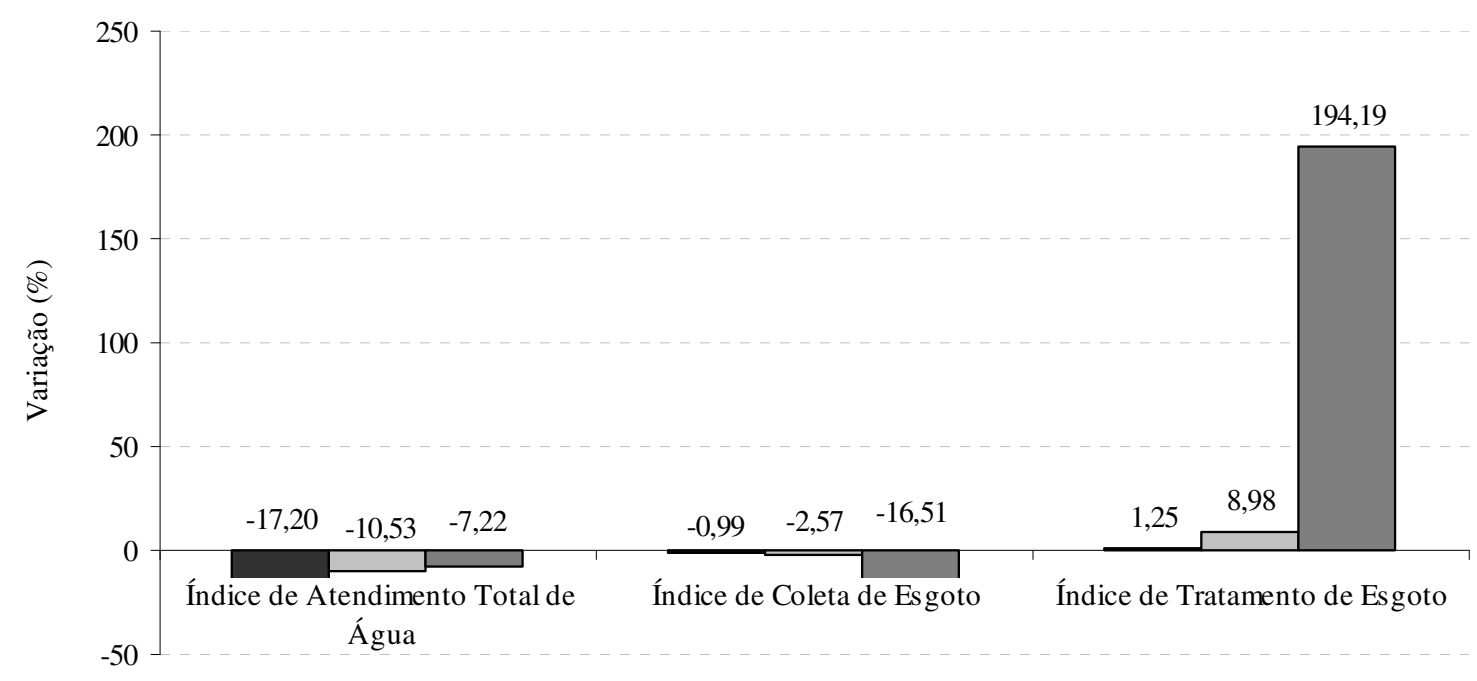

Prestador Regional $\square$ Prestador Local Público $\square$ Prestador Local Privado

\begin{tabular}{l|c|c|c}
\hline \multirow{2}{*}{$\begin{array}{c}\text { Indicador / } \\
\text { Prestador }\end{array}$} & \multicolumn{3}{|c}{ Variação do Desvio-Padrão (2000-2004) - em \% } \\
\cline { 2 - 4 } & $\begin{array}{c}\text { Atendimento de } \\
\text { Água }\end{array}$ & Coleta de Esgoto & $\begin{array}{c}\text { Tratamento de } \\
\text { Esgoto }\end{array}$ \\
\hline Regional & 1,02 & 15,89 & $-28,15$ \\
Local Público & 87,88 & 2,68 & $-7,42$ \\
Local Privado & 11,14 & 34,91 & 69,28 \\
\hline
\end{tabular}

Fonte: Ministério das Cidades, SNIS (2000 e 2004). Elaboração própria.

\section{Gráfico 3.6}

Saneamento básico no Brasil: variação dos índices de atendimento total de água, de coleta e de tratamento de esgoto (valor médio e desvio-padrão), segundo o tipo de prestador (2000 e 2004)

$\underline{\text { Indicadores econômicos, financeiros e administrativos }}$

A análise da evolução do desempenho dos prestadores de serviços de saneamento básico também pode ser realizada levando em consideração aspectos econômicos, financeiros e administrativos. Para isso, foram selecionados sete indicadores: (i) índice de economias por pessoal total, (ii) índice de pessoal próprio por mil ligações, (iii) tarifa média praticada, (iv) 
tarifa média de água, (v) tarifa média de esgoto e (vi) índice de evasão de receita e (vii) índice de desempenho financeiro.

A evolução dos dois primeiros é apresentada no gráfico 3.7. Observa-se que todos os prestadores apresentaram, na média, aumento de produtividade - nos dois indicadores, as maiores variações foram as apresentadas pelos locais privados. Deve-se destacar que o aumento da produtividade não ocorreu em todas as entidades que compõem os grupos de prestadores. Ou seja, a variação dos valores médios foi influenciada por melhoras de desempenho de uma ou algumas entidades pertencentes à amostra e não de todas.

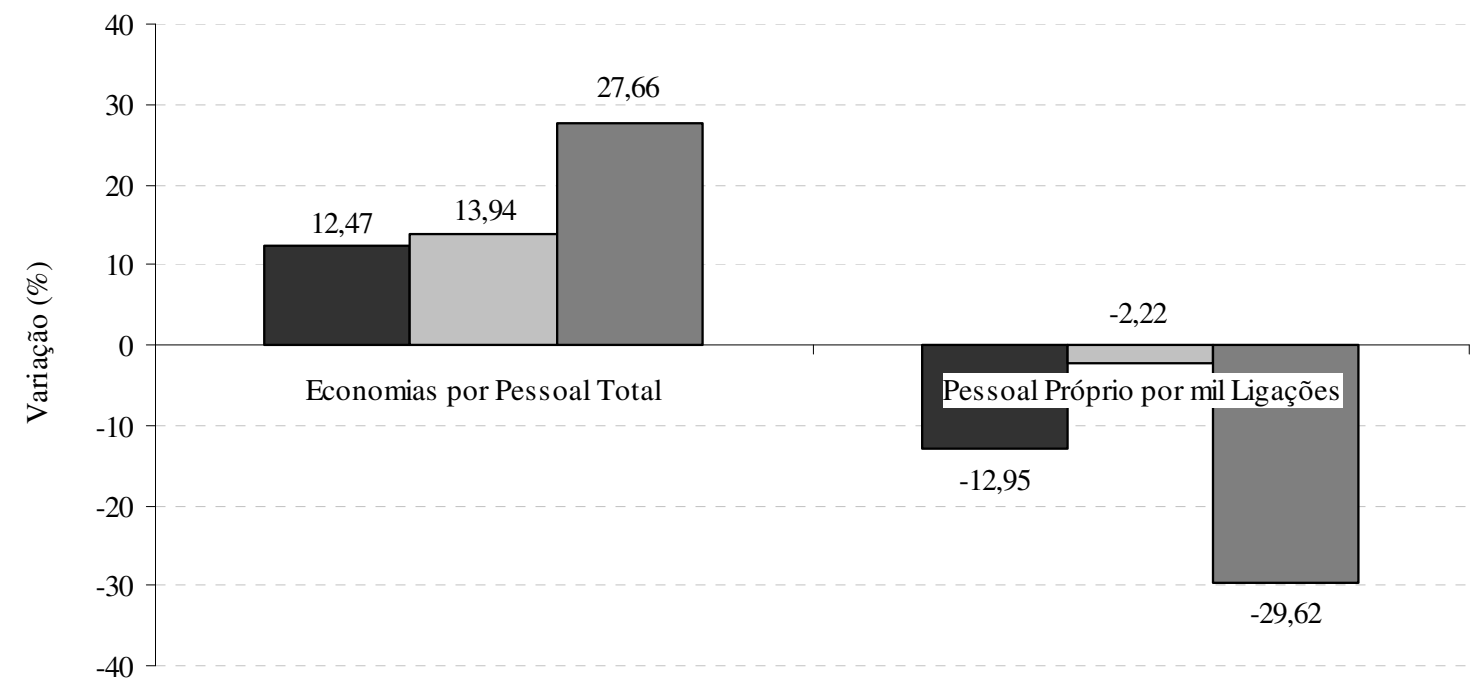

Prestador Regional $\square$ Prestador Local Público $\square$ Prestador Local Privado

\begin{tabular}{l|c|c}
\hline \multirow{2}{*}{$\begin{array}{c}\text { Indicador / } \\
\text { Prestador }\end{array}$} & \multicolumn{2}{|c}{ Variação do Desvio-Padrão (2000-2004) - em \% } \\
\cline { 2 - 3 } & $\begin{array}{c}\text { Economias por Pessoal } \\
\text { Total }\end{array}$ & $\begin{array}{c}\text { Pessoal Próprio por mil } \\
\text { Ligações }\end{array}$ \\
\hline Regional & 17,84 & $-21,22$ \\
Local Público & 54,75 & 8,93 \\
Local Privado & 30,37 & $-39,10$ \\
\hline
\end{tabular}

Fonte: Ministério das Cidades, SNIS (2000 e 2004). Elaboração própria.

\section{Gráfico 3.7}

Saneamento básico no Brasil: variação dos índices de economias por pessoal total e de pessoal próprio por mil ligações (valor médio e desvio-padrão), segundo o tipo de prestador (2000 e 2004) 
O gráfico 3.8, por sua vez, mostra a evolução das tarifas médias. É possível observar que estas aumentaram nos três tipos de prestadores e que esse aumento não ocorreu de forma uniforme em nenhum deles. Destaca-se o fato das tarifas médias terem aumentado mais nos locais privados. Comparando a evolução das tarifas dos dois serviços, em cada um dos prestadores, verifica-se uma maior variação da tarifa média de água nos locais privados e uma maior elevação da tarifa média de esgoto nos regionais e nos locais públicos.

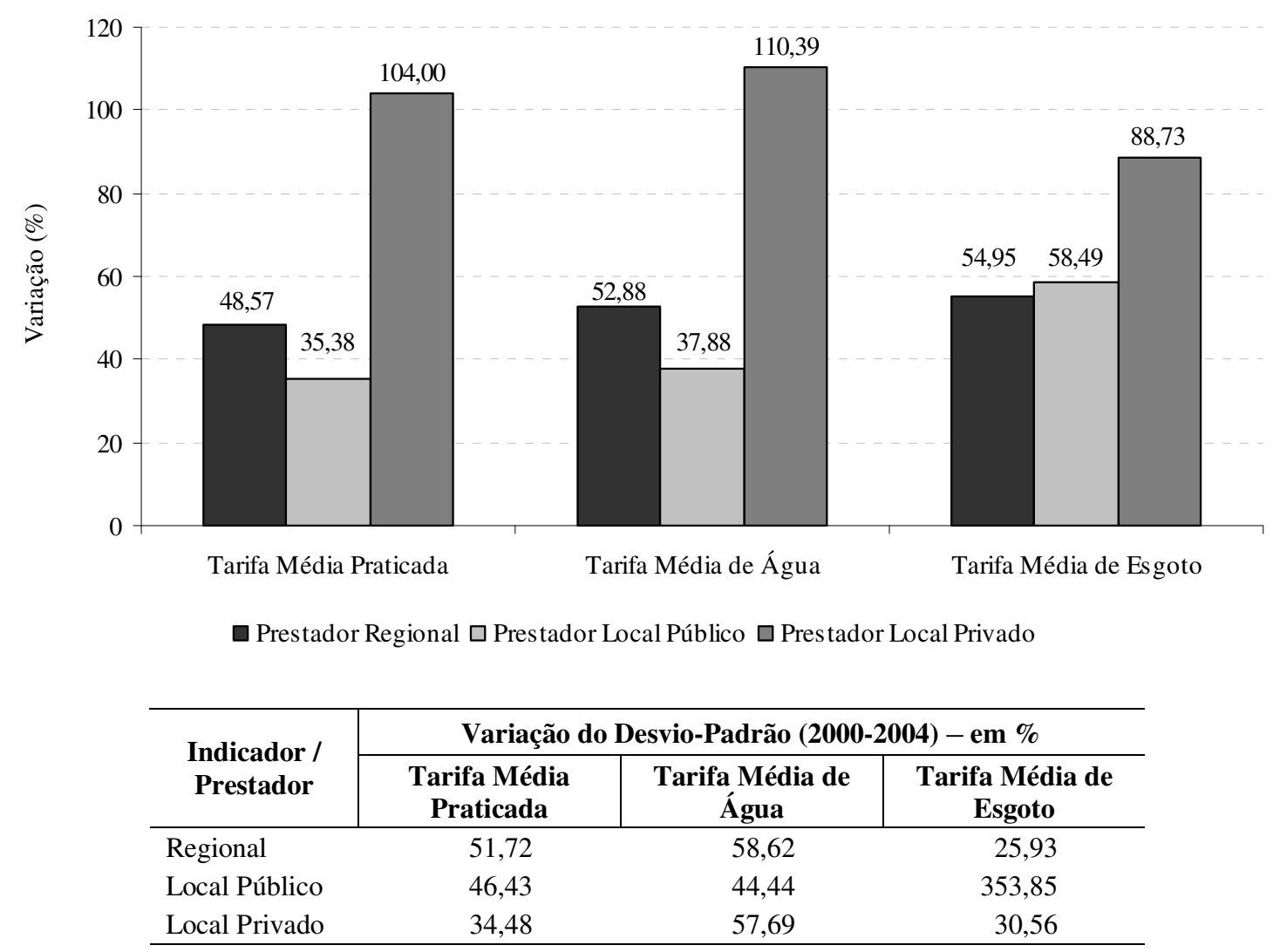

Fonte: Ministério das Cidades, SNIS (2000 e 2004). Elaboração própria.

\section{Gráfico 3.8}

Saneamento básico no Brasil: variação das tarifas médias praticadas, de água e de esgoto (valor médio e desvio-padrão), segundo o tipo de prestador (2000 e 2004)

Finalmente, o gráfico 3.9 apresenta a variação dos índices de evasão de receita e de desempenho financeiro. É possível observar que ocorreu uma piora de desempenho nos 
regionais, no caso do índice de evasão de receitas, e nos locais públicos, no caso do índice de desempenho financeiro. Nos demais casos, ocorreu uma melhora do desempenho médio, destacando-se a grande redução do índice médio de evasão de receitas dos locais privados. Deve-se apontar também que só é possível observar um aumento da padronização (redução do desvio-padrão) no caso dos índices de evasão de receita das entidades regionais e privadas.

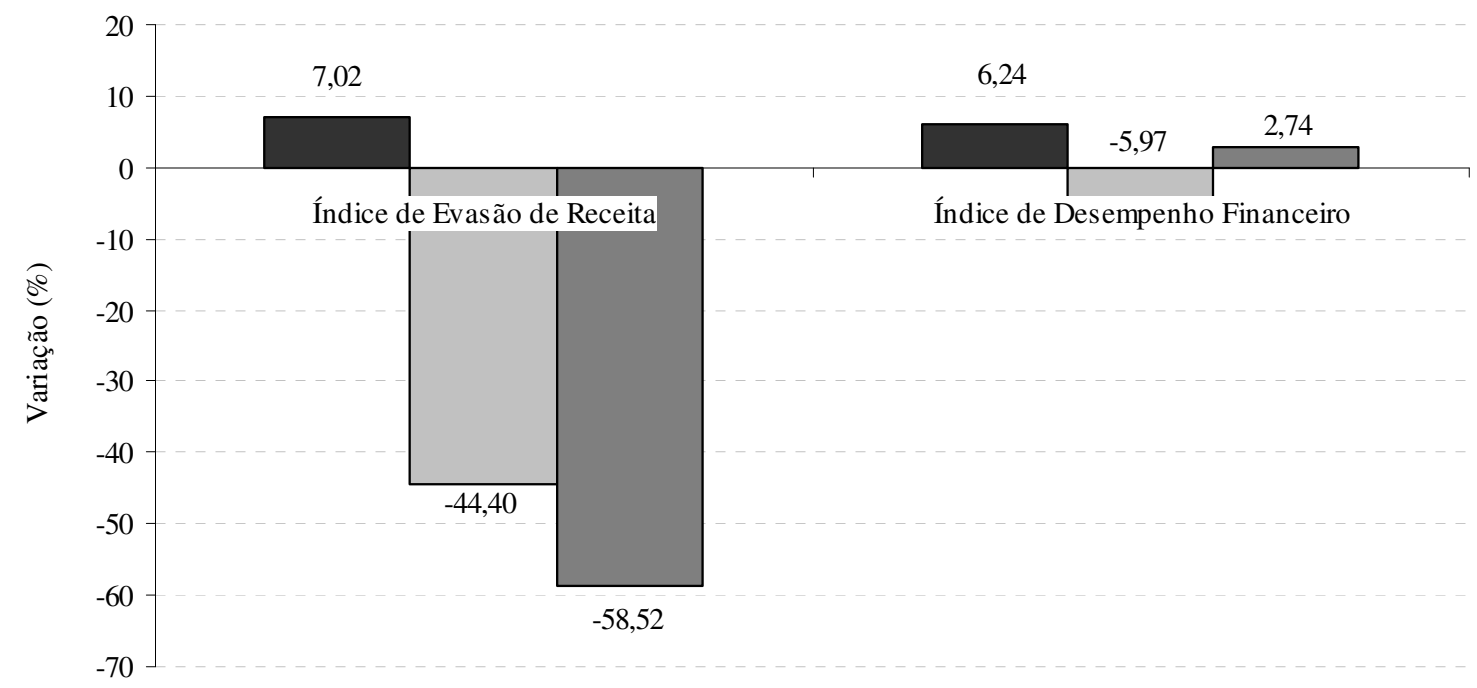

Prestador Regional $\square$ Prestador Local Público $\square$ Prestador Local Privado

\begin{tabular}{l|c|c}
\hline \multirow{2}{*}{$\begin{array}{c}\text { Indicador / } \\
\text { Prestador }\end{array}$} & Variação do Desvio-Padrão (2000-2004) - em \% \\
\cline { 2 - 3 } & Evasão de Receita & $\begin{array}{c}\text { Desempenho } \\
\text { Financeiro }\end{array}$ \\
\hline Regional & $-50,33$ & 4,28 \\
Local Público & 1,87 & 11,32 \\
Local Privado & $-56,82$ & 79,08 \\
\hline
\end{tabular}

Fonte: Ministério das Cidades, SNIS (2000 e 2004). Elaboração própria.

\section{Gráfico 3.9}

Saneamento básico no Brasil: variação dos índices de evasão de receita e de desempenho financeiro (valor médio e desvio-padrão), segundo o tipo de prestador (2000 e 2004)

A análise da evolução dos indicadores econômicos, financeiros e administrativos mostrou, portanto, que os prestadores locais privados foram os únicos que, na média, apresentaram melhora de desempenho em todos os indicadores analisados. Contudo, os locais 
privados também foram os prestadores que mais elevaram, na média, suas tarifas. Além disso, foi possível observar que as melhoras de desempenho ocorreram, de uma maneira geral, em apenas algumas entidades existentes na amostra.

$\underline{\text { Indicadores de qualidade }}$

Para avaliar a evolução do desempenho em relação a aspectos de qualidade, foram selecionados dois indicadores, ilustrados no gráfico 3.10: (i) o índice de duração média das intermitências e (ii) o índice de extravasamento de esgoto por extensão de rede.

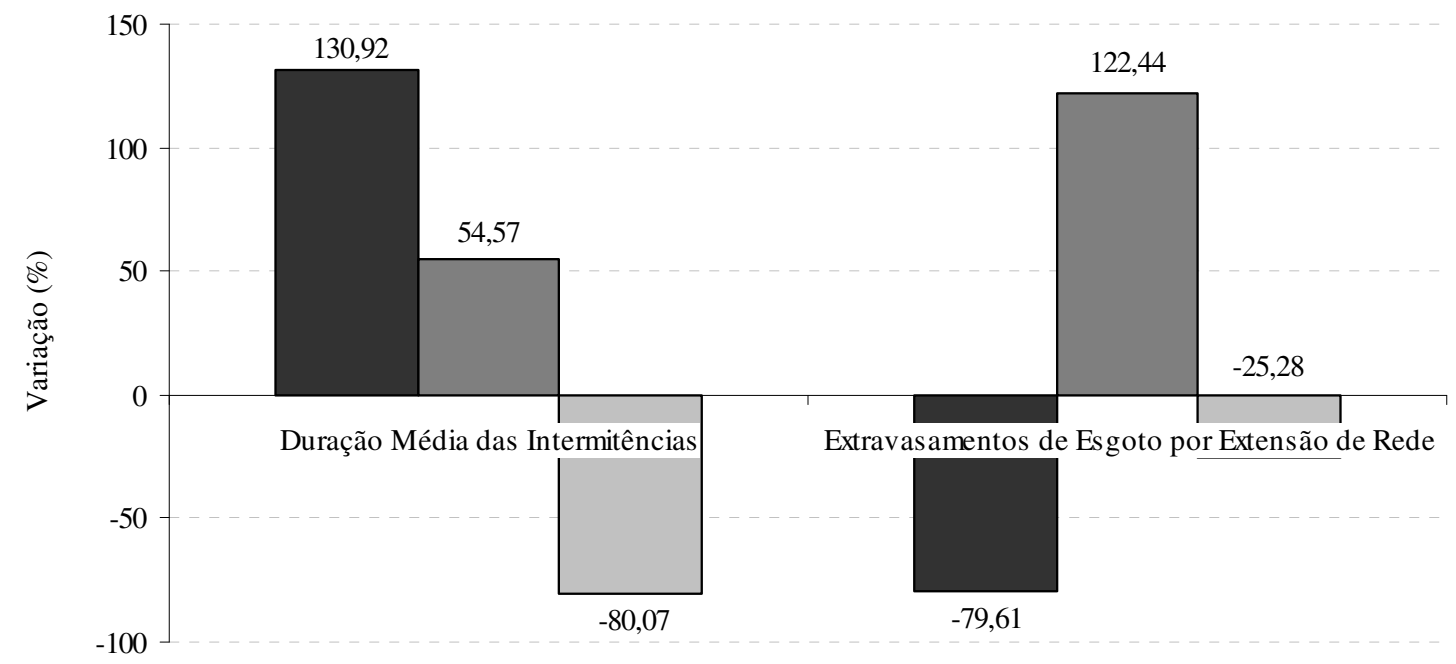

Prestador Regional $\square$ Prestador Local Público $\square$ Prestador Local Privado

\begin{tabular}{l|c|c}
\hline \multirow{2}{*}{$\begin{array}{c}\text { Indicador / } \\
\text { Prestador }\end{array}$} & \multicolumn{2}{|c}{ Variação do Desvio-Padrão (2000-2004) - em \% } \\
\cline { 2 - 3 } & $\begin{array}{c}\text { Duração Média das } \\
\text { Intermitências }\end{array}$ & $\begin{array}{c}\text { Extravasamentos de } \\
\text { Esgoto }\end{array}$ \\
\hline Regional & 503,82 & $-68,50$ \\
Local Público & 63,56 & 105,48 \\
Local Privado & $-85,18$ & $-56,03$ \\
\hline
\end{tabular}

Fonte: Ministério das Cidades, SNIS (2000 e 2004). Elaboração própria.

\section{Gráfico 3.10}

Saneamento básico no Brasil: variação dos índices de duração média das intermitências e de extravasamentos de esgoto (valor médio e desvio-padrão), segundo o tipo de prestador (2000 e 2004) 
Assim como nas anteriores, a análise da evolução dos indicadores de qualidade sugere que o desempenho médio dos prestadores locais privados é o que mais melhorou entre 2000 e 2004. Deve-se destacar que o aumento do desempenho desses prestadores não foi decorrência de um esforço para reverter uma situação inicial desfavorável - conforme é possível observar na tabela 50 do Apêndice, eles já possuíam, em 2000, desempenho médio superior aos demais em alguns dos indicadores analisados.

\section{Restriç̃os à expansão dos investimentos}

No início do capítulo, foi comentada a existência de uma série de questões que dificultam a expansão dos investimentos em saneamento básico no Brasil. Algumas delas já foram discutidas ao longo do trabalho - problemas institucionais, poucas fontes alternativas de financiamento e características do déficit de acesso domiciliar aos serviços. Resta avaliar a baixa geração de excedentes - conseqüência direta do fraco desempenho apresentado pelos prestadores de serviços - e aprofundar o debate sobre os impactos das regras fiscais. Tais análises serão realizadas na presente seção.

\subsection{Baixa geracão de excedentes}

De acordo com Parlatore (2000), o saneamento básico brasileiro acumulou, ao longo dos anos, "uma longa lista de problemas": (i) preferência à ampliação da produção de água, ao invés da redução de perdas e da racionalização do consumo; (ii) atuação deficiente na área comercial - falta de cadastro adequado de usuários, baixa medição do consumo e inexistência 
de políticas e de estruturas tarifárias ideais, assim como de regras eficazes de corte por falta de pagamento -; (iii) atendimento deficiente aos usuários - demora ou falta de resposta às solicitações e dificuldades na comunicação -; (iv) aumento excessivo do quadro de pessoal, em razão do uso político da organização; (v) atraso em relação às oportunidades de modernização gerencial e tecnológica, contribuindo para a elevação dos custos operacionais e (vi) descontinuidade administrativa, associada à gestão não profissional (p. 290-1).

Moreira (1998) também destaca alguns problemas observados no setor: (i) significativas perdas de faturamento - decorrentes tanto de perdas físicas (água produzida e não contabilizada) quanto comerciais (água produzida, distribuída, consumida e não medida) -; (ii) intermitência no fornecimento de água tratada; (iii) baixo índice de produtividade de pessoal; (iv) esgotos sem tratamento e (vi) baixo padrão de qualidade (p. 192-3).

Carmo e Távora Júnior (2003), utilizando dados do SNIS para o ano de 2000, realizaram um estudo para determinar o grau de eficiência técnica dos vinte e seis prestadores regionais de saneamento básico - vinte e cinco CESBs e a autarquia estadual do Acre. Adotaram, para isso, a metodologia de Análise Envoltória de Dados (DEA), por meio da qual é possível obter uma fronteira não-paramétrica de eficiência. Os resultados mostraram que existe um relevante número de companhias ineficientes e que a região Sudeste é a mais eficiente, seguida pelo Sul, Centro-Oeste, Norte e, por último, Nordeste.

Ohira (2005), por sua vez, utilizou dados do SNIS referentes ao ano de 2002 para calcular uma fronteira estocástica da função custo dos prestadores de serviços que atuam no Estado de São Paulo. Os resultados obtidos sinalizaram que esses prestadores apresentam um grande intervalo em relação às fronteiras de custo estimada. "Isso indica que existe um significativo potencial para o aprimoramento das empresas, buscando uma redução de custo (para os mesmos níveis de prestação de serviço) ou, alternativamente, elas poderiam - com o mesmo custo - expandir os serviços prestados" (p. 88). 
Portanto, além do déficit de acesso aos serviços - discutido no capítulo anterior - o saneamento básico brasileiro apresenta sérios problemas de eficiência na utilização da capacidade já instalada. Ou seja, uma parte significativa dos prestadores apresenta um fraco desempenho operacional, econômico, financeiro e administrativo, assim como não conseguem ofertar os serviços de maneira adequada, tanto em termos quantidade como de qualidade.

As ineficiências observadas podem ter origem em causas diversas. De um lado, podem refletir razões fora do controle humano. Altos custos na obtenção de água para abastecimento e/ou dificuldades na implantação das redes de água e esgoto (causada por variáveis topográficas ou geológicas) são exemplos dessa natureza. Por outro lado, as ineficiências podem estar relacionadas com fatores humanos. Deficiências gerenciais na administração das empresas de saneamento básico e a falta de fiscalização do uso correto dos recursos orçamentários dessas empresas são, tipicamente, as principais fontes do desperdício e malversão no uso de recursos, resultando no consequiente aumento dos custos e o aparecimento de ineficiências (OHIRA, 2005, p. 88-9).

Segundo Mejia et alii (2003), deve-se destacar também o fato das "autoridades

[federais], estaduais e municipais tende[re]m a politizar o processo decisório" dos prestadores de serviços - mesmo os privados -, além de interferirem diretamente em seu gerenciamento. "Consequentemente, os gestores dos serviços com freqüência não dispõem de autonomia para operar de forma eficiente" (p. 32). Trata-se do fenômeno chamado por Spiller e Savedoff (1999) de "equilíbrio de baixo nível” - comentado no primeiro capítulo.

\footnotetext{
Nesse tipo de equilíbrio, existe um círculo vicioso entre o oportunismo do governo, preços abaixo dos custos de fornecimento, ausência de investimentos e a baixa qualidade dos serviços de utilidade pública. [...] Com poucas exceções, a qualidade dos serviços de abastecimento urbano de água e de esgotamento sanitário no Brasil é de baixo nível. Esse resultado está associado ao modelo institucional e regulatório adotado. No entanto, as particularidades no caso brasileiro deixam mais evidente que o baixo nível está também associado às condições econômicas, uma vez que os estados e municípios de maior renda possuem serviços de alta qualidade, independentemente do sistema regulatório (FARIA; NOGUEIRA; MUELLER, 2005, p. 481).
}

$\mathrm{Na}$ seção anterior, observou-se que, em alguns indicadores, o desempenho médio dos prestadores de serviços melhorou significativamente entre 2000 e 2004. Essa melhora, contudo, não eliminou a baixa eficiência apresentada por grande parte das entidades que ofertam serviços de saneamento básico - na maioria dos casos, ocorreu um aumento dos desvios-padrão, ou seja, diminuiu a padronização dos índices das entidades que compõem 
cada grupo de prestador analisado. Além disso, o desempenho médio dos prestadores ainda não é ideal.

Nesse contexto, é importante comentar mais detalhadamente alguns indicadores analisados na terceira seção: (i) tarifas médias, (ii) índice de perdas de faturamento, (iii) índice de perdas na distribuição, (iv) índice de hidrometração e (v) índice de pessoal próprio por mil ligações.

Em relação às tarifas, deve-se destacar que os prestadores locais públicos foram os que apresentaram os menores valores médios em 2004 e os locais privados foram os que mais expandiram esse valor entre 2000 e 2004. As tarifas médias menores nos prestadores locais públicos pode ser resultado tanto de facilidades tributárias como da maior dificuldade política de se cobrar os consumidores, pela proximidade entre o eleitor e o gestor do(s) serviço(s). Já a maior expansão nos prestadores locais privados, pode ser resultado de regras de reajustes definidos nos contratos de concessões.

Faria, Nogueira e Mueller (2005), utilizando a amostra de prestadores do SNIS com dados referentes ao ano de 1999, constatou que, "na maior parte dos casos analisados, a tarifa média cobrada não paga o custo dos serviços por metro cúbico, principalmente quando prestados por companhias estaduais de saneamento (CESBs)" (p. 507). Por meio da amostra de 2004 do SNIS, também é possível verificar esse fato. Observa-se, na tabela 3.12, que 43\% dos prestadores apresentavam, naquele ano, tarifas médias inferiores às despesas totais com os serviços - no grupo dos regionais, essa proporção era de $75 \%$.

Em relação às perdas de água na distribuição, Mejia et alii (2003) afirmam que níveis elevados não apenas afetam o desempenho financeiro das companhias, como também desperdiçam um valioso e escasso recurso (p. 34). Esses mesmos autores salientam que, "tendo em vista os crescentes custos incorridos no desenvolvimento de novas fontes de suprimento de água, muitas vezes situadas a grandes distâncias, e o aumento da competição 
pela água entre vários setores usuários, as companhias de saneamento não podem se dar ao luxo de desperdiçar água” (p. 34).

Tabela 3.12

Saneamento básico no Brasil: tarifa média praticada e despesa total com os serviços por $\mathbf{m}^{3}$ faturado, segundo o tipo de prestador do serviço (2004)

\begin{tabular}{l|c|c|c|c}
\hline $\begin{array}{c}\text { Indicador } / \\
\text { Prestador }\end{array}$ & $\begin{array}{c}\text { Tarifa Média Praticada } \\
(\mathrm{a}) \\
\left(\mathrm{R} \$ / \mathrm{m}^{3}\right)\end{array}$ & $\begin{array}{c}\text { Despesa Total com os } \\
\text { Serviços }(\mathrm{b}) \\
\left(\mathrm{R} \$ / \mathrm{m}^{3}\right)\end{array}$ & $\begin{array}{c}\text { (a) - (b) } \\
\left(\mathrm{R} \$ / \mathrm{m}^{3}\right)\end{array}$ & $\begin{array}{c}\text { (a) - (b) negativo } \\
\text { (quantidade de } \\
\text { prestadores) }\end{array}$ \\
\hline Regional & 1,56 & 1,90 & $-0,34$ & $18(75 \%)$ \\
Local & 0,83 & 0,80 & 0,03 & $101(41 \%)$ \\
Privada & 1,33 & 1,10 & 0,23 & $7(29 \%)$ \\
Total & $\mathbf{0 , 9 4}$ & $\mathbf{0 , 9 2}$ & $\mathbf{0 , 0 2}$ & $\mathbf{1 2 6}(\mathbf{4 3 \%})$ \\
\hline
\end{tabular}

Fonte: Ministério das Cidades, SNIS (2004). Elaboração própria.

$\mathrm{Na}$ seção anterior, observou-se que os prestadores locais privados são os que apresentam um menor índice de perdas de faturamento. Contudo, esse índice é de aproximadamente $27 \%$, um valor bastante elevado - nos regionais, esse índice é superior a 40\%. Conforme já foi apontado, as perdas de faturamento decorrem, grosso modo, de perdas na distribuição e de falta de micromedição (hidrometração) do consumo. Os índices de perdas na distribuição dos prestadores também são bastante elevados - aproximadamente $49 \%$ nos regionais e um pouco mais que $25 \%$ nos demais prestadores - e uma grande parcela das ligações ativas de água ainda não é micromedida (índice de hidrometração) - $12 \%$ nos locais públicos e aproximadamente $25 \%$ nos demais prestadores.

Segundo Idelovitch e Ringskog (1995), o excesso de pessoal é um outro importante indicador de ineficiência na provisão de serviços de saneamento básico, uma vez que caracteriza uma baixa produtividade dos prestadores. Esses autores relatam que um prestador eficiente, seguindo padrões internacionais, é aquele que possui dois ou três empregados para cada mil ligações de água (p. 9). Meija et alii (2003), por sua vez, afirmam que o número 
ideal seria de dois funcionários por mil ligações, independentemente de ser ligação de água ou de esgoto - "embora o número ideal dependa das condições locais" (p. 32).

Conforme foi observado na seção anterior, o número médio de pessoal próprio por mil ligações em qualquer tipo de prestador de serviços existente no Brasil já é superior a três - se também for considerado o pessoal terceirizado, esse número é maior. Ou seja, de acordo com os padrões internacionais os prestadores são, na média, ineficientes no que se refere à produtividade do pessoal.

A principal conseqüência do fraco desempenho apresentado por grande parte dos prestadores de serviços de saneamento básico é a baixa geração de excedentes para a realização de investimentos no setor. Tal fato pode ser constatado por meio de duas estimações. Na primeira, o objetivo é avaliar se algumas variáveis de desempenho impactam sobre a probabilidade do prestador gerar excedente ou, pelo menos, cobrir suas despesas - ou seja, resultado (receita operacional total menos despesa total) maior ou igual a zero. $\mathrm{Na}$ segunda, o objetivo é estimar se o resultado de um prestador influencia os investimentos realizados por este - o que parece ser óbvio, mas que vale a pena ser comprovado econometricamente. Os dados necessários são disponibilizados pelo SNIS - amostra de prestadores referente ao ano de 2004.

Primeiramente, foi estimado, pelo método Probit, um modelo bastante simples, em que: (i) a variável dependente binária assume o valor um, se o resultado do prestador for maior ou igual a zero, ou o valor zero, caso contrário e (ii) as variáveis explicativas são três indicadores de desempenho - índice de perdas na distribuição, índice de hidrometração e índice de pessoal próprio por mil ligações. Os resultados da estimação são apresentados na tabela 3.13. Foram obtidos os seguintes sinais para os coeficientes e os efeitos marginais das variáveis explicativas: (i) positivo, para o índice de hidrometração, e (ii) negativos, para os índices de perdas na distribuição de pessoal próprio por mil ligações. 
Tabela 3.13

Resultados da estimação: variável dependente binária resultado do prestador (2004)

\begin{tabular}{|c|c|c|}
\hline Resultado do Prestador & Coeficiente & Efeito Marginal \\
\hline Índice de Perdas na Distribuição & $\begin{array}{c}-0,0071 * * \\
(0,0038)\end{array}$ & $\begin{array}{c}-0,0027 * * \\
(0,0014)\end{array}$ \\
\hline Índice de Hidrometração & $\begin{array}{l}0,0119 * \\
(0,0024)\end{array}$ & $\begin{array}{l}0,0045 * \\
(0,0009)\end{array}$ \\
\hline Índice de Pessoal Próprio por mil ligações & $\begin{array}{c}-0,1421 * \\
(0,0406)\end{array}$ & $\begin{array}{c}-0,0536 * \\
(0,0160)\end{array}$ \\
\hline Constante & $\begin{array}{c}0,3046 \\
(0,2791) \\
\end{array}$ & \\
\hline $\mathbf{y}=\operatorname{Pr}(\mathbf{y})($ predict $)$ & & 0,6304 \\
\hline Número de Observações & & 328 \\
\hline LR $\operatorname{chi}^{2}(10)$ & & 45,67 \\
\hline Prob $>$ chi $^{2}$ & & 0,0000 \\
\hline Pseudo-R2 & & 0,1091 \\
\hline
\end{tabular}

Obs.: Erro-padrão entre parênteses.

* Significativo a $1 \%$.

** Significativo a $10 \%$.

A seguir, estimou-se, pelo método dos Mínimos Quadrados Ordinários, um modelo mais simples ainda, em que as variáveis dependentes contínuas são: (i) investimentos realizados, pelo prestador, em água e (ii) investimentos realizados, pelo prestador, em esgoto. A única variável explicativa (contínua) considerada foi o resultado (receita operacional total menos despesa total) do prestador. Os resultados obtidos são apresentados na tabela 3.14. Observa-se que o sinal do coeficiente da variável explicativa é positivo.

Tabela 3.14

Resultados da estimação: variável dependente contínua investimentos realizados (2004)

\begin{tabular}{ccc}
\hline $\begin{array}{c}\text { Variável Dependente } / \\
\text { Explicativa }\end{array}$ & Investimento em Água & Investimento em Esgoto \\
\hline Resultado do Prestador & $0,4001 *$ & $0,7095 *$ \\
Número de Observações & $(0,0262)$ & $(0,0399)$ \\
F $(1,345)$ & 347 & 348 \\
Prob $>$ F & 232,54 & 316,18 \\
$\mathbf{R}^{2}$ & 0,0000 & 0,0000 \\
$\mathbf{R}^{2}$ Ajustado & $\mathbf{0 , 4 0 2 6}$ & $\mathbf{0 , 4 7 7 5}$ \\
\hline
\end{tabular}

Obs.: Erro-padrão entre parênteses.

* Significativo a $1 \%$. 
Portanto, os resultados das estimações comprovam que a probabilidade de um prestador apresentar resultado maior ou igual a zero aumenta à medida que melhora o seu desempenho - diminuição das perdas na distribuição e do pessoal próprio por mil ligações e aumento da hidrometração - e que, quanto mais elevado for esse resultado, maiores serão os investimentos realizados em água e em esgoto: (i) o prestador terá mais recursos próprios para investir ou (ii) sua capacidade de pagamento será maior, o que aumenta a chance de obtenção de empréstimos para realizar investimentos.

\section{$\underline{\text { Receita, despesa e resultado dos prestadores de serviços }}$}

Para finalizar esse item, é importante comparar o resultado dos diferentes tipos prestadores de serviços. Primeiramente, deve-se apontar que, na amostra de prestadores do SNIS referente ao ano de 2004, 35\% das entidades apresentavam resultado negativo, ou seja, suas receitas operacionais totais eram menores do que as suas despesas totais. No grupo dos regionais, $50 \%$ das entidades apresentavam resultado negativo - nos locais públicos e nos locais privados, essa proporção era de $34 \%$ e de $30 \%$, respectivamente. Tais fatos podem ser observados na tabela 3.15 .

Tabela 3.15

Saneamento básico no Brasil: distribuição dos prestadores da amostra, segundo a abrangência espacial e o resultado obtido (2004)

\begin{tabular}{l|c|c|c|c|c}
\hline \multirow{2}{*}{ Prestador } & \multirow{2}{*}{$\begin{array}{c}\text { Total } \\
\text { (número de entidades) }\end{array}$} & \multicolumn{2}{c|}{ Resultado Positivo } & \multicolumn{2}{c}{ Resultado Negativo } \\
\cline { 3 - 6 } & Quantidade & \% Total & Quantidade & \% Total \\
\hline Regional & 24 & 12 & $50 \%$ & 12 & $50 \%$ \\
Local Público & 293 & 194 & $66 \%$ & 99 & $34 \%$ \\
Local Privado & 27 & 19 & $70 \%$ & 8 & $30 \%$ \\
Total & $\mathbf{3 4 4}$ & $\mathbf{2 2 5}$ & $\mathbf{6 5 \%}$ & $\mathbf{1 1 9}$ & $\mathbf{3 5 \%}$ \\
\hline
\end{tabular}

Fonte: Ministério das Cidades, SNIS (2004). Elaboração própria. 
A tabela 3.16, por sua vez, mostra que o maior resultado total, em 2004, foi o dos prestadores regionais, seguidos pelos locais públicos e, por último, pelos locais privados. Contudo, os maiores resultados totais dos regionais e dos locais públicos decorrem, em parte, do maior número de municípios atendidos pelos primeiros e da maior quantidade de entidades do segundo tipo. Dessa forma, a comparação do resultado médio (resultado total do grupo divido pelo número de entidades) é mais relevante.

Tabela 3.16

Saneamento básico no Brasil: receita total, despesa total e resultado (total e médio), segundo o tipo de prestador (2004)

\begin{tabular}{|c|c|c|c|c|}
\hline Prestador & $\begin{array}{c}\text { Receita Operacional Total } \\
\text { (R\$ milhões) }\end{array}$ & $\begin{array}{l}\text { Despesa Total } \\
\text { (R\$ milhões) }\end{array}$ & $\begin{array}{l}\text { Resultado Total } \\
\text { (R\$ milhões) }\end{array}$ & $\begin{array}{l}\text { Resultado Médio } \\
\text { (R\$ milhões) }\end{array}$ \\
\hline Regional (1) & $13.996,62$ & $13.607,97$ & 388,65 & 16,19 \\
\hline Regional (2) & $9.354,13$ & $9.331,06$ & 23,07 & 1,00 \\
\hline Local Público & $2.259,86$ & $2.012,97$ & 246,90 & 0,84 \\
\hline Local Privado & 442,99 & 411,48 & 31,50 & 1,17 \\
\hline \multicolumn{5}{|c|}{ Prestadores Regionais } \\
\hline Caerd/RO & 42,88 & 75,11 & $-32,24$ & $-32,24$ \\
\hline Deas/AC & 4,05 & 13,99 & $-9,94$ & $-9,94$ \\
\hline Caer/RR & 21,88 & 32,54 & $-10,65$ & $-10,65$ \\
\hline Cosanpa/PA & 124,16 & 235,71 & $-111,55$ & $-111,55$ \\
\hline Caesa/AP & 21,31 & 36,60 & $-15,29$ & $-15,29$ \\
\hline Saneatins/TO & 79,06 & 70,25 & 8,81 & 8,81 \\
\hline Caema/MA & 140,70 & 219,88 & $-79,18$ & $-79,18$ \\
\hline Agespisa/PI & 104,02 & 182,74 & $-78,72$ & $-78,72$ \\
\hline Cagece/CE & 351,55 & 306,99 & 44,56 & 44,56 \\
\hline Caern/RN & 176,33 & 161,36 & 14,96 & 14,96 \\
\hline Cagepa/PB & 215,96 & 226,90 & $-10,93$ & $-10,93$ \\
\hline Compesa/PE & 446,74 & 424,41 & 22,33 & 22,33 \\
\hline Casal/AL & 116,37 & 124,30 & $-7,93$ & $-7,93$ \\
\hline Deso/SE & 144,67 & 142,63 & 2,04 & 2,04 \\
\hline Embasa/BA & 625,05 & 665,60 & $-40,55$ & $-40,55$ \\
\hline Saneago/GO & 477,14 & 466,01 & 11,12 & 11,12 \\
\hline Caesb/DF & 484,67 & 494,19 & $-9,52$ & $-9,52$ \\
\hline Copasa/MG & $1.316,97$ & $1.277,53$ & 39,44 & 39,44 \\
\hline Cesan/ES & 276,23 & 205,42 & 70,81 & 70,81 \\
\hline Cedae/RJ & $1.894,21$ & $1.869,36$ & 24,85 & 24,85 \\
\hline Sabesp/SP & $4.642,49$ & $4.276,91$ & 365,58 & 365,58 \\
\hline Sanepar/PR & $1.104,70$ & 917,28 & 187,43 & 187,43 \\
\hline Casan/SC & 355,48 & 350,45 & 5,02 & 5,02 \\
\hline Corsan/RS & 830,02 & 831,81 & $-1,8$ & $-1,8$ \\
\hline
\end{tabular}

Fonte: Ministério das Cidades, SNIS (2004). Elaboração própria.

(1) Prestadores regionais incluindo a Sabesp (companhia estadual do Estado de São Paulo).

(2) Prestadores regionais excluindo a Sabesp (companhia estadual do Estado de São Paulo). 
Analisando o resultado médio, observa-se uma alteração em relação ao anterior: o desempenho dos prestadores locais privados torna-se melhor do que o dos locais públicos. Deve-se ressaltar também que o maior resultado (total e médio) dos prestadores regionais é influenciado pelo desempenho de uma única entidade pertencente ao grupo, a Sabesp - CESB do Estado de São Paulo. Se os dados dessa CESB forem desconsiderados, observa-se que o resultado total do grupo é inferior aos dos demais e o resultado médio ao dos locais privados. Destaca-se ainda o fato do resultado médio ser pequeno em quase todos os prestadores, exceto nos regionais incluindo a Sabesp.

A evolução do resultado médio dos diferentes tipos de prestadores de serviços de saneamento básico, entre 2000 e 2004, é ilustrada no gráfico $3.11^{9}$.

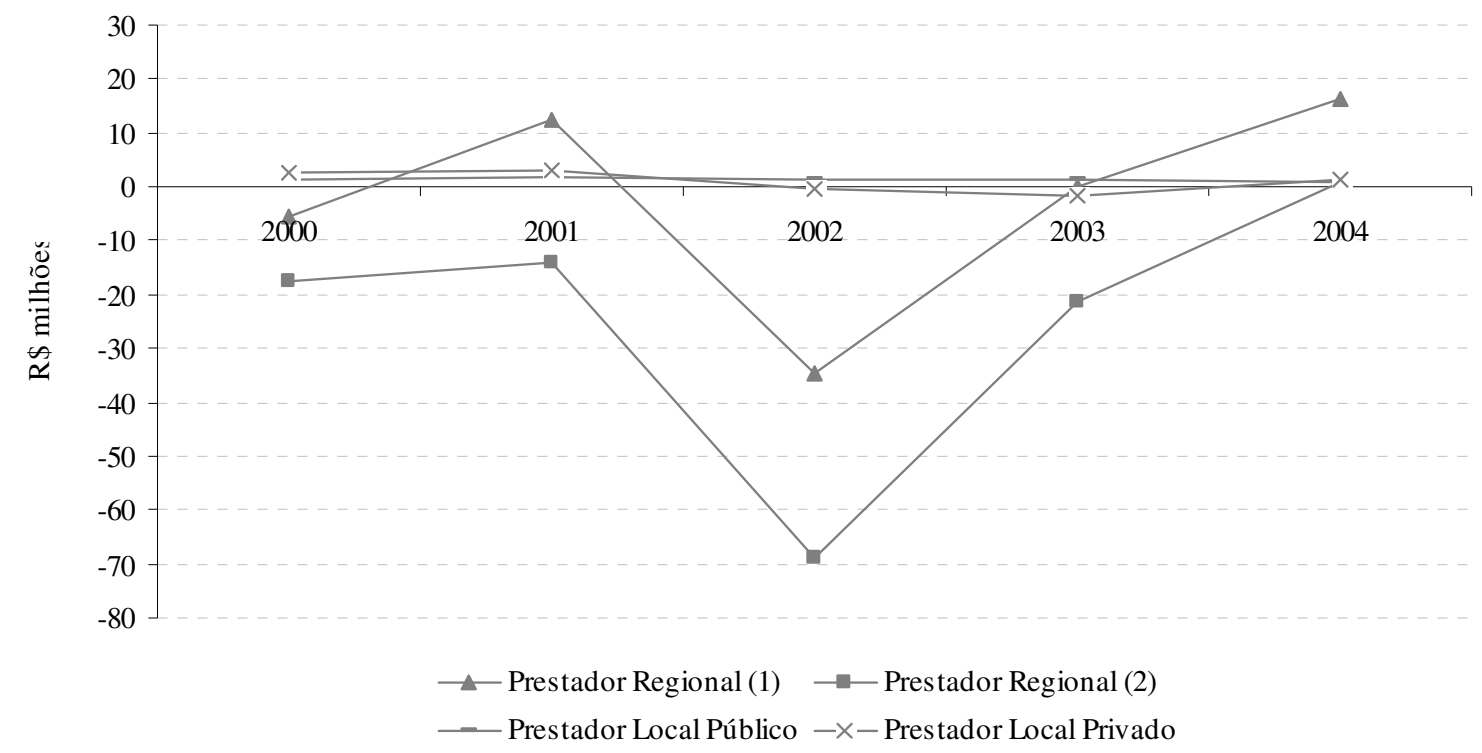

Fonte: Ministério das Cidades, SNIS (2000 e 2004). Elaboração própria.

(1) Prestadores regionais incluindo a Sabesp (companhia estadual do Estado de São Paulo).

(2) Prestadores regionais excluindo a Sabesp (companhia estadual do Estado de São Paulo).

\section{Gráfico 3.11}

Saneamento básico no Brasil: evolução do resultado médio, segundo o tipo de prestador (2000 e 2004)

\footnotetext{
${ }^{9}$ Os dados utilizados para a confecção desse gráfico estão no Apêndice - tabela 51.
} 
Observa-se, no gráfico 3.11, que o resultado médio dos regionais variou bastante de um ano para o outro, atingindo, inclusive, valores bem abaixo de zero - apenas em 2004, o valor médio dos regionais sem a Sabesp foi positivo. Nos locais públicos e privados, a variação foi pequena e, em nenhum ano, estes apresentaram um resultado médio muito alto - ou seja, em nenhum ano, geraram elevados excedentes.

Por último, também é importante avaliar o resultado médio de cada tipo de prestador segundo as grandes regiões e o Estado de São Paulo - o que pode ser feito por meio da análise dos dados apresentados na tabela 3.17.

Tabela 3.17

Saneamento básico no Brasil: resultado médio (R\$ milhões), segundo o tipo de prestador do serviço, as grandes regiões e o Estado de São Paulo (2004)

\begin{tabular}{l|c|c|c|c}
\hline $\begin{array}{c}\text { Prestador / } \\
\text { Região }\end{array}$ & Regional & Local Público & Local Privado & Total \\
\hline Norte & $-28,48$ & 0,11 & $-2,27$ & $-6,94$ \\
Nordeste & $-14,83$ & 0,15 & $*$ & $-1,47$ \\
Centro-Oeste (1) & 0,53 & 0,08 & 0,14 & 0,11 \\
Centro-Oeste (2) & 5,56 & 0,08 & 0,14 & 0,24 \\
Sudeste (3) & 125,17 & 1,65 & 2,45 & 5,67 \\
Sudeste (4) & 45,03 & 0,92 & 2,54 & 3,28 \\
São Paulo & 365,58 & 2,27 & 2,30 & 7,95 \\
Sul & 63,55 & 0,96 & 6,58 & 4,68 \\
Brasil & $\mathbf{1 6 , 1 9}$ & $\mathbf{0 , 8 4}$ & $\mathbf{1 , 1 7}$ & $\mathbf{1 , 8 4}$ \\
\hline
\end{tabular}

Fonte: Ministério das Cidades, SNIS (2004). Elaboração própria.

(1) Centro-Oeste incluindo o Distrito Federal.

(2) Centro-Oeste excluindo o Distrito Federal.

(3) Sudeste incluindo São Paulo.

(4) Sudeste excluindo São Paulo.

* Não há esse tipo de prestador na região.

Observa-se que os prestadores regionais localizados no Norte e no Nordeste apresentaram, em 2004, resultado médio negativo, o mesmo ocorrendo com os locais privados que atuam nessa última região. Nas demais regiões e no Estado de São Paulo, todos os prestadores apresentaram resultado positivo - destaca-se o fato do resultado médio do Sudeste ser superior aos demais em todos os tipos de prestadores. 


\subsection{Regras fiscais}

Em um setor cuja provisão dos serviços é realizada, predominantemente, pelos estados e pelos municípios, como o saneamento básico brasileiro - conforme ficou claro no primeiro capítulo -, o endividamento subnacional apresenta-se como uma importante fonte de "alavancagem" dos recursos necessários para a realização dos investimentos. Trata-se, porém, de um assunto polêmico que gera acirrado debate.

Para seus defensores, o endividamento subnacional, num contexto de crescimento das despesas de capital, é fundamental, uma vez que possibilita uma maior flexibilidade orçamentária - antecipa receitas e permite a realização e a manutenção de despesas. Gera-se, assim, uma distribuição eqüitativa dos recursos, tanto em termos setoriais como intertemporais. Peterson (2000), por exemplo, afirma que o endividamento promove uma “eqüidade inter-geracional”, compatibilizando o período de pagamento da dívida com o tempo de vida/consumo do projeto (p. 6) - ou seja, a geração beneficiada pelos serviços é aquela que paga por sua implantação.

Deve-se ressaltar que, para isso ocorrer, o endividamento tem de ser usado somente em investimentos capazes de gerar retornos financeiros futuramente (MUSGRAVE; MUSGRAVE, 1973). Nos investimentos de caráter exclusivamente social - não geram retorno financeiro no futuro -, é aconselhável o financiamento com recursos fiscais, assim como nos gastos correntes. Caso contrário, não ocorrerá uma "eqüidade inter-geracional", mas sim uma transferência para o futuro dos custos dos benefícios desfrutados hoje.

Já para seus críticos, o endividamento subnacional poderia ser usado de acordo com interesses políticos, viabilizando despesas com objetivos eleitorais e deixando os encargos para os próximos administradores. Além disso, restringiria a condução eficiente da gestão macroeconômica, uma vez que, para os críticos, há uma incompatibilidade entre a 
descentralização fiscal - e a conseqüente necessidade de endividamento subnacional - e a estabilização econômica - argumentam que a condução da política fiscal é uma função federal, por esta ser intimamente relacionada à política monetária, que continua sendo uma responsabilidade central (GREMAUD; TONETO JÚNIOR, 2000, p. 4).

É importante apontar que em muitos dos países, citados pelos críticos como exemplos de localidades onde o endividamento subnacional se tornou parte fundamental do excessivo déficit público - Argentina, Colômbia, Hungria, Rússia, entre outros -, as esferas subnacionais tomaram recursos para financiar gastos correntes, o que, conforme foi comentado anteriormente, não é apropriado - efeito inter-geracional negativo.

Destaca-se também o fato de que alguns países - Suíça e Canadá, por exemplo - terem conduzido programas de descentralização que auxiliaram a manutenção de políticas macroeconômicas estáveis - conseqüência de ganhos de eficiência na gestão dos recursos. Ou seja, é possível existir um alto nível de descentralização financeira sem que a estabilidade macroeconômica nacional seja comprometida. Para isso ocorrer, é fundamental a existência de um arcabouço institucional adequado que controle mais estritamente as finanças subnacionais, sem chegar ao extremo de proibir o endividamento dessas esferas de governo. Ou seja, o endividamento subnacional não precisa ser proibido, mas deve ser controlado para não se tornar excessivo.

O que seria endividamento excessivo? Peterson (2000) aponta três interpretações diferentes para essa questão. Para os envolvidos diretamente na transação - grosso modo, aqueles que emprestam e as esferas subnacionais (tomadores) -, endividamento excessivo seria aquele acima da capacidade de pagamento, ou seja, haveria o risco de default. De acordo com a perspectiva de eficiência econômica, endividamento excessivo ocorre quando os estados e os municípios tomam recursos para financiar projetos com taxas de retorno inferiores a outros projetos ou ao custo do capital - o crédito poderia ser mais produtivo se 
fosse realocado. Há também a visão macroeconômica, na qual endividamento excessivo é aquele que financia déficit corrente, diminuindo o crédito que poderia ser utilizado para financiar investimentos e podendo ter efeitos sobre a estabilidade do país - esse conceito é o mais utilizado para justificar o controle sobre o endividamento subnacional (p. 16).

Para controlar o endividamento subnacional, evitando que ele se torne excessivo, é importante a definição de um quadro regulatório apropriado que permita a elevação da dívida de longo prazo dos estados e dos municípios apenas para financiar aumentos de investimentos de capital - como é caso dos investimentos em saneamento básico.

\begin{abstract}
Diversos países desenvolveram regras para limitação de endividamento público, quer de forma direta, com limites para o montante, quer de forma indireta, limitando-se os fatores que aumentam a dívida pública, como o nível de gastos ou de déficit público. [Essas] regras fiscais teriam o papel de assegurar credibilidade para a política econômica, garantindo o equilíbrio intertemporal do orçamento do governo, e de evitar, ou pelo menos reduzir, a geração de externalidades negativas de um país (LIMA, 2002, p. 4).
\end{abstract}

No Brasil, as regras e os limites fiscais ${ }^{10}$ referentes ao endividamento subnacional foram previstos na Lei de Responsabilidade Fiscal (LRF). A LRF, promulgada em de 4 de maio de 2000, "configura um sistema de planejamento, execução orçamentária e disciplina fiscal, até então inexistente" (OLIVEIRA, 2000, p. 5), estabelecendo normas de finanças públicas voltadas para a responsabilidade na gestão fiscal. Ou seja, pode ser considerada como um código de conduta que busca disciplinar os administradores públicos de todo o país - relativos tanto aos três poderes (executivo, legislativo e judiciário) como às três esferas de governo (federal, estadual e municipal) -, tornando-os compromissados com metas e limites que visam a melhora da administração das contas públicas. De acordo com a própria lei, partiu-se do princípio de que

a responsabilidade na gestão fiscal pressupõe a ação planejada e transparente, em que se previnem riscos e corrigem desvios capazes de afetar o equilíbrio das contas públicas, mediante o cumprimento de metas de resultados entre receitas e despesas e

10 "Entende-se regra fiscal como uma restrição legal ou constitucional a determinadas variáveis fiscais como endividamento, déficit, gastos etc." (LIMA, 2002, p. 4). "Por "limites fiscais", entendemos os parâmetros determinados pela legislação em sentido amplo - Constituição, leis, resoluções e similares - para a atividade financeira do ente público" (OLIVEIRA FILHO, 2005, p. 163). 
a obediência a limites e condições no que tange a renúncia de receita, geração de despesas com pessoal, da seguridade social e outras, dívidas consolidada e mobiliária, operações de crédito, inclusive por antecipação de receita, concessão de garantia e inscrição em Restos a Pagar (LEI COMPLEMENTAR Nº 101, 2000, art. $\left.1^{\mathrm{o}}, \S 1^{\mathrm{o}}\right)$

Outras definições importantes da LRF referem-se ao comportamento de um governante em um ano de eleição e à necessidade de uma administração pública mais transparente, por meio de ampla divulgação dos planos, orçamentos e leis de diretrizes orçamentárias, inclusive com a publicação de um Relatório de Gestão Fiscal, no qual todos os administradores públicos devem prestar conta. Além disso, também previu sanções e penalidades que devem ser adotadas no caso do descumprimento de alguma de suas definições - complementa-a, nesse sentido, a Lei $\mathrm{n}^{\mathrm{o}} 10.028$ de 2000, conhecida como Lei de Crimes Fiscais.

Antes de comentar mais detalhadamente as definições da LRF em relação ao endividamento subnacional, deve-se apontar que, para este se viabilizar, é de suma importância o desenvolvimento de sistemas de crédito subnacional. Conforme salienta Peterson (2000), os sistemas de crédito subnacional têm como principal função fazer com que ocorra o "encontro" entre aqueles que demandam recursos - autoridades subnacionais - e aqueles que ofertam recursos individualmente ou por meio de instituições financeiras (p. 1). Ou seja, o objetivo é prover recursos (créditos) para financiar os projetos de investimentos das autoridades subnacionais ${ }^{11}$.

Além de facilitarem o acesso a outras fontes de financiamento, os sistemas de crédito a esferas subnacionais podem ajudar na melhora da eficiência dos investimentos e da provisão dos serviços, dado que os governos beneficiados pelos recursos passam a perceber o "verdadeiro custo" do capital, buscando projetos e preços mais realistas.

11 Para a implantação de sistemas de crédito subnacional em países em desenvolvimento, dois "grandes paradigmas" apresentam-se: (i) o modelo europeu, baseado em bancos especializados e (ii) o modelo norteamericano, baseado em títulos. Além disso, para o início do desenvolvimento, é comum, no mundo todo, a criação de instituições monopolistas públicas - bancos estatais ou fundos de desenvolvimento - que emprestam às autoridades subnacionais, introduzindo o crédito subnacional, até que a iniciativa privada sinta-se atraída a participar desse mercado. Para mais detalhes, ver Peterson (2000). 
Peterson (2000) e Fernandes (2000) apontam três condições que devem ser observadas para que o mercado de crédito subnacional se desenvolva e passe a apresentar um bom desempenho: (i) sistema tributário moderno, com distribuição clara de receitas e encargos; (ii) clareza das finanças estaduais e municipais, com regras explícitas sobre prestação de contas e transparência, bem como sobre as responsabilidades dos administradores, e (iii) definição, de maneira clara, justa e lógica, dos limites e dos controles sobre o endividamento.

A distribuição clara de receitas e encargos entre as diferentes esferas de poder é importante, pois, caso contrário, "as autoridades não podem elaborar orçamentos eficientes, estender seu horizonte de planejamento por um período mais longo, dar garantias aceitáveis aos seus credores, nem implantar, operacionalizar ou, eventualmente, regular seus diversos projetos" (FERNANDES, 2000, p. 6).

Conforme foi apontado no primeiro capítulo, a Constituição de 1988 aprofundou o processo de descentralização fiscal que já vinha sendo implementado desde 1984. Esse processo, contudo, acabou gerando alguns problemas, destacando-se a descentralização "forçada" de encargos, que prejudica o desenvolvimento de sistemas de crédito municipal. Essa situação só começou a ser revista em meados dos anos 1990. No entanto, muito ainda tem de ser feito para solucionar o problema da distribuição de encargos no país.

Por outro lado, a LRF satisfaz a segunda condição necessária - clareza das finanças estaduais e municipais. Isto porque a Lei, ao estabelecer normas de finanças públicas voltadas para a responsabilidade na gestão fiscal, acabou contribuindo para o disclosure das finanças dos estados e dos municípios brasileiros. A transparência da administração pública é tão importante para a LRF, que todos os administradores públicos são obrigados a publicar, a cada quatro meses, o Relatório de Gestão Fiscal, no qual estes prestam conta aos cidadãos.

A questão do endividamento subnacional também é tratada na LRF, assim como, nas posteriores Resoluções no 40 e no 43 do Senado Federal - previstas na lei. Nessas resoluções, 
definiu-se que a capacidade de endividamento de um governo subnacional, por meio das chamadas operações de crédito - entre as quais, se encontram os empréstimos bancários e os títulos municipais - é igual a $16 \%$ da sua receita corrente líquida ${ }^{12}$. Além disso, o pagamento anual de amortizações, juros e demais encargos da dívida não pode ser superior a $11,5 \%$ da receita corrente líquida e a dívida consolidada não poderá exceder, após o prazo de quinze exercícios contados a partir do ano subseqüente à promulgação da $L R F$, a 1,2 vezes o montante dessa receita ${ }^{13}$.

Portanto, a LRF e as conseqüentes Resoluções do Senado Federal podem ser consideradas como um avanço, uma vez que facilitaram o controle e a padronização das contas municipais. Ou seja, garantiram uma maior transparência das finanças estaduais e municipais e estipularam regras de endividamento - pré-requisitos fundamentais para o desenvolvimento de sistemas de crédito subnacional.

Contudo, ao mesmo tempo em que representaram um avanço, a LRF e as Resoluções do Senado Federal podem ser consideradas como mecanismos coercivos e punitivos, agindo no "policiamento" das condutas dos governos locais. Isto porque, ao estipularem regras gerais de endividamento que devem ser cumpridas e que são rígidas e universais a todos os estados e municípios, acabaram impondo sérias limitações à obtenção de recursos que poderiam ser utilizados para investimentos com rentabilidade futura suficiente para suprir as obrigações da dívida e, em alguns casos, obter lucro - tanto é verdade que muitos setores de infra-estrutura urbana, inclusive o saneamento básico, atraem a iniciativa privada em busca de rentabilidade.

\footnotetext{
12 Somatório das receitas tributárias, de contribuições, patrimoniais, industriais, agropecuárias, de serviços, transferências correntes e outras receitas também correntes, menos a contribuição dos servidores para o custeio do seu sistema de previdência e assistência social.

13 Deve ser respeitado também o artigo 167, inciso III da Constituição de 1988, que veda a realização de operações de crédito que excedam as despesas de capital, ressalvados os créditos suplementares ou especiais com finalidade precisa, aprovados pelo Poder Legislativo por maioria absoluta. "Esse comando traz a chamada "regra de ouro", que pretende coibir o financiamento, via operação de crédito, de despesas correntes. É matéria orçamentária, ou seja, o limite das operações de crédito é o montante das despesas de capital previsto na lei orçamentária anual" (NASCIMENTO; GERARDO, 2003, p. 9).
} 
Simonetti (2006) relata que uma das conseqüências da LRF foi a concentração de um grande volume de dívidas nos grandes municípios. "Antes de 2000, quarenta municípios estavam acima dos limites estabelecidos na LRF. O número caiu para doze em 2004. A capital paulista, quarta maior cidade do planeta, é responsável por $49,76 \%$ do total [da dívida dos municípios]" (p. 29). Menezes (2005), por sua vez, constatou que a LRF reduziu os investimentos como um todo e, especificamente, as despesas com infra-estrutura. O autor apontou três fatores como as possíveis causas dessa redução: (i) restrição de gastos em anos eleitorais - momento em que, historicamente, os investimentos são maiores -; (ii) "engessamento" de grande parte do orçamento subnacional, comprometido com despesas vinculadas, e (iii) restrições ao endividamento (p. 797).

O endividamento subnacional no Brasil também é controlado, mesmo que indiretamente, pelas resoluções do Conselho Monetário Nacional, que dispõem sobre o contingenciamento de crédito ao setor público. É importante destacar que tais resoluções assumem todos os pré-requisitos sobre os limites individuais de endividamento para cada esfera de governo definidos na LRF e nas resoluções do Senado Federal, mas introduzem dificuldades adicionais, principalmente definindo limites globais e por instituição financeira para operações com o setor público como um todo. Conforme foi apontado no primeiro capítulo, atualmente, o limite global para operações de crédito com o setor público, relacionadas ao saneamento básico, é de $\mathrm{R} \$ 2,2$ bilhões - além disso, deve ser respeitado o limite de $45 \%$ do patrimônio líquido de cada instituição para operações com o setor publico.

Uma outra resolução importante para o setor, não apontada anteriormente, é a de $n^{o}$ 3.347, de janeiro de 2006, entidades do Sistema Brasileiro de Poupança e Empréstimo (SBPE) a direcionarem até $2 \%$ das aplicações obrigatórias de recursos da poupança para o financiamento de projetos de investimentos de concessionárias privadas de saneamento ou para os municípios - ou consórcio de municípios que, em conjunto, tenham mais de cem mil 
habitantes - contratarem estudos técnicos para a estruturação de modelos de parceria entre o setor público e o setor privado no setor. Trata-se, portanto, de um incentivo para o aumento da participação privada no setor.

\subsection{Baixa geracão de excedentes e regras fiscais: conseqüências}

O Ministério das Cidades, para a concretização de operações de crédito relacionadas ao saneamento básico, adota as etapas de análise apresentadas no quadro 3.2. Por meio desse quadro, fica claro que o desempenho do prestador (eficiência) é um fatores analisados - isso ocorre na quinta etapa (hierarquização e habilitação). Comprova-se, assim, que um prestador de serviço, seja ele público ou privado, precisa apresentar um bom desempenho (eficiência) para obter empréstimos.

\section{Quadro 3.2}

Etapas para a concretização de operações de crédito com o Ministério das Cidades

\begin{tabular}{|c|c|}
\hline Etapas & Caracterização \\
\hline \multirow{2}{*}{$1^{\mathrm{a}}$} & $\underline{\text { Apresentação da Carta-Consulta }}$ \\
\hline & $\rightarrow$ após protocoladas, integram o conjunto de operações analisadas por técnicos do Ministério \\
\hline \multirow{2}{*}{$2^{\mathrm{a}}$} & Enquadramento Prévio \\
\hline & $\rightarrow$ definição de quais modalidades de serviços obterão financiamentos \\
\hline \multirow[b]{2}{*}{$3^{\mathrm{a}}$} & Análise Institucional \\
\hline & $\begin{array}{l}\rightarrow \text { análise da forma jurídica pela qual o prestador está constituído, fazendo exigências em função } \\
\text { desta }\end{array}$ \\
\hline \multirow{2}{*}{$4^{\mathrm{a}}$} & $\underline{\text { Análise de Viabilidade }}$ \\
\hline & $\rightarrow$ análises de risco de crédito e de sustentabilidade do empreendimento pretendido \\
\hline \multirow{3}{*}{$5^{\mathrm{a}}$} & Hierarquização e Habilitação \\
\hline & $\begin{array}{l}\rightarrow \text { hierarquização segundo critérios que consideram a situação da saúde do município beneficiado, } \\
\text { a eficiência do prestador de serviço, o avanço na preparação do projeto de engenharia, o } \\
\text { percentual da contrapartida do tomador e o estágio da obra a ser financiada, privilegiando-se } \\
\text { aquelas para as quais o financiamento permitiria sua conclusão }\end{array}$ \\
\hline & $\begin{array}{l}\rightarrow \text { habilitação considerando os limites impostos pelo CMN, a disponibilidade do orçamento das } \\
\text { fontes onerosas e a hierarquização das operações }\end{array}$ \\
\hline
\end{tabular}

Fonte: MCidades (2005, p. 9-13). Elaboração própria. 
Pode-se observar também que a habilitação das operações só é realizada se os limites impostos pelo CMN forem respeitados - contingenciamento de crédito ao setor público. Para se ter uma idéia, a CEF recebeu, em 2006, "mais de 2,2 mil pedidos de financiamento, no valor de 16 bilhões de reais, sendo 14 bilhões do setor público. Entretanto, o Conselho Monetário Nacional só autorizou a liberação de 2,2 bilhões de reais, sendo 2 bilhões de responsabilidade da CEF” (FERNANDES JÚNIOR, 2006, p. 24).

É importante destacar que muitos desses pedidos são de prestadores sem capacidade de pagamento, fazendo com que os recursos, mesmo sendo restritos, não sejam totalmente utilizados. Contribui para isso o fato das instituições financeiras, em muitos momentos, não conseguirem expandir o crédito para o saneamento básico em função de grande parte de suas operações com o setor público já estarem comprometidas com outros segmentos - ou seja, as instituições já atingiram o limite de $45 \%$ do seu patrimônio líquido para operações de crédito com o setor público.

Além disso, "certas prefeituras ou governos estaduais não podem ter acesso [a esses recursos], por já terem estourado os limites de endividamento definidos pela Lei de Responsabilidade Fiscal (LRF)" (FERNANDES JÚNIOR, 2006, p. 24). Esse argumento poderia ser contestado pelo fato, apontado anteriormente, de apenas doze municípios, em 2004, estarem acima do limite de endividamento imposto pela LRF. Contudo, muitos municípios não estouraram o limite, mas estão próximos dele, o que inibe o endividamento.

\section{Investimentos realizados pelos prestadores}

Nas seções anteriores, foi comparado o desempenho dos prestadores de serviços em relação a aspectos operacionais, econômicos, financeiros, administrativos, de qualidade e de 
cobertura. Agora, o objetivo é compará-los em relação aos investimentos realizados - destino e origem dos recursos.

O gráfico 3.12 mostra os investimentos per capita anuais médios (água e esgoto) realizados, de 2000 a 2004, pelos diferentes tipos de provedores de serviços. Deve-se apontar, primeiramente, que o investimento em água foi superior ao de esgoto em todos os prestadores. É importante destacar, também, que os locais privados investiram mais do que os demais, tanto em esgoto como em água - nesse último serviço, a diferença é significativamente maior. Os prestadores regionais investiram mais em esgoto do que os locais públicos, o contrário ocorrendo no caso da água.

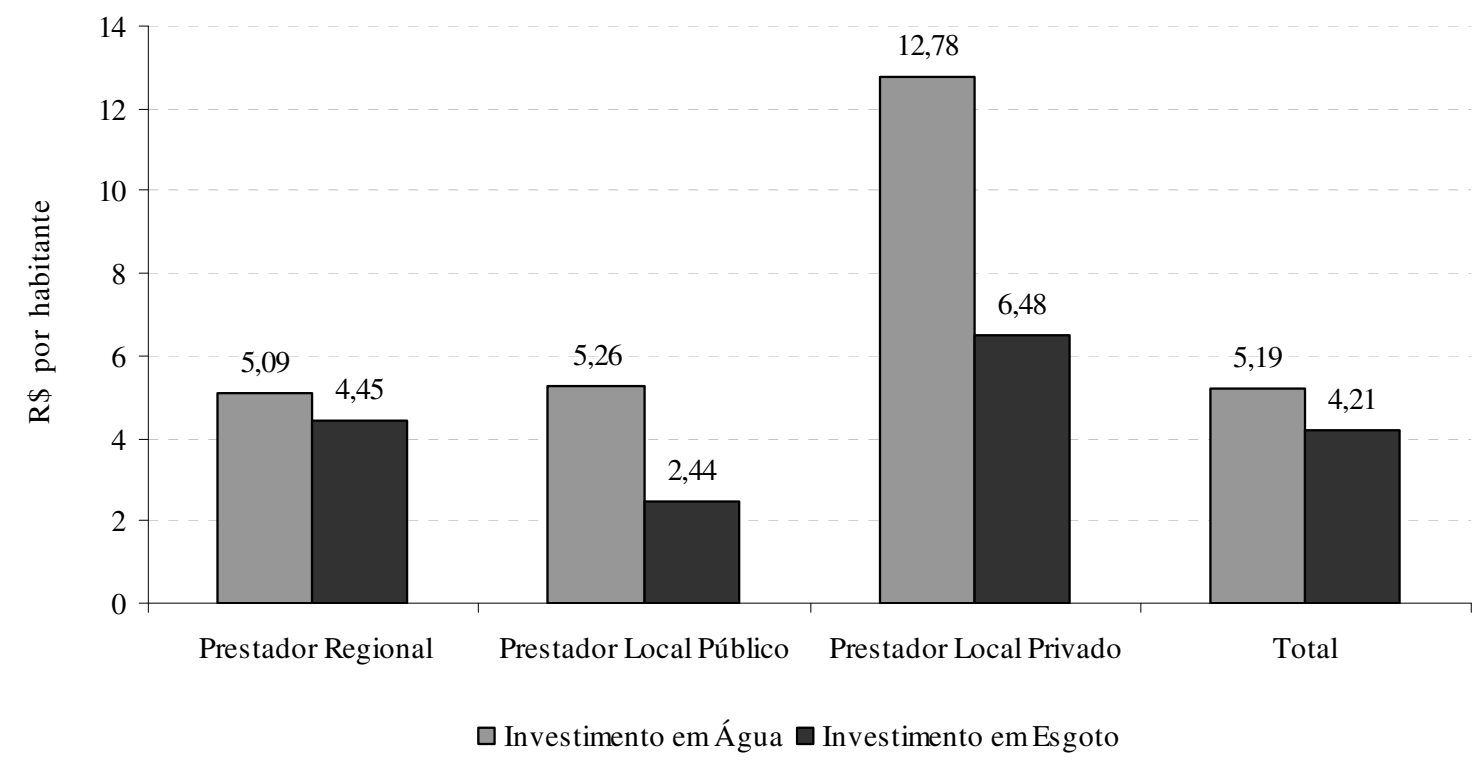

Fonte: Ministério das Cidades, SNIS (2000, 2001, 2002, 2003 e 2004). Elaboração própria.

\section{Gráfico 3.12}

Saneamento básico no Brasil: investimento per capita anual médio (água e esgoto), segundo o tipo de prestador (2000-2004)

Na tabela 3.18, é possível observar os investimentos per capita anuais médios (água e esgoto) realizados, de 2000 a 2004, pelos prestadores de serviços em cada uma das regiões 
brasileiras e no Estado de São Paulo. Em relação à água, observa-se que os investimentos realizados pelos locais privados foram superiores aos demais em todas as regiões em que existia um prestador desse tipo - e no Estado de São Paulo. Além disso, é possível verificar que o investimento médio em água maior nos locais públicos, em comparação aos regionais, deve-se ao grande investimento realizado pelos locais localizados no Centro-Oeste - nas demais regiões, seus investimentos em água foram inferiores aos dos regionais.

Tabela 3.18

Saneamento básico no Brasil: investimento per capita anual médio, segundo o tipo de prestador do serviço, as grandes regiões e o Estado de São Paulo (2000-2004)

\begin{tabular}{|c|c|c|c|c|}
\hline $\begin{array}{c}\text { Prestador / } \\
\text { Região }\end{array}$ & Regional & Local Público & Local Privado & Total \\
\hline \multicolumn{5}{|c|}{ Água (R\$ milhões) } \\
\hline Norte & 5,44 & 1,43 & 12,73 & 5,15 \\
\hline Nordeste & 3,59 & 2,06 & $*$ & 3,44 \\
\hline Centro-Oeste (1) & 5,75 & 9,41 & 11,88 & 7,52 \\
\hline Centro-Oeste (2) & 5,64 & 9,41 & 11,88 & 7,47 \\
\hline Sudeste (3) & 5,00 & 5,01 & 14,51 & 5,12 \\
\hline Sudeste (4) & 4,39 & 4,01 & 17,46 & 4,52 \\
\hline São Paulo & 6,38 & 5,85 & 8,62 & 6,27 \\
\hline Sul & 6,61 & 5,66 & 9,91 & 6,54 \\
\hline Brasil & 5,09 & 5,26 & 12,78 & 5,19 \\
\hline \multicolumn{5}{|c|}{ Esgoto (R\$ milhões) } \\
\hline Norte & 0,62 & 0,57 & 0,45 & 0,62 \\
\hline Nordeste & 1,74 & 0,33 & $*$ & 1,60 \\
\hline Centro-Oeste (1) & 14,42 & 1,80 & 1,38 & 8,85 \\
\hline Centro-Oeste (2) & 14,43 & 1,80 & 1,38 & 8,82 \\
\hline Sudeste (3) & 7,30 & 4,71 & 14,60 & 6,97 \\
\hline Sudeste (4) & 4,97 & 3,38 & 19,28 & 4,98 \\
\hline São Paulo & 12,59 & 5,81 & 5,23 & 10,76 \\
\hline Sul & 4,56 & 2,21 & 15,80 & 4,39 \\
\hline Brasil & $\mathbf{4 , 4 5}$ & 2,44 & 6,48 & 4,21 \\
\hline
\end{tabular}

Fonte: Ministério das Cidades, SNIS (2000, 2001, 2002, 2003 e 2004). Elaboração própria.

(1) Centro-Oeste incluindo o Distrito Federal.

(2) Centro-Oeste excluindo o Distrito Federal.

(3) Sudeste incluindo São Paulo.

(4) Sudeste excluindo São Paulo.

* Não há esse tipo de prestador na região.

Em relação ao esgoto, os investimentos realizados pelos locais privados são superiores aos demais apenas nas regiões Sudeste e Sul - bastante elevados, o que influencia o resultado total. Comparando os regionais e os locais públicos, observa-se que os primeiros investem 
mais em esgoto em todas as regiões e no Estado de São Paulo. Destaca-se o grande investimento realizado pela CESB desse estado (Sabesp) - conforme foi visto anteriormente, essa CESB apresenta um elevado resultado (receita operacional menos despesa total), ou seja, gera bastante excedente, fundamental para a realização de investimentos com recursos próprios ou para captar recursos por meio de endividamento (capacidade de pagamento).

\section{$\underline{5.1}$ Investimentos e características municipais $^{14}$}

Os investimentos per capita anuais médios (água e esgoto) realizados, de 2000 a 2004, também podem ser avaliados levando em consideração a população e a taxa de urbanização apresentada pelos municípios em 2000, de modo que seja possível sinalizar se tem ocorrido um esforço para reverter as características do déficit de acesso discutidas no segundo capítulo - maior concentração nos municípios de pequeno porte e com baixa taxa de urbanização.

Para a realização dessa análise, serão utilizadas as amostras de municípios do SNIS referentes aos anos de 2000 a 2004 - até o momento, estavam sendo usadas as amostras de prestadores. Deve-se destacar que a idéia original era também utilizar a renda municipal per capita mensal. No entanto, foi constatado que, nas amostras do SNIS, existem apenas municípios que possuíam, em 2000, renda per capita mensal superior a três salários-mínimos, o que prejudicaria a análise.

Considerando a população do município, o gráfico 3.13 mostra que os investimentos realizados em água pelos locais privados foram superiores aos dos demais em quase todos os extratos populacionais. No caso do esgoto, isso só ocorre nos municípios de até cinco mil habitantes e entre cem mil e quinhentos mil habitantes. Deve-se destacar que não há uma

\footnotetext{
${ }^{14}$ As análises do presente item, para facilitar a visualização, serão realizadas por meio de gráficos. Os dados utilizados para a confecção desses gráficos estão no Apêndice - tabelas 52 e 53.
} 
tendência clara de elevação dos investimentos (água e esgoto) à medida que aumenta o porte dos municípios - essa tendência só é observada nos investimentos em esgoto realizados pelos regionais e pelos locais públicos.
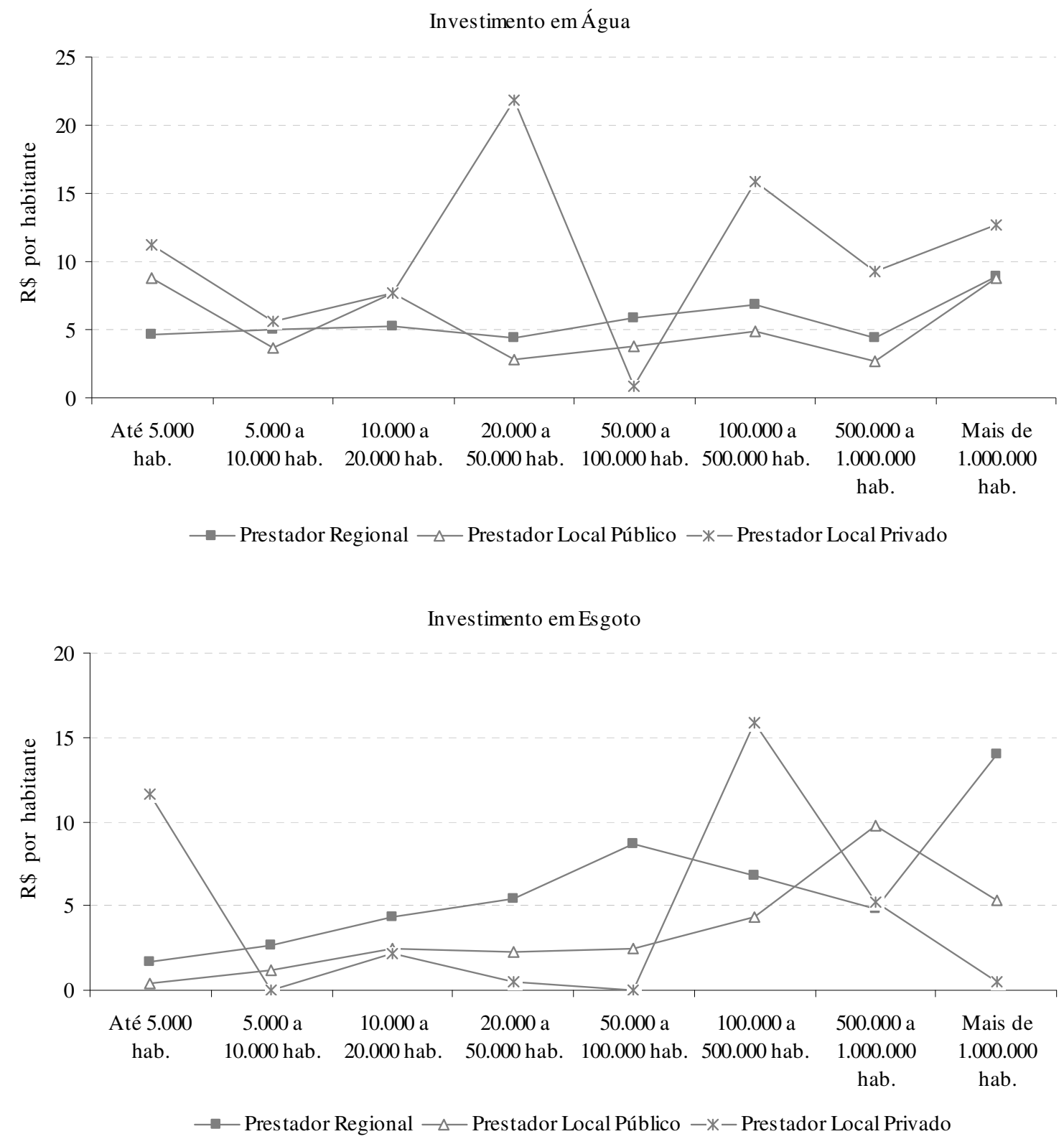

Fonte: Ministério das Cidades e IBGE, SNIS (2000 a 2004) e Censo Demográfico de 2000. Elaboração própria.

\section{Gráfico 3.13}

Saneamento básico no Brasil: investimento per capita anual médio (água e esgoto), segundo o tipo de prestador e o porte (tamanho da população) dos municípios (2000-2004) 
Por último, o gráfico 3.14 apresenta os investimentos per capita anuais médios realizados, de 2000 a 2004, em água e em esgoto, segundo o tipo de prestador e a taxa de urbanização dos municípios em 2000.
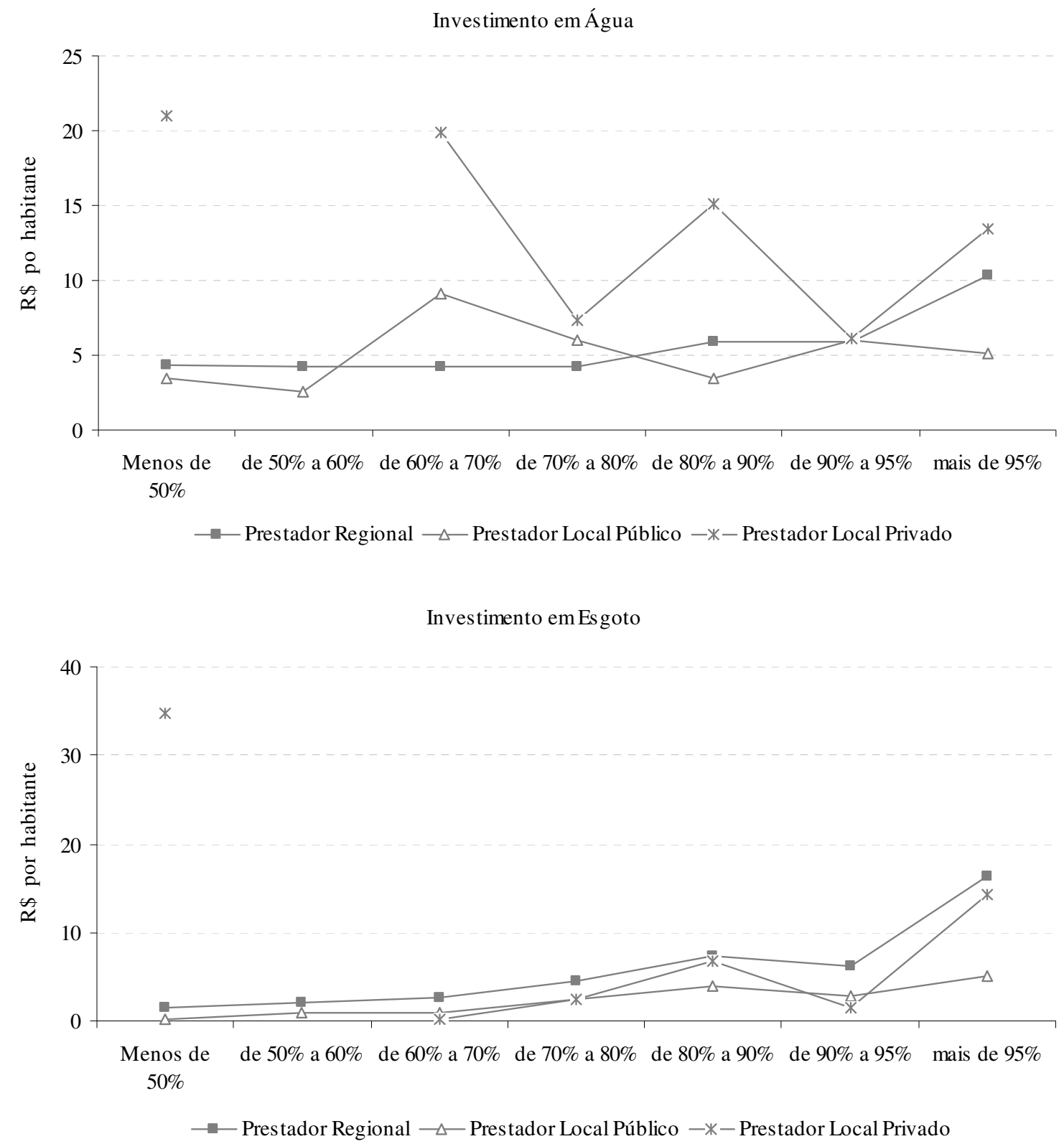

Fonte: Ministério das Cidades e IBGE, SNIS (2000 a 2004) e Censo Demográfico de 2000. Elaboração própria.

\section{Gráfico 3.14}

Saneamento básico no Brasil: investimento per capita anual médio (água e esgoto), segundo o tipo de prestador e a taxa de urbanização dos municípios (2000-2004) 
No gráfico 3.14, é possível observar que os investimentos em água dos locais privados foram superiores aos dos demais em quase todos os extratos populacionais. No caso do esgoto, isso só ocorreu nos municípios de até cinco mil habitantes - nos outros, os investimentos dos regionais foram os mais elevados. No caso da água, não se verifica uma tendência clara de elevação dos investimentos em função do crescimento da urbanização em nenhum dos prestadores. Já no caso do esgoto, essa tendência, apesar de pequena, é observada em todos os prestadores - mas, nos privados, o maior investimento ocorreu nos municípios com menores populações (até cinco mil habitantes).

A análise realizada no presente item mostrou, portanto, que os investimentos per capita anuais médios (água e esgoto) realizados, de 2000 a 2004, não foram influenciados, de maneira significativa, pela população e pela taxa de urbanização dos municípios. Por um lado, isso é benéfico, uma vez que não agravou os desequilíbrios de acesso discutidos no segundo capítulo - o que ocorreria se tivesse sido observada uma relação positiva significativa entre os investimentos e as características municipais. Por outro lado, porém, é negativo, uma vez que também não reduziu esses desequilíbrios - o que ocorreria se tivesse sido constatada uma relação negativa significativa entre os investimentos e as características municipais.

\subsection{Origem dos recursos investidos}

Os prestadores de serviços de saneamento básico no Brasil realizam investimentos utilizando três tipos de recursos: (i) próprios - provenientes dos serviços prestados -; (ii) onerosos - financiamentos reembolsáveis por meio de amortizações, juros e outros encargos e (iii) não onerosos (não reembolsáveis) - transferências orçamentárias, recursos a fundo perdido, programas especiais etc. O gráfico 3.15 apresenta a participação de cada um desses 
tipos de recursos no total investido pelos prestadores em 2004 - em função de uma regra contábil, o sistema também considera as despesas capitalizáveis como uma fonte de recursos para investimentos ${ }^{15}$

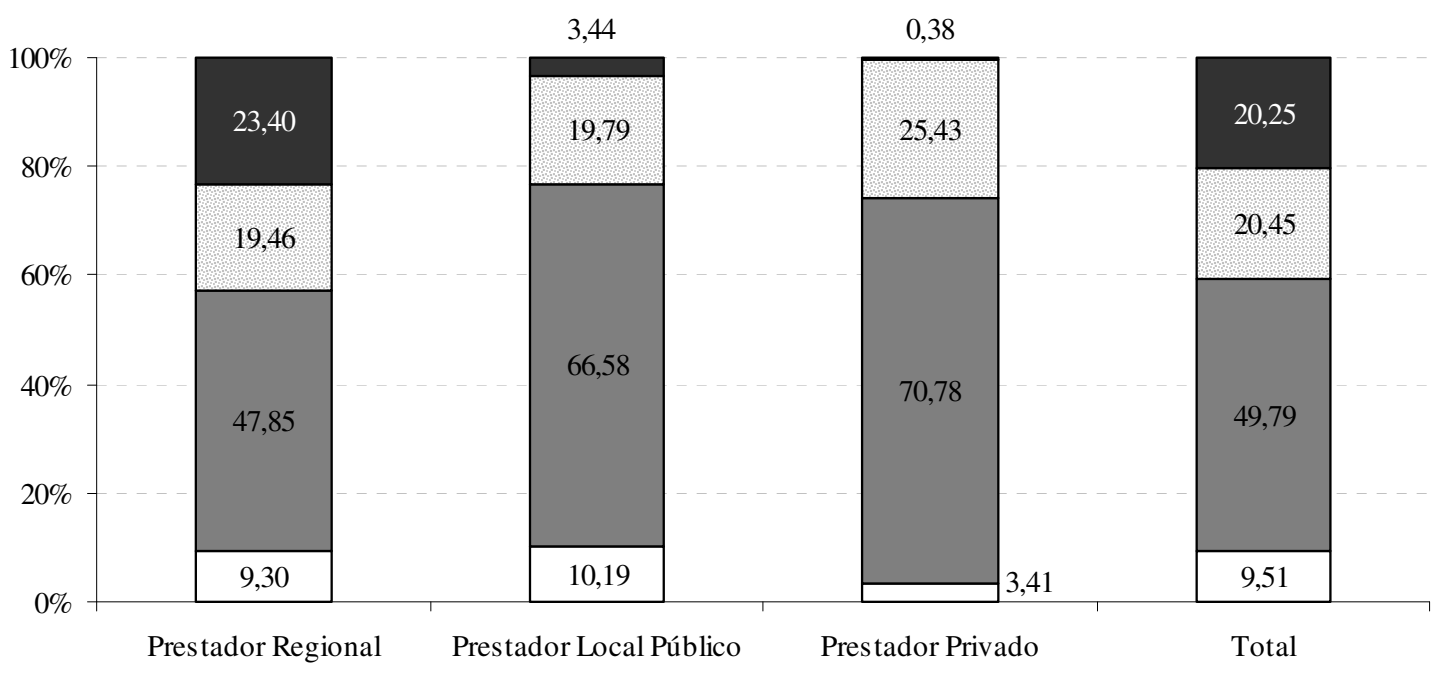

$\square$ Despesas capitalizáveis $\square$ Recursos próprios $\square$ Recursos onerosos $\square$ Recursos não onerosos

Fonte: Ministério das Cidades, SNIS (2004). Elaboração própria.

\section{Gráfico 3.15}

Saneamento básico no Brasil: origem dos recursos investidos, segundo o tipo de prestador (2004)

Observa-se, no gráfico 3.15, que grande parte dos investimentos realizados, em 2004, por todos os prestadores de serviços originou-se de recursos próprios. Ou seja, as regras fiscais limitam o endividamento, fazendo com que a maioria dos investimentos seja realizada com recursos próprios, mas estes também são escassos - em função da baixa geração de excedentes, apontada anteriormente. Destacam-se, também, os seguintes aspectos: (i) recursos não onerosos significativos apenas nos regionais e (ii) recursos onerosos mais elevados nos locais privados, o que reflete a maior facilidade destes para obter empréstimos, por não

\footnotetext{
${ }^{15}$ Despesas capitalizáveis é o valor anual das despesas realizadas com o funcionamento das áreas do prestador de serviços que, pelas suas finalidades (projetos e fiscalização de obras, por exemplo), a Contabilidade adota o procedimento de capitalizar nos respectivos custos (projetos e obras), não contabilizando como despesas de exploração (SNIS, 2004).
} 
estarem sujeitos aos limites de endividamento impostos pela LRF e pelas Resoluções do Senado e do CMN.

Origem dos investimentos federais em saneamento básico (2003-2006)

De acordo com o MCidades (2006), entre janeiro de 2003 e junho de 2006, "foram comprometidos (contratos com recursos onerosos e empenhos de recursos não onerosos) $\mathrm{R} \$$ 10,563 bilhões e desembolsados (efetivamente pagos) R\$ 4,48 bilhões". No âmbito do governo federal, recursos onerosos são os financiamentos do FGTS e do BNDES e recursos não onerosos são os recursos orçamentários. Conforme pode ser observado na tabela 3.19, “os financiamentos representam 58\% dos recursos comprometidos, enquanto os recursos orçamentários são responsáveis por 54\% dos desembolsos realizados” (p. 1)

Tabela 3.19

Saneamento básico no Brasil: gastos federais, segundo a origem dos recursos (jan/2003-jun/2004)

\begin{tabular}{c|c|c|c|c|c}
\hline \multirow{2}{*}{$\begin{array}{c}\text { Origem / } \\
\text { Situação }\end{array}$} & Total & \multicolumn{2}{|c|}{ Recursos Onerosos } & \multicolumn{2}{c}{ Recursos não Onerosos } \\
\cline { 3 - 6 } & (R\$ bilhões) & R\$ bilhões & \% Total & R\$ bilhões & \% Total \\
\hline Comprometidos & 10,563 & 6,134 & 58,07 & 4,429 & 41,93 \\
Desembolsados & 4,480 & 2,063 & 46,86 & 2,417 & 53,96 \\
\hline
\end{tabular}

Fonte: MCidades (2006, p. 1).

O FGTS foi a principal fonte dos recursos federais destinados ao saneamento básico durante o período (49\% do total comprometido). Na sequiência, vieram os recursos não onerosos $(42 \%)$ e, por último, os recursos do BNDES (9\%). Do total de recursos não onerosos comprometidos com o setor, $35 \%$ foram destinados ao Ministério das Cidades, $49 \%$ para a Funasa, $14 \%$ para o Ministério do Interior e 2\% para os demais órgãos do governo - o que comprova a fragmentação dos recursos federais apontada no primeiro capítulo. Tais fatos são ilustrados no gráfico 3.16 . 


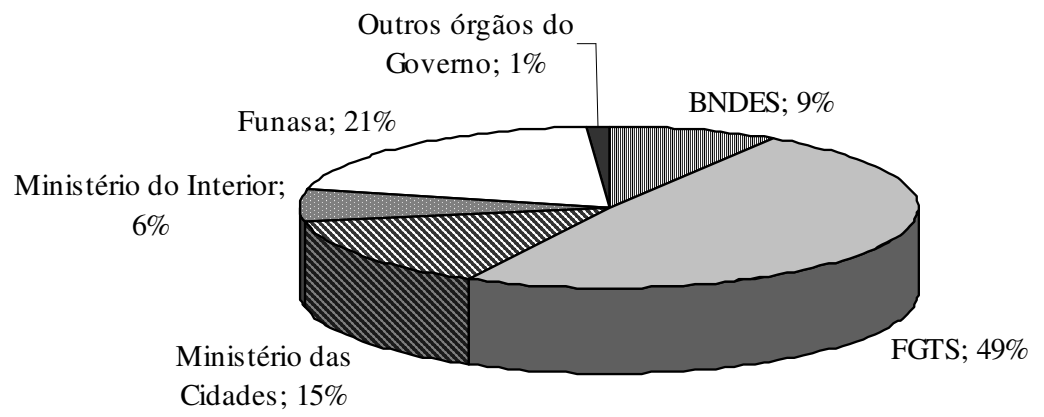

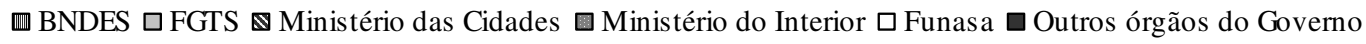

\begin{tabular}{lcc}
\hline \multicolumn{1}{c|}{ Região } & Recursos onerosos contratados & Recursos não onerosos empenhados \\
\hline Norte & $7 \%$ & $10 \%$ \\
Nordeste & $25 \%$ & $43 \%$ \\
Centro-Oeste & $10 \%$ & $17 \%$ \\
Sudeste & $47 \%$ & $22 \%$ \\
Sul & $11 \%$ & $8 \%$ \\
\hline
\end{tabular}

Fonte: MCidades (2006, p. 1-2). Elaboração própria.

\section{Gráfico 3.16}

Saneamento básico no Brasil: recursos comprometidos pelo governo federal, segundo a fonte e o destino (jan/2003-jun2006)

No gráfico 3.16, também é possível observar a distribuição dos recursos onerosos contratados e dos recursos não onerosos empenhados entre as grandes regiões geográficas brasileiras. A contratação dos recursos onerosos tem beneficiado mais os municípios da região Sudeste, "onde existem melhores condições sócio-econômicas para arcar com os custos do financiamento [...]. Em contrapartida, [...] 53\% dos recursos não onerosos estão sendo aplicados nas Regiões Norte e Nordeste, onde são mais restritas as possibilidades de autofinanciamento" (MCIDADES, 2006, p. 1). 


\section{Descentralizacão e desestatizacão: solucões? (consideracões finais)}

O quadro 3.3 resume os principais fatos sinalizados pelas análises realizadas na segunda seção do presente capítulo. Observa-se que o acesso a abastecimento de água por rede geral era maior nos prestadores locais públicos, tanto em 1991 como em 2000 - esse tipo de provedor apresentou, inclusive, o maior crescimento do acesso a água no período. Em relação à coleta de esgoto por rede geral, no primeiro ano analisado, o acesso era maior nos locais públicos, mas, no segundo ano, esses foram "ultrapassados" pelos locais privados - tipo de provedor que apresentou o maior crescimento do acesso a esgoto no período.

Quadro 3.3

Saneamento básico no Brasil: qual é o tipo de prestador que apresenta os melhores indicadores de acesso por rede geral? (1991 e 2000)

\begin{tabular}{|c|c|c|c|}
\hline Indicador & Regional & $\begin{array}{c}\text { Local } \\
\text { Público }\end{array}$ & $\begin{array}{c}\text { Local } \\
\text { Privado }\end{array}$ \\
\hline - Acesso a abastecimento de água por rede geral (2000) & & $\mathrm{X}$ & \\
\hline - Acesso a coleta de esgoto por rede geral (2000) & & & $\mathrm{X}$ \\
\hline - Acesso a abastecimento de água por rede geral (1991) & & $\mathrm{X}$ & \\
\hline - Acesso a coleta de esgoto por rede geral (1991) & & $\mathrm{X}$ & \\
\hline - Variação do acesso a abastecimento de água (1991-2000) & & $\mathrm{X}$ & \\
\hline - Variação do acesso a coleta de esgoto (1991-2000) & & & $\mathrm{X}$ \\
\hline
\end{tabular}

O quadro 3.4, por sua vez, resume as análises realizadas na terceira seção, na qual o desempenho dos provedores de serviços de saneamento básico foi comparado em relação a diversos aspectos: operacionais, de cobertura, econômicos, financeiros, administrativos e de qualidade. Conforme pode ser observado nesse quadro, os dados sugerem que, de uma maneira geral, os locais públicos e os locais privados apresentavam, em 2004, um desempenho superior ao dos regionais - uma vez que estes possuíam melhor desempenho apenas em quatro dos trinta e cinco indicadores analisados. No caso da maior padronização, eram nos locais públicos que ocorriam as maiores diferenças dos índices entre as entidades 
pertencentes ao grupo - apenas em quatro indicadores esse grupo de prestador apresentava menor desvio-padrão.

Quadro 3.4

Saneamento básico no Brasil: qual é o tipo de prestador com melhor desempenho? (2004)

\begin{tabular}{|c|c|c|c|c|c|c|}
\hline \multirow[b]{2}{*}{ Prestador / Indicador } & \multicolumn{3}{|c|}{ Valor Médio } & \multicolumn{3}{|c|}{ Desvio-Padrão } \\
\hline & $\begin{array}{c}\text { Regio- } \\
\text { nal }\end{array}$ & $\begin{array}{c}\text { Local } \\
\text { Público }\end{array}$ & $\begin{array}{c}\text { Local } \\
\text { Privado }\end{array}$ & $\begin{array}{c}\text { Regio- } \\
\text { nal }\end{array}$ & \begin{tabular}{|c|} 
Local \\
Público
\end{tabular} & \begin{tabular}{|c} 
Local \\
Privado
\end{tabular} \\
\hline - Índice de perdas de faturamento (\%) & & & $\mathrm{X}$ & $\mathrm{X}$ & & \\
\hline - Índice de perdas na distribuição (\%) & & $\mathrm{X}$ & & $\mathrm{X}$ & & \\
\hline - Índice de hidrometração (\%) & & & $\mathrm{X}$ & & & $\mathrm{X}$ \\
\hline - Densidade de economias por ligação (econ./lig.) & $\mathrm{X}$ & & & & $\mathrm{X}$ & \\
\hline - Extensão da rede de água por ligação (m/ligação) & & $\mathrm{X}$ & & $\mathrm{X}$ & & \\
\hline - Consumo médio de água (m³/mês/economia) & & $\mathrm{X}$ & & $\mathrm{X}$ & & \\
\hline - Consumo médio per capita (1/hab./dia) & & $\mathrm{X}$ & & $\mathrm{X}$ & & \\
\hline - Índice de atendimento urbano (\% da população) & & $\mathrm{X}$ & & & & $\mathrm{X}$ \\
\hline - Índice de atendimento total de água (\% da pop.) & & $\mathrm{X}$ & & & & $\mathrm{X}$ \\
\hline - Índice de coleta de esgoto $(\%)$ & & $X$ & & $X$ & & \\
\hline - Índice de tratamento de esgoto $(\%)$ & $\mathrm{X}$ & & & $\mathrm{X}$ & & \\
\hline - Índice de esgoto tratado por água consumida (\%) & $\mathrm{X}$ & & & $\mathrm{X}$ & & \\
\hline - Índice de atendimento urbano (\% da população) & & $\mathrm{X}$ & & $\mathrm{X}$ & & \\
\hline - Índice de atendimento total de esgoto (\% da pop.) & & $\mathrm{X}$ & & $\mathrm{X}$ & & \\
\hline - Índice de produtividade (economias/ pessoal total) & & & $X$ & $X$ & & \\
\hline - Pessoal próprio por mil ligações (água e esgoto) & & & $\mathrm{X}$ & & & $\mathrm{X}$ \\
\hline - Despesa total com serviço por $\mathrm{m}^{3}$ faturado $(\mathrm{R} \$$ ) & & $\mathrm{X}$ & & & & $\mathrm{X}$ \\
\hline - Despesa de exploração por $\mathrm{m}^{3}$ faturado $(\mathrm{R} \$)$ & & $\mathrm{X}$ & & & & $\mathrm{X}$ \\
\hline - Despesa de exploração por economia (R\$) & & $\mathrm{X}$ & & & & $\mathrm{X}$ \\
\hline - Despesa média anual por empregado $(\mathrm{R} \$)$ & & $\mathrm{X}$ & & & $\mathrm{X}$ & \\
\hline - Despesa com pessoal / despesa de exploração (\%) & & & $\mathrm{X}$ & $\mathrm{X}$ & & \\
\hline - Tarifa média praticada $(\mathrm{R} \$$ ) - água e esgoto & & $\mathrm{X}$ & & & & $\mathrm{X}$ \\
\hline - Tarifa média de água & & $\mathrm{X}$ & & & $\mathrm{X}$ & \\
\hline - Tarifa média de esgoto & & $\mathrm{X}$ & & $\mathrm{X}$ & & \\
\hline - Índice de evasão de receita (\%) & & $\mathrm{X}$ & & $\mathrm{X}$ & & \\
\hline - Margem da despesa de exploração (\%) & & & $\mathrm{X}$ & $\mathrm{X}$ & & \\
\hline - Dias de faturamento comprometidos & & & $\mathrm{X}$ & & & $\mathrm{X}$ \\
\hline - Índice de desempenho financeiro (\%) & & & $\mathrm{X}$ & $\mathrm{X}$ & & \\
\hline - Duração média dos serviços executados (h./serv.) & $X$ & & & & $X$ & \\
\hline - Duração média das paralisações (h./paralisação) & & & $\mathrm{X}$ & & & $\mathrm{X}$ \\
\hline - Duração média das intermitências (h./interrupção) & & & $\mathrm{X}$ & & & $\mathrm{X}$ \\
\hline - Cloro residual e turbidez fora do padrão (\%) & & & $\mathrm{X}$ & & & $\mathrm{X}$ \\
\hline - Análises de coliformes fecais fora do padrão (\%) & & & $\mathrm{X}$ & & & $\mathrm{X}$ \\
\hline - Extravasamentos de esgoto (extravas./Km) & & $\mathrm{X}$ & & & & $\mathrm{X}$ \\
\hline
\end{tabular}


$\mathrm{Na}$ terceira seção, também foi avaliada a evolução do desempenho dos prestadores entre 2000 e 2004. De acordo com o quadro 3.5, os regionais e os locais públicos melhoraram seu desempenho em seis dos doze indicadores analisados e os locais privados em dez dos doze - o aumento do desempenho desses últimos, conforme já foi comentado anteriormente, não foi decorrência de um esforço para reverter uma situação inicial desfavorável, uma vez que já possuíam, em 2000, desempenho médio superior aos demais prestadores em alguns dos indicadores analisados. Deve-se destacar que a melhora de desempenho não ocorreu de maneira uniforme em todas as entidades pertencentes aos grupos de prestadores - em muitos dos indicadores, ocorreu uma diminuição da padronização (aumento dos desvios-padrão).

Quadro 3.5

Saneamento básico no Brasil: quais são os tipos de prestadores que apresentaram melhora de desempenho? (2000-2004)

\begin{tabular}{l|c|c|c}
\hline \multicolumn{1}{c|}{ Prestador / Indicador } & Regional & Local Público & Local Privado \\
\hline - Índice de perdas de faturamento (\%) & & $\mathrm{X}$ & $\mathrm{X}$ \\
- Índice de perdas na distribuição (\%) & & $\mathrm{X}$ & $\mathrm{X}$ \\
- Índice de hidrometração (\%) & $\mathrm{X}$ & & $\mathrm{X}$ \\
- Índice de atendimento total de água (\% da pop.) & & & \\
- Índice de coleta de esgoto (\%) & $\mathrm{X}$ & $\mathrm{X}$ & $\mathrm{X}$ \\
- Índice de tratamento de esgoto (\%) & $\mathrm{X}$ & $\mathrm{X}$ & $\mathrm{X}$ \\
- Índice de produtividade (economias / pessoal total) & $\mathrm{X}$ & $\mathrm{X}$ & $\mathrm{X}$ \\
- Pessoal próprio por mil ligações (água e esgoto) & & $\mathrm{X}$ & $\mathrm{X}$ \\
- Índice de evasão de receita (\%) & $\mathrm{X}$ & & $\mathrm{X}$ \\
- Índice de desempenho financeiro (\%) & & & $\mathrm{X}$ \\
- Duração média das intermitências (h./interrupção) & $\mathrm{X}$ & & $\mathrm{X}$ \\
- Extravasamentos de esgoto (extravas./Km) &
\end{tabular}

Finalmente, o quadro 3.6 resume os principais fatos sinalizados pelas análises realizadas na quarta e na quinta seções. Os prestadores locais privados são os que apresentaram, em 2004, o maior resultado médio. Além disso, esse tipo de provedor de serviço foi o que mais investiu, entre 2000 e 2004, no setor - tanto em água como em esgoto. 
Quadro 3.6

Saneamento básico no Brasil: qual é o tipo de prestador que apresenta maior resultado médio?

Qual investe mais?

\begin{tabular}{l|c|c|c}
\hline \multicolumn{1}{c|}{ Prestador / Indicador } & Regional & Local Público & Local Privado \\
\hline - Resultado médio * & $2^{\circ}$ & $3^{\circ}$ & $1^{\circ}$ \\
- Investimento em água & $3^{\circ}$ & $2^{\circ}$ & $1^{o}$ \\
- Investimento em esgoto & $2^{\circ}$ & $3^{o}$ & $1^{\circ}$ \\
\hline
\end{tabular}

* Nesse indicador, está sendo considerado o resultado das regionais sem a Sabesp.

As análises realizadas sugerem, portanto, que uma maior descentralização e uma maior desestatização no setor poderiam gerar ganhos de eficiência e de cobertura, uma vez que os prestadores locais públicos e os prestadores locais privados existentes atualmente apresentam, de uma maneira geral, desempenho médio e acesso aos serviços superiores aos dos regionais. No caso dos privados, também é importante destacar que esse tipo de provedor é o que mais investe, tanto em água como em esgoto.

O investimento superior nos privados decorre tanto do melhor desempenho médio geração de excedentes e capacidade de pagamento pelos empréstimos - como da maior facilidade destes para se endividarem, uma vez que não estão sujeitos aos limites de endividamento impostos pela LRF e pelas Resoluções do Senado e do CMN. 


\section{CONSIDERAÇÕES FINAIS}

Conforme foi comentado na introdução, o objetivo principal do presente trabalho era identificar e avaliar os fatores que restringem a expansão dos investimentos no saneamento básico brasileiro. Para alcançar tal objetivo, a dissertação foi dividida em três capítulos.

No primeiro capítulo, além do histórico do setor, foi analisada a situação institucional atual do saneamento básico no Brasil. Constatou-se que o setor enfrenta uma série de problemas institucionais - políticas "pontuais e desarticuladas", fragmentação das responsabilidades e dos recursos federais, indefinições regulatórias e irregularidades contratuais. Tais problemas dificultam a adoção de ações coordenadas, reduzem a qualidade dos investimentos e desestimulam um aumento da participação privada no setor - contribui, para isso, o mercado de financiamento de longo prazo pouco desenvolvido no país.

Deve-se destacar que o quadro regulatório, ao mesmo tempo em que impõe limites ao desenvolvimento do setor, também possui importantes definições relacionadas à qualidade e ao impacto ambiental - Lei dos Recursos Hídricos e Lei nº 9.984 (criação da ANA) -, assim como a formas de gestão e de "alavancagem" dos recursos - Lei das Licitações, Lei das Concessões, Lei das PPPs, Lei dos Consórcios, Programa de Incentivo à Implementação de Projetos de Interesse Social (PIPS) e Lei dos Consórcios Públicos e Gestão Associada. Com a promulgação do novo marco regulatório - lei já sancionada pelo Presidente da República -, grande parte das indefinições acabará, garantindo uma maior credibilidade e, consequientemente, uma maior atratividade ao setor. Restará sair a definição do STF sobre a titularidade dos serviços a nova política nacional ser implementada - o que poderá reduzir o problema da fragmentação de recursos. 
No segundo capítulo, o déficit de acesso domiciliar aos serviços de saneamento básico foi caracterizado e sua evolução avaliada. Observou-se que este se concentra, principalmente, nas regiões menos desenvolvidas e nos municípios de menor porte, menor taxa de urbanização, menor renda per capita e localizados no interior, assim como nos domicílios rurais e de baixa renda. Ou seja, o déficit está intimamente relacionado ao perfil de renda dos consumidores - capacidade de pagamento (tarifas) - e à existência de economias de escala e de densidade no setor - maior facilidade de ofertar os serviços em grandes concentrações populacionais (aglomerações), uma vez que a expansão e a manutenção destes tendem a ter custos reduzidos à medida que aumenta o tamanho da população a ser atingida.

Finalmente, no terceiro capítulo, foi comparado o desempenho (eficiência) dos diferentes tipos de provedores de serviços de saneamento básico existentes atualmente no Brasil. Constatou-se que, de uma maneira geral, os prestadores locais público e os prestadores locais privados apresentam desempenho médio e acesso aos serviços superiores aos dos regionais e que os privados investem mais do que os demais, tanto em água como em esgoto.

No terceiro capítulo, também foi aprofundada a discussão - iniciada no primeiro capítulo - sobre as regras fiscais que restringem o endividamento e, consequentemente, o investimento público em saneamento básico: (i) limites de endividamento, (ii) metas de superávit e (iii) contingenciamento de crédito ao setor público. Tais metas são importantes para a condução estável da política macroeconômica, contudo, poderiam ser mais flexíveis. A LRF e as Resoluções do Senado Federal, por exemplo, poderiam permitir que estados e municípios, mesmo não estando em condições fiscais "ótimas", se endividassem para financiar projetos que apresentam possibilidade de rentabilidade futura - uma possibilidade seria a obtenção de recursos baseada no fluxo de tarifas e nas garantias oferecidas.

Após as análises realizadas ao longo dos três capítulos, pode-se dizer que todos os problemas investigativos da dissertação foram respondidos. Por se tratar da conclusão mais 
relevante da presente dissertação, é importante destacar a resposta do principal problema proposto: a descentralização e a maior participação da iniciativa privada podem ser consideradas soluções ideais para a retomada dos investimentos no setor (conseguiriam elevar a eficiência e, conseqüentemente, a capacidade dos provedores de alavancarem recursos)?

Conforme já foi apontado, as análises realizadas no terceiro capítulo mostraram que os prestadores locais públicos e os prestadores locais privados apresentam, no geral, melhor desempenho e que os privados investem mais. Tais fatos sugerem, portanto, que uma maior descentralização e uma maior desestatização no saneamento básico brasileiro poderiam gerar ganhos de eficiência e de cobertura.

No entanto, dificilmente será possível alcançar a universalização do acesso apenas com uma maior participação privada ou uma maior descentralização das decisões e da provisão dos serviços, uma vez que o déficit de acesso está concentrado em localidades com maior custo e menor capacidade de pagamento pelos serviços (tarifas), o que reduz o retorno econômico dos investimentos. Ou seja, será necessário que o governo federal continue a atuar ativamente no setor, investindo e planejando as ações de todos os agentes existentes. 


\section{REFERÊNCIAS BIBLIOGRÁFICAS}

ABICALIL, M. T. "Uma nova agenda para o saneamento". In: Sedu/PR. O Pensamento do Setor Saneamento no Brasil: perspectivas futuras, Brasília, 2002.

ABREU, M. P. "Inflação, estagnação e ruptura". In: ABREU, M. P. (org). A Ordem do Progresso. 15ª ed. Rio de Janeiro, Campus, 1990.

AESBE. "Visão econômica do saneamento". 36º Fórum de Debates Projeto Brasil - Política de Saneamento: balanços e aprimoramentos, Agência Dinheiro Vivo, out. 2006.

AFONSO, J. R. R. et alii. Breves notas sobre o federalismo fiscal no Brasil. s.d. Disponível em $<$ http://www.federativo.bndes.gov.br>. Acesso em: 01 jun. 2002.

ANDRADE, T. A.; LOBÃO, W. J. A. “Tarifação social no consumo residencial de água”. Textos para Discussão do IPEA, Rio de Janeiro, no 438: p. 1-59, out. 1996.

ARAUJO, E.; OLIVEIRA, P. A. "Receita municipal: A importância das transferências do FPM e do SUS". Informe-se BNDES, no 28, jun. 2001

ASCHAUER, D. A. "Is public expenditure productive?". Journal of Monetary Economics, Holland, no 23: p. 177-2000, 1989.

BAER, M. O rumo perdido: a crise fiscal e financeira do Estado brasileiro. Rio de Janeiro, Paz e Terra, 1993.

BANCO MUNDIAL. Infra-estrutura para o desenvolvimento. Relatório sobre o desenvolvimento mundial 1994, Rio de Janeiro: Fundação Getúlio Vargas, 1994.

BARAT, J. O financiamento da infra-estrutura urbana: os impasses, as perspectivas institucionais, as perspectivas financeiras. In: IPEA. Infra-estrutura: perspectivas de reorganização (financiamento), Brasília. 1998.

BIELSCHOWSKY, R.. Investimento e reformas no Brasil: indústria e infra-estrutura nos anos 1990. $1^{a}$ ed. Brasília, IPEA, CEPAL, 2002.

BNDES. "Serviços de saneamento básico - níveis de atendimento". Informes Infra-Estrutura, Rio de Janeiro, nº 5: BNDES, dez. 1996.

. "Tratamento de esgoto: tecnologias acessíveis". Informes Infra-Estrutura, Rio de Janeiro, no 16: BNDES, mar. 1997. 
. "Setor de saneamento - rumos adotados". Informes Infra-Estrutura, Rio de Janeiro, n 20: BNDES, mar. 1998a.

. "Saneamento: o objetivo é a eficiência". Informes Infra-Estrutura, Rio de Janeiro, no 23: BNDES, jun. 1998b.

. "Fotografia da participação privada no setor de saneamento". Informes Infra-Estrutura, Rio de Janeiro, no 33: BNDES, out. 1999.

- "Relatório sobre Privatizações". Publicação preparada pela Área de Desestatização e Reestruturação (AD), jul. 2002. Disponível em <http://www.bndes.gov.br>. Acesso em: 20 jan. 2006.

BRASIL. Constituição Federal de 1988. Disponível em <http://www.senado.gov.br>. Acesso em: 05 jan. 2006.

. Lei Complementar $n^{\circ}$ 101. Lei de Responsabilidade Fiscal, maio, 2000. Disponível em $<$ http://www.senado.gov.br>. Acesso em: 20 jan. 2006.

Lei ${ }^{\circ}$ 8.666. Lei de Licitações, jun. 1993. Disponível em <http://www.senado.gov.br>. Acesso em: 26 fev. 2006.

Lei $\mathrm{n}^{\circ}$ 8.987. Lei de Concessões, fev. 1995. Disponível em <http://www.senado.gov.br>. Acesso em: 05 jan. 2006. 2006 .

Lei $n^{\circ}$ 9.074. jul. 1995. Disponível em <http://www.senado.gov.br>. Acesso em: 05 jan.

. Lei $\mathrm{n}^{\mathrm{o}}$ 9.433. Lei dos Recursos Hídricos, jan. 1997. Disponível em $<$ http://www.senado.gov.br>. Acesso em: 05 jan. 2006.

2006.

Lei no 9.984. jul. 2000. Disponível em <http://www.senado.gov.br>. Acesso em: 05 jan. \begin{tabular}{l} 
Lei $\mathrm{n}^{\mathrm{o}}$ 10.028. Lei de Crimes Fiscais, out. 1993. Disponível em \\
\hline <http://www.senado.gov.br>. Acesso em: 26 fev. 2006.
\end{tabular}

. Lei $n^{\circ}$ 10.735. Programa de Incentivo à Implementação de Projetos de Interesse Social (PIPS), 2003. Disponível em <http://www.senado.gov.br>. Acesso em: 26 fev. 2006.

- Lei no 11.079. Lei de Parcerias Público-Privadas, 2004. Disponível em <http://www.senado.gov.br>. Acesso em: 26 fev. 2006. 
. Lei $n^{\circ}$ 11.107. Lei de Consórcios Públicos e Gestão Associada, 2005. Disponível em <http://www.senado.gov.br>. Acesso em: 26 fev. 2006.

- Resolução $\mathrm{n}^{\mathrm{o}} 40$ do Senado Federal. dez. 2001. Disponível em <http://www.senado.gov.br>. Acesso em: 26 fev. 2006.

Resolução $\mathrm{n}^{\mathrm{o}} 43$ do Senado Federal. dez. de 2001. Disponível em <http://www.senado.gov.br>. Acesso em: 26 fev. 2006.

- Resolução $\mathrm{n}^{\mathrm{o}} 2.827$ do Conselho Monetário Nacional. Disponível em <http://www.bacen.gov.br>. Acesso em: 26 fev. 2006.

- Resolução $\mathrm{n}^{\mathrm{o}} 3.153$ do Conselho Monetário Nacional. 2003. Disponível em $<\mathrm{http}$ ://www.bacen.gov.br>. Acesso em: 26 fev. 2006.

- Resolução $\mathrm{n}^{\mathrm{o}} 3.347$ do Conselho Monetário Nacional. 2006. Disponível em <http://www.bacen.gov.br>. Acesso em: 20 dez. 2006.

. Projeto de Lei $\mathrm{n}^{\circ}$ 5.296: diretrizes para os serviços de saneamento básico e Política Nacional de Saneamento Básico (PNS). 2005. Disponível em <http://www.cidades.gov.br>. Acesso em: 01 jan. 2006.

BORSOI, Z. M. F.; TORRES, S. D. A. “A política de recursos hídricos no Brasil”. 1997. Disponível em: <http://www.bndes.gov.br>. Acesso em: 01 jun. 2006.

CARMO, C. M.; TÁVORA JÚNIOR, J. L. "Avaliação da eficiência técnica das empresas de saneamento brasileiras utilizando a metodologia DEA". Anais do XXI Encontro Nacional de Economia, Porto Seguro: ANPEC, 2003. Disponível em: www.anpec.org.br. Acesso em: 01 abr. 2006.

CARNEIRO, D. D. “Crise e esperança: 1974-1980. In: ABREU, M. P. (org). A Ordem do Progresso, Editora Campus, $15^{\mathrm{a}}$ tiragem, 1990..

Censos Demográficos 1970, 1980, 1991 e 2000. Brasília, IBGE, 1970, 1980, 1991 e 2000.

EXAME. Anuário Exame 2006-2007: infra-estrutura. São Paulo: Abril, nov. 2006.

FARIA, R. C.; NOGUEIRA, J. M.; MUELLER, B. "Política de precificação do setor de saneamento urbano brasileiro: as evidências do equilíbrio de baixo nível". Estudos Econômicos, São Paulo, v. 5, nº 3: jul./set., 2005.

FERNANDES, A. G. "Sistemas de crédito local: o que ensinam as experiências internacionais". Informe-se BNDES, $\mathrm{n}^{\circ}$ 13: maio, 2000. 
FERNANDES JÚNIOR, O. "Hora da decisão". Desafios do desenvolvimento. Brasília, IPEA, ano $3, n^{\circ} 28$, nov. 2006.

FERREIRA, C. K. L. Financiamento da indústria e infra-estrutura no Brasil: crédito de longo prazo e mercado de capitais. 1996. 123f. Tese de Doutorado em Economia - Instituto de Economia, Universidade de Campinas, Campinas.

FERREIRA, P. C.; ISSLER, J. V. Growth, increasing returns, and public infrastructure: time series evidence. 1995. Programa de Seminários Acadêmicos - Instituto de Pesquisas Econômicas, Universidade de São Paulo, São Paulo.

; MALLIAGROS, T. G. "O impacto da infra-estrutura sobre o crescimento da produtividade do setor privado e do produto brasileiro". Ensaios Econômicos da EPGE, Rio de Janeiro, nº 315: ago. 1997.

FINNERTY, J. D. Project Finance: engenharia financeira baseada em ativos. Rio de Janeiro, Qualitymark, 1998.

FIOCCA, D. "As parcerias público-privadas na sustentação de um novo ciclo de desenvolvimento". Ministério do Planejamento, Orçamento e Gestão, 2004. Disponível em <http://www.mpo.gov.br>. Acesso em: 01 jan. 2006.

FOSTER, V. "Policy issues for the water and sanitation sectors". IFM96-101, Washington, 1996, mimeo.

FUJIWARA, T. "A privatização beneficia os pobres? Os efeitos da desestatização do saneamento básico na mortalidade infantil”. XXXIII Encontro Nacional de Economia, ANPEC, 2005.

GALIANI, S.; GERTLER, P.; SCHARGRODSKY, E. "Water for life: the impact of the privatization of water services on child mortality". Journal of Political Economy, v. 113, n. 1, 2005 .

GASPAR, E. "Financiamento ao setor de saneamento". $36^{\circ}$ Fórum de Debates Projeto Brasil Política de Saneamento: balanços e aprimoramentos, Agência Dinheiro Vivo, out. 2006.

GIAMBIAGI, F.; ALÉM, A. C. Finanças Públicas: teoria e prática no Brasil. $2^{\mathrm{a}}$ ed. Rio de Janeiro, Campus, 2001.

GOMES, G. M.; MAC DOWELL, M. C. "Descentralização política, federalismo fiscal e criação de municípios: o que é mau para o econômico nem sempre é bom para o social". Textos para Discussão do IPEA, $\mathrm{n}^{\circ}$ 706, fev. 2000.

GRAMLICH, E. M. "Infrastructure investment: a review essay". Journal of Economic Literature, Washington, D.C., v. 32: p. 1176-1196, set. 1994. 
GREMAUD, A. P. "Descentralização na América Latina: Benefícios, Armadilhas e Requisitos". Curso de Relações Fiscais Intergovernamentais, 2000, mimeo.

; TONETO JR., R. "Descentralização e endividamento municipal: formas, limites e possibilidades". Textos para Discussão - Série Economia - da FEA/USP Ribeirão Preto, Ribeirão Preto. 2000.

GREENE, W.H. Econometric Analysis. $3^{\mathrm{a}}$ ed. New Jersey, Prentice Hall, 1997.

IDELOVITCH, E.; RINGSKOG, K. Private sector participation in water supply and sanitation in Latin America. Washington, D.C.: World Bank, 1995.

JOHNSTON, J.; DINARDO, J. Métodos Econométricos. 4ª ed. Lisboa, Mc Graw Hill, 2001.

JOURAVLEV, A. S. Water utility regulation: issues and options for Latin America and the Caribbean. Economic Commission for Latin America and the Caribbean (ECLAC), Oct. 2000.

LAGO, L. A. C. "A Retomada do Crescimento e as Distorções do "Milagre": 1967 - 1973". In: ABREU, M. P. (org). A Ordem do Progresso, Editora Campus, 15ª tiragem, 1990.

LIMA, E. C. P. Disciplina fiscal no Brasil: atuais instituições garantem equilíbrios permanentes? 2002. Prêmio Tesouro Nacional de Monografias, Secretaria do Tesouro Nacional, Brasília.

MAGALHÃES, R. A. Planasa: intervenção pioneira do governo federal na matéria. Seminário Os Desafios do Saneamento Ambiental, Regulamentação e Padrões de Financiamento. São Paulo, 1993.

MEJIA, A. et alii. “Água, redução de pobreza e desenvolvimento sustentável”. Série Água Brasil (Banco Mundial), Brasília, nº 4: jun. 2003.

MELLO, M. F. "Privatização do setor de saneamento no Brasil: quatro experiências e muitas lições". Textos para Discussão da PUC-RIO, Rio de Janeiro, n 447: p. 1-23, set. 2001.

MCIDADES. O desafio da universalização do saneamento ambiental no Brasil. Ministério das Cidades, 2002. Disponível em <http:// www.cidades.gov.br >. Acesso em: 01 ago. 2002.

. "O financiamento do saneamento básico em 2003/2004: piloto de uma nova abordagem para o investimento público no Brasil?". Ministério das Cidades, dez. 2004. Disponível em $<$ http:// www.cidades.gov.br>. Acesso em: 01 out. 2005.

"Investimentos federais em saneamento: 01 de janeiro de 2003 a 15 de junho de 2006". Ministério das Cidades, jun. 2006. 
MOREIRA, T. Saneamento básico: desafios e oportunidades. s.d. Disponível em: $<$ http://www.bndes.gov.br>. Acesso em: 05 fev. 2002.

. O processo de privatização mundial: tendências recentes e perspectivas para o Brasil, mimeo. 1994.

. "A hora e a vez do saneamento". Revista do BNDES, Rio de Janeiro, n 10: dez. 1998.

MOTTA, R. S. "Questões regulatórias do setor de saneamento no Brasil". Notas Técnicas do IPEA, Rio de Janeiro, $\mathrm{n}^{\circ}$ 5: jan. 2004.

MPO/Sepurb/IPEA. "Saneamento: modernização e parceria com o setor privado". Série Modernização do Setor Saneamento, Brasília, no 16: p. 1-40. s.d.

. "Diagnóstico do setor de saneamento: estudo econômico e financeiro". Série Modernização do Setor Saneamento, Brasília, no 7: p. 1-250, 1995.

MUNNELL, A. H. "Infrastructure investment and economic growth". Journal of Economic Perspectives, Wasghington, D.C., v. 6, $\mathrm{n}^{\mathrm{o}}$ 4: p. 189-198, 1992.

MUSGRAVE, R. A.; MUSGRAVE, P. B. Finanças Públicas. $1^{\text {a }}$ ed. Rio de Janeiro: Campus, 1973.

NASCIMENTO, E. R.; GERARDO, J. C. Dois anos da Lei de Responsabilidade Fiscal. Brasília, Ministério da Fazenda, Tesouro Nacional, 2003.

OHIRA, T. H. Fronteira de eficiência em serviços de saneamento básico no Estado de São Paulos. 2005. 110f. Dissertação de Mestrado em Economia Aplicada - Escola Superior de Agricultura Luiz de Queiroz, Universidade de Campinas, Piracicaba.

OLIVEIRA, W. Lei de Responsabilidade Fiscal: principais aspectos concernentes aos municípios. 2000. Câmara dos Deputados, Consultoria de Orçamento e Fiscalização Financeira. Disponível em <http://www.tesouro.fazenda.gov.br>. Acesso em: 26 fev. 2006.

OLIVEIRA FILHO, A. "Limites fiscais para operações de crédito de projetos públicos de saneamento ambiental: a experiência do BNDES com a flexibilização através da Resolução BACEN no 3.153/2003. Saneamento Ambiental, BNDES, Brasília: p. 161/81, mar. 2005.

. "Institucionalização e desafios da Política Nacional de Saneamento: um balanço prévio". Saneamento e Municípios, Brasília, Assemae, jun-ago. 2006.

PARLATORE, A. C. Privatização do setor de saneamento no Brasil. In: BNDES. A privatização no Brasil: $O$ caso das utilidades públicas, Rio de Janeiro. 2000. 
PEIXOTO, J. B. "O barulho da água: os municípios e a gestão dos serviços de saneamento". Água e Vida, São Paulo, 1994

PETERSON, G. "Building local credit systems". Urban Management Program, Washington, D.C.: World Bank, p. 1-68, Apr. 2000.

PNAD. Pesquisa Nacional por Amostra de Domicílios 2000, 2001, 2002, 2003 e 2004. Brasília, IBGE, 2000, 2001, 2002, 2003 e 2004.

PNSB. Pesquisa Nacional de Saneamento Básico de 1989 e de 2000. Brasília, IBGE, 1989 e 2000 .

POF. Pesquisa de Orçamentos Familiares 2002-2003. Brasília, IBGE, 2003.

REES, J. A. "Regulation and private participation in the water and sanitation sector". TAC Background Papers, Global Water Partnership, Technical Advisory Committee, $\mathrm{n}^{\circ}$ 1: 1998.

REIS, J. G.; URANI, A. Uma visão abrangente das transformações recentes no Brasil. In: GIAMBIAGI, F.; REIS, J. G.; URANI, A.. Reformas no Brasil: balanço e agenda, $1^{\text {a }}$ ed. Rio de Janeiro, Nova Fronteira, 2004.

RESENDE, A. L. "Estabilização e reforma: 1964-1967. In: ABREU, M. P. (org). A Ordem do Progresso, Editora Campus, 15ª tiragem, 1990.

REZENDE, F. "Federalismo fiscal no Brasil". Revista de Economia Política, volume 15, $\mathrm{n}^{\circ} 3$ (59), jul./set. 1995.

REZENDE, F. "Fiscal decentralization and big cities financing in Brazil". Textos para Discussão do IPEA, nº 612, dez. 1998.

RIGOLON, F. J. Z.; PICCININI, M. S. "O investimento em infra-estrutura e a retomada do crescimento econômico sustentado". Textos para Discussão do BNDES, Rio de Janeiro, no 63: dez. 1997.

SANTOS, A. M. P. et alii.. Federalismo no Brasil: análise da descentralização financeira da perspectiva das cidades médias. s.d. Disponível em: <http: // www.nemesis.org.br>. Acesso em: 05 jun. 2002.

SHIRLEY, M. M. "The politics and economics of reforming urban water systems". World Bank, 2000, mimeo.

SIMONETTI, E. "Na conta certa". Desafios do desenvolvimento. Brasília, IPEA, ano 3, n 28, nov. 2006. 
SNIS. Diagnósticos dos Serviços de Água e Esgoto 2000, 2001, 2002, 2003 e 2004. Brasília, Ministério das Cidades, 2000, 2001, 2002, 2003 e 2004.

SPILLER, P. T.; SAVEDOFF, W. D. Spilled water: institutional commitment in the provision of water services. Washington, D.C., Inter-American Development Bank, 1999.

TAVARES, M. C. Da substituição de importações ao capitalismo financeiro: ensaios sobre economia brasileira. Rio de Janeiro, Zahar, 1975

MENEZES, R. T. "Impactos da Lei de Responsabilidade Fiscal sobre os componentes de despesa dos municípios brasileiros". X Prêmio Tesouro Nacional, ESAF, 2005.

TONETO JÚNIOR, R. A situação atual do saneamento básico no Brasil: problemas e perspectivas. 2004. 323f. Teses de Livre Docência em Economia - Faculdade de Economia, Administração e Contabilidade de Ribeirão Preto, Universidade de São Paulo, Ribeirão Preto.

; SAIANI, C.C.S. Restrições à expansão dos investimentos no saneamento básico brasileiro. 2005. X Encontro Nacional de Economia Política, Sociedade Brasileira de Economia Política.

TUROLLA, F. A. "Política de saneamento básico: avanços recentes e opções futuras de políticas públicas”. Textos para Discussão do IPEA, Brasília, no 922: p. 1-26, dez. 2002.

WOOLDRIDGE, J. M. Introductory Econometrics. Pioneira Thomson Learning, 20 ed, 2002. 


\section{APÊNDICE}

\section{Tabela 1}

Brasil: PIB per capita estadual e do Distrito Federal, segundo as grandes regiões, e ranking estadual (2000)

\begin{tabular}{|c|c|c|c|}
\hline Região & Estado & PIB per capita $(\mathrm{R} \$)$ & Posição \\
\hline \multirow{7}{*}{ Norte } & Acre & 3.048 & $20^{\circ}$ \\
\hline & Amapá & 4.216 & $13^{\circ}$ \\
\hline & Amazonas & 6.663 & $8^{\circ}$ \\
\hline & Pará & 3.007 & $21^{\circ}$ \\
\hline & Rondônia & 3.888 & $14^{\circ}$ \\
\hline & Roraima & 3.347 & $17^{\circ}$ \\
\hline & Tocantins & 2.117 & $25^{\circ}$ \\
\hline \multirow{9}{*}{ Nordeste } & Alagoas & 2.471 & $24^{\circ}$ \\
\hline & Bahia & 3.666 & $15^{\circ}$ \\
\hline & Ceará & 2.774 & $22^{\circ}$ \\
\hline & Maranhão & 1.616 & $27^{\circ}$ \\
\hline & Paraíba & 2.670 & $23^{\circ}$ \\
\hline & Pernambuco & 3.655 & $16^{\circ}$ \\
\hline & Piauí & 1.863 & $26^{\circ}$ \\
\hline & Rio Grande do Norte & 3.319 & $18^{\circ}$ \\
\hline & Sergipe & 3.283 & $19^{\circ}$ \\
\hline \multirow{4}{*}{ Centro-Oeste } & Distrito Federal & 14.224 & $1^{0}$ \\
\hline & Goiás & 4.276 & $12^{\circ}$ \\
\hline & Mato Grosso & 5.297 & $11^{\circ}$ \\
\hline & Mato Grosso do Sul & 5.656 & $10^{\circ}$ \\
\hline \multirow{4}{*}{ Sudeste } & Espírito Santo & 6.880 & $6^{0}$ \\
\hline & Minas Gerais & 5.888 & $9^{0}$ \\
\hline & Rio de Janeiro & 9.513 & 3o \\
\hline & São Paulo & 9.919 & $2^{\circ}$ \\
\hline \multirow{3}{*}{ Sul } & Paraná & 6.847 & $7^{0}$ \\
\hline & Rio Grande do Sul & 8.302 & $4 \%$ \\
\hline & Santa Catarina & 7.844 & $5^{\circ}$ \\
\hline
\end{tabular}

Fonte: IBGE, PIB Municipal. Elaboração própria. 
Tabela 2

Brasil: proporção de domicílios com acesso simultâneo a água e a esgoto por rede geral, segundo o porte (tamanho da população) dos municípios, as grandes regiões e o Estado de São Paulo (2000)

\begin{tabular}{l|c|c|c|c|c|c|c|c|c}
\hline \multicolumn{1}{c}{$\begin{array}{c}\text { Região / } \\
\text { Porte }\end{array}$} & N & NE & CO (1) & CO (2) & SE (3) & SE (4) & $\begin{array}{c}\text { São } \\
\text { Paulo }\end{array}$ & S & Brasil \\
\hline até 5.000 hab. & 1,02 & 8,48 & 1,85 & 1,85 & 51,79 & 42,86 & 63,05 & 2,96 & $\mathbf{2 1 , 6 3}$ \\
5.000 a 10.000 hab. & 0,39 & 12,15 & 4,35 & 4,35 & 54,80 & 46,44 & 71,89 & 6,79 & $\mathbf{2 4 , 2 1}$ \\
10.000 a 20.000 hab. & 1,29 & 14,67 & 5,91 & 5,91 & 57,93 & 50,05 & 71,90 & 13,05 & $\mathbf{2 6 , 2 0}$ \\
20.000 a 50.000 hab. & 1,20 & 20,25 & 12,70 & 12,70 & 65,81 & 53,87 & 78,96 & 22,74 & $\mathbf{3 4 , 3 9}$ \\
50.000 a 100.000 hab. & 4,11 & 31,76 & 19,27 & 19,27 & 70,08 & 64,09 & 75,72 & 28,37 & $\mathbf{4 3 , 7 3}$ \\
100.000 a 500.000 hab. & 8,45 & 40,89 & 29,89 & 29,89 & 74,40 & 66,13 & 81,42 & 37,21 & $\mathbf{5 5 , 8 6}$ \\
500.000 a 1.000.000 hab. & $*$ & 29,46 & 18,49 & 18,49 & 71,25 & 55,55 & 85,56 & $*$ & $\mathbf{5 5 , 9 1}$ \\
mais de 1.000.000 hab. & 27,44 & 55,88 & $\mathbf{7 9 , 0 9}$ & $\mathbf{7 0 , 7 1}$ & 84,51 & 81,83 & 86,49 & 63,92 & $\mathbf{7 3 , 9 9}$ \\
Total & $\mathbf{9 , 6 4}$ & $\mathbf{3 1 , 3 7}$ & $\mathbf{3 3 , 7 1}$ & $\mathbf{2 2 , 7 3}$ & $\mathbf{7 3 , 4 8}$ & $\mathbf{6 4 , 5 6}$ & $\mathbf{8 1 , 7 5}$ & $\mathbf{2 9 , 8 7}$ & $\mathbf{5 0 , 2 9}$ \\
\hline
\end{tabular}

Fonte: IBGE, Censo Demográfico de 2000. Elaboração própria.

(1) Centro-Oeste incluindo o Distrito Federal.

(2) Centro-Oeste excluindo o Distrito Federal.

(3) Sudeste incluindo São Paulo.

(4) Sudeste excluindo São Paulo.

* Não há município com esse porte na região.

Tabela 3

Brasil: proporção de domicílios com acesso simultâneo a água e a esgoto por rede geral, segundo a taxa de urbanização dos municípios, as grandes regiões e o Estado de São Paulo (2000)

\begin{tabular}{l|c|c|c|c|c|c|c|c|c}
\hline $\begin{array}{c}\text { Região / Taxa de } \\
\text { Urbanização }\end{array}$ & N & NE & CO (1) & CO (2) & SE (3) & SE (4) & $\begin{array}{c}\text { São } \\
\text { Paulo }\end{array}$ & S & Brasil \\
\hline menos de 50\% & 1,07 & 12,02 & 1,31 & 1,31 & 28,49 & 27,09 & 34,98 & 6,18 & 11,48 \\
de 50\% a 60\% & 2,29 & 17,07 & 1,96 & 1,96 & 40,23 & 38,38 & 51,50 & 9,78 & $\mathbf{1 8 , 6 7}$ \\
de 60\% a 70\% & 2,82 & 23,65 & 4,75 & 4,75 & 48,70 & 47,58 & 51,90 & 13,84 & $\mathbf{2 4 , 2 8}$ \\
de 70\% a 80\% & 0,98 & 30,13 & 6,55 & 6,55 & 60,29 & 57,33 & 66,18 & 18,84 & $\mathbf{3 3 , 2 3}$ \\
de 80\% a 90\% & 9,29 & 36,74 & 12,85 & 12,85 & 67,74 & 60,00 & 78,63 & 25,97 & $\mathbf{4 3 , 0 6}$ \\
de 90\% a 95\% & 1,82 & 28,34 & 20,70 & 20,70 & 83,02 & 64,58 & 87,37 & 35,76 & $\mathbf{6 6 , 2 3}$ \\
mais de 95\% & 21,93 & 47,10 & $\mathbf{5 6 , 0 8}$ & $\mathbf{4 0 , 6 4}$ & 76,32 & 72,54 & 80,76 & 43,98 & $\mathbf{6 2 , 6 9}$ \\
Total & $\mathbf{9 , 6 4}$ & $\mathbf{3 1 , 3 7}$ & $\mathbf{3 3 , 7 1}$ & $\mathbf{2 2 , 7 3}$ & $\mathbf{7 3 , 4 8}$ & $\mathbf{6 4 , 5 6}$ & $\mathbf{8 1 , 7 5}$ & $\mathbf{2 9 , 8 7}$ & $\mathbf{5 0 , 2 9}$ \\
\hline
\end{tabular}

Fonte: IBGE, Censo Demográfico de 2000. Elaboração própria.

(1) Centro-Oeste incluindo o Distrito Federal.

(2) Centro-Oeste excluindo o Distrito Federal.

(3) Sudeste incluindo São Paulo.

(4) Sudeste excluindo São Paulo. 


\section{Tabela 4}

Brasil: proporção de domicílios com acesso simultâneo a água e a esgoto por rede geral, segundo a renda per capita mensal dos municípios, as grandes regiões e o Estado de São Paulo (2000)

\begin{tabular}{l|c|c|r|r|r|r|r|r|r}
\hline $\begin{array}{c}\text { Região / } \\
\text { Renda }\end{array}$ & N & NE & CO (1) & CO (2) & SE (3) & SE (4) & $\begin{array}{c}\text { São } \\
\text { Paulo }\end{array}$ & S & Brasil \\
\hline até 1 S.M. & 1,29 & 20,47 & 0,78 & 0,78 & 32,34 & 31,82 & 41,67 & 5,04 & $\mathbf{1 8 , 0 8}$ \\
de 1 a 2 S.M. & 12,96 & 37,04 & 13,83 & 13,83 & 59,66 & 55,92 & 67,89 & 19,02 & $\mathbf{3 9 , 6 2}$ \\
de 2 a 3 S.M. & 18,85 & 52,27 & 25,89 & 25,89 & 78,77 & 74,20 & 81,06 & 29,83 & $\mathbf{5 6 , 8 0}$ \\
mais de 3 S.M. & $*$ & 57,23 & $\mathbf{7 7 , 1 2}$ & $\mathbf{6 6 , 1 1}$ & 85,93 & 81,39 & 88,40 & 58,52 & $\mathbf{8 1 , 3 5}$ \\
Total & $\mathbf{9 , 6 4}$ & $\mathbf{3 1 , 3 7}$ & $\mathbf{3 3 , 7 1}$ & $\mathbf{2 2 , 7 3}$ & $\mathbf{7 2 , 7 4}$ & $\mathbf{6 4 , 5 6}$ & $\mathbf{8 1 , 7 5}$ & $\mathbf{2 9 , 8 7}$ & $\mathbf{5 0 , 2 9}$ \\
\hline
\end{tabular}

Fonte: IBGE, Censo Demográfico de 2000. Elaboração própria.

S.M.: Salário mínimo.

(1) Centro-Oeste incluindo o Distrito Federal.

(2) Centro-Oeste excluindo o Distrito Federal.

(3) Sudeste incluindo São Paulo.

(4) Sudeste excluindo São Paulo.

* Não há município com essa renda per capita na região.

Tabela 5

Brasil: proporção de domicílios com acesso simultâneo a água e a esgoto por rede geral, segundo o tipo de município, as grandes regiões e o Estado de São Paulo (2000)

\begin{tabular}{l|r|c|r|r|r|r|r|r|r}
\hline Região / Tipo de Município & N & NE & CO (1) & CO (2) & SE (3) & SE (4) & $\begin{array}{c}\text { São } \\
\text { Paulo }\end{array}$ & S & Brasil \\
\hline Capital * & 23,34 & 47,53 & 66,64 & 51,53 & 85,10 & 82,10 & 87,62 & 62,18 & $\mathbf{6 7 , 7 2}$ \\
Região Metropolitana ** & 3,60 & 27,18 & 13,38 & 13,38 & 64,43 & 53,72 & 73,33 & 26,22 & $\mathbf{5 0 , 7 6}$ \\
Municípios do Interior & 1,95 & 24,76 & 13,11 & 13,11 & 72,01 & 60,96 & 83,72 & 23,73 & $\mathbf{4 1 , 2 5}$ \\
Total & $\mathbf{9 , 6 4}$ & $\mathbf{3 1 , 3 7}$ & $\mathbf{3 3 , 7 1}$ & $\mathbf{2 2 , 7 3}$ & $\mathbf{7 2 , 7 4}$ & $\mathbf{6 4 , 5 6}$ & $\mathbf{8 1 , 7 5}$ & $\mathbf{2 9 , 8 7}$ & $\mathbf{5 0 , 2 9}$ \\
\hline
\end{tabular}

Fonte: IBGE, Censo Demográfico de 2000. Elaboração própria.

(1) Centro-Oeste incluindo o Distrito Federal.

(2) Centro-Oeste excluindo o Distrito Federal - no caso, excluindo a Capital Federal (Brasília).

(3) Sudeste incluindo São Paulo.

(4) Sudeste excluindo São Paulo.

* Capitais estaduais e Federal (Brasília).

** Municípios pertencentes a uma região metropolitana. 
Tabela 6

Brasil: proporção de domicílios com acesso simultâneo a água e a esgoto por rede geral, segundo a renda domiciliar mensal, as grandes regiões, o Distrito Federal e o Estado de São Paulo (2000)

\begin{tabular}{l|c|c|c|c|c|c|c|c|c|c}
\hline $\begin{array}{c}\text { Região / } \\
\text { Renda }\end{array}$ & N & NE & $\begin{array}{c}\text { CO } \\
(1)\end{array}$ & $\begin{array}{c}\text { CO } \\
(2)\end{array}$ & $\begin{array}{c}\text { Distrito } \\
\text { Federal }\end{array}$ & SE (3) & SE (4) & $\begin{array}{c}\text { São } \\
\text { Paulo }\end{array}$ & Sul & Brasil \\
\hline menos de 1 S.M. & 4,57 & 20,96 & 19,22 & 12,92 & 71,21 & 57,96 & 49,35 & 70,24 & 18,91 & $\mathbf{3 2 , 1 0}$ \\
de 1 a 2 S.M. & 5,34 & 24,07 & 19,47 & 12,77 & 72,87 & 59,16 & 52,42 & 69,31 & 19,04 & $\mathbf{3 4 , 4 0}$ \\
de 2 a 3 S.M. & 7,02 & 28,83 & 23,63 & 16,00 & 79,92 & 65,33 & 58,27 & 73,55 & 22,93 & $\mathbf{4 2 , 0 7}$ \\
de 3 a 5 S.M. & 9,00 & 34,81 & 28,88 & 19,83 & 84,33 & 71,11 & 63,60 & 78,25 & 26,87 & $\mathbf{4 9 , 4 4}$ \\
de 5 a 10 S.M. & 14,14 & 43,54 & 40,24 & 28,80 & 88,48 & 78,75 & 70,84 & 84,68 & 33,19 & $\mathbf{5 9 , 6 8}$ \\
de 10 a 20 S.M. & 20,04 & 51,84 & 55,27 & 41,21 & 89,78 & 85,71 & 78,72 & 90,44 & 42,92 & $\mathbf{6 9 , 1 5}$ \\
mais de 20 S.M. & 25,01 & 59,10 & 66,19 & 51,65 & 85,71 & 89,92 & 84,43 & 93,53 & 53,38 & $\mathbf{7 6 , 0 4}$ \\
Total & $\mathbf{9 , 6 4}$ & $\mathbf{3 1 , 3 7}$ & $\mathbf{3 3 , 7 1}$ & $\mathbf{2 2 , 7 3}$ & $\mathbf{8 3 , 9 0}$ & $\mathbf{7 3 , 4 8}$ & $\mathbf{6 4 , 5 6}$ & $\mathbf{8 1 , 7 5}$ & $\mathbf{2 9 , 8 7}$ & $\mathbf{5 0 , 2 9}$ \\
\hline
\end{tabular}

Fonte: IBGE, Censo Demográfico de 2000. Elaboração própria.

S.M.: Salário mínimo.

(1) Centro-Oeste incluindo o Distrito Federal.

(2) Centro-Oeste excluindo o Distrito Federal.

(3) Sudeste incluindo São Paulo.

(4) Sudeste excluindo São Paulo.

\section{Tabela 7}

Brasil: proporção de domicílios com acesso simultâneo a água e a esgoto por rede geral, segundo a renda domiciliar per capita mensal, as grandes regiões, o Distrito Federal e o Estado de São Paulo (2000)

\begin{tabular}{l|c|c|c|c|c|c|c|c|c|c}
\hline $\begin{array}{c}\text { Região / } \\
\text { Renda }\end{array}$ & N & NE & $\begin{array}{c}\text { CO } \\
(1)\end{array}$ & $\begin{array}{c}\text { CO } \\
(2)\end{array}$ & $\begin{array}{c}\text { Distrito } \\
\text { Federal }\end{array}$ & $\begin{array}{c}\text { SE } \\
(3)\end{array}$ & $\begin{array}{c}\text { SE } \\
(4)\end{array}$ & $\begin{array}{c}\text { São } \\
\text { Paulo }\end{array}$ & Sul & Brasil \\
\hline menos de 1 S.M. & 5,86 & 24,36 & 20,76 & 13,36 & 75,98 & 60,60 & 53,25 & 70,26 & 19,95 & $\mathbf{3 5 , 8 2}$ \\
de 1 a 2 S.M. & 11,98 & 39,55 & 33,07 & 23,45 & 86,41 & 74,39 & 66,38 & 81,22 & 27,97 & $\mathbf{5 3 , 8 8}$ \\
de 2 a 3 S.M. & 16,92 & 47,81 & 44,72 & 32,65 & 89,13 & 80,88 & 72,77 & 86,66 & 34,72 & $\mathbf{6 2 , 9 6}$ \\
de 3 a 5 S.M. & 19,80 & 52,17 & 52,80 & 40,13 & 88,88 & 84,93 & 77,50 & 90,02 & 41,44 & $\mathbf{6 8 , 4 6}$ \\
de 5 a 10 S.M. & 24,08 & 57,25 & 62,23 & 48,41 & 87,74 & 88,62 & 82,34 & 93,00 & 49,49 & $\mathbf{7 4 , 0 7}$ \\
de 10 a 20 S.M. & 26,74 & 62,06 & 67,77 & 53,09 & 85,54 & 90,68 & 85,81 & 94,11 & 57,72 & $\mathbf{7 8 , 5 2}$ \\
mais de 20 S.M. & 27,37 & 63,77 & 68,97 & 52,87 & 86,25 & 91,05 & 86,37 & 94,28 & 61,64 & $\mathbf{8 0 , 2 7}$ \\
Total & $\mathbf{9 , 6 4}$ & $\mathbf{3 1 , 3 7}$ & $\mathbf{3 3 , 7 1}$ & $\mathbf{2 2 , 7 3}$ & $\mathbf{8 3 , 9 0}$ & $\mathbf{7 3 , 4 8}$ & $\mathbf{6 4 , 5 6}$ & $\mathbf{8 1 , 7 5}$ & $\mathbf{2 9 , 8 7}$ & $\mathbf{5 0 , 2 9}$ \\
\hline
\end{tabular}

Fonte: IBGE, Censo Demográfico de 2000. Elaboração própria.

S.M.: Salário mínimo.

(1) Centro-Oeste incluindo o Distrito Federal.

(2) Centro-Oeste excluindo o Distrito Federal.

(3) Sudeste incluindo São Paulo.

(4) Sudeste excluindo São Paulo. 


\section{Tabela 8}

Brasil: proporção de domicílios com acesso a serviços de saneamento básico, segundo o porte dos municípios, as grandes regiões e o Estado de São Paulo (1970)

\begin{tabular}{|c|c|c|c|c|c|c|c|c|}
\hline $\begin{array}{c}\text { Região / } \\
\text { Porte }\end{array}$ & $\mathbf{N}$ & $\mathbf{N E}$ & $\mathrm{CO}$ & SE (3) & SE (4) & $\begin{array}{c}\text { São } \\
\text { Paulo }\end{array}$ & $\mathbf{S}$ & Brasil \\
\hline \multicolumn{9}{|c|}{ Água - Rede Geral (\% dos domicílios) } \\
\hline até 5.000 hab. & 3,36 & 0,93 & 2,08 & 24,38 & 25,20 & 22,64 & 6,31 & 7,61 \\
\hline 5.000 a 10.000 hab. & 4,59 & 1,80 & 4,86 & 25,35 & 23,12 & 30,31 & 5,64 & 7,13 \\
\hline 10.000 a 20.000 hab. & 4,40 & 2,81 & 7,26 & 29,67 & 27,61 & 34,11 & 8,11 & $\mathbf{9 , 0 2}$ \\
\hline 20.000 a 50.000 hab. & 7,39 & 5,20 & 9,52 & 32,65 & 26,15 & 40,88 & 11,62 & 14,32 \\
\hline 50.000 a 100.000 hab. & 5,61 & 8,32 & 25,40 & 39,39 & 33,09 & 52,45 & 19,91 & 25,20 \\
\hline 100.000 a 500.000 hab. & 41,36 & 27,19 & 48,86 & 62,87 & 61,79 & 64,53 & 39,50 & 53,74 \\
\hline 500.000 a 1.000 .000 hab. & 55,54 & 13,16 & $*$ & 35,24 & 35,24 & $*$ & 68,24 & 48,45 \\
\hline mais de 1.000 .000 hab. & $*$ & 52,80 & $*$ & 61,45 & 46,46 & 64,30 & $*$ & $\mathbf{5 9 , 7 1}$ \\
\hline Total & 19,82 & 12,32 & 19,90 & 51,56 & $\mathbf{4 5 , 5 8}$ & $\mathbf{5 8 , 5 6}$ & 25,27 & 33,23 \\
\hline \multicolumn{9}{|c|}{ Esgoto - Rede Geral (\% dos domicílios) } \\
\hline até 5.000 hab. & 0,00 & 0,00 & 0,00 & 5,94 & 6,69 & 4,33 & 0,00 & 1,42 \\
\hline 5.000 a 10.000 hab. & 0,00 & 0,29 & 0,00 & 10,65 & 8,94 & 14,42 & 0,00 & 1,97 \\
\hline 10.000 a 20.000 hab. & 0,00 & 0,14 & 0,04 & 12,79 & 11,62 & 15,30 & 0,14 & 2,27 \\
\hline 20.000 a 50.000 hab. & 0,00 & 0,31 & 1,93 & 14,94 & 11,77 & 18,94 & 0,79 & 4,43 \\
\hline 50.000 a 100.000 hab. & 0,15 & 0,89 & 5,08 & 22,87 & 18,20 & 32,56 & 3,14 & 11,25 \\
\hline 100.000 a 500.000 hab. & 0,00 & 5,83 & 26,30 & 38,45 & 34,38 & 44,75 & 9,70 & 28,82 \\
\hline 500.000 a 1.000 .000 hab. & 8,25 & 2,82 & $*$ & 9,84 & 9,84 & $*$ & 38,53 & 21,19 \\
\hline mais de 1.000 .000 hab. & $*$ & 14,99 & $*$ & 5,85 & 36,61 & 0,00 & $*$ & 7,69 \\
\hline Total & $\mathbf{1 , 5 5}$ & 2,40 & 7,41 & 24,03 & 24,93 & 22,96 & 7,27 & 13,41 \\
\hline \multicolumn{9}{|c|}{ Fossa Séptica (\% dos domicílios) } \\
\hline até 5.000 hab. & 0,14 & 0,49 & 1,62 & 4,31 & 5,00 & 2,83 & 4,46 & 2,17 \\
\hline 5.000 a 10.000 hab. & 0,75 & 0,53 & 3,09 & 4,81 & 4,18 & 6,22 & 4,58 & 2,36 \\
\hline 10.000 a 20.000 hab. & 1,00 & 0,97 & 3,49 & 6,75 & 6,74 & 6,77 & 6,79 & 3,36 \\
\hline 20.000 a 50.000 hab. & 1,67 & 2,22 & 4,86 & 6,74 & 5,02 & 8,91 & 9,06 & 5,10 \\
\hline 50.000 a 100.000 hab. & 1,54 & 3,35 & 8,73 & 6,77 & 6,49 & 7,34 & 11,55 & 6,84 \\
\hline 100.000 a 500.000 hab. & 20,22 & 11,91 & 16,41 & 15,99 & 19,03 & 11,26 & 18,59 & 15,87 \\
\hline 500.000 a 1.000 .000 hab. & 19,71 & 22,22 & $*$ & 23,20 & 23,20 & $*$ & 22,42 & 22,17 \\
\hline mais de 1.000 .000 hab. & $*$ & 19,77 & $*$ & 54,24 & 8,34 & 62,98 & $*$ & 47,31 \\
\hline Total & 7,29 & 5,52 & 7,59 & 19,86 & 12,64 & 28,33 & 12,80 & $\mathbf{1 3 , 5 5}$ \\
\hline
\end{tabular}

Fonte: IBGE, Censo Demográfico de 1970. Elaboração própria.

(3) Sudeste incluindo São Paulo.

(4) Sudeste excluindo São Paulo.

* Não há município com esse porte na região. 
Tabela 9

Brasil: proporção de domicílios com acesso a serviços de saneamento básico, segundo o porte dos municípios, as grandes regiões e o Estado de São Paulo (1980)

\begin{tabular}{|c|c|c|c|c|c|c|c|c|}
\hline $\begin{array}{c}\text { Região / } \\
\text { Porte }\end{array}$ & $\mathbf{N}$ & NE & $\mathrm{CO}$ & SE (3) & SE (4) & $\begin{array}{c}\text { São } \\
\text { Paulo }\end{array}$ & $\mathbf{S}$ & Brasil \\
\hline \multicolumn{9}{|c|}{ Água - Rede Geral (\% dos domicílios) } \\
\hline até 5.000 hab. & 15,60 & 9,19 & 8,60 & 39,51 & 32,66 & 48,12 & 21,11 & 26,99 \\
\hline 5.000 a 10.000 hab. & 13,35 & 12,04 & 16,26 & 42,92 & 35,45 & 55,97 & 23,68 & 25,72 \\
\hline 10.000 a 20.000 hab. & 16,53 & 14,10 & 18,14 & 48,48 & 40,38 & 60,75 & 28,70 & 27,72 \\
\hline 20.000 a 50.000 hab. & 18,81 & 20,31 & 26,66 & 56,26 & 44,51 & 71,45 & 37,13 & 34,41 \\
\hline 50.000 a 100.000 hab. & 26,81 & 28,76 & 45,21 & 67,44 & 59,83 & 75,41 & 56,64 & 50,84 \\
\hline 100.000 a 500.000 hab. & 36,76 & 60,23 & 54,72 & 78,43 & 67,47 & 87,51 & 70,95 & 70,61 \\
\hline 500.000 a 1.000 .000 hab. & 80,18 & $*$ & 45,97 & 72,36 & 54,42 & 84,48 & $*$ & 70,66 \\
\hline mais de 1.000 .000 hab. & $*$ & 62,33 & 94,69 & 88,56 & 84,60 & 92,27 & 91,04 & 85,32 \\
\hline Total & 39,28 & 31,66 & 41,76 & 72,66 & 63,08 & 82,37 & 52,04 & 54,99 \\
\hline \multicolumn{9}{|c|}{ Esgoto - Rede Geral (\% dos domicílios) } \\
\hline até 5.000 hab. & 0,00 & 0,05 & 0,32 & 14,82 & 14,11 & 15,71 & 0,01 & 7,99 \\
\hline 5.000 a 10.000 hab. & 0,00 & 0,40 & 0,90 & 24,45 & 18,46 & 34,93 & 0,10 & 8,94 \\
\hline 10.000 a 20.000 hab. & 0,00 & 0,24 & 0,56 & 30,79 & 24,08 & 40,97 & 1,84 & $\mathbf{9 , 7 4}$ \\
\hline 20.000 a 50.000 hab. & 0,23 & 1,04 & 3,52 & 38,59 & 27,53 & 52,89 & 3,89 & 12,50 \\
\hline 50.000 a 100.000 hab. & 1,11 & 2,79 & 8,45 & 46,11 & 44,18 & 48,12 & 8,26 & 20,87 \\
\hline 100.000 a 500.000 hab. & 2,18 & 14,65 & 20,80 & 57,35 & 47,15 & 65,79 & 13,42 & 36,38 \\
\hline 500.000 a 1.000 .000 hab. & 16,71 & $*$ & 27,11 & 40,89 & 4,59 & 65,35 & $*$ & 32,82 \\
\hline mais de 1.000 .000 hab. & $*$ & 20,30 & 47,01 & 65,32 & 72,43 & 58,67 & 52,94 & 56,85 \\
\hline Total & 5,16 & 5,78 & 14,55 & 50,95 & 45,66 & 56,32 & 12,30 & 28,31 \\
\hline \multicolumn{9}{|c|}{ Fossa Séptica (\% dos domicílios) } \\
\hline até 5.000 hab. & 3,97 & 5,27 & 2,47 & 6,99 & 3,71 & 11,13 & 16,22 & 7,31 \\
\hline 5.000 a 10.000 hab. & 2,04 & 4,31 & 2,80 & 5,73 & 3,82 & 9,05 & 18,19 & 7,37 \\
\hline 10.000 a 20.000 hab. & 3,96 & 4,28 & 2,76 & 8,80 & 6,35 & 12,53 & 19,61 & 8,49 \\
\hline 20.000 a 50.000 hab. & 6,59 & 7,11 & 2,79 & 9,91 & 7,98 & 12,40 & 24,51 & 11,15 \\
\hline 50.000 a 100.000 hab. & 12,21 & 11,28 & 6,09 & 13,26 & 9,92 & 16,76 & 30,93 & 16,45 \\
\hline 100.000 a 500.000 hab. & 10,78 & 23,31 & 1,38 & 16,80 & 19,40 & 14,65 & 44,46 & 22,46 \\
\hline 500.000 a 1.000 .000 hab. & 35,82 & $*$ & 0,98 & 21,32 & 39,19 & 9,29 & $*$ & 22,16 \\
\hline mais de 1.000 .000 hab. & $*$ & 33,48 & 33,08 & 14,68 & 7,38 & 21,51 & 28,22 & 19,51 \\
\hline Total & 15,83 & 12,94 & 7,74 & 13,72 & 11,18 & 16,29 & 28,89 & 15,75 \\
\hline
\end{tabular}

Fonte: IBGE, Censo Demográfico de 1980. Elaboração própria.

(3) Sudeste incluindo São Paulo.

(4) Sudeste excluindo São Paulo.

* Não há município com esse porte na região. 
Tabela 10

Brasil: proporção de domicílios com acesso a serviços de saneamento básico, segundo o porte dos municípios, as grandes regiões e o Estado de São Paulo (1991)

\begin{tabular}{|c|c|c|c|c|c|c|c|c|}
\hline $\begin{array}{c}\text { Região / } \\
\text { Porte }\end{array}$ & $\mathbf{N}$ & NE & $\mathrm{CO}$ & SE (3) & SE (4) & $\begin{array}{c}\text { São } \\
\text { Paulo }\end{array}$ & $\mathbf{S}$ & Brasil \\
\hline \multicolumn{9}{|c|}{ Água - Rede Geral (\% dos domicílios) } \\
\hline Até 5.000 hab. & 27,47 & 36,17 & 43,67 & 55,85 & 49,52 & 64,83 & 37,08 & 46,37 \\
\hline 5.000 a 10.000 hab. & 25,84 & 32,09 & 43,21 & 57,54 & 50,99 & 69,49 & 38,61 & 42,41 \\
\hline 10.000 a 20.000 hab. & 25,46 & 28,61 & 53,29 & 59,60 & 52,85 & 70,57 & 48,32 & 42,32 \\
\hline 20.000 a 50.000 hab. & 28,09 & 34,26 & 67,50 & 69,56 & 60,24 & 80,74 & 60,66 & 49,87 \\
\hline 50.000 a 100.000 hab. & 30,58 & 52,82 & 55,53 & 81,98 & 76,65 & 87,73 & 74,36 & 66,71 \\
\hline 100.000 a 500.000 hab. & 53,30 & 74,05 & 50,25 & 87,93 & 81,91 & 93,19 & 85,47 & $\mathbf{8 2 , 8 7}$ \\
\hline 500.000 a 1.000 .000 hab. & 79,84 & 87,46 & 87,84 & 89,47 & 78,83 & 94,23 & 97,43 & $\mathbf{8 8 , 8 0}$ \\
\hline Mais de 1.000 .000 hab. & $*$ & 88,31 & 89,11 & 96,58 & 94,67 & 98,39 & $*$ & 94,01 \\
\hline Total & 44,81 & 52,83 & 75,21 & 84,76 & 78,23 & 91,07 & 70,94 & $\mathbf{7 1 , 5 7}$ \\
\hline \multicolumn{9}{|c|}{ Esgoto - Rede Geral (\% dos domicílios) } \\
\hline Até 5.000 hab. & 0,00 & 0,76 & 0,00 & 34,88 & 29,35 & 42,73 & 0,54 & 18,11 \\
\hline 5.000 a 10.000 hab. & 0,31 & 1,03 & 0,00 & 39,45 & 30,62 & 55,56 & 0,36 & 13,76 \\
\hline 10.000 a 20.000 hab. & 0,06 & 0,52 & 2,79 & 41,72 & 32,91 & 56,04 & 2,55 & 13,26 \\
\hline 20.000 a 50.000 hab. & 0,68 & 1,92 & 7,71 & 49,53 & 36,05 & 65,69 & 6,10 & 17,39 \\
\hline 50.000 a 100.000 hab. & 1,02 & 3,53 & 1,16 & 62,88 & 53,54 & 72,97 & 7,83 & 28,11 \\
\hline 100.000 a 500.000 hab. & 2,51 & 21,71 & 28,23 & 66,37 & 54,81 & 76,46 & 17,17 & 44,35 \\
\hline 500.000 a 1.000 .000 hab. & 2,19 & 22,31 & 19,81 & 56,98 & 14,39 & 76,03 & 46,27 & 44,74 \\
\hline Mais de 1.000 .000 hab. & $*$ & 22,56 & 75,28 & 75,99 & 65,26 & 86,13 & $*$ & 60,49 \\
\hline Total & $\mathbf{1 , 0 5}$ & 8,88 & 41,72 & 63,41 & 50,38 & 76,02 & 13,68 & 36,51 \\
\hline \multicolumn{9}{|c|}{ Fossa Séptica (\% dos domicílios) } \\
\hline Até 5.000 hab. & 1,75 & 3,72 & 9,00 & 3,53 & 3,25 & 7,57 & 20,68 & 4,63 \\
\hline 5.000 a 10.000 hab. & 2,99 & 7,01 & 6,11 & 8,15 & 7,96 & 9,08 & 22,79 & 10,58 \\
\hline 10.000 a 20.000 hab. & 4,95 & 6,31 & 2,51 & 10,68 & 11,61 & 9,04 & 29,18 & 12,39 \\
\hline 20.000 a 50.000 hab. & 10,53 & 7,96 & 7,54 & 11,87 & 13,01 & 10,05 & 36,26 & 14,57 \\
\hline 50.000 a 100.000 hab. & 19,81 & 15,11 & 6,98 & 20,39 & 37,33 & 9,57 & 42,67 & 22,97 \\
\hline 100.000 a 500.000 hab. & 30,77 & 21,23 & 1,86 & 10,91 & 20,65 & 7,06 & 53,50 & 24,56 \\
\hline 500.000 a 1.000 .000 hab. & 54,68 & 35,92 & 2,33 & 16,31 & 20,25 & 9,18 & 41,34 & 19,11 \\
\hline Mais de 1.000 .000 hab. & $*$ & 31,39 & 12,04 & 8,53 & 10,59 & 4,80 & $*$ & 20,60 \\
\hline Total & 28,39 & 15,35 & 7,53 & 10,66 & 14,12 & 7,32 & 40,23 & 17,78 \\
\hline
\end{tabular}

Fonte: IBGE, Censo Demográfico de 1991. Elaboração própria.

(3) Sudeste incluindo São Paulo.

(4) Sudeste excluindo São Paulo.

* Não há município com esse porte na região. 
Tabela 11

Brasil: proporção de domicílios com acesso a serviços de saneamento básico, segundo a taxa de urbanização dos municípios, as grandes regiões e Estado de São Paulo (1970)

\begin{tabular}{|c|c|c|c|c|c|c|c|c|}
\hline $\begin{array}{l}\text { Região / Taxa de } \\
\text { Urbanização }\end{array}$ & $\mathbf{N}$ & NE & $\mathrm{CO}$ & SE (3) & SE (4) & São Paulo & $\mathbf{S}$ & Brasil \\
\hline \multicolumn{9}{|c|}{ Água - Rede Geral (\% dos domicílios) } \\
\hline menos de $50 \%$ & 5,69 & 4,10 & 6,39 & 22,24 & 18,85 & 33,33 & 10,89 & 10,10 \\
\hline de $50 \%$ a $60 \%$ & 5,91 & 14,36 & 13,70 & 41,33 & 36,42 & 47,14 & 25,40 & 30,02 \\
\hline de $60 \%$ a $70 \%$ & 19,57 & 17,45 & 34,31 & 47,41 & 42,38 & 54,09 & 28,74 & 38,01 \\
\hline de $70 \%$ a $80 \%$ & $*$ & 24,76 & 44,61 & 54,29 & 42,81 & 60,93 & 50,64 & 48,12 \\
\hline de $80 \%$ a $90 \%$ & $*$ & 26,31 & 39,28 & 60,95 & 57,57 & 62,31 & 48,18 & 53,17 \\
\hline de $90 \%$ a $95 \%$ & 54,13 & 18,92 & 69,48 & 68,00 & 53,58 & 76,30 & 43,19 & 52,78 \\
\hline mais de $95 \%$ & $*$ & 53,77 & 52,74 & 66,50 & 69,76 & 63,01 & 75,56 & 64,94 \\
\hline Total & 19,82 & 12,32 & 19,90 & 51,56 & 45,58 & 58,56 & 25,27 & 33,23 \\
\hline \multicolumn{9}{|c|}{ Esgoto - Rede Geral (\% dos domicílios) } \\
\hline menos de $50 \%$ & 0,03 & 0,28 & 0,90 & 8,70 & 6,86 & 14,73 & 1,07 & 2,45 \\
\hline de $50 \%$ a $60 \%$ & 0,00 & 2,00 & 5,48 & 22,00 & 18,25 & 26,44 & 4,68 & 12,48 \\
\hline de $60 \%$ a $70 \%$ & 0,00 & 2,09 & 2,24 & 26,24 & 23,06 & 30,46 & 4,93 & 17,10 \\
\hline de $70 \%$ a $80 \%$ & $*$ & 7,39 & 6,09 & 33,76 & 22,14 & 40,48 & 12,96 & 23,61 \\
\hline de $80 \%$ a $90 \%$ & $*$ & 3,08 & 10,05 & 40,63 & 41,18 & 40,41 & 9,52 & 28,96 \\
\hline de $90 \%$ a $95 \%$ & 5,42 & 4,28 & 16,45 & 47,63 & 26,43 & 59,84 & 25,31 & 28,69 \\
\hline mais de $95 \%$ & $*$ & 14,15 & 33,56 & 23,70 & 40,80 & 5,39 & 40,19 & 23,84 \\
\hline Total & 1,55 & 2,40 & 7,41 & 24,03 & 24,93 & 22,96 & 7,27 & 13,41 \\
\hline \multicolumn{9}{|c|}{ Fossa Séptica (\% dos domicílios) } \\
\hline menos de $50 \%$ & 1,21 & 1,62 & 3,41 & 4,53 & 4,20 & 5,62 & 7,08 & 3,65 \\
\hline de $50 \%$ a $60 \%$ & 2,47 & 5,78 & 7,49 & 8,21 & 8,81 & 7,50 & 16,04 & 9,42 \\
\hline de $60 \%$ a $70 \%$ & 5,24 & 6,91 & 18,16 & 8,99 & 8,24 & 9,99 & 20,67 & 10,88 \\
\hline de $70 \%$ a $80 \%$ & $*$ & 8,57 & 14,49 & 9,39 & 12,58 & 7,54 & 22,25 & 12,49 \\
\hline de $80 \%$ a $90 \%$ & * & 11,96 & 16,28 & 11,49 & 8,27 & 12,78 & 22,80 & 13,68 \\
\hline de $90 \%$ a $95 \%$ & 22,22 & 22,37 & 14,29 & 12,06 & 15,77 & 9,92 & 24,07 & 17,45 \\
\hline mais de $95 \%$ & $*$ & 21,94 & 15,89 & 38,52 & 22,09 & 56,11 & 22,16 & 34,63 \\
\hline Total & 7,29 & $\mathbf{5 , 5 2}$ & $\mathbf{7 , 5 9}$ & 19,86 & 12,64 & 28,33 & 12,80 & 13,55 \\
\hline
\end{tabular}

Fonte: IBGE, Censo Demográfico de 1970. Elaboração própria.

(3) Sudeste incluindo São Paulo.

(4) Sudeste excluindo São Paulo.

* Não há município com essa taxa de urbanização na região. 
Tabela 12

Brasil: proporção de domicílios com acesso a serviços de saneamento básico, segundo a taxa de urbanização dos municípios, as grandes regiões e Estado de São Paulo (1980)

\begin{tabular}{|c|c|c|c|c|c|c|c|c|}
\hline $\begin{array}{c}\text { Região / Taxa de } \\
\text { Urbanização }\end{array}$ & $\mathbf{N}$ & NE & $\mathrm{CO}$ & SE (3) & SE (4) & São Paulo & $\mathbf{S}$ & Brasil \\
\hline \multicolumn{9}{|c|}{ Água - Rede Geral (\% dos domicílios) } \\
\hline menos de $50 \%$ & 16,15 & 13,91 & 12,38 & 30,47 & 27,70 & 42,06 & 21,86 & 18,51 \\
\hline de $50 \%$ a $60 \%$ & 41,22 & 39,28 & 18,83 & 47,86 & 45,90 & 52,00 & 44,81 & 41,42 \\
\hline de $60 \%$ a $70 \%$ & 49,95 & 38,37 & 30,43 & 57,68 & 52,12 & 64,92 & 51,42 & 48,68 \\
\hline de $70 \%$ a $80 \%$ & 39,47 & 46,26 & 43,02 & 67,26 & 61,90 & 73,02 & 57,86 & 56,65 \\
\hline de $80 \%$ a $90 \%$ & 74,73 & 54,75 & 56,18 & 74,06 & 64,69 & 79,77 & 69,94 & 69,92 \\
\hline de $90 \%$ a $95 \%$ & $*$ & 69,21 & 66,56 & 77,53 & 69,44 & 80,75 & 71,81 & 74,68 \\
\hline mais de $95 \%$ & 85,05 & 67,78 & 71,73 & 85,22 & 79,28 & 90,55 & 88,08 & 82,49 \\
\hline Total & 39,28 & 31,66 & 41,76 & 72,66 & 63,08 & 82,37 & 52,04 & 54,99 \\
\hline \multicolumn{9}{|c|}{ Esgoto - Rede Geral (\% dos domicílios) } \\
\hline menos de $50 \%$ & 0,01 & 0,60 & 0,28 & 14,56 & 13,50 & 19,00 & 0,83 & 3,15 \\
\hline de $50 \%$ a $60 \%$ & 0,00 & 10,50 & 0,85 & 27,79 & 25,54 & 32,56 & 5,21 & 13,11 \\
\hline de $60 \%$ a $70 \%$ & 7,27 & 0,71 & 2,85 & 39,05 & 33,52 & 46,26 & 8,45 & 17,91 \\
\hline de $70 \%$ a $80 \%$ & 2,76 & 4,58 & 10,09 & 49,70 & 44,61 & 55,17 & 15,08 & 25,01 \\
\hline de $80 \%$ a $90 \%$ & 15,14 & 11,93 & 5,97 & 59,15 & 53,18 & 62,79 & 14,73 & 39,37 \\
\hline de $90 \%$ a $95 \%$ & $*$ & 17,80 & 23,27 & 64,18 & 53,99 & 68,22 & 4,44 & 43,10 \\
\hline mais de $95 \%$ & 17,43 & 19,37 & 36,27 & 58,55 & 59,80 & 57,42 & 38,80 & 49,98 \\
\hline Total & 5,16 & 5,78 & 14,55 & 50,95 & 45,66 & 56,32 & 12,30 & 28,31 \\
\hline \multicolumn{9}{|c|}{ Fossa Séptica (\% dos domicílios) } \\
\hline menos de $50 \%$ & 6,70 & 5,28 & 3,12 & 7,04 & 6,41 & 9,67 & 16,92 & $\mathbf{7 , 7 5}$ \\
\hline de $50 \%$ a $60 \%$ & 11,29 & 11,35 & 2,29 & 11,77 & 12,98 & 9,20 & 23,40 & 13,54 \\
\hline de $60 \%$ a $70 \%$ & 9,11 & 13,16 & 4,00 & 9,67 & 7,14 & 12,97 & 26,87 & 14,04 \\
\hline de $70 \%$ a $80 \%$ & 15,02 & 15,83 & 1,98 & 9,78 & 8,93 & 10,69 & 29,97 & 15,62 \\
\hline de $80 \%$ a $90 \%$ & 37,20 & 20,37 & 6,62 & 8,87 & 7,96 & 9,42 & 34,52 & 17,22 \\
\hline de $90 \%$ a $95 \%$ & $*$ & 16,94 & 1,66 & 8,84 & 5,34 & 10,23 & 61,47 & 21,35 \\
\hline mais de $95 \%$ & 32,15 & 35,64 & 17,96 & 18,04 & 14,62 & 21,11 & 36,76 & 22,14 \\
\hline Total & 15,83 & 12,94 & 7,74 & 13,72 & 11,18 & 16,29 & 28,89 & 15,75 \\
\hline
\end{tabular}

Fonte: IBGE, Censo Demográfico de 1980. Elaboração própria.

(3) Sudeste incluindo São Paulo.

(4) Sudeste excluindo São Paulo.

* Não há município com essa taxa de urbanização na região. 
Tabela 13

Brasil: proporção de domicílios com acesso a serviços de saneamento básico, segundo a taxa de urbanização dos municípios, as grandes regiões e Estado de São Paulo (1991)

\begin{tabular}{|c|c|c|c|c|c|c|c|c|}
\hline $\begin{array}{l}\text { Região / Taxa de } \\
\text { Urbanização }\end{array}$ & $\mathbf{N}$ & NE & $\mathrm{CO}$ & SE (3) & SE (4) & São Paulo & $\mathbf{S}$ & Brasil \\
\hline \multicolumn{9}{|c|}{ Água - Rede Geral (\% dos domicílios) } \\
\hline Menos de $50 \%$ & 17,76 & 28,26 & 37,93 & 40,39 & 39,88 & 43,82 & 33,61 & 30,36 \\
\hline de $50 \%$ a $60 \%$ & 27,27 & 44,02 & 35,00 & 56,14 & 55,08 & 60,19 & 53,18 & 47,62 \\
\hline de $60 \%$ a $70 \%$ & 64,53 & 53,52 & 52,02 & 65,91 & 65,55 & 66,88 & 61,59 & 60,80 \\
\hline de $70 \%$ a $80 \%$ & 37,42 & 58,39 & 62,34 & 72,20 & 70,45 & 75,41 & 71,18 & 66,47 \\
\hline de $80 \%$ a $90 \%$ & 36,94 & 70,85 & 65,28 & 78,46 & 74,17 & 83,89 & 76,33 & 75,35 \\
\hline de $90 \%$ a $95 \%$ & 19,70 & 83,20 & 86,50 & 89,80 & 88,57 & 90,72 & 85,27 & 86,53 \\
\hline mais de $95 \%$ & 75,43 & 88,40 & 73,69 & 93,99 & 91,44 & 95,69 & 94,30 & 92,52 \\
\hline Total & 44,81 & 52,83 & 75,21 & 84,76 & 78,23 & 91,07 & 70,94 & $\mathbf{7 1 , 5 7}$ \\
\hline \multicolumn{9}{|c|}{ Esgoto - Rede Geral (\% dos domicílios) } \\
\hline Menos de $50 \%$ & 0,04 & 2,32 & 0,00 & 20,35 & 18,62 & 31,87 & 0,98 & 4,58 \\
\hline de $50 \%$ a $60 \%$ & 2,81 & 2,34 & 0,00 & 34,80 & 32,75 & 42,63 & 3,69 & 11,68 \\
\hline de $60 \%$ a $70 \%$ & 1,63 & 1,87 & 8,44 & 41,75 & 39,38 & 48,05 & 3,87 & 14,21 \\
\hline de $70 \%$ a $80 \%$ & 0,00 & 7,00 & 3,44 & 50,25 & 43,45 & 62,68 & 8,85 & 25,39 \\
\hline de $80 \%$ a $90 \%$ & 0,00 & 13,08 & 0,00 & 56,05 & 42,07 & 73,74 & 7,63 & 34,08 \\
\hline de $90 \%$ a $95 \%$ & 0,00 & 15,20 & 69,22 & 75,12 & 65,28 & 82,42 & 20,75 & 50,21 \\
\hline mais de $95 \%$ & 1,62 & 25,16 & 16,00 & 71,77 & 61,36 & 78,72 & 29,67 & 58,33 \\
\hline Total & $\mathbf{1 , 0 5}$ & $\mathbf{8 , 8 8}$ & 41,72 & 63,41 & $\mathbf{5 0 , 3 8}$ & 76,02 & 13,68 & 36,51 \\
\hline \multicolumn{9}{|c|}{ Fossa Séptica (\% dos domicílios) } \\
\hline Menos de $50 \%$ & 7,70 & 6,10 & 4,61 & 5,00 & 3,38 & 15,82 & 21,37 & 8,72 \\
\hline de $50 \%$ a $60 \%$ & 16,63 & 9,99 & 1,31 & 8,41 & 7,60 & 11,49 & 28,68 & 13,34 \\
\hline de $60 \%$ a $70 \%$ & 46,33 & 14,41 & 7,67 & 7,76 & 7,16 & 9,33 & 34,78 & 22,19 \\
\hline de $70 \%$ a $80 \%$ & 17,55 & 14,05 & 6,47 & 10,36 & 11,61 & 8,07 & 34,75 & 17,75 \\
\hline de $80 \%$ a $90 \%$ & 17,68 & 20,43 & 6,66 & 10,51 & 13,38 & 6,87 & 50,99 & 21,67 \\
\hline de $90 \%$ a $95 \%$ & 21,91 & 24,86 & 10,33 & 4,61 & 4,80 & 4,48 & 46,27 & 19,86 \\
\hline mais de $95 \%$ & 48,98 & 32,79 & 3,40 & 12,73 & 20,59 & 7,49 & 52,43 & 20,46 \\
\hline Total & 28,39 & 15,35 & $\mathbf{7 , 5 3}$ & 10,66 & 14,12 & 7,32 & 40,23 & 17,78 \\
\hline
\end{tabular}

Fonte: IBGE, Censo Demográfico de 1991. Elaboração própria.

(3) Sudeste incluindo São Paulo.

(4) Sudeste excluindo São Paulo.

* Não há município com essa taxa de urbanização na região. 


\section{Tabela 14}

Brasil: proporção de domicílios com acesso a serviços de saneamento básico, segundo a renda per capita mensal dos municípios, as grandes regiões e o Estado de São Paulo (1970)

\begin{tabular}{|c|c|c|c|c|c|c|c|c|}
\hline $\begin{array}{c}\text { Região / } \\
\text { Renda }\end{array}$ & $\mathbf{N}$ & NE & CO & SE (3) & SE (4) & São Paulo & $\mathbf{S}$ & Brasil \\
\hline \multicolumn{9}{|c|}{ Água - Rede Geral (\% dos domicílios) } \\
\hline Até 1 S.M. & 19,82 & 12,32 & 16,86 & 43,26 & 39,01 & 50,93 & 20,12 & 26,30 \\
\hline de 1 a 2 S.M. & $*$ & $*$ & 71,60 & 70,48 & 81,47 & 68,12 & 68,24 & $\mathbf{7 0 , 1 9}$ \\
\hline de 2 a 3 S.M. & $*$ & * & $*$ & 85,46 & 85,46 & $*$ & $*$ & 85,46 \\
\hline mais de 3 S.M. & $*$ & $*$ & $*$ & 89,29 & 89,29 & $*$ & $*$ & 89,29 \\
\hline Total & 19,82 & 12,32 & 19,90 & 51,56 & 45,58 & 58,56 & 25,27 & 33,23 \\
\hline \multicolumn{9}{|c|}{ Esgoto - Rede Geral (\% dos domicílios) } \\
\hline Até 1 S.M. & 1,55 & 2,40 & 4,53 & 21,76 & 17,14 & 30,09 & 3,52 & 10,19 \\
\hline de 1 a 2 S.M. & $*$ & $*$ & 56,42 & 22,13 & 59,77 & 14,04 & 38,53 & 25,19 \\
\hline de 2 a 3 S.M. & $*$ & $*$ & $*$ & 80,95 & 80,95 & $*$ & $*$ & $\mathbf{8 0 , 9 5}$ \\
\hline mais de 3 S.M. & $*$ & $*$ & $*$ & 87,18 & 87,18 & $*$ & $*$ & 87,18 \\
\hline Total & 1,55 & 2,40 & 7,41 & 24,03 & 24,93 & 22,96 & 7,27 & 13,41 \\
\hline \multicolumn{9}{|c|}{ Fossa Séptica (\% dos domicílios) } \\
\hline Até 1 S.M. & 7,29 & 5,52 & 7,78 & 12,13 & 13,35 & 9,93 & 11,64 & $\mathbf{9 , 4 3}$ \\
\hline de 1 a 2 S.M. & $*$ & $*$ & 4,49 & 44,81 & 14,31 & 51,36 & 22,42 & 40,77 \\
\hline de 2 a 3 S.M. & $*$ & $*$ & $*$ & 1,69 & 1,69 & $*$ & $*$ & 1,69 \\
\hline mais de 3 S.M. & $*$ & $*$ & $*$ & 0,69 & 0,69 & $*$ & $*$ & 0,69 \\
\hline Total & 7,29 & 5,52 & $\mathbf{7 , 5 9}$ & 19,86 & 12,64 & 28,33 & 12,80 & 13,55 \\
\hline
\end{tabular}

Fonte: IBGE, Censo Demográfico de 1970. Elaboração própria.

S.M.: Salário mínimo.

(3) Sudeste incluindo São Paulo.

(4) Sudeste excluindo São Paulo.

* Não há município com essa renda per capita na região. 
Tabela 15

Brasil: proporção de domicílios com acesso a serviços de saneamento básico, segundo a renda per capita mensal dos municípios, as grandes regiões e o Estado de São Paulo (1980)

\begin{tabular}{|c|c|c|c|c|c|c|c|c|}
\hline $\begin{array}{c}\text { Região / } \\
\text { Renda }\end{array}$ & $\mathbf{N}$ & NE & CO & SE (3) & SE (4) & São Paulo & $\mathbf{S}$ & Brasil \\
\hline \multicolumn{9}{|c|}{ Água - Rede Geral (\% dos domicílios) } \\
\hline Até 1 S.M. & 19,62 & 9,41 & 4,29 & 38,53 & 32,42 & 47,91 & 24,68 & 22,94 \\
\hline de 1 a 2 S.M. & 10,27 & 11,28 & 16,39 & 45,77 & 39,14 & 56,94 & 25,29 & 21,95 \\
\hline de 2 a 3 S.M. & 29,03 & 19,98 & 22,86 & 54,75 & 48,31 & 66,44 & 34,70 & $\mathbf{3 5 , 5 8}$ \\
\hline mais de 3 S.M. & 44,17 & 34,90 & 45,28 & 74,74 & 65,37 & 83,79 & 55,76 & $\mathbf{5 8 , 5 9}$ \\
\hline Total & 39,28 & 31,66 & 41,76 & 72,66 & 63,08 & 82,37 & 52,04 & 54,99 \\
\hline \multicolumn{9}{|c|}{ Esgoto - Rede Geral (\% dos domicílios) } \\
\hline Até 1 S.M. & 0,00 & 0,00 & 0,57 & 13,21 & 10,32 & 17,63 & 0,61 & 4,80 \\
\hline de 1 a 2 S.M. & 0,01 & 0,17 & 1,13 & 28,62 & 23,75 & 36,85 & 1,43 & 6,72 \\
\hline de 2 a 3 S.M. & 0,04 & 1,06 & 2,17 & 38,59 & 32,02 & 50,52 & 3,21 & $\mathbf{1 4 , 4 1}$ \\
\hline mais de 3 S.M. & 6,54 & 6,81 & 16,47 & 52,71 & 47,92 & 57,33 & 14,03 & $\mathbf{3 0 , 8 3}$ \\
\hline Total & 5,16 & 5,78 & 14,55 & 50,95 & 45,66 & 56,32 & 12,30 & 28,31 \\
\hline \multicolumn{9}{|c|}{ Fossa Séptica (\% dos domicílios) } \\
\hline Até 1 S.M. & 4,43 & 3,02 & 1,14 & 5,54 & 3,77 & 8,27 & 10,33 & 5,33 \\
\hline de 1 a 2 S.M. & 2,19 & 3,34 & 2,78 & 6,12 & 3,68 & 10,24 & 16,26 & 6,36 \\
\hline de 2 a 3 S.M. & 6,93 & 5,04 & 1,72 & 6,10 & 5,53 & 7,14 & 15,84 & 7,43 \\
\hline mais de 3 S.M. & 18,77 & 14,69 & 8,59 & 14,42 & 11,93 & 16,83 & 31,28 & $\mathbf{1 7 , 0 3}$ \\
\hline Total & 15,83 & 12,94 & $\mathbf{7 , 7 4}$ & 13,72 & 11,18 & 16,29 & 28,89 & 15,75 \\
\hline
\end{tabular}

Fonte: IBGE, Censo Demográfico de 1980. Elaboração própria.

S.M.: Salário mínimo.

(3) Sudeste incluindo São Paulo.

(4) Sudeste excluindo São Paulo. 
Tabela 16

Brasil: proporção de domicílios com acesso a serviços de saneamento básico, segundo a renda per capita mensal dos municípios, as grandes regiões e o Estado de São Paulo (1991)

\begin{tabular}{|c|c|c|c|c|c|c|c|c|}
\hline $\begin{array}{c}\text { Região / } \\
\text { Renda }\end{array}$ & $\mathbf{N}$ & NE & CO & SE (3) & SE (4) & São Paulo & $\mathbf{S}$ & Brasil \\
\hline \multicolumn{9}{|c|}{ Água - Rede Geral (\% dos domicílios) } \\
\hline Até 1 S.M. & 23,28 & 32,14 & 29,03 & 51,05 & 52,12 & 33,84 & 23,29 & $\mathbf{3 1 , 5 8}$ \\
\hline de 1 a 2 S.M. & 33,80 & 63,45 & 39,39 & 60,72 & 58,68 & 61,95 & 46,00 & $\mathbf{5 2 , 5 9}$ \\
\hline de 2 a 3 S.M. & 46,32 & 85,40 & 70,15 & 76,26 & 47,19 & 79,50 & 71,99 & 75,06 \\
\hline mais de 3 S.M. & 78,47 & 93,80 & 88,22 & 86,36 & 79,43 & 94,11 & 88,58 & 86,81 \\
\hline Total & 44,81 & 52,83 & 75,21 & 84,76 & 78,23 & 91,07 & 70,94 & $\mathbf{7 1 , 5 7}$ \\
\hline \multicolumn{9}{|c|}{ Esgoto - Rede Geral (\% dos domicílios) } \\
\hline Até 1 S.M. & 0,04 & 1,40 & 0,00 & 29,20 & 30,02 & 15,85 & 0,11 & 1,74 \\
\hline de 1 a 2 S.M. & 0,78 & 10,00 & 4,56 & 36,82 & 32,32 & 39,55 & 1,97 & 8,01 \\
\hline de 2 a 3 S.M. & 3,00 & 21,77 & 19,43 & 54,62 & 19,63 & 58,51 & 9,44 & $\mathbf{2 3 , 8 1}$ \\
\hline mais de 3 S.M. & 2,38 & 28,57 & 59,89 & 65,11 & 51,48 & 80,35 & 26,66 & $\mathbf{5 7 , 0 7}$ \\
\hline Total & $\mathbf{1 , 0 5}$ & $\mathbf{8 , 8 8}$ & 41,72 & 63,41 & $\mathbf{5 0 , 3 8}$ & 76,02 & 13,68 & 36,51 \\
\hline \multicolumn{9}{|c|}{ Fossa Séptica (\% dos domicílios) } \\
\hline Até 1 S.M. & 5,45 & 7,54 & 11,64 & 6,09 & 5,76 & 11,38 & 11,25 & 7,40 \\
\hline de 1 a 2 S.M. & 18,02 & 16,51 & 5,17 & 8,68 & 7,06 & 9,67 & 22,04 & 17,39 \\
\hline de 2 a 3 S.M. & 25,20 & 30,07 & 2,74 & 10,24 & 16,12 & 9,59 & 41,92 & 29,09 \\
\hline mais de 3 S.M. & 51,69 & 34,01 & 9,58 & 10,78 & 14,31 & 6,84 & 51,89 & 17,68 \\
\hline Total & 28,39 & 15,35 & $\mathbf{7 , 5 3}$ & 10,66 & 14,12 & 7,32 & 40,23 & $\mathbf{1 7 , 7 8}$ \\
\hline
\end{tabular}

Fonte: IBGE, Censo Demográfico de 1991. Elaboração própria.

S.M.: Salário mínimo.

(3) Sudeste incluindo São Paulo.

(4) Sudeste excluindo São Paulo. 
Tabela 17

Brasil: proporção de domicílios com acesso a serviços de saneamento básico, segundo a renda do chefe da família, as grandes regiões, o Estado de São Paulo e o Distrito Federal (1970)

\begin{tabular}{|c|c|c|c|c|c|c|c|c|c|c|}
\hline Região / Renda & $\mathbf{N}$ & NE & CO (1) & $\mathrm{CO}(2)$ & $\begin{array}{l}\text { Distrito } \\
\text { Federal }\end{array}$ & SE (3) & SE (4) & $\begin{array}{c}\text { São } \\
\text { Paulo }\end{array}$ & Sul & Brasil \\
\hline \multicolumn{11}{|c|}{ Água - Rede Geral (\% dos domicílios) } \\
\hline menos de 1 S.M. & 8,97 & 4,65 & 6,26 & 5,44 & 36,91 & 23,41 & 18,29 & 34,09 & 9,23 & 11,27 \\
\hline de 1 a 2 S.M. & 18,64 & 20,58 & 20,06 & 14,65 & 51,44 & 47,19 & 45,26 & 49,26 & 21,67 & 34,20 \\
\hline de 2 a 3 S.M. & 37,88 & 43,85 & 45,41 & 34,97 & 73,16 & 65,42 & 67,89 & 63,29 & 40,64 & 56,81 \\
\hline de 3 a 5 S.M. & 56,34 & 54,96 & 50,87 & 40,59 & 84,68 & 75,83 & 78,97 & 73,50 & 51,81 & 68,38 \\
\hline de 5 a 10 S.M. & 74,48 & 72,20 & 69,37 & 58,16 & 94,97 & 87,63 & 89,98 & 85,73 & 69,96 & $\mathbf{8 2 , 3 7}$ \\
\hline de 10 a 20 S.M. & 86,39 & 85,63 & 82,17 & 72,17 & 99,21 & 94,67 & 95,66 & 93,84 & 83,00 & 91,51 \\
\hline Mais de 20 S.M. & 89,18 & 88,64 & 82,47 & 73,83 & 98,61 & 96,09 & 96,65 & 95,71 & 83,58 & $\mathbf{9 3 , 5 3}$ \\
\hline Total & 19,82 & 12,32 & 19,90 & 14,42 & 66,67 & 51,56 & 45,58 & 58,56 & 25,27 & 33,23 \\
\hline \multicolumn{11}{|c|}{ Esgoto - Rede Geral (\% dos domicílios) } \\
\hline menos de 1 S.M. & 0,42 & 0,53 & 1,06 & 0,87 & 8,40 & 8,45 & 6,80 & 11,90 & 1,44 & 3,09 \\
\hline de 1 a 2 S.M. & 0,70 & 2,91 & 4,66 & 3,00 & 14,33 & 19,76 & 19,20 & 20,37 & 3,70 & 11,64 \\
\hline de 2 a 3 S.M. & 2,30 & 8,74 & 16,75 & 10,33 & 33,83 & 30,59 & 34,57 & 27,16 & 10,47 & 23,07 \\
\hline de 3 a 5 S.M. & 4,90 & 12,66 & 22,71 & 14,36 & 50,16 & 38,64 & 48,65 & 31,21 & 17,93 & 31,34 \\
\hline de 5 a 10 S.M. & 10,82 & 22,82 & 39,78 & 26,03 & 71,19 & 48,36 & 67,07 & 33,18 & 32,71 & 42,38 \\
\hline mais de 10 S.M. & 22,75 & 34,74 & 59,27 & 42,66 & 87,57 & 54,83 & 84,08 & 30,33 & 48,70 & 51,66 \\
\hline Mais de 20 S.M. & 25,59 & 39,41 & 61,69 & 46,62 & 89,86 & 48,71 & 90,22 & 19,93 & 53,71 & 48,67 \\
\hline Total & $\mathbf{1 , 5 5}$ & 2,40 & 7,41 & 4,30 & 34,45 & 24,03 & 24,93 & 22,96 & 7,27 & 13,41 \\
\hline \multicolumn{11}{|c|}{ Fossa Séptica (\% dos domicílios) } \\
\hline menos de 1 S.M. & 1,79 & 1,56 & 2,06 & 1,94 & 6,51 & 6,74 & 4,51 & 11,40 & 3,29 & 3,42 \\
\hline de 1 a 2 S.M. & 4,95 & 8,61 & 7,00 & 6,61 & 9,29 & 16,26 & 14,54 & 18,10 & 10,10 & 12,63 \\
\hline de 2 a 3 S.M. & 15,06 & 21,87 & 18,64 & 18,63 & 18,67 & 28,38 & 24,84 & 31,43 & 23,81 & 26,08 \\
\hline de 3 a 5 S.M. & 28,40 & 30,59 & 24,42 & 25,57 & 20,64 & 33,71 & 24,85 & 40,28 & 33,21 & 32,86 \\
\hline de 5 a 10 S.M. & 46,55 & 41,72 & 30,02 & 35,67 & 17,11 & 37,52 & 20,13 & 51,63 & 40,67 & 38,29 \\
\hline mais de 10 S.M. & 53,01 & 46,33 & 25,66 & 35,31 & 9,21 & 38,34 & 10,32 & 61,81 & 37,56 & 38,75 \\
\hline Mais de 20 S.M. & 55,73 & 44,13 & 22,82 & 32,23 & 5,23 & 46,01 & 5,76 & 73,92 & 33,34 & 43,77 \\
\hline Total & 7,29 & 5,52 & 7,59 & 7,12 & 12,75 & 19,86 & 12,64 & 28,33 & 12,80 & 13,55 \\
\hline
\end{tabular}

Fonte: IBGE, Censo Demográfico de 1970. Elaboração própria.

S.M.: Salário mínimo.

(1) Centro-Oeste incluindo o Distrito Federal.

(2) Centro-Oeste excluindo o Distrito Federal.

(3) Sudeste incluindo São Paulo.

(4) Sudeste excluindo São Paulo. 


\section{Tabela 18}

Brasil: proporção de domicílios com acesso a serviços de saneamento básico, segundo a renda domiciliar mensal, as grandes regiões, o Distrito Federal e o Estado de São Paulo (1980)

\begin{tabular}{|c|c|c|c|c|c|c|c|c|c|c|}
\hline Região / Renda & $\mathbf{N}$ & $\mathbf{N E}$ & CO (1) & CO (2) & \begin{tabular}{|l|} 
Distrito \\
Federal \\
\end{tabular} & SE (3) & SE (4) & $\begin{array}{c}\text { São } \\
\text { Paulo }\end{array}$ & Sul & Brasil \\
\hline \multicolumn{11}{|c|}{ Água - Rede Geral (\% dos domicílios) } \\
\hline menos de 1 S.M. & 18,81 & 13,39 & 15,18 & 13,00 & 79,34 & 35,19 & 28,20 & 55,40 & 20,54 & 19,41 \\
\hline de 1 a 2 S.M. & 25,57 & 26,99 & 27,68 & 20,34 & 87,82 & 52,24 & 46,51 & 61,78 & 36,08 & 37,96 \\
\hline de 2 a 3 S.M. & 38,79 & 42,64 & 40,63 & 30,59 & 93,46 & 66,87 & 59,86 & 74,71 & 49,76 & 55,14 \\
\hline de 3 a 5 S.M. & 50,93 & 57,37 & 51,11 & 40,21 & 95,47 & 77,53 & 70,79 & 83,19 & 60,57 & 68,67 \\
\hline de 5 a 10 S.M. & 66,68 & 75,18 & 65,12 & 54,27 & 97,82 & 87,93 & 83,46 & 90,94 & 73,34 & 82,21 \\
\hline de 10 a 20 S.M. & 77,66 & 86,21 & 79,29 & 69,36 & 99,16 & 94,26 & 92,29 & 95,54 & 81,93 & 90,29 \\
\hline Mais de 20 S.M. & 70,49 & 66,31 & 77,10 & 62,39 & 99,08 & 92,90 & 90,39 & 94,88 & 79,14 & 85,39 \\
\hline Total & 39,28 & 31,66 & 41,76 & 31,40 & 94,69 & 72,66 & 63,08 & 82,37 & 52,04 & 54,99 \\
\hline \multicolumn{11}{|c|}{ Rede Geral - Esgoto (\% dos domicílios) } \\
\hline menos de 1 S.M. & 0,98 & 0,96 & 2,27 & 1,58 & 22,57 & 18,32 & 14,20 & 30,23 & 2,55 & 5,09 \\
\hline de 1 a 2 S.M. & 1,42 & 2,64 & 4,98 & 2,92 & 21,81 & 29,22 & 26,98 & 32,96 & 4,49 & 12,95 \\
\hline de 2 a 3 S.M. & 2,79 & 6,07 & 8,64 & 5,40 & 25,71 & 40,70 & 38,72 & 42,92 & 7,54 & 22,72 \\
\hline de 3 a 5 S.M. & 5,20 & 11,09 & 13,87 & 9,27 & 32,58 & 51,09 & 50,21 & 51,83 & 11,76 & 33,61 \\
\hline de 5 a 10 S.M. & 11,48 & 20,13 & 26,84 & 17,47 & 55,06 & 65,23 & 66,28 & 64,53 & 20,65 & 49,02 \\
\hline mais de 10 S.M. & 23,14 & 33,08 & 48,40 & 30,86 & 83,49 & 79,93 & 81,52 & 78,89 & 34,32 & 64,93 \\
\hline Mais de 20 S.M. & 26,12 & 29,68 & 53,36 & 32,37 & 84,68 & 83,48 & 82,01 & 84,64 & 39,13 & 65,78 \\
\hline Total & 5,16 & 5,78 & 14,55 & 8,20 & 47,01 & 50,95 & 45,66 & 56,32 & 12,30 & 28,31 \\
\hline \multicolumn{11}{|c|}{ Fossa Séptica (\% dos domicílios) } \\
\hline menos de 1 S.M. & 4,99 & 4,44 & 2,16 & 1,35 & 25,99 & 8,42 & 6,98 & 12,57 & 8,99 & 5,74 \\
\hline de 1 a 2 S.M. & 7,36 & 10,25 & 5,70 & 1,76 & 37,99 & 13,45 & 11,78 & 16,24 & 16,11 & 12,00 \\
\hline de 2 a 3 S.M. & 13,23 & 17,79 & 9,30 & 2,63 & 44,42 & 16,19 & 14,15 & 18,48 & 26,32 & 17,89 \\
\hline de 3 a 5 S.M. & 21,00 & 25,68 & 11,95 & 3,55 & 46,13 & 17,00 & 14,26 & 19,31 & 36,92 & 21,96 \\
\hline de 5 a 10 S.M. & 33,66 & 34,99 & 12,19 & 4,95 & 33,99 & 14,92 & 11,39 & 17,29 & 46,76 & 23,07 \\
\hline mais de 10 S.M. & 43,33 & 39,28 & 8,22 & 5,24 & 14,18 & 10,34 & 7,16 & 12,41 & 45,95 & 19,58 \\
\hline Mais de 20 S.M. & 37,91 & 27,42 & 8,81 & 5,86 & 13,21 & 8,04 & 6,87 & 8,97 & 38,30 & 16,01 \\
\hline Total & 15,83 & 12,94 & $\mathbf{7 , 7 4}$ & 2,78 & 33,08 & 13,72 & 11,18 & 16,29 & 28,89 & 15,75 \\
\hline
\end{tabular}

Fonte: IBGE, Censo Demográfico de 1980. Elaboração própria.

S.M.: Salário mínimo.

(1) Centro-Oeste incluindo o Distrito Federal.

(2) Centro-Oeste excluindo o Distrito Federal.

(3) Sudeste incluindo São Paulo.

(4) Sudeste excluindo São Paulo. 
Tabela 19

Brasil: proporção de domicílios com acesso a serviços de saneamento básico, segundo a renda domiciliar mensal, as grandes regiões, o Distrito Federal e o Estado de São Paulo (1991)

\begin{tabular}{|c|c|c|c|c|c|c|c|c|c|c|}
\hline Região / Renda & $\mathbf{N}$ & NE & CO (1) & $\mathbf{C O}(2)$ & $\begin{array}{l}\text { Distrito } \\
\text { Federal }\end{array}$ & SE (3) & SE (4) & $\begin{array}{c}\text { São } \\
\text { Paulo }\end{array}$ & Sul & Brasil \\
\hline \multicolumn{11}{|c|}{ Água - Rede Geral (\% dos domicílios) } \\
\hline menos de 1 S.M. & 26,60 & 26,85 & 57,22 & 49,20 & 77,76 & 68,02 & 55,77 & 86,98 & 39,36 & 38,95 \\
\hline de 1 a 2 S.M. & 24,69 & 34,88 & 52,50 & 46,58 & 68,59 & 60,73 & 56,53 & 74,44 & 46,94 & 43,43 \\
\hline de 2 a 3 S.M. & 29,34 & 46,42 & 55,66 & 48,21 & 74,17 & 69,19 & 65,94 & 75,89 & 55,27 & 54,83 \\
\hline de 3 a 5 S.M. & 38,39 & 57,90 & 64,99 & 56,78 & 81,23 & 78,48 & 75,11 & 83,61 & 67,39 & 67,27 \\
\hline de 5 a 10 S.M. & 51,43 & 72,90 & 74,63 & 65,92 & 86,95 & 87,08 & 83,41 & 90,47 & 76,40 & $\mathbf{7 9 , 8 8}$ \\
\hline de 10 a 20 S.M. & 66,67 & 85,95 & 85,18 & 77,34 & 92,75 & 93,27 & 90,54 & 94,94 & 84,50 & 89,23 \\
\hline Mais de 20 S.M. & 77,59 & 92,23 & 94,79 & 88,22 & 97,45 & 96,62 & 95,01 & 97,47 & 90,69 & 94,33 \\
\hline Total & 44,81 & 52,83 & 75,21 & 63,81 & 89,20 & 84,76 & 78,23 & 91,07 & 70,94 & $\mathbf{7 1 , 5 7}$ \\
\hline \multicolumn{11}{|c|}{ Esgoto - Rede Geral (\% dos domicílios) } \\
\hline menos de 1 S.M. & 0,34 & 1,94 & 19,76 & 6,65 & 53,35 & 40,06 & 26,79 & 60,60 & 4,94 & 12,03 \\
\hline de 1 a 2 S.M. & 0,15 & 2,61 & 17,34 & 6,05 & 47,95 & 34,21 & 27,45 & 56,28 & 4,30 & 11,78 \\
\hline de 2 a 3 S.M. & 0,35 & 4,55 & 19,72 & 5,84 & 54,21 & 41,42 & 34,69 & 55,27 & 5,73 & 17,79 \\
\hline de 3 a 5 S.M. & 0,64 & 6,94 & 25,71 & 8,06 & 60,60 & 50,67 & 42,97 & 62,40 & 7,94 & 25,84 \\
\hline de 5 a 10 S.M. & 1,29 & 12,87 & 35,97 & 11,67 & 70,33 & 62,63 & 52,50 & 71,96 & 11,87 & 38,92 \\
\hline mais de 10 S.M. & 2,44 & 22,87 & 51,46 & 20,30 & 81,53 & 74,57 & 64,43 & 80,73 & 18,63 & 53,62 \\
\hline Mais de 20 S.M. & 4,98 & 38,77 & 73,39 & 35,27 & 88,80 & 86,58 & 79,69 & 90,24 & 34,37 & 69,05 \\
\hline Total & 1,05 & $\mathbf{8 , 8 8}$ & 41,72 & 13,59 & 75,40 & 63,41 & 50,38 & 76,02 & 13,68 & 36,51 \\
\hline \multicolumn{11}{|c|}{ Fossa Séptica (\% dos domicílios) } \\
\hline menos de 1 S.M. & 8,43 & 5,32 & 6,78 & 2,61 & 17,48 & 8,83 & 9,75 & 7,41 & 16,47 & 7,63 \\
\hline de 1 a 2 S.M. & 7,69 & 7,83 & 6,51 & 1,85 & 19,15 & 10,14 & 10,54 & 8,83 & 21,96 & 10,41 \\
\hline de 2 a 3 S.M. & 11,20 & 11,65 & 6,89 & 2,85 & 16,92 & 12,11 & 12,98 & 10,32 & 28,03 & 14,35 \\
\hline de 3 a 5 S.M. & 16,70 & 16,33 & 7,91 & 3,08 & 17,45 & 12,72 & 14,64 & 9,78 & 35,78 & 18,17 \\
\hline de 5 a 10 S.M. & 27,72 & 23,50 & 8,07 & 3,83 & 14,07 & 12,37 & 16,53 & 8,53 & 45,71 & 21,85 \\
\hline mais de 10 S.M. & 44,83 & 30,74 & 6,99 & 4,69 & 9,22 & 10,62 & 16,54 & 7,03 & 53,63 & 22,67 \\
\hline Mais de 20 S.M. & 62,96 & 34,02 & 7,83 & 6,28 & 8,46 & 6,74 & 11,27 & 4,33 & 49,19 & 18,92 \\
\hline Total & 28,39 & 15,35 & 7,53 & 3,74 & 12,03 & 10,66 & 14,12 & 7,32 & 40,23 & 17,78 \\
\hline
\end{tabular}

Fonte: IBGE, Censo Demográfico de 1991. Elaboração própria.

S.M.: Salário mínimo.

(1) Centro-Oeste incluindo o Distrito Federal.

(2) Centro-Oeste excluindo o Distrito Federal.

(3) Sudeste incluindo São Paulo.

(4) Sudeste excluindo São Paulo. 
Tabela 20

Brasil: proporção de domicílios com acesso a serviços de saneamento básico, segundo a renda domiciliar mensal, as grandes regiões, o Distrito Federal e o Estado de São Paulo (2001)

\begin{tabular}{|c|c|c|c|c|c|c|c|c|c|c|}
\hline Região / Renda & $\mathbf{N}$ & NE & CO (1) & $\mathbf{C O}(2)$ & \begin{tabular}{|l|} 
Distrito \\
Federal \\
\end{tabular} & SE (3) & SE (4) & $\begin{array}{c}\text { São } \\
\text { Paulo }\end{array}$ & Sul & Brasil \\
\hline \multicolumn{11}{|c|}{ Água - Rede Geral (\% dos domicílios) } \\
\hline menos de 1 S.M. & 75,73 & 91,61 & 74,21 & 71,36 & 88,69 & 87,21 & 80,14 & 95,08 & 73,19 & 85,78 \\
\hline de 1 a 2 S.M. & 75,14 & 91,65 & 75,17 & 73,49 & 86,80 & 85,26 & 81,04 & 91,44 & 76,37 & 84,59 \\
\hline de 2 a 3 S.M. & 76,01 & 91,44 & 74,58 & 72,54 & 89,14 & 88,20 & 84,16 & 93,29 & 79,62 & 85,75 \\
\hline de 3 a 5 S.M. & 75,84 & 93,74 & 78,41 & 76,52 & 90,27 & 92,17 & 87,91 & 96,18 & 82,88 & $\mathbf{8 8 , 8 6}$ \\
\hline de 5 a 10 S.M. & 76,75 & 94,17 & 84,38 & 82,93 & 90,55 & 95,52 & 92,27 & 97,99 & 87,33 & 92,13 \\
\hline de 10 a 20 S.M. & 78,41 & 95,31 & 88,03 & 85,69 & 93,13 & 97,19 & 95,63 & 98,18 & 91,37 & $\mathbf{9 4 , 5 7}$ \\
\hline Mais de 20 S.M. & 66,98 & 92,96 & 90,31 & 88,47 & 92,62 & 97,83 & 96,67 & 98,54 & 94,17 & 95,01 \\
\hline Total & 75,77 & $\mathbf{9 2 , 5 9}$ & 79,76 & 77,36 & $\mathbf{9 0 , 5 3}$ & 92,16 & 87,83 & 96,18 & 83,57 & 89,07 \\
\hline \multicolumn{11}{|c|}{ Esgoto - Rede Geral (\% dos domicílios) } \\
\hline menos de 1 S.M. & 3,91 & 16,99 & 18,64 & 9,47 & 72,42 & 58,32 & 49,93 & 68,08 & 15,63 & 29,98 \\
\hline de 1 a 2 S.M. & 2,88 & 21,46 & 20,05 & 12,40 & 75,70 & 60,84 & 53,05 & 72,50 & 16,79 & $\mathbf{3 4 , 7 1}$ \\
\hline de 2 a 3 S.M. & 3,64 & 25,39 & 23,59 & 15,96 & 81,03 & 66,84 & 58,80 & 77,08 & 17,39 & 40,37 \\
\hline de 3 a 5 S.M. & 4,79 & 30,17 & 28,42 & 19,73 & 84,19 & 74,96 & 65,46 & 83,97 & 20,57 & 49,22 \\
\hline de 5 a 10 S.M. & 8,36 & 39,85 & 39,14 & 27,94 & 87,12 & 80,60 & 70,31 & 88,42 & 26,37 & 58,26 \\
\hline mais de 10 S.M. & 15,74 & 51,07 & 54,90 & 38,66 & 90,42 & 86,47 & 76,94 & 92,51 & 34,31 & 67,86 \\
\hline Mais de 20 S.M. & 18,64 & 59,35 & 63,68 & 45,29 & 86,83 & 89,61 & 80,90 & 94,90 & 44,50 & $\mathbf{7 4 , 0 8}$ \\
\hline Total & 6,08 & 28,04 & 31,98 & $\mathbf{2 0 , 8 6}$ & 84,12 & 74,62 & 64,18 & 84,43 & 23,45 & 48,82 \\
\hline \multicolumn{11}{|c|}{ Fossa Séptica (\% dos domicílios) } \\
\hline menos de $1 \mathrm{~S} . \mathrm{M}$. & 35,76 & 19,37 & 11,67 & 11,38 & 13,39 & 13,00 & 13,78 & 12,09 & 25,92 & 18,36 \\
\hline de 1 a 2 S.M. & 36,24 & 23,47 & 13,05 & 13,43 & 10,27 & 12,57 & 14,04 & 10,37 & 37,19 & 21,11 \\
\hline de 2 a 3 S.M. & 46,13 & 26,43 & 12,04 & 12,41 & 9,21 & 12,42 & 15,04 & 9,08 & 45,75 & 23,57 \\
\hline de 3 a 5 S.M. & 52,58 & 30,57 & 13,71 & 14,87 & 6,23 & 11,57 & 16,12 & 7,26 & 49,92 & 24,66 \\
\hline de 5 a 10 S.M. & 61,92 & 34,03 & 15,33 & 17,65 & 5,37 & 11,35 & 18,16 & 6,17 & 55,97 & 25,91 \\
\hline mais de 10 S.M. & 64,50 & 34,52 & 12,62 & 15,05 & 7,29 & 8,96 & 16,70 & 4,05 & 55,76 & 22,93 \\
\hline Mais de 20 S.M. & 69,12 & 33,06 & 16,22 & 21,05 & 10,15 & 8,11 & 15,80 & 3,44 & 49,63 & 20,54 \\
\hline Total & 49,72 & 26,90 & 13,49 & 14,63 & 8,15 & 11,29 & 15,89 & 6,97 & 48,33 & 23,23 \\
\hline
\end{tabular}

Fonte: IBGE, PNAD de 2001. Elaboração própria.

S.M.: Salário mínimo.

(1) Centro-Oeste incluindo o Distrito Federal.

(2) Centro-Oeste excluindo o Distrito Federal.

(3) Sudeste incluindo São Paulo.

(4) Sudeste excluindo São Paulo. 
Tabela 21

Brasil: proporção de domicílios com acesso a serviços de saneamento básico, segundo a renda domiciliar mensal, as grandes regiões, o Distrito Federal e o Estado de São Paulo (2002)

\begin{tabular}{|c|c|c|c|c|c|c|c|c|c|c|}
\hline Região / Renda & $\mathbf{N}$ & NE & CO (1) & CO (2) & $\begin{array}{l}\text { Distrito } \\
\text { Federal } \\
\end{array}$ & SE (3) & SE (4) & $\begin{array}{c}\text { São } \\
\text { Paulo }\end{array}$ & Sul & Brasil \\
\hline \multicolumn{11}{|c|}{ Água - Rede Geral (\% dos domicílios) } \\
\hline menos de 1 S.M. & 76,65 & 88,50 & 76,99 & 74,88 & 91,11 & 86,96 & 80,87 & 94,70 & 73,48 & 72,25 \\
\hline de 1 a 2 S.M. & 74,82 & 90,82 & 72,96 & 70,99 & 85,32 & 86,39 & 82,52 & 92,15 & 79,25 & 92,06 \\
\hline de 2 a 3 S.M. & 72,41 & 91,62 & 76,44 & 74,77 & 87,71 & 88,67 & 84,06 & 94,24 & 80,56 & $\mathbf{8 8 , 2 4}$ \\
\hline de 3 a 5 S.M. & 70,93 & 92,92 & 79,33 & 77,69 & 89,45 & 91,92 & 87,28 & 96,37 & 83,44 & 84,49 \\
\hline de 5 a 10 S.M. & 71,55 & 94,83 & 85,11 & 83,21 & 92,79 & 95,69 & 92,63 & 97,93 & 87,82 & 78,08 \\
\hline de 10 a 20 S.M. & 72,27 & 95,34 & 87,58 & 85,50 & 92,78 & 97,36 & 96,08 & 98,23 & 91,56 & 96,38 \\
\hline Mais de 20 S.M. & 64,52 & 95,77 & 91,42 & 90,40 & 92,66 & 98,49 & 98,15 & 98,72 & 95,01 & $\mathbf{9 0 , 5 8}$ \\
\hline Total & 72,25 & 92,10 & $\mathbf{8 0 , 3 3}$ & 78,02 & 90,48 & 92,40 & 88,17 & 96,39 & 84,52 & $\mathbf{8 9 , 1 7}$ \\
\hline \multicolumn{11}{|c|}{ Esgoto - Rede Geral (\% dos domicílios) } \\
\hline menos de 1 S.M. & 2,60 & 17,51 & 17,80 & 10,50 & 73,95 & 55,72 & 45,85 & 68,78 & 15,35 & 29,20 \\
\hline de 1 a 2 S.M. & 2,22 & 22,81 & 21,36 & 13,13 & 78,54 & 61,27 & 52,02 & 75,33 & 18,13 & 35,27 \\
\hline de 2 a 3 S.M. & 2,88 & 26,35 & 24,29 & 16,28 & 81,82 & 66,41 & 56,60 & 78,45 & 21,00 & 41,46 \\
\hline de 3 a 5 S.M. & 3,64 & 33,22 & 28,77 & 19,79 & 85,59 & 73,76 & 62,07 & 85,02 & 23,45 & 49,83 \\
\hline de 5 a 10 S.M. & 5,28 & 43,02 & 39,89 & 27,78 & 89,49 & 81,17 & 69,64 & 89,65 & 27,75 & 59,22 \\
\hline mais de 10 S.M. & 10,15 & 57,72 & 49,69 & 34,03 & 88,96 & 86,30 & 75,31 & 93,73 & 38,66 & 68,53 \\
\hline Mais de 20 S.M. & 13,40 & 64,89 & 63,55 & 47,16 & 83,73 & 89,91 & 81,61 & 95,50 & 44,61 & $\mathbf{7 4 , 4 6}$ \\
\hline Total & 4,23 & 30,21 & 32,43 & 21,10 & 84,73 & 74,33 & 62,42 & 85,70 & 25,72 & 49,50 \\
\hline \multicolumn{11}{|c|}{ Fossa Séptica (\% dos domicílios) } \\
\hline menos de 1 S.M. & 39,91 & 18,17 & 10,16 & 8,91 & 19,79 & 14,62 & 16,61 & 12,00 & 30,90 & 18,79 \\
\hline de 1 a 2 S.M. & 45,50 & 20,20 & 11,79 & 10,86 & 18,29 & 13,65 & 16,88 & 8,73 & 38,89 & 21,28 \\
\hline de 2 a 3 S.M. & 50,27 & 23,72 & 10,40 & 9,69 & 15,43 & 14,00 & 18,25 & 8,80 & 46,51 & 23,75 \\
\hline de 3 a 5 S.M. & 59,83 & 27,35 & 13,00 & 13,04 & 12,74 & 12,90 & 19,19 & 6,84 & 51,19 & 25,16 \\
\hline de 5 a 10 S.M. & 69,69 & 28,90 & 14,39 & 16,02 & 7,71 & 11,76 & 19,94 & 5,76 & 54,59 & 25,45 \\
\hline mais de 10 S.M. & 73,20 & 25,51 & 20,16 & 24,23 & 9,98 & 10,06 & 18,85 & 4,12 & 52,46 & 22,83 \\
\hline Mais de 20 S.M. & 76,88 & 27,69 & 21,53 & 27,91 & 13,69 & 8,38 & 15,73 & 3,42 & 49,49 & 20,95 \\
\hline Total & 56,68 & 23,51 & 13,70 & 13,89 & 12,82 & 12,34 & 18,39 & $\mathbf{6 , 5 7}$ & 48,67 & 23,40 \\
\hline
\end{tabular}

Fonte: IBGE, PNAD de 2002. Elaboração própria.

S.M.: Salário mínimo.

(1) Centro-Oeste incluindo o Distrito Federal.

(2) Centro-Oeste excluindo o Distrito Federal.

(3) Sudeste incluindo São Paulo.

(4) Sudeste excluindo São Paulo. 
Tabela 22

Brasil: proporção de domicílios com acesso a serviços de saneamento básico, segundo a renda domiciliar mensal, as grandes regiões, o Distrito Federal e o Estado de São Paulo (2003)

\begin{tabular}{|c|c|c|c|c|c|c|c|c|c|c|}
\hline Região / Renda & $\mathbf{N}$ & NE & CO (1) & CO (2) & \begin{tabular}{|l|} 
Distrito \\
Federal \\
\end{tabular} & SE (3) & SE (4) & $\begin{array}{c}\text { São } \\
\text { Paulo }\end{array}$ & Sul & Brasil \\
\hline \multicolumn{11}{|c|}{ Água - Rede Geral (\% dos domicílios) } \\
\hline menos de 1 S.M. & 78,64 & 91,60 & 77,80 & 74,27 & 92,93 & 89,20 & 82,51 & 96,89 & 75,32 & 87,34 \\
\hline de 1 a 2 S.M. & 76,85 & 91,67 & 76,36 & 74,01 & 90,67 & 86,71 & 83,13 & 91,61 & 81,77 & 86,20 \\
\hline de 2 a 3 S.M. & 71,39 & 91,10 & 75,50 & 72,95 & 93,91 & 89,91 & 85,63 & 94,94 & 81,51 & 86,62 \\
\hline de 3 a 5 S.M. & 74,18 & 92,31 & 79,27 & 77,48 & 91,22 & 92,47 & 87,45 & 97,09 & 84,22 & 88,99 \\
\hline de 5 a 10 S.M. & 74,33 & 93,53 & 86,96 & 85,00 & 94,12 & 95,39 & 91,51 & 98,14 & 86,73 & 91,97 \\
\hline de 10 a 20 S.M. & 75,52 & 94,34 & 88,95 & 87,03 & 93,27 & 96,72 & 95,18 & 97,79 & 91,05 & 94,04 \\
\hline Mais de 20 S.M. & 72,24 & 93,78 & 90,56 & 87,28 & 94,46 & 97,73 & 96,03 & 98,79 & 93,14 & 95,02 \\
\hline Total & $\mathbf{7 4 , 5 3}$ & 92,04 & 80,62 & 77,85 & 92,94 & 92,25 & 87,79 & 96,41 & 84,63 & 89,19 \\
\hline \multicolumn{11}{|c|}{ Esgoto - Rede Geral (\% dos domicílios) } \\
\hline menos de 1 S.M. & 2,64 & 21,05 & 23,30 & 12,41 & 76,70 & 61,66 & 52,05 & 73,32 & 14,91 & 32,29 \\
\hline de 1 a 2 S.M. & 2,65 & 25,48 & 23,14 & 14,59 & 78,11 & 64,46 & 56,59 & 75,47 & 19,02 & 38,65 \\
\hline de 2 a 3 S.M. & 3,16 & 28,37 & 26,19 & 18,16 & 85,50 & 70,88 & 61,04 & 82,66 & 21,79 & 44,27 \\
\hline de 3 a 5 S.M. & 4,28 & 35,71 & 29,33 & 21,40 & 83,57 & 77,12 & 66,31 & 87,16 & 24,60 & 52,25 \\
\hline de 5 a 10 S.M. & 7,04 & 46,55 & 44,77 & 32,45 & 89,55 & 83,09 & 71,99 & 90,98 & 29,58 & 61,76 \\
\hline mais de 10 S.M. & 11,97 & 55,37 & 57,79 & 43,14 & 90,26 & 88,65 & 79,94 & 94,66 & 36,60 & 69,81 \\
\hline Mais de 20 S.M. & 13,50 & 58,83 & 68,59 & 53,64 & 85,96 & 92,18 & 84,67 & 96,86 & 44,36 & 75,18 \\
\hline Total & 4,63 & 31,26 & 34,10 & 23,00 & 85,06 & 76,38 & $\mathbf{6 5 , 5 0}$ & 86,69 & 25,99 & $\mathbf{5 0 , 7 1}$ \\
\hline \multicolumn{11}{|c|}{ Fossa Séptica (\% dos domicílios) } \\
\hline menos de $1 \mathrm{~S} . \mathrm{M}$ & 40,43 & 15,78 & 11,38 & 10,23 & 17,05 & 10,16 & 11,72 & 8,27 & 39,01 & 17,41 \\
\hline de 1 a 2 S.M. & 42,22 & 19,84 & 11,41 & 10,61 & 16,57 & 12,61 & 15,20 & 8,98 & 44,85 & 20,85 \\
\hline de 2 a 3 S.M. & 49,13 & 23,21 & 11,15 & 11,31 & 10,00 & 12,30 & 16,82 & 6,89 & 48,25 & 23,18 \\
\hline de 3 a 5 S.M. & 57,47 & 25,34 & 13,35 & 13,53 & 12,08 & 10,70 & 16,69 & 5,15 & 52,43 & 24,09 \\
\hline de 5 a 10 S.M. & 64,18 & 28,00 & 13,34 & 14,45 & 9,28 & 10,77 & 18,15 & 5,53 & 53,49 & 24,07 \\
\hline mais de 10 S.M. & 66,96 & 30,24 & 12,40 & 14,00 & 8,86 & 7,94 & 14,65 & 3,31 & 54,01 & 21,78 \\
\hline Mais de 20 S.M. & 74,59 & 33,00 & 15,78 & 18,13 & 13,05 & 6,34 & 12,44 & 2,53 & 51,49 & 20,46 \\
\hline Total & 52,51 & 22,42 & 12,38 & 12,48 & 11,93 & 10,78 & 16,04 & $\mathbf{5 , 8 1}$ & 50,20 & 22,38 \\
\hline
\end{tabular}

Fonte: IBGE, PNAD de 2003. Elaboração própria.

S.M.: Salário mínimo.

(1) Centro-Oeste incluindo o Distrito Federal.

(2) Centro-Oeste excluindo o Distrito Federal.

(3) Sudeste incluindo São Paulo.

(4) Sudeste excluindo São Paulo. 
Tabela 23

Brasil: proporção de domicílios com acesso a serviços de saneamento básico, segundo a renda domiciliar mensal, as grandes regiões, o Distrito Federal e o Estado de São Paulo (2004)

\begin{tabular}{|c|c|c|c|c|c|c|c|c|c|c|}
\hline Região / Renda & $\mathbf{N}$ & NE & CO (1) & CO (2) & $\begin{array}{l}\text { Distrito } \\
\text { Federal } \\
\end{array}$ & SE (3) & SE (4) & $\begin{array}{c}\text { São } \\
\text { Paulo }\end{array}$ & Sul & Brasil \\
\hline \multicolumn{11}{|c|}{ Água - Rede Geral (\% dos domicílios) } \\
\hline menos de 1 S.M. & 76,35 & 89,11 & 82,14 & 77,93 & 97,12 & 87,61 & 82,99 & 93,48 & 76,08 & 86,03 \\
\hline de 1 a 2 S.M. & 70,31 & 91,10 & 78,23 & 76,00 & 92,01 & 87,81 & 83,56 & 93,44 & 82,17 & 86,24 \\
\hline de 2 a 3 S.M. & 66,66 & 90,80 & 77,27 & 75,12 & 94,88 & 89,25 & 84,73 & 94,56 & 82,49 & 86,18 \\
\hline de 3 a 5 S.M. & 66,72 & 92,11 & 82,08 & 80,17 & 94,97 & 93,20 & 88,59 & 97,29 & 84,12 & $\mathbf{8 8 , 9 3}$ \\
\hline de 5 a 10 S.M. & 72,64 & 93,98 & 86,23 & 84,14 & 95,31 & 95,86 & 92,77 & 98,13 & 87,64 & 92,06 \\
\hline de 10 a 20 S.M. & 70,72 & 93,79 & 88,34 & 86,30 & 92,77 & 96,99 & 94,63 & 98,70 & 90,79 & $\mathbf{9 3 , 5 2}$ \\
\hline Mais de 20 S.M. & 63,07 & 93,18 & 91,91 & 89,66 & 94,39 & 95,95 & 92,16 & 98,93 & 91,18 & $\mathbf{9 3 , 5 0}$ \\
\hline Total & 69,23 & $\mathbf{9 1 , 5 2}$ & 82,23 & 79,61 & 94,23 & 92,60 & 88,20 & 96,73 & 85,13 & 89,04 \\
\hline \multicolumn{11}{|c|}{ Esgoto - Rede Geral (\% dos domicílios) } \\
\hline menos de 1 S.M. & 2,46 & 21,12 & 26,27 & 12,75 & 80,00 & 61,50 & 53,05 & 72,55 & 14,17 & $\mathbf{3 1 , 3 4}$ \\
\hline de 1 a 2 S.M. & 2,66 & 26,68 & 23,26 & 15,04 & 76,22 & 67,68 & 60,34 & 77,54 & 18,89 & 39,07 \\
\hline de 2 a 3 S.M. & 2,75 & 29,86 & 25,79 & 19,03 & 82,02 & 72,36 & 64,12 & 82,24 & 19,28 & 44,20 \\
\hline de 3 a 5 S.M. & 4,18 & 37,00 & 28,74 & 20,58 & 84,69 & 79,20 & 68,88 & 88,37 & 21,95 & 52,44 \\
\hline de 5 a 10 S.M. & 7,04 & 47,29 & 40,16 & 29,11 & 88,67 & 84,87 & 75,07 & 92,04 & 28,01 & 60,98 \\
\hline mais de 10 S.M. & 9,77 & 57,80 & 53,95 & 39,08 & 86,49 & 89,56 & 80,85 & 95,84 & 33,39 & 68,12 \\
\hline Mais de 20 S.M. & 13,19 & 58,74 & 67,46 & 47,85 & 89,04 & 85,26 & 75,47 & 92,99 & 44,14 & 72,04 \\
\hline Total & 4,42 & 32,87 & 33,24 & 22,38 & 84,39 & 78,11 & 68,18 & 87,52 & 24,48 & 50,88 \\
\hline \multicolumn{11}{|c|}{ Fossa Séptica (\% dos domicílios) } \\
\hline menos de 1 S.M. & 31,19 & 17,75 & 7,36 & 6,27 & 11,67 & 11,15 & 13,44 & 8,15 & 39,15 & 18,29 \\
\hline de 1 a 2 S.M. & 40,86 & 18,88 & 8,40 & 6,98 & 17,54 & 10,77 & 13,74 & 6,77 & 47,92 & 20,43 \\
\hline de 2 a 3 S.M. & 48,79 & 21,82 & 8,22 & 7,62 & 13,19 & 10,56 & 14,31 & 6,07 & 49,85 & 22,23 \\
\hline de 3 a 5 S.M. & 56,94 & 24,13 & 8,57 & 8,16 & 11,33 & 9,72 & 15,80 & 4,33 & 54,97 & 23,72 \\
\hline de 5 a 10 S.M. & 64,28 & 26,91 & 10,37 & 10,78 & 8,58 & 8,91 & 16,45 & 3,40 & 57,47 & 24,33 \\
\hline mais de 10 S.M. & 72,11 & 24,27 & 12,55 & 13,40 & 10,68 & 6,92 & 13,70 & 2,04 & 56,73 & 22,56 \\
\hline Mais de 20 S.M. & 68,04 & 20,72 & 13,02 & 15,25 & 10,56 & 9,51 & 18,49 & 2,41 & 50,03 & 19,02 \\
\hline Total & 51,44 & 21,29 & $\mathbf{9 , 3 1}$ & 8,77 & 11,89 & 9,63 & 15,14 & $\mathbf{4 , 4 1}$ & 52,88 & 22,12 \\
\hline
\end{tabular}

Fonte: IBGE, PNAD de 2004. Elaboração própria.

S.M.: Salário mínimo.

(1) Centro-Oeste incluindo o Distrito Federal.

(2) Centro-Oeste excluindo o Distrito Federal.

(3) Sudeste incluindo São Paulo.

(4) Sudeste excluindo São Paulo. 
Tabela 24

Brasil: proporção de domicílios urbanos e rurais com acesso a serviços de saneamento básico, segundo as grandes regiões, o Distrito Federal e o Estado de São Paulo (1970-1991)

\begin{tabular}{|c|c|c|c|c|c|c|}
\hline \multirow{2}{*}{$\begin{array}{c}\text { Localização / } \\
\text { Região }\end{array}$} & \multicolumn{2}{|c|}{$\begin{array}{l}\text { Água - Rede Geral } \\
\text { (\% dos domicílios) }\end{array}$} & \multicolumn{2}{|c|}{$\begin{array}{l}\text { Esgoto - Rede Geral } \\
\text { (\% dos domicílios) }\end{array}$} & \multicolumn{2}{|c|}{$\begin{array}{c}\text { Fossa Séptica } \\
\text { (\% dos domicílios })\end{array}$} \\
\hline & Urbano & Rural & Urbano & Rural & Urbano & Rural \\
\hline \multicolumn{7}{|c|}{1970} \\
\hline Norte & 4,39 & 1,01 & 0,35 & 0,00 & 1,60 & 0,47 \\
\hline Nordeste & 28,65 & 0,55 & 5,65 & 0,06 & 12,79 & 0,27 \\
\hline Centro-Oeste (1) & 1,99 & 19,90 & 0,03 & 7,41 & 1,13 & 7,59 \\
\hline Centro-Oeste (2) & 30,83 & 1,92 & 9,90 & 0,02 & 14,84 & 1,07 \\
\hline Distrito Federal & 68,22 & 10,33 & 34,75 & 1,12 & 12,80 & 8,44 \\
\hline Sudeste (3) & 66,74 & 5,54 & 31,55 & 1,23 & 25,27 & 3,45 \\
\hline Sudeste (4) & 63,93 & 4,46 & 35,71 & 0,77 & 17,22 & 2,39 \\
\hline São Paulo & 69,50 & 7,75 & 27,44 & 2,19 & 33,21 & 5,63 \\
\hline Sul & 49,48 & 3,32 & 15,18 & 0,10 & 24,56 & 2,13 \\
\hline Brasil & 54,85 & 2,66 & 22,62 & $\mathbf{0 , 3 9}$ & 21,98 & 1,63 \\
\hline \multicolumn{7}{|c|}{1980} \\
\hline Norte & 7,02 & 5,59 & 0,97 & 0,18 & 2,56 & 5,14 \\
\hline Nordeste & 58,07 & 3,33 & 10,26 & 0,98 & 22,91 & 2,26 \\
\hline Centro-Oeste (1) & 1,66 & 41,76 & 0,17 & 14,55 & 1,78 & 7,74 \\
\hline Centro-Oeste (2) & 48,50 & 1,62 & 12,84 & 0,13 & 3,52 & 1,50 \\
\hline Distrito Federal & 97,44 & 4,26 & 48,36 & 2,65 & 33,49 & 19,52 \\
\hline Sudeste (3) & 84,39 & 7,11 & 59,38 & 3,90 & 14,17 & 11,19 \\
\hline Sudeste (4) & 77,63 & 5,58 & 56,42 & 3,17 & 12,11 & 7,54 \\
\hline São Paulo & 90,48 & 10,21 & 62,05 & 5,39 & 16,03 & 18,58 \\
\hline Sul & 77,23 & 3,45 & 18,47 & 0,42 & 38,32 & 10,73 \\
\hline Brasil & 76,20 & 4,30 & 39,56 & 1,46 & 19,76 & 6,18 \\
\hline \multicolumn{7}{|c|}{1991} \\
\hline Norte & 67,70 & 8,93 & 1,70 & 0,72 & 35,17 & 8,69 \\
\hline Nordeste & 78,34 & 9,71 & 13,23 & 1,56 & 22,90 & 2,63 \\
\hline Centro-Oeste (1) & 84,25 & 5,27 & 47,07 & 0,38 & 7,65 & 6,58 \\
\hline Centro-Oeste (2) & 75,36 & 4,85 & 16,34 & 0,00 & 4,11 & 2,00 \\
\hline Distrito Federal & 93,59 & 6,89 & 79,30 & 1,88 & 11,37 & 24,62 \\
\hline Sudeste (3) & 93,50 & 11,54 & 70,40 & 4,92 & 10,56 & 11,49 \\
\hline Sudeste (4) & 90,23 & 9,42 & 58,67 & 2,89 & 15,46 & 6,45 \\
\hline São Paulo & 96,37 & 16,17 & 80,74 & 9,33 & 6,25 & 22,42 \\
\hline Sul & 90,72 & 7,62 & 17,88 & 0,24 & 47,35 & 17,50 \\
\hline Brasil & 88,30 & 9,61 & 45,47 & 1,99 & 20,40 & 8,16 \\
\hline
\end{tabular}

Fonte: IBGE, Censos Demográficos de 1970, 1980 e 1991. Elaboração própria.

(1) Centro-Oeste incluindo o Distrito Federal.

(2) Centro-Oeste excluindo o Distrito Federal.

(3) Sudeste incluindo São Paulo.

(4) Sudeste excluindo São Paulo. 
Tabela 25

Brasil: proporção de domicílios urbanos e rurais com acesso a serviços de saneamento básico, segundo as grandes regiões, o Distrito Federal e o Estado de São Paulo (2001-2004)

\begin{tabular}{|c|c|c|c|c|c|c|}
\hline \multirow{2}{*}{$\begin{array}{l}\text { Localização / } \\
\text { Região }\end{array}$} & \multicolumn{2}{|c|}{$\begin{array}{l}\text { Água - Rede Geral } \\
\text { (\% dos domicílios) }\end{array}$} & \multicolumn{2}{|c|}{$\begin{array}{c}\text { Esgoto - Rede Geral } \\
\text { (\% dos domicílios) }\end{array}$} & \multicolumn{2}{|c|}{$\begin{array}{c}\text { Fossa Séptica } \\
(\% \text { dos domicílios })\end{array}$} \\
\hline & Urbano & Rural & Urbano & Rural & Urbano & Rural \\
\hline \multicolumn{7}{|c|}{2001} \\
\hline Norte & 75,98 & 45,79 & 6,20 & 0,59 & 50,55 & 4,68 \\
\hline Nordeste & 96,18 & 57,69 & 32,91 & 3,20 & 29,46 & 12,97 \\
\hline Centro-Oeste (1) & 87,00 & 14,98 & 36,12 & 1,14 & 14,77 & 3,36 \\
\hline Centro-Oeste (2) & 85,38 & 14,47 & 23,97 & 0,19 & 16,36 & 2,85 \\
\hline Distrito Federal & 93,64 & 21,20 & 87,17 & 14,76 & 8,12 & 10,64 \\
\hline Sudeste (3) & 97,10 & 24,53 & 79,58 & 10,98 & 11,18 & 12,94 \\
\hline Sudeste (4) & 94,84 & 12,70 & 70,25 & 3,81 & 16,62 & 8,43 \\
\hline São Paulo & 99,10 & 42,83 & 87,99 & 22,11 & 6,28 & 19,94 \\
\hline Sul & 94,87 & 24,78 & 27,99 & 0,96 & 51,30 & 33,30 \\
\hline Brasil & 94,86 & 30,89 & 54,47 & 4,90 & 23,78 & 17,49 \\
\hline \multicolumn{7}{|c|}{2002} \\
\hline Norte & 72,74 & 37,73 & 4,31 & 0,70 & 57,18 & 13,19 \\
\hline Nordeste & 96,09 & 56,29 & 35,78 & 3,08 & 25,97 & 9,71 \\
\hline Centro-Oeste (1) & 87,84 & 15,17 & 36,71 & 1,56 & 14,37 & 8,61 \\
\hline Centro-Oeste (2) & 86,44 & 14,41 & 24,49 & 0,00 & 15,40 & 4,30 \\
\hline Distrito Federal & 93,49 & 24,40 & 87,53 & 24,01 & 10,10 & 70,39 \\
\hline Sudeste (3) & 96,94 & 27,62 & 78,99 & 12,44 & 12,10 & 15,18 \\
\hline Sudeste (4) & 94,52 & 15,17 & 67,79 & 4,94 & 19,32 & 8,81 \\
\hline São Paulo & 99,14 & 45,53 & 89,26 & 23,65 & 5,48 & 24,69 \\
\hline Sul & 95,51 & 27,45 & 30,74 & 1,69 & 50,32 & 40,22 \\
\hline Brasil & 94,72 & 33,06 & 55,13 & 5,44 & 23,70 & 19,35 \\
\hline \multicolumn{7}{|c|}{2003} \\
\hline Norte & 74,99 & 50,01 & 4,68 & 0,00 & 53,72 & 1,19 \\
\hline Nordeste & 95,91 & 60,20 & 37,21 & 3,23 & 24,52 & 12,24 \\
\hline Centro-Oeste (1) & 88,91 & 14,75 & 38,84 & 1,32 & 13,44 & 5,48 \\
\hline Centro-Oeste (2) & 87,21 & 13,38 & 26,81 & 0,08 & 14,22 & 2,24 \\
\hline Distrito Federal & 95,79 & 32,31 & 88,04 & 18,70 & 10,25 & 51,08 \\
\hline Sudeste (3) & 96,90 & 27,43 & 81,25 & 13,05 & 10,42 & 15,00 \\
\hline Sudeste (4) & 94,51 & 13,33 & 71,57 & 4,76 & 16,51 & 10,43 \\
\hline São Paulo & 99,06 & 48,49 & 90,08 & 25,98 & 4,87 & 22,13 \\
\hline Sul & 95,23 & 28,62 & 30,84 & 1,29 & 51,90 & 42,04 \\
\hline Brasil & 94,80 & 34,68 & 56,61 & 5,49 & 22,59 & 19,96 \\
\hline \multicolumn{7}{|c|}{2004} \\
\hline Norte & 75,01 & 34,02 & 5,38 & 0,79 & 57,74 & 27,55 \\
\hline Nordeste & 96,04 & 56,52 & 39,15 & 2,60 & 22,65 & 14,70 \\
\hline Centro-Oeste (1) & 90,54 & 18,57 & 37,71 & 1,98 & 9,69 & 6,66 \\
\hline Centro-Oeste (2) & 89,21 & 15,44 & 26,01 & 0,24 & 9,72 & 2,97 \\
\hline Distrito Federal & 96,13 & 57,03 & 87,58 & 24,67 & 9,58 & 55,06 \\
\hline Sudeste (3) & 97,04 & 28,97 & 82,78 & 14,45 & 9,16 & 16,05 \\
\hline Sudeste (4) & 94,56 & 15,52 & 74,00 & 5,78 & 15,71 & 9,03 \\
\hline São Paulo & 99,30 & 48,90 & 90,81 & 27,83 & 3,17 & 26,88 \\
\hline Sul & 95,53 & 30,57 & 28,95 & 1,21 & 55,54 & 39,03 \\
\hline Brasil & 94,98 & 35,40 & 57,13 & 5,20 & 22,24 & 21,27 \\
\hline
\end{tabular}

Fonte: IBGE, PNAD de 2001, 2002, 2003 e 2004. Elaboração própria.

(1) Centro-Oeste incluindo o Distrito Federal.

(2) Centro-Oeste excluindo o Distrito Federal

(3) Sudeste incluindo São Paulo.

(4) Sudeste excluindo São Paulo. 
Tabela 26

Resultados das estimações: variável dependente acesso a abastecimento de água por rede geral (1970)

\begin{tabular}{|c|c|c|c|c|c|c|c|c|}
\hline $\begin{array}{c}\text { Abastecimento } \\
\text { de Água } \\
\text { (Rede Geral) }\end{array}$ & $\begin{array}{c}\text { Coefici- } \\
\text { ente }\end{array}$ & $\begin{array}{c}\text { Efeito } \\
\text { Marginal }\end{array}$ & $\begin{array}{c}\text { Coefici- } \\
\text { ente }\end{array}$ & $\begin{array}{c}\text { Efeito } \\
\text { Marginal }\end{array}$ & $\begin{array}{c}\text { Coefici- } \\
\text { ente }\end{array}$ & $\begin{array}{c}\text { Efeito } \\
\text { Marginal }\end{array}$ & $\begin{array}{c}\text { Coefici- } \\
\text { ente }\end{array}$ & $\begin{array}{c}\text { Efeito } \\
\text { Marginal }\end{array}$ \\
\hline $\begin{array}{c}\text { Ln (Renda } \\
\text { Mensal do Chefe } \\
\text { da Família) }\end{array}$ & $\begin{array}{l}0,601 * \\
(0,003)\end{array}$ & $\begin{array}{l}0,168 * \\
(0,001) \\
{[0,885]}\end{array}$ & & & & & & \\
\hline $\begin{array}{l}\text { Ln (População } \\
\text { do Município) }\end{array}$ & & & $\begin{array}{l}0,067 * \\
(0,002)\end{array}$ & $\begin{array}{c}0,019 * \\
(0,0005) \\
{[0,221]}\end{array}$ & & & & \\
\hline $\begin{array}{l}\text { Taxa de } \\
\text { Urbanização do } \\
\text { Município }\end{array}$ & & & & & $\begin{array}{l}0,888 * \\
(0,010)\end{array}$ & $\begin{array}{l}0,251 * \\
(0,003)\end{array}$ & & \\
\hline $\begin{array}{c}\text { Ln (Renda } \\
\text { Municipal per } \\
\text { capita Mensal) }\end{array}$ & & & & & & & $\begin{array}{l}0,514 * \\
(0,004)\end{array}$ & $\begin{array}{l}0,146 * \\
(0,001) \\
{[0,618]}\end{array}$ \\
\hline $\begin{array}{l}\text { Localização do } \\
\text { Domićlio }\end{array}$ & $\begin{array}{l}-1,639 * \\
(0,007)\end{array}$ & $\begin{array}{c}-0,410 * \\
(0,001)\end{array}$ & $\begin{array}{c}-1,845 * \\
(0,007)\end{array}$ & $\begin{array}{c}-0,458 * \\
(0,001)\end{array}$ & $\begin{array}{c}-1,651 * \\
(0,007)\end{array}$ & $\begin{array}{c}-0,412 * \\
(0,001)\end{array}$ & $\begin{array}{c}-1,650 * \\
(0,007)\end{array}$ & $\begin{array}{c}-0,413 * \\
(0,001)\end{array}$ \\
\hline Dummy Norte & $\begin{array}{l}-0,525 * \\
(0,016)\end{array}$ & $\begin{array}{c}-0,116 * \\
(0,003)\end{array}$ & $\begin{array}{c}-0,632 * \\
(0,015)\end{array}$ & $\begin{array}{c}-0,137 * \\
(0,002)\end{array}$ & $\begin{array}{c}-0,560 * \\
(0,016)\end{array}$ & $\begin{array}{c}-0,123 * \\
(0,003)\end{array}$ & $\begin{array}{c}-0,341 * \\
(0,015)\end{array}$ & $\begin{array}{c}-0,084 * \\
(0,003)\end{array}$ \\
\hline Dummy Nordeste & $\begin{array}{l}-0,706 * \\
(0,008)\end{array}$ & $\begin{array}{c}-0,170 * \\
(0,002)\end{array}$ & $\begin{array}{c}-0,990 * \\
(0,007)\end{array}$ & $\begin{array}{c}-0,232 * \\
(0,001)\end{array}$ & $\begin{array}{c}-0,884 * \\
(0,007)\end{array}$ & $\begin{array}{c}-0,209 * \\
(0,001)\end{array}$ & $\begin{array}{c}-0,552 * \\
(0,007)\end{array}$ & $\begin{array}{c}-0,140 * \\
(0,002)\end{array}$ \\
\hline $\begin{array}{c}\text { Dummy } \\
\text { Centro-Oeste (2) }\end{array}$ & $\begin{array}{l}-0,761 * \\
(0,015)\end{array}$ & $\begin{array}{c}-0,151 * \\
(0,002)\end{array}$ & $\begin{array}{c}-0,796 * \\
(0,014)\end{array}$ & $\begin{array}{c}-0,161 * \\
(0,002)\end{array}$ & $\begin{array}{c}-0,711 * \\
(0,013)\end{array}$ & $\begin{array}{c}-0,147 * \\
(0,002)\end{array}$ & $\begin{array}{c}-0,587 * \\
(0,013)\end{array}$ & $\begin{array}{c}-0,129 * \\
(0,002)\end{array}$ \\
\hline $\begin{array}{l}\text { Dummy Distrito } \\
\text { Federal }\end{array}$ & & & & & $\begin{array}{c}-0,141 * \\
(0,027)\end{array}$ & $\begin{array}{c}-0,037 * \\
(0,007)\end{array}$ & & \\
\hline $\begin{array}{c}\text { Dummy Sudeste } \\
\text { (4) }\end{array}$ & $\begin{array}{l}-0,01 * * \\
(0,007)\end{array}$ & $\begin{array}{c}-0,004 * * \\
(0,002)\end{array}$ & $\begin{array}{c}-0,105^{*} \\
(0,006)\end{array}$ & $\begin{array}{c}-0,029 * \\
(0,002)\end{array}$ & $\begin{array}{c}-1,114 * \\
(0,006)\end{array}$ & $\begin{array}{c}-0,031 * \\
(0,002)\end{array}$ & & \\
\hline Dummy Sul & $\begin{array}{l}-0,429 * \\
(0,008)\end{array}$ & $\begin{array}{c}-0,106 * \\
(0,002)\end{array}$ & $\begin{array}{c}-0,415 * \\
(0,008)\end{array}$ & $\begin{array}{c}-0,106 * \\
(0,002)\end{array}$ & $\begin{array}{c}-0,307 * \\
(0,008)\end{array}$ & $\begin{array}{c}-0,080 * \\
(0,002)\end{array}$ & $\begin{array}{c}-0,283 * \\
(0,007)\end{array}$ & $\begin{array}{c}-0,074 * \\
(0,002)\end{array}$ \\
\hline Constante & $\begin{array}{l}-2,978 * \\
(0,019)\end{array}$ & & $\begin{array}{c}-0,364 * \\
(0,021)\end{array}$ & & $\begin{array}{c}-0,253 * \\
(0,010)\end{array}$ & & $\begin{array}{c}-2,054 * \\
(0,021)\end{array}$ & \\
\hline $\begin{array}{c}\mathbf{y}=\operatorname{Pr} \text { (agua) } \\
\text { (predict) }\end{array}$ & \multicolumn{2}{|c|}{0,198780} & \multicolumn{2}{|c|}{0,207552} & \multicolumn{2}{|c|}{0,203156} & \multicolumn{2}{|c|}{0,204640} \\
\hline $\begin{array}{l}\text { Número de } \\
\text { Observações }\end{array}$ & \multicolumn{2}{|c|}{425.566} & \multicolumn{2}{|c|}{464.016} & \multicolumn{2}{|c|}{464.016} & \multicolumn{2}{|c|}{464.016} \\
\hline LR $\operatorname{chi}^{2}(10)$ & \multicolumn{2}{|c|}{$229.543,26$} & \multicolumn{2}{|c|}{$203.461,42$} & \multicolumn{2}{|c|}{$210.029,82$} & \multicolumn{2}{|c|}{$214.865,72$} \\
\hline Prob $>$ chi $^{2}$ & \multicolumn{2}{|r|}{0,0000} & \multicolumn{2}{|c|}{0,0000} & \multicolumn{2}{|r|}{0,0000} & \multicolumn{2}{|r|}{0,0000} \\
\hline Pseudo-R $^{2}$ & \multicolumn{2}{|r|}{0,4249} & \multicolumn{2}{|c|}{0,3471} & \multicolumn{2}{|r|}{0,3583} & \multicolumn{2}{|r|}{0,3666} \\
\hline
\end{tabular}

Obs.: Erro-padrão entre parênteses e elasticidades entre colchetes, calculadas na forma d(y) / d(lnx).

* Significativo a $1 \%$.

** Significativo a $5 \%$. 
Tabela 27

Resultados das estimações: variável dependente acesso a abastecimento de água por rede geral (1980)

\begin{tabular}{|c|c|c|c|c|c|c|c|c|}
\hline $\begin{array}{c}\text { Abastecimento } \\
\text { de Água } \\
\text { (Rede Geral) }\end{array}$ & $\begin{array}{l}\text { Coefici- } \\
\text { ente }\end{array}$ & $\begin{array}{c}\text { Efeito } \\
\text { Marginal }\end{array}$ & $\begin{array}{l}\text { Coefici- } \\
\text { ente }\end{array}$ & $\begin{array}{c}\text { Efeito } \\
\text { Marginal }\end{array}$ & $\begin{array}{l}\text { Coefici- } \\
\text { ente }\end{array}$ & $\begin{array}{c}\text { Efeito } \\
\text { Marginal }\end{array}$ & $\begin{array}{l}\text { Coefici- } \\
\text { ente }\end{array}$ & $\begin{array}{c}\text { Efeito } \\
\text { Marginal }\end{array}$ \\
\hline $\begin{array}{c}\text { Ln (Renda } \\
\text { Domiciliar) }\end{array}$ & $\begin{array}{l}0,289 * \\
(0,002)\end{array}$ & $\begin{array}{c}0,115 * \\
(0,0007) \\
{[1,078]}\end{array}$ & & & & & & \\
\hline $\begin{array}{l}\text { Ln (População } \\
\text { do Município) }\end{array}$ & & & $\begin{array}{l}0,117 * \\
(0,001)\end{array}$ & $\begin{array}{c}0,047 * \\
(0,0004) \\
{[0,546]}\end{array}$ & & & & \\
\hline $\begin{array}{c}\text { Taxa de } \\
\text { Urbanização do } \\
\text { Município }\end{array}$ & & & & & $\begin{array}{l}0,858 * \\
(0,009)\end{array}$ & $\begin{array}{l}0,342 * \\
(0,003)\end{array}$ & & \\
\hline $\begin{array}{c}\text { Ln (Renda } \\
\text { Municipal per } \\
\text { capita Mensal) }\end{array}$ & & & & & & & $\begin{array}{l}0,242 * \\
(0,003)\end{array}$ & $\begin{array}{l}0,097 * \\
(0,001) \\
{[0,977]}\end{array}$ \\
\hline $\begin{array}{l}\text { Localização do } \\
\text { Domicílio }\end{array}$ & $\begin{array}{l}-2,200 * \\
(0,006)\end{array}$ & $\begin{array}{c}-0,685 * \\
(0,001)\end{array}$ & $\begin{array}{l}-2,123 * \\
(0,006)\end{array}$ & $\begin{array}{c}-0,670 * \\
(0,001)\end{array}$ & $\begin{array}{c}-2,055 * \\
(0,006)\end{array}$ & $\begin{array}{c}-0,653 * \\
(0,001)\end{array}$ & $\begin{array}{l}-2,243 * \\
(0,006)\end{array}$ & $\begin{array}{l}-0,689 * \\
(0,0009)\end{array}$ \\
\hline Dummy Norte & $\begin{array}{c}-0,618 * \\
(0,011)\end{array}$ & $\begin{array}{c}-0,234 * \\
(0,004)\end{array}$ & $\begin{array}{c}-0,639 * \\
(0,011)\end{array}$ & $\begin{array}{c}-0,239 * \\
(0,004)\end{array}$ & $\begin{array}{c}-0,505 * \\
(0,011)\end{array}$ & $\begin{array}{c}-0,192 * \\
(0,004)\end{array}$ & $\begin{array}{c}-0,678 * \\
(0,011)\end{array}$ & $\begin{array}{c}-0,251 * \\
(0,003)\end{array}$ \\
\hline $\begin{array}{l}\text { Dummy } \\
\text { Nordeste }\end{array}$ & $\begin{array}{c}-0,819 * \\
(0,006)\end{array}$ & $\begin{array}{c}-0,313 * \\
(0,002)\end{array}$ & $\begin{array}{c}-0,905 * \\
(0,006)\end{array}$ & $\begin{array}{c}-0,341 * \\
(0,002)\end{array}$ & $\begin{array}{c}-0,822 * \\
(0,006)\end{array}$ & $\begin{array}{c}-0,311 * \\
(0,002)\end{array}$ & $\begin{array}{c}-1,010 * \\
(0,006)\end{array}$ & $\begin{array}{c}-0,374 * \\
(0,002)\end{array}$ \\
\hline $\begin{array}{c}\text { Dummy } \\
\text { Centro-Oeste } \\
\text { (2) }\end{array}$ & $\begin{array}{c}-1,221 * \\
(0,010)\end{array}$ & $\begin{array}{c}-0,404 * \\
(0,002)\end{array}$ & $\begin{array}{c}-1,129 * \\
(0,010)\end{array}$ & $\begin{array}{c}-0,378 * \\
(0,002)\end{array}$ & $\begin{array}{c}-1,167 * \\
(0,010)\end{array}$ & $\begin{array}{c}-0,383 * \\
(0,002)\end{array}$ & $\begin{array}{c}-1,277 * \\
(0,010)\end{array}$ & $\begin{array}{c}-0,407 * \\
(0,002)\end{array}$ \\
\hline $\begin{array}{c}\text { Dummy Distrito } \\
\text { Federal }\end{array}$ & $\begin{array}{l}0,570 * \\
(0,031)\end{array}$ & $\begin{array}{l}0,215 * \\
(0,010)\end{array}$ & $\begin{array}{l}0,380 * \\
(0,029)\end{array}$ & $\begin{array}{l}0,148 * \\
(0,011)\end{array}$ & $\begin{array}{l}0,469 * \\
(0,029)\end{array}$ & $\begin{array}{l}0,182 * \\
(0,011)\end{array}$ & $\begin{array}{l}0,465 * \\
(0,030)\end{array}$ & $\begin{array}{l}0,181 * \\
(0,011)\end{array}$ \\
\hline $\begin{array}{c}\text { Dummy Sudeste } \\
\text { (4) }\end{array}$ & $\begin{array}{c}-0,446 * \\
(0,006)\end{array}$ & $\begin{array}{c}-0,176 * \\
(0,002)\end{array}$ & $\begin{array}{c}-0,495 * \\
(0,006)\end{array}$ & $\begin{array}{c}-0,194 * \\
(0,002)\end{array}$ & $\begin{array}{c}-0,471 * \\
(0,006)\end{array}$ & $\begin{array}{c}-0,184 * \\
(0,002)\end{array}$ & $\begin{array}{c}-0,515 * \\
(0,006)\end{array}$ & $\begin{array}{c}-0,200 * \\
(0,002)\end{array}$ \\
\hline Dummy Sul & $\begin{array}{c}-0,515 * \\
(0,007)\end{array}$ & $\begin{array}{l}-0,200 * \\
(0,002)\end{array}$ & $\begin{array}{c}-0,431 * \\
(0,007)\end{array}$ & $\begin{array}{c}-0,169 * \\
(0,003)\end{array}$ & $\begin{array}{c}-0,434 * \\
(0,007)\end{array}$ & $\begin{array}{c}-0,169 * \\
(0,003)\end{array}$ & $\begin{array}{c}-0,553 * \\
(0,007)\end{array}$ & $\begin{array}{c}-0,213 * \\
(0,002)\end{array}$ \\
\hline Constante & $\begin{array}{c}-1,543 * \\
(0,018) \\
\end{array}$ & & $\begin{array}{c}-0,215 * \\
(0,014) \\
\end{array}$ & & $\begin{array}{l}0,488 * \\
(0,009) \\
\end{array}$ & & $\begin{array}{c}-1,213 * \\
(0,034) \\
\end{array}$ & \\
\hline 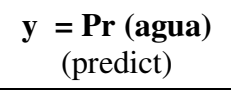 & \multicolumn{2}{|c|}{0,504411} & \multicolumn{2}{|c|}{0,493477} & \multicolumn{2}{|c|}{0,485564} & \multicolumn{2}{|c|}{0,487632} \\
\hline $\begin{array}{l}\text { Número de } \\
\text { Observações }\end{array}$ & \multicolumn{2}{|c|}{632.758} & \multicolumn{2}{|c|}{647.570} & \multicolumn{2}{|c|}{647.570} & \multicolumn{2}{|c|}{647.570} \\
\hline $\operatorname{LR} \operatorname{chi}^{2}(10)$ & \multicolumn{2}{|c|}{$385.471,22$} & \multicolumn{2}{|c|}{$384.998,83$} & \multicolumn{2}{|c|}{$382.829,46$} & \multicolumn{2}{|c|}{$378.874,53$} \\
\hline Prob $>$ chi $^{2}$ & \multicolumn{2}{|c|}{0,0000} & \multicolumn{2}{|c|}{0,0000} & \multicolumn{2}{|c|}{0,0000} & \multicolumn{2}{|r|}{0,0000} \\
\hline Pseudo-R $^{2}$ & \multicolumn{2}{|c|}{0,4423} & \multicolumn{2}{|c|}{0,4306} & \multicolumn{2}{|c|}{0,4282} & \multicolumn{2}{|c|}{0,4238} \\
\hline
\end{tabular}

Obs.: Erro-padrão entre parênteses e elasticidades entre colchetes, calculadas na forma d(y) / d $(\ln x)$.

* Significativo a $1 \%$. 
Tabela 28

Resultados das estimações: variável dependente acesso a abastecimento de água por rede geral (1991)

\begin{tabular}{|c|c|c|c|c|c|c|}
\hline $\begin{array}{c}\text { Abastecimento de Água } \\
\text { (Rede Geral) }\end{array}$ & Coeficiente & $\begin{array}{c}\text { Efeito } \\
\text { Marginal }\end{array}$ & Coeficiente & $\begin{array}{c}\text { Efeito } \\
\text { Marginal }\end{array}$ & Coeficiente & $\begin{array}{c}\text { Efeito } \\
\text { Marginal }\end{array}$ \\
\hline Ln (Renda Domiciliar) & $\begin{array}{l}0,263 * \\
(0,003)\end{array}$ & $\begin{array}{l}0,086 * \\
(0,001) \\
{[0,981]}\end{array}$ & $\begin{array}{l}0,308 * \\
(0,003)\end{array}$ & $\begin{array}{c}0,102 * \\
(0,0010) \\
{[1,166]}\end{array}$ & $\begin{array}{l}0,260 * \\
(0,003)\end{array}$ & $\begin{array}{l}0,085 * \\
(0,001) \\
{[0,977]}\end{array}$ \\
\hline $\begin{array}{l}\text { Ln (População do } \\
\text { Município) }\end{array}$ & $\begin{array}{l}0,110 * \\
(0,002)\end{array}$ & $\begin{array}{c}0,036 * \\
(0,0006) \\
{[0,400]}\end{array}$ & & & & \\
\hline $\begin{array}{c}\text { Taxa de Urbanização do } \\
\text { Município }\end{array}$ & & & $\begin{array}{l}0,010 * \\
(0,002)\end{array}$ & $\begin{array}{c}0,003 * \\
(0,0006)\end{array}$ & & \\
\hline $\begin{array}{l}\text { Ln (Renda Municipal } \\
\text { per capita Mensal) }\end{array}$ & & & & & $\begin{array}{l}0,300 * \\
(0,005)\end{array}$ & $\begin{array}{l}0,099 * \\
(0,002) \\
{[1,079]}\end{array}$ \\
\hline $\begin{array}{l}\text { Localização do } \\
\text { Domicílio }\end{array}$ & $\begin{array}{c}-2,215 * \\
(0,007)\end{array}$ & $\begin{array}{l}-0,715 * \\
(0,0017)\end{array}$ & $\begin{array}{c}-2,273 * \\
(0,007)\end{array}$ & $\begin{array}{c}-0,744 * \\
(0,002)\end{array}$ & $\begin{array}{c}-2,157 * \\
(0,007)\end{array}$ & $\begin{array}{l}-0,717 * \\
(0,002)\end{array}$ \\
\hline Dummy Norte & $\begin{array}{c}-0,972 * \\
(0,013)\end{array}$ & $\begin{array}{c}-0,366 * \\
(0,005)\end{array}$ & $\begin{array}{c}-1,018 * \\
(0,013)\end{array}$ & $\begin{array}{c}-0,385 * \\
(0,005)\end{array}$ & $\begin{array}{c}-0,797 * \\
(0,014)\end{array}$ & $\begin{array}{c}-0,299 * \\
(0,005)\end{array}$ \\
\hline Dummy Nordeste & $\begin{array}{c}-0,539 * \\
(0,010)\end{array}$ & $\begin{array}{c}-0,186 * \\
(0,003)\end{array}$ & $\begin{array}{c}-0,590 * \\
(0,009)\end{array}$ & $\begin{array}{c}-0,207 * \\
(0,003)\end{array}$ & $\begin{array}{c}-0,273 * \\
(0,011)\end{array}$ & $\begin{array}{l}-0,093 * \\
(0,004)\end{array}$ \\
\hline $\begin{array}{c}\text { Dummy } \\
\text { Centro-Oeste (2) }\end{array}$ & $\begin{array}{l}-0,775 * \\
(0,022)\end{array}$ & $\begin{array}{c}-0,292 * \\
(0,009)\end{array}$ & $\begin{array}{l}-0,870 * \\
(0,022)\end{array}$ & $\begin{array}{c}-0,331 * \\
(0,008)\end{array}$ & $\begin{array}{c}-0,736 * \\
(0,022)\end{array}$ & $\begin{array}{l}-0,278 * \\
(0,009)\end{array}$ \\
\hline Dummy Distrito Federal & $\begin{array}{c}-0,446 * \\
(0,034)\end{array}$ & $\begin{array}{c}-0,162 * \\
(0,009)\end{array}$ & $\begin{array}{l}-0,205 * \\
(0,034)\end{array}$ & $\begin{array}{c}-0,072 * \\
(0,012)\end{array}$ & $\begin{array}{c}-0,311 * \\
(0,034)\end{array}$ & $\begin{array}{l}-0,111 * \\
(0,013)\end{array}$ \\
\hline Dummy Sudeste (4) & $\begin{array}{l}-0,092 * \\
(0,010)\end{array}$ & $\begin{array}{c}-0,030 * \\
(0,003)\end{array}$ & $\begin{array}{l}-0,308 * \\
(0,010)\end{array}$ & $\begin{array}{c}-0,106 * \\
(0,003)\end{array}$ & $\begin{array}{c}-0,742 * \\
(0,012)\end{array}$ & $\begin{array}{l}-0,265 * \\
(0,004)\end{array}$ \\
\hline Dummy Sul & $\begin{array}{c}-0,298 * \\
(0,010)\end{array}$ & $\begin{array}{l}-0,102 * \\
(0,004)\end{array}$ & $\begin{array}{l}-0,409 * \\
(0,010)\end{array}$ & $\begin{array}{l}-0,145 * \\
(0,004)\end{array}$ & $\begin{array}{c}-0,307 * \\
(0,010)\end{array}$ & $\begin{array}{l}-0,107 * \\
(0,004)\end{array}$ \\
\hline Constante & $\begin{array}{r}-2,764 * \\
(0,039)\end{array}$ & & $\begin{array}{c}-1,965 * \\
(0,037) \\
\end{array}$ & & $\begin{array}{c}-4,723 * \\
(0,058) \\
\end{array}$ & \\
\hline $\mathbf{y}=\operatorname{Pr}($ agua $)$ (predict) & \multicolumn{2}{|c|}{$\mathbf{0 , 7 3 7 6 9 7}$} & \multicolumn{2}{|c|}{$\mathbf{0 , 7 3 0 2 0 7}$} & \multicolumn{2}{|c|}{$\mathbf{0 , 7 3 3 1 7 0}$} \\
\hline $\begin{array}{l}\text { Número de } \\
\text { Observações }\end{array}$ & \multicolumn{2}{|c|}{362.052} & \multicolumn{2}{|c|}{362.052} & \multicolumn{2}{|c|}{362.052} \\
\hline$L R \operatorname{chi}^{2}(10)$ & \multicolumn{2}{|c|}{$228.579,78$} & \multicolumn{2}{|c|}{$224.423,84$} & \multicolumn{2}{|c|}{$228.385,45$} \\
\hline Prob $>$ chi $^{2}$ & \multicolumn{2}{|c|}{0,0000} & \multicolumn{2}{|c|}{0,0000} & \multicolumn{2}{|c|}{0,0000} \\
\hline Pseudo-R $^{2}$ & \multicolumn{2}{|c|}{0,5031} & \multicolumn{2}{|c|}{0,4939} & \multicolumn{2}{|c|}{0,5026} \\
\hline
\end{tabular}

Obs.: Erro-padrão entre parênteses e elasticidades entre colchetes, calculadas na forma d(y) / d(lnx).

* Significativo a $1 \%$. 
Tabela 29

Resultados das estimações: variável dependente acesso a coleta de esgoto por rede geral (1970)

\begin{tabular}{|c|c|c|c|c|c|c|c|c|}
\hline $\begin{array}{c}\text { Coleta de } \\
\text { Esgoto } \\
\text { (Rede Geral) } \\
\end{array}$ & $\begin{array}{l}\text { Coefici- } \\
\text { ente }\end{array}$ & $\begin{array}{c}\text { Efeito } \\
\text { Marginal }\end{array}$ & $\begin{array}{l}\text { Coefici- } \\
\text { ente }\end{array}$ & $\begin{array}{c}\text { Efeito } \\
\text { Marginal }\end{array}$ & $\begin{array}{l}\text { Coefici- } \\
\text { ente }\end{array}$ & $\begin{array}{c}\text { Efeito } \\
\text { Marginal }\end{array}$ & $\begin{array}{l}\text { Coefici- } \\
\text { ente }\end{array}$ & $\begin{array}{c}\text { Efeito } \\
\text { Marginal }\end{array}$ \\
\hline $\begin{array}{c}\text { Ln (Renda } \\
\text { Mensal do Chefe } \\
\text { da Família) }\end{array}$ & $\begin{array}{l}0,450 * \\
(0,003)\end{array}$ & $\begin{array}{c}0,033 * \\
(0,0005) \\
{[0,175]}\end{array}$ & & & & & & \\
\hline $\begin{array}{l}\text { Ln (População } \\
\text { do Município) }\end{array}$ & & & $\begin{array}{l}0,045 * \\
(0,002)\end{array}$ & $\begin{array}{c}0,008 * \\
(0,0003) \\
{[0,089]}\end{array}$ & & & & \\
\hline $\begin{array}{c}\text { Taxa de } \\
\text { Urbanização do } \\
\text { Município }\end{array}$ & & & & & $\begin{array}{l}0,602 * \\
(0,012)\end{array}$ & $\begin{array}{l}0,050 * \\
(0,001)\end{array}$ & & \\
\hline $\begin{array}{c}\text { Ln (Renda } \\
\text { Municipal per } \\
\text { capita Mensal) }\end{array}$ & & & & & & & $\begin{array}{l}0,446 * \\
(0,005)\end{array}$ & $\begin{array}{c}0,037 * \\
(0,0006) \\
{[0,157]}\end{array}$ \\
\hline $\begin{array}{l}\text { Localização do } \\
\text { Domicílio }\end{array}$ & $\begin{array}{c}-1,537 * \\
(0,015)\end{array}$ & $\begin{array}{l}-0,117 * \\
(0,0009)\end{array}$ & & & $\begin{array}{c}-1,626 * \\
(0,014)\end{array}$ & $\begin{array}{c}-0,138 * \\
(0,001)\end{array}$ & $\begin{array}{c}-1,548 * \\
(0,014)\end{array}$ & $\begin{array}{l}-0,129 * \\
(0,0009)\end{array}$ \\
\hline Dummy Norte & $\begin{array}{c}-1,117 * \\
(0,033)\end{array}$ & $\begin{array}{l}-0,034 * \\
(0,0005)\end{array}$ & $\begin{array}{l}-1,341 * \\
(0,027)\end{array}$ & $\begin{array}{l}-0,098 * \\
(0,0006)\end{array}$ & $\begin{array}{c}-1,150 * \\
(0,030)\end{array}$ & $\begin{array}{l}-0,040 * \\
(0,0006)\end{array}$ & $\begin{array}{c}-0,896 * \\
(0,030)\end{array}$ & $\begin{array}{l}-0,036 * \\
(0,0006)\end{array}$ \\
\hline Dummy Nordeste & $\begin{array}{c}-0,744 * \\
(0,011)\end{array}$ & $\begin{array}{l}-0,042 * \\
(0,0007)\end{array}$ & $\begin{array}{l}-1,182 * \\
(0,009)\end{array}$ & $\begin{array}{l}-0,149 * \\
(0,0009)\end{array}$ & $\begin{array}{c}-0,894 * \\
(0,010)\end{array}$ & $\begin{array}{l}-0,057 * \\
(0,0007)\end{array}$ & $\begin{array}{c}-0,571 * \\
(0,011)\end{array}$ & $\begin{array}{l}-0,039 * \\
(0,0007)\end{array}$ \\
\hline $\begin{array}{c}\text { Dummy } \\
\text { Centro-Oeste (2) }\end{array}$ & $\begin{array}{c}-0,594 * \\
(0,020)\end{array}$ & $\begin{array}{l}-0,027 * \\
(0,0006)\end{array}$ & $\begin{array}{l}-0,895 * \\
(0,016)\end{array}$ & $\begin{array}{l}-0,087 * \\
(0,0008)\end{array}$ & $\begin{array}{c}-0,596 * \\
(0,019)\end{array}$ & $\begin{array}{l}-0,031 * \\
(0,0006)\end{array}$ & $\begin{array}{c}-0,421 * \\
(0,019)\end{array}$ & $\begin{array}{l}-0,025 * \\
(0,0008)\end{array}$ \\
\hline $\begin{array}{c}\text { Dummy Distrito } \\
\text { Federal }\end{array}$ & $\begin{array}{l}0,182 * \\
(0,030)\end{array}$ & $\begin{array}{l}0,016 * \\
(0,003)\end{array}$ & & & $\begin{array}{l}0,103 * \\
(0,027)\end{array}$ & $\begin{array}{l}0,009 * \\
(0,003)\end{array}$ & $\begin{array}{l}0,193 * \\
(0,028)\end{array}$ & $\begin{array}{l}0,019 * \\
(0,003)\end{array}$ \\
\hline $\begin{array}{c}\text { Dummy Sudeste } \\
\text { (4) }\end{array}$ & $\begin{array}{l}0,330 * \\
(0,007)\end{array}$ & $\begin{array}{l}0,028 * \\
(0,0008)\end{array}$ & $\begin{array}{l}0,102 * \\
(0,006)\end{array}$ & $\begin{array}{l}0,018 * \\
(0,001)\end{array}$ & $\begin{array}{l}0,232 * \\
(0,007)\end{array}$ & $\begin{array}{l}0,022 * \\
(0,0007)\end{array}$ & $\begin{array}{l}0,351 * \\
(0,007)\end{array}$ & $\begin{array}{c}0,034 * \\
(0,0008)\end{array}$ \\
\hline Dummy Sul & $\begin{array}{c}-0,401 * \\
(0,010)\end{array}$ & $\begin{array}{l}-0,024 * \\
(0,0005)\end{array}$ & $\begin{array}{l}-0,666 * \\
(0,008)\end{array}$ & $\begin{array}{l}-0,086 * \\
(0,0008)\end{array}$ & $\begin{array}{c}-0,346 * \\
(0,009)\end{array}$ & $\begin{array}{l}-0,024 * \\
(0,0006)\end{array}$ & $\begin{array}{c}-0,278 * \\
(0,009)\end{array}$ & $\begin{array}{l}-0,020 * \\
(0,0006)\end{array}$ \\
\hline Constante & $\begin{array}{c}-3,287 * \\
(0,021) \\
\end{array}$ & & $\begin{array}{l}-1,321 * \\
(0,021)\end{array}$ & & $\begin{array}{c}-1,100 * \\
(0,012)\end{array}$ & & $\begin{array}{c}-2,829 * \\
(0,027) \\
\end{array}$ & \\
\hline 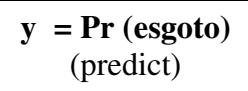 & \multicolumn{2}{|c|}{$\mathbf{0 , 0 3 3 0 5 7}$} & \multicolumn{2}{|c|}{$\mathbf{0 , 0 9 5 3 3 2}$} & \multicolumn{2}{|c|}{0,038601} & \multicolumn{2}{|c|}{0,038194} \\
\hline $\begin{array}{l}\text { Número de } \\
\text { Observações }\end{array}$ & \multicolumn{2}{|c|}{425.565} & \multicolumn{2}{|c|}{464.015} & \multicolumn{2}{|c|}{464.015} & \multicolumn{2}{|c|}{464.015} \\
\hline LR $\operatorname{chi}^{2}(10)$ & \multicolumn{2}{|c|}{$106.540,54$} & \multicolumn{2}{|c|}{$45.896,41$} & \multicolumn{2}{|c|}{$93.722,60$} & \multicolumn{2}{|c|}{$98.794,95$} \\
\hline Prob $>$ chi $^{2}$ & \multicolumn{2}{|c|}{0,0000} & \multicolumn{2}{|c|}{0,0000} & \multicolumn{2}{|c|}{0,0000} & \multicolumn{2}{|r|}{0,0000} \\
\hline Pseudo-R ${ }^{2}$ & \multicolumn{2}{|c|}{0,3171} & \multicolumn{2}{|r|}{0,1271} & \multicolumn{2}{|c|}{0,2596} & \multicolumn{2}{|r|}{0,2736} \\
\hline
\end{tabular}

Obs.: Erro-padrão entre parênteses e elasticidades entre colchetes, calculadas na forma d(y) / d(lnx).

* Significativo a $1 \%$.

** Significativo a $5 \%$. 
Tabela 30

Resultados das estimações: variável dependente acesso a coleta de esgoto por rede geral (1980)

\begin{tabular}{|c|c|c|c|c|c|c|c|c|}
\hline $\begin{array}{c}\text { Coleta de } \\
\text { Esgoto } \\
\text { (Rede Geral) } \\
\end{array}$ & $\begin{array}{l}\text { Coefici- } \\
\text { ente }\end{array}$ & $\begin{array}{c}\text { Efeito } \\
\text { Marginal }\end{array}$ & $\begin{array}{l}\text { Coefici- } \\
\text { ente }\end{array}$ & $\begin{array}{c}\text { Efeito } \\
\text { Marginal }\end{array}$ & $\begin{array}{l}\text { Coefici- } \\
\text { ente }\end{array}$ & $\begin{array}{c}\text { Efeito } \\
\text { Marginal }\end{array}$ & $\begin{array}{l}\text { Coefici- } \\
\text { ente }\end{array}$ & $\begin{array}{c}\text { Efeito } \\
\text { Marginal }\end{array}$ \\
\hline $\begin{array}{c}\text { Ln (Renda } \\
\text { Domiciliar) }\end{array}$ & $\begin{array}{l}0,303 * \\
(0,0017)\end{array}$ & $\begin{array}{l}0,069 * \\
(0,004) \\
{[0,642]}\end{array}$ & & & & & & \\
\hline $\begin{array}{l}\text { Ln (População } \\
\text { do Município) }\end{array}$ & & & $\begin{array}{l}0,116 * \\
(0,001)\end{array}$ & $\begin{array}{c}0,027 * \\
(0,0003) \\
{[0,316]}\end{array}$ & & & & \\
\hline $\begin{array}{c}\text { Taxa de } \\
\text { Urbanização do } \\
\text { Município }\end{array}$ & & & & & $\begin{array}{l}1,296 * \\
(0,011)\end{array}$ & $\begin{array}{l}0,284 * \\
(0,002)\end{array}$ & & \\
\hline $\begin{array}{c}\text { Ln (Renda } \\
\text { Municipal per } \\
\text { capita Mensal) }\end{array}$ & & & & & & & $\begin{array}{l}0,373 * \\
(0,004)\end{array}$ & $\begin{array}{c}0,085 * \\
(0,0009) \\
{[0,861]}\end{array}$ \\
\hline $\begin{array}{l}\text { Localização do } \\
\text { Domicílio }\end{array}$ & $\begin{array}{l}-1,618 * \\
(0,009)\end{array}$ & $\begin{array}{l}-0,267 * \\
(0,0009)\end{array}$ & $\begin{array}{c}-1,515 * \\
(0,009)\end{array}$ & $\begin{array}{l}-0,267 * \\
(0,0009)\end{array}$ & $\begin{array}{c}-1,383 * \\
(0,009)\end{array}$ & $\begin{array}{c}-0,232 * \\
(0,001)\end{array}$ & $\begin{array}{c}-1,641 * \\
(0,009)\end{array}$ & $\begin{array}{l}-0,277 * \\
(0,0009)\end{array}$ \\
\hline Dummy Norte & $\begin{array}{l}-1,558 * \\
(0,015)\end{array}$ & $\begin{array}{l}-0,153 * \\
(0,0008)\end{array}$ & $\begin{array}{c}-1,510 * \\
(0,015)\end{array}$ & $\begin{array}{l}-0,159 * \\
(0,0008)\end{array}$ & $\begin{array}{c}-1,386 * \\
(0,015)\end{array}$ & $\begin{array}{l}-0,142 * \\
(0,0008)\end{array}$ & $\begin{array}{c}-1,553 * \\
(0,015)\end{array}$ & $\begin{array}{l}-0,155 * \\
(0,0008)\end{array}$ \\
\hline $\begin{array}{l}\text { Dummy } \\
\text { Nordeste }\end{array}$ & $\begin{array}{l}-1,357 * \\
(0,007)\end{array}$ & $\begin{array}{c}-0,221 * \\
(0,001)\end{array}$ & $\begin{array}{c}-1,370 * \\
(0,007)\end{array}$ & $\begin{array}{c}-0,233 * \\
(0,001)\end{array}$ & $\begin{array}{c}-1,283 * \\
(0,007)\end{array}$ & $\begin{array}{c}-0,207 * \\
(0,001)\end{array}$ & $\begin{array}{c}-1,481 * \\
(0,006)\end{array}$ & $\begin{array}{c}-0,240 * \\
(0,001)\end{array}$ \\
\hline $\begin{array}{c}\text { Dummy } \\
\text { Centro-Oeste } \\
\text { (2) }\end{array}$ & $\begin{array}{l}-1,383 * \\
(0,012)\end{array}$ & $\begin{array}{l}-0,151 * \\
(0,0008)\end{array}$ & $\begin{array}{c}-1,254 * \\
(0,012)\end{array}$ & $\begin{array}{l}-0,153 * \\
(0,0008)\end{array}$ & $\begin{array}{c}-1,283 * \\
(0,012)\end{array}$ & $\begin{array}{l}-0,141 * \\
(0,0008)\end{array}$ & $\begin{array}{c}-1,397 * \\
(0,012)\end{array}$ & $\begin{array}{l}-0,153 * \\
(0,0008)\end{array}$ \\
\hline $\begin{array}{c}\text { Dummy Distrito } \\
\text { Federal }\end{array}$ & $\begin{array}{l}-0,351 * \\
(0,017)\end{array}$ & $\begin{array}{c}-0,065 * \\
(0,003)\end{array}$ & $\begin{array}{c}-0,432 * \\
(0,016)\end{array}$ & $\begin{array}{c}-0,080 * \\
(0,002)\end{array}$ & $\begin{array}{c}-0,403 * \\
(0,016)\end{array}$ & $\begin{array}{c}-0,070 * \\
(0,002)\end{array}$ & $\begin{array}{c}-0,418 * \\
(0,016)\end{array}$ & $\begin{array}{c}-0,075 * \\
(0,002)\end{array}$ \\
\hline $\begin{array}{c}\text { Dummy Sudeste } \\
\text { (4) }\end{array}$ & $\begin{array}{l}-0,071 * \\
(0,005)\end{array}$ & $\begin{array}{c}-0,016 * \\
(0,001)\end{array}$ & $\begin{array}{c}-0,113 * \\
(0,005)\end{array}$ & $\begin{array}{c}-0,025 * \\
(0,001)\end{array}$ & $\begin{array}{c}-0,096 * \\
(0,005)\end{array}$ & $\begin{array}{c}-0,020 * \\
(0,001)\end{array}$ & $\begin{array}{c}-0,143 * \\
(0,005)\end{array}$ & $\begin{array}{c}-0,031 * \\
(0,001)\end{array}$ \\
\hline Dummy Sul & $\begin{array}{l}-1,184 * \\
(0,007)\end{array}$ & $\begin{array}{l}-0,173 * \\
(0,0009)\end{array}$ & $\begin{array}{c}-1,053 * \\
(0,007)\end{array}$ & $\begin{array}{l}-0,167 * \\
(0,0009)\end{array}$ & $\begin{array}{c}-1,055 * \\
(0,007)\end{array}$ & $\begin{array}{l}-0,154 * \\
(0,0009)\end{array}$ & $\begin{array}{c}-1,194 * \\
(0,007)\end{array}$ & $\begin{array}{l}-0,175 * \\
(0,0009)\end{array}$ \\
\hline Constante & $\begin{array}{l}-2,702 * \\
(0,017)\end{array}$ & & $\begin{array}{c}-1,218 * \\
(0,014) \\
\end{array}$ & & $\begin{array}{c}-0,889 * \\
(0,011) \\
\end{array}$ & & $\begin{array}{c}-3,549 * \\
(0,039) \\
\end{array}$ & \\
\hline 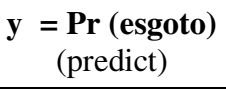 & \multicolumn{2}{|c|}{0,143445} & \multicolumn{2}{|c|}{0,150191} & \multicolumn{2}{|c|}{0,136576} & \multicolumn{2}{|c|}{0,145137} \\
\hline $\begin{array}{l}\text { Número de } \\
\text { Observações }\end{array}$ & \multicolumn{2}{|c|}{632.300} & \multicolumn{2}{|c|}{647.125} & \multicolumn{2}{|c|}{647.125} & \multicolumn{2}{|c|}{647.125} \\
\hline LR $\operatorname{chi}^{2}(10)$ & \multicolumn{2}{|c|}{$266.894,62$} & \multicolumn{2}{|c|}{$255.580,17$} & \multicolumn{2}{|c|}{$256.886,07$} & \multicolumn{2}{|c|}{$252.496,09$} \\
\hline Prob $>$ chi $^{2}$ & \multicolumn{2}{|r|}{0,0000} & \multicolumn{2}{|c|}{0,0000} & \multicolumn{2}{|c|}{0,0000} & \multicolumn{2}{|r|}{0,0000} \\
\hline Pseudo-R ${ }^{2}$ & \multicolumn{2}{|r|}{0,3547} & \multicolumn{2}{|c|}{0,3347} & \multicolumn{2}{|c|}{0,3364} & \multicolumn{2}{|r|}{0,3307} \\
\hline
\end{tabular}

Obs.: Erro-padrão entre parênteses e elasticidades entre colchetes, calculadas na forma d(y) / d(lnx).

* Significativo a $1 \%$. 
Tabela 31

Resultados das estimações: variável dependente acesso a coleta de esgoto por rede geral (1991)

\begin{tabular}{|c|c|c|c|c|c|c|}
\hline $\begin{array}{c}\text { Coleta de Esgoto } \\
\text { (Rede Geral) }\end{array}$ & Coeficiente & $\begin{array}{c}\text { Efeito } \\
\text { Marginal }\end{array}$ & Coeficiente & $\begin{array}{c}\text { Efeito } \\
\text { Marginal }\end{array}$ & Coeficiente & $\begin{array}{c}\text { Efeito } \\
\text { Marginal }\end{array}$ \\
\hline Ln (Renda Domiciliar) & $\begin{array}{l}0,314 * \\
(0,003)\end{array}$ & $\begin{array}{c}0,084 * \\
(0,0008) \\
{[0,956]}\end{array}$ & $\begin{array}{l}0,353 * \\
(0,003)\end{array}$ & $\begin{array}{c}0,094 * \\
(0,0008) \\
{[1,076]}\end{array}$ & $\begin{array}{c}0,2940 * \\
(0,003)\end{array}$ & $\begin{array}{c}0,077 * \\
(0,0008) \\
{[0,882]}\end{array}$ \\
\hline $\begin{array}{l}\text { Ln (População do } \\
\text { Município) }\end{array}$ & $\begin{array}{l}0,083 * \\
(0,001)\end{array}$ & $\begin{array}{c}0,022 * \\
(0,0004) \\
{[0,247]}\end{array}$ & & & & \\
\hline $\begin{array}{c}\text { Taxa de Urbanização do } \\
\text { Município }\end{array}$ & & & $\begin{array}{l}0,024 * \\
(0,002)\end{array}$ & $\begin{array}{l}0,006 * \\
(0,0005)\end{array}$ & & \\
\hline $\begin{array}{l}\text { Ln (Renda Municipal } \\
\text { per capita Mensal) }\end{array}$ & & & & & $\begin{array}{l}0,374 * \\
(0,005)\end{array}$ & $\begin{array}{l}0,098 * \\
(0,001) \\
{[1,072]}\end{array}$ \\
\hline Localização do Domicílio & $\begin{array}{c}-1,574 * \\
(0,013)\end{array}$ & $\begin{array}{l}-0,289 * \\
(0,0013)\end{array}$ & $\begin{array}{c}-1,696 * \\
(0,013)\end{array}$ & $\begin{array}{l}-0,304 * \\
(0,0013)\end{array}$ & $\begin{array}{c}-1,529 * \\
(0,013)\end{array}$ & $\begin{array}{c}-0,278 * \\
(0,001)\end{array}$ \\
\hline Dummy Norte & $\begin{array}{c}-2,773 * \\
(0,027)\end{array}$ & $\begin{array}{l}-0,230 * \\
(0,001)\end{array}$ & $\begin{array}{l}-2,850 * \\
(0,027)\end{array}$ & $\begin{array}{l}-0,231 * \\
(0,0012)\end{array}$ & $\begin{array}{c}-2,580 * \\
(0,027)\end{array}$ & $\begin{array}{c}-0,221 * \\
(0,001)\end{array}$ \\
\hline Dummy Nordeste & $\begin{array}{c}-1,710 * \\
(0,009)\end{array}$ & $\begin{array}{l}-0,319 * \\
(0,0016)\end{array}$ & $\begin{array}{c}-1,740 * \\
(0,009)\end{array}$ & $\begin{array}{l}-0,324 * \\
(0,0016)\end{array}$ & $\begin{array}{c}-1,415 * \\
(0,009)\end{array}$ & $\begin{array}{c}-0,274 * \\
(0,002)\end{array}$ \\
\hline $\begin{array}{c}\text { Dummy } \\
\text { Centro-Oeste (2) }\end{array}$ & $\begin{array}{c}-1,736 * \\
(0,025)\end{array}$ & $\begin{array}{l}-0,186 * \\
(0,0011)\end{array}$ & $\begin{array}{c}-1,814 * \\
(0,025)\end{array}$ & $\begin{array}{l}-0,188 * \\
(0,0011)\end{array}$ & $\begin{array}{c}-1,654 * \\
(0,025)\end{array}$ & $\begin{array}{l}-0,180 * \\
(0,0012)\end{array}$ \\
\hline Dummy Distrito Federal & $\begin{array}{l}-0,205 * \\
(0,025)\end{array}$ & $\begin{array}{l}-0,050 * \\
(0,0054)\end{array}$ & $\begin{array}{c}-0,067 * \\
(0,025)\end{array}$ & $\begin{array}{c}-0,017 * \\
(0,006)\end{array}$ & $\begin{array}{c}-0,180 * \\
(0,025)\end{array}$ & $\begin{array}{c}-0,043 * \\
(0,005)\end{array}$ \\
\hline Dummy Sudeste (4) & $\begin{array}{c}-0,328 * \\
(0,008)\end{array}$ & $\begin{array}{l}-0,080 * \\
(0,0018)\end{array}$ & $\begin{array}{c}-0,500 * \\
(0,007)\end{array}$ & $\begin{array}{l}-0,117 * \\
(0,0016)\end{array}$ & $\begin{array}{c}-1,103 * \\
(0,010)\end{array}$ & $\begin{array}{c}-0,216 * \\
(0,002)\end{array}$ \\
\hline Dummy Sul & $\begin{array}{c}-1,718 * \\
(0,009)\end{array}$ & $\begin{array}{l}-0,266 * \\
(0,0014)\end{array}$ & $\begin{array}{c}-1,799 * \\
(0,009)\end{array}$ & $\begin{array}{l}-0,273 * \\
(0,0014)\end{array}$ & $\begin{array}{c}-1,692 * \\
(0,009)\end{array}$ & $\begin{array}{c}-0,259 * \\
(0,001)\end{array}$ \\
\hline Constante & $\begin{array}{c}-3,977 * \\
(0,036)\end{array}$ & & $\begin{array}{c}-3,413 * \\
(0,034)\end{array}$ & & $\begin{array}{c}-6,867 * \\
(0,055)\end{array}$ & \\
\hline $\begin{array}{c}\mathbf{y}=\underset{(\text { predict })}{\operatorname{Pr}(\text { esgoto })} \\
\end{array}$ & \multicolumn{2}{|c|}{0,184040} & \multicolumn{2}{|c|}{0,184465} & \multicolumn{2}{|c|}{0,179441} \\
\hline $\begin{array}{l}\text { Número de } \\
\text { Observações }\end{array}$ & \multicolumn{2}{|c|}{361.414} & \multicolumn{2}{|c|}{361.414} & \multicolumn{2}{|c|}{361.414} \\
\hline $\operatorname{LR} \operatorname{chi}^{2}(10)$ & \multicolumn{2}{|c|}{$203.468,91$} & \multicolumn{2}{|c|}{$200.218,66$} & \multicolumn{2}{|c|}{$207.067,07$} \\
\hline Prob $>$ chi $^{2}$ & \multicolumn{2}{|c|}{0,0000} & \multicolumn{2}{|c|}{0,0000} & \multicolumn{2}{|c|}{0,0000} \\
\hline Pseudo-R2 & \multicolumn{2}{|c|}{0,4421} & \multicolumn{2}{|c|}{0,4350} & \multicolumn{2}{|c|}{0,4499} \\
\hline
\end{tabular}

Obs.: Erro-padrão entre parênteses e elasticidades entre colchetes, calculadas na forma d(y) / d(lnx).

* Significativo a $1 \%$. 
Tabela 32

Resultados das estimações: variável dependente acesso a fossa séptica (1970)

\begin{tabular}{|c|c|c|c|c|c|c|c|c|}
\hline Fossa Séptica & $\begin{array}{c}\text { Coefici- } \\
\text { ente }\end{array}$ & $\begin{array}{c}\text { Efeito } \\
\text { Marginal }\end{array}$ & $\begin{array}{c}\text { Coefici- } \\
\text { ente }\end{array}$ & $\begin{array}{c}\text { Efeito } \\
\text { Marginal }\end{array}$ & $\begin{array}{c}\text { Coefici- } \\
\text { ente }\end{array}$ & $\begin{array}{c}\text { Efeito } \\
\text { Marginal }\end{array}$ & $\begin{array}{l}\text { Coefici- } \\
\text { ente }\end{array}$ & $\begin{array}{c}\text { Efeito } \\
\text { Marginal }\end{array}$ \\
\hline $\begin{array}{c}\text { Ln (Renda } \\
\text { Mensal do Chefe } \\
\text { da Família) }\end{array}$ & $\begin{array}{l}0,405 * \\
(0,003)\end{array}$ & $\begin{array}{c}0,056 * \\
(0,0005) \\
{[0,296]}\end{array}$ & & & & & & \\
\hline $\begin{array}{l}\text { Ln (População } \\
\text { do Município) }\end{array}$ & & & $\begin{array}{l}0,251 * \\
(0,002)\end{array}$ & $\begin{array}{c}0,036 * \\
(0,0003) \\
{[0,411]}\end{array}$ & & & & \\
\hline $\begin{array}{l}\text { Taxa de } \\
\text { Urbanização do } \\
\text { Município }\end{array}$ & & & & & $\begin{array}{l}1,201 * \\
(0,012)\end{array}$ & $\begin{array}{c}0,169 * \\
(0,0017)\end{array}$ & & \\
\hline $\begin{array}{l}\text { Ln (Renda } \\
\text { Municipal per } \\
\text { capita Mensal) }\end{array}$ & & & & & & & $\begin{array}{l}0,456 * \\
(0,005)\end{array}$ & $\begin{array}{c}0,066 * \\
(0,0008) \\
{[0,279]}\end{array}$ \\
\hline $\begin{array}{l}\text { Localização do } \\
\text { Domicílio }\end{array}$ & $\begin{array}{c}-0,993 * \\
(0,009)\end{array}$ & $\begin{array}{l}-0,131 * \\
(0,0010)\end{array}$ & $\begin{array}{c}-0,903 * \\
(0,008)\end{array}$ & $\begin{array}{c}-0,121 * \\
(0,001)\end{array}$ & $\begin{array}{c}-0,861 * \\
(0,009)\end{array}$ & $\begin{array}{c}-0,114 * \\
(0,001)\end{array}$ & $\begin{array}{c}-0,991 * \\
(0,008)\end{array}$ & $\begin{array}{c}-0,135 * \\
(0,001)\end{array}$ \\
\hline Dummy Norte & $\begin{array}{c}-0,507 * \\
(0,019)\end{array}$ & $\begin{array}{l}-0,049 * \\
(0,0009)\end{array}$ & $\begin{array}{c}-0,328 * \\
(0,019)\end{array}$ & $\begin{array}{l}-0,037 * \\
(0,0016)\end{array}$ & $\begin{array}{c}-0,474 * \\
(0,019)\end{array}$ & $\begin{array}{l}-0,048 * \\
(0,0013)\end{array}$ & $\begin{array}{c}-0,297 * \\
(0,019)\end{array}$ & $\begin{array}{l}-0,035 * \\
(0,0018)\end{array}$ \\
\hline Dummy Nordeste & $\begin{array}{c}-0,475 * \\
(0,009)\end{array}$ & $\begin{array}{c}-0,057 * \\
(0,001)\end{array}$ & $\begin{array}{c}-0,391 * \\
(0,009)\end{array}$ & $\begin{array}{c}-0,049 * \\
(0,001)\end{array}$ & $\begin{array}{c}-0,515 * \\
(0,008)\end{array}$ & $\begin{array}{l}-0,062 * \\
(0,0009)\end{array}$ & $\begin{array}{c}-0,276 * \\
(0,001)\end{array}$ & $\begin{array}{c}-0,037 * \\
(0,001)\end{array}$ \\
\hline $\begin{array}{c}\text { Dummy } \\
\text { Centro-Oeste (2) }\end{array}$ & $\begin{array}{c}-0,463 * \\
(0,016)\end{array}$ & $\begin{array}{c}-0,047 * \\
(0,001)\end{array}$ & $\begin{array}{c}-0,053 * \\
(0,016)\end{array}$ & $\begin{array}{c}-0,007 * \\
(0,002)\end{array}$ & $\begin{array}{c}-0,325 * \\
(0,015)\end{array}$ & $\begin{array}{l}-0,037 * \\
(0,0014)\end{array}$ & $\begin{array}{c}-0,285 * \\
(0,015)\end{array}$ & $\begin{array}{c}-0,034 * \\
(0,001)\end{array}$ \\
\hline $\begin{array}{l}\text { Dummy Distrito } \\
\text { Federal }\end{array}$ & $\begin{array}{c}-0,729 * \\
(0,035)\end{array}$ & $\begin{array}{l}-0,059 * \\
(0,001)\end{array}$ & $\begin{array}{l}-0,290 * \\
(0,033)\end{array}$ & $\begin{array}{c}-0,033 * \\
(0,003)\end{array}$ & $\begin{array}{c}-0,802 * \\
(0,033)\end{array}$ & $\begin{array}{c}-0,062 * \\
(0,001)\end{array}$ & $\begin{array}{c}-0,628 * \\
(0,033)\end{array}$ & $\begin{array}{l}-0,058 * \\
(0,0017)\end{array}$ \\
\hline $\begin{array}{l}\text { Dummy Sudeste } \\
\text { (4) }\end{array}$ & $\begin{array}{c}-0,409 * \\
(0,007)\end{array}$ & $\begin{array}{l}-0,049 * \\
(0,0008)\end{array}$ & $\begin{array}{l}-0,164 * \\
(0,007)\end{array}$ & $\begin{array}{l}-0,022 * \\
(0,0009)\end{array}$ & $\begin{array}{c}-0,436 * \\
(0,007)\end{array}$ & $\begin{array}{l}-0,052 * \\
(0,0007)\end{array}$ & $\begin{array}{c}-0,328 * \\
(0,007)\end{array}$ & $\begin{array}{l}-0,042 * \\
(0,0008)\end{array}$ \\
\hline Dummy Sul & $\begin{array}{c}-0,199 * \\
(0,008)\end{array}$ & $\begin{array}{l}-0,025 * \\
(0,001)\end{array}$ & & & $\begin{array}{c}-0,014 * \\
(0,008)\end{array}$ & $\begin{array}{c}-0,002 * \\
(0,001)\end{array}$ & $\begin{array}{c}-0,059 * \\
(0,008)\end{array}$ & $\begin{array}{l}-0,008 * \\
(0,0011)\end{array}$ \\
\hline Constante & $\begin{array}{c}-2,854 * \\
(0,019) \\
\end{array}$ & & $\begin{array}{l}-3,810 * \\
(0,025) \\
\end{array}$ & & $\begin{array}{r}-1,483 * \\
(0,012) \\
\end{array}$ & & $\begin{array}{c}-2,736 * \\
(0,026) \\
\end{array}$ & \\
\hline $\begin{array}{c}\mathbf{y}=\operatorname{Pr}(\mathbf{f o s s a}) \\
\text { (predict) }\end{array}$ & \multicolumn{2}{|c|}{0,072860} & \multicolumn{2}{|c|}{0,075238} & \multicolumn{2}{|c|}{$\mathbf{0 , 0 7 3 9 7 3}$} & \multicolumn{2}{|c|}{0,077286} \\
\hline $\begin{array}{l}\text { Número de } \\
\text { Observações }\end{array}$ & \multicolumn{2}{|c|}{425.565} & \multicolumn{2}{|c|}{464.015} & \multicolumn{2}{|c|}{464.015} & \multicolumn{2}{|c|}{464.015} \\
\hline LR $\operatorname{chi}^{2}(10)$ & \multicolumn{2}{|c|}{$76.143,86$} & \multicolumn{2}{|c|}{$83.000,22$} & \multicolumn{2}{|c|}{$73.239,01$} & \multicolumn{2}{|c|}{$70.449,19$} \\
\hline Prob $>$ chi $^{2}$ & \multicolumn{2}{|r|}{0,0000} & \multirow{2}{*}{\multicolumn{2}{|c|}{$\begin{array}{l}0,0000 \\
0,2272\end{array}$}} & \multicolumn{2}{|c|}{0,0000} & \multicolumn{2}{|c|}{0,0000} \\
\hline Pseudo-R ${ }^{2}$ & & 0,2244 & & & &, 2005 & & 0,1928 \\
\hline
\end{tabular}

Obs.: Erro-padrão entre parênteses e elasticidades entre colchetes, calculadas na forma $\mathrm{d}(\mathrm{y}) / \mathrm{d}(\ln \mathrm{x})$.

* Significativo a $1 \%$.

** Significativo a $5 \%$. 
Tabela 33

Resultados das estimações: variável dependente acesso a fossa séptica (1980)

\begin{tabular}{|c|c|c|c|c|c|c|c|c|}
\hline Fossa Séptica & \begin{tabular}{c|}
$\begin{array}{c}\text { Coefici- } \\
\text { ente }\end{array}$ \\
\end{tabular} & $\begin{array}{c}\text { Efeito } \\
\text { Marginal } \\
\end{array}$ & $\begin{array}{l}\text { Coefici- } \\
\text { ente }\end{array}$ & \begin{tabular}{|c|} 
Efeito \\
Marginal \\
\end{tabular} & $\begin{array}{c}\text { Coefici- } \\
\text { ente }\end{array}$ & $\begin{array}{c}\text { Efeito } \\
\text { Marginal } \\
\end{array}$ & $\begin{array}{c}\text { Coefici- } \\
\text { ente }\end{array}$ & \begin{tabular}{|c|} 
Efeito \\
Marginal
\end{tabular} \\
\hline $\begin{array}{c}\text { Ln (Renda } \\
\text { Domiciliar) }\end{array}$ & $\begin{array}{l}0,083 * \\
(0,0016)\end{array}$ & $\begin{array}{c}0,018 * \\
(0,0004) \\
{[0,169]}\end{array}$ & & & & & & \\
\hline $\begin{array}{l}\text { Ln (População } \\
\text { do Município) }\end{array}$ & & & $\begin{array}{l}0,052 * \\
(0,001)\end{array}$ & $\begin{array}{c}0,011 * \\
(0,0002) \\
{[0,131]}\end{array}$ & & & & \\
\hline $\begin{array}{c}\text { Taxa de } \\
\text { Urbanização do } \\
\text { Município }\end{array}$ & & & & & $\begin{array}{l}0,845 * \\
(0,010)\end{array}$ & $\begin{array}{l}0,178 * \\
(0,002)\end{array}$ & & \\
\hline $\begin{array}{c}\text { Ln (Renda } \\
\text { Municipal per } \\
\text { capita Mensal) }\end{array}$ & & & & & & & $\begin{array}{l}0,157 * \\
(0,003)\end{array}$ & $\begin{array}{c}0,034 * \\
(0,0007) \\
{[0,339]}\end{array}$ \\
\hline $\begin{array}{l}\text { Localização do } \\
\text { Domicílio }\end{array}$ & $\begin{array}{c}-0,671 * \\
(0,005)\end{array}$ & $\begin{array}{l}-0,126 * \\
(0,0008)\end{array}$ & $\begin{array}{c}-0,649 * \\
(0,006)\end{array}$ & $\begin{array}{l}-0,121 * \\
(0,0009)\end{array}$ & $\begin{array}{c}-0,457 * \\
(0,006)\end{array}$ & $\begin{array}{c}-0,087 * \\
(0,001)\end{array}$ & $\begin{array}{c}-0,687 * \\
(0,005)\end{array}$ & $\begin{array}{l}-0,127 * \\
(0,0008)\end{array}$ \\
\hline Dummy Norte & $\begin{array}{l}0,204 * \\
(0,011)\end{array}$ & $\begin{array}{c}0,049 * \\
(0,0028)\end{array}$ & $\begin{array}{l}0,221 * \\
(0,011)\end{array}$ & $\begin{array}{l}0,053 * \\
(0,003)\end{array}$ & $\begin{array}{c}0,357^{*} \\
(0,011)\end{array}$ & $\begin{array}{l}0,089 * \\
(0,003)\end{array}$ & $\begin{array}{l}0,200 * \\
(0,011)\end{array}$ & $\begin{array}{l}0,047 * \\
(0,003)\end{array}$ \\
\hline $\begin{array}{l}\text { Dummy } \\
\text { Nordeste }\end{array}$ & $\begin{array}{l}0,115 * \\
(0,006)\end{array}$ & $\begin{array}{c}0,026^{*} \\
(0,0014)\end{array}$ & $\begin{array}{l}0,114 * \\
(0,006)\end{array}$ & $\begin{array}{l}0,025 * \\
(0,001)\end{array}$ & $\begin{array}{l}0,231 * \\
(0,006)\end{array}$ & $\begin{array}{l}0,052 * \\
(0,001)\end{array}$ & $\begin{array}{l}0,059 * \\
(0,006)\end{array}$ & $\begin{array}{l}0,013 * \\
(0,001)\end{array}$ \\
\hline $\begin{array}{c}\text { Dummy } \\
\text { Centro-Oeste } \\
\text { (2) }\end{array}$ & $\begin{array}{c}-0,813 * \\
(0,015)\end{array}$ & $\begin{array}{l}-0,114 * \\
(0,0011)\end{array}$ & $\begin{array}{c}-0,737 * \\
(0,015)\end{array}$ & $\begin{array}{c}-0,106 * \\
(0,001)\end{array}$ & $\begin{array}{c}-0,701 * \\
(0,015)\end{array}$ & $\begin{array}{c}-0,101 * \\
(0,001)\end{array}$ & $\begin{array}{c}-0,815 * \\
(0,015)\end{array}$ & $\begin{array}{c}-0,112 * \\
(0,001)\end{array}$ \\
\hline $\begin{array}{c}\text { Dummy Distrito } \\
\text { Federal }\end{array}$ & $\begin{array}{l}0,485 * \\
(0,017)\end{array}$ & $\begin{array}{l}0,133 * \\
(0,006)\end{array}$ & $\begin{array}{l}0,444 * \\
(0,017)\end{array}$ & $\begin{array}{l}0,118 * \\
(0,005)\end{array}$ & $\begin{array}{l}0,444 * \\
(0,017)\end{array}$ & $\begin{array}{l}0,117 * \\
(0,005)\end{array}$ & $\begin{array}{l}0,450 * \\
(0,017)\end{array}$ & $\begin{array}{l}0,120 * \\
(0,005)\end{array}$ \\
\hline $\begin{array}{c}\text { Dummy Sudeste } \\
\text { (4) }\end{array}$ & $\begin{array}{c}-0,169 * \\
(0,006)\end{array}$ & $\begin{array}{l}-0,035 * \\
(0,001)\end{array}$ & $\begin{array}{c}-0,167 * \\
(0,006)\end{array}$ & $\begin{array}{c}-0,034 * \\
(0,001)\end{array}$ & $\begin{array}{c}-0,152 * \\
(0,006)\end{array}$ & $\begin{array}{c}-0,031 * \\
(0,001)\end{array}$ & $\begin{array}{c}-0,183 * \\
(0,006)\end{array}$ & $\begin{array}{c}-0,037 * \\
(0,001)\end{array}$ \\
\hline Dummy Sul & $\begin{array}{l}0,590 * \\
(0,006)\end{array}$ & $\begin{array}{l}0,156 * \\
(0,0018)\end{array}$ & $\begin{array}{l}0,648 * \\
(0,006)\end{array}$ & $\begin{array}{l}0,172 * \\
(0,002)\end{array}$ & $\begin{array}{l}0,700 * \\
(0,006)\end{array}$ & $\begin{array}{l}0,186 * \\
(0,002)\end{array}$ & $\begin{array}{l}0,587 * \\
(0,006)\end{array}$ & $\begin{array}{l}0,153 * \\
(0,002)\end{array}$ \\
\hline Constante & $\begin{array}{c}-1,743 * \\
(0,017)\end{array}$ & & $\begin{array}{c}-1,603 * \\
(0,015)\end{array}$ & & $\begin{array}{c}-1,697 * \\
(0,010)\end{array}$ & & $\begin{array}{c}-2,533 * \\
(0,035)\end{array}$ & \\
\hline $\begin{array}{c}\mathbf{y}=\operatorname{Pr}(\mathbf{f o s s a}) \\
\text { (predict) }\end{array}$ & \multicolumn{2}{|c|}{0,135085} & \multicolumn{2}{|c|}{0,132147} & \multicolumn{2}{|c|}{0,129506} & \multicolumn{2}{|c|}{0,131970} \\
\hline $\begin{array}{l}\text { Número de } \\
\text { Observações }\end{array}$ & \multicolumn{2}{|c|}{632.300} & \multicolumn{2}{|c|}{647.125} & \multicolumn{2}{|c|}{647.125} & \multicolumn{2}{|c|}{647.125} \\
\hline LR chi²(10) & \multicolumn{2}{|c|}{$46.667,95$} & \multicolumn{2}{|c|}{$48.257,35$} & \multicolumn{2}{|c|}{$53.741,67$} & \multicolumn{2}{|c|}{$48.170,95$} \\
\hline Prob $>$ chi $^{2}$ & \multicolumn{2}{|c|}{0,0000} & \multicolumn{2}{|c|}{0,0000} & \multicolumn{2}{|c|}{0,0000} & \multicolumn{2}{|r|}{0,0000} \\
\hline Pseudo-R ${ }^{2}$ & \multicolumn{2}{|c|}{0,0845} & \multicolumn{2}{|r|}{0,0862} & \multicolumn{2}{|r|}{0,0960} & \multicolumn{2}{|r|}{0,0861} \\
\hline
\end{tabular}

Obs.: Erro-padrão entre parênteses e elasticidades entre colchetes, calculadas na forma d(y) / d(lnx).

* Significativo a $1 \%$. 
Tabela 34

Resultados das estimações: variável dependente acesso a fossa séptica (1991)

\begin{tabular}{|c|c|c|c|c|c|c|}
\hline Fossa Séptica & Coeficiente & $\begin{array}{c}\text { Efeito } \\
\text { Marginal }\end{array}$ & Coeficiente & $\begin{array}{c}\text { Efeito } \\
\text { Marginal }\end{array}$ & Coeficiente & $\begin{array}{c}\text { Efeito } \\
\text { Marginal }\end{array}$ \\
\hline Ln (Renda Domiciliar) & $\begin{array}{l}0,105 * \\
(0,0027)\end{array}$ & $\begin{array}{c}0,023 * \\
(0,0006) \\
{[0,268]}\end{array}$ & $\begin{array}{l}0,203 * \\
(0,0025)\end{array}$ & $\begin{array}{c}0,047 * \\
(0,0006) \\
{[0,539]}\end{array}$ & $\begin{array}{l}0,104 * \\
(0,003)\end{array}$ & $\begin{array}{c}0,023 * \\
(0,0006) \\
{[0,264]}\end{array}$ \\
\hline $\begin{array}{l}\text { Ln (População do } \\
\text { Município) }\end{array}$ & $\begin{array}{l}0,079 * \\
(0,001)\end{array}$ & $\begin{array}{c}0,018 * \\
(0,0003) \\
{[0,196]}\end{array}$ & & & & \\
\hline $\begin{array}{c}\text { Taxa de Urbanização do } \\
\text { Município }\end{array}$ & & & $\begin{array}{l}0,010 * \\
(0,001)\end{array}$ & $\begin{array}{r}0,002 * \\
(0,0003)\end{array}$ & & \\
\hline $\begin{array}{l}\text { Ln (Renda Municipal } \\
\text { per capita Mensal) }\end{array}$ & & & & & $\begin{array}{l}0,228 * \\
(0,005)\end{array}$ & $\begin{array}{l}0,051 * \\
(0,001) \\
{[0,556]}\end{array}$ \\
\hline $\begin{array}{l}\text { Localização do } \\
\text { Domicílio }\end{array}$ & $\begin{array}{c}-0,511 * \\
(0,008)\end{array}$ & $\begin{array}{l}-0,099 * \\
(0,0013)\end{array}$ & & & $\begin{array}{c}-0,516 * \\
(0,008)\end{array}$ & $\begin{array}{c}-0,100 * \\
(0,001)\end{array}$ \\
\hline Dummy Norte & $\begin{array}{l}1,010 * \\
(0,012)\end{array}$ & $\begin{array}{l}0,321 * \\
(0,004)\end{array}$ & $\begin{array}{l}0,833 * \\
(0,012)\end{array}$ & $\begin{array}{l}0,261 * \\
(0,004)\end{array}$ & $\begin{array}{l}1,100 * \\
(0,012)\end{array}$ & $\begin{array}{l}0,356^{*} \\
(0,005)\end{array}$ \\
\hline Dummy Nordeste & $\begin{array}{l}0,722 * \\
(0,009)\end{array}$ & $\begin{array}{c}0,188 * \\
(0,0025)\end{array}$ & $\begin{array}{l}0,599 * \\
(0,009)\end{array}$ & $\begin{array}{c}0,158 * \\
(0,0025)\end{array}$ & $\begin{array}{l}0,875 * \\
(0,010)\end{array}$ & $\begin{array}{l}0,234 * \\
(0,003)\end{array}$ \\
\hline $\begin{array}{c}\text { Dummy } \\
\text { Centro-Oeste (2) }\end{array}$ & & & $\begin{array}{c}-0,160 * \\
(0,032)\end{array}$ & $\begin{array}{c}-0,034 * \\
(0,006)\end{array}$ & & \\
\hline Dummy Distrito Federal & $\begin{array}{l}0,117 * \\
(0,028)\end{array}$ & $\begin{array}{l}0,028 * \\
(0,007)\end{array}$ & $\begin{array}{l}0,221 * \\
(0,028)\end{array}$ & $\begin{array}{l}0,057 * \\
(0,008)\end{array}$ & $\begin{array}{l}0,156 * \\
(0,028)\end{array}$ & $\begin{array}{l}0,038 * \\
(0,007)\end{array}$ \\
\hline Dummy Sudeste (4) & $\begin{array}{l}0,593 * \\
(0,009)\end{array}$ & $\begin{array}{c}0,154 * \\
(0,0027)\end{array}$ & $\begin{array}{l}0,428 * \\
(0,009)\end{array}$ & $\begin{array}{l}0,111 * \\
(0,002)\end{array}$ & $\begin{array}{l}0,039 * \\
(0,012)\end{array}$ & $\begin{array}{l}0,009 * \\
(0,003)\end{array}$ \\
\hline Dummy Sul & $\begin{array}{l}1,438 * \\
(0,009)\end{array}$ & $\begin{array}{l}0,450 * \\
(0,003)\end{array}$ & $\begin{array}{l}1,256 * \\
(0,008)\end{array}$ & $\begin{array}{l}0,393 * \\
(0,003)\end{array}$ & $\begin{array}{l}1,392 * \\
(0,008)\end{array}$ & $\begin{array}{l}0,433 * \\
(0,003)\end{array}$ \\
\hline Constante & $\begin{array}{c}-3,690 * \\
(0,034)\end{array}$ & & $\begin{array}{c}-3,918 * \\
(0,031)\end{array}$ & & $\begin{array}{c}-5,198 * \\
(0,055)\end{array}$ & \\
\hline $\mathbf{y}=\operatorname{Pr}($ fossa) (predict) & \multicolumn{2}{|c|}{0,140056} & \multicolumn{2}{|c|}{0,148628} & \multicolumn{2}{|c|}{0,140137} \\
\hline $\begin{array}{l}\text { Número de } \\
\text { Observações }\end{array}$ & \multicolumn{2}{|c|}{361.414} & \multicolumn{2}{|c|}{361.414} & \multicolumn{2}{|c|}{361.414} \\
\hline$L R \operatorname{chi}^{2}(10)$ & \multicolumn{2}{|c|}{$43.439,26$} & \multicolumn{2}{|c|}{$32.753,07$} & \multicolumn{2}{|c|}{$42.977,49$} \\
\hline Prob $>$ chi $^{2}$ & \multicolumn{2}{|c|}{0,0000} & \multicolumn{2}{|c|}{0,0000} & \multicolumn{2}{|c|}{0,0000} \\
\hline Pseudo-R ${ }^{2}$ & \multicolumn{2}{|c|}{0,1318} & \multicolumn{2}{|c|}{0,0994} & \multicolumn{2}{|c|}{0,1304} \\
\hline
\end{tabular}

Obs.: Erro-padrão entre parênteses e elasticidades entre colchetes, calculadas na forma d(y) / d(lnx).

* Significativo a $1 \%$. 
Tabela 35

Resultados das estimações (2004)

\begin{tabular}{|c|c|c|c|c|c|c|c|c|}
\hline \multirow[b]{2}{*}{ Variável } & \multicolumn{4}{|c|}{ Abastecimento de Água } & \multicolumn{2}{|c|}{ Coleta de Esgoto } & \multicolumn{2}{|c|}{ Fossa Séptica } \\
\hline & $\begin{array}{c}\text { Coefici- } \\
\text { ente }\end{array}$ & \begin{tabular}{|c|} 
Efeito \\
Marginal
\end{tabular} & $\begin{array}{l}\text { Coefici- } \\
\text { ente }\end{array}$ & \begin{tabular}{|c|} 
Efeito \\
Marginal
\end{tabular} & $\begin{array}{c}\text { Coefici- } \\
\text { ente }\end{array}$ & $\begin{array}{c}\text { Efeito } \\
\text { Marginal } \\
\end{array}$ & $\begin{array}{c}\text { Coefici- } \\
\text { ente }\end{array}$ & \begin{tabular}{|c|} 
Efeito \\
Marginal
\end{tabular} \\
\hline $\begin{array}{l}\text { Ln (Renda } \\
\text { Domiciliar) }\end{array}$ & $\begin{array}{l}0,012 * \\
(0,002)\end{array}$ & $\begin{array}{c}0,002 * \\
(0,0004) \\
{[0,016]}\end{array}$ & & & $\begin{array}{l}0,021 * \\
(0,001)\end{array}$ & $\begin{array}{c}0,008 * \\
(0,0006) \\
{[0,057]}\end{array}$ & $\begin{array}{l}0,012 * \\
(0,001)\end{array}$ & $\begin{array}{c}0,004 * \\
(0,0004) \\
{[0,026]}\end{array}$ \\
\hline $\begin{array}{l}\text { Localização do } \\
\text { Domicílio }\end{array}$ & & & $\begin{array}{c}-1,963 * \\
(0,015)\end{array}$ & $\begin{array}{c}-0,575 * \\
(0,005)\end{array}$ & $\begin{array}{c}-1,920 * \\
(0,025)\end{array}$ & $\begin{array}{c}-0,456 * \\
(0,002)\end{array}$ & $\begin{array}{c}-0,334 * \\
(0,015)\end{array}$ & $\begin{array}{c}-0,088 * \\
(0,003)\end{array}$ \\
\hline Dummy Norte & $\begin{array}{c}-1,261 * \\
(0,025)\end{array}$ & $\begin{array}{c}-0,369 * \\
(0,009)\end{array}$ & $\begin{array}{c}-1,452 * \\
(0,030)\end{array}$ & $\begin{array}{c}-0,386 * \\
(0,011)\end{array}$ & $\begin{array}{c}-2,808 * \\
(0,024)\end{array}$ & $\begin{array}{c}-0,517 * \\
(0,002)\end{array}$ & $\begin{array}{l}1,823 * \\
(0,022)\end{array}$ & $\begin{array}{l}0,637 * \\
(0,006)\end{array}$ \\
\hline Dummy Nordeste & $\begin{array}{c}-0,350 * \\
(0,024)\end{array}$ & $\begin{array}{c}-0,070 * \\
(0,005)\end{array}$ & $\begin{array}{c}-0,374 * \\
(0,030)\end{array}$ & $\begin{array}{c}-0,059 * \\
(0,005)\end{array}$ & $\begin{array}{c}-1,465 * \\
(0,017)\end{array}$ & $\begin{array}{c}-0,461 * \\
(0,004)\end{array}$ & $\begin{array}{l}0,815 * \\
(0,021)\end{array}$ & $\begin{array}{l}0,268 * \\
(0,007)\end{array}$ \\
\hline $\begin{array}{c}\text { Dummy } \\
\text { Centro-Oeste (2) }\end{array}$ & $\begin{array}{c}-1,001 * \\
(0,026)\end{array}$ & $\begin{array}{c}-0,277 * \\
(0,009)\end{array}$ & $\begin{array}{c}-1,077 * \\
(0,032)\end{array}$ & $\begin{array}{c}-0,257 * \\
(0,010)\end{array}$ & $\begin{array}{c}-1,984 * \\
(0,022)\end{array}$ & $\begin{array}{c}-0,441 * \\
(0,002)\end{array}$ & $\begin{array}{l}0,377 * \\
(0,027)\end{array}$ & $\begin{array}{l}0,124 * \\
(0,010)\end{array}$ \\
\hline $\begin{array}{c}\text { Dummy Distrito } \\
\text { Federal }\end{array}$ & $\begin{array}{c}-0,271 * \\
(0,042)\end{array}$ & $\begin{array}{c}-0,057 * \\
(0,010)\end{array}$ & $\begin{array}{c}-0,449 * \\
(0,048)\end{array}$ & $\begin{array}{c}-0,083 * \\
(0,011)\end{array}$ & $\begin{array}{c}-0,182 * \\
(0,033)\end{array}$ & $\begin{array}{c}-0,068 * \\
(0,012)\end{array}$ & $\begin{array}{l}0,529 * \\
(0,035)\end{array}$ & $\begin{array}{l}0,182 * \\
(0,013)\end{array}$ \\
\hline $\begin{array}{c}\text { Dummy Sudeste } \\
\text { (4) }\end{array}$ & $\begin{array}{c}-0,654 * \\
(0,024)\end{array}$ & $\begin{array}{c}-0,149 * \\
(0,006)\end{array}$ & $\begin{array}{c}-0,768 * \\
(0,030)\end{array}$ & $\begin{array}{c}-0,145 * \\
(0,007)\end{array}$ & $\begin{array}{c}-0,682 * \\
(0,018)\end{array}$ & $\begin{array}{c}-0,239 * \\
(0,006)\end{array}$ & $\begin{array}{l}0,636 * \\
(0,022)\end{array}$ & $\begin{array}{l}0,212 * \\
(0,008)\end{array}$ \\
\hline Dummy Sul & $\begin{array}{c}-0,724 * \\
(0,024)\end{array}$ & $\begin{array}{l}-0,171 * \\
(0,007)\end{array}$ & $\begin{array}{c}-0,668 * \\
(0,030)\end{array}$ & $\begin{array}{l}-0,124 * \\
(0,007)\end{array}$ & $\begin{array}{c}-1,983 * \\
(0,019)\end{array}$ & $\begin{array}{c}-0,501 * \\
(0,003)\end{array}$ & $\begin{array}{l}1,975 * \\
(0,021)\end{array}$ & $\begin{array}{l}0,671 * \\
(0,006)\end{array}$ \\
\hline Constante & $\begin{array}{l}1,744 * \\
(0,025)\end{array}$ & & $\begin{array}{l}2,272 * \\
(0,027)\end{array}$ & & $\begin{array}{l}1,181 * \\
(0,019)\end{array}$ & & $\begin{array}{c}-1,776 * \\
(0,022) \\
\end{array}$ & \\
\hline $\begin{array}{c}\mathbf{y}=\operatorname{Pr}(\mathbf{y}) \\
\text { (predict) }\end{array}$ & & 395181 & & 27561 & & 92775 & & 18664 \\
\hline $\begin{array}{l}\text { Número de } \\
\text { Observações }\end{array}$ & & 98.786 & & 99.852 & & 04.985 & & 04.985 \\
\hline$L R \operatorname{chi}^{2}(10)$ & & 582,52 & & 298,82 & 43. & 955,18 & & 920,54 \\
\hline Prob > chi ${ }^{2}$ & & 0,0000 & & 0,0000 & & 0,0000 & & 0,0000 \\
\hline Pseudo-R ${ }^{2}$ & & 0,0635 & & 0,3062 & & 0,3052 & & 0,1910 \\
\hline
\end{tabular}

Obs.: Erro-padrão entre parênteses e elasticidades entre colchetes, calculadas na forma d(y) / d(lnx).

* Significativo a $1 \%$. 
Tabela 36

Brasil: variação da proporção de domicílios com acesso a serviços de saneamento básico, segundo as grandes regiões, o Distrito Federal e o Estado de São Paulo (1970-2000)

\begin{tabular}{l|r|r|r|r|r|r|r|r}
\hline & \multicolumn{8}{c}{ Variação Anual Média (\%) } \\
\cline { 2 - 9 } Serviço / Região & \multicolumn{3}{|c|}{ Água (Rede Geral) } & \multicolumn{4}{c}{ Esgoto (Rede Geral) } \\
\cline { 2 - 9 } & $\mathbf{1 9 7 0 -}$ & $\mathbf{1 9 8 0 -}$ & $\mathbf{1 9 7 0 -}$ & $\mathbf{1 9 9 1 -}$ & $\mathbf{1 9 7 0 -}$ & $\mathbf{1 9 8 0 -}$ & $\mathbf{1 9 7 0 -}$ & $\mathbf{1 9 9 1 -}$ \\
& $\mathbf{1 9 8 0}$ & $\mathbf{1 9 9 1}$ & $\mathbf{1 9 9 1}$ & $\mathbf{2 0 0 0}$ & $\mathbf{1 9 8 0}$ & $\mathbf{1 9 9 1}$ & $\mathbf{1 9 9 1}$ & $\mathbf{2 0 0 0}$ \\
\hline Norte & 9,82 & 1,28 & 6,00 & 0,85 & 23,29 & $-7,24$ & $-1,54$ & 109,10 \\
Nordeste & 15,70 & 6,08 & 15,66 & 2,92 & 14,08 & 4,88 & 12,86 & 30,26 \\
Centro-Oeste (1) & 10,99 & 7,28 & 13,24 & $-0,28$ & 9,64 & 16,98 & 22,05 & $-1,76$ \\
Centro-Oeste (2) & 11,78 & 9,38 & 16,31 & 1,10 & 9,07 & 5,98 & 10,29 & 8,79 \\
Distrito Federal & 4,20 & $-0,53$ & 1,61 & $-0,06$ & 3,65 & 5,49 & 5,66 & 1,31 \\
Sudeste (3) & 4,09 & 1,51 & 3,07 & 0,48 & 11,20 & 2,22 & 7,80 & 2,03 \\
Sudeste (4) & 3,84 & 2,18 & 3,41 & 0,69 & 8,32 & 0,94 & 4,86 & 3,69 \\
São Paulo & 4,07 & 0,96 & 2,64 & 0,30 & 14,53 & 3,18 & 11,00 & 0,91 \\
Sul & 10,59 & 3,30 & 8,61 & 1,44 & 6,92 & 1,02 & 4,20 & 13,82 \\
Brasil & $\mathbf{6 , 5 5}$ & $\mathbf{2 , 7 4}$ & $\mathbf{5 , 4 9}$ & $\mathbf{1 , 0 0}$ & $\mathbf{1 1 , 1 1}$ & $\mathbf{2 , 6 3}$ & $\mathbf{8 , 2 0}$ & $\mathbf{4 , 6 3}$ \\
\hline
\end{tabular}

Fonte: IBGE, Censos Demográficos de 1970, 1980, 1991 e 2000. Elaboração própria.

(1) Centro-Oeste incluindo o Distrito Federal.

(2) Centro-Oeste excluindo o Distrito Federal.

(3) Sudeste incluindo São Paulo.

(4) Sudeste excluindo São Paulo.

Tabela 37

Brasil: variação da proporção de domicílios com acesso a serviços de saneamento básico, segundo o porte dos municípios (1970-2000)

\begin{tabular}{|c|c|c|c|c|c|c|c|c|}
\hline \multirow{3}{*}{ Serviço / Porte } & \multicolumn{8}{|c|}{ Variação Anual Média (\%) } \\
\hline & \multicolumn{4}{|c|}{ Água (Rede Geral) } & \multicolumn{4}{|c|}{ Esgoto (Rede Geral) } \\
\hline & $\begin{array}{c}1970- \\
1980\end{array}$ & $\begin{array}{c}1980- \\
1991 \\
\end{array}$ & $\begin{array}{c}1970- \\
1991 \\
\end{array}$ & $\begin{array}{c}1991- \\
2000\end{array}$ & $\begin{array}{c}1970- \\
1980 \\
\end{array}$ & $\begin{array}{c}1980- \\
1991 \\
\end{array}$ & $\begin{array}{c}1970- \\
1991 \\
\end{array}$ & $\begin{array}{c}1991- \\
2000 \\
\end{array}$ \\
\hline Até 5.000 hab. & 25,47 & 6,53 & 24,25 & 1,79 & 46,27 & 11,51 & 55,97 & 2,56 \\
\hline 5.000 a 10.000 hab. & 26,07 & 5,90 & 23,56 & 3,88 & 35,38 & 4,90 & 28,50 & 9,16 \\
\hline 10.000 a 20.000 hab. & 20,73 & 4,79 & 17,58 & 3,96 & 32,91 & 3,29 & 23,05 & 11,81 \\
\hline 20.000 a 50.000 hab. & 14,03 & 4,08 & 11,82 & 3,18 & 18,22 & 3,56 & 13,93 & 11,61 \\
\hline 50.000 a 100.000 hab. & 10,18 & 2,84 & 7,84 & 1,53 & 8,55 & 3,15 & 7,14 & 6,71 \\
\hline 100.000 a 500.000 hab. & 3,14 & 1,58 & 2,58 & 0,46 & 2,62 & 1,99 & 2,57 & 3,35 \\
\hline 500.000 a 1.000 .000 hab. & 4,58 & 2,33 & 3,97 & 0,06 & 5,49 & 3,30 & 5,29 & 3,31 \\
\hline Mais de 1.000 .000 hab. & 4,29 & 0,93 & 2,74 & 0,09 & 63,93 & 0,58 & 32,70 & 2,71 \\
\hline Total & 6,55 & 2,74 & 5,49 & 1,00 & 11,11 & 2,63 & 8,20 & 4,63 \\
\hline
\end{tabular}

Fonte: IBGE, Censos Demográficos 1970, 1980, 1991 e 2000. Elaboração própria. 
Tabela 38

Brasil: variação da proporção de domicílios com acesso a serviços de saneamento básico, segundo a taxa de urbanização dos municípios (1970-2000)

\begin{tabular}{l|cc|c|c|c|c|c|c}
\hline \multirow{2}{*}{$\begin{array}{c}\text { Serviço / Taxa } \\
\text { de Urbanização }\end{array}$} & \multicolumn{3}{|c|}{ Água (Rede Geral) } & \multicolumn{4}{c}{ Esgoto (Rede Geral) } \\
\cline { 2 - 10 } & $\mathbf{1 9 7 0 -}$ & $\mathbf{1 9 8 0 -}$ & $\mathbf{1 9 7 0 -}$ & $\mathbf{1 9 9 1 -}$ & $\mathbf{1 9 7 0 -}$ & $\mathbf{1 9 8 0}-$ & $\mathbf{1 9 7 0 -}$ & $\mathbf{1 9 9 1 -}$ \\
& $\mathbf{1 9 8 0}$ & $\mathbf{1 9 9 1}$ & $\mathbf{1 9 9 1}$ & $\mathbf{2 0 0 0}$ & $\mathbf{1 9 8 0}$ & $\mathbf{1 9 9 1}$ & $\mathbf{1 9 9 1}$ & $\mathbf{2 0 0 0}$ \\
\hline Menos de 50\% & 8,33 & 5,82 & 9,55 & 3,69 & 2,86 & 4,13 & 4,14 & 18,68 \\
de 50\% a 60\% & 3,80 & 1,36 & 2,79 & 1,35 & 0,51 & $-0,99$ & $-0,31$ & 7,72 \\
de 60\% a 70\% & 2,81 & 2,26 & 2,86 & 0,08 & 0,47 & $-1,88$ & $-0,80$ & 8,76 \\
de 70\% a 80\% & 1,77 & 1,58 & 1,82 & 0,76 & 0,59 & 0,14 & 0,36 & 3,88 \\
de 80\% a 90\% & 3,15 & 0,71 & 1,99 & 0,32 & 3,60 & $-1,22$ & 0,84 & 3,46 \\
de 90\% a 95\% & 4,15 & 1,44 & 3,04 & 0,41 & 5,02 & 1,50 & 3,57 & 3,85 \\
mais de 95\% & 2,70 & 1,11 & 2,02 & $-0,19$ & 10,97 & 1,52 & 6,89 & 1,15 \\
Total & $\mathbf{6 , 5 5}$ & $\mathbf{2 , 7 4}$ & $\mathbf{5 , 4 9}$ & $\mathbf{1 , 0 0}$ & $\mathbf{1 1 , 1 1}$ & $\mathbf{2 , 6 3}$ & $\mathbf{8 , 2 0}$ & $\mathbf{4 , 6 3}$ \\
\hline
\end{tabular}

Fonte: IBGE, Censos Demográficos 1970, 1980, 1991 e 2000. Elaboração própria.

Tabela 39

Brasil: proporção de domicílios com acesso a serviços de saneamento básico, segundo a renda domiciliar mensal $(\mathbf{1 9 8 0 - 2 0 0 0 )}$

\begin{tabular}{l|c|c|c|c}
\hline \multirow{2}{*}{ Serviço / Renda } & \multicolumn{4}{|c}{ Variação Anual Média (\%) } \\
\cline { 2 - 5 } & \multicolumn{2}{|c}{ Água (Rede Geral) } & \multicolumn{2}{c}{ Esgoto (Rede Geral) } \\
\cline { 2 - 5 } & $\mathbf{1 9 8 0 - 1 9 9 1}$ & $\mathbf{1 9 9 1 - 2 0 0 0}$ & $\mathbf{1 9 8 0 - 1 9 9 1}$ & $\mathbf{1 9 9 1 - 2 0 0 0}$ \\
\hline menos de 1 S.M. & 9,15 & 8,06 & 12,40 & 23,35 \\
de 1 a 2 S.M. & 1,31 & 10,56 & $-0,82$ & 41,05 \\
de 2 a 3 S.M. & $-0,05$ & 7,10 & $-1,97$ & 29,03 \\
de 3 a 5 S.M. & $-0,19$ & 4,05 & $-2,10$ & 18,88 \\
de 5 a 10 S.M. & $-0,26$ & 1,85 & $-1,87$ & 10,43 \\
de 10 a 20 S.M. & $-0,11$ & 0,57 & 0,45 & 5,48 \\
Mais de 20 S.M. & 0,95 & $-0,08$ & $\mathbf{2 , 6 3}$ & $\mathbf{4}, 06$ \\
Total & $\mathbf{2 , 7 4}$ & $\mathbf{1 , 0 0}$ & $\mathbf{4 3}$ \\
\hline
\end{tabular}

Fonte: IBGE, Censos Demográficos 1980, 1991 e 2000. Elaboração própria.

Tabela 40

Brasil: variação da proporção de domicílios com acesso a serviços de saneamento básico, segundo a localização dos domicílios (1970-2000)

\begin{tabular}{l|c|c|c|c|c|c|r|r}
\hline & \multicolumn{8}{c}{ Variação Anual Média (\%) } \\
\cline { 2 - 9 } Serviço / Localização & \multicolumn{4}{|c|}{ Água (Rede Geral) } & \multicolumn{4}{c}{ Esgoto (Rede Geral) } \\
\cline { 2 - 9 } & $\mathbf{1 9 7 0 -}$ & $\mathbf{1 9 8 0}-$ & $\mathbf{1 9 7 0 -}$ & $\mathbf{1 9 9 1 -}$ & $\mathbf{1 9 7 0 -}$ & $\mathbf{1 9 8 0}-$ & $\mathbf{1 9 7 0 -}$ & $\mathbf{1 9 9 1 -}$ \\
& $\mathbf{1 9 8 0}$ & $\mathbf{1 9 9 1}$ & $\mathbf{1 9 9 1}$ & $\mathbf{2 0 0 0}$ & $\mathbf{1 9 8 0}$ & $\mathbf{1 9 9 1}$ & $\mathbf{1 9 9 1}$ & $\mathbf{2 0 0 0}$ \\
\hline Zona Urbana & 3,89 & 1,44 & 2,90 & 0,19 & 7,49 & 1,36 & 4,81 & 3,06 \\
Zona Rural & 6,70 & 11,23 & 12,44 & 9,92 & 27,44 & 3,30 & 19,54 & 17,64 \\
Total & $\mathbf{6 , 5 5}$ & $\mathbf{2 , 7 4}$ & $\mathbf{5 , 4 9}$ & $\mathbf{1 , 0 0}$ & $\mathbf{1 1 , 1 1}$ & $\mathbf{2 , 6 3}$ & $\mathbf{8 , 2 0}$ & $\mathbf{4 , 6 3}$ \\
\hline
\end{tabular}

Fonte: IBGE, Censos Demográficos 1970, 1980, 1991 e 2000. Elaboração própria. 
Tabela 41

Brasil: distribuição dos municípios em 2000, segundo o porte (tamanho da população) dos municípios, as grandes regiões e o Estado de São Paulo (\%)

\begin{tabular}{l|r|r|r|r|r|r|r|r|r}
\hline \multicolumn{1}{c|}{$\begin{array}{c}\text { Região / } \\
\text { Porte }\end{array}$} & N & NE & CO (1) & CO (2) & SE (3) & SE (4) & $\begin{array}{c}\text { São } \\
\text { Paulo }\end{array}$ & S & Brasil \\
\hline até 5.000 hab. & 21,83 & 14,61 & 32,06 & 32,13 & 25,59 & 24,10 & 27,91 & 34,08 & 24,03 \\
5.000 a 10.000 hab. & 20,27 & 22,38 & 24,44 & 24,49 & 24,14 & 28,19 & 17,83 & 26,49 & 23,77 \\
10.000 a 20.000 hab. & 25,17 & 32,85 & 23,09 & 23,15 & 20,74 & 22,51 & 17,98 & 20,10 & 25,10 \\
20.000 a 50.000 hab. & 23,16 & 22,16 & 13,90 & 13,93 & 16,25 & 14,94 & 18,29 & 11,48 & 17,54 \\
50.000 a 100.000 hab. & 6,46 & 5,43 & 3,81 & 3,82 & 6,43 & 5,18 & 8,37 & 4,49 & 5,48 \\
100.000 a 500.000 hab. & 2,67 & 2,07 & 2,02 & 2,02 & 5,94 & 4,38 & 8,37 & 3,19 & 3,52 \\
500.000 a 1.000.000 hab. & 0,00 & 0,34 & 0,22 & 0,22 & 0,67 & 0,50 & 0,93 & 0,00 & 0,33 \\
mais de 1.000.000 hab. & 0,45 & 0,17 & 0,45 & 0,22 & 0,24 & 0,20 & 0,31 & 0,17 & 0,24 \\
Total & $\mathbf{1 0 0 , 0 0}$ & $\mathbf{1 0 0 , 0 0}$ & $\mathbf{1 0 0 , 0 0}$ & $\mathbf{1 0 0 , 0 0}$ & $\mathbf{1 0 0 , 0 0}$ & $\mathbf{1 0 0 , 0 0}$ & $\mathbf{1 0 0 , 0 0}$ & $\mathbf{1 0 0 , 0 0}$ & $\mathbf{1 0 0 , 0 0}$ \\
\hline
\end{tabular}

Fonte: IBGE, Censo Demográfico 2000. Elaboração própria.

(1) Centro-Oeste incluindo o Distrito Federal.

(2) Centro-Oeste excluindo o Distrito Federal.

(3) Sudeste incluindo São Paulo.

(4) Sudeste excluindo São Paulo.

Tabela 42

Brasil: distribuição dos municípios em 2000, segundo a taxa de urbanização dos municípios, as grandes regiões e o Estado de São Paulo (\%)

\begin{tabular}{l|r|r|r|r|r|r|r|r|r}
\hline $\begin{array}{c}\text { Região / Taxa } \\
\text { de Urbanização }\end{array}$ & N & NE & CO (1) & CO (2) & SE (3) & SE (4) & $\begin{array}{c}\text { São } \\
\text { Paulo }\end{array}$ & S & Brasil \\
\hline menos de 50\% & 51,67 & 52,77 & 16,59 & 16,63 & 18,92 & 27,29 & 5,89 & 45,30 & 38,00 \\
de 50\% a 60\% & 14,70 & 16,28 & 10,09 & 10,11 & 11,04 & 15,04 & 4,81 & 11,22 & 13,01 \\
de 60\% a 70\% & 12,47 & 12,70 & 21,30 & 21,35 & 12,55 & 14,24 & 9,92 & 9,84 & 12,73 \\
de 70\% a 80\% & 10,02 & 9,46 & 21,30 & 21,35 & 18,68 & 17,73 & 20,16 & 12,34 & 13,84 \\
de 80\% a 90\% & 6,90 & 5,43 & 20,18 & 20,22 & 18,25 & 12,65 & 26,98 & 11,48 & 11,88 \\
de 90\% a 95\% & 2,23 & 1,57 & 6,73 & 6,74 & 9,88 & 6,97 & 14,42 & 5,09 & 5,28 \\
mais de 95\% & 2,00 & 1,79 & 3,81 & 3,60 & 10,67 & 6,08 & 17,83 & 4,75 & 5,26 \\
Total & $\mathbf{1 0 0 , 0 0}$ & $\mathbf{1 0 0 , 0 0}$ & $\mathbf{1 0 0 , 0 0}$ & $\mathbf{1 0 0 , 0 0}$ & $\mathbf{1 0 0 , 0 0}$ & $\mathbf{1 0 0 , 0 0}$ & $\mathbf{1 0 0 , 0 0}$ & $\mathbf{1 0 0 , 0 0}$ & $\mathbf{1 0 0 , 0 0}$ \\
\hline
\end{tabular}

Fonte: IBGE, Censo Demográfico 2000. Elaboração própria.

(1) Centro-Oeste incluindo o Distrito Federal.

(2) Centro-Oeste excluindo o Distrito Federal.

(3) Sudeste incluindo São Paulo.

(4) Sudeste excluindo São Paulo. 
Tabela 43

Brasil: distribuição dos municípios em 2000, segundo a renda municipal per capita mensal, as grandes regiões e o Estado de São Paulo (\%)

\begin{tabular}{l|c|r|r|r|r|r|r|r|r}
\hline \multicolumn{1}{c|}{ Região / Renda } & N & NE & CO (1) & CO (2) & SE (3) & SE (4) & $\begin{array}{c}\text { São } \\
\text { Paulo }\end{array}$ & S & Brasil \\
\hline até 1 S.M. & 75,95 & 96,03 & 21,30 & 21,35 & 23,10 & 35,36 & 4,03 & 13,55 & 49,00 \\
de 1 a 2 S.M. & 22,94 & 3,53 & 68,83 & 68,99 & 60,16 & 56,47 & 65,89 & 69,37 & 41,33 \\
de 2 a 3 S.M. & 1,11 & 0,39 & 7,85 & 7,87 & 14,61 & 7,37 & 25,89 & 15,27 & 8,47 \\
mais de 3 S.M. & --- & 0,06 & 2,02 & 1,80 & 2,12 & 0,80 & 4,19 & 1,81 & 1,20 \\
Total & $\mathbf{1 0 0 , 0 0}$ & $\mathbf{1 0 0 , 0 0}$ & $\mathbf{1 0 0 , 0 0}$ & $\mathbf{1 0 0 , 0 0}$ & $\mathbf{1 0 0 , 0 0}$ & $\mathbf{1 0 0 , 0 0}$ & $\mathbf{1 0 0 , 0 0}$ & $\mathbf{1 0 0 , 0 0}$ & $\mathbf{1 0 0 , 0 0}$ \\
\hline
\end{tabular}

Fonte: IBGE, Censo Demográfico 2000. Elaboração própria.

(1) Centro-Oeste incluindo o Distrito Federal.

(2) Centro-Oeste excluindo o Distrito Federal

(3) Sudeste incluindo São Paulo.

(4) Sudeste excluindo São Paulo.

Tabela 44

Brasil: distribuição dos domicílios em 2000, segundo a localização do domicílio, as grandes regiões,

o Distrito Federal e o Estado de São Paulo (\%)

\begin{tabular}{l|c|c|r|r|r|r|r|r|r|r}
\hline $\begin{array}{c}\text { Região / } \\
\text { Localização }\end{array}$ & $\mathbf{N}$ & NE & CO (1) & CO (2) & $\begin{array}{r}\text { Distrito } \\
\text { Federal }\end{array}$ & SE (3) & SE (4) & $\begin{array}{c}\text { São } \\
\text { Paulo }\end{array}$ & S & Brasil \\
\hline Zona Urbana & 72,29 & 71,51 & 86,77 & 84,88 & 95,83 & 91,48 & 88,92 & 93,91 & 82,16 & 83,34 \\
Zona Rural & 27,71 & 28,49 & 13,23 & 15,12 & 4,17 & 8,52 & 11,08 & 6,09 & 17,84 & 16,66 \\
Total & $\mathbf{1 0 0 , 0 0}$ & $\mathbf{1 0 0 , 0 0}$ & $\mathbf{1 0 0 , 0 0}$ & $\mathbf{1 0 0 , 0 0}$ & $\mathbf{1 0 0 , 0 0}$ & $\mathbf{1 0 0 , 0 0}$ & $\mathbf{1 0 0 , 0 0}$ & $\mathbf{1 0 0 , 0 0}$ & $\mathbf{1 0 0 , 0 0}$ & $\mathbf{1 0 0 , 0 0}$ \\
\hline
\end{tabular}

Fonte: IBGE, Censo Demográfico 2000. Elaboração própria.

(1) Centro-Oeste incluindo o Distrito Federal.

(2) Centro-Oeste excluindo o Distrito Federal.

(3) Sudeste incluindo São Paulo.

(4) Sudeste excluindo São Paulo.

Tabela 45

Brasil: distribuição dos domicílios em 2000, segundo a renda domiciliar mensal, as grandes regiões, o

Distrito Federal e o Estado de São Paulo (\%)

\begin{tabular}{l|r|r|r|r|r|r|r|r|r|r}
\hline \multicolumn{1}{c|}{ Região / Renda } & N & NE & CO (1) & CO (2) & $\begin{array}{l}\text { Distrito } \\
\text { Federal }\end{array}$ & SE (3) & SE (4) & $\begin{array}{c}\text { São } \\
\text { Paulo }\end{array}$ & S & Brasil \\
\hline menos de 1 S.M. & 23,19 & 32,06 & 13,39 & 14,62 & 7,51 & 10,70 & 13,37 & 8,17 & 10,84 & 17,14 \\
de 1 a 2 S.M. & 20,61 & 23,13 & 16,82 & 18,19 & 10,23 & 11,80 & 14,77 & 8,98 & 14,34 & 16,01 \\
de 2 a 3 S.M. & 13,36 & 13,12 & 13,55 & 14,49 & 9,05 & 11,38 & 12,66 & 10,16 & 12,44 & 12,27 \\
de 3 a 5 S.M. & 16,48 & 13,24 & 18,92 & 19,72 & 15,06 & 18,81 & 18,90 & 18,74 & 20,18 & 17,47 \\
de 5 a 10 S.M. & 15,01 & 10,28 & 19,01 & 18,61 & 20,93 & 24,06 & 21,19 & 26,78 & 23,21 & 19,48 \\
de 10 a 20 S.M. & 7,04 & 4,85 & 9,99 & 8,59 & 16,68 & 13,61 & 11,26 & 15,83 & 11,71 & 10,40 \\
mais de 20 S.M. & 4,31 & 3,33 & 8,32 & 5,77 & 20,53 & 9,65 & 7,85 & 11,36 & 7,29 & 7,23 \\
Total & $\mathbf{1 0 0 , 0 0}$ & $\mathbf{1 0 0 , 0 0}$ & $\mathbf{1 0 0 , 0 0}$ & $\mathbf{1 0 0 , 0 0}$ & $\mathbf{1 0 0 , 0 0}$ & $\mathbf{1 0 0 , 0 0}$ & $\mathbf{1 0 0 , 0 0}$ & $\mathbf{1 0 0 , 0 0}$ & $\mathbf{1 0 0 , 0 0}$ & $\mathbf{1 0 0 , 0 0}$ \\
\hline
\end{tabular}

Fonte: IBGE, Censo Demográfico 2000. Elaboração própria.

(1) Centro-Oeste incluindo o Distrito Federal.

(2) Centro-Oeste excluindo o Distrito Federal.

(3) Sudeste incluindo São Paulo.

(4) Sudeste excluindo São Paulo. 
Tabela 46

Brasil: distribuição dos domicílios sem acesso aos serviços (\%), segundo a renda domiciliar mensal (2000)

\begin{tabular}{l|c|c|c}
\hline \multicolumn{1}{c|}{ Região / Renda } & Água (Rede Geral) & $\begin{array}{c}\text { Coleta de Esgoto } \\
\text { (Rede Geral) }\end{array}$ & $\begin{array}{c}\text { Coleta de Esgoto (Rede Geral) } \\
\text { ou Fossa Séptica }\end{array}$ \\
\hline menos de 1 S.M. & 31,76 & 19,12 & 22,89 \\
de 1 a 2 S.M. & 23,84 & 20,08 & 23,05 \\
de 2 a 3 S.M. & 13,45 & 14,55 & 15,58 \\
de 3 a 5 S.M. & 14,32 & 18,75 & 18,19 \\
de 5 a 10 S.M. & 10,53 & 16,94 & 13,83 \\
de 10 a 20 S.M. & 3,83 & 6,90 & 4,55 \\
mais de 20 S.M. & 2,26 & 3,65 & 1,91 \\
Total & $\mathbf{1 0 0 , 0 0}$ & $\mathbf{1 0 0 , 0 0}$ & $\mathbf{1 0 0 , 0 0}$ \\
\hline
\end{tabular}

Fonte: IBGE, Censo Demográfico 2000. Elaboração própria.

Tabela 47

Brasil: distribuição dos municípios (2006), segundo o tipo de prestador (abrangência de atuação)

\begin{tabular}{l|cc|cc}
\hline \multicolumn{1}{c|}{ Prestador } & $\begin{array}{c}\text { Municípios com Abastecimento de } \\
\text { Água (Rede Geral) }\end{array}$ & $\begin{array}{c}\text { Municípios com Coleta de Esgoto } \\
\text { (Rede Geral) }\end{array}$ \\
\hline Regional & $3.890 \quad(70 \%)$ & 855 & $(15 \%)$ \\
Local (Público e Privado) & 1.534 & $(28 \%)$ & 2.012 & $(36 \%)$ \\
Microrregional & 22 & $(0,4 \%)$ & 8 & $(0,1 \%)$ \\
Brasil & $\mathbf{5 . 4 4 6}(\mathbf{9 8 , 4 \%})$ & $\mathbf{2 . 8 7 5}(\mathbf{5 1 , 1 \% )}$ \\
\hline \multicolumn{2}{r}{ Número Total de Municípios Existentes } \\
\hline
\end{tabular}

Fonte: Aesbe (2006). 
Tabela 48

Resultados das estimações com dummies tipos de prestadores: variável dependente acesso a

abastecimento de água por rede geral (1991)

\begin{tabular}{|c|c|c|c|c|c|c|}
\hline $\begin{array}{l}\text { Abastecimento de } \\
\text { Água por Rede Geral }\end{array}$ & Coeficiente & $\begin{array}{c}\text { Efeito } \\
\text { Marginal } \\
\end{array}$ & Coeficiente & $\begin{array}{c}\text { Efeito } \\
\text { Marginal } \\
\end{array}$ & Coeficiente & $\begin{array}{c}\text { Efeito } \\
\text { Marginal } \\
\end{array}$ \\
\hline $\begin{array}{l}\text { Ln (Renda Domiciliar } \\
\text { Mensal) }\end{array}$ & $\begin{array}{l}0,2911 * \\
(0,0042)\end{array}$ & $\begin{array}{c}0,0588 * \\
(0,0008) \\
{[0,6900]}\end{array}$ & $\begin{array}{l}0,4471 * \\
(0,0037)\end{array}$ & $\begin{array}{l}0,1006 * \\
(0,0008) \\
{[1,1810]}\end{array}$ & $\begin{array}{l}0,2840 * \\
(0,0042)\end{array}$ & $\begin{array}{l}0,0584 * \\
(0,0008) \\
{[0,6856]}\end{array}$ \\
\hline $\begin{array}{l}\text { Ln (População do } \\
\text { Município) }\end{array}$ & $\begin{array}{l}0,1534 * \\
(0,0026)\end{array}$ & $\begin{array}{c}0,0310 * \\
(0,0005) \\
{[0,3819]}\end{array}$ & & & & \\
\hline $\begin{array}{c}\text { Taxa de Urbanização } \\
\text { do Município }\end{array}$ & & & $\begin{array}{l}0,0299 * \\
(0,0026)\end{array}$ & $\begin{array}{l}0,0067 * \\
(0,0006)\end{array}$ & & \\
\hline $\begin{array}{l}\text { Ln (Renda Municipal } \\
\text { per capita } \text { Mensal) }\end{array}$ & & & & & $\begin{array}{l}0,4272 * \\
(0,0071)\end{array}$ & $\begin{array}{l}0,0879 * \\
(0,0015) \\
{[1,0016]}\end{array}$ \\
\hline $\begin{array}{l}\text { Localização do } \\
\text { Domicílio }\end{array}$ & $\begin{array}{l}-1,9422 * \\
(0,0115)\end{array}$ & $\begin{array}{c}-0,6265 * \\
(0,0038)\end{array}$ & & & $\begin{array}{l}-1,9310 * \\
(0,0115)\end{array}$ & $\begin{array}{c}-0,6260 * \\
(0,0038)\end{array}$ \\
\hline Dummy Norte & $\begin{array}{c}-0,8929 * \\
(0,0175)\end{array}$ & $\begin{array}{c}-0,2609 * \\
(0,0063)\end{array}$ & $\begin{array}{c}-1,4487 * \\
(0,0147)\end{array}$ & $\begin{array}{c}-0,4917 * \\
(0,0054)\end{array}$ & $\begin{array}{c}-0,7866 * \\
(0,0176)\end{array}$ & $\begin{array}{c}-0,2253 * \\
(0,0062)\end{array}$ \\
\hline Dummy Nordeste & $\begin{array}{l}-0,3680 * \\
(0,0131)\end{array}$ & $\begin{array}{c}-0,0835 * \\
(0,0032)\end{array}$ & $\begin{array}{c}-0,6270 * \\
(0,0111)\end{array}$ & $\begin{array}{c}-0,1674 * \\
(0,0033)\end{array}$ & $\begin{array}{l}-0,1039 * \\
(0,0141)\end{array}$ & $\begin{array}{c}-0,0221 * \\
(0,0031)\end{array}$ \\
\hline $\begin{array}{c}\text { Dummy } \\
\text { Centro-Oeste (2) }\end{array}$ & $\begin{array}{c}-1,0352 * \\
(0,0355)\end{array}$ & $\begin{array}{r}-0,3246 * \\
(0,0139)\end{array}$ & $\begin{array}{c}-1,1533 * \\
(0,0336)\end{array}$ & $\begin{array}{r}-0,3895 * \\
(0,0133)\end{array}$ & $\begin{array}{l}-1,0026 * \\
(0,0355)\end{array}$ & $\begin{array}{r}-0,3148 * \\
(0,0139)\end{array}$ \\
\hline $\begin{array}{l}\text { Dummy Distrito } \\
\text { Federal }\end{array}$ & $\begin{array}{c}-0,4459 * \\
(0,0341)\end{array}$ & $\begin{array}{c}-0,1131 * \\
(0,0103)\end{array}$ & $\begin{array}{c}-0,2928 * \\
(0,0308)\end{array}$ & $\begin{array}{c}-0,0759 * \\
(0,0090)\end{array}$ & $\begin{array}{c}-0,3974 * \\
(0,0336)\end{array}$ & $\begin{array}{c}-0,1001 * \\
(0,0100)\end{array}$ \\
\hline Dummy Sudeste (4) & & & $\begin{array}{c}-0,3097 * \\
(0,0110)\end{array}$ & $\begin{array}{c}-0,0751 * \\
(0,0028)\end{array}$ & $\begin{array}{c}-1,0243 * \\
(0,0166)\end{array}$ & $\begin{array}{c}-0,2671 * \\
(0,0050)\end{array}$ \\
\hline Dummy Sul & $\begin{array}{c}-0,1524 * \\
(0,0145)\end{array}$ & $\begin{array}{c}-0,0327 * \\
(0,0033)\end{array}$ & $\begin{array}{c}-0,4940 * \\
(0,0121)\end{array}$ & $\begin{array}{c}-0,1315 * \\
(0,0036)\end{array}$ & $\begin{array}{c}-0,2164 * \\
(0,0140)\end{array}$ & $\begin{array}{c}-0,0484 * \\
(0,0034)\end{array}$ \\
\hline Dummy Local Público & $\begin{array}{l}0,0848 * \\
(0,0110)\end{array}$ & $\begin{array}{l}0,0166 * \\
(0,0021)\end{array}$ & & & & \\
\hline Dummy Local Privado & $\begin{array}{c}-0,3686 * \\
(0,0203)\end{array}$ & $\begin{array}{c}-0,0898 * \\
(0,0058)\end{array}$ & $\begin{array}{c}-0,4285 * \\
(0,0191)\end{array}$ & $\begin{array}{c}-0,1171 * \\
(0,0061)\end{array}$ & $\begin{array}{c}-0,5277 * \\
(0,0202)\end{array}$ & $\begin{array}{c}-0,1399 * \\
(0,0065)\end{array}$ \\
\hline Dummy Microrregional & & & $\begin{array}{c}-0,3973 * \\
(0,0437)\end{array}$ & $\begin{array}{c}-0,1082 * \\
(0,0166)\end{array}$ & & \\
\hline Constante & $\begin{array}{c}-3,7520 * \\
(0,0572) \\
\end{array}$ & & $\begin{array}{c}-3,7966 * \\
(0,0437) \\
\end{array}$ & & $\begin{array}{c}-6,4145 * \\
(0,0869) \\
\end{array}$ & \\
\hline $\mathbf{y}=\operatorname{Pr}($ agua $)($ predict $)$ & \multicolumn{2}{|c|}{0,878269} & \multicolumn{2}{|c|}{0,857614} & \multicolumn{2}{|c|}{0,875022} \\
\hline $\begin{array}{l}\text { Número de } \\
\text { Observações }\end{array}$ & \multicolumn{2}{|c|}{213.628} & \multicolumn{2}{|c|}{213.628} & \multicolumn{2}{|c|}{213.628} \\
\hline LR $\operatorname{chi}^{2}(10)$ & \multicolumn{2}{|c|}{$83.204,80$} & \multicolumn{2}{|c|}{$37.808,55$} & \multicolumn{2}{|c|}{$83.352,58$} \\
\hline Prob $>$ chi $^{2}$ & \multicolumn{2}{|c|}{0,0000} & \multicolumn{2}{|c|}{0,0000} & \multicolumn{2}{|c|}{0,0000} \\
\hline Pseudo-R ${ }^{2}$ & \multicolumn{2}{|c|}{0,4018} & \multicolumn{2}{|c|}{0,1826} & \multicolumn{2}{|c|}{0,4025} \\
\hline
\end{tabular}

Obs.: Erro-padrão entre parênteses e elasticidades entre colchetes, calculadas na forma d(y) / d(lnx).

* Significativo a $1 \%$. 
Tabela 49

Resultados das estimações com dummies tipos de prestadores: variável dependente acesso a

coleta de esgoto por rede geral (1991)

\begin{tabular}{|c|c|c|c|c|c|c|}
\hline $\begin{array}{c}\text { Coleta de Esgoto por } \\
\text { Rede Geral } \\
\end{array}$ & Coeficiente & $\begin{array}{c}\text { Efeito } \\
\text { Marginal } \\
\end{array}$ & Coeficiente & $\begin{array}{c}\text { Efeito } \\
\text { Marginal } \\
\end{array}$ & Coeficiente & $\begin{array}{c}\text { Efeito } \\
\text { Marginal } \\
\end{array}$ \\
\hline $\begin{array}{l}\text { Ln (Renda Domiciliar } \\
\text { Mensal) }\end{array}$ & $\begin{array}{l}0,3231 * \\
(0,0036)\end{array}$ & $\begin{array}{l}0,1231 * \\
(0,0013) \\
{[1,4443]}\end{array}$ & $\begin{array}{l}0,3574 * \\
(0,0033)\end{array}$ & $\begin{array}{l}0,1363 * \\
(0,0012) \\
{[1,5993]}\end{array}$ & $\begin{array}{l}0,3029 * \\
(0,0037)\end{array}$ & $\begin{array}{l}0,1149 * \\
(0,0013) \\
{[0,0543]}\end{array}$ \\
\hline $\begin{array}{l}\text { Ln (População do } \\
\text { Município) }\end{array}$ & $\begin{array}{l}0,1230 * \\
(0,0021)\end{array}$ & $\begin{array}{l}0,0469 * \\
(0,0008) \\
{[0,5776]}\end{array}$ & & & & \\
\hline $\begin{array}{c}\text { Taxa de Urbanização } \\
\text { do Município }\end{array}$ & & & $\begin{array}{l}0,0321 * \\
(0,0046)\end{array}$ & $\begin{array}{l}0,0123 * \\
(0,0018)\end{array}$ & & \\
\hline $\begin{array}{l}\text { Ln (Renda Municipal } \\
\text { per capita } \text { Mensal) }\end{array}$ & & & & & $\begin{array}{l}0,5387 * \\
(0,0066)\end{array}$ & $\begin{array}{l}0,2044 * \\
(0,0025) \\
{[1,3762]}\end{array}$ \\
\hline $\begin{array}{l}\text { Localização do } \\
\text { Domicílio }\end{array}$ & $\begin{array}{l}-1,1811^{*} \\
(0,0174)\end{array}$ & $\begin{array}{c}-0,3456 * \\
(0,0031)\end{array}$ & $\begin{array}{c}-1,3005 * \\
(0,0169)\end{array}$ & $\begin{array}{c}-0,3678 * \\
(0,0027)\end{array}$ & $\begin{array}{c}-1,1226 * \\
(0,0177)\end{array}$ & $\begin{array}{c}-0,3313 * \\
(0,0033)\end{array}$ \\
\hline Dummy Norte & $\begin{array}{l}-2,6113 * \\
(0,0343)\end{array}$ & $\begin{array}{c}-0,4368 * \\
(0,0015)\end{array}$ & $\begin{array}{c}-2,84001 * \\
(0,0344)\end{array}$ & $\begin{array}{c}-0,4448 * \\
(0,0014)\end{array}$ & $\begin{array}{l}-2,4234 * \\
(0,0346)\end{array}$ & $\begin{array}{c}-0,4254 * \\
(0,0016)\end{array}$ \\
\hline Dummy Nordeste & $\begin{array}{c}-1,3567 * \\
(0,0102)\end{array}$ & $\begin{array}{c}-0,4106 * \\
(0,0023)\end{array}$ & $\begin{array}{c}-1,4656 * \\
(0,0100)\end{array}$ & $\begin{array}{c}-0,4336 * \\
(0,0022)\end{array}$ & $\begin{array}{c}-1,0463 * \\
(0,0113)\end{array}$ & $\begin{array}{c}-0,3364 * \\
(0,0029)\end{array}$ \\
\hline $\begin{array}{c}\text { Dummy } \\
\text { Centro-Oeste (2) }\end{array}$ & $\begin{array}{l}-1,1912 * \\
(0,0387)\end{array}$ & $\begin{array}{c}-0,3156 * \\
(0,0053)\end{array}$ & $\begin{array}{c}-1,4368 * \\
(0,0382)\end{array}$ & $\begin{array}{l}-0,3442 * \\
(0,0037)\end{array}$ & $\begin{array}{c}-1,0789 * \\
(0,0385)\end{array}$ & $\begin{array}{c}-0,2963 * \\
(0,0060)\end{array}$ \\
\hline $\begin{array}{c}\text { Dummy Distrito } \\
\text { Federal }\end{array}$ & $\begin{array}{c}-0,1014 * * \\
(0,0248)\end{array}$ & $\begin{array}{c}-0,0380 * * \\
(0,0091)\end{array}$ & $\begin{array}{c}-0,0510 * * \\
(0,0250)\end{array}$ & $\begin{array}{c}0,0193 * * \\
(0,0094)\end{array}$ & $\begin{array}{c}-1,4346 * \\
(0,0247)\end{array}$ & $\begin{array}{c}-0,0531 * \\
(0,0089)\end{array}$ \\
\hline Dummy Sudeste (4) & $\begin{array}{c}-0,1722 * \\
(0,0100)\end{array}$ & $\begin{array}{c}-0,0647 * \\
(0,0037)\end{array}$ & $\begin{array}{c}-0,4782 * \\
(0,0085)\end{array}$ & $\begin{array}{c}-0,1740 * \\
(0,0029)\end{array}$ & $\begin{array}{c}-1,4204 * \\
(0,0145)\end{array}$ & $\begin{array}{c}-0,4384 * \\
(0,0034)\end{array}$ \\
\hline Dummy Sul & $\begin{array}{l}-1,4067 * \\
(0,0107)\end{array}$ & $\begin{array}{c}-0,3970 * \\
(0,0021)\end{array}$ & $\begin{array}{c}-1,5546 * \\
(0,0104)\end{array}$ & $\begin{array}{c}-0,4219 * \\
(0,0019)\end{array}$ & $\begin{array}{c}-1,4236 * \\
(0,0106)\end{array}$ & $\begin{array}{c}-0,3963 * \\
(0,0021)\end{array}$ \\
\hline Dummy Local Público & $\begin{array}{l}0,3362 * \\
(0,0089)\end{array}$ & $\begin{array}{l}0,1309 * \\
(0,0035)\end{array}$ & $\begin{array}{l}0,2174 * \\
(0,0087)\end{array}$ & $\begin{array}{l}0,0842 * \\
(0,0034)\end{array}$ & $\begin{array}{l}0,2529 * \\
(0,0088)\end{array}$ & $\begin{array}{l}0,0978 * \\
(0,0035)\end{array}$ \\
\hline Dummy Local Privado & $\begin{array}{l}-0,1407 * \\
(0,0180)\end{array}$ & $\begin{array}{c}-0,0524 * \\
(0,0066)\end{array}$ & $\begin{array}{c}-0,2775 * \\
(0,0087)\end{array}$ & $\begin{array}{c}-0,1007 * \\
(0,0062)\end{array}$ & $\begin{array}{c}-0,2724 * \\
(0,0181)\end{array}$ & $\begin{array}{c}-0,0982 * \\
(0,0061)\end{array}$ \\
\hline Dummy Microrregional & $\begin{array}{l}-2,2807 * \\
(0,1884)\end{array}$ & $\begin{array}{c}-0,3788 * \\
(0,0031)\end{array}$ & $\begin{array}{c}-2,5397 * \\
(0,1890)\end{array}$ & $\begin{array}{c}-0,3831 * \\
(0,0020)\end{array}$ & $\begin{array}{l}-2,2006 * \\
(0,1845)\end{array}$ & $\begin{array}{l}-0,3725^{*} \\
(0,0035)\end{array}$ \\
\hline Constante & $\begin{array}{c}-4,8072 * \\
(0,0463) \\
\end{array}$ & & $\begin{array}{c}-3,5361 * \\
(0,0403) \\
\end{array}$ & & $\begin{array}{c}-8,9321 * \\
(0,0789) \\
\end{array}$ & \\
\hline $\begin{array}{c}\mathbf{y}=\operatorname{Pr}(\text { esgoto }) \\
(\text { predict })\end{array}$ & \multicolumn{2}{|c|}{0,381014} & \multicolumn{2}{|c|}{$\mathbf{0 , 3 8 2 3 7 3}$} & \multicolumn{2}{|c|}{$\mathbf{0 , 3 7 5 9 2 3}$} \\
\hline $\begin{array}{l}\text { Número de } \\
\text { Observações }\end{array}$ & \multicolumn{2}{|c|}{213.195} & \multicolumn{2}{|c|}{213.195} & \multicolumn{2}{|c|}{213.195} \\
\hline LR $\operatorname{chi}^{2}(10)$ & \multicolumn{2}{|c|}{$101.800,17$} & \multicolumn{2}{|c|}{$98.304,41$} & \multicolumn{2}{|c|}{$105.180,06$} \\
\hline Prob $>$ chi $^{2}$ & \multicolumn{2}{|c|}{0,0000} & \multicolumn{2}{|c|}{0,0000} & \multicolumn{2}{|c|}{0,0000} \\
\hline Pseudo-R ${ }^{2}$ & \multicolumn{2}{|c|}{0,3472} & \multicolumn{2}{|c|}{0,3353} & \multicolumn{2}{|c|}{0,3587} \\
\hline
\end{tabular}

Obs.: Erro-padrão entre parênteses e elasticidades entre colchetes, calculadas na forma d(y) / d(lnx).

* Significativo a $1 \%$.

** Significativo a $5 \%$. 
Tabela 50

Saneamento básico no Brasil: evolução de alguns indicadores (valor médio e desvio-padrão), segundo o tipo de prestador do serviço (2000-2004)

\begin{tabular}{|c|c|c|c|c|c|c|}
\hline \multirow[b]{2}{*}{ Ano / Prestador / Indicador } & \multicolumn{3}{|c|}{2000} & \multicolumn{3}{|c|}{2004} \\
\hline & Regional & $\begin{array}{c}\text { Local } \\
\text { Público }\end{array}$ & $\begin{array}{c}\text { Local } \\
\text { Privado }\end{array}$ & Regional & $\begin{array}{c}\text { Local } \\
\text { Público }\end{array}$ & $\begin{array}{c}\text { Local } \\
\text { Privado }\end{array}$ \\
\hline \multirow[t]{2}{*}{ - Índice de perdas de faturamento $(\%)$} & 42,27 & 32,34 & 39,57 & 44,19 & 31,64 & 35,41 \\
\hline & $(14,93)$ & $(17,96)$ & $(14,21)$ & $(14,71)$ & $(17,28)$ & $(16,94)$ \\
\hline \multirow[t]{2}{*}{ - Índice de perdas na distribuição (\%) } & 46,60 & 33,58 & 40,74 & 48,67 & 31,78 & 37,07 \\
\hline & $(14,38)$ & $(15,57)$ & $(16,80)$ & $(13,14)$ & $(17,58)$ & $(19,51)$ \\
\hline \multirow[t]{2}{*}{ - Índice de hidrometração $(\%)$} & 74,39 & 84,14 & 80,23 & 75,43 & 83,38 & 90,43 \\
\hline & $(24,02)$ & $(25,63)$ & $(22,76)$ & $(27,17)$ & $(27,44)$ & $(13,12)$ \\
\hline \multirow{2}{*}{$\begin{array}{l}\text { - Índice de atendimento total de água } \\
\text { (\% da pop.) }\end{array}$} & 86,20 & 96,74 & 94,81 & 71,37 & 86,55 & 87,96 \\
\hline & $(16,74)$ & $(9,65)$ & $(7,90)$ & $(16,91)$ & $(18,13)$ & $(8,78)$ \\
\hline \multirow[t]{2}{*}{ - Índice de coleta de esgoto $(\%)$} & 29,25 & 68,13 & 68,93 & 28,96 & 66,38 & 57,55 \\
\hline & $(18,19)$ & $(29,88)$ & $(21,71)$ & $(21,08)$ & $(30,68)$ & $(29,29)$ \\
\hline \multirow[t]{2}{*}{ - Índice de tratamento de esgoto $(\%)$} & 73,60 & 41,63 & 12,05 & 74,52 & 45,37 & 35,45 \\
\hline & $(46,75)$ & $(46,52)$ & $(22,72)$ & $(33,59)$ & $(43,07)$ & $(38,46)$ \\
\hline \multirow{2}{*}{$\begin{array}{l}\text { - Índice de produtividade (economias / } \\
\text { pessoal total) }\end{array}$} & 291,81 & 222,46 & 351,80 & 328,19 & 253,47 & 449,10 \\
\hline & $(119,22)$ & $(105,94)$ & $(133,85)$ & $(140,49)$ & $(163,94)$ & $(174,5)$ \\
\hline \multirow{2}{*}{$\begin{array}{l}\text { - Pessoal próprio por mil ligações (água e } \\
\text { esgoto) }\end{array}$} & 4,17 & 4,05 & 3,68 & 3,63 & 3,96 & 2,59 \\
\hline & $(4,10)$ & $(1,68)$ & $(1,56)$ & $(3,23)$ & $(1,83)$ & $(0,95)$ \\
\hline \multirow[t]{2}{*}{ - Índice de evasão de receita (\%) } & 12,11 & 2,41 & 15,84 & 12,96 & 1,34 & 6,57 \\
\hline & 24,12 & 12,84 & 14,01 & 11,98 & 13,08 & 6,05 \\
\hline \multirow[t]{2}{*}{ - Índice de desempenho financeiro $(\%)$} & 82,36 & 116,19 & 114,25 & 87,50 & 109,25 & 117,38 \\
\hline & 23,62 & 35,78 & 16,06 & 24,63 & 39,83 & 28,76 \\
\hline \multirow{2}{*}{$\begin{array}{l}\text { - Duração média das intermitências } \\
\text { (h./interrupção) }\end{array}$} & 7,60 & 3,94 & 32,27 & 17,55 & 6,09 & 6,43 \\
\hline & $(11,27)$ & $(3,65)$ & $(61,47)$ & $(68,05)$ & $(5,97)$ & $(9,11)$ \\
\hline \multirow{2}{*}{$\begin{array}{l}\text { - Extravasamentos de esgoto } \\
\text { (extravas./Km) }\end{array}$} & 19,27 & 2,05 & 7,16 & 3,93 & 4,56 & 5,35 \\
\hline & $(28,38)$ & $(3,65)$ & $(9,12)$ & $(8,94)$ & $(7,50)$ & $(4,01)$ \\
\hline
\end{tabular}

Fonte: Ministério das Cidades, SNIS (2000 e 2004). Elaboração própria. Obs.: Desvio-padrão entre parênteses. 
Tabela 51

Saneamento básico no Brasil: receita total, despesa total e resultado (total e médio), segundo

o tipo de prestador (2000-2003)

\begin{tabular}{|c|c|c|c|c|c|}
\hline Prestador & $\begin{array}{c}\text { Receita } \\
\text { Operacional Total } \\
\text { (R\$ milhões) }\end{array}$ & $\begin{array}{c}\text { Despesa Total } \\
\text { (R\$ milhões) }\end{array}$ & $\begin{array}{l}\text { Resultado Total } \\
\text { (R\$ milhões) }\end{array}$ & $\begin{array}{l}\text { Resultado Médio } \\
\text { (R\$ milhôes) }\end{array}$ & $\begin{array}{l}\text { Resultado Negativo } \\
\text { (quantidade de } \\
\text { prestadores) * }\end{array}$ \\
\hline \multicolumn{6}{|c|}{2000} \\
\hline Regional (1) & $9.224,78$ & $9.369,10$ & $-144,32$ & $-5,55$ & $17 \quad(26)$ \\
\hline Regional (2) & $5.766,82$ & $6.208,53$ & $-441,70$ & $-17,67$ & $17 \quad(25)$ \\
\hline Local & $1.271,33$ & $1.062,44$ & 208,89 & 1,49 & 36 (140) \\
\hline Privada & 222,49 & 186,31 & 36,18 & 2,41 & $0 \quad(15)$ \\
\hline \multicolumn{6}{|c|}{2001} \\
\hline Regional (1) & $9.769,96$ & $9.453,97$ & 315,99 & 12,64 & $17 \quad(25)$ \\
\hline Regional (2) & $6.226,45$ & $6.569,16$ & $-342,71$ & $-14,28$ & $17 \quad$ (24) \\
\hline Local & $1.594,81$ & $1.354,69$ & 240,12 & 1,58 & 32 (152) \\
\hline Privada & 246,01 & 208,25 & 37,76 & 3,15 & $2 \quad(12)$ \\
\hline \multicolumn{6}{|c|}{2002} \\
\hline Regional (1) & $11.060,85$ & $11.929,45$ & $-868,60$ & $-34,74$ & $19 \quad(25)$ \\
\hline Regional (2) & $7.098,41$ & $8.749,21$ & $-1.650,80$ & $-68,78$ & 19 (24) \\
\hline Local & $1.998,38$ & $1.687,45$ & 310,93 & 1,53 & 51 (203) \\
\hline Privada & 383,24 & 387,48 & $-4,24$ & $-0,35$ & $4 \quad(12)$ \\
\hline \multicolumn{6}{|c|}{2003} \\
\hline Regional (1) & $12.692,51$ & $12.693,39$ & $-0,88$ & $-0,04$ & $16 \quad(25)$ \\
\hline Regional (2) & $8.384,98$ & $8.899,08$ & $-514,10$ & $-21,42$ & $16 \quad(24)$ \\
\hline Local & $2.267,34$ & $1.937,31$ & 330,03 & 1,31 & $66(252)$ \\
\hline Privada & 441,88 & 463,47 & $-21,59$ & $-1,66$ & $4 \quad(13)$ \\
\hline
\end{tabular}

Fonte: Ministério das Cidades, SNIS (2000, 2001, 2002 e 2003). Elaboração própria.

(1) Prestadores regionais incluindo a Sabesp (companhia estadual do Estado de São Paulo).

(2) Prestadores regionais excluindo a Sabesp (companhia estadual do Estado de São Paulo).

* Número total de entidades pertencentes ao tipo de prestador entre parêntesis. 
Tabela 52

Saneamento básico no Brasil: investimento per capita anual médio, segundo o tipo de prestador do serviço e o porte dos municípios (2000-2004)

\begin{tabular}{|c|c|c|c|c|}
\hline $\begin{array}{c}\text { Prestador / } \\
\text { Porte } \\
\end{array}$ & Regional & Local Público & Local Privado & Total \\
\hline \multicolumn{5}{|c|}{ Água (R\$ milhões) } \\
\hline Até 5.000 hab. & 4,68 & 8,77 & 11,23 & 5,15 \\
\hline 5.000 a 10.000 hab. & 4,99 & 3,70 & 5,58 & 4,87 \\
\hline 10.000 a 20.000 hab. & 5,27 & 7,66 & 7,71 & 5,52 \\
\hline 20.000 a 50.000 hab. & 4,44 & 2,84 & 21,81 & 4,38 \\
\hline 50.000 a 100.000 hab. & 5,87 & 3,84 & 0,82 & 5,43 \\
\hline 100.000 a 500.000 hab. & 6,82 & 4,87 & 15,82 & 6,40 \\
\hline 500.000 a 1.000 .000 hab. & 4,43 & 2,70 & 9,23 & 4,31 \\
\hline Mais de 1.000.000 hab. & 8,90 & 8,84 & 12,73 & 9,18 \\
\hline Total & 5,09 & 5,26 & 12,78 & 5,19 \\
\hline \multicolumn{5}{|c|}{ Esgoto (R\$ milhões) } \\
\hline Até 5.000 hab. & 1,67 & 0,43 & 11,58 & 1,64 \\
\hline 5.000 a 10.000 hab. & 2,63 & 1,21 & 0,00 & 2,49 \\
\hline 10.000 a 20.000 hab. & 4,35 & 2,43 & 2,14 & 4,14 \\
\hline 20.000 a 50.000 hab. & 5,42 & 2,26 & 0,45 & 4,99 \\
\hline 50.000 a 100.000 hab. & 8,68 & 2,45 & 0,00 & 7,33 \\
\hline 100.000 a 500.000 hab. & 6,80 & 4,37 & 15,82 & 6,40 \\
\hline 500.000 a 1.000 .000 hab. & 4,80 & 9,78 & 5,25 & 5,93 \\
\hline Mais de 1.000 .000 hab. & 13,96 & 5,31 & 0,45 & 11,59 \\
\hline Total & 4,45 & 2,44 & 6,48 & 4,21 \\
\hline
\end{tabular}

Fonte: Ministério das Cidades, SNIS (2000, 2001, 2002, 2003 e 2004). Elaboração própria. 
Tabela 53

Saneamento básico no Brasil: investimento per capita anual médio, segundo o tipo de prestador do serviço e a taxa de urbanização dos municípios (2000-2004)

\begin{tabular}{l|c|c|c|c}
\hline $\begin{array}{c}\text { Prestador / Taxa de } \\
\text { Urbanização }\end{array}$ & Regional & Local Público & Local Privado & Total \\
\hline \multicolumn{4}{c}{ Água (R\$ milhões) } \\
Menos de 50\% & 4,37 & 3,47 & 21,00 & 4,32 \\
de 50\% a 60\% & 4,22 & 2,58 & $*$ & 4,08 \\
de 60\% a 70\% & 4,22 & 9,09 & 19,90 & 4,53 \\
de 70\% a 80\% & 4,25 & 5,99 & 7,36 & 5,56 \\
de 80\% a 90\% & 5,84 & 3,40 & 15,10 & 5,93 \\
de 90\% a 95\% & 5,91 & 6,01 & 6,08 & $\mathbf{5 , 1 9}$ \\
mais de 95\% & 10,34 & 5,09 & 13,45 & 1,46 \\
Total & $\mathbf{5 , 0 9}$ & $\mathbf{5 , 2 6}$ & $\mathbf{1 2 , 7 8}$ & 1,90 \\
& & & 2,46 \\
Menos de 50\% & 1,51 & Esgoto (R\$ milhões) & 34,73 & 4,26 \\
de 50\% a 60\% & 1,99 & 0,27 & $*$ & 6,70 \\
de 60\% a 70\% & 2,69 & 0,92 & 0,14 & 5,51 \\
de 70\% a 80\% & 4,60 & 0,90 & 2,50 & 13,89 \\
de 80\% a 90\% & 7,30 & 2,40 & 6,82 & $\mathbf{4 , 2 1}$ \\
de 90\% a 95\% & 6,24 & 3,94 & 1,41 & 14,31 \\
mais de 95\% & 16,40 & 2,80 & $\mathbf{6 , 4 8}$ & \\
Total & $\mathbf{4 , 4 5}$ & 5,13 & $\mathbf{2 , 4 4}$ & \\
\hline
\end{tabular}

Fonte: Ministério das Cidades, SNIS (2000, 2001, 2002, 2003 e 2004). Elaboração própria.

* Não há município atendido por esse tipo de prestador. 